\title{
WestVirginiaUniversity
}

THE RESEARCH REPOSITORY @ WVU

1933

\section{The Negro Miner in West Virginia}

James Tamplin Laing

The Ohio State University

Follow this and additional works at: https://researchrepository.wvu.edu/wvrhc-digitized

Part of the Appalachian Studies Commons, and the United States History Commons

\section{Recommended Citation}

Laing, James Tamplin, "The Negro Miner in West Virginia" (1933). Digitized Materials. 1.

https://researchrepository.wvu.edu/wvrhc-digitized/1

This Dissertation is brought to you for free and open access by the West Virginia \& Regional History Center at The Research Repository @ WVU. It has been accepted for inclusion in Digitized Materials by an authorized administrator of The Research Repository @ WVU. For more information, please contact ian.harmon@mail.wvu.edu. 
THE OHIO STATE UNIVERSITY LIBRARIES

Regulations Governing the Use of Manuscript Theses and Dissertations

Typescript copies of theses and dissertations submitted for the master's and doctor's degrees and deposited in The Ohio State Universty Libraries are available for examination, but are to be used only with due regard to the priority rights of the authors. Bibliographical references may be noted, but extended passages or the whole may not be published without securing previous written permission of the author When permission has been granted, proper credit must appear in the published work.

This thesis or dissertation has been used in accordance with the above regulations by the persons listed below. The borrowing library Is obligated to secure the signature of each user.

NAME AND ADDRESS OF USER

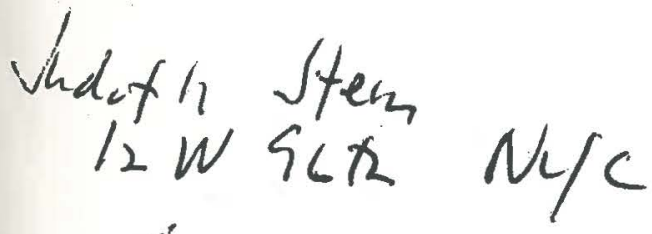

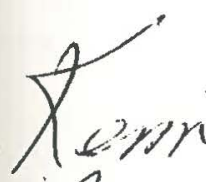

Ka .x 2 c wiva.Thach

mongering, w. l\%o.25)36
BORROWING LIBRARY

CONY

w. Vary th
DATE

$10-15-73$

$2-1775$

OMB

$3-10-76$

Corer. Studier LNIBC

5401 Wilkes Cue-

Baltimore ind 21228

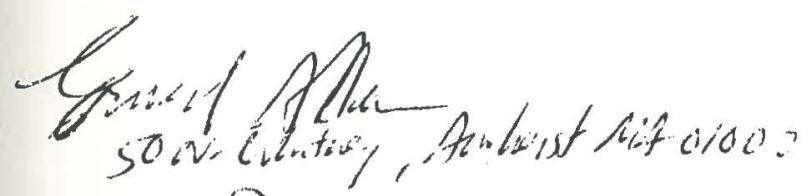

(ogling

$1 / 2 / 94$

Barre dComnell

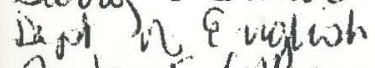

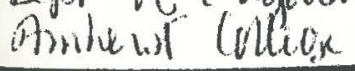

G rankest, ma oi dod

fruillascman

$1 / 1 / x_{0}$ 
THE NEGRO UIMER IU WRST VIRAIAIA

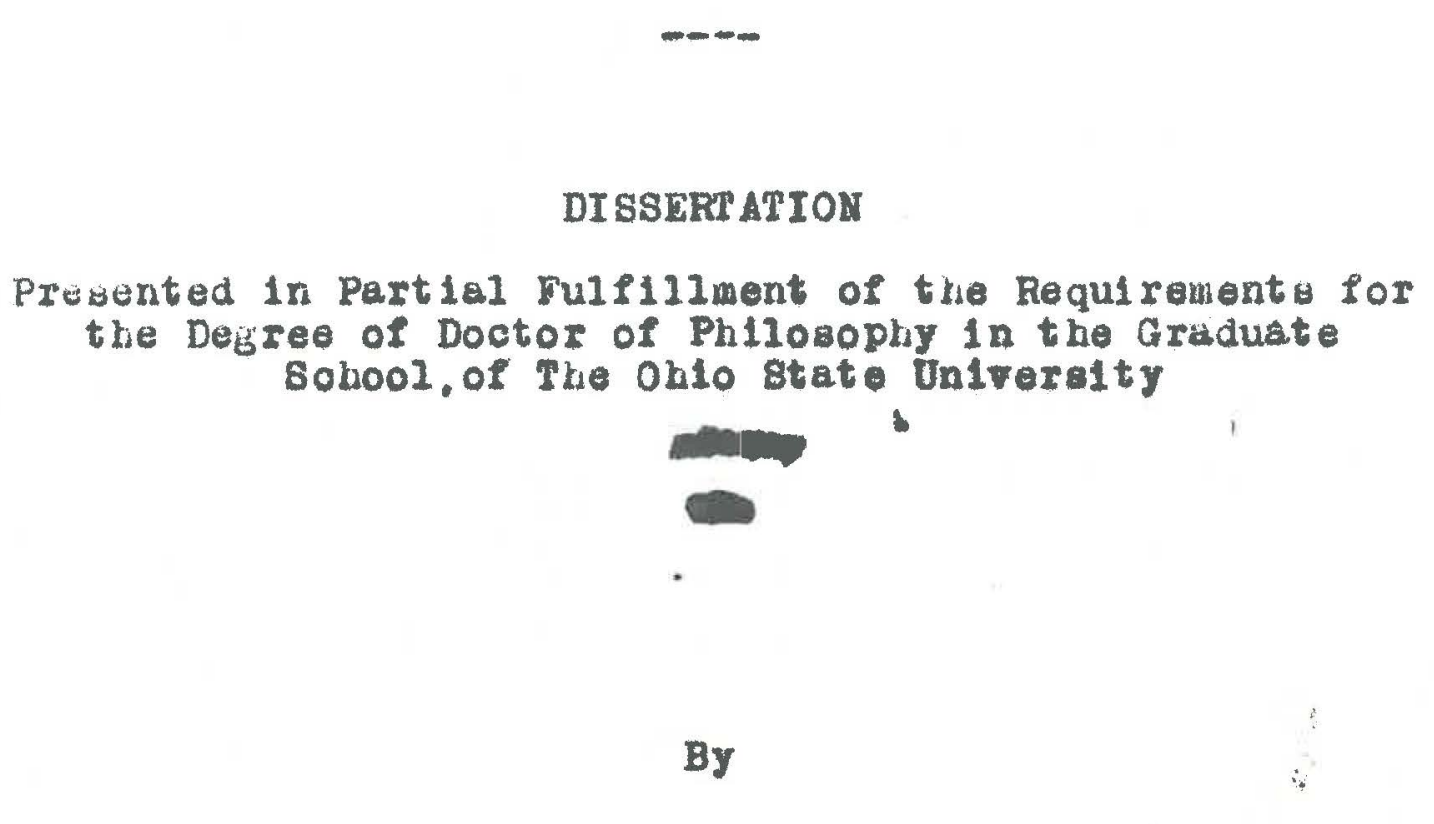

\section{SSERT ATION}

Presented in Partial Fulfillment of the Requirement reo of Doctor of Philosophy in the araduate

By

JAUES TAMPLIII LAINO, A. B., H. A.

The Ohlo State Unlveralty

1933

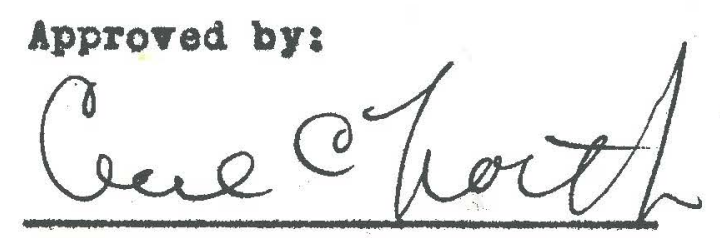


TABLE OF CORTENS

Chapter

Page

I. PURPOSE AND METHOD,.................

II. HISTORY OP UTHTHO AND OF THE NECRO HINFR

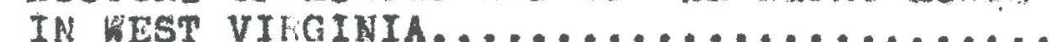

16

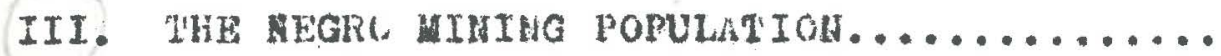

IV. UIGRETQRY CIAEACTET OF THE NEGRO MINIMG POPULATION. S**.

V. THE FUNCTION PRRPORHED BY THE HEORO MTMER. 167

VI. THE EFPICIENCY OF PHE NFGRO MINER. 208

VII. THE NEOKO KINER AND HIS EARNINGS. 273

VIII. THE COMPAHY-OWWED TOWN,.............. 301

IX. THE FAMILX........................ 326

X. EDUCATION.......................... 367

XI. LEISURE TIME ACTIVITTES............... 392

XII. RiblaI

XIII. SOCIAL STATUS...................... \$5O

XIV. RAGE RELATIONS................... 465

XV. PROSRLCT.......................... 498 Appendix.......................... 511 


\section{OHAPTER I \\ PURPO8E AND METHOD}

I. SCOPE AND PURPOBE.-

A large number of the otudies of the American

Negro whloh have appeared in reont years have been devoted to a disousalon of his place on the economio front. One cannot contemplate this faot without realizing that authorities have looked upon the oponomic as one of the most frultful approaches to the study of reoe relations. The logic of such a position becomes immediately apparent. It is 1mposs1ble to think of the American Negro apart from the economio systen. He had his origin and his boing within 1t. He was brought to Amerioa not mo moh a a man, or beouuse of the humanitarian efforto of his captors who, even at that early time, had the ldea of "the white man's burden." He was brought as a sort of humen, or near-human oog, whloh, upon arrival In Amerloe, was fitted into the Amerioan ooonomio machinery.

In Amerioa the statug of the Negro beoame fixed. The wh1t master, although the master-alave relation was forelgn to the mores of northern Lurope, woon became accommodated to the aystem. The laves thomselves perhaps had not so far to go as did the1r masters in becoming habltuated to the economlo system. Slevery was the basle of a great I Reuter, E. B., The Amerloan Race Problem Crowe11, 1937, pp. 101-103. 


\section{2}

deal of African agrlculture and induatry. Thus, we have the acceptance of status by both groups and this status became a part of the growing American mores. Due to the completeness of the accominodation of both races we dil not have a race prejudioe in early Amerlos in the sense that we have it today. It was only when a new statu was created by a crisis that we have the development of the modern prenomenon.

What actually bappened, of course, with the freeing of the Negro was that there was suddenly created a new statue for which nelther whites nor Vegroes were prepared. Culturally defined behavior patterns, which control the aotivity and thoughts of men, have very little respect for proclamations of enancipation or constitutional amendmenta. Thus, we have a new situation in which the behavior oatterns of the old system persist as a culture lag. In such a situation have antagonlsas and prejudices growing up which did not exid in the old order in the same degree. Hore and more we are coming to see that what we have been thinking of as race or color prejudice is more nearly a class or caste prejudice. For the person caught up and conditioned in the prevalling culture tyoe in America, however, whiteness and blackness are symbols which call forth antagonistic att13 IbId., pp. 103-104. of the Academy of political and Social Science, Vol. CXXXX, No. 229, November 1328, pp. 1-5. See also Park, R. E. Bases of Race Prejudice, Annals, Vo1. CXXXX, No. 239, November 1328, pp. 11-30. 
tudes a sort of conditioned reflex. Such clase or osate attitudes have thelr basis in the economio syatem where the Negro oooupled definite, low poeition.

It was ponelderation of suoh facts as there that 5

lod the writex to make en earlier atudy of the avallable 11terature of Negro eonomio oondltions of all typer from 1880 to 1989. It was found that there were three fairly we11-defined trends in the attitudes of the writers of this 11terature, whioh oorresponded somemat to three different periode between these years. of oourse, it ahould be olear1y stated that all of the trends were present in all three perioda, but that they were muob more dominant in one than In the others.

In the first perlod, which wa roughly from 1880 to 1300, there was muoh skeptiolem and general attitude of unoertainty as to the coonomio worth of the Negro. Proposala for wholesale oolonisation or deportation were somewhat oominon and ertously oonsldered by gome, Such att 1tudes are eal1y understood when one oonsiders the oond1tion of the Iogroes at that t1me. In the elghties the Negro, for the moet part, wa more of lebs controlled by the hangover of the lave coonowy. Many had migrated and had become vagranta. The unfortunate group, marked off Inescapably by defintte physigal oharacterlstios, beoane

4 Horth, C. C., 8oc1al Problems and Soclal Planning. MCG ruw-H111, 1932, pp. 359-300.

5 The Trends and Anelys1s of the L1terature of Amerlcan Tegro Eoonomlc Conditiong, 1880-1929, unpublished I. A. Thes18, Ohio Btate UnIversity, 1929. 


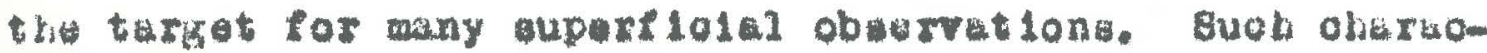

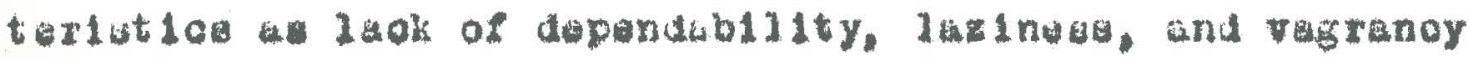

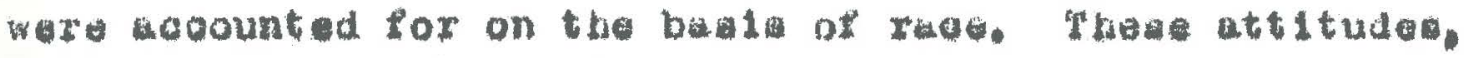

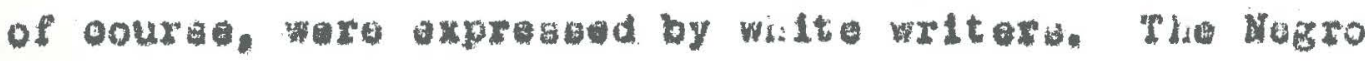

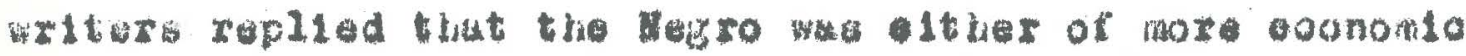

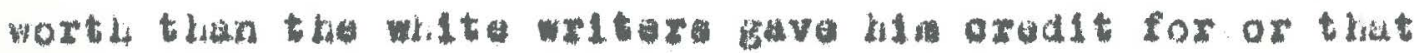
Wh inoompetenoy wag duo to his laok of opportunity.

The Geond tendenay was one of axhortation on the part of both logro and whiti witore, Tho dominant emphas

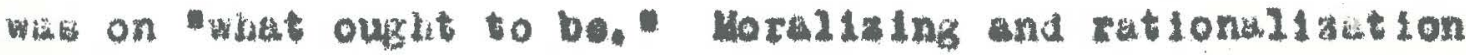

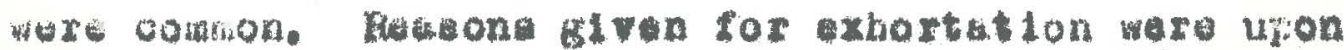
otL10al. raliglous, and moral grounds or any oomblnution of the thrae. Bome of the Horro writera refleoted the sume oonacrvative, combert orildish attitude of depondenco on the wht to to lond the wy whoh had 1 to origin in the alave b

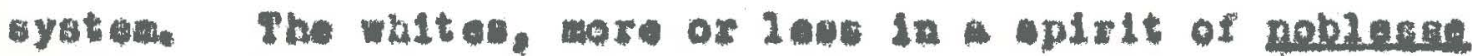

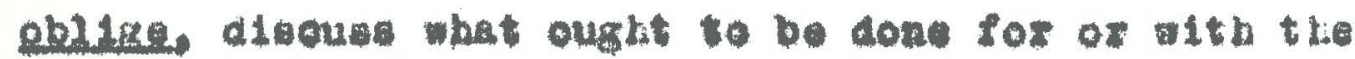
Nebroos.

A1though these two tendenoles Lavo beon prosent In all thrae of these perlode thoy hre been oonsplououaly

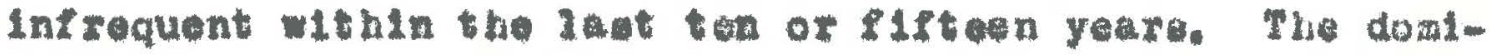
nant trand of 1 ate hus been rallanoe upon tuota ard upon fuot IInding. The volume devotod to the Hegro by the Annit: of the Anerion Aoterey of Polltiond ani Bocial Solanoe in November, 1938, is good axmpla, The papera ut reolal

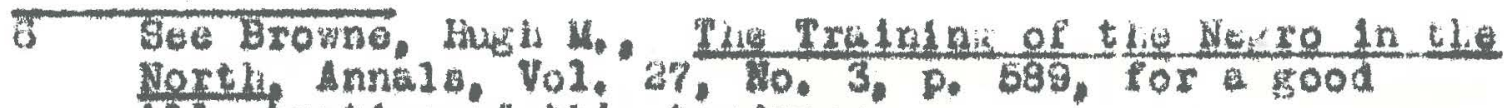
112utstation of this tondenay. 
and bi-raolal conferenoes oontaln little extortation and much stat1stioal material. The att1tude seoms to bes "Lat us first have the faota - then prooeed to the question of what ought to be done about themo"

The prosent study is an attempt to 1117 in some measure this demand for factual material. It is not to minimize the 1mportanoe of the problow of Boolal economy here involved to say that we shal deal almost xolusively with a desoription of the Negro's 11 e and place in the mining industry. The ohoos in oertain aspoots of our economlo iffe 18 perhaps nowhere more evident than in the cool 1ndustry. That ohaor will not be auperceded with order exoept through some wide and deliberate social planning 18 almost exionat16. The need for a disoussion of this aspect 18 most urgent. However, there is a oleavage at this point in the division of 1abor. The very breadth of soope of the present atudy 111 not admit of further inolusion.

As has been pointed out, moh I1terature has been published deallag with the Negro worker in various fielde. Comparatively 1ittle, however, of thls literature has been concerned with the vagro miner. The flrst writing in this field was an artiole by G. T. Surfeoe, of Yalo University, published in 1909. Professor Surface is not defintte as to just where he made his studies, but his titlo indioates that they wore in the "Central Appaluoliun Flold," It is

7 Surface, G. T., The Nerro Mine Laborer: Central Appalaolitan Coal Tleld Innals of the Amorican Academy of Polltical and Social solenoe, Vo1. 33, Maroh 1909, pp. 338-352. 
probable, however, that Weat Virginla mines were viaited by bim. Professor Surface, coming from the Yale soientifio sohool, was primarily interested in the efficienoy of the Negro, and it is this subjeot whoh his artiole disousses. With the establishment of the Bureau of Negro Velfare and Statiatios by the state of West Virginia in 19al, data ooncerning the Negro miner began to oome out in the reports publiohed overy two yeare. The Bureau investigated the Wegro's part in the strike of 1925 in northern West V1rginia. This report oocuples about 82 pages of the report. The 19a728 report givee a turee-page survey of the occupations of the Negro in the mining industry oovering about 6,721 miners, The 1929-30 report has not yet been publiohed.

The first detalled study of the Negro miner was by Gerald I. Allen, who wrote hls master's thesls on the Negro Coal Miner in the Plttoburgh Dietriot at the Univeraity of Pittoburgh in 1837. Mr. M1len's study was primariIy coonomio, dealing mostiy with the Megro during the strike In the PItteburgh areb, although he deroted a few of the ro pages to ouoh matter a eduoation, housing probleme, vice, the need for self-help, what the coal operator can do, eto. However, these subjects were dealt with necosarily in a very oursory manner, sometimes ilttie more than a paragraph or a fow sentenoes being deroted to each. In his thesis 8 Mr. Allen ays: "Probably Weot V1rginle presents the most B AIlen, G. E. The Hegro Coal Miner in the Pittaburib D1strict. p. 9. (Unpubilshed Magter/s theolg) 
Interesting fleld of study of the Negro ooal miner in the b1tualnous Industry,"

In 1930 two books, one by Charles 8. Johnwon and 10

the other by Lorenzo Greeneand Carter G. Woodson, appeared. These booke, however, from their general nature could devote only very linted apeoe to the Negro miner. Dr. Johnson gives only a brief atatement as to the loostion of Hagro rolner and IIttle.0160, 11 areon and woodion give a slghtly longer treatment, about ix pages, in thoir work. Their work 18 essontialiy a survey of the Begro in various eoonomio flelds, especially of the galns made in each industry in recont years. Some valuablo material is includod in these pages, but the writer feels that oertain etatements made in regard to the progress of the Megro in the mining industry of West Virginia are somewhat over-anguine and misleading.

The most valuablo work on the Megro miner lins bean done by Abram L, Harris, Dr, Harris, Professor of Economico at Howard Univeralty, was formerly professor of cononios at West VIrginia state colloge. It was he who investigated the Negro in the northern West Virginia etrike in 1925 for the Bureau of Negro Pelfere and Statiotion. His finding were publisked in the report of the Bureau for 1925-1926. Profesoor harrio publiahed in 2920 a short artiole in 9 The Hogro in Amerigan dv1lization, Holt, $193 \mathrm{U}$. 10 The Negro page Larner, Aasociated Publialers, 1930. 11 Pp. 48-50.

$12 \mathrm{Pp}, 259-234$.

13 8ee pp. 263-234.

14 Pp. 23-39. 
opportunity. His ohlef work, and the beat work yet to appear, was in the volume in whloh he collaborated with Sterling Spero, published in 1931. 18 Professor Harrio devotes two ohapters to the Negro miner, one on the Negro in the Coal unes and the other on the Negro and the United Mine Workere. 18 wh1le it 18 possible to point out one or two minor errors, of no conequenoe, Professor Harrls has done a splendid pieos of work in both chapters. The disoussion, however, as in the cese of Allen's and Surface's etudies, is moatly eoonomio. Dr. Herris gives the bulk of His space to a disouseion of the Negro in timer of $1 \mathrm{abor}$ trouble and etrike. So edequately, however, have these subjeots been covered that no obapters on these subjects are inoluded in the present otudy.

Although very 11 tt lo has aotually been written conoerning the Negro miner either in West Virginia or in the United States, his position in the mining industry of West V1rginia 1a ruther atriking. In 1830 thero wero 107,833 persons mployed in the mining industry of West Virginla of whom 23,533 were Negroee, whioh number. 1o much larger than that of any other atate. The estimated number in other states employing Negro miners in oonsiderable numbers in 1931 was Alabama, 17,000; Kentuoky, nearly

15 February number.

16 The Blaok Worker, Columbia Un1versity Press, 1931.

17 Pp. 306-245.

18 Pp. 352-382.

19 W. Va. Dept. of Minea, Annual Report, 1930. 
10,000; V1rginia and Tannessee, 3,500, and it is probable that tlis estimate is quite a liberal one. Although the Negroes form only 6,6 per cent of the population of the State they congtitute 21,8 per cont of the industry. Approximately three-fourths of all Negro males of elxteen yesrs of age and over were making thelr 21 ving in the mining industry a.s early as 192z, Coupled with this diaproportionate percentage in the industry is the interasting factor of equal payment for Negroes and wites in the aine jobo throughout the industry. Th1s comblnation, voinewhat unique, presents some intereating questions as to its offects, both upon the Negroes and the other eroups engaged in the Industry and upon the incuetzy it aele,

The purposes, then, of the present study are, in general, two-fold: Firat, to diseues the or $1 \mathrm{~g} 1 \mathrm{n}$, development, and present otatus of the Negro in the mining industry. Seoond, to desoribe in manner somewhet iml lar to The

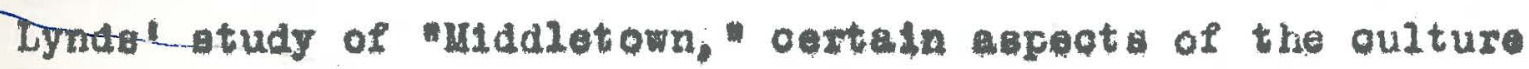
pattern of the enining flelds, partioularly with referonoe to the Negro and his part in 1t. The ohaptere will roughly follow in the order ouggested by these purposes, The flret w11l attempt to give those fats concerning the Nagro mining population whioh are basio to an underatanding of such metters as inter- and Intra-group relations, woolal deferentiation, etc., whloh follow.

20 Rochester, A. Labor and Coal. Internationil, 1931, pp. 86-87.

aI Va, Bureau of Nesro Weltare and stutiotlos, Report, 1921-1922, p. 13. 


\section{METHOD. -}

One of the elret probleme whioh had to be met was the docision as to just what bhould conetitute the sample for the fleld work. In order not to plok the sample upon a mere a priont balis or upon the grounde of oonventence it was thought best to go into the history of mining in West Virginla as well a the history of the Negro miner flrst. This history wa not to be found in one epot but was obtained from many different sources. The resources of the State Library of West Virginia at Charleston were first exploited. All avallable state, county, or seation histories were read. Feat Virginia has required an annual report from the ohlef mine ingpector ino the year 1883, all of which reportis were read. Otber original data in the form of flles of old newspapers and census reports were searohed. other material was galned by correspondenoe with state and national offlciale, as well as old settlers in more than one seotion of Weet Virginla. Personal interviews were had with many more.

The result of th1s investigation was that the writer deolded that the study would largely be restricted to the southern count1es, where the bulk of the Negro mining population is and has been since the beginning of the coal industry in the atate. While there is mininis carried on cormerolally in thirty-five of the fifty-five oounties of Weat Virginia, the oount1es of MoDowell, Raleigh, Fayette, 22 Seo chaptors II, III, and IV for a more fuIl disousalon. 
Logan, and Kanawha had in 1931 Negro mining population of 16,050 or 76.6 per oent of all the segro miners in the state. Further. we flad that these and the other southern countiea contain 85,4 per oent of all the legro miners in the state. No county outside the southern division of the state had a Negro mining population of 1,000 or more. The fire oountiea mentloned above had $6,092,3,832,3,050,2,212$, and 1,054 respootively, No other counties had a many as one thousand Negro miners, althougb Meroer County, another southern county, had 965. The lleld work wa accordingly reatrioted to the sout hern fleld. (see map)

MLners' sohedules were taken in MoDowell, Mercer, Raleigh, Fayette, Logan, and Kanawho oount1es. Theoe count1es represent four falfly well-defined ming fields, which differ In age, working oonditions, and various other respeots, The New River-Kanawha F192d 18 served for the most part by the Gheapeake and Ohio Ra1lroad and is looated largely on the Kanawha RIver and 1 to tributaries. This fleld inoludes Kanawha and Fayette count1es. The Logan Fleld is also served by a branoh of the Ohesapeak and Ohio Rallroad, but is wideIy separated Irow the New Rlver-Kanawha Fleld. Raleigh County is looated in two flelde, the Now River and the WindIng Gulf, but 18 largely in the 2atter. It is oerved by the Chesapeake and Ohio and the Virginian rallroads. The Pocaliontes Field includee MoDowell and Mercer counties and is served by the Norfolk and Weatern and the Virginian rallroads. (aee map for looation) 
These minere' sohedules represented miners in 38 different mining towng. In taking the obodules, howevor, two different polloles were followed. One was to study an entire town and interview every arallable miner. Since most of these operat 10as did not have more than 100 to 200 Negro winers, and most of them fower, this polloy was quite practlaable. The other was to take soliedules of a portion of the minerg and then to talk wh lo leadere, teachers, preachers. eto., about the population of that partiaular town. six kundred of these miner's aokedulea were taken.

Two sctedules were used the miner's sohedule already rantioned and an employer's sohedule. This latter soliedule was wostly an attitude soliedule. Host of the enployera were interviowed porsonally and certain of the questione were designed to ouggeot the material wanted ratler than to usk for it direotly. In thia way, many employer attitudes were learned although not recorded on the soledule. Forty-four employer's Bobedules ware taken expreasing opin10ns of these employers of more than 12,000 native whiteg, more than 9,000 Negroes, and more than 5,000 forelgnera, The schedules contain, thus, omployer opinton and certuin uspeots of employer policy conoerning approximately 43 per oent of the Negro minera of the state.

To get a more objeotive polat of view in regard to the effiolonoy of the Negro oonoldorable time was apent in the atudy of pay-zolls of three differont companieg in three different flelde. Since the Kegro and otber groups are paid 
at the sane wage sateg. It was assumed that the pay-rolla vould indloate omething of the relative earning power. regularity of work, eto. Since the miner works more or 1088 as he ploager, quitting when ho feele he has worked long enough. That 18,11 he deoldea to may off for a few day lic may do so. Mtis pay-rol1 study was one of the most diffloult parta of the study, as employere do not arrange them for purposen of resecrah, No separation cooording to reoe, nationality, or oooupation was made except the broad olass floution between "oompany work and mining." "oompany jobo" are thoge for whloh a delly, weekly, of monthly wage is pald. Mining Fefers to coal loading, ooal outting, oto., whlch 1s pald for by tonnage. The writer elmply had to apend tire In the offloes walting for an ldle moment of clerk or bookkeepers, who were moet helpful in thie work.

The taking of sohedules and pay-roll studies were only a part of the study, however, Fherever poaslble, the writer stayed in the mining towns, which fact gave him opportunity to talk with the miners of both raoes during the 1 r 1elsure hours a well as observe thelr eot1ritieg of varlous gorte. Where this was not poselble, boadquarters wore made at the nearest town. within a lew minutes drive of the mines. Interviews were held with preachers, teachers, leaders, many employers wooe sohedules were not taken, dootors, Becretarles and other offloere of the various operator's associat1ons, and other porsons from whom any information could be obtalned in regard to the situation in the ining fields. 
Where personal interview has not been posalble, oorrespondenoe over a perlod of two years has been oarried on with variou Individuala, Cooparation wa also obtained from several Negro publio sohool and oollege officlal through whom it wa posalble to get student pepers written upon subjeots guggeated by the writer. It would be imposible to enumerate individualiy all the souroes of information. While sohedules ware obtainod from miners in 38 different mining towns it is aafe to aly that the number of pleces viaited would number conslderably more than a hundred. Several thousand miles were oovered by automoblle wh1le other places were visited where it was posible to go only by railroad or on foot.

In mothodologtoal terme, several approaohes were ut1lized in thia study, The historioal method was employed, especialy in getting matorial for the firat few chapters. The statiatical method was used to a certain extent throughout. Certain inportant trends in the I1fe of the Negro miner could be stown in quantitative terms only. In the attempt to desoribe the Megro oulture in the mining fields a modification of the so-oalled ethnographioal method was used. In attacking a problem as broad as bas been the writer's in the present study, however, no method" is suffiolent unto 1tself. In approaohing eaoh speolf 10 pert of the study the writer has used those methods within the realin of his ability that he deemed would boet produoe the facts in that area. 


\section{CHAPRER II}

HISTORY OF MINING AND OF THE NEGRO

MINER IN WEST VIRGINIA

\section{HISTORY OF MTNING}

\section{Early History}

Just when coal was lirat discovered in those oounties of old Virginia whiob, after their separation from the mother state in 1862, oame to be known as West Virginia 10 a matter that w11 probsbly never be definitely known. OddIy enough, no student or acholar has as yet seen flt to wite any exhaustive treatise on the history of coal mining in West Virginia. Consequentiy, what data there are must be gathered ohlefly from brief and soattered sources. Although there were quite a number of early oounty hietories written, the authors, without exoeption, eeem to be muoh more interested In Indian battios than in the economio and Industrial phases of history. Th1 faot is not so surprialng when one remembers thet there was no mining on any oonalderable soale before the civil Far.

The first mention of coal in West Virginia of whtoh we have any reoord was made by John Peter Lalley who I This name wa not adopted, however, without a good bit of a strugg10. The name, Kanawhe, was proposed but was rejeoted. One delegate sald that several of his constituents thought it too hard a nare to spell. Another delegate wanted Virginia in the name beoause it reminded him of the Virgin Niary, (Callahan, J. H., Semi-Centennial History of W. VE. Charleston, 1913, p. 145.) 
found "a great plenty of coals" on a rlver whioh he named, in 1742, Coul River, The stream, which now flows through a developed coal fleld, still bears the name he gave it. Christopher Gist, In what is now Wood County, saw "a little branoh that was full of coal" in Maroh, 1751. George Washington mentions in his notes taken on hla trip to the Ohlo River that he saw "oole hill on fire." From other records this coal was supposed to ho located in what is now known as the village of Weat columbla.

These meager referenoes are about the limit of what was known about west VIrginla coal prior to the nineteenth century. Suoh altuation, however, is not 80 strange when one remembers that the Trans-AIlogheny frontier was puahed weatward only with the greateat diffloulty and that only toward the latter part of the century were many permanent settlements made. At the beginning of the nineteenth century about the only people using Weat Virginia

3 Lawall, C. E., Given, I. A. \& Kennedy, H. G., Mining Methods in $T_{\text {. Va }} \mathrm{W}, \mathrm{Va}$, Univ. Engineering Experiment sta. Regearoh Bulietin, No. 4, Morgantown, 1929, p. 3. Aloo Lafdley, W, S. History of Charleston and Kanawha Gounty, R1chmond-ArnoId, Oh1cago, 1911, p, 315.

4 IbId.

5 IOIO

6 Callahan, op, oit., pp, 14-47, It hould be noted, however, that coal was known on branches of the Monongahela in the northern part of what 18 now Hest VIrginla before 1800. In the eastern counties, moreover, coal saams had long been opened on both sldes of the Jemes River for everal inlles fifteen or twenty miles above Richmond. These pite were owned by different persons and vere worked to an extent equal to the domand. By 1789 coal wa exported to Philadelphila in considerable quantities. (Bi ahop, J. Leander, History of Manufactures in the U, S. Edward Young Co., PhI1., 1868, V01. I, p. 605, V01. II, p. 35). 
coals were the cross-roads blaoksmithe or some ploneer whose oabin happoned to be situated near an outorop. Hovever, after 1800 we have Inoreasing numbers of definite disooveries of the various ooal velns in different parts of the state. In 1800 , Phllip sull found the Plttsourgh sean on the Pooatalloo River in Putnam County, within thirty miles of the present eapltal of the Btate.

A Trenok plyaician and botantet, F. A. Mlobaux, sair a flve to olx foot stratur of coal between whoeling and west ulberty in ohlo County on July 16, 1803, whioh he aentlons in his wravele to the Festward of the Allegheny Mountains. It was not, however, until 1810 that the people of wheeling began to use ooal in their dwelling whloh was obtained from the flrst mine dis10

oovered near that olty. Conred Cotte, an experfenced miner, came to Wheeling from P1ttoburgh at that time for the purpose of maklng coel avallable to the residents of the 11

northern metropolis of Virginia. Cotta preaumably got hlo experience in the coal mines of Penneylrania.

It was not domest10 consumption, however, that gave the greatest impetus to the early developaent of the

7 Ib1d. P. 352.

8 Lawal \& others, op. oft., p. 3.

3 Ibid.

10 Ibld, p. 4, Although, as has been polnted out, (supra, p. ) coal had been used for a considerable period in the eatern oounties of VIrgints, and even exported to Philadelpula, we have little reason to belleve that, prior to 18J0, much of this coal was used for Industrial purposes; for, as Viotor Clark has indicated, "In the Elgtiteonth Century the only great resource of the atiantic alope that was not applied to Industry was coal." (History of Manufeotures. 1790-

11 I01d. 
cosl industry. The two most important leotors in the early days were the beginnings of the salt Industry and of ateam navigation on the Ohlo, Kanawha, and Monongahela rivers.

The lirst alt furnao on the Great Kanawha River In Kanawhe Oounty was bulit in 2797 near the present site 13 of Charleston.

Ten yesre later the method of manufacture was Improved by the Puffner brothere and soon the "Kanawha Balines" became widely known. The manufaoture of sult 13 developed rapldiy. In 1814,600,000 buskels were produoed. It was in conneotion with the aelt industry that the ood Induatry of the Great Kanawhe Valley was atarted. John P. Turner, How Torker, disoovered coal there and opened a mine in 1817 for the purpose of supplying the 15

Kanawha Sulines. The salt industry provided work for many people in the furnaces themsolvea. othere bullt keel boate and distrlbuted the nufsotured produat along the Ohio 16

Fiver und its tributarlea, Evidently alt was not the only comnodity tuken down the rivere, for a olnolnnat 1 mer12. Callahan, og o1t., p. 51.

13 Joseph Ruffner carn to the Kanawha Valley in 1734 and was inaking galt by 1807. (Amerloan Journal of Solence end Arts, Vol. 29, January 1836, p. 117)

14 Callahan, op, c1t., p. 51.

15 Lewall \& others, og, oft., $p, 4$; Laldley, og, oft. c. 315. Col. David Ruffner first used coal in 1819. He make it clear that coal was not uaed unt1l the avallable oupplles of wood were exhauted. After col. Ruffner used coal his example was promptly followad by others. (Amerioan Journal of Solence and Arta, Vol. 39, January 1830, p. 119)

16 Callahan, ope olt. p. 51. Cinolnnet in 1820 lmported 46,000 barrels of salt from the Conemaurh works in Pennsylvania and from those upon the Kenhawa (Kanawhe), in Virginia," (Drake, B., and Menefleld, E. D., Clnolnnat1 in 1823. Morgan, Dodge, and F1sher, Cinolnnati, 1827, pp. 76-77) 
chant estimated that in 1818116,000 bushels of ooal were used that year between the nouth of the Kanawha and the Falls of the ohio.

$$
\text { The Tost Virginia, or, rather, Virginla, galt }
$$
industry continued to grow wh rapid strides until the Kanewha Valley boame what was perhapa the ollef ealt produoIng area in the country. Profeasor william Barton Pogers, of the University of Virginia, was sent by the state to survey the land over the Alfoghenies. He visited all the mines in what 10 now Weat. V1rginfa botween 1836 and 1840 . He stated in bls report in 1840, his ceoond, that there were ninoty furnaces along the Kanawhe River which ado ennually a milison bushels of alt and consumed five milion bushels or two hundred thoumand tons of coal, sine hundred and ninety-11ve miners and workmen were employed and $1,301,855$ was invested in the industry. Thls growth continued unt 1 about 1853, From then unt11 1857 the salt industry of the Kanawh Valley wag Impoverished by the development of the Ohlo River Salt Company as well as by oertain developmenta 17 Lawall \& others, on cit. p. 4. At the close of the War of 1813 the ofty of Cinoinnat 1 had glass works, four cotton mills, a woolen faotory, white lead works, flour and lumber mila, furnt ture ohops, and a barrel factory usine putent meolinery. Several of these establishraents were operated by stearn and "though at filst not necessarily ucing coal, moon catie to depend upon that fued, which. wa cheukly brough down the river." (clark, op. olt., p. 346)

18 Laldey, ofe glt, $\mathrm{p}, 315$.

19 Lawal1 \& others, op. Elt., p. 4. 
In Mason County, Virginis, and Heigs County, Oblo. 20 The number of furnoces on the Kanawhe declined rapidiy after that time. However, the demand for coal did not suffer as great a deoline due to the mining of cannel coal and the production of oannel coal oll wioh will be dealt with 31 later,

The other arly impetus given to the coel industry was the developinent of river travel and the consequent use of coal by the boats on the rivara. The importance of river travel was early reoognized by the Isw-makers of V1rginia. Ferrieg began to appear as early as 1776, were firmly estab$116 \mathrm{hed}$ by 1785, and, by 1803, were found over the onto and the Little Kanawhe at Parkersburg, at the mouth of Flaling Creek and Guyandott River (which now flows through Hunt ington), as well as over the Great Kanawba at the mouth of Coal 20 Callahan, op. o1t., p. 83. Charlea Clot, in a book published in 1859, Indicates the change of market when he says: "Until within a short period, the Kanawha salines were our prinolpal souroes of Bupply, but the best quality and largest quantity are now dertved from our own state - - alt being extensively made in and adjucent to Pomeroy, Melga county." (cinelnnat1 in 1859. Cincinnat 1, 1859, p. 363.) The production of salt, however, varled a great deal from year to year. The two peak years in the Industry were 1846 and 1850 when $3,344,786$ and $3,143,100$ bush lo were produced reapeotively. The production from 1853 to 1857 was as follows:

$$
\begin{aligned}
& \text { Yoar } \\
& \hline 1853 \\
& 1854 \\
& 1855 \\
& 1856 \\
& 1857
\end{aligned}
$$$$
\begin{gathered}
\text { Ne. of bushe } 18 \\
\hline 3,429,910 \\
3,333,863 \\
1,483,548 \\
1,264,049 \\
1,236,749
\end{gathered}
$$

The production thereafter never reaohed 2,001, 000 bushels and had deolined to 967,465 buakeis in 1875. (Laldloy, op. o1t., pp. 138-139) 
22

River. It was not merely the establiahment of ferries, however, that made travel faster and more easy at this time. Aa early a 1785, when the Potomac was oleared of rook at Harper's Ferry, the atate took aotion to provide for river transportation. The Leglelature pased the first aot prov1ding for the extengion of navigation of the Monongarela and Hest Fork Itvera in 1793 . Suoh a project was to mak It posalbie to travel in osnoes or flat boats.

The Invention of the steamboat was of the greatest Importanoe for the coal Industry. In 2784, James Rumbey. wio was employed by the Potoma Company (which inoluded George Wabington among it memberal to improve the navigam tion of the Potomeo, wa eucoesalul in private at eamboat experiment at Shepherdstom. In 1786, however, at the aame place he was able to propel his boat by atean agelnat the ourrent at the rate of about four milee per hour, 25 This experiment thus antedated the simliar one of Robert Fulton on the Hudson over twenty years. In 1809. N10holas Roosevelt came to Ohlo as an agent of Robert Fulton and Chanoe110r LIVIngetion of Hew, to Inveatigate the question of possible navigation on the western rivers. Finding the onlo River open and alao some coal deposits, he atored some coal aboard and burned 1 in the Hew Orleans, the flrst boat 26 weet of the Allegheny lountalns, trial trips belng held 23 IbId. P. 53.

23 TbId.

34 IbId.

35 IbId. p. 60.

26 Drake \& Manofleld, ope elt., p. 73; Lawall \& others, op. oft., p. 4. 
in 1811-13.

27

The effeots of Mr. Roosevelt "a experiment were not long in boaring frult, for, in 1819, the steamer Robert Thompson oame up the Kanawha RIver ae far as Rod House 28

Shoals. Thia partioular boat wan not able to run the current at thie point, but the next year the "Andrew Donnally," a steamer bullt for Donnally and Noyes, salt makers, made the first suocessful mun to Charleston and thus Inaugurated an era of ateam nevigation between

37 Callahan, op o1t., p. 53. It ohould not be assumed, however, that steamboat and versally befan to use coal Immediately. Doubtless some of the boats on tive upper Ohio did oo but those on the M1s818sippl and lower Ohio, as well as those on the Kanawha, certalnly did not do oo very soon. An Engl1sh traveler from New Orleans to Clnolnnati on the Steamer George Washington says: "...wood belng the only fuel made use of, they (river stearers) are conbequent ly not incommoded by the effeots of the dense snoke so annoyine in some of our at eam ressels." (Bullock, M., Skatch of a Journey Through the Western States of North America 1 rom New orleans, by the Miselosigpl, oblo, city of Clnolnnat and Fal1e of Niggara, to Naw York, in 1827. "London, 1827, p. x11.) By 1841, howerer, the use of conl by ateankoats wa extensive enough to Induce a Cinclnnat 1 coal dealer to advertize "Steamboat supplied on the shortest not1ce." (Advert1zement in the appendix of C1st, Charles, Ginolnnaty in 1841, published by the author, Cinolnnat 1, 1841)

28 Hale, John P., H1story of the Great Kanawha Valley, 1891, Vol. I, p. 199. 
29

Charleston and polnt of the Oblo. Stimulated by the inablilty of the "Robert Thompson" to arcend the shoala it Red House the state direoted the James River and Kanawhe Company to improve the navigation of the river so that a olunnel of three feet of water could be had at all times during the year from the mouth of the river ut Point Pleasant (two miles above Gallipolia, Ohlo) and Kanawbia Falla, alstange of about a hundred miles. Paokets soon began to run from Charleaton to Gallipolis onoe a woek. later three times week, and, finalyy, in 2845, dally. 30 Tila service continued unt1 the Civil War.

phis development of the river aervice not only provlded a demand for oos on 1 t own behalf; but provlded also a means of ohlpment to weet the demands of other places and other 1ndustries, In 1819, David Bradshaw opened a mine on the Ohio alde of the river acrose from Mason C1ty, in Mason County. He mined 1,200 bushels of doal that year. 31

29 Ibld. Some 1 des of the growth of the river ateam travel and ehipping la obtained from the increasing number of boats on the Ohlo alno 1a11. The following table will show the number bulit eaoh nucossive year?

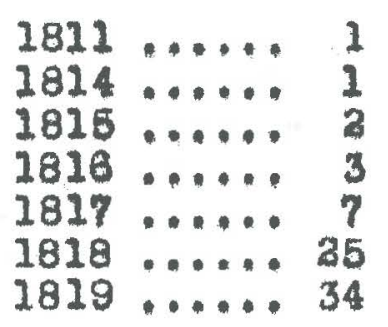

Total 215

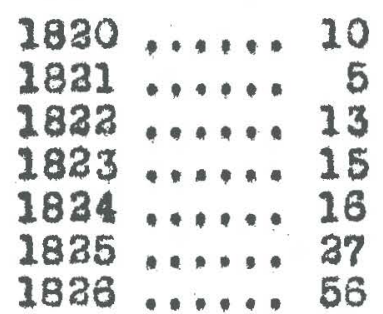

$1826 \ldots \ldots 56$

(Drake \& Mansfield, epe elt, p. 73) of these, only 125 remained in servioe by 3838 . Ninety had ceased to operate - 28 sunk on anaga; 6 burned; 1 gtove by 100 I sunk by another boat; and the remainder were worn out. (Ibld., pp. 73-4)

30 Ibid, P. 54.

31 Lawali \& others, epe elt., p. 5. 
In 1932, Samuel Pomeroy, the founder of Pomeroy, put a thousand bushels of coal from the mine mentioned above on board a New Orleans boat to be ahlpped from there to Boston. However, the boat ank in the Ohto and this Iong-distanoe enterpriae wan never renewed. George Birthlat le began ehipping down the Ohlo from alne between C11fton and West Columbia in Mason County the sam year.

By 1840 , mining operat 1ons were open in eight of the Virginia oounties whioh later beame part of West Virginia, eooording to the census of that year. 33 Although no differentiation 18 made botween col mining and other forms, It is to be assumed that most of those engaged in bining were ood minere. Acoording to the census, Kanawha County had a hundred and efxty persons engaged in inining; Mason County had five; Monongal1a County hed one hundred

32 Ibld. Some of this coal doubtless was used in the fugt developing iron industry growing up in Liwrenoe County, Oli10, and Greenup County, Kentucky on both sldes of the Ohio River about this time, Four or 11ve of the iron furnaces in Greenup county used 0081 in 1837. (Clark, ope ait. p. 33..) Wheling mines were aloo supplying the manufaoturing plants as well as domeatic trade in 1836. (American Journal of Sal ence and Arta, Vol. 29, January $1838, p .80$.) The manufaoturing industry was, no doubt, the chief aource of demand for fuel along the lower ohio rather than domestio oonsumption, as coal had not yet oome into its own. Drake and Mansfield gay of Cinoinnati in 1826: Wood is the ohief artiole of futi; which is boated down the ohio and Licklng rivers, or brought in wagons from the tdjacent country. Coal, from the mines above, is brourht to the oity in oonslderable quantities, but is not yet extensively used, exoept in the manufacturing ostabil shmenta." (00. clt., p. 32) In 1836 Cincinnat1 used 200,020 bushels of 0081 for whioh it paid $\$ 20,000$.

33 Census of 1840, Vol, I, pp, 213-214. (No census prlor to this date giver any data on coal inining in Virginla.) 
and twenty-elght; Ohio County (Including whoeling) had elghty-five; Brooke County (adjoining Ohlo) had twelve; Hardy County had three; Jefferson County had forty-two; and Marshall county had four. ${ }^{34}$ In another volume of the oensus reports of 1840 , however, sorne eeemingly contradia tory flgures are given. The elgures on coal wining in the weatern seotion, of V1rginia are as follows:

34 U, S, Consug, 1840, Vol. I, (enumeration) pt. 213-14. AIthough Kanawha is by far the greatest producer of coal in 1840 it $1 \mathrm{~g}$ very 1 ikely that its produots were consured mostly by be galt furnaos in the stute and leas of its tonnage ohipped to points out alds the state than was the oase of onio County. A coal dealer in Cinoinnat i advertized in 1841: Keeps constantly on hand Youghlograny, Brownsville, and Wheellns, coal of the best quelity," (Cist, on, clt.)

35 Compilied from the Ceneus Compendium, $00.151-17 \%$. It is interesting to note here that, although coal mining in the eastarn countiea of Virginia had been conducted for a long perlod, the western sountles produoed over three times as moh tonnage as the eastern oountios in 1840. This is eapooially interesting insamuoh as the eastern "sea coal" as distributed along the eastern coast from Baltimore to Boston and was, for many yeare, the olife source of home consumption (ciark, on eit." f. 333). As early as 1820 the annual output was supposed to kave approached 50,000 tons. The peak of production in the eastern counties, however, vis reached early, the chesterfield distri ot reached its meximum productivity about 1833 (Blohop, ofe oft.

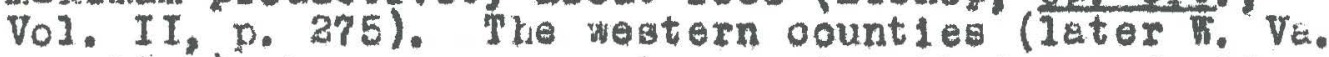
counties), however, were inoreasing thels produotion yeur by year. The superiority of the western coal countios is indicated by the fact that the eactern oountios (Cheaterfield, Gooohland, Henrico, and Powhatan) with lmost ive times as much capltal invested, and 1th 185 more men employed, produced lees than one third nuch cosl in 1840. (Census Compendium) 
THELE 1. AMOUMP OT COAL PRODUCTION, MTLBHAR OF' MEN DOARLOYRD, AND CAPITAL INVESTED IN WESTERA VI BGI HIA ET COMTISS, 1840

\begin{tabular}{|c|c|c|c|}
\hline County & $\begin{array}{c}\text { 10. of Bushol: } \\
\text { Eroduced }\end{array}$ & $\begin{array}{l}\text { No. Yon } \\
\text { Dmployed }\end{array}$ & $\begin{array}{l}\text { Capltal } \\
\text { Inrented }\end{array}$ \\
\hline $\begin{array}{l}\text { Brooke } \\
\text { Harri son }\end{array}$ & $\begin{array}{l}194.574 \\
200,940\end{array}$ & 33 & $\$ 3.900$ \\
\hline Kanawha & $6.325,000$ & 209 & 206.105 \\
\hline Logan & 2,000 & & \\
\hline $\begin{array}{l}\text { Monongal1a } \\
\text { On10 }\end{array}$ & $\begin{array}{r}167,200 \\
1.178 .000\end{array}$ & $\begin{array}{l}73 \\
85\end{array}$ & 27.500 \\
\hline $\begin{array}{l}\text { Chlo } \\
\text { Preiton } \\
\text { sylor }\end{array}$ & $\begin{array}{l}3,150 \\
2,500\end{array}$ & $\begin{array}{l}4 \\
1\end{array}$ & 1,150 \\
\hline rotal & $8,073,364$ & 405 & $\$ 228,655$ \\
\hline
\end{tabular}

If we add to these the number of men employed in other types of mining as given in the census aompendium of 1840 we may see the extent of the dispartity. The flgurea for the men employed in certain other induetries, but olassifled under mining, are contalned in Table 3. 37

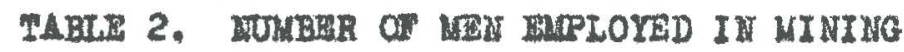

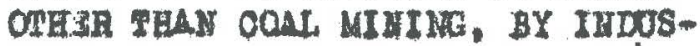
TRY AMD OCONTY IR VIDEIUTA, 1840

\begin{tabular}{c} 
County Iron salt $\begin{array}{c}\text { Granite. } \\
\text { Marbie, } \\
\text { etc. }\end{array}$ \\
\hline
\end{tabular}

Bericeley

Braxton

Hardy

Jeffercon

Kanawha

Monongalla

Morgan

Clo

potal

2

30

80

65

115

\section{8}

421

12

64

36 Pp. 166-167.

37 Ib1d. pp. 106-167. 
Thus, we see that in the volume on enumeration the census gives the flgure of all persons engaged in mining in Kanmita County as only 165 and in the compendium the figure on coal mining alone $1 \mathrm{~s}$ 309. If to this 1 igure 18 added the 421 persons engaged in the galt industry, which is oonaidored under the head of mining by the census, the total persong in all kinds of mining in Kanawha County in 1840 was not 165, as recorded in the firat volume, but 430. There le apparentiy no explanation for thlo aeming error in the census tables a it is to be asumed that both volumes were oomplied from the same soliedules.

Not only does there appear a diaparity between the census figures themselves, but there is also considerable difference between them and the flgures glven by Profeasor Rogers in $h_{1}$ report of 1840 , quoted before. 38 His figures on the combined salt and ooal Industries in Kanawha County. were a total of 395 workmen, against a bare 430 by the oensua. The question would logloally arlas as to whother the figures of Profersor Rogers or the onsus are the more reliable. Although the writer was unable to read Professor Rogers' report in the original and, of oourge, does not know his method of colleoting his flgures, he prefers to accept them in preference to the consus figures unless the censur teohnlque of 1840 was much more effeotive than that of 1920 in the mining fields, Conoerning the taking of oensus data in the minlng flelde, the Bureau of Negro Labor 38 Supra, p. 
and Statiat10a has the following to an:

We wre basing all of the flgures relatIng to population upon the U. S. Censur reporta, beoulse they are offlolal, but we know them to be glaringly insocurate as regerds Negroos in coal mining oampe. For examples on al $x$ coal minlng operat Iong in MoDowell Dounty a representative of the McDovell T1me, a Negro newspaper, ohecked the Nezro population behind the oensus enumerator in 1920 and found 148 Negro men who were not enuinerated. This la acoounted for by reason of the faot that a large.number of Negroes working in and sbout the mines batch" in shant1es, that 18, in mining parlanoe, one or more men IIve in company-owned houses and do thelr own cooklng. When they leave the house to work. It is locked and no one is there unt 11 they return from work. The oensue enumerator passed wille they were at work and did not return. It 18 estimated by the MoDowell IImes, based ucon 1ta investigation in MoDowell County elone, that approximately 2,000 Negroes were not eaumerated, and this condition prevalled throughout the coal mining of lon of the state.

There 1s 11ttle reason to belleve that the oensus reports of 1840 were teken with more care then was the one of 1920. Suffloe it to say that, whother one aooepts the flgures of the census or those of Professor Rogers, it is olear that by 1840 some degree of development had taken place in the coal industry, espeolally in regard to domestio consumption -1ther by the steambosts, by the salt Industry, and, to some extent, by industry outalde the state.

In 1841 there oocurred the discovery of a product that was later destined practlcally to eliminate coal from

39 State of West Virginia. Burasu of Negro Welfare and Statist1ca, Recort, 1921-22, $\mathrm{f}$. 12. Kathleen Bruce says: "Tl.e returns of the census of 1840 cannot be aocented as exact, but ther at least reveal the general eoonomio trend, " V1rginia Iron Manufecture in the slave Era, Contury, 1931, p, 83) 
domeat 10 une in cortila part of the Kanawha valiey. W1111am Tompkins "st ruck" natural gas noar Malden and used 1t for bolling alt. He wa the first person in Amerioa to utilize natural gas for manufaoturing purposes. However, there 18 no eyidenoe that his discovery had any marked effect on the ooneumption of ooal at that time. In 1848 Sutton Matthews disoovered the lrst cannel coal known in the Kanawha valloy, porhaps tho flrat in Amerloa, on Falling Rock oreek, a tributary of the Elk R1ver near Charleaton. This discovery was to have far more immediate effeot on the industry of the Kanawha Valley than was the disoovery of natural gas. The mining of cannel coel rove in a very few yeara to take the plaoe of Balt mining. whloh was soon to 42

be a "vantshing induatry." The reports of the Kanawha coal deposits by Profoseor Rogere attracted much forelgn captal, whloh began to flow into the oannel coal industry in the later forties. In addition, another tributary of the Kanawha in Kanawha County, Coal River, wa inade navlguble. Work began about 1847-48 by W, Mayton and hlo residence engineer, Mr. MoCloud, on a yotem of looks and dains which were to be used unt 11 the civil War began.

Development oontinued in other parta of the atate as well as Kanawhe between 1840 and 1850. In 1843 the Baltimore and Ohio Rallroad was completed to Piedmont, in 40 Hele, John P., op olt., Vol. I, p. 167. 41 Ibld., p. 167.

48 Callahan, op, olt. p. 87.

43 Capehart, Stephen P. Coalsmouth, W. Va. Historical Magazine, Vol, 5, No. 1, January 1905, p. 46. 
Mineral County. Shlprants at onoe began to be made to Baltimore and Philadolphla, whlok faot stimulatca greatly 44

the mining operatione in the eastern Pantandle. Four yeurs later the first mines were opened at Mest Colunbla 45

in ilas on Oounty on the Ohlo fiver. Small shipinents by 48

river from Mason County ware started in 1847.

Although the census of 1850 showed only a total

of 1,044 persons engaged in ogal mining, of whioh only 348 47

were niners, the decade which followed that ooneus wae one or rather rapid development in the coal industry. In 1852 Mas dis City was planned by coal operators and in 1853 and 1354 Ohio River operations were opened at clifton and 48

liartford clty reapootively, all in Mason Gounty. Corporetions were formed as early an 1854 for the dovelopinent of the western Virginla coal flelda and by 1860 twenty-ilve 44 Lawall \& othera, ore elt.; p. 5. 45 Ibid.

46 Callahan, op, clt., p. 352.

47 Census of 1850, p. 272. Again it is quest lonable vituather the oensus $f$ igures are entirely rellable. Bruoe saye: that in 1841 nearly a thousand men ware at work in the Hiolmond ooal flelda...." (20, ctt.. p. 95.) Certalnly if there were nearly thousand men in the Rlobmond field alone it would stand to reason that there wore more than 1,044 in the ent1re state, which would inolude all of the wostern counties.

48 Lawall \& othera, ope olt, p. 5. Callehan, 20, alt. p. 83, 
of these oompanies had organized.

Several of these com panies had organized botween 1849 and 1856 for the purpose of developing the cannel coal resources on the Kanawha, 48

EIk, and Cosl Rivers.

Hale polnt out that the firat

shipments of coal on a commerolal ocale commenoed in 2865 50

and 1856. In 1857 the Kanewhe Cannel Coel Mining and

Lanufacturing Company ereoted a faotory in Charlegton for the purpoes of making oannel a0al o12. 51 some years later another of these factories was built about thisty miles ferther up the Kanawhe Valley at Cennelton. In 1858,

48 Ibld., p. 5. The Point Pleasant (Mason County) Independent Republican (Iøsue of october 4, 1855) givea an account of a coal convention held at Charleston on sept. 15, 1855. The follow Ing companies vero represented, the names in some instances identify ing the location of their developmenta: The paint Creek Co., Great Western Mining and Mfg. Co., Forks of Coal Co., Mt. Carbon Coal Co., Wyoming Coal Co., Mithoomah Gannel Coal Co., Old Dominion Coal Co., Kanawha Coal Co. Coal Fiver and Kanawha Mining and Mfg. Co., Cannel Coal Co. of Coal River, Coal River Navigation Co., Ploneer Coul Co.' Virginia Cannel Coal Co. of Peytona, Coal RIver, Iron HIII Coal Co., Kanawha Salt Co.

43 Callahan, ope elt. D. 87

50 Fiale, J. P., OP, Olt., p. 187. As has buen polnted out above (note 34, p. 37), It is I1kely that Kanawia corl was not so well known out gide ths state ds was the Ohio (Wheoling) and Penneylvania ooals. Dr. Drake in his "Narrative and Stitiatical Vlew of Cincinnat 1 in 1815 points out that ooal was brought from P1ttoburgh by that dute (quotod in Bullook, op, o1t., appendi $x$ ). In 1841 Brownsv1lle and Youghlogany coals, both Penneylvania ooals, were advertized with theoling coal. (100. olt., p. 8) Even in the year 1858 the Pennsylvanis coals cont inued to constitute an important part of the coal on the cincinnati markets, there being sxtymelght coal yards there in that year. (C1st, C. Cincinnat I In 1859, published by the author, Cinolnnati, 1859, p. 355.)

51 Callahan, J. M. op. o1t. p. 87.

52 Interview with the writer's mother, whode father wa auperintendent at this operation ehortiy after the C.1v11 War. 
the Corwin Cannel Coel Company ereoted another factory at u112 Creek, seven miles up the RIk River from Charleston. 53 Callahan point out the faot that the varlous companies advert1zed for alf 028s8e日 of laborers in 1858 und that they were in a prosperous oondition by 1860 . It is an interesting question here as to whether this labor policy was in any way influenoed by publio sentiment at tria tire. On Ootober 10, 1859, the editor of the Kanawha Valley Star, published at Charleaton, wrote sorawhat at length editorlally expressing grave oonoern to to what the prevalling polloy (at that time) of having outside capital develop the industry and then renting them Negro slaves to be used in these fuotories meant for the future prosperity of the 56 valloy.

In any uvent, the number of cannel coal oll fuctories increased. The onsus of 1880 show that they appeared not only in Kanawha County but in every ooal field of the state, with the poselble exoeption of the eastern Panhandle and on the Oh10 RIver. Kanawha County bad four coal oll establishmente which employed a bundred and twenty57 one hande; Fayette County, although it had no coal operatlons, had one for the manufacture of coal ofl, employing 58 40 hands, just over the IIne from Kanawha County; Marion 53 Callahan, J. M, epe o1t, p, 87. 54 Ibid.

55 Kanawhe Valley Star. Charleston, October 10, 1859, 56 Census of 1860, Volume on Manufactures, pp. 607-638, 57 Ib1d, p. 619 . 58 Ib1d, p. 607. 
County, in the extreme northern part of the atate, had ono factory whilo eaployed ton hands.

The oensur of 1860 ghowed that there had been wore gain in tho number of miners over the figures of 1850 , ulthough the growth is not as otriking as might have been suspectud whon one oonsiders how many new enterprliseo were begun in the decade from 1850 to 1880 . The total number of miners in Virginia is atown to be 2,112. This figure Indicater a gein of aixty-eight, However, the number of operations in the different oounties in western Virglaia does not indioate that they have all the miners by any means. It should be colnted out here, I think, that there is very iltile unlformity in the uses of cortain torus in the different oensuses. That faot may account for some of the apparent fallures to how all the data. One ounsu refer to "Minera" while another may refer to "Porsone in Mining." One of these may be a more $11 \mathrm{mited}$ term than the other. I know of no way of determining just what the terme Include. However, Table 3 bhows sorothing of the distribution of mining hande in the oounties of weatern Vireinia. 59 Ib10, p. 621. 


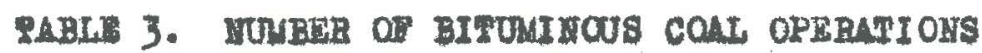
AMD NULBHA OI HANDS BMPLOTED IN WESPER VI RAIMIA BY COCRTY, 1860

\begin{tabular}{lcc}
\hline County & $\begin{array}{c}\text { Mramber of } \\
\text { Operation }\end{array}$ & $\begin{array}{c}\text { Mamber of } \\
\text { Hande }\end{array}$ \\
\hline Brooke & 2 & 50 \\
Zangutio & 3 & 43 \\
Marlon & 1 & 20 \\
Mason & 2 & 280 \\
Oh10 & 3 & 51 \\
Putnam & 1 & 2 \\
\hline Total & 11 & 446 \\
\hline
\end{tabular}

Here, agaln, we must conolude elther that the historian is indocurate or the consus incomplete. If we compare the llat of counties in which there were coal optritions in 60

leto with the liat above (Table 3) we will notioe that oome of the countias naned a having mining operations in 1840 do not have thom in 1860. Doos this fact woan that thowe dount 1es oeidsea that developmental I think not. As whe pointed out above, the completion of the Baltinore and Ohto Rallroad in 1843 opened up the eatern Paniantlo Ileld, Yet no Eastorn Pankandle oounty ta Inoluded in the l13t for 1860. Preaton County, wh1ch had an Investrent of over a thousand dollars in 1840 is also not inoluded. Since these countios are now anong those important in the coal industry, I do not conalder it likely that operations ware discont tnued after onoe atarting, eapoolally when wo BO Supra, (Tablo 1), p. 28. 61 Supra, p. 6a Supra, p. 
have historioal evidence to the contrary. Further than those seenings omiasions alrasdy mentioned, Hale polnts out that in the year 1855-1853 there were large shlpment of coal froia Cannelton and from Elk River, In addition, he say that abipment of oplint coad from Field's Creak, in Kanciwkia Oounty, Pálnt Creak, in Kanawha County, and Armatronk creak, in Fayette County $3_{4}$ ware begun. 03 Ocalburgh Minas were oponed also in 1359. Fayetto County 10 not 11stad as a cosl-productno county in the oonous of 18 iso. The and other evidenos, oem to Indioate that porhapa the historioal writera are to be trueted here rather than the census reportis.

The ere of prosperity and rapld development wa. retarded or postponed by the war. In op1te of this fact the produotion of coal inoreased aomewhat every year of the war. For Inatance, the produotion of ooal in 1863 was 444,648 short tone 454,888 in 1864 ; and 487,397 in 1865 . At the olose of the war, however, there was a pronounced awakening of interest in the development of the resouroes of llest V1rginia. A pamphlet pub11shed in 1305 tells of this opportunity for outalde oapital. It mentiona the valuable mer in Msion County and announces that Mr, Alfred Edwarda of New York has recently commenced to 83 Hale, J. P., ope elt. Vol. I, D. 199. 64 Flrst Annual Report of the Inspeotor of Mines, 3tate of 1 . Va. 1883, p. 30 .

65 White, I. C., speolal artiole in dallakan, ope olt., p. 390 . 
develop coal property on Cabin Creek" in Kanawha County. At the same time the "Minefred Coal Company, on Field'a Creok nearby, are now over two hundred yards into the main h111." In 1865 the Aver111 Coal Company began operations at the mouth of the Pocatallco River at 1 ts confluenoe with 68

the Kanswha, while not far away the mine of the larmet, Suth Coal and Mining Company was opened the same year in Putnam County, The followlag year the Peytona Cannel

Coal Company prepared to open 1te operation on Coal RIver 70

In Boone County. In 1869 operation also began in Weyne County up the Big Sandy VeIley, the 11rst openings in that 71

valley, Two mines were opon and operating in Monongalia County by 1870. 73

Aa a reault of thi renewed development the produetion of ooal ateadily increased every year of the decade to 1870 with one exception. The production from 1865 to 1870 was as follows: 73

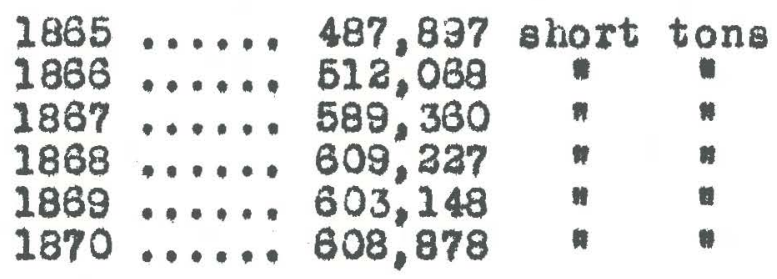

66 The OII-Dorado of Weat Viritnia," American Hewo Co., New York, 1865, p. 2.

67 I019.

68 Lawall \& others, op, oft, p. 5.

69 W. Va. State Depurtment of unes, Repont of 1895, p. 28.

70 Callahan, J. U., oge olt., p. 353.

71 Ib1d.

72 Lawall \& others, op. aft. p. 5.

73 White, I. C.. The Mineral Resources of W. Va., Speoial artiole in Callahan, ope olt. p. 390. 
The tonnage produced in 1870 wa distributed over the counties mentioned in Table 4.

$$
74
$$

TABLE 4. MURBER ON BITUMIYOUS COAL OPERATIONS

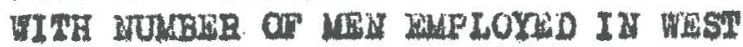
VI BOIMIA BY COUNHIHS, 1870

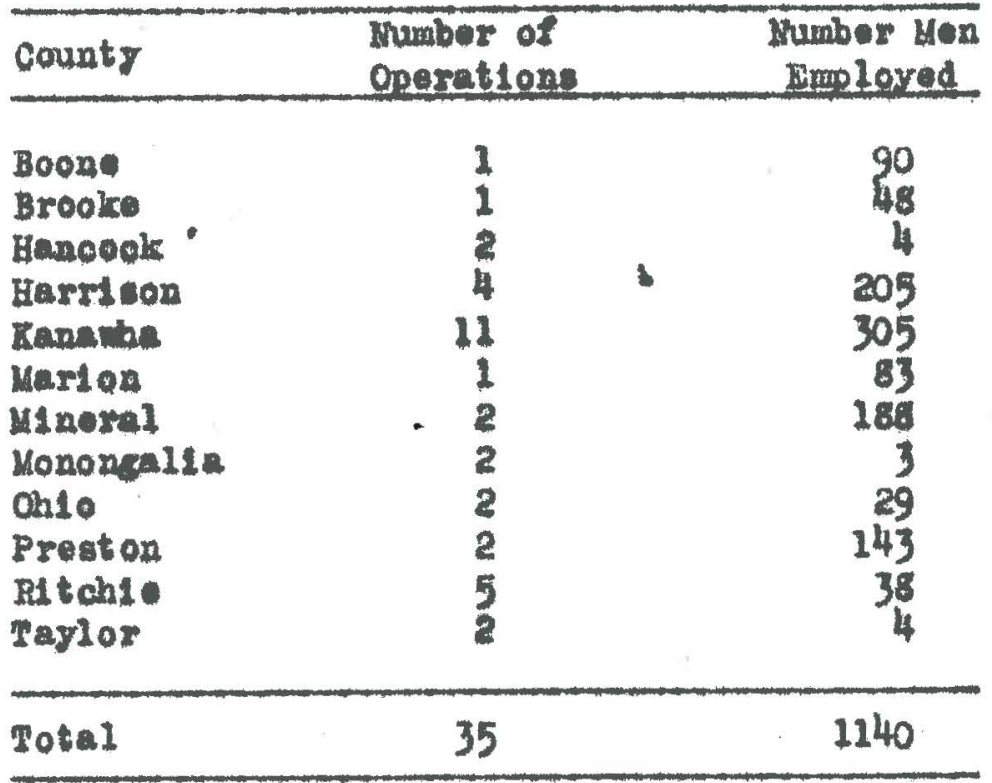

Even a cursory glance at the table above will Indioate somethling of the rapld devolopment both in the number of operatione and in the number of men employed. The gain in number of operations is shown by the faot that there were three and one half times the number in 1870 as of men employed. Such figures ahould indicate that the signilioant development in the ood Industry in west Virginla ocourred after the C1v11 Mar, although plans for 74 Census of 1870, Vol. III. The census gives 4I, not 35, establiohments but the total seems to be as glven above. In Vol. I the statement is made that there are 1525 in mining, of which 830 were natives of the U. $S$. 75 Compare Table 3, p. 36. 
that development began in the latter part of the decade of .78

1850 to 1830. Such a atatement is not meant to mintinize the place of Virginia in coal production in the united States, nor the place of the vestern counties in ooal production in Virginia. Virginia had long held second place (Pennaylvania belng first) in the production of bituininous 77

coal. Further, as has already been polnted out, the weatern countlea had as early as 1840 greatly outatrippod the eastern countiea in production. ${ }^{78}$ The 1mportant thing for our study, however, is that before the C1vil Mar and immedately after it the coal induatry had undergone relam tively 11 tt le development and that relatively few men were employed in mining in Test Virginia.

It may thus become apparent why the writer has chosen to discuss the history and development from the beginnings of mining in the restern counties of Virginia up to the Civil har under the caption of Early History and Development. The C1V11 花r would appear to be the dividing line between the conditions of small production and sall numbers engaged in mining and the conditions of rap1d development with greatly increased numbers. Te ahall now pass on, in more general terms, to the period from 1870 to the present.

76 Supra, po.

77 Clark, V. S., ope cit., p. 331.

78 See note, p. 


\section{Derelopment Sinoe the Civ11 Wax}

It is not the provino of thls chapter to go into the history of mining in the period from the Civil Wur to the present in any degree of detall. The sources of information are much more avallable and muob more complete reoords have beon kopt, as well as boing in the memory of many poople atill 11ving. All that w1ll be attempted is a brief atatement of the extent and nature of the developments that have taken plaoe, with eapeolal emphasis on those phases which affoct the Negro miner in our later discuseions.

In Table $4(p, 39)$ the coal produclas count1es of the gtute in 1870 are 11eted. The twelve count les ment loned would seem to Indioate a wide range of the ooal inlustry at that time. However, when we analyze the countles as to thelr location wo shall seo that they are greatly limited by the means of traneportation. They are, without exoeption, located on some river where navigation is posalble or on some main-line railroad. For Inotano, Ohto, Brooke, and hanoock countios are all lookted on the OhIo River. Harricon, Marion, Preston, Ritohle, and Taylor are served by the Baltimore and Ob10 Rallroad in the northern fleld. Kanawha County was corved by the Kanawhe river and by a fow branch Iines whloh brought the coal to the river for shipment. Boone County was looated on Coal River. The trangportation factor ame to be one of the ondef items in the development of the ooal industry. 
Concerning the protuction of coal by the western 79

oounties in 1840 Clark says:

"Soft coal was raned in the west, but could not be conveyed to tite seabcard."

Thla lack of connection between the count les east and atest of the nountains wes a barrier to communcation and trade Whlch certain persona had long labored to obliterate. The bullding of the Chesapeak and Dhto Rallroad, which was finally to cocome the connecting 1 ink between VIrginia and West Virjinla, was a consunmation which cene only after the fallure of other compani os over a period of yeara. The Loulsa Central Pallroad was incorporated in 1838 for the purpose of bullding a road to the west. This comcany was succeeded by the Virginia Central which bulit its road as far wegt as Covington, Virginia. An extension of this road, wiol was to conrect Chesapeake Bay whth the oblo R1ver. called the Covington and Ohio abandoned its projeot in 1861. The Chesapeake and Ohlo was the successor to thls road.

The otory of the bullding of this road, which was accomplished not without some local opposition, is one of the most interesting in West Virginia annals. Its mention here 1 justified only because of two very lmportant facts: 31

The road wa bullt largely by Negro labor and 1ta completion opaned up one of the most important of the Heat V1rginia coal flelds - the New River Field. The road was flnally flnished on January 39.1873 and the spoolal traln 79 Clark, V. S. op. elt. p. 331.

80 Callahan, op. alt. 0. 191.

81 I01d, p. 193. 
of the prealdant of the road proceeded from Richmond down New River, along the Kanawha, through Teays Valley, to the Ohlo Rlver at Huntington. Thus, the Kanawha fleld was provided wit an outlet other than by river and a bagis was lald for the openting of a new and richer coal field along Hew RIver, which is the name by whloh the Great Kanawha is known from Gauley Bridge, 䍂est Virginia, to 1 ts source in North Carolina. It should not be inferred that this development took place wth eleotrio rapidity, however. The firat engines had to be flred with cordwood, rather than coal, and for aeveral gears the tonnage was very 11 ght. 33

Development continued to go on, howgrer, in all flelde in the decade between 1870 and 1880 . Ploneer Mine was opened on the Kanawhe above Charleston in 1873 and Coal Valley nine at the present town of Xontgomery in 1874. In 1373, John ivuttal1, an Engl1 shman, come from Pennsyligenia and began operations in Sewell Mountain on New River in 85

Fayette County. The ilrat ghipment of coal, however, over the Chesapeake and Ohio Railroad was made at Qulnntinont, 36

farther east, in 1873, where the f1rst iron furnace and

8 Coal operators Htis whon the wrlter has talked would insist that he 16 in error in this statement. They insist that it was the coal derelopment that lald the bas1s for the rallroad rather than vioe versa.

83 Callahan, op. olt. p. 132.

84 West Virginle Dept. of Minea, First Annual Redort. 1833 , p. 16.

85 Lawali \& others, ope clt., D. 5.

86 Interview with the writer s unole, John Laing, who came to the New R1ver Field in 1833. 
flist coke works on New River were established the same 37

year. Flve years later, in 1879, Villian Fyant eatablishel the flrst ooke works on Kanswha Rlver. For a rumber of years the coke industry wea quite important, but is now almogt forgotion in the coal fields of Fest Virsiria. Although the Chesapeeke and Onlo Rall road provided an outlet by tall for Kanama cosl, the pines which had been shipoing by river continued to do so. In 1875 nine nines on the Kanewha R1ver produced 301,000 tona of coal, of milch 101,000 were burned in the salt furnaces along the river. The other 200,000 were stipped down the river to market, accoraing to one source. The eatinats of the Departinent of Mines for all river ghipments for that year was only 30

131,933. At that time practically all the coal siloced by river was shlpped on alther the Kanawha or the Onio rivera. Diffioulty because of the delay in the completion of dams on the Monongahela limited shipments there.

Pailroad building continued throwhout the atate, the nileage increasing from three hundred and efghty-aeven miles in 1870 to $1 \mathrm{x}$ hundred and ninaty-one m11es in 1880. The general development throughout the atate lo reflected in the increased number of operations as well as the nuiber encloyed in 1880, which are stom in Table 5 : 87 Fale, J. P., opectt, Vol, I, p. 167. 88 Ib10.

89 Lawall \& others, oce olt, pp, 5-6. 90 State of 1. . Va., Report of Cblef Mine Inspeotor, 1837, p. 45.

91 Callahan, oo, cit., see note, p.

32 Census of 1880, p. 56.

93 Census of 1830, Vo1. XV, pp. 670-71. 
TABLE 5. HOUBAR OF SITUIYOUS COAL OPAEATIOHS

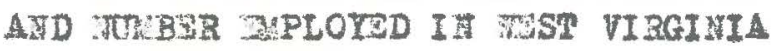
BY canvi IS, 1880

\begin{tabular}{|c|c|c|}
\hline County & $\begin{array}{l}\text { Number of } \\
\text { ogerations }\end{array}$ & $\begin{array}{c}\text { Number stan } \\
\text { Employed }\end{array}$ \\
\hline $3 a r b o u r$ & 1 & 3 \\
\hline Boone & 1 & 100 \\
\hline STooke & 10 & 74 \\
\hline Dodarldge & 1 & 2 \\
\hline Payette & 13 & 354 \\
\hline Grant & 2 & 4 \\
\hline Hancock & 7 & 37 \\
\hline Earreson & 9 & 241 \\
\hline Kanawhe & 15 & 1.347 \\
\hline i.enta & 3 & 4 \\
\hline Larton & 16 & 148 \\
\hline Marahal1 & 6 & 122 \\
\hline steson & 4 & 279 \\
\hline MInoral & 3 & 99 \\
\hline Uonongalla & 7 & 24 \\
\hline Oblo & 14 & 366 \\
\hline Pleasant & 1 & 7 \\
\hline Preaton & 4 & 250 \\
\hline Putram & 1 & 300 \\
\hline Randolph & 2 & 7 \\
\hline Adteb10 & 1 & 4 \\
\hline Taylor & 4 & 204 \\
\hline Tัต & 2 & 4 \\
\hline Tood & 2 & 17 \\
\hline Total & 129 & 4,497 \\
\hline
\end{tabular}

It w11 be seen readily that the decade from 1370 to 1880 mas one of great development, the number of operations inoreasing almost four times and the number of men employed inoreasing over three times the number in 1870 . While there were only trelve counties in which thero were operations in 1870 there were twenty-four in 1890. It w11 be noticed also that, wille Kanawha County continues to lead in number of men employed, Fayette County 18 second, although 1 ts development ras only made possible by the 
opening of the Chesapeake and Ohlo Rallroad in 1873. Although, as Harris hes polnted out, 94 the northern West Virginia fleld developed muoh later than the southern, the number of northern countie appear with greater frequency In the list of oounties in Table 5 (Barbour, Brooke, Doddridge, Grant, Hanoook, Harrison, Lewlo, Marion, Marahall, Mineral, Monongal1s, Ohlo, Preston, Randolph, Aitolile, Taylor, Wetzei, and Food being morthern oounties). Likewise, the figurea on tonnage produoed indioate the rapld development of the deoade. The produotion of the entire atate from 1870 to 1880 was as follow日:

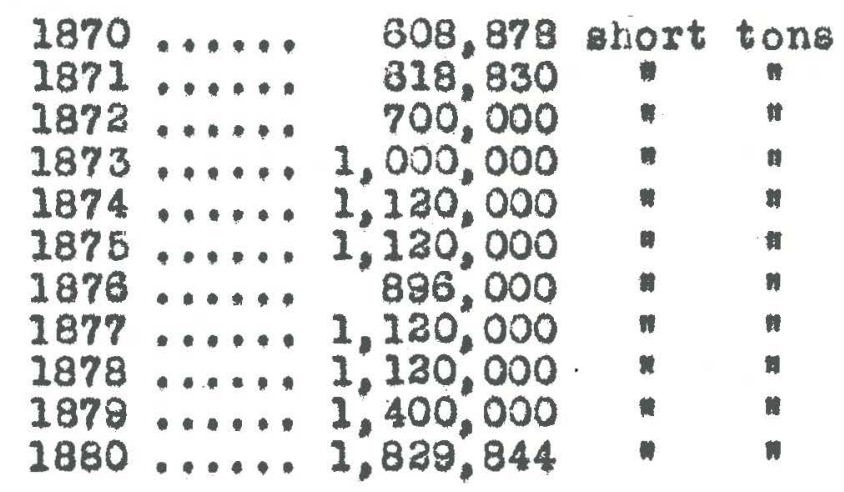

Rallroads continued to open up, not merely whole filelds due to main line oonstruction, but brunoh lines began to extend up the various oreeks where coal beds were looated. A standard gauge Rallway was bullt during the years 1881-82 up Cabin Creok, a tributary of the Kanawha, for a distanoe of nine miles opening up what has alnoe become one of the olief flelds of Kanawha County. Like-

94 Opportuntty, February 1930.

95 Complled from Annual Reports of the state Mire Inspeotor.

96 Irst Annual Report of the state Mine Inspeotor, 1883, p. 20. 
wise in 1881-82 a three loot gauge road was bullt up Paint Creak, aloo a tributary of the Kanawha River in Kanawha 87

County, This aems to be the firat extensive rallroad bullding up Paint Creek although a Rlchmond paper mentions a locomotive whioh was old by the Tredegar Iron Works, of Richmond, to the "Paint Creek Company of Kanawha, Virginta" as early as 2855. In 1883-84 the Winf frede branah of the Chesapeske and Ohjo was bullt from plnifrede, on the Kanawha River, for several miles up Fleld's oreak, $99^{\circ}$ The narrowgeuge road built somewhat ear21er from the main 11 ne of the Chesapeake and Oh1o to Ansted in Fayette County, was changed to broad gauge in 1889. 100

The road construation mentioned above was all branch line conneotion. The ohief event, however, so fur as the development of the coel industry is concerned in the decade between 1880 and 1890 , wes the bullding of the Norfolk and Western Rallroad, thereby opening up the Pooabontas coll s1eld in MoDowell and Mercer counties in the extreme couthern part of the atate. Perhaps to Major Jed Hotchk1ss, of staunton. V1rginia, more than any other man, is due the oredit for the development of the irmense Poodhontas ooal field. He explored and helped develop this foreat area whloh faot led to the bullding of the rallroad from Virginia, through thi territory, toward the west. 97 Ib]a.. P. 23. 98 Quoted in Bruoe, op. 01t., p. 286. 99 Lawall \& others, epe oft, p. 7. 100 Callahan, ope olt., p. 196. 
The New Fiver division terrinating at Pocahontas, VIrg Inla, just across the state 11ne, was construoted in 1881-82, and 101

large shlpment of coal were made in 1883. Next came the building of the Flat Top extension in 1884 to Elkhorn. The Elkhorn tunnel was oompleted in 1886 and the road extended gradually wegtward unt 11 in 1892 it reached aoross the Ohto Biver te Kenova. The ooal lands of Mercer, MoDowe11, Mingo, and Wayne count1 be were thus made ave1lable for extenelve development. The opening of thia fleld, directly adjacent to old Virginia, greatly important oo far a the Negro miner is concerned, as will later be shown.

Wh1le the bullding of the Norfolk and Weatern was by far the most importent event in the deosde from 1880 to 1890 the ooal Industry was nomewhat affected also by the bullding of the Ohio Central (now the New York Central) from the Oblo River at Callipolis up the Kanawha valley to Charleston in 1884, 104 while the Ohio River road was oompleted from Wheeling to Huntington in 1888.105 However, no new large flelde were opened during this perlod except that ocoarioned by the butlding of the Norfolk and Western Ra11way.

By 1890 both the Now River 11eld, mainly in Fayette County, and the Pooakontas Field, which included I0I Hale, J. P., ope o1t., Vol. I, p. 168.

103 Callahan, op. olt., p. 317.

103 Ib1d.

104 Hale, one oit. Vol. I, p. 188. 105 Lawail \& others, op. oit., p. 6. 
Meroer and MoDowell count 1e日, opentng in 1884 and 1888-89 106

respeotively, bad developed rapidiy. The following table, made from the only avallable souroes of information, 107

w11 Indioate something of the growth up to 1891, in the counties that were later to beope important in the coal Industry:

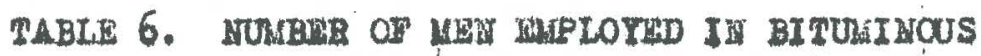
COAT MIUING BY COUXIRS, 1883-1891

\begin{tabular}{|c|c|c|c|c|}
\hline \multirow{2}{*}{ County } & \multicolumn{4}{|c|}{ Tear } \\
\hline & 1883 & 1888 & 1889 & 1891 \\
\hline raytto & 1,460 & 2.953 & 2,675 & 3,656 \\
\hline Kanana & 1,853 & 2.370 & 2,088 & 2,710 \\
\hline Lart on & 173 & 478 & 431 & 1.329 \\
\hline MCDowell & & & 742 & 1,497 \\
\hline uercer & & 1,136 & 1,396 & 2.104 \\
\hline Monongalle & & & 125 & 60 \\
\hline other & 2.857 & 2,037 & 1.747 & 1,722 \\
\hline w. Va, & 5.343 & 8.974 & 9,204 & 14,078 \\
\hline
\end{tabular}

The growth of coal ming had been so rapid during the perlod following 1870 and the outlook for contlaued growth so great that the office of Inepeotor of Mines was Indioation of the increase in the number of mines inoe that time may be geined from the faot that in 1883 the one Inspeotor was supposed to vist all the mines in Feat Vire Inia and make a thorough inspection of each. The first

106 Report of the State Inspoctor of Mines, 1888, p. 37. 107 Reports of the State Inspeptor of Mines for 1883, 1888,1899 , and 1891. The report for other years were destroyed in the Capitol f1re in 1921.

108 Roport of the state Inspootor of Mines, 1883, p. 1. 
report tells of his proposed route:

I deternined ucon the following route as the one

I should follow in ay tour of 1napeotion, viz.: to begin at Raymond City, the most westerly mine on the Great Kanawha river, and work thence eastwardly to Oulnalinont on Ney River, in Fayette County, thence to Piedmont in Mineral County, and from there restrurtiy along the $B$ \& $O$ Fallroad and the Parkersburg branoh of the same unt 11 I should hare vialted all the mines on that porm tion of sald rallroad thence northwardly, from Grifton, along the gain atar of the Baltimore and onio raliroad to wheeling, and up the ohio river to all the mine in the "Paniandie;" thence down the onlo to the minea in Mason County.

Today there axe trenty-alx district ane inspectora, three inspectors-at-largo, as well as five safety directors doing the work whloh one man mas aupoosed to do in 1883 . $^{110}$ The quotation above is included to emphesizo again the relativeIy late development of coal mining on a large scale in west Virginia. There zere one hunired and two operatione in 111

1883 whlle in 1930 there wore seven hundred and seventynine. 113

The next fleld to be opened, whloh later came to have eigniflcance for our study, :ag Logan County. Although 110,50 , and 86 men were roported to be working in Lozan 113 County in the mines in 1894, 1895, and 1896 respootively, there is no more mention made of Logan County in the nine reports unt11 1904. Evident Iy the nines mentioned at the $109 \cdot$ I01d. 0. 4.

110 T. Va. Dept. of Mines, Annual Report, 1330, pp. 3-4. 111 Report of Inapeator of Hines, 1833.

113 W. Va. Dopt, of Mines, Annual Report, 1930, pp. 18-51. 113 T. Va. Dept. Of Mines, Annual Reports, 1894, 1895, 1890. 
earlier date were meraly 1002 enterprlsea. In 1904, however, 131 men were reported as working in the mines. The Chesapeake and Ohlo Ra1lroad extended 1t B Ine to Logan 116

in 1904,

Thio 11eld, wh1lo late in starting its develop. ment, has come to oocupy econd place to the Pookhontag Fleld only, and in 1987 it took firat plaoe in production 116

for that year.

Th1 development took place in lese than thirty years, for in 1803, although two minea were boing opened before the oompletion of the rallroad, no coal was shl pped that year.

We shall pess over the minor developments in already establishod 1101 de and go on to the developments which led to the opening of the mines in Raleigh County. pertioularly in that ootion later known as the Winding Gulf Field. The flrat mine in Rale1gh County, now one of the ohief oounties in the produotion of coal, was eatabIishod at Royal, located on the Hew RIver and the Chesa118 peake and Ohto Rallroad, in 1890, The bullding of the Virginlan Ra11way, however, opened up a muoh wider fleld in this oounty from whith are obtalned some of the elnest coals in the state. The Virginian grew out of a plen to provide an outlet to tidewater for operations not adequate. ly served by extating rallrocds. The oulmination of this II4 Va. Dept, of Mines, Annual Report, 2904, f. B.. 115 Lawlall \& others, ope eft. p. 8.

116 State of W. Va., Dept, of Mines, Annual Report, 1930, pp. 88-89.

117 T. Va. Dept, of Minea, Annual Report, 1903, p. 113. 118 I. Va. Dept, of Minea, Annual Report, 1904, p. 214. 
plan caine with the merging of the Deepweter Rallroad in Fayette County with the Tidewater Rallroad of Virginia. 119 In 1909 the road provided conneotions between Deepwater on the Kanawho River through Fayotte, Ralelgh, Wyoming, and Meroer countioe into Virginia. $120^{\circ}$

With the opening of the area made poesible by the buliding of the Virginlan Rallway the last of the great fieldo in Fest Virginla was mado avallable, Later developmente have been merely extenelon of the great undertakinge already atarted. A further discusaion of these developments at this point the writer doo not deem essential to the present atudy. Suffiolent of the historical background of development in the oount ie studied has been given to serve as a perspeptive in the later ohapters. Thlo much is indispenseble to a otudy of thl kind; more than this, superf I uous.

II. HIBTORY OF THE MERO MINER IN WEST VIRGINIA

As we have eeen, the sources of information on the history of mining in West Virginia are both soattered and meager and not only are suoh sources oonoerning the hlatory of the Negro miner extremely meager but so soattered, apparently, that no one has attempted to put thom together. As. was the case of the minlng of coal, the flrst information conoerning the Negro as a miner relates not to 119 Callaban, op, olt, p. 231. 130 Lawall \& othera, op. oft., p. 8. 
West Virginie, but to the oounties of 01d Virginia. Since mining atarted there at an early date, a we have seen, and - Ino Negro slavea were muoh more numerous there than in the western counties, It 1 perhaps the logical place to look for their early use as miners. The earlieat mention, whloh the writer ha been able to find, of the Negro as a miner was made by a Fronob traveler in the colonies. He described the Virginla mines at Dover as employlng five hundred Negroes, in worklnge already one hundred and twenty 121

feet deep. Dover 10 looated on the north bank of the James River in Gooohland County about twonty miles from Richmond. This mine, in addition to the Midiothian mine, opened in 1835, and the Clover H1ll mine, opened in 1839, were later depended upon greatly by the Confederaoy from 1861 to 1865.132 These mines, with oertain other smalles mines in Chesterfield and Amella oounties, such as the Maidenhead mine, opened in 1821; Gowrie; w111s, Brown, and Company, 1816; Trabue's 01d P1ts; Creek Company of Colliers, 1837; and the Moody and Johnson mine, came to be known a 133

the Riohmond coal flelds.

In 1841 nearly a thousand men, malnly Negro alaves, with only a few white men from Virginia and Great Britain, were at work in the Riohmond coal flelds. Th4 The saver in these early mines oould be ut11lzed with 11ttlo apeolal training.

III Clark, V. S., op. cit., p. 331.

123 Bruce, ope oit., Appondix I, map and p. 452.

123 Ibid.

134 Ib1d. p. 95

135 Ibld.: p. 106. 
Debow's Rev10w reports that proposals had been made to use save labor more generally in the quarrying and working of grantte, as well as in the wining of coal. 123 Vian Virginla also proposed to use Negroes on publio worka. Perhaps no state had made wider use than did Virginia of her alaves, Their use in the iron furnaces and factorles of V1rginia, gayo Professor Bruce, olearly demonstrates that "The ooonointo historians batve been curiously in error In their dogmatic atatement a that the negro slave oould not be profitably used as a factory hand." It is quite possible, however, that the western oount les of Virginia may have used slaves lese profitably, if we may belleve one of the factions in the convention called to create the new oonstitution for the etate of West Virginia, which sald:

"Make West V1rginia free and she will invite 1mmigrants. Her coal and her iron oan be mined only by free labor. Negro slavery 1 s wasteful everywhere, but leas profitable in Woet Virglnie than in any part of the southern etates."

Eagt Virginia, however, did not seem to suffer from this unprofitablo use of Negroea in the mines. That delightful narrator and traveler, who ta one of the joys of the historian, says of the Virginis mines:

126 Debow's Review, Vo1, IX, July-Dec, 1850, p. 435. 127 Wesley, Charlos H., Nezro Labor in the United States, Vanguard, 1927, p. 7 .

128 op. o1t., p. 231.

129 Callahan, op. a1t., pp. 149-150.

130 01mat ead, Frederlok Law, 1 Journey in the Seaboard Slave States, Mason \& Bros,. N. T., 1856, pp. 47-48. 
"Yesterday I visitad a coal-pit: the majority of the mining laborers are alaves, and uncomonly at bletio and line-looking negroes; but a considertable number of white hands are also employed, and they ocoupy all the reaponsible posts. The slaves are, some of them, owned by the Mining Company; but the most are hired of thelr owners at from $\$ 120$ to \$200 a year, the company boarding and olothing them. (I have the Impresaion that I hourd it was oustomary to give thom a certain allowance of money and let them find their own board).

The ooal from these beds is of apeolal value for gas manufactur and is ahlpped, for that purpose, to all the large towns on the At lant 10 seaboard, even beyond Boston. It is delivered to shipping at RIohmond at $15 \$$ a bushel: about 30 bushels go to a ton."

About the time Mr. Olmatead published his book there were running in the Richmond Dally D1spatoh during December and January of certain yeara advertizement for Negro miners. It would seem, then, that in the ante-bellum period in eastern Virginla that Negro glaves were used quite generally if not almoat exolualvoly.

Just when Negroes were firat used in the oountieg of Test Virginia as miners is not known. Ve do know, however, that mining began in ohlo County about 1810,13 , in $^{2}$ Kanawha in 1817, In Hason County in 1832, in Brooke Harrlson, Logan, Monogal1a, Preston and Tyler by 1840, In Mineral County in the decade between 1840 and 1850, and In Marion and Putnam oount 10a by $18600^{137}$ The follow-

131 Bruce, ene o1t., p. 246.

133 Supra, p.

133 Supra, p.

134 Supra, P.

136 Supra, p.

136 Supra, p.

137 Supra, p. 
Ing table will give some 1 dea 31 so of the number of Negroes in eaoh county of importance for our gtudy in the ante- and poot-bellum perioda: 138

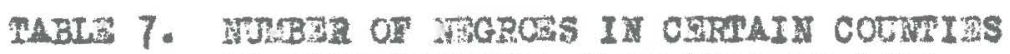
IN WEST VIEGIJIA TROA 1790 TO 1870

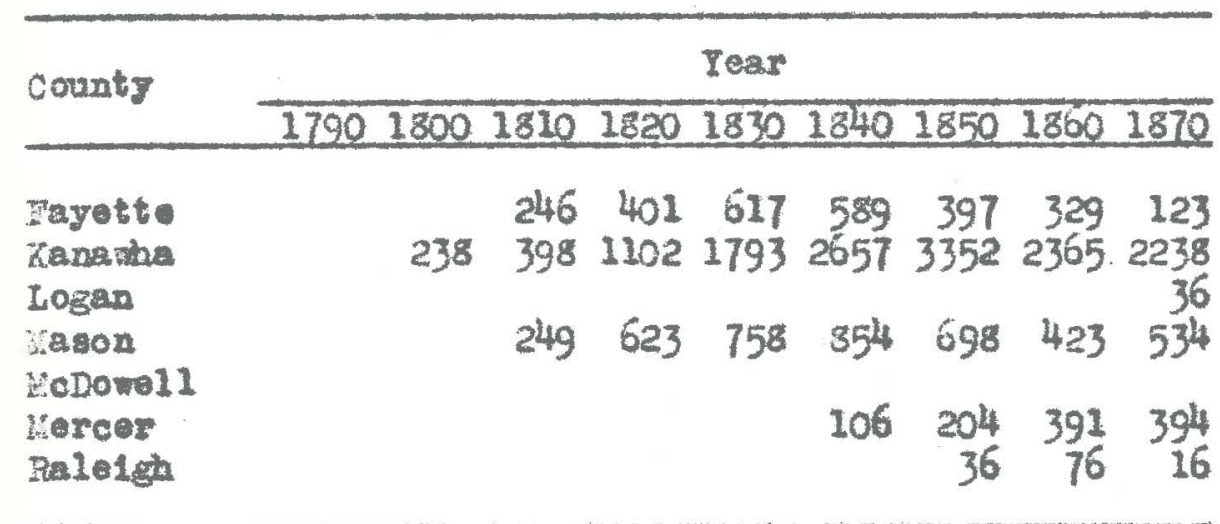

Although, as has been sald, it is not possible to say juat when alares began to work in the mines in the pastern countleg, it has bean posible to verffy the fact that Negro slaves workd in the coal industry both in Mason and Kanawha count1es before the Civil mar. $32 a v e s$ owned oy R. C. M. Lovell worked in the mines in Mason County before this time. Mr. Lovell followed the prevalling oustom mentloned by 01 nstead and sented bla Negroes to the mining comçanies. The slavea lived in slave quarters and thelr wajes tere collected by their naster. There vere very few Negroes in the mines of Mason County, according to one informant, 140 and they worked in the mines with iree labor. These Negroes, who worked at Mason, Virginla, went to the 138 Census of 1870, Compendium, pp. 100-103.

139 Supra, p.

140 Mr. F. M. Munaw. 
State of Oblo after the Civil Far and did not remain in 141

mining after manolpation.

Hason County 1a loouted on the Ohio River, and, henoe, was just acroes the river from free territory. Aa a result, rather extrome measures were taken at one place to keep the laves from esoaping while working in the mines, A sort of atpokade was bullt in whioh the Negroes were put after working in the lnos in tho daytime. ${ }^{143}$ This old struoture, which atood for a number of years after the Civil War, was populariy known as the "nigger pen." This praotice would Indioate that slaves must have been used considerably, wlthough the informant above insists that tho number were never $18 \pi g e$.

It wa the good fortune of the writer, quite by ohunoe, to enoounter one of these old sleves while interviewing the miners in Kanawha County, This old man was ot11l hale and hearty at the age of ainety. His father, a alave in Mason County, althourh they had been originally brought from east Virglats by their owner, Hr. John Lewis, was one of those leaving for Ohlo after the was. His son, however, tired of Ohlo and returned to Point Pleasant. He. then worked on a stamboat, worked the talt furnaces, and finally oame to the mining tields of Kanawha County. I4I AII the dat above were beoured by correspondence with Mr. F. M. Mumaw, of Mason, W. Va., age 88 on Ootober 23. 1931 .

142 Interview with Mr. Clifford C. Myers, W. Va. State Historian, in charge of Department of Archives and History, Charleston, W. Va. 
He has been mining ino 1877, being then thirty-five year of age, having worked at many different places. He has, howerer, been on Cabin creok tor over thirty yeare. At present he has been put off, due to the age $11 \mathrm{mit}$ held by the oompany, without a pansion. He lives with life two Bons who are both miners. He aubstantlated the faot that Hegro slaves were ued in minlag.

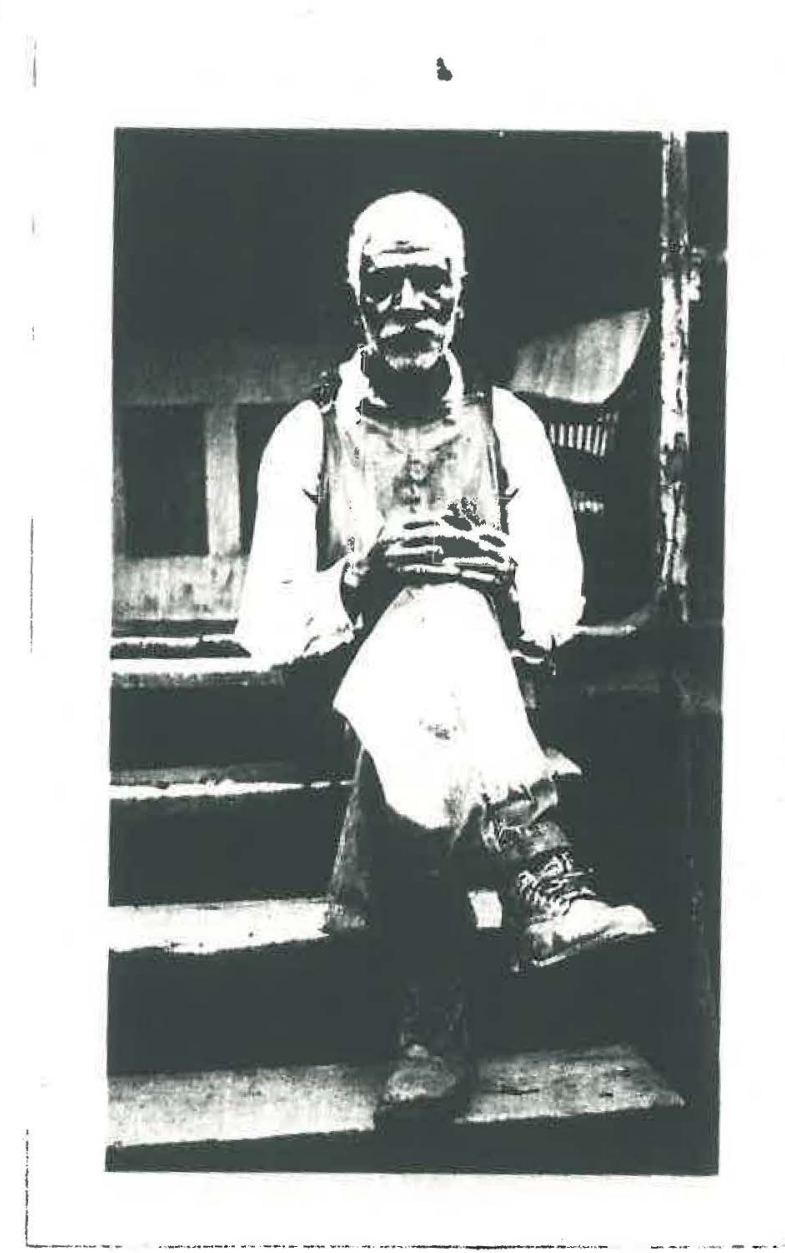

IIIuatration 1 .

The oldest Negro miner interviewed, an ex-slave, are 90. 
The use of Negro alaveg in the mines of Kanswha County was moh more widesprsad than in Vason County. It mill be remembered that coal wa first used in the Kanawis valley in conjunction with the manufacture of alt, raplacIns wood for that purpose. This coul was wined larsely by 143

Negro slaves. Because of the lack of knowledge of Ventilation, the openings were not driven into the hllis very far. The coal was pusked out in small oars by the slaves. Not only were the slaves uad in the mines thenselves, wut were also employed in the cannel coal oll factories whil on 144 became somewhat prevalent in the flftles. The omers of the alaves leased them to the owners of the factoriea, who were usually oltizens of free states. ${ }^{145}$ Kanaina Who were uaually olt 240 County had over three thousand alavea in 1350, and it is quite likely that a goodly number of them rere used in the mines and the factories.

After the Civil far something of the unrest and movement among the Negroes in certain other states were reflected in Test V1rginia. There was a declded tendency

143 Correspondence with $M r$. C. C. Diokinson of the Kanawha Salt porka, halden, Ta., Vir. Dickinson's father, Ur. J. Q. Dickinson, was one of the ploneers in the salt business in this vicinity.

144 Kanawhe Valley Star, October 10, 1859, p. 2.

145 Ioja.

140 Supra, Table 7. A list of Charleston aitizens in 1836 IVea "Dock \& Gabe, colored, cosl haulers," (Hale, John $P_{j}$, Trans-Allerheny Ploneers, Cincinnati, 1386, p. 334) Just what is neant by the term, coal haulers, is Indefinite. It mey mean haulere of coal in the mines or 1 t may mean draylng the coal to the homes of the c1tizens. 
for the newly-emanolpated ireedmen, "the Nex-Isshy, " to nove out from where they rare located if only for a time. Such a tendenoy was the logical behavior pattern such a group intight be expected to follow for both psyohological 149

and sociological reasons. Being reared in a cultural

milieu in whioh the greatest value ras put ucon freedom, in which his only sharing was through a religlous sublimation, the Negro reacted to the new situation in such a ray as to realize a new experience whi on he had long anticipated and at the same time to announce hi freedom in a consplcuous and overt manner. Thi movement roughly took two forms: a movement from plantation to tom and ofty, 150 and a morement from the atate of residenoe prior to emancipation to other states, in which latter novement whttes as well as 151

Negroes partioipated. The movement did not always result in permanent $10 s 8$ of the Negroes, as there was a tendency for nany of them to filter baok into the communities they had left. The followl hig table gives sone indication of this movement in certain Neat Virginia counties:

147 Dodge, Dav1d, Free Negroes of North Carolina, At lant10 Jonthiy, vol. 47, Jan, 1986, p. 28. Thls term was used by the freed slaves to differentiate themselves Irom those free before Emanolpation by snendment. The free Negroes were known as "old Issue" and the freed as "new 18sue."

148 See Taylor, A. A. The Negro in South Carolina During the Reconotruction. Assoclatod Publishers, 1924, cassim, also hia Negro in the Peconstruotion of Virginia, Assoclat ed Publ1shers, 1926.

149 See Miller, Herbert A., Raceg, Nations, and Classes. Lippincott, 1924, pp. 32-34,

150 Taylor, A. A. The Negro in the Recongtruotion of

151 V1rzinie p. 85. 


\section{2}

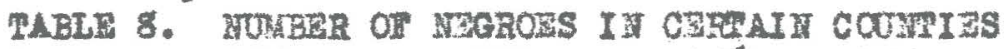

IN TSW VIRIMIA FRO 1360 TO 1880

\begin{tabular}{|c|c|c|c|}
\hline \multirow{2}{*}{ County } & \multicolumn{3}{|c|}{ Tear } \\
\hline & 1860 & 1370 & 1380 \\
\hline Jayet te & 281 & 118 & 1122 \\
\hline Ianswha & 2365 & 2238 & 2870 \\
\hline Logan & 149 & 162 & 109 \\
\hline zebowe11 & & & 3 \\
\hline Mason & 423 & 534 & 559 \\
\hline Mercer & 391 & 384 & 366 \\
\hline Raled ga & 76 & 16 & 71 \\
\hline
\end{tabular}

It will be not1ced that in Fayette, Kanawha and Rale1gh countles there ras a deorease in the number of Negroes between 1860 and 1370 , with a corresponding increase between 1370 and 1880. Mason County, on the other hand, shows an increase in all three periods. Mason County is located on the Ohlo Rlver and may have proved a stopping polnt for many in their westward trok toward greater 153

economic advantage, since it offered both work on the farns and in the wines, not to mention the boat yards in the county. In Mercer County 29 out of the 391 Negroes were free in $18300^{154}$ since sercer County is adjacent to the vestern oounties of Virginia it is probable that some of the gain in 1870 and 1880 was due to $\mathrm{mlg}$ ration of Negro farmers from Virginia. The tendenoy of Virginia Negroea to come to West Virginia started early and has continued 155

to the present time. Neither Mercer nor Logan were

158 Census of 1380, Vo1. I, D. 414.

153 Tesley, G. H. op. olt., p. 137.

154 Consus of 1860 Vol. I, pp. $513-517$.

155 See Chapter III. 
coal counties during this perlod and, hence, probably attraoted Negro farmera to ome extent, ulthough Logan County had lost rome of 1 to Negroes by 1880.

West Virginia, due to the post-bellum unrest axong Negrous, wa more of a gainer than a 20ser in Negro population. In 1870 , before the great development in the ooal flelde, there were 17,980 Negroes. 156 Jeffercon, Berkeley, Hampshire, and Hard oounties In the Eastern Panhandle, Greenbrier and Monros counties on the Virginia border, and Kanawhe oounty eaoh oontalned more than one thoum send Negroe - - two-thirde of the Negro population of the 157

state. Sinoe Kanawha was the only one of these counties that mines extenafvely, the rest bolng agricultural for the most part. It oan be read11y geen that the bulk of the Negro population was in other ocoupations than winlng at this date.

In the deosde aftar 1870, however, it w111 be remembered that much development in the coal Industry and muoh rallroad building took plaoe, West Virginia and onlo by 187 a provldad a demand for rallroad laborers to whom were paid wages of $\$ 1.50$ or $\$ 1.75$ a day ${ }^{158}$ a correspond ent of the Ginolnnati Conmerolal wrote:

I am informed by the contractors that the negroes make the most falthful hands they can get.

I58 State of W. Va., Hureau of Negro Welfare and Statistics, Report, 1921-22, p. 12.

157 Ibid.

158 Taylor, epe clt., p. 95.

159 Quoted in Taylor, Ibid., p. 97. 
This 18 the perlod, 1 will be remembered, of the bullding of the Chesapeake and Ohlo Rallroad. Thls road had about 160

five thousand Negro laborers in 1871, In fact, one could say with great deal of accuraoy that this inportant road was largely bullt by Nagro laborers from Virginia. The important oontibution that the Negro laboring group mado in this work oan only be realized whon the diffloulty of the tagk 1s known. As Callahan says: ${ }^{163}$ whe full otory of the work dope. would tell of hardshipa and dangere bravely borne, and of the falth and patience of sk112 and intelligenoe." The country was one of the wildest and h111lest in southorn and eastern weat Virglnia. The naterials for construotion were brought in wagons over oountry roads or floated down the Groenbriex river in bateaux.

After the work of construction was completed many of the Negroes remalned either to work on the rallroad or to work in the nowly opened ooal mines of the New River 183

alstriot. Up to the year 1885 ninety per cenis of the miners in the New fiver Fleld were Negroes. ${ }^{164}$ Thereafter. the competition of the Southern thropean began to be felt somewhat, In 1880 , there were only 25 forelgners out of 160 माव. P. 215.

161 Callahan, ope oft., p. 183; Taylor, op. olt., p. 114. 162 IbId.

163 Ib1d, p. 192.

164 Interview with Wr. John Laing.

165 Suffern, Arthur E. Conolliation and Arbltrution in the Coal Industry of America Houghton Miffin, 1915, p. 36. 
160

had increased to 1,375, while the number of Nerroes vas 167

3,015. However, the forelign eloment tas brought in only then the nativa white and ferro pomlation backine inadequate. Thus, the polioy in Fest Virginda twe not displacement of Hejro and native mitte labor by foraign labor but herely supplementation of their labor. Boarolty of Negro labor caused a resort to labor agencied in the southorn stiaties. Mining compantes writing to on agenoy in Rlohnond made it 139

a condition that no mhites should be sent to them.

Across the border in Virginla the polloy was one of $113-$ 170 placement.

Several years after the comoletion of the chesspake and Ohio Rallroad, the Norfolic and Nestern ras bullt, from about 1331 to 1392. Negroes took fully as large a part in the building of that rallroad as they did in the bullding of the Chasapeare and onlo. 171 iany of these ramained, not only to mork in the coal Ilaida, but to work 172

as permanent anployees on the rallroad 1tself. At that

t1me, before the advent of the Brotherhood of Engineers and Tiremen, aome of the better positlone were open to the Negro. Although the numbers were never very large, there rere sone firemen. There was only one of thege early flremen left in 136 Census of 18э0, Vol. II.

16 ? Ibld.

138 Herria, Abran L., The Blook Vorker, Columbia University Press, 1931, p. 314.

169 Taylor, op. olt., pp. $97-38$.

170 U. S. Immigration Comission, Abstract.

171 Weloh Da11y Newg, Sept. 31, 1936.

$173 \mathrm{Ib}+\mathrm{d}$ 


\section{3}

1928, running on the Northfork divialon. Negro brakemen existed in 3 reater numbers and sevarel were st11l running in 1928. However, as a rule, when these old mokers drop out their places are fiven to white men el!gible to the "Brotherhoods."

As was shown in Table 8, there were only 3 Negroes 174

In MoDotell County in 1880. By 1990 this number had inoreased to $1,591 .^{175}$ since koDowell county opened up about 1888, it can be seen ith $^{\text {th }}$ wat rapldity and in that numbers the Negroes cene. These numbera were in pert brought in from the south in "transportation cars." These wero almply Hegroes whose transportation had been pald from the south by certain companieg. They pald back, in arti por the conpanles, the money that had boen advanced to them. Sost of these were either single men or married men who came without thelr families. They later, in many cases, sent for their fanilied and often induced their friends to cone also. Since there were only 734 minerg in HoDowel1 County 176

In 1890, it can be seen that the Negroes doubtless constituted the bulk of them. They have continued to play an 1 mportant role in MoDowell County, and today there are far nore Negro miners in MoDomell. County than any other in tho state.

Hercer County started 1t development several

years beiore JcDowell Gounty and, for a tine, led any other I73 Ibld. p. 0.
174 Supra, o.
175 Census of 1390, Vol. II, p. 435.
178 Censu of 1390, Vol. II, p. 418. 
county in the Pooahontag Field in the number of Negroes employed. In 1880 there ware nine mines open which em177

ployed 1,232 men. The Megro population inoreased from 178

366 In 1880 to 2,023 in 1890.

Th1s county $11 \mathrm{kew} 1 \mathrm{~s}$

exhib1ts an enormous growth of Negro population symohronous with the opening of the ra11roads and winos in that oounty. The faot that the Negroea were in the majority in this county gave rise to gome probleme whioh w111 be disoused in later chapter. 178

The number of Negroes in Kanawha County 11kew1se continued to grow. By 1890 it had a population of 3,408 Negroes, although Fayette County had $3,054 .^{180}$ Within the next ten year Fayette County was to aurpaes Kanawha County In the number of Negroos and has held the odge ever alnoe. One of the most distingulshed of Amerloan Negroes apent his boyhood days in Kanawha County. The atepfather of Booker T. Washington, running away from his Virginia master and followling the Federal soldlera, wandered into west VIrginla. He seoured employment in the allt furneger at Malden, Weat VIrginia, about e1x mila abore Charleston on the Kanawha 182

River. Aa soon ar fredom was deolared he sent for bia

177 Iolde, pp. $417-418$.

178 Io1d. p. 435.

179 The writer's maternal grandfather, W1111am Tamplin, was manager of the Goodw111 uine, 'beginning about 1888 and muoh of this later material was obtalned from his mot her.

180 Census of 1890, Vol. II, p. 438.

181 Washington, Booker. T, Up From Slavery, A. L. Burt, 1900, p. 34.

183 Tashington, Booker T. Story of yy Life and Work. W. H. Ferguson \& Co., cinoInnat1, 1901, p. 20. 
wife and her children, who made the trip overland in a wagon, there belng no rallroad connection as yet with old Virglnia. 183 Booker T. Mashington, himegle, as soon as he was large enough, worked in the selt furnece and taught himself to read by watohing the marking on the salt 184

barrels, Later he was put to work in the ooal mine 185

that aupplied this salt furnace. Thle ovent was not to

Wabington' liking and he refors to it as "the unpleasant coal mine experience," 186 Conodung it, ho ays

After I had worked in the salt furnace for some time, work was seoured for me in a coslmine whioh was operated malnly for the purpose of securing fuel for the alt-furnace. Work in the ooal-mine I always dreaded, One reason for this was that any one who worked in a coal-mine was always unolean, at least while at work, and it wes a very bard job to get one's skin clean after the day's work was over. Then it was fully a mile from the opening of the coalmine to the face of the ooal, and all, of oourse, was in the blackest durkneas. I do not beliere that one ever exper1ences anywhere else auch darkness as he doea in a coal-mine. The mine wa divided into a large number of different "rooms" or departments, and, as I never was able to learn the location of ali these roome, I many times found myself lost in the mine, To add to the horror of being lost, sometimes my $11 \mathrm{ght}$ would go out, and then, $1 f^{\circ}$ I atd not happen to have a matoh. I would wander about in the darkness unt 1 I by ohance I found some one to give me a 11ght. The work wa not only hard, but it was dangeroup. There wab always the danger of being blown to pleces by a preinature explosion of powder, or of being orushed by faling slate. Accidents from one or the other of these causes were frequently ooourIlng, and this kept me in oonatent fear. Hany

183 Washington, Uo eroh Slavery, pp. 24-25.

184 Washington, stery of Yy L1fe and Work, pp. 23-24.

185 Ib1d. p. 23 .

186 Ib10.

187. Washington, Up From slavery, pp. 38-39. 
chlldren of the tenderast yeare were compelled then, as 18 now true I fear, (188) in most coalmining diatriota, to apend a large part of their I1ver in theso 0oal-mines, wth iltie opportunity to get an education, and, what 1s worse, I have often noted that, as a rule, young boyo who begin $11 f e$ in a ooal-mine are often physically and menta1ly dwarfed. They goon 1090 ambltion to do anything loe than to continue as a coal-miner.

It was from Malden that Washington left for Hempton and 189

later returnod for a perlod of teabing.

when the finding Gulf rield in Ralelgh and TyomIng counties was opened up through the bullding of the Virginian Ra1lroad in 1909 tho Hagro bgain played the part of plonser. When operatore in other flelde were proopeoting in the linding Gulf conl area thoy took along their 180

trusted Negroes. Many of these Hegroes who helped to open up the al nes in this neweat fleld are still working et these same places. Ralelgh County coal mines are looated partly in the Now River Field and partly in the Winding Gulf rield. Conequently, it had sowe Megroes before the latter flold was developed. In 1908 Rale1gh County had 383 Vegroes, 948 nat 1 ve whitos, and 843 forelgn 191

born. In 1909 the number of Yegroes bad Inoreased to

188 OhI Iabor laws in West V1rginia now prohibit underground work under 18.

189 Tashington, Up from Slavery, p. 87.

190 The writer knew one Negro who was brought from the New River sield by one employer and taken to the Kanawha Field where be worked for about ten years, and was finaliy taken to the Minding Gult Field whera he died. His wh dow 18 et 111 oared for by this company.

191 Figures complied from Dept, of Mines, Annual Roports. for these yeara. 
455 and the native whites to $1,032$. In 1910 the number of Negroes had jumped to 715 and the number of the native whites to 1,873 . Thus, in this two yoar perlod the native whites increased 176 per cent and the vegroes increased 180 per cent. The 3 rowth of Negro population in Raleigh County has been steady unt 11 today it is the second county in the number of Negro miners.

As was the case in dealing with the history of, mining in Feat Virfinla, our purcose here has not been to wite exhaustively on the plstory of the Negro in mining. A great many historloal points will be brought out in later chapters, as, in each oase, the attempt 7111 be made to trace the discusion to the past as well as the present. In any instance involving interpretation this praotioe, to the wrter, seems wlsest as a matter of method. The purpose in this chapter has been, then to present somewhet briefly tho part of the Negro in the opening of the various flelds involved in this study as well as to traoe his history in minting as far back as any record of his part in it existo. which mas found, in this case, to be in old V1rginia. Whlle there had always extsted some habitudinal and psychto

193 T. Va. Dept. of Mines, Annual Report, 1910, 0. 105. It is 1 mpossible here to give the figures for the forelgn born, and, indeed, the flgures for the Negroes and native white are no doubt inaocurate. The prac tice of giving natlonal and raolal jroups began with the report of 1907 and many ines gave incomplete materlal. The number of men of unknom national1tien in Raleigh County in 1909 was 798, and for 1910, 344.

193 W. Va. Dept. of Mines, Annual Report, 1330, p. 12a. 
184

as well as spatiel i olation, between the eastern oount198 and the Transmontaln, ${ }^{195}$ the mobllity of oulture tralts and the erequenoy of contact botween the eat and west would indioat that mining practices and labor poli0108 in the east were very I1kely famlilar to the vestern oountios and, snce the castern countieg beld priority in experionoe in mintag. were probably not without their effeots. With this objective in mind we may very briefly summarize some of the chice polnta of the Negro's hilatory in West Virginla mining.

There is abundant evidenoe of the use of Negro andrs on larje soale in the eastern oobl oounties of Virglnis in the olghteentib century. Iis use inoreased before the Civil War unt1l upwards of one thousand Negroes were employed in the filahnond coal field by 2841. In West Virfinla oounties, kowever, the numbere of all raoes in lining were not laxge until a considerable perlod after the Civil War. The numbers of Hegroes involvod in inining under the slave reglmo axe indefinite. It lo known, however, that they ware used in Mason County in the mines and in the coel oll factories of Kanawhe County. Sinoe Negroes were in greater mumbers in Kanawha County at that time then any other county in the etate it is probable thet they were ueed in the mines in this oounty ar well.

\footnotetext{
194 See Lumley, F, E. Prlnolples of Soololory, MeGrawli111, 1928, pp. 118-123.

195 See Ambler, Chaxles H., Seotlonaliom in Virginia, Chloago, 1910, pasilm.
} 
Following the omanolpation of the blaves there was some movement from the mining oounties to other plaos, which finot to evidenoed by the Densus of 1670. However. with the building of the Oteaspeake and Otlo Ra1lway and the congequent opening of the Hew Fiver cosi fleld the Hogro population here inoreased rapldy. These nevoomera, wostly from Vireinla, remalned as employees of the rallroud and the new wines, in conslderable numbers, The increase from 1871 on 1s Indlated in the Census of 1880. The great part whloh the Negroes played in the building of the chesapeake and Ohlo Rallroad was re-enacted In the bullding of the Norfolk and Festern Fallroud from 1881-1892. These workers 11kewise romelned in the otate in great numberm. The Negroes algo played a large part in the building of the Virginian Rallway and in the opening of the Winding Gulf Flold in Ralelgh and Hyoring oounties. Hany operators, active in existing coal lielda, took with them truated and tried Negroes who helped them in the opening of other minea in the now fleld.

The hlstory of the Negro miner then begins before the clv1l Var, in oertain countiea, obiefly lason and Kanawhe. In addition, he has been continuousiy employed In Fayet te County inoe 1873, In Meroer alnce 1883, in MoDowe1l since 1887, In Ralelgh since 1830 (although not In great number unt 11 the opentne of the Virginian Ra11way in 1909), in Locan sinoe 1904, and in Wyoming sinoe 1909. The use of the Megro in mining lius led to the rapid 
196

inorease of Negro population in the state: 17,980 in $1870 ; 35,886$ in $1880 ; 32,890$ in $1890 ; 43,499$ in 1900 ; 64,373 in $1910,66,345$ in $29804^{297}$ and 114,833 in 1930 . $^{198}$

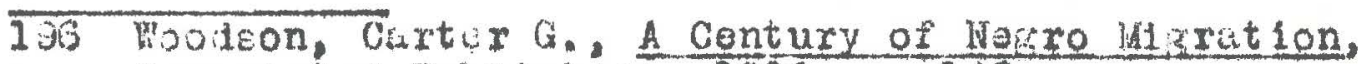
Associated Publishers, 1918, D. 146.

197 Bureau of Nezro Melfare and Statistias, Annual Revort, 1935-26, p, 143.

128 Census of 1930, Population Bulletin, Wost Vireinia, Composition and Charaoteriotios of the Population, issued Apr11 25, $1931, p, 5$. 


\section{CHAPTEF III}

THE NEGRO MINING POPULATION

I. THE NEGRO IN THE MINING POPULATION OF THE UNITED STATES

The Negro has never played a oonsplouous part in the unthraolte coal mining induatry. In $1330^{2}$ there were 147,453 persons einployed in the anthracite induatry. of these, 03,345 or 47.2 per cent were native whites; 77,765 or 53.8 per cent were foreigners; and only 46 Negrous. The explanation of this minute representation in this industry 11 es in the looation, economlo features, and tram dition of the industry itself. The mining of anthreolte coal is restrioted to a much smaller area than bituminous cosl, being, for the most part, found in Ponnsylvania. It is moh more urbanized then is the case with bituminous

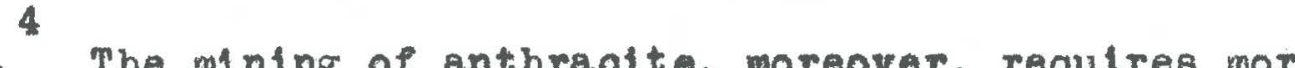
coal. The mining of anthraoite, moreover, requires more sk1li than does the mining of bituminous, henoe, the unsk1lied worker from the southern etates. The market for 1abor, in dull times, in the enthraoite Industry is in these urbanlzed centers where ok11led workers are more avallable than in the more or less 1solated bituminous coal mining comminity. The present writer would add that another factor in the situation is that many southern

I Figures are not yet avaliable for 1930.

3 Report of the United States Coal Comm1sa10n, 1925, Pt. 3, p. 548 .

3 Harr1a, The Black Morker, p. 207.

4 Report of the United States Coal Commission, Pt. 3, pp. 1413-1414. 
Negroea, already baving experience in the mining of bitumlnous coal in 12abama, naturally apply for positions in that Induatry rather than try to break the deadilnes of a new induatry.

In bituminous coal mining, on the other hand, Negroes in 1820 constituted 8.1 per ent of the ent1re work1ng foroe of the induatry. There were 525,153 persons engaged in the Induetry of whow 310,719 or 59,2 per cent were native whitea 171,890 or 32.7 per cent were forelgnore; and 48,443 or 8.1 per oent wero Negroes. The distribution of these workere is shown in Table $9:$

TABLD 9. MACIAL AND MAPIOUAL COAPOSI IION ON BITUWINOUS COAL OPRRATIVS IN THE UNITHD STATES BI STAIES: 1920

\begin{tabular}{|c|c|c|c|c|c|c|}
\hline \multirow{2}{*}{ State } & \multicolumn{2}{|c|}{ Nat 1 vo Dhite } & \multicolumn{2}{|c|}{ Colored } & \multicolumn{2}{|c|}{ Forelgn } \\
\hline & Number & $\begin{array}{l}\text { Pex } \\
\text { cent }\end{array}$ & number & $\begin{array}{l}\text { Per } \\
\text { cent }\end{array}$ & rumber & $\begin{array}{l}\text { Per } \\
\text { cent }\end{array}$ \\
\hline $\begin{array}{l}\text { Fomnsyl vanla } \\
\text { iest VIrgtala } \\
\text { Ill1 nols } \\
\text { Ohlo } \\
\text { Indiana } \\
\text { Alabama } \\
\text { Other tate. }\end{array}$ & $\begin{array}{r}68,843 \\
55,491 \\
47,836 \\
32.322 \\
29.947 \\
5,667 \\
80,613\end{array}$ & $\begin{array}{l}43.2 \\
60.1 \\
59.3 \\
67.6 \\
81.1 \\
43.7 \\
75.2\end{array}$ & $\begin{array}{r}2.288 \\
18.376 \\
1.927 \\
902 \\
384 \\
6.843 \\
11.723\end{array}$ & $\begin{array}{r}1.4 \\
19.9 \\
2.4 \\
1.9 \\
1.6 \\
52.7 \\
10.9\end{array}$ & $\begin{array}{r}88.381 \\
18.490 \\
30.851 \\
14.606 \\
4.252 \\
469 \\
14.941\end{array}$ & $\begin{array}{r}55.4 \\
20.0 \\
38.3 \\
30.5 \\
17.3 \\
3.6 \\
13.9\end{array}$ \\
\hline rotal & 310.719 & 100.0 & 42,443 & 100.0 & 171,990 & 100.0 \\
\hline
\end{tabular}

It will be seen that the Negro has a aubatantlal percentage of the minlng population in only two atater, Alabama and West Virginia. Alabama is the only atate in which he 18 5 U. 8. Coal Commise1on Report, Pt. 3, p. 1422. 6 Ibld. 
In actual majority. However, in numbera, the West Virginla Negro population is more than twloe a large as that of Alabama.

II. THE NEGRO IN THב MINING POPULATION OF WEST VIBAINIA.-

\section{The Present Mining Population}

The 192011 gures are the latest avallable show Ing the comparative racial dietribution in the coal mining stateg of Anerloa. However, muoh later flgures are to be had for the state of Deat V1rglaid. Since 1920 the Negro population has inoreased from 18,376 to 31,514 in 1931. The following table w11 ahow the raolal and national distribution of operatives in the mines of West VIrginla in 8

that year:

7 W. Ve. Dept. of Mnes, Report, 1932, p. 122.

8 Compliad rom Ibld, pp. 118-121. 


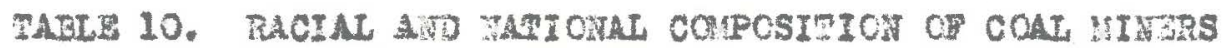
II WEST VIGIMA BY COJUIIS: 1931

\begin{tabular}{|c|c|c|c|c|c|c|c|c|}
\hline \multirow{2}{*}{ County } & \multicolumn{2}{|c|}{ Wat1ve whis to } & \multicolumn{2}{|c|}{ Jegros } & \multicolumn{2}{|c|}{ Borelgners } & \multicolumn{2}{|c|}{ Totals } \\
\hline & rumber & $\begin{array}{l}\text { Per } \\
\text { cont }\end{array}$ & rumber & $\begin{array}{l}\text { Per } \\
\text { cent }\end{array}$ & Xumber & $\begin{array}{l}\text { Per } \\
\text { cent }\end{array}$ & Tumber & $\begin{array}{l}\text { Far } \\
\text { cent }\end{array}$ \\
\hline Barbour & 1.309 & 72.2 & 117 & 6.4 & 388 & 21.4 & 1,814 & 100.0 \\
\hline Boone & 1.877 & 74.7 & 289 & 11.5 & 347 & 13.8 & 2.513 & 100.0 \\
\hline Braxt on & 114 & 98.3 & & & 2 & 1.7 & 116 & 100.0 \\
\hline Broole & 327 & 25.8 & 240 & 19.0 & 697 & 55.2 & 1.263 & 100.0 \\
\hline clay & 521 & 85.8 & 39 & 6.5 & 47 & 7.7 & 607 & 100.0 \\
\hline Bayette & 7.553 & 63.1 & 3.060 & 25.6 & 1.355 & 11.3 & 11.958 & 100.0 \\
\hline c1ìmer & 27 & 100.0 & & & & & 27 & 100.0 \\
\hline Grant & 132 & 93.5 & 3 & 2.2 & 6 & 4.3 & 141 & 100.0 \\
\hline Greenbrtaz & 1,348 & 78.5 & 221 & 12.9 & 147 & 8.6 & 1.716 & 100.0 \\
\hline ganeock & 30 & 69.8 & & & 13 & 30.2 & 43 & 100.0 \\
\hline 蔀年1 & 2,183 & 64.9 & 267 & 5.0 & 1.011 & 30.1 & 3.361 & 100.0 \\
\hline Taname & 4,626 & 76.6 & 1.054 & 17.5 & 355 & 5.9 & 6.035 & 100.0 \\
\hline Leat: & 17 & 100.0 & & & & & 17 & 100.0 \\
\hline Lincola & 100 & 36.2 & 15 & 12.9 & 1 & .9 & 116 & 100.0 \\
\hline Logan & 6.443 & 59.7 & 2,212 & 20.5 & 2,139 & 19.8 & 10.794 & 100.0 \\
\hline Sarton & 2.417 & 50.5 & 393 & 18.7 & 1,468 & 30.8 & 4.778 & 100.0 \\
\hline Sarshall & 620 & 50.0 & 106 & 8.6 & 513 & 41.4 & 1.239 & 100.0 \\
\hline Mason & 34 & 100.0 & & & & & 34 & 100.0 \\
\hline IC Jave11 & 9.027 & 51.2 & 6,092 & 34.6 & 2.503 & 14.2 & 17.622 & 100.0 \\
\hline Nercer & 2.273 & 65.6 & 265 & 27.8 & 238 & 6.3 & 3.476 & 100.0 \\
\hline Ml meral & 468 & 97.5 & & & 12 & 2.5 & 480 & 100.0 \\
\hline N1 ngo & 2,766 & 74.8 & 610 & 10.5 & 322 & 8.7 & 3,698 & 100.0 \\
\hline Zonongalla & 2.257 & 50.3 & 591 & 13.2 & 1,636 & 36.5 & 4.484 & 100.0 \\
\hline Mícholas & 122 & 96.1 & & & 5 & 3.9 & 127 & 100.0 \\
\hline Ohio & 319 & 19.4 & 439 & 26.7 & 388 & 53.9 & 1,046 & 100.0 \\
\hline Preston & 1,490 & 82.9 & 23 & 1.3 & 233 & 15.8 & 1.796 & 100.0 \\
\hline Put nera & 456 & 79.3 & 116 & 20.2 & 3 & .5 & 575 & 100.0 \\
\hline ale1 h & 6.848 & $56 . \overline{8}$ & 3.632 & 30.1 & 1.567 & 13.1 & 12.047 & 100.0 \\
\hline Zando lph & 478 & 87.7 & 3 & .6 & 64 & 11.7 & 545 & 100.0 \\
\hline Paylor & 782 & 84.9 & 20 & 2.1 & 119 & 13.0 & 921 & 100.0 \\
\hline Tucker & 564 & 88.6 & 17 & 1.9 & 302 & 9.5 & 883 & 100.0 \\
\hline Ipshur & 263 & 94.9 & $i$ & .4 & 13 & 4.7 & 277 & 100.0 \\
\hline Tayne & 181 & 100.0 & & & & & 181 & 100.0 \\
\hline Hebster & 769 & 99.9 & & & 1 & .1 & 770 & 100.0 \\
\hline 7yomlas & 1,053 & 58.7 & 589 & 32.9 & 151 & 8.4 & 1.793 & 100.0 \\
\hline
\end{tabular}

7. $7 \mathrm{a}$.

$\begin{array}{llllllll}59.844 & 61.1 & 21.514 & 21.9 & 16,595 & 17.0 & 97.953 & 100.0\end{array}$ 
There are lifty-aix oount les in weat Virglnda, IhIty-five of these oounties produce ool on a commerolal basis. Hegro miners are found in twenty-alx of these count1es. With one excoption, there is no oounty in West Virinia where as many as 500 miners are engaged in the industry in whloh some Nagroes are not found. The one exception 1a Webster, In whioh are mployed 770 miners, all native whitio except one. Needlea to ay, none of the major produolag coal oount iss are whout Negroes in some proportion, of the-nine oounties in whloh no Negroes are anployed only II ve had many as one hundred men employed. The total of all men employed in these nine count 108 was only 1,845 or 1,88 per cont of the minlng populam tyion of the atate. Thoir combined produotion of coal for 2931 was only 513,545 tons $^{9}$ or .5 per cent of the entire production for the state. It 18 interesting to note that one of these oount1es which now has no Negroes in the mining population, Mason County, was one of the countios whioh employed Negro slaves before the Clvil War. At present, however, thls oounty has only elght mines with a total of 84 men employed, These are all native whites. on the other hand, those counties whioh lod in the produotion of coal in 1931 were also those which led in the number of Negroes. MoDowell, which has led the state in tonnage every year oince 1903, exoept in 19a7, 9 W. Va. Dept. of Mines, Heport of 1931 , p. 84. 10 Ibjd. p. 87. Logan county led in 1927. 


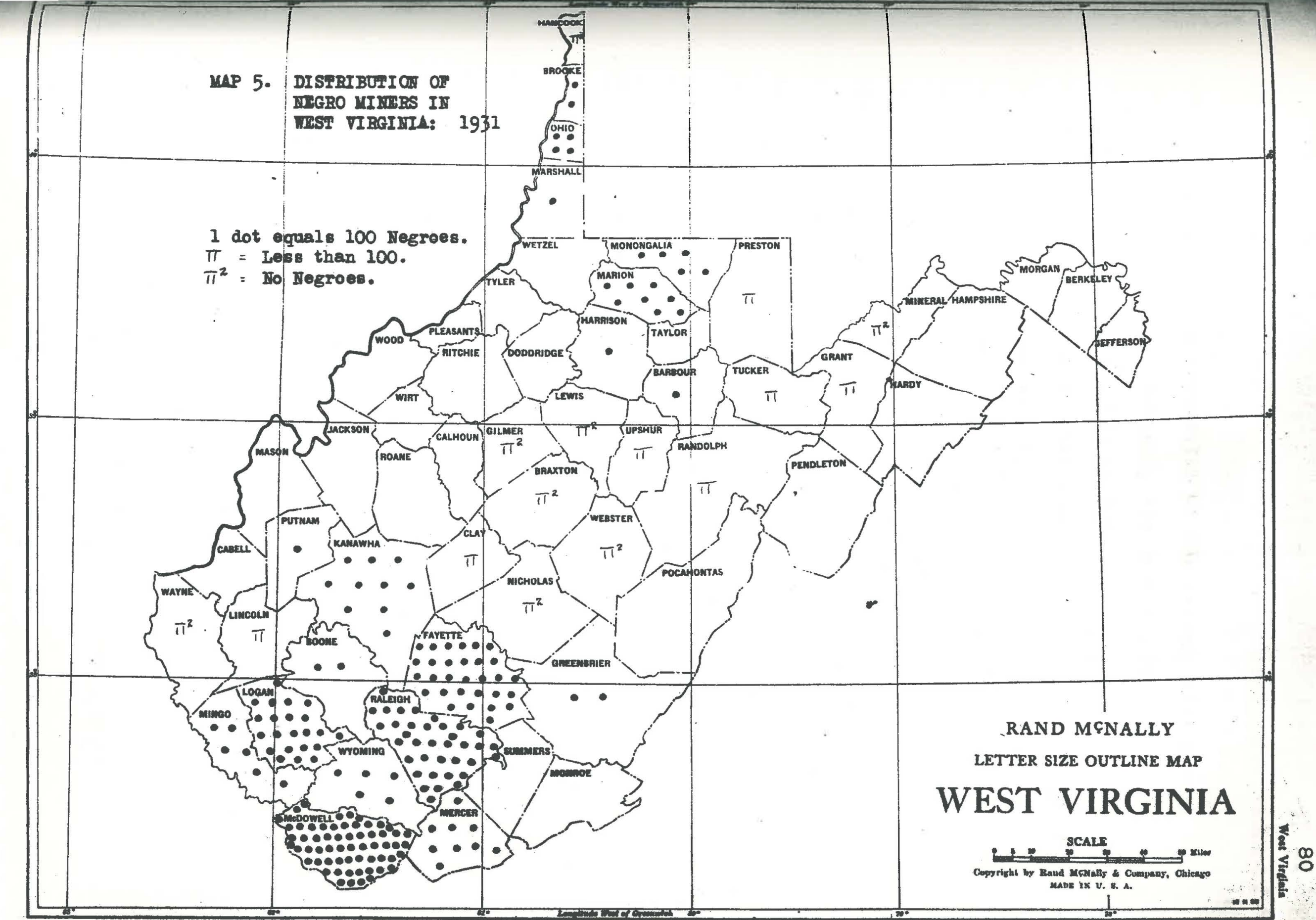

MAP 5. DISTRTBUIIOA OI DTGRO VIXISBS II

Negroes. $\pi=$ Less than 100 .

= Io Negroes.

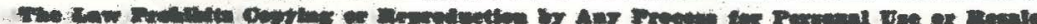


has the largest Jegro population of my county, with 3,033 Negro miners employed. Palelgh, the eecond county in number of Negroes, wh 3,533 Negroes emsloyed, has been tilid in the proluction of coal gince 1932. Fiyette, with 3,060 Negro miners employed, ia the third in Nagro posulam tion and fourth in the production of cosl. Logan, rith ?.312 Negroes, was second in the production of coal. Kanawha, flfth in the number of Negroes, was seventh in production. These countles, as pell as the less 1mportant count1ea, from the stendpolnt of Negroes employed, sare ranked in production and Negro population in the following 11 table:

11 Complled.from Dept. of Mines Report, 1331 


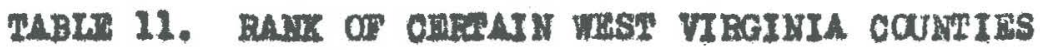

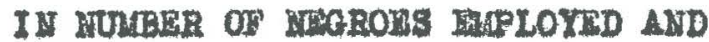
PRODUCRI OA OP COAL 2931

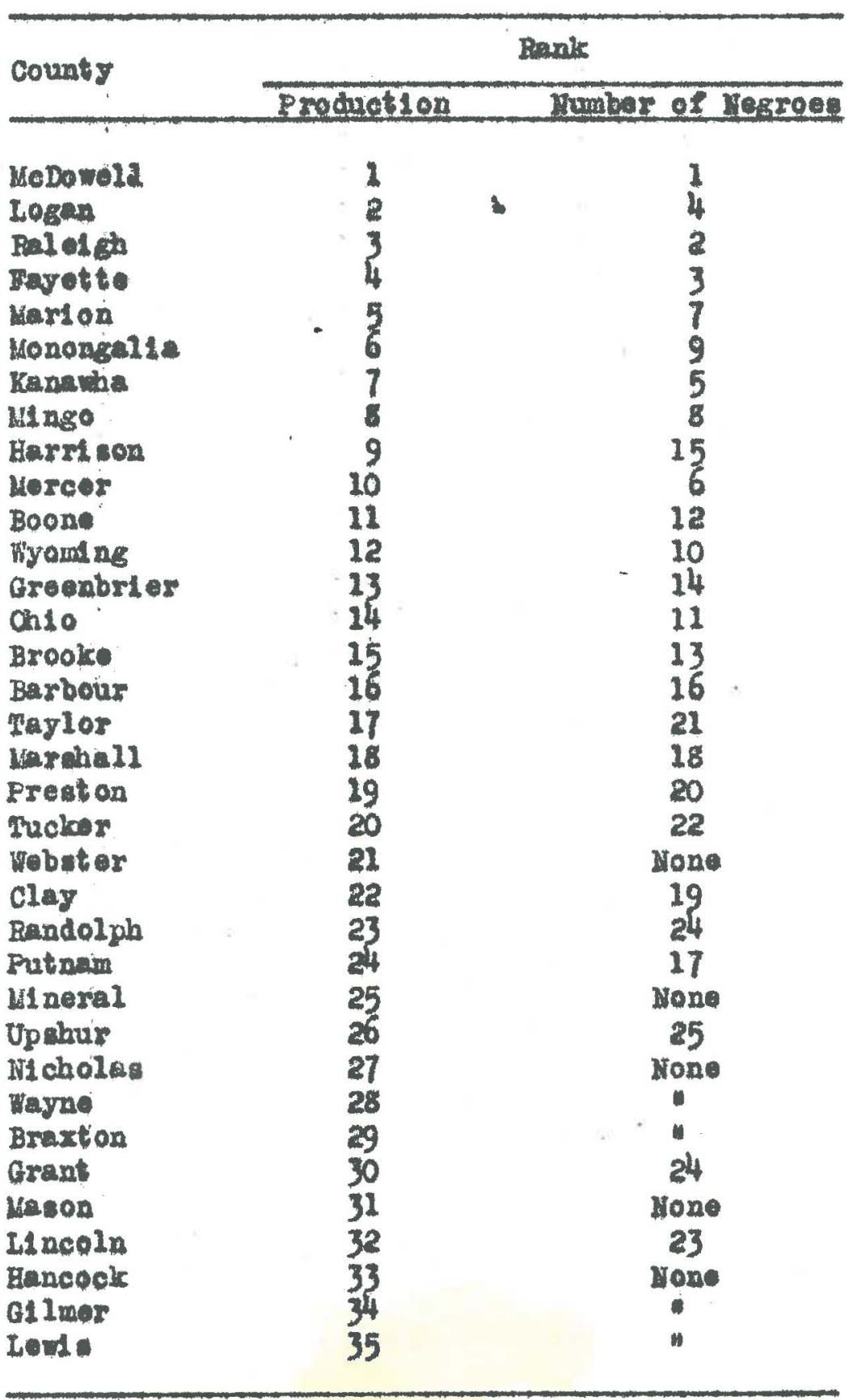


If one were to dra a Iine through the oentere (see map) of Pleagants, Fitohto, G1Imer, Braxton, Rebater, and Pooahontas count1es, the state may bo, so far as tho Megro ia conoerned, divided oonventently into a northern and a couthern division. Q12mer, Braxton, and Webster are minlng oounties, but employ no Hegro miners, henoe, they are unimportant for our otudy. Any oounty south and weat of the Iine way be conaldered in the eouthern fleld and any county north and east of the 11 ne may be conoldered as belonging to the northern ileld.

The Negro population of West Virginia is largely conoentratid in the couthern oount 10e. MoDowell, Ralelgh, Fayette. Logan, Kanamha, and Maroer, the firat six counties in point of Negro minlng populetion are all in the southern area. Marion County, the oventh in point of Nagro minins population is in the northern seotion, es are Monongalia, Ohto, Brooke, and Harrison, ranking ninth, eleventh, thirtaenth, and fiftenth rospootively. The counties in the southorn seotion inoluding. In addition to the oix already mentioned, Wyomint, Mingo, Putnaw, Boone, Clay, and Groenbrier contain 18,834 Negro miners or 87.8 par cent of the Nagro mining population of the state. The countles in which the eohedules of Negro miners were taken were the firet If in population: MoDowell, Ralefgh, Rayotte, Logan, and Kanawha. These five count1es have a Negro mining population of 16,050 or 74,6 per cent of all the Negro ridners in the state or 85.4 per cont of the Negro 
miners in the southern seotion,

Not only is the Negro population larger in the Bouthern counties, but it ooouples also a larger place in the minling laduatry in the southern oountios. In no northern county do the Hegros oongtitute as moh as 30 per oent of the minlng population. In three of the southern coun$t i \in g$, MoDowel2, Rallelgb, and Hyoming, the Negroea constitute more than 30 per osen of the total number of miners, with 34.6, 30.1, and 32.9 par cont respeotirely. Oh10 County, in the northern Ileld, whll it has only 433 Negroes, 23.7 per cent of 1 ts mining population belong to that group. In the soutbern section, however, there are four oounties in whloh the Negroes oonstitut between 20 and 30 per oent of the minfing population. In three of the northern oountiog the Nogroes are between 10 and a per cent of the mining population, while in the outhern oounties there are flve in this olase. In the northern Ileld, in nine oounties the Hegroes oonstitut less thun 10 per cont and in seven others there are no Negroos. In the southern count 1e日, howerer. Negroes oonstitute more than 10 por cont in every oounty where there are legroes enployed at all. Two counties in the southern geation do not employ Negroes, Enough ha been ald to deronatrate clearly that the southern oount1es, whob constituted the fleld for the present etudy, are the important counties in the state so far es the Negro 10 ooncerned.

The nativo whtte oonstitute an aotual majority 
in every county, botb in the northern and southern seotions, exoept in the two northern Panhandle oount les of Brooke and 0h10. Here the nutive ghites constitute only 35.3 and 19.4 per cent respectively. The explanation of this small number of native thltes is partly in the raot that these counties sre contiguous wh Popnoylvania, in which stato the forelgnborn constitute a inajority. In both countiea the foreignborn aning population is more then fifty per cent of the entire mintar population, The vegroes in Ohio County outnumbar the native wites but the Negroes form a smaller part in 3rooke County. Another factor wilch is partiy responalble for the mall number of native mhites in these counties is the tendenoy of the native mitteg to leare a fleld after a strike. After the strike of 190a, many of the native whites of the "better clase" went to the IIdde 13

Fest. Between the yesrs of 1920 and 132 a the Negro population in both countle almost dcubled during and after the 1 abor troubles about 1931. There as another decided increase botween the years of 1325 and 1337 , after the 14 strike of 1325. Fith these exceptions, the native Fintes are everywhere in a majority, belng in some counties, as we noted, the only racial or national group. It should bo said, hovever, that these countles are negligiblo in 1raportance as mining counties. The percentage of native whites II U. S. Immigration Commisalon, Report (on Bituminous Coal Uining), 1311, Vo1. 7, p. 153.

13 Bureau of Negro Telfare \& Stat1at10s, Report, $1935-33,0.23$.

14 Bureau of Negro ielfare \& Stat1st10s, Report, $1327-23, p_{0}$. 16. 
In the mining induatry of the atate is 61.1.

The peroentage of the forelgn-born in the varloue oount1es throughout the state fluotuatea more than that of the Negro. The peroentage rang is from zero in Wayne. 15 Mason. Lewds, and $01 \mathrm{Imer}$ to 55.3 per oent in Brooke County. As has already boon mentioned, the forelgn-born are the majofity group in the ming population of both Ohio and Brooke oountie in the northern Panhandle. Marshall County, also anhandle oounty, oomes next with 41,4 per cent forelgn-born. Four other northern counties, Hancock, Harrieon, Marion, and Monongalia, have between 30 and 40 per cent fore1gn-born. Barbour County is the only county to have botween 20 and 30 per cent of this group. Logan County has the largest percentage of forelgn-born of any of the southern count1es, Ith 19.8 per cent. MoDowe1l, the county with the largest number of Hegroes ab well ab the largest percentage, has 14.2 per cent forelgn-born. Raleigh, Fayette, and Boone, outhern oount1ea, have 13.0, 11.3, and 13.8 per oent reapeotively. Preston, the only other county baving between 10 and 20 per cent forelgn-born with 15.8, 1s northern county. A1l other oounties have 1 ess than 10 per cent forelgn-born. It w11 be clearly seen that, just as the Negro wa more important than any other minority group in the southern countiea, the forelgnborn bolds a larger plaoe in the northorn counties than does the Negro. There is not aingle county in the 15 These counties also had no Negroes employed. 
northern seotion in which the peroentage of the foreignborn 1 is not larger than that of the Negro. On the other kand, with one exoeption, there is no oounty in the southarn section in which the percentage of Negroes is not lurger than that of the farelgn-born. The exoeption is CIay County, whioh has 39 Negroea and 47 forelgn-born, or 3.5 and 7.7 per oent respeatively. The peroentage of the forelgn-born in the ontire otate is maller than that of the Negroes, belng 17.0 as oompared to thelf 31.9 per cent.

\section{Time Diatribution of the Mining Population}

As has already been ment loned, the Negroes and the native whites were the groups relled upon by the early operatore in opening up and developing the various $1102 \mathrm{ds}$. not only in West Virginia but throughout the South. The forelgner, especlally the Bouth-European, wes Introduoed into Weat Virginia oosl 101 ds in $2 a \pi g$ numbers muoh later than in the neigluboring states of Penneylvania and Orio. In 1870 out of total mining population of 1,525 there were only four natives of South turope mployed. 17 By 1880 this number hed grown very ittle, a there were only zis non-Engl1 oh apeak1ng workers out of total of 4,497 . In 1890 there were 6,314 native whttes, 2, 016 Nogroea, and 1,375 forelgners employed in the mines of the state.

I6 See Reports of the U. S. Inalgration Comintsion, 1911, vol, 7 ; p. 136 .

17 Suffurn, ope oit, p. 36.

18 Ib1d.

19 Reports of the U. S. Immigration Commiasion, 1911, Vol, 7, p. 136. 
However, only a11 of theae were Irom oountries other than those of northern Europe. One thoupand and two of this group were of Ingli ab-peaking national1t1es, and 162 were Germans.

The rapla expanaion of the industry following 1890 is the ohiet factor making for the lncraas of the element in the mining flelds ordinarily thought of as morelgn." It should be pointed out that the South Europeans were brought in only after the native supply of labor had proven Inadequate. Between 1890 and 1908 the produotion of coal had lnoreaned almost $81 x-101 \mathrm{~d}$ in Weat Virisinia, with an output of $5,643,946$ tons in 1890 and $40,040,311$ tons 32

in 190\%. In these years, ooourred the remarkuble developmenta, not only in the ofd flelds of the state, but also in the important Norfolk and Western (Pocahontas) and Logen filelds.

In the opening of the Pooahontas Flold ell the 33

nutives poselble were uaed. The Nezroes of Viminia were 24

dopended upon from the very firat, but the oupply eoon becaine inadequate. Aocording to the Report of the United States Coal Cominalon. "Tho Negroes proved to be good employees, but, like the native white people, were Inolined to be irregular workers. It wa bard to get enough wen of these two raoe to keep up with the expansion in the 20 I01d: p, 330.

21 IDId: P. 135.

23 T. Va, Dept, of Minea, Reports of 1890 and 1307.

33 Reports of the U. S. Coal Commlasion, Vol. 7, p. 156. 24 Ibid, D. 145. 
indugtry. ${ }^{25}$ As a result of this ragt, in 1884 or 1885 a few Hagyara were Induoed to come to the seotion from Pannsylvania. with the ldea of atarting the flow of 1 mulgration to the Pooahonta F1e1d. A few Slovaks followed, but the 26 mulibere of both wore small in the early years. Sinoe 10u6, when better rallroad conneotione wero pompluted to the Hidle West, Imulgrant labor Las been oomion. The resulta of the use of Imigrant labor ifter 1600 is ahom by the otatistios on mining and quarrying in West Virginia in 1839 . There were in that year 22,028 nutive whites of native parents, 1,181 aative whites of foreign parenta. 4,620 Negroes and 2,068 forelgn-born en27

lioyed. There were more foralgnera from the southern Luropein countries than formerly among these, but at111 not L lurde percentage. The tendenoy, however, to aupolement nitive white and Negro labor by bringing in large numbere of couthern and eatern European 1 malgranto wa Iul1y under way in the yeare from 1900 to 1907. 28

\section{A. early as 1894 a few rami118 of forelgners}

from aouthern and eastern curope wore introduced at Gien Jean in Fayette County. By 1887 in both Kanawha and Fayette countiee smell number of these Immigranta were to bo found. However, those were confined to a very few mines. During the etrike of 1902 many of these forelgners, as well

\begin{tabular}{lll}
\hline 25 & IbId. \\
26 & IbId & 156. \\
27 & Ibid. p. 136. \\
28 & IbId. p. 137. \\
29 & IbId. p. 151.
\end{tabular}


30

as native whiteo, were brought in from the North. Many. Negroes pertiolpated in this atrike, for they made up about 50 per cent of the workers of the largest mines in the southern count 1es, After the atrike their numbers were somewhat depleted. Many of the whites left the fleld aloo after thl strike, and their places were fillod by a steady influx of forelgners and Negroes from Virginia and North Carolina, The forelgnèr, however, supplanted the former population proportion of the Negroes to a considerable degree for a number of years, as a reference to the following table will indloate.

33

TABLE 12. RACIAL AND MAPIOALC COAPOSITION OF MINSRS IN THE INEW RIVRR - KAMAMHA TIMLD: 1908

\begin{tabular}{|c|c|c|c|c|c|c|c|c|}
\hline \multirow{2}{*}{ Group } & \multicolumn{2}{|c|}{ Fayette } & \multicolumn{2}{|c|}{ Ralelgh } & \multicolumn{2}{|c|}{ Kanawha } & \multicolumn{2}{|c|}{ Total } \\
\hline & Mumber & $\begin{array}{l}\text { Por } \\
\text { cont }\end{array}$ & Number & $\begin{array}{l}\text { Por } \\
\text { cent }\end{array}$ & Arumber & $\begin{array}{l}\text { Pox } \\
\text { cont }\end{array}$ & Number & $\begin{array}{l}\text { Per } \\
\text { cent }\end{array}$ \\
\hline $\begin{array}{l}\text { Hative walto } \\
\text { Negro } \\
\text { Forelga-bora }\end{array}$ & $\begin{array}{l}5.852 \\
3.493 \\
3.030\end{array}$ & $\begin{array}{l}47.2 \\
28.2 \\
24.6\end{array}$ & $\begin{array}{r}1.425 \\
465 \\
681\end{array}$ & $\begin{array}{l}55.0 \\
18.0 \\
27.0\end{array}$ & $\begin{array}{r}5,985 \\
900 \\
1,256\end{array}$ & $\begin{array}{l}73.5 \\
11.0 \\
15.5\end{array}$ & $\begin{array}{r}13,262 \\
4,858 \\
4,967\end{array}$ & $\begin{array}{l}57.4 \\
21.0 \\
21.6\end{array}$ \\
\hline Total & 12,375 & 100.0 & 2,571 & 100.0 & 8,141 & 100.0 & 23,087 & 200.0 \\
\hline
\end{tabular}

Wo may sumarize our discussion of the introduction of the forelgn-born, then, by saying that it was due to two main oauges, the rapld expansion of the industry and the lack of native labor. Acoording to the Immigration

30 IbId.

31 Johnson, The Negro in Amerlcan Civilization, pp. $48-49$.

32 Report of the U. 8. Immigration Comm1ssion, V01. 7, p. 153 .

33 Intd. p. 158. 
Comntagion the laok of sufliolent native labor is due to a leok of efflotenoy and en unwillingness to work in the mines at all times during the year in the okge of the native white, thelr insuficient numbers due to irregular work habite in the oase of the Negro, and the nooesalty for a large labor supply in times of labor troubles and 34

otrikes. The introduction of mining mohinery in the aarly nineties also tended to dioplace the Negro, slnoe lie wa skilled in plok'mining, whlle many forelgners were okilled in the use of this mahinexy.

The northern oount 108 of Weat Virginia have always employed, a we have pointed out, more of the forelign-born than Negroes, unlike the southern oount1es, and inere proximlty to an ample supply la perhaps the best explanstion, Pennsylvanta and Ohlo have always used the forelgn-born in lerge numbera. The so-08lled Elk Garden Distrlot, inoluding the counties of Tucker, Mineral, and Grant oounties, and the ralrmont Dietriot, inoluding Barbour, Herrison, Marion, Monongalia, Preston, and Taylor counties, had a large number of these southern Luropeans in 1911. The Amerioan wh1tes oonstituted 52.5 per cent of the inining population and the Negroes 3.4 per cont. The other 44,1 per oent were forelgn-born and were distributed nationaliy as follows: Italians 38,6 per oent; Magyars 6.5 per cent; Pol1eh 5.5 per cent; 8lovaks 5.5 per cent; 34 IbId. P. a20. 35 Johnson, op cest, p. 49. 36 Barris, A, L, Opportunity, February 1926, p. 47. 
Croation 3,0 per cent; Engliah and Germans 3.0 per cent: and the additional 3.0 per cent were made up of otlier south eastern European nat 1onalities. 37 This flow of 1 malgration 1nto the Weat Virginia lelda has been oontinuous. In the perfod between 1910 and 1915 there was some falling off in the stream of Imatgration to Ohto, greater deorease in both Indiana and IIIInola, sl1ght Inorease in Pennsylvanla; but Veat Virginle bowed very marked increase, gatting more than her proportionate share even in the period between 1915 and 1920, when the stream of imigration 38

almoat oam to a otop. Sino the atrike of 1925 the Negroes have been somowhat more abundent in this northern fleld, but the forelgner at111 romains in greater numbers. The following table w11 ahow the relative percentages of the native whites, Negroes, and foreigners in the state 39

from 1907 to 1931.

37 Reports of the U. S. Immigration Cominasion, VoI. 7 , p. 147.

38 Report of the U, S, Coal Comiealon, 1935, Pt, 3, p. 1416.

33 Conplled from the Wh. Va. Dapt. Annual Feporto, 19.571931. Unfortunately, the Dept. of M1nes seoured no detic on raglal or national composition of inizers before 1907. 
TABIF 13. RACIAL AND MTIOUAL COAPOSITION OF WIST VIROINIA MINERS: 1907-1931

\begin{tabular}{|c|c|c|c|c|c|c|c|c|}
\hline \multirow{3}{*}{ Year } & \multicolumn{2}{|c|}{ Nat1ve wates } & \multicolumn{2}{|c|}{ Hegroe } & \multicolumn{2}{|c|}{ Porelgn-born } & \multicolumn{2}{|c|}{ Total } \\
\hline & & Per & & Por & & Per & & Per \\
\hline & number & cent & number & cent. & Niunger & cent & Number & cent \\
\hline 1907 & 20,409 & 30.2 & 9,908 & 17.6 & \multirow{5}{*}{\multicolumn{2}{|c|}{ (noe note 40) }} & 56,209 & 100.0 \\
\hline 1908 & 23.979 & & 11.270 & 18.6 & & & 60,484 & 100.0 \\
\hline 1909 & 24,696 & & 10,550 & 16.9 & & & 62.189 & 100.0 \\
\hline 1910 & 28,301 & & 12,087 & 17.7 & & & 68.135 & 100.0 \\
\hline 1911 & 30,094 & 42.6 & 11.950 & 16.9 & & & 70.644 & 100.0 \\
\hline 1912 & 31.696 & & 13.403 & 19.2 & 24,512 & 35.3 & 69,611 & 100.0 \\
\hline 1913 & 32,612 & 45.4 & 14.506 & 20.6 & 23.203 & 34.0 & 70,321 & 100.0 \\
\hline 1914 & 36,101 & 46.3 & 13.357 & 17.1 & 28.583 & 36.6 & 78,041 & 100.0 \\
\hline 1915 & 37.918 & 46.6 & 11, & 14.5 & 33.392 & 38.9 & 81,328 & 100.0 \\
\hline 1916 & 41,048 & 51.3 & 15.060 & 18.8 & 23.950 & 29.9 & 80,058 & 100.0 \\
\hline 1917 & 49.237 & 55.3 & 18,128 & 20.4 & 21.300 & 24.3 & 88.665 & 100.0 \\
\hline 1918 & 51,468 & 55.8 & 17.829 & 19.3 & 22.835 & 24.9 & 92,132 & 100.0 \\
\hline 1919 & 51,404 & 56.2 & 16,481 & 17.9 & 23,681 & 25.9 & 91.566 & 100.0 \\
\hline 1920 & 56,913 & 58.5 & 18,391 & & 22,122 & 22.7 & 97.426 & 100.0 \\
\hline 1921 & 64,373 & 55.2 & 20,781 & 17.8 & 31.572 & 27.0 & 116,727 & 100.0 \\
\hline 1922 & 58,274 & 54.3 & 21,388 & 19.7 & 28,047 & 26.0 & 107.709 & 100.0 \\
\hline 1923 & 70.460 & 58.2 & 22,421 & 18.4 & 28,399 & 23.4 & 121,280 & 200.0 \\
\hline 1924 & 65.583 & 56.6 & 22,796 & 19.6 & 27.585 & 23.8 & 115.964 & 100.0 \\
\hline 1925 & 66.799 & 59.8 & 23.990 & 21.5 & 20,919 & 18.7 & 111,708 & 100.0 \\
\hline 1926 & 73,601 & 61.0 & 24,798 & 20.6 & 22.239 & 18.4 & 120,638 & 100.0 \\
\hline 1927 & 72.141 & 60.3 & 25.335 & 21.2 & 22.142 & 18.5 & 119,618 & 100.0 \\
\hline 1928 & 68.236 & 60.6 & 23.987 & 21.2 & 20,528 & 18.2 & 112,751 & 100.0 \\
\hline 1929 & 65.325 & 60.8 & 23.941 & 22.3 & 18,127 & 16.9 & 107.393 & 100.0 \\
\hline 1930 & 66.022 & 61.2 & 23.523 & 21.8 & 18,287 & 17.0 & 107.832 & 100.0 \\
\hline 1931 & 59.844 & & & 21.9 & 16.595 & 16.9 & 97.953 & 100.0 \\
\hline
\end{tabular}

40 Due to the initiation of reports on nat lonalities in 1907 the returns for that year and those following were very incomplete until 1912. The number of miners of unknown national1t1es for those years were: 13,115 in 1907, 8,707 in 1908, 10,661 in 1909, 7,545 in 1910, and 6,305 in 2911 . 
Considering the atate as a wole, then, we nay aay. In summary, that the Negroes and nut Ive whitas conatituted the bulk of the raining population unt1 I after the beginning of the great expansion of the industry in 1892. In 1890, the ditribution was as followe: Native whiteo 64.8 per oent. Negroes 20.8 per cent; and the forelgn-born 14. 4 per oent. By 1899, in the mine and quarries of the atate the distibution was: Native whiteo 33.5 per cent. Negroes 33.3 per oent. und the folelgn-born 14.3 per cent. However, after the strike of 2902 the native whitea and Negroes were both applanted by forelgnerc oo that by 1907 the percentage of native whites had fallen to 36.3 per cent and that of the Iegroes to 17.6. From that time on however, there has been a teady gronth in the peroentage of native white unt11 in 1931 the native whitos were more than sixty per oent of the mining population. The number of forelgn-born, however, exoeeded the number of Negroes ovory year from 1807 unt11 19a5, the year of the great etrike In nortbern West V1rglnis, 8inoe 1935 the Nezroes heve out numbered the forelgn-born every year. The Negro mining population in the various oountles from 1907 to 1931 may bo seen in Tables 14 and 15. It $1 \mathrm{~s}$ unfortunate for our study that annual 1 gures are not avallablo prior to 1907. The Department of Unes made no attempt to secure such data before that date. 41 Census of 1990, Vol. II. 4 U. S. Imrigration Roporta, 1311. Vo1. 7, p. 135. 


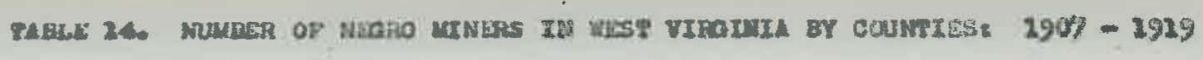

\begin{tabular}{|c|c|c|c|c|c|c|c|c|c|c|c|c|c|}
\hline County & 1907 & 1208 & 2909 & 2920 & 1921 & 1212 & 1923 & 1914 & 3225 & 3226 & 3217 & 1218 & 1922 \\
\hline Earbour & 76 & 74 & 68 & 2 & 67 & 67 & 84 & B4 & 67 & 64 & 65 & 97 & 205 \\
\hline Boese & & & 4 & 13 & 23 & 63 & 46 & 68 & 214 & 151 & 95 & 257 & 205 \\
\hline Branten & 1 & 2 & 2 & 4 & 7 & 9 & 3 & 9 & 7 & 0 & 49 & 72 & 55 \\
\hline Broctse & 36 & 8 & 38 & 29 & 12 & 27 & 4 & at & 55 & 52 & 49 & 4 & 192 \\
\hline cas & & & & & & 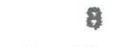 & 28 & 89 & 13 & 78 & 50 & 54 & 47 \\
\hline Faysutte & 2,702 & 9,092 & 2,949 & 3,209 & 3.959 & 3,091 & 3.554 & 2,836 & 2,620 & 3,024 & 3,234 & 3,097 & 2,055 \\
\hline Gumar & & & & & & & 9 & 9 & 11 & 3 & 6 & & a \\
\hline Gevent: & & & 13 & & & 25 & & & 1 & & & & \\
\hline Grwanheres & & & 2 & & & & & & & & & & \\
\hline Ferratean & 151 & 146 & 132 & 84 & 70 & 227 & $10 x$ & 104 & 139 & 89 & 300 & 520 & 44 \\
\hline Yunathe & 693 & 654 & 626 & 777 & 864 & 975 & 850 & 895 & 690 & 924 & 890 & 1,009 & 645 \\
\hline \multicolumn{14}{|l|}{ Lerit } \\
\hline Lnamin & & 7 & & & 3 & & & 5 & 3 & 90 & 46 & 21 & 37 \\
\hline Lagan & 23 & 167 & 201 & 253 & 120 & 223 & 374 & $\triangle B A$ & 480 & 675 & 2.395 & 1.535 & 1,605 \\
\hline melon & 203 & 128 & 117 & 96 & 125 & 145 & 162 & 223. & 193 & 294 & 573 & 580 & 40 \\
\hline xarbex & 3 & 10 & 3 & 1 & 30 & 55 & 6 & 9 & 5 & 7 & 12 & 15 & 20 \\
\hline rasoan & 4 & 7 & B & 9 & & 8 & & & & & 2 & & \\
\hline Honon 11 & 4,300 & 5.237 & 4,419 & 5.275 & 5,274 & 5,394 & 5.732 & 5,040 & 4,350 & 6,429 & 6,914 & 6,411 & 5,897 \\
\hline Hereser & 1,022 & $6 / 4$ & 927 & 1.2155 & 934 & 1,214 & 1,247 & 1,264 & 1,176 & 1,222 & 1,105 & 1.167 & 975 \\
\hline Hetatine & 24 & 17 & 16 & 22 & 17 & 25 & 18 & 15 & 22 & 13 & 19 & 7 & 5 \\
\hline unge & 123 & 212 & 243 & 224 & 228 & 491 & 565 & 962 & $2 a 1$ & 289 & 487 & 485 & 490 \\
\hline tranaperat & 22 & 10 & 5 & 50 & 3 & 36 & 4 & 4 & & 4 & 29 & 61 & 89 \\
\hline Mataines & & & 2 & 12 & & 10 & 5 & & & & & & 2 \\
\hline onto & 28 & 12 & 6 & 22 & 37 & 55 & 28 & 37 & 26 & 24 & 57 & 89 & 62 \\
\hline Prestom & 41 & 18 & 23 & 17 & 36 & 197 & 25 & 39 & 33 & 30 & 43 & & 46 \\
\hline Proteran & 10 & 101 & 210 & 51 & 60 & 293 & 144 & 149 & 145 & 104 & 96 & 79 & 64 \\
\hline Pexeln & 309 & 383 & 455 & 75 & 856 & 997 & 2.292 & 1,422 & 1,255 & 1,319 & 1,923 & 1.794 & 2,799 \\
\hline Dandolgh & & 6 & & 1 & 1 & 30 & 4 & 2 & 5 & 5 & $\mathbf{n}$ & 15 & 28 \\
\hline \multicolumn{14}{|l|}{ Sutamas: } \\
\hline Tovio: & 21. & 13 & 14 & 6 & 11 & 24 & 37 & 30 & 20 & 18 & 23 & 46 & 16 \\
\hline rudcer: & 75 & 84 & 74 & 66 & 88 & 70 & 83 & 59 & 59 & 94 & 40 & 89 & 70 \\
\hline Uptous & 22 & 5 & 3 & & 1 & 2 & & 2 & 1 & & 2 & 1 & 4 \\
\hline Suno & & 4 & & 1 & 1 & 2 & & & 1 & 1 & 2 & 1 & 1 \\
\hline Evoding & & & & & & & 5 & 28 & 75 & $2 / 4$ & 442 & 443 & 409 \\
\hline Tolala & 2.200 & 12.720 & 20.550 & 22,092 & 11,250 & 13.403 & 14,506 & 13,357 & 12.035 & 15,060 & 29.128 & 17,029 & 16,431 \\
\hline
\end{tabular}




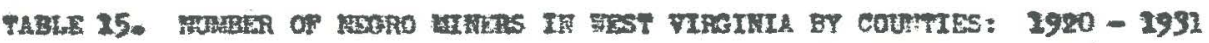

\begin{tabular}{|c|c|c|c|c|c|c|c|c|c|c|c|c|}
\hline Count & 1220 & 3923 & 1922 & 1923 & 1924 & 1925 & 1926 & 1927 & 2928 & 2922 & 1930 & 2931 \\
\hline Barbour & 246 & 24 & 22 & 161 & 166 & 97 & 98 & 131 & 165 & 137 & 92 & 117 \\
\hline Eoone & 302 & 298 & 358 & 426 & 460 & 431 & $3 \times 4$ & 393 & 305 & 36 & 223 & 209 \\
\hline Exaxton & 34 & 33 & 30 & 42 & 24 & 35 & 22 & 31 & 14 & 22 & & \\
\hline Eroots & 128 & 258 & 244 & 385 & 320 & 263 & 261 & 347 & 394 & 919 & 365 & 240 \\
\hline ans & 34 & 67 & 109 & 106 & 76 & 93 & 79 & 113 & 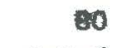 & 79 & 66 & 39 \\
\hline montte & $3,0,6$ & 3,260 & 2,552 & 3,204 & 2,967 & 3,136 & 3,062 & 3.177 & 3,926 & 3,316 & 3,436 & 3,060 \\
\hline exlow & 8 & B & 10 & 16 & 7 & 5 & 4 & 8 & 15 & 1 & & \\
\hline Exant & & 5 & & & 2 & 3 & 2 & 2 & 4 & 11 & & 3 \\
\hline cruomberer & & & 190 & 111 & 169 & 200 & 297 & 26 & 173 & $\mathbf{n} 77$ & 233 & 22 \\
\hline Derriteon & 506 & $m$ & 66 & oss & 757 & 48 & 459 & 42 & 42 & 201 & 278 & 167 \\
\hline Exuming & 68 & 1,290 & $2,0,0$ & 2,462 & 1,373 & 1,560 & 1,548 & 1,391 & 902 & $m$ & 2,000 & 2,054 \\
\hline Lowi: & 2 & 2 & 2 & & & & & & & & & \\
\hline Heceln & 17 & 32 & 24 & 6 & 59 & 32 & 62 & 55 & 24 & 36 & 36 & 25 \\
\hline Lowan & 1,752 & 2,068 & 3,002 & 2,45 & $29 n 2$ & 2,74 & 2,760 & 2,094 & $, 2,512$ & $2, \sqrt{12}$ & 2,106 & 2,212 \\
\hline turtan & 693 & 692 & 592 & 703 & 642 & 1,203 & 1,642 & 2,606 & $47<2$ & 1,675 & 1.420 & 69 \\
\hline Exindal & 24 & 97 & 76 & 6 & 2 & 24 & 127 & 223 & 236 & 32 & 127 & 106 \\
\hline \multicolumn{13}{|l|}{ moxn } \\
\hline NoboneII & 6,905 & $6 \times 10$ & 6,499 & 5,996 & 6,407 & $6.7 \times 6$ & 6.937 & 6.594 & 6,536 & 6,861 & 6,695 & 6,092 \\
\hline vartear & $8 x 9$ & 1,008 & 1,021 & 978 & 877 & 929 & 925 & 973 & 1,063 & 1,022 & 992 & 965 \\
\hline inder & 3 & $\mathbf{z}$ & & & 1 & 3 & & & & & & \\
\hline $\tan 80$ & 53 & 528 & 65 & ece & 727 & 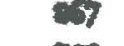 & 05 & 650 & 78 & $7 \%$ & 750 & 610 \\
\hline Hencolin & 155 & 209 & 34 & $3 / 5$ & 30 & 703 & 2,30 & 565 & 731 & $8 x 2$ & 721 & 591 \\
\hline Itome & 4 & 6 & 3 & & & & & & & & & \\
\hline ato & 13 & 93 & 184 & 212 & 22 & 175 & 82 & 427 & 519 & 489 & 48 & 39 \\
\hline Proctan & .38 & 38 & 38 & 50 & 25 & $\mathbf{x}$ & 5 & 34 & 22 & 19 & 29 & 23 \\
\hline Putunen & 56 & 4 & 46 & 9 & 9 & 87 & 52 & 45 & $a$ & 39 & 37 & 116 \\
\hline melets & $2,-156$ & 2,608 & $27 n$ & 2.934 & 2,696 & 3,366 & 3,107 & 3,40 & 3,48 & 3,51 & 3,613 & 3.692 \\
\hline Andaph & 20 & 2 & 39 & 37 & 22 & 14 & 18 & 15 & 12 & 2 & & 3 \\
\hline somente & & & 4 & & & & 2 & & & & & \\
\hline exhor & 4 & 4 & 35 & 68 & 2 & 12 & 22 & 4 & 37 & 22 & 29 & 20 \\
\hline Trober & 60 & 75 & 4 & 46 & 57 & $\Rightarrow$ & 28 & 91 & 34 & 34 & 17 & 17 \\
\hline Upmear & 5 & 9 & 28 & 24 & 13 & 17 & 26 & 15 & 7 & 6 & 3 & 1 \\
\hline White & 1 & 1 & & & & & 1 & & & & & \\
\hline itater & 574 & 26 & 275 & Ess & 20 & 200 & 02 & 276 & 500 & 525 & 630 & 509 \\
\hline stase & 20,31 & 30.721 & $u_{1}+28$ & $22+1$ & $2-76$ & 28,00 & 24790 & 25,532 & $23-997$ & $34 \times 1$ & $x+5$ & 22,25 \\
\hline
\end{tabular}




\section{Axe Dietribution}

It is probably true that the Hegro mining population 18 somewhat older than the white group. Mining is by no means an eagy ocoupation and he who remains in the more mental jobs mat have unusual atamina or else be foroed to remain in it by ciroumatanoes other, than his own wishes, The fact that the Negro ooouples positions whioh be doea not care for or for whioh he no more "raclally adapted" than any other group is oomonplaoe. ${ }^{43}$ wherever the Negro turns he is constantly hodged in by oultural "deadIines that make his pasing from one oocupation to another more to his taste very diffloult. This faotor is undoubtedly operative in keeping many a Negro in the ooal flelds. In faot, his disatiafeotion with oonditions, and his inability to leave thom, is a oultural faot of a great deal of importanoe, as w111 appear in some of the disoussions in the later chapters of this study. Wany of these miners did not come to West Virginla with the idea of staylng, but were attraoted by the comparatively hlgh wage and a certain freedom. They intended to accumulato oertain anount of wealth, whloh feat many of them were led to belleve would be quite eary in Weat Virginia, and then to return to their homer in the south or east. However, many of thein found that it was muoh harder to $d 18 \mathrm{gold}$, in the form of coal, from the h111s of Weat Virginia than the 43 Cf. Feldman, Herman, Reolal Fuotorg in Amerioan Indugtry, Harpers, 1931, pp. 34ff. 
storiea of prosperity had indioated. Having taken on the added burden of a 1 amlly, many of them remalned although never satiafied. This disatiafaotion bar been inculcated in their sone, who tend to avold the mines. The nowoomers from the south are sometimes well along in years before leaving the south.

The ages of the Negro miners studied were somewhat older than those found by the United Stateo Coal Comuision who had aoceas to the facilities of the sohedules of the 1920 oensua. The aotual disperity between the

TABLE 26. 44 COLPARISON OF THE AGES OF ALI MIINERS IN WIST VIMAIMA IN 1920 WITH THOSE OF 600 MEORO UIMAR IN 1932

\begin{tabular}{|c|c|c|c|c|}
\hline \multirow[b]{2}{*}{ Age: } & \multicolumn{2}{|c|}{ Al1 ut nor: } & \multicolumn{2}{|c|}{ Hegro uL ner: } \\
\hline & Number & $\begin{array}{l}\text { Por } \\
\text { cent }\end{array}$ & Humber & $\begin{array}{l}\text { Por } \\
\text { cent }\end{array}$ \\
\hline 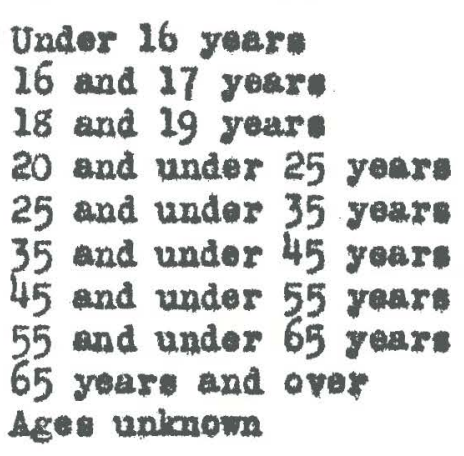 & $\begin{array}{r}379 \\
4,227 \\
5,890 \\
15,968 \\
28,206 \\
21,239 \\
11,345 \\
3,750 \\
1,211 \\
242\end{array}$ & $\begin{array}{r}.4 \\
4.5 \\
6.3 \\
17.3 \\
30.6 \\
23.0 \\
12.3 \\
4.2 \\
7.2 \\
.3\end{array}$ & $\begin{array}{c}\text { (seo no } \\
1 \\
10 \\
64 \\
156 \\
185 \\
105 \\
51 \\
9 \\
19\end{array}$ & $\begin{array}{r}45) \\
.2 \\
1.7 \\
10.7 \\
26.0 \\
30.8 \\
17.5 \\
8.5 \\
1.5 \\
3.1\end{array}$ \\
\hline Total & 92.357 & 100.0 & 600 & 100.0 \\
\hline
\end{tabular}

census figures and those representing the real ages of the Negro ininers would probably be greater than that shown in 44 Figures for all miners taken from Report of the U. S. Cosl Comint ssion, 1925, Pt. 3, p. 1420.

45 W. Va, law now forblds employment under 17. Boys of 17 may work under the tutelage of the1r fathers. 
Table 16. Ther was a tendenoy for the older Negro Minero to misrepresent their ages, The west Virginie Compeneation law gets its upport from the mining oompanies and the rate of eaoh oompany 1o determined by its agoldent rate of the previous year, This laot lead the oompanies to disorininate in favor of younger employees in hiring men. Consequently, it was not unusual to find wegro miners giving or 60

the1r ages as 35 when $55 /$ would have been muoh nearer the truth, The ages expressed in the table are the ages as given by the miners. Up to a certain age, however, the answers were apparently trutheul. It w121 be notlood that the modal age for all the minera in 1920 was from 35 to 35 years. The modal age for the Negro minere, however, wa from 35 to 45 years, Probably the larger percentage oinployed in the 18 and 28 year age group is due to the differenoe between the extreme prosperity of 1930 and the depressed conditions in 2932. In 1920, the era when miners "wore o11k ohlite" and drove expensive autorob110e, many of the boys of those ages went 1nto the mines. In 193a, many of the minera' song of these agee were 1dle, even those who customar1ly worked in the mines.

\section{Marital Status}

The only Iigures with which any comparison in the matter of the marttal status of Negro minere in 1932 can be mide are the figures of the United States Coel Commision taken from the 1920 ceneus sohedules, Two years could 
hardly be ploked in which the dfflcultien of oomparison would be greater. The yoar 1920 was, as has been already pointed out, a year of great prosperity in which certain coal companies pald 100 per cent dividende, some even more. The year 1932, on the contraxy, is one of greatest depresslon, the mining population dropping from approximately 120,000 in 1927 to 108 s than 95,000 in 1932. 46 Iy, there is a deal of dfferenoe in the maxital status of suob a population as that of 1920 and that of 1932.

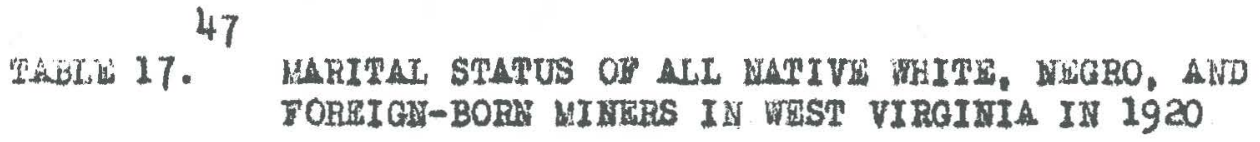

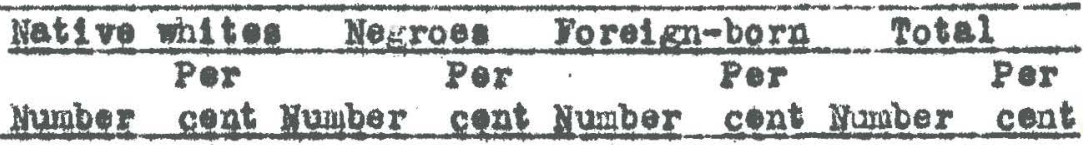

singlo Married, wlo present Karrled, wlo not present Hidowed and di woroed Martial atatu unknown
18,718

33,068

1,727

1,919 59 $\begin{array}{ll}33.7 & 6.709 \\ 59.6 & 9.576\end{array}$ $3.11,222$ 3.5

\section{4}

52.17 .801

6.72 .914 4.6 .2
Conerquent-

\section{Sotel}

55.491100 .018 .376100 .018 .490100 .092 .357100 .0

Not only is there a differenos of eaonomto conditions in the mining flelde, but the methods of oompliation were different in the oase of the present study. The censur data records the faot of whother a wife was present in the home or not, but does not attempt to say whether the parties 46 Address of R. M. Lamb1e, Chlef of the Departiment of Minea of the State of Fest VIrginia before Kanawha Valloy Mining Institute, Cannoiton, W. Va., Jan. 13, 1933.

47 Complled from Report of the U. S, Coal Commision, Pt. 3, p. 1506. 
were separated or not. The present study, on the other hund, emphasiaed the question ar to whether the parente were living apart boause of marital difficulties or merely because of economis reason. In the study of the Negro oincr thia dietinetion is important. A number of the ininere, a has been mentioned, maintain homes for thelr familles in the olties, on the farm, or in a nelghboring town. Thus, the 11gures are hardy comparable, but are given for that thay aro worth.

\section{TLBLI 18. MARTTAL STAFUS OR 600 HEGRO MTMES III VDST VIBCIUIA4 1932}

\begin{tabular}{|c|c|c|}
\hline Marttal statu & Mamber & Per cent \\
\hline $\begin{array}{l}\text { Single } \\
\text { Married } \\
\text { separated } \\
\text { Widowed and if rorced }\end{array}$ & $\begin{array}{r}105 \\
456 \\
4 \\
35\end{array}$ & $\begin{array}{r}17.5 \\
76.0 \\
.7 \\
5.8\end{array}$ \\
\hline Total & 600 & 100.0 \\
\hline
\end{tabular}

The flrot differenoe between the two tables is that the present otudy reveals a smaller percentage of angle men in the industry. In faot, the average for the state in 1930 was wore than twioe that of the atudy. Such a fict, however, is not wurpriaing in view of the rapid deoline in minine population binos 1987, soncomitant with the dexreasion. Two facts may be introduoed to expliain this difference. When times boome dull and work is 1 rregular the unattaohed naner is the first to leave. Many of 
the single men left the mines for other occupations. More Important, probably, 18 the faot that the oompanies tend to keep thelf married men, from whom they get rent as well as a lerger trade in the company store. If men bave to be digoharged on eooount of a neoosary out in labor force, the single men are let out 11rat. Another reason is the fact that benevolent employera are more prone to out off the alnglo men in order to oause the least amount of suffering on the part of the families of breadwinnors. As liag been polnted out before, In 1920 many of the ohlldren of minero also worked in the mines. Today these boys of workinis aje are not employed by the nines. These faots would lariely aocount for the disparity in the figures. The very gmall number of "separated" miners probably has a very diroot relationship to the present eoonomio conditions also. The "separated" alao is unattached, except in the oases of the father continuing as the findly hoad and maintalning the home for the ohildren, and 1 a apt to be one of the first to leave the inines under prossure of poor work or disoberge. Another faotor, whloh will be dlaousad more fully in a later obapter, 18 the ruther 200no narital ties that exist ainong oertain groups and whi oh makes quastionablo the truth of many of the anowers given. The older age of the Negro miners, however, coupled with theis living hablts would Indicate that the large majority of the Negro miners at the present time are 11 ving a married men. 


\section{GLAPTER IV \\ SIGRATOEY CEARACI

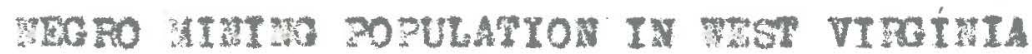

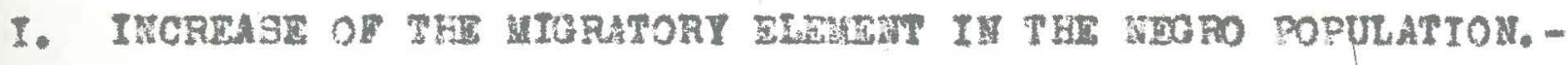

Tho novenent of Weyroea fron other otatos lnto

Weat Virifinla started atrly. Al has been polnted out abov, biere mas a leoldod movement reotmard imodiatoly followin? the Clv11 Far. The bullaing of rallroada from 197) to 1393 brought thousande of Negroes to the New Donlnion from other gtates. The concomitant opaning of the nining flel is prov1led work for others. As a rosult, the charmoter of the Tegro porulation yrex loas and lesa nat170. Boforo the Great mining setivity following 1970, tha Vegro porulation

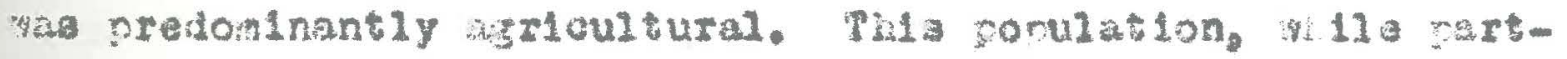
ly migratory in oburacter, was, 1 rom the nature of 1 ta $000-$ noale function. lose 21kely to ba ron-nutro than a porulation created by a adden demand for labor. The following table J111 11luatrate the tand alnoe 1330 s $^{3}$

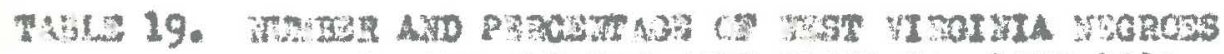

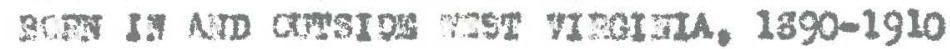

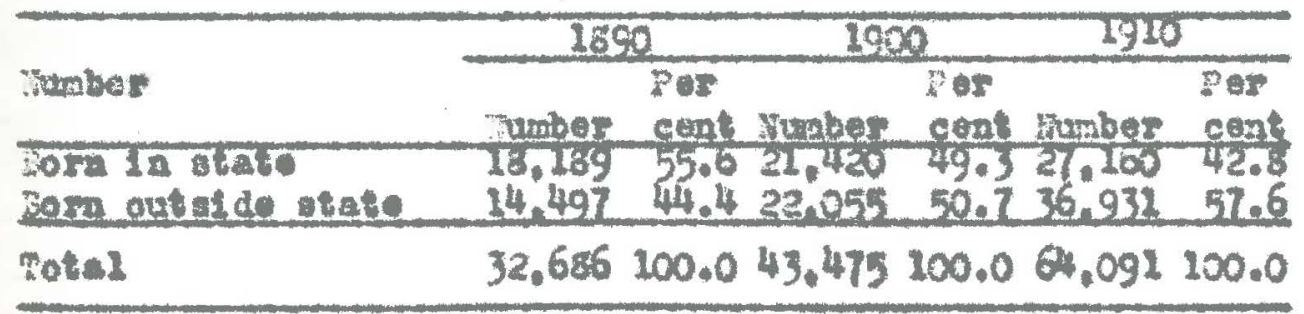


It w112 be peen, thua, that the peroentage of tione born in the state deoremed rom 55,0 por cont in 1890 to 43.8 per ant In 1910. Reoent report of the 1330 consus wow that the native-born Megroes constitutod only 40.8 per oent in that year. At the ane time there ooourred a mot phenomenal inorease of Hegro population. In the decade betwen 1870 and 2880 there was an Inorembe of 44 por cont 1 from 1880 to 1890 dn Inorease of ay por cents from 1890 to 1900 an Inoreaso of 33 per cant/ 1 rom 2900 to 1910 un Inorgate of 48 per oents und frow 1910 to $1930 \mathrm{en}$ inoretse of 35 per oent. This trond had oontimued in the

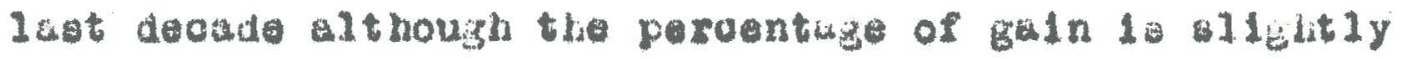
lower than in the previous doowde. The total Negro popular tion In 1930 was 114,893, whilo in 2830 it was ondy $33,345$. The parcontage of inorabe was, thus, 33 per oent, wlinost

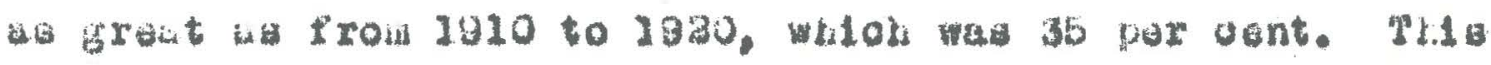
disproportionate growti of the Nogro popujation bes inarwated the peraentage of the entire population for the Nisto sroup frola 5.3 per ount in 1910 to b. 6 per ount in 1935. Ito 1 meortanoe of thew figuros for our wtudy is due to the faot that mora thun 75 par cent of the Negro

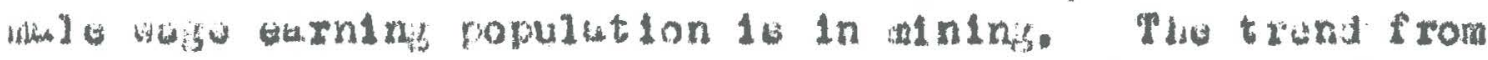

3 Flftwenth Cenous, 193\%, Faprint of Chopter 1, Vol, II, Rarorto on population, 3. 3.3. 35.

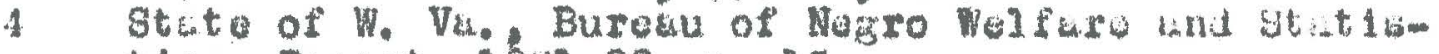
t10s, Raport, 13:3-23, p. 13.

b Plfteanth Cansus, 1330, Population Bulletin, W. Vk. Composition \& Climagtarlistias of the Porulation, p. 5. i Told.

7 Buroun of Hegro telfure 8tatist10s, Report, 1121-3a, p. 13. 
the agrloultural to the ralning population 1 witown by the fiat that the total Nogro rural fiaria population wa ondy

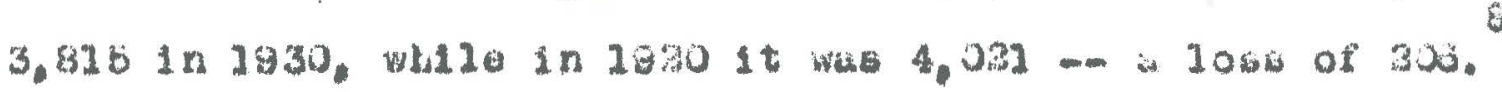

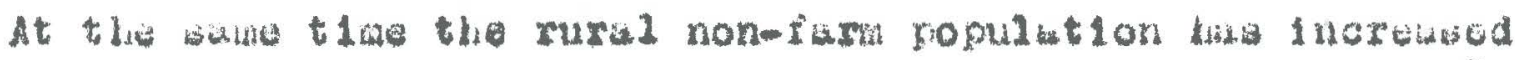

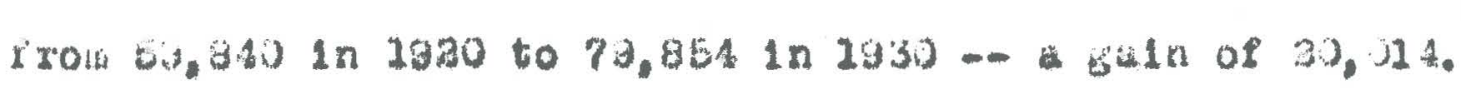

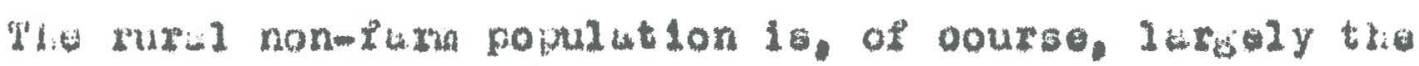
tuln Inic popul tition.

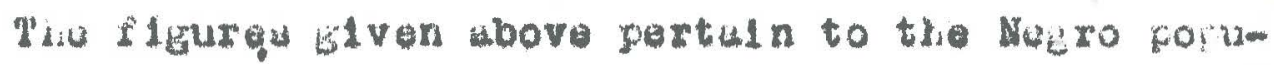

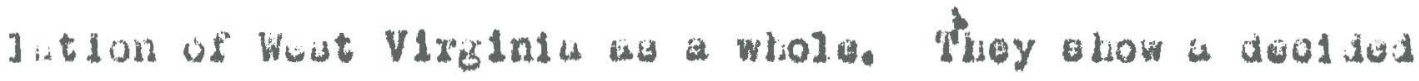

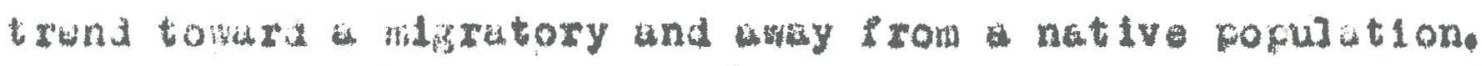

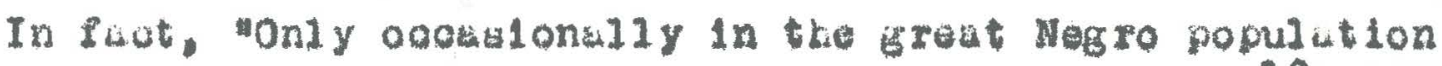
over twonty-five years of age do we seo a native. " liowever, we have deen this Nogrow have boen employed in the mining

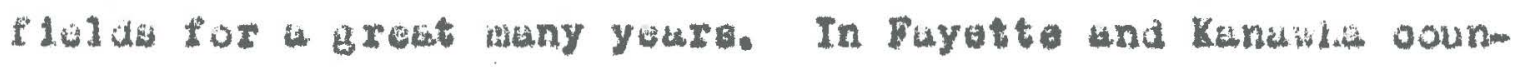
tios thoy have besn uaed oontinuoubly for at least axty ycars, In keroer oounty for at loset elfty yours, In HoDoweld for forty-1ive, in Logan for twonty-nino, and in Rulelgh for over twenty throurhout the oounty and in woate parte for over forty yeara. 11 On might $10 \mathrm{~g} 10 \mathrm{ally}$ euppose that, although the stiate as a whole might be losa nutive than it whe, In these countios, at least, there would be is I kell hood of finding a IHrger nat lve populstion. Sucl. however, 1s not the aase for two ohl of rebeons which w111 be dealt with in the pages to follow.

8 Population Bullatin, ope elts, D. B.

9 Ib1d.

10 Buraau of Negro Velfare atat1ation, Roport, 13al-za, p. 13.

21 Supre, p. 
II. Thie PFESEMT MIH TNO POPULATIOA,-

A] though, as was pointed out above, onu bitglit exceot to flind a 2arger paroentase of nativo in the older wining s101de, the taking of gohodules in thirty-e ist different mining oommint les and the pialting of many nore revouled no atriking differenos between thom, In thot, It revaliod no disoernible difference in regard to the nutivIty of tho population und ata it was that there was posilbly a aomabat lariger poraentage of Virginis Hagroes in the counties adjoont to VIreInla. Even there the ditficronoa visis not constderable, As a matter of faot, the trend toward a mallex peroentage of nktive Begrose las pursisted. The native population wad only 33,347 or 39,0 per ocnt of the total Negro population in 12a0. The flgurew for 1930 are not yet avallable, but it is J1kely that they will aso raflect the trand. The plwoe of birth of the Nogroes Prom whom cokeduleo were obtulned is shown in rable 2 .

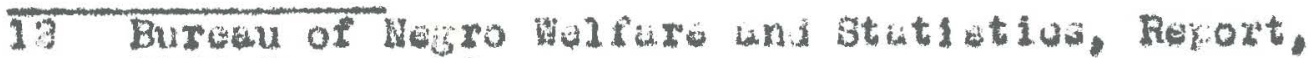
$1023-14,10$. 


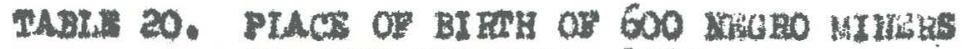
IN kas? vtrotma, 1932

\begin{tabular}{|c|c|c|}
\hline state & Wuraber & Per cent \\
\hline 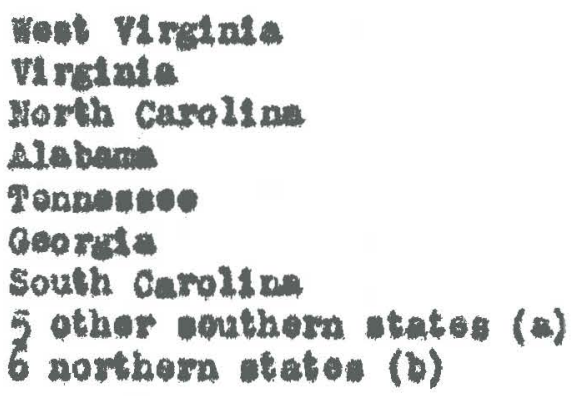 & $\begin{array}{l}84 \\
287 \\
71 \\
27 \\
27 \\
15 \\
16 \\
13\end{array}$ & $\begin{array}{l}14.0 \\
47.8 \\
11.8 \\
11.2 \\
4.5 \\
3.3 \\
2.5 \\
2.7 \\
2.2\end{array}$ \\
\hline 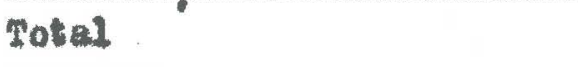 & 1600 & 100.0 \\
\hline
\end{tabular}

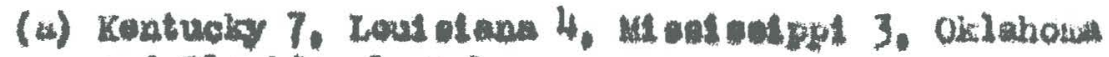
and Nlordda, 2 wach.

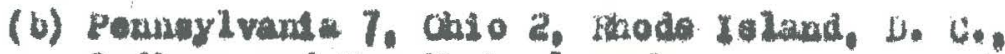
Induene and wo York, i oxdh.

The mot etriking thing ahown by the table above 1. the faot that only 84 or 14 per oent of the $12 x$ hundred

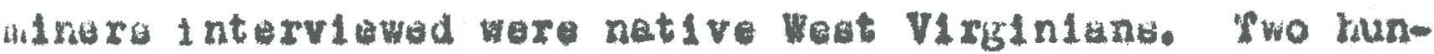
dred und alghty aeven or 47,8 per oent of than were born in VIrglnia - almot three and one hall thes the nuabar born In Wewt V1rginla. Both North Carolina- und Mlabakimborn ulners were al nost as frequently met as Wast Virifinine with $/ 1$ and 67 each respeotively. There are four prinalpal reasons for this arall peroentage of natives atures the West VIrginia Negro mineral A. West Virginia has been wore or Iess of a stopging plaoe for the Negro on his way althar to the weat of to the north. B. The ohlldren of Megro 


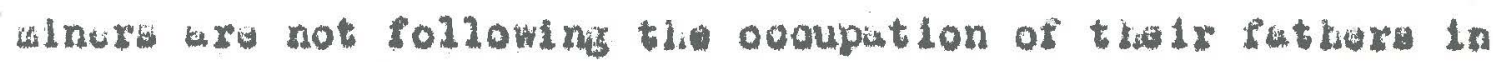

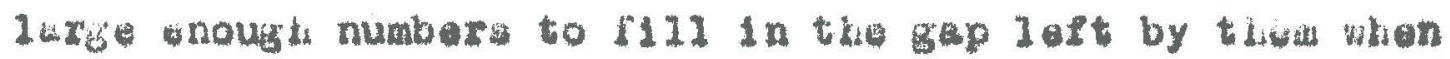

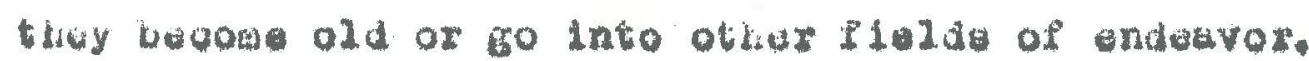

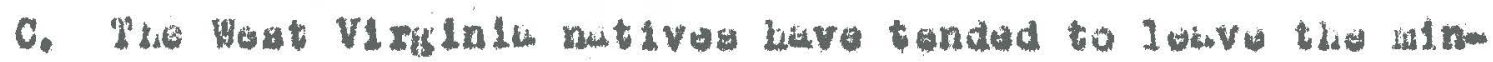

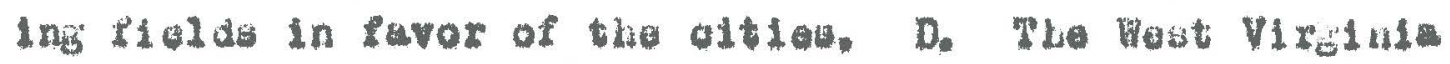

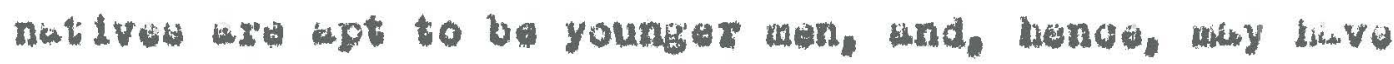
boon unguod in taking the solodula to grouter axtont thun the rasried men.

(4) The trond of wovament thrdugh West virginid to the wat und nortis has oontlaned over a porlod of ywart. Many of these migrunto oome to vent Virglale where. in the pust. work has uaumily been plentiful. Av oomparad with the poor coonomic postion of many of the tenant furmeru.

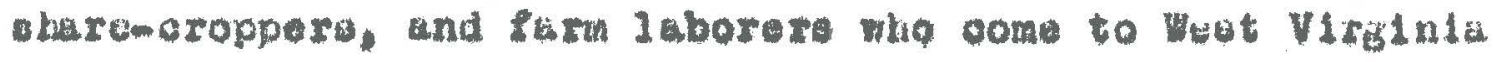
from the wouth, the lost VIrgint winer has lad more money

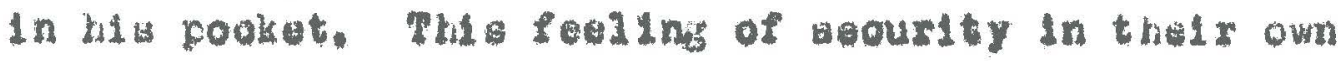
econoulo aufflolenoy las urged many of thom to try tholr

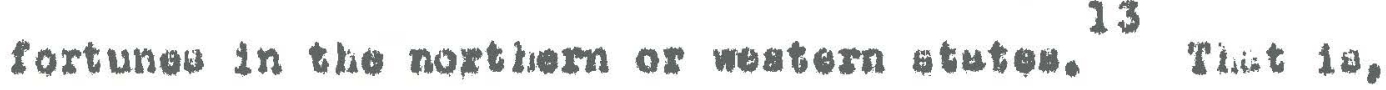
they way otay in the mines tot fer yare and them ibovo. The olilaren born to theae minerw who look upon the alnco

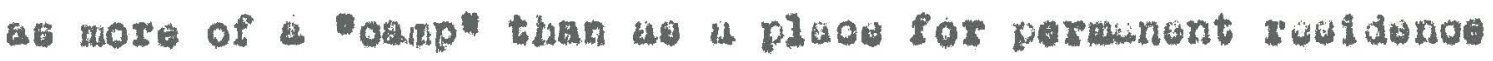
aro tuxen with tho purento and, Lonoe, do not resuin to awel1 the thde of the notive-born Negro.

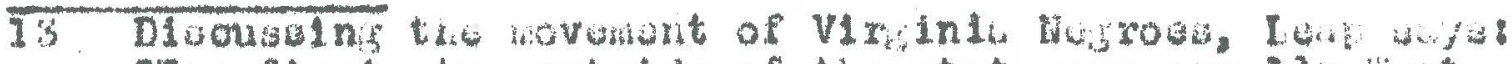

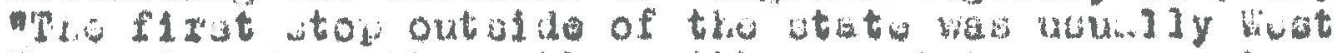
V1

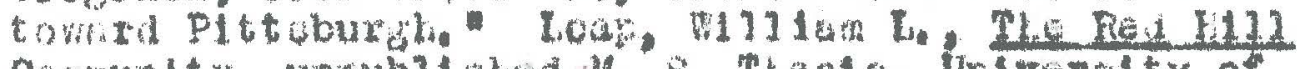

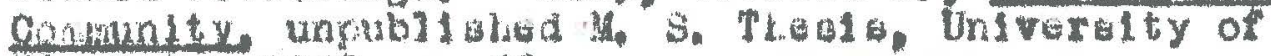
VIrEInt, 1930, p. 33.
} 
While the number of Jegroes, born in weot Virelalit. who lotve the etate 1 not 1 argo ar oompared with the number of those born in other atates who oowe to Hobt V1xinlia, yet there is a oonstunt movement of theed Nogroes to othor plioes. In 2920 there ware 11,770 vegrous born in Weot V1 ribinic wiso were seking their fortune in othar atstes. vilde thoos born elowhere ilving in weat Virgunie numberad $52,233^{24}$

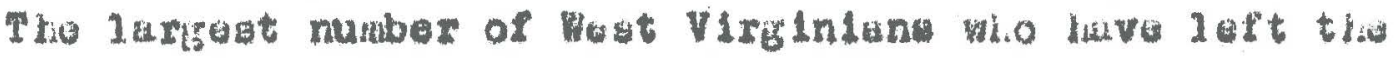
atate have gone to tha nelghboring stato of OLlo whore 3,158 16

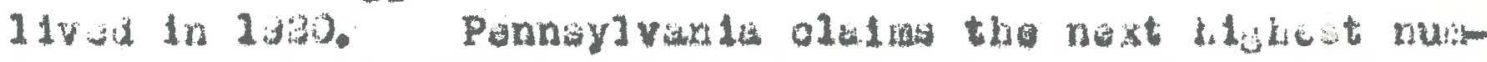

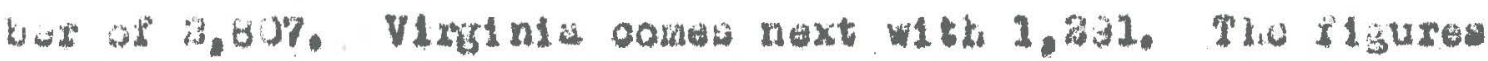

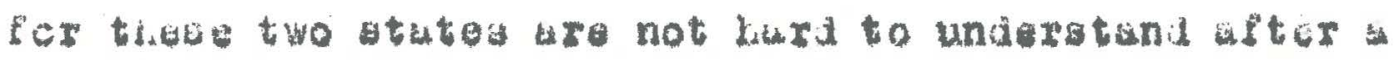
of

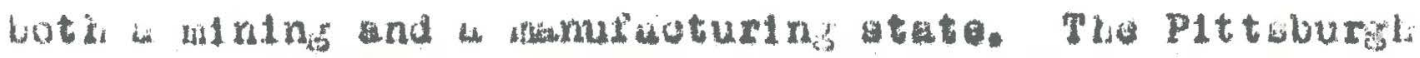
dietriot, thus, ofsared tivo attriations to the Wet Virinfian, an opportunity to work in the alty and, falling in that, nolghooring wines on whit oh the could fall brak in an anerifonoy. The Wout Virednis Masro has reoponded. Alter the abrogution of the Jackonv1110 Agrement of 1917 by the opurators in the P1ttoburg diatriot and the coming of an

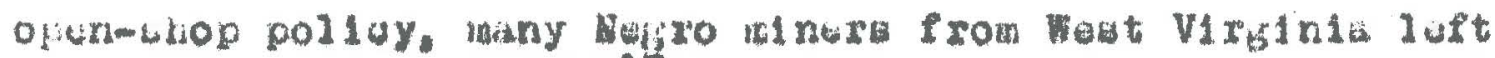
17

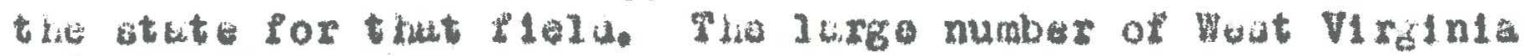

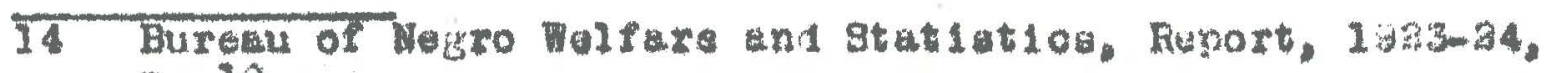
p. 10.

15 Ibld a , Mark, M, L. Megroes in Columbus, 2j\%, P. 33 iff.

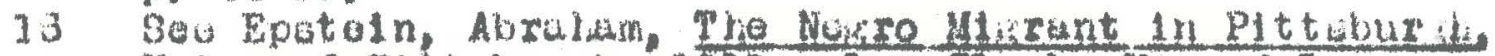

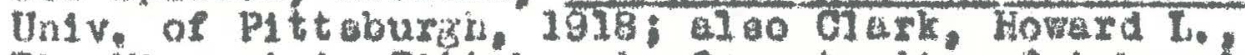
The Uigrant in Pittshurah opportunity, ootober $\{j 3$.

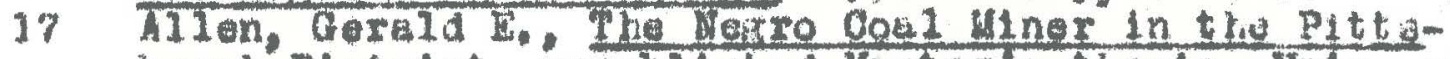

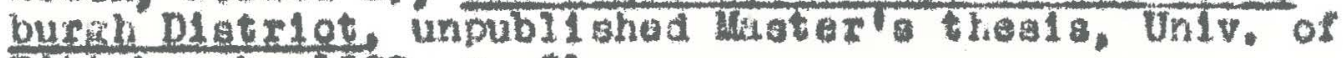
PIttaburish, 1937, P. 31, 
natives who buve returned to virginia aro lusely the olilaxen of Vixplatang who buve spent number of your in the

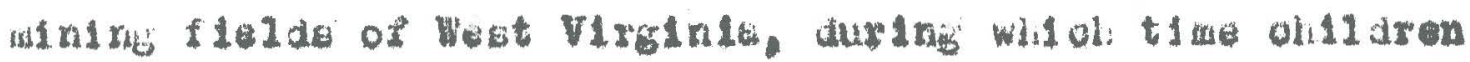
Leve ben born, wha then later returnod to Virginla, wany of thes to the is rarma.

No of twe thto bealdes Oh10, Pennsyluala, and

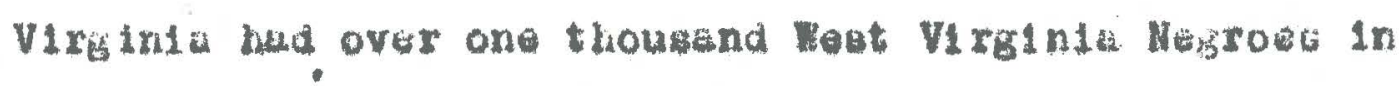

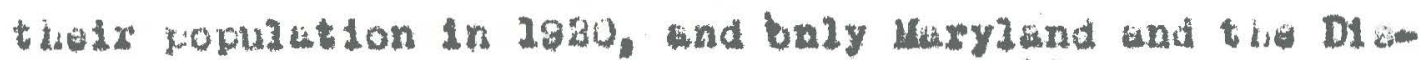

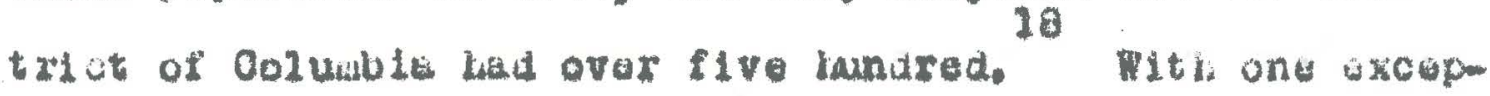

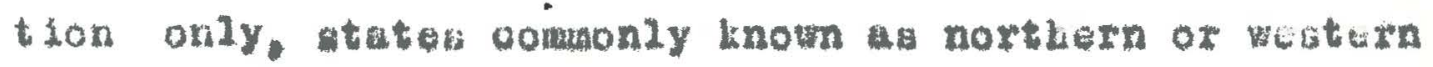
stutea have recelved nore Magroeg frow Wat Viring thin Wust Virginla bas recelved frow them, the one oxoeption $1 \mathrm{a}$ Veraont, only z veot Virginlana 21vo in this gtato, while

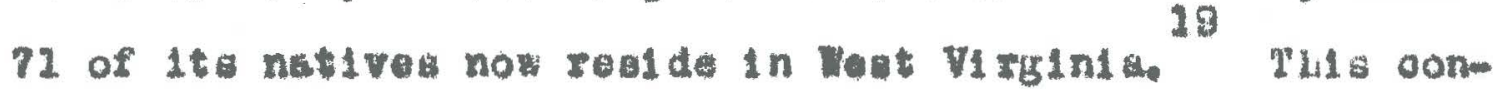
stunt movenent, howerex, is one of the contributing fhotore to tho selativaly mall number of Feot Virsintis nistivos in the Negro mining population.

(B) There is much evldenoe that the ohlidren of andre are not following thels parents in the occupation of

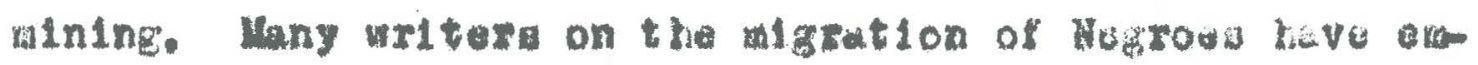
plabled the econom a "pull" of the northern atstas in stimulating the constant strean of Magroes to louve thatr

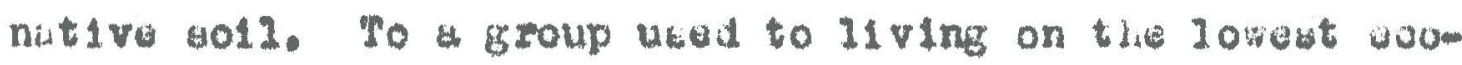

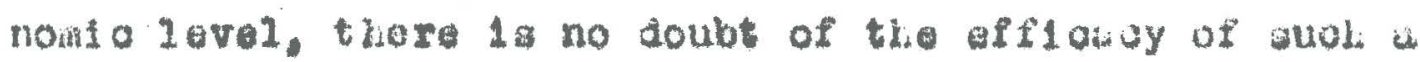
fuotor. hovevor, tha desiru for bettar wduoution for thelr I8 Bureau of Wogro Helfare stutist10a, Heport, 1933-34. 19 1010 
ohlldren and grater priv1legea for both thelr ald1dren and thamelvas tas 100 been most potent foroe. 30 Tivae ablldren, living asught womething of thols parente dealro for mor dea1rable cond1tione, bave tonded to seek thelr fortunew In otbex oogupatione than oota minlng. 8ome, of course. Luve followed in the footetepe of thalx parants. oven working at the athe operation, as thest paronts did. but never in groat enough mubera to 111 the gap laft by thelr perents. The witer found It very diffloult to get

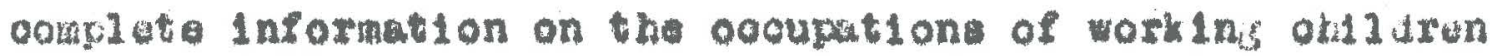
unlesa they ware 11ving at homo. In whob cuse they wor

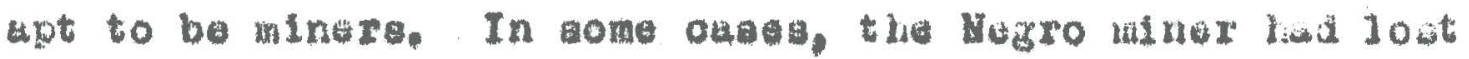
track of his orilaran, who had gone to other stated and could give no information. susplalon, on the purt of wome. of tho wrlter's roal objootive in gathering the intoration Ied them to be rery outlous woout talling the lowition of sone or daublere who wore not in the home. However, it

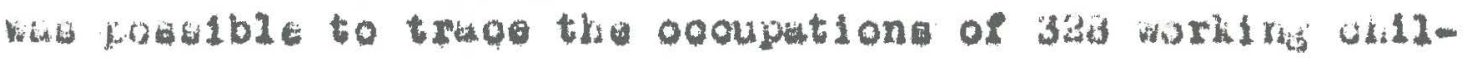

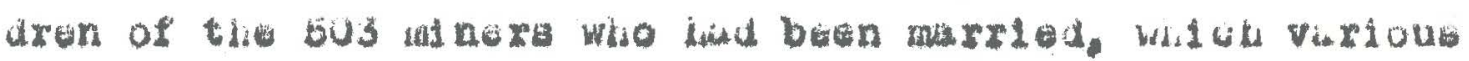
ooculat lone we stown in Pable al.

20 See U, 3, Dapt, of L, bor, Divlaton of Nuspo Economics,

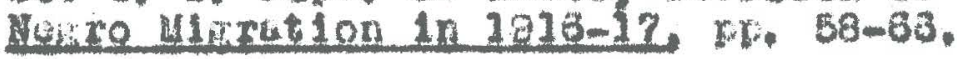




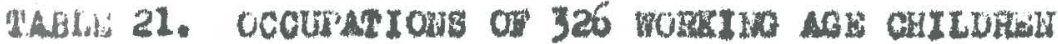

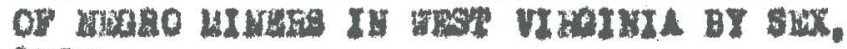

- 1932

\begin{tabular}{|c|c|c|}
\hline \multirow{2}{*}{ cecugint tou } & \multicolumn{2}{|c|}{ ramber } \\
\hline & Non & Resien \\
\hline 1. HI ner & 94 & \\
\hline 2. Houmevifo & & be \\
\hline $\begin{array}{l}\text { 3. romu worker } \\
\text { 4. tiot el woricor }\end{array}$ & 6 & \\
\hline 5. Temober & & 5 \\
\hline 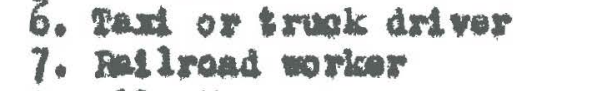 & 3 & \\
\hline 8. A11 othere & $10(a)$ & 3 (b) \\
\hline $\begin{array}{l}\text { 9. College tuduns } \\
\text { 10. Unmonged - }\end{array}$ & 4 & \\
\hline IIving of hom & al & 34 \\
\hline pedifted & 31 & 37 \\
\hline rotel & 278 & 148 \\
\hline
\end{tabular}

(a) Baker, restaurant cook, doll wery boy, arakes ot, foundry workeor, karage workex, janllor, whechl ni ut.

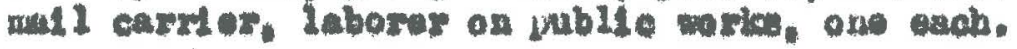

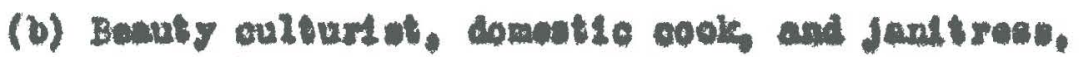
ont each. 
As las been pointed out, the table above 1 is vory

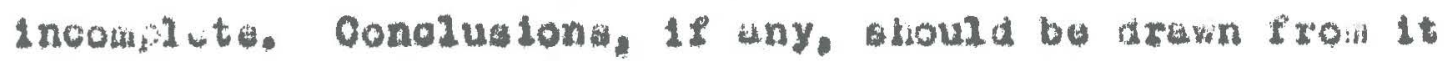
only upor un underetanding of its libititions, ind with its Inoompleteness fully in wind. It probably stowe a rolutiver Iy ereater number in mining thwn io cotually the oawe. Min-

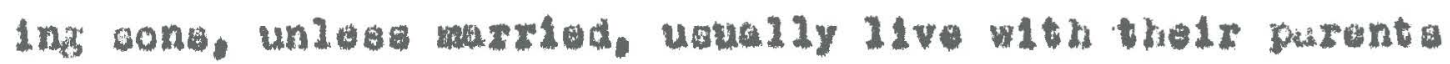

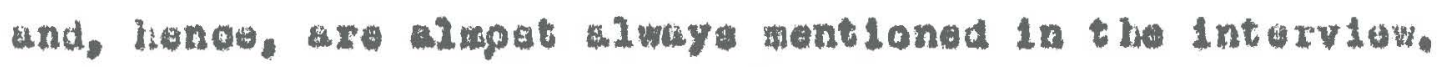
Other cons, more remote, are somatimos not mentioned for the reasone belore given. In addelon, in order not to

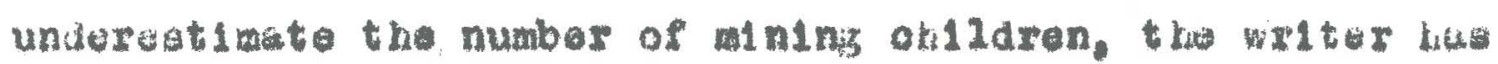
11日tod as minor any boy of minlng legal age roportiod a

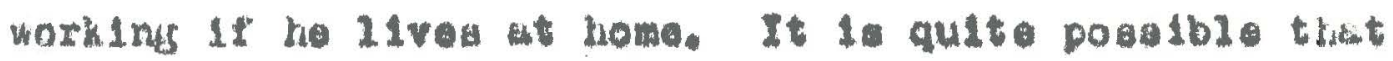
sone of those boya ware not working in the ulnea, wh in

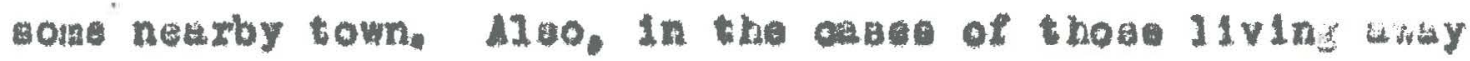
from howe for whon no oooupation was epoofflad (1tein $3 E_{\text {, }}$ Tuble 21). It la quite 11keIy that the majority of these wor in occupation other than minlng. Tho rtbex $24 r_{g} 0$ number of unemployad ohllaren ataylng lowe (itom 34 ) is probubly a depreselon" ptienomenon, Tho writur twikid with

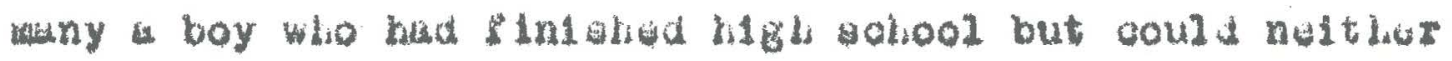

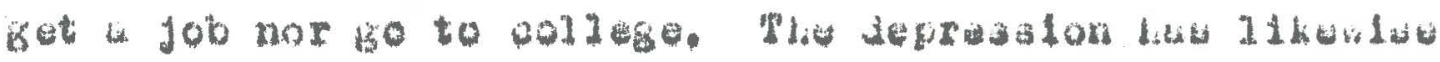
brougt a number of ohlliren buck into the wathe thelds

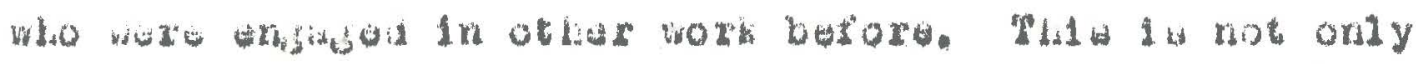
true of the Netro, but 1 a al wo true of the wonts of the 31

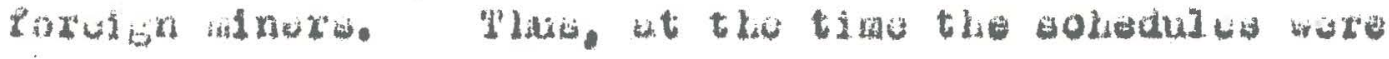

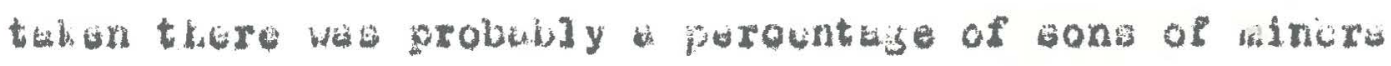

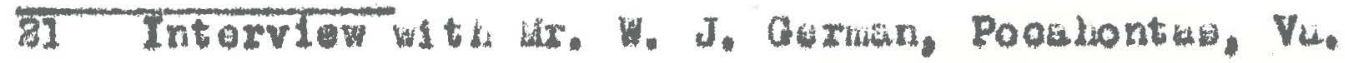


buck in the mine moh bove normal. The tablo aloge a total of 94 or 53,33 por oont of axj male ohildron su enGuged in minine. Tilrty-four or 28.68 por oent ware wnLexed in oocupations definttaly other than ining. Phity or 13,03 per oont ware work $1 n_{\text {s }}$ away frota howe, but it wate not poselble to asoertain definitoly what tholr oooukitiona wite. It is likely that wany in thie group were aso work11. In oocupations other than ming. Both the throgrimal

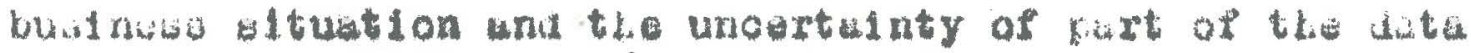

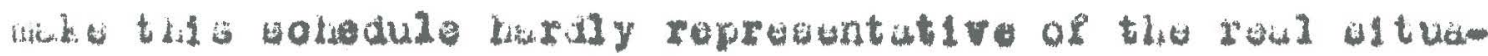
tion.

A mols bottor Index of the extent to wiloh oli1dren tond to follow tho ocouption of thel fiathers in the minin; flold is obtained from the oocupationa of the

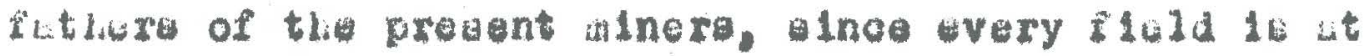
labs one generation old, The minere lud littlo objection to answering the question the to the ocouplation of thels fotherb. tho fisther in many cases bol as dokd. Tuble 32 w11 revad the relatively and number whose fithera fore miners. 


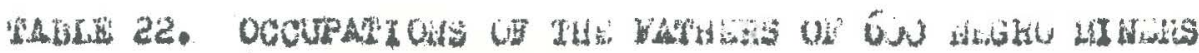
ID WEI VIECIUIA, $193 \%$

\begin{tabular}{|c|c|c|}
\hline oceruption & anarabo: & $\begin{array}{l}\text { Pereentes } \\
\text { detrlbution }\end{array}$ \\
\hline dexulne told & 310 & 20.3 \\
\hline Yatmot & 285 & \\
\hline Tarm Iabotor (22) & 52 & \\
\hline Jarm manaser & 1 & \\
\hline Jarmes-prwacher & 1 & \\
\hline cattie rules & 1 & \\
\hline conl uning atal. & 160 & 529 \\
\hline Mrese & $\mathbf{1 5 \%}$ & \\
\hline Hermpreacher & 12 & \\
\hline 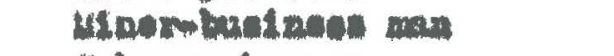 & & \\
\hline colvo workes & .2 & \\
\hline stable ans & 1 & \\
\hline stable bont & 1 & \\
\hline hat 1roud workar & 22 & 3.8 \\
\hline other witne or quarry workeres & 3 & .5 \\
\hline Dagtory werkes & 8 & 2.4 \\
\hline 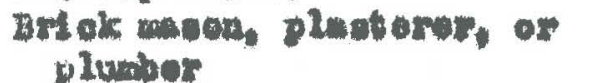 & 5 & \\
\hline Bleoloum th & 4 & .7 \\
\hline Berber & 4 & .7 \\
\hline Drenoher. & 4 & .7 \\
\hline Storakeeper & 3 & .5 \\
\hline Davoloyoe in pablie worke & 3 & .5 \\
\hline Hothler & 2 & 3 \\
\hline Treant of & 2 & $\cdot 3$ \\
\hline Shoornalats & 2 & .3 \\
\hline All other & 21 (a) & 2.2 \\
\hline Unilmon & 27 & \\
\hline Total & 600 & 100.0 \\
\hline
\end{tabular}

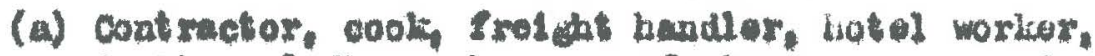

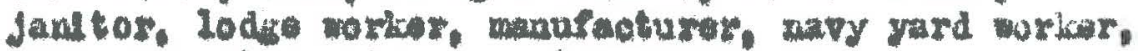
ovarnoer. save, tachor, 1 exph.

a3 Farm laborer rafers to Negroeg workins for other Nerroes or whitea. Farner refore to one who. elther through ranting or ownd ns. runs hla own farm. 
The Fiter, beoming interogted in the relatively

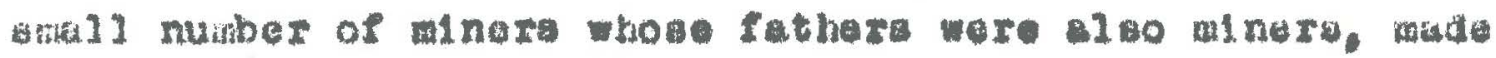
1t a polnt to dieouse the fuot with operutore in the rainlng flelds. Thls condtion had extsted for a number of youra. One superintendent in HoDowell County, in dioussing the

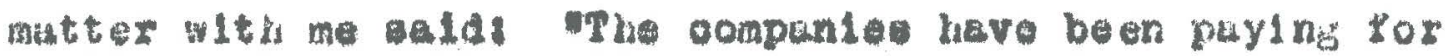
aduoation for many yoarn. I thougth I would koop truck and wee whe happened. I did so - and for ten yare we hevo not gatten winer' trom a miner'a tapliy. " other anployoro

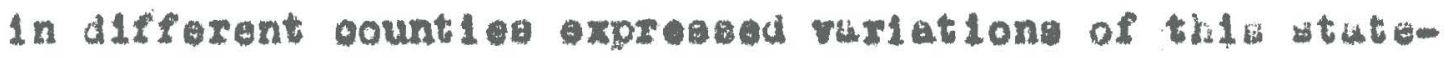
ment. One employer in the Pooklontas coal fleld just over the border in Virginla, howerer, expresead hil profurenco

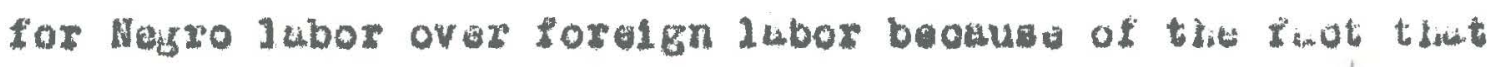
the Nesro bu law objection to his ohilaren's workins in ti.e. snow than the foralgn worker. As we whlked toguthur

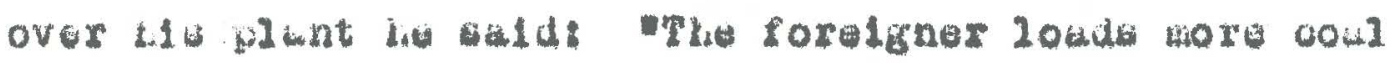
than the Mogro doca -- but in all round destrability lie doos not nousure up to the Nogro. For inatanoe, the for-

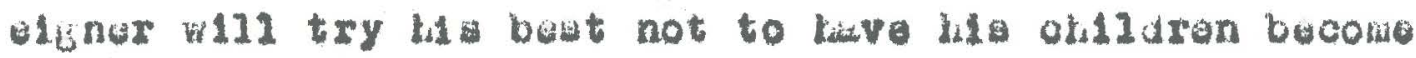
coul 10uders. The llegro does not oure wbout that, Sonethaw be sot four or tive good loadera from one fandy." In this conneation, howaver, it thould be pointed out that

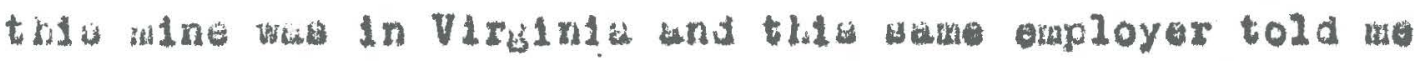
thet the Nogro working In Viridids, oven though juwt over the Ino from weat Virigla was so differunt fron tho vest VIrigin Negro that le bid a diferent labor polloy for his mines in the two atatea. Talk with Megro teachera, 
problors, and Iavdere apport the fut that the ohlldren tona to lature the minas. Another tendenoy of the olilidren 1o to work for tiw in the whos anditon iso into other Iines of wark, wowe of them atcining distinotion in thas chowen flelda. Booker $T$. Whandngton and Cartar G. Foodion wre well-known examploa.

The fact thut the native woot Virginia ininera are younger than those born outalde the state would ween to be an evidenoe of the operation of this tendenoy of the Waet VIx 1 inla winer to work whlle in the mines and then to to the altien or outalde the state. In the sol lowlng tablo the differenoe in oge betweon thes two group 18 otrikinsIy 112 ust rat ad.

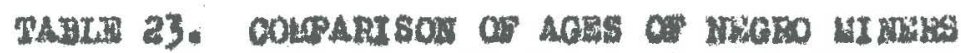

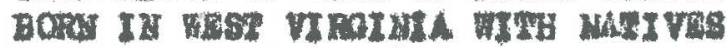
OF CTHAR ETATRS: 1932

\begin{tabular}{|c|c|c|c|c|}
\hline \multirow[t]{2}{*}{ A } & \multicolumn{2}{|c|}{ 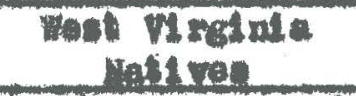 } & \multicolumn{2}{|c|}{ othare } \\
\hline & Muth & Per een: & Arrescer & Rer sen \\
\hline $\begin{array}{l}27 \text { yeare } \\
18 \text { and } 19 \\
20 \text { under } 25 \\
25 \text { under } 50 \\
30 \text { under } 35 \\
35 \text { under } 40 \\
40 \text { under } 45 \\
45 \text { under } 50 \\
50 \text { under } 55 \\
\text { over } 55 \\
\text { Not dien }\end{array}$ & $\begin{array}{l}5 \\
28 \\
18 \\
12 \\
10 \\
4 \\
2 \\
3 \\
2\end{array}$ & $\begin{array}{r}6.0 \\
34.1 \\
23.0 \\
14.6 \\
12.2 \\
4.9 \\
2.4 \\
3.7 \\
.0\end{array}$ & $\begin{array}{l}1 \\
5 \\
55 \\
71 \\
96 \\
75 \\
57 \\
43 \\
60 \\
17\end{array}$ & $\begin{array}{r}.2 \\
1.0 \\
7.2 \\
11.0 \\
14.2 \\
19.2 \\
15.0 \\
11.4 \\
8.6 \\
12.0\end{array}$ \\
\hline rotal & 84 & 100.0 & 516 & 100.0 \\
\hline
\end{tabular}

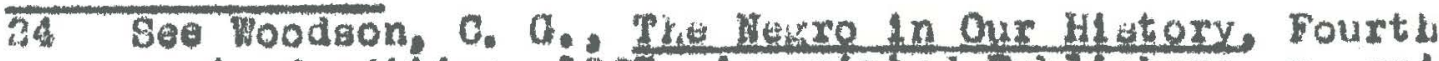

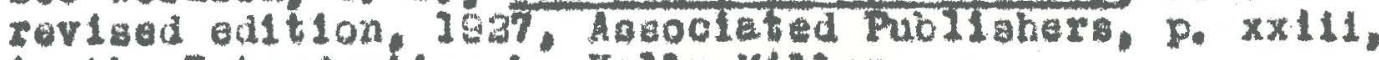
in the Int roduotion by Kelly M111er. 
Pikre was ono thiner born outalde the atate aged 17. There were no Weat VIrginla native minera that young. In the 38 and 19 yeur group, however. almost 6 per oont of the West Viriginit group were found, wille those born out aldo the state had lese than 1 por cent in that olase, Exatly one third of the veat VIrginia natives were between the $4 g e s$ of 20 and 24 inolus1ve. Whille 1 eas than 7 per cent of those born outside of the otate fell in that alase. With tha exoeption of the one sevent een-yearmold boy tho nat ives had a larger nerowntage in every age group up to and 1noludIng that between 30 and under 35. In every age group above that thoes born outside the eitate had oonslderably more. The oldeat native miner was 54 so that there wero none in the uge group of 55 and over. The non-natives, hovever. had wore than 11 per cont of thetx 3 roup in that alusa. More apeolfleully there were 32 non-native or $0.3 j 1$ far cont in the tse group between 53 and 59,19 or 3.635 ver out letween 30 and 64,4 or .775 per cent between as and 60,4 or .775 per oent betwern 70 and 76 , and 1 or .133 per wont over 75. Phe disparity of age between the nistivas and

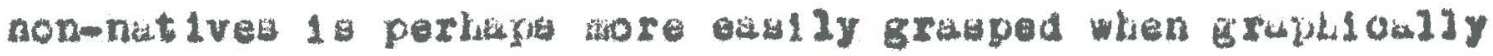
111uatrutud, to in Fig. 1 . 
Inother factor thet tends to bend aany obljuren Into other oooupatione 13, we bave indioatad, the oojeotion of the parents themelves to thelr ollduren'a buooding miners. It 18 perhape folk judgment of wide diffusion in Ainerloa that chlldren ahould, whenever posible, escura the hard experiences of the purente and that the way of evoupe

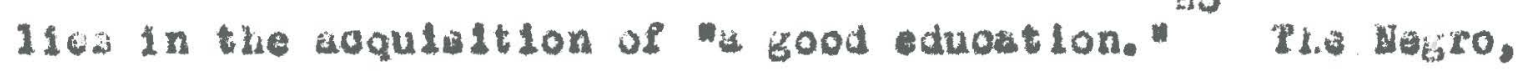
being subject to our oulture typo, has inoorporited this trist 1nto difu own butavior pattaras to a contiderable ex-

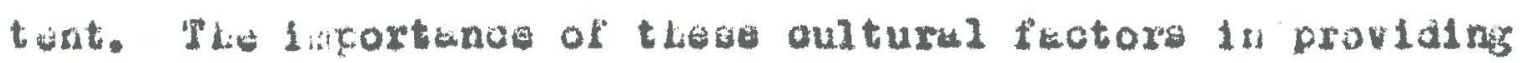

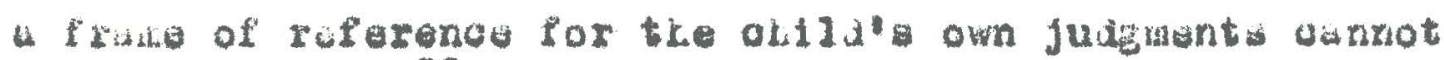
23

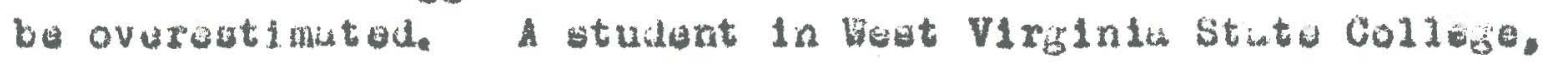

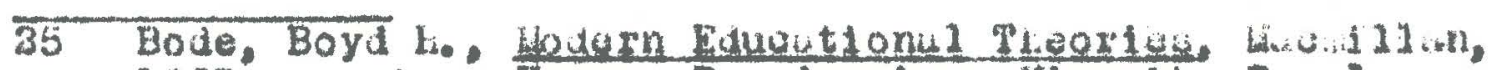
1337, Pusslin.; Youns, D., Arexioan Minority Pooplea, c. $41 \mathrm{~s}$.

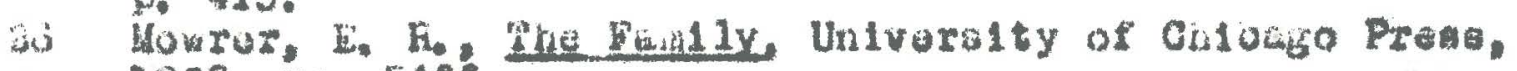
1332. DF. G4ff. 
the largert Negro college in the atate. tella in a theme Lueignient of the opposition of his parents to bie entering 27

the entnea!

When I had reaohed the age of seventeen, when boys are permitted to enter the mined to work under the tutelige of thelx fathera. I wa deteralned to do 30. Hy paranta objeotad to thio plan, bowevor, and it was iare tran a yoar 2ater boforo I was pormit tod to onter tho minas. Novertielabo, aftex my parelatent requento, for I was déturminod to becose aqqualinted with (tho) colning altuation, I was ofrinted wy who" Anotber student, in theme on

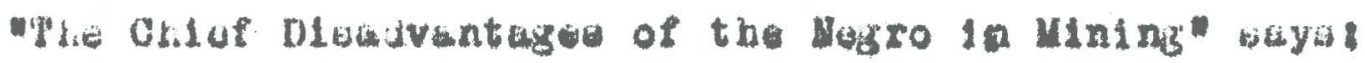
one of the wout outatanding diagdvantages for the Hegro

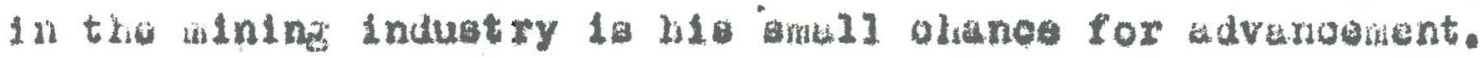

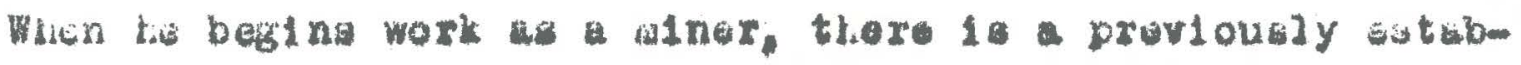

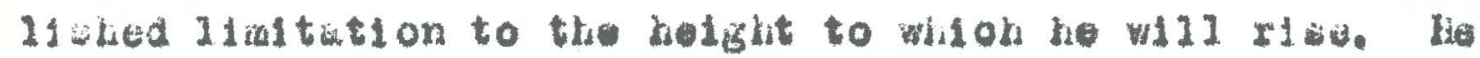

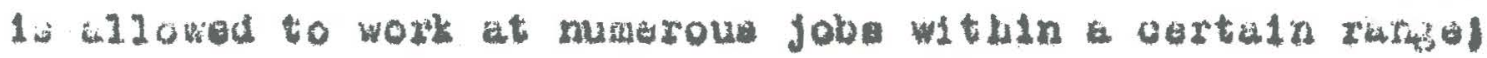
but beyond trat mange de doe not watenow."

Tha quotationg above aro taken frow thanew witten by college studente, More or less the end at ituide

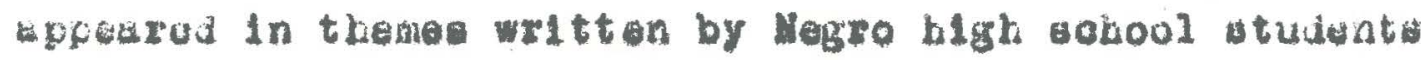

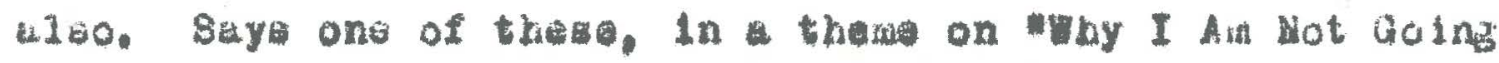
To Bacome a Miner." In the beginning alner la thoust

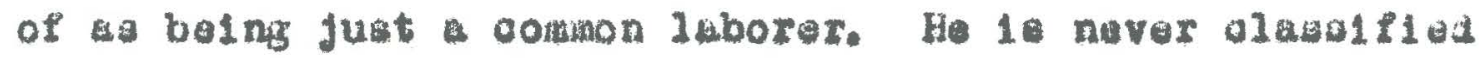
In goolety very bigh, for to $1 \mathrm{~s}$ looked upon an an inferlor."

37 These themes, wloh were glvan the suggeetion of the writer, were des ligned a regular work and the studenta did not know that any ot her than olaba-roju use was to be made of them. 


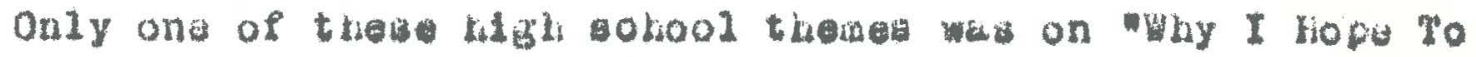

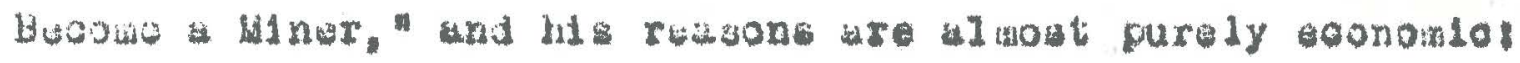

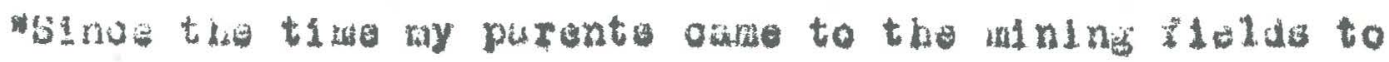

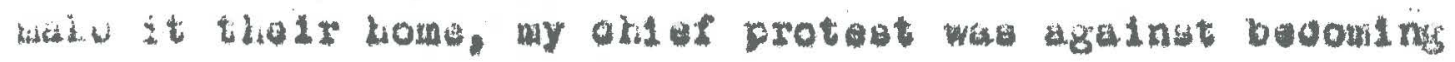

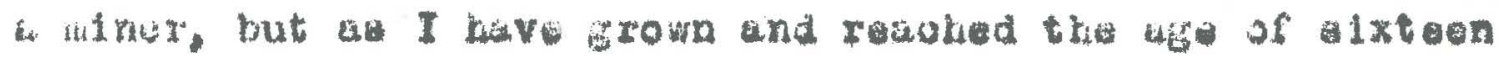

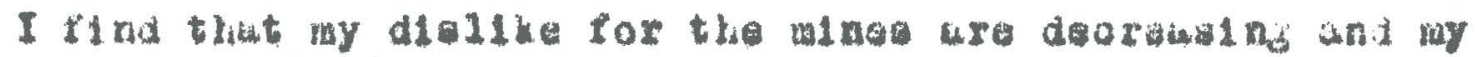

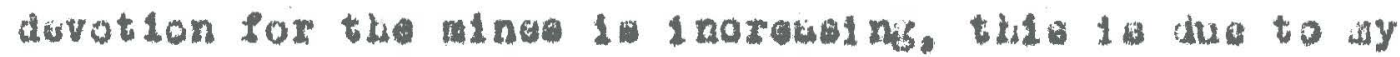

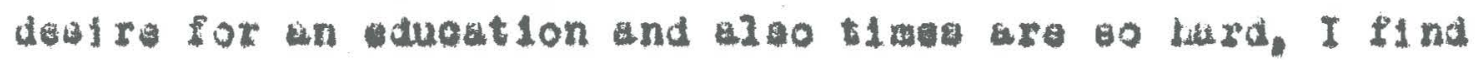
that I wuat have work to got olotisng, books, and other

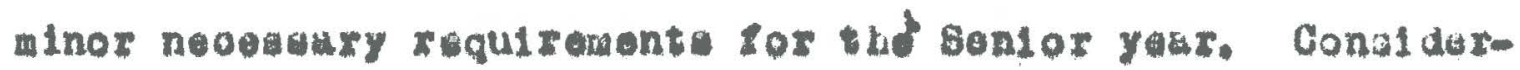

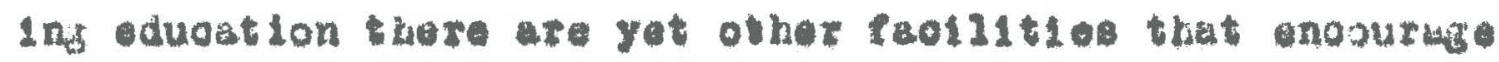

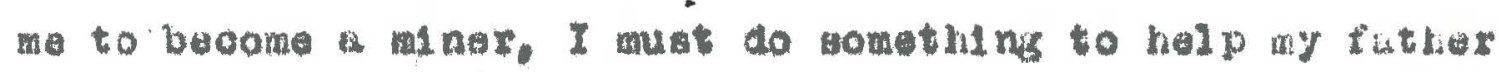
who in growing waker and weaker as reaul of 1 cborlne or In other worde tuning. and I tind that wy only obunow la to rasort to the ooul minas. Thone attitudes. wloh - re widely held by the young Negroes, have baun powertul "cush" In forolng them to cook other woxk. Thto is purt lauIarly true of the oblidran who go on to IIntsh high uctool

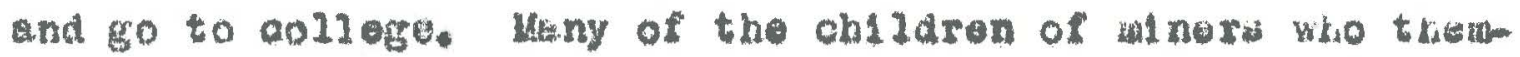
aelvea becone minere top solool in the ardy sfidis. The

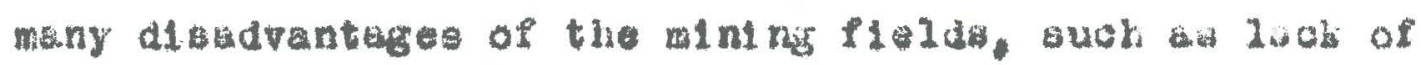
Intellectuel stimulus. the inellgibllity to bany of tia botter positione in the induatry. wa contrabed afth the

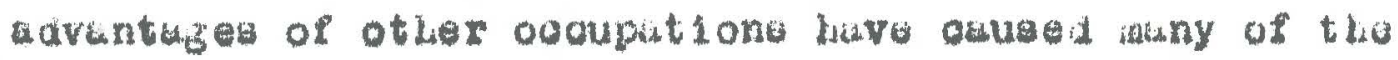

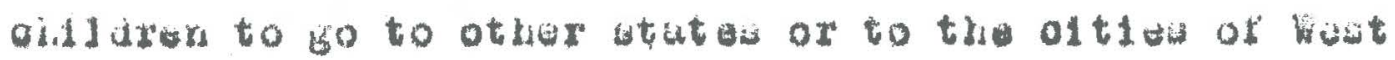
V1rinla, puttoulaxly to the istor. 
(c) The writer has observod for number of yeara the tendenoy for the Negro Miner, partioulardy the more enorictio

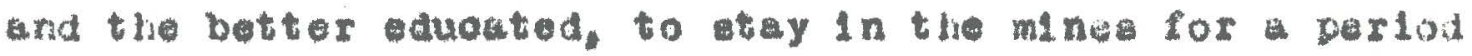
of yeare and then, after saring money, to come elther to one of the larger of the of the atate or to one of the numeroue 11ttle towns, many of which have thelr Nagro mectlon. The Nagro urban population of the otate in 1930 wis 31,324 willo 3 is

tide rural was 83, 369. Charlaston in 1930 bad to Negro ropu-

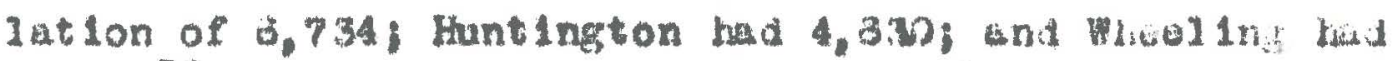
33

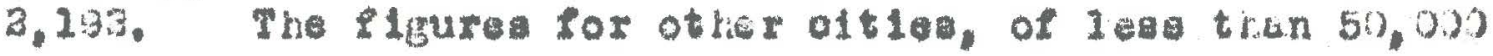

ure not yet avaliable but they w111 add othor thoupunda to

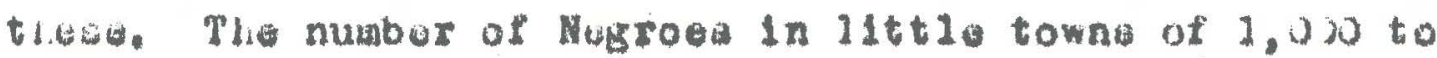

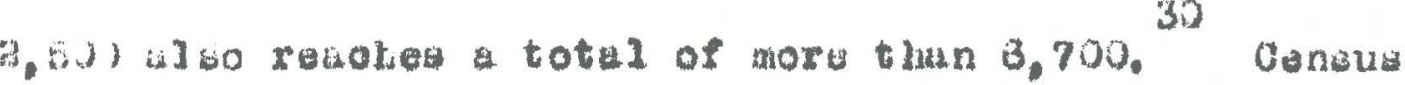

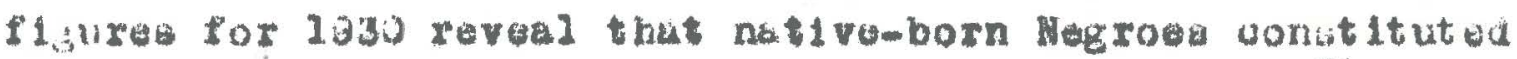
5.3.2 per cant of the Negro population of difmeraton. The nom native has oome here for the expreas furm

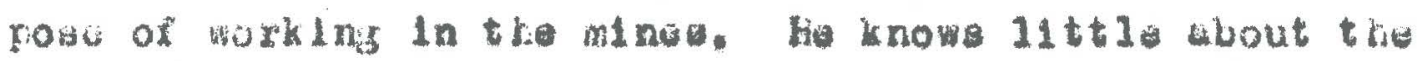
wiate and the opportuntios and advantiages of the odtaw. Further, as a rule his ooonomlo statue in tha minl $\mathrm{n}_{\mathrm{s}}$ flelde

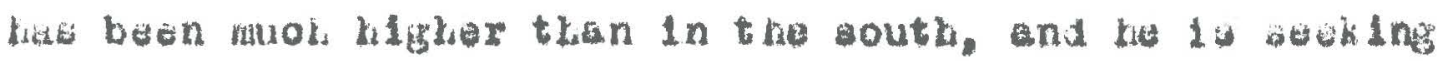
aconowia betturment nore than a olty home. The West Virginla nativea, howevar, tare 11 kely to know worw of the opportunities of the state and wre more likely to weok them, 23. Porujation Bulietin, 15th Oonoua, labued April 25, 1232, E. 5.

23 Io14. p. 47.

30 Thlo: 10.

31 Reprint of Chapter 4, Vol. II, Report on Populist ton, p. 73. Figures on other olttes are not avaliable cia they are given only for eltles of more than 5,000 Ne,gro population. 
It is not at all unuouel to find an oldex nutive alner livIn in tho alning town wnd keeplag his fuwlly in the alty. Thore 1 is a oultural afferentiation between these nonnut1ves, furtloulardy of the fux 3outh, and the ficut V1r-

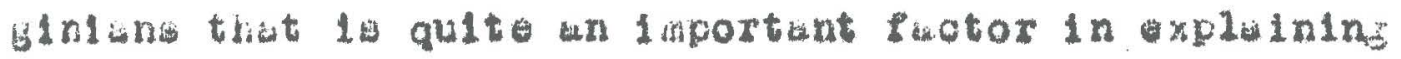

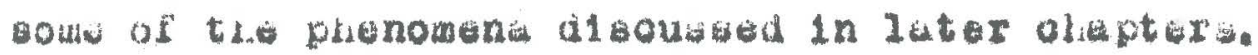

(D) Thi last remon malgned for the andil perconting of Imitivio whe that, due to the younger age of the west virginiuns, they were more apt to be out when the interviow

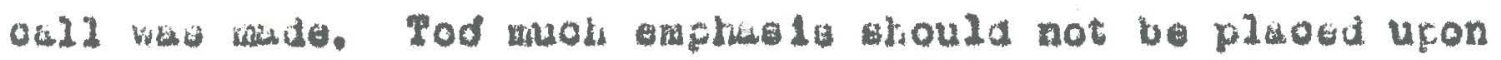
thit rekson, for 1t would wooount, the nost, for but is mall perontuge of the difference between the proportion of tha native und the non-native. The deprobad woonomio conditions, whilo took from many Hegro automobl to owner h1s part2y-pald-for oar, kept many a youns man in the uinInt town, emusing himself by vialting with his nolghbori. who would in otber times have beon in the near-by wald towno secking other amuewents. Consequently, both nit I vos and non-nutives ware more avalleble for Intervlewa tian would bave boen the oase in more propperous tines, Henoe, wh10 It 10 quite posalbje that native were misoed in 2arger proportion than the non-native the proportionat represented in Tuble probubly represent tho approxidute situation. Interviews with many aployere did weiglors of both racos have oubetantiated tilio view,

The main sourae of norimidive Nurro fopulution in

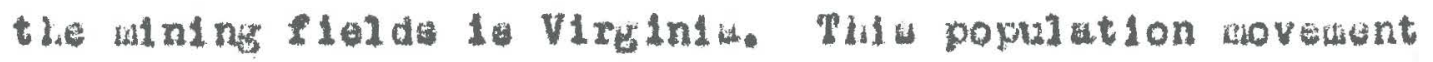




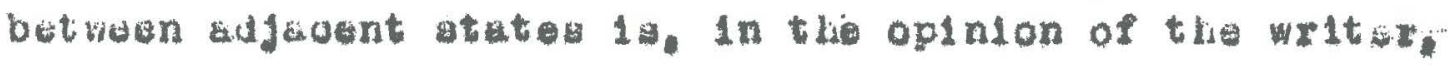
one of the most interesting and aligniflcant parte of tho entire study. Certalniy many of the polnt to be dicousoed upon the bus of these proliminary ohaptera must bo vlowad In the light of this movement. This movement, whith we huve oeen dates biok to tho Reconotruotion days in V1riglo when Negro labor waik nooded in Ohio. Indiana, and Wout VIrginta. paralota to the prosent time. In 1920 there wero

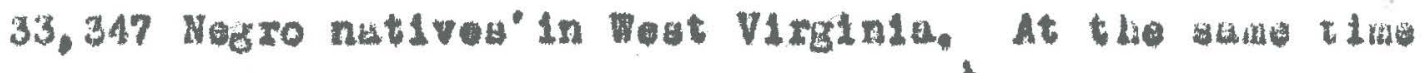
there were 23,315 Iegroes 1101 g in vost Virginl a who were born in V1rginis -. only 4,03a 100 e than the natived. 33 The atute with the noxt hlgheat number of nutives in gud $^{2}$

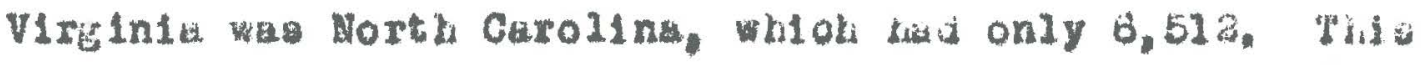
faot would Indioate that the Megro wovament into Wust

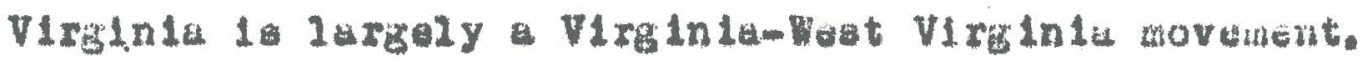
Froxiduty, of courde, 10 b1g fuotor in the

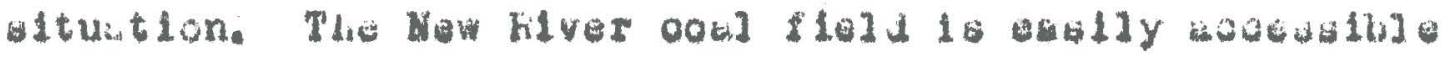
to the wotern countios of Viriginta by mans of the Clede-

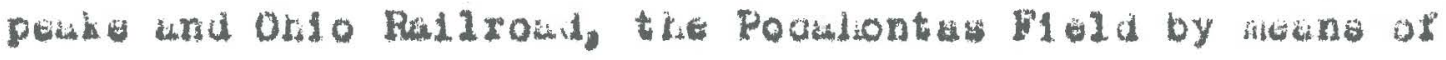
the Norfolk and Weatern, and the whang Gulf Hej a by the

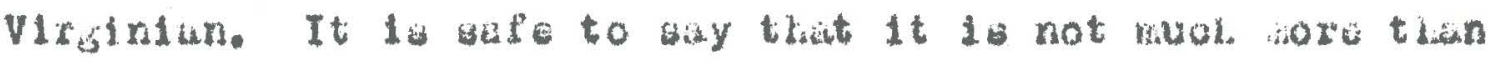

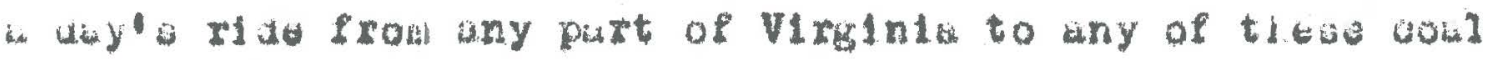

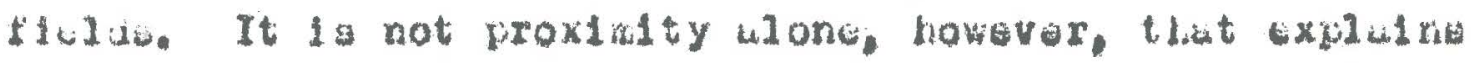

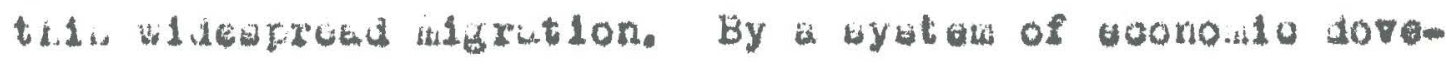

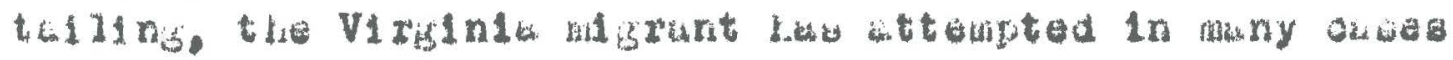

\footnotetext{
33 Supres,

33 Bureau of Vogro velfure and stutistios, Fieport. 1923-24, p. 10,
} 
to keep one foot in Weat Virginiu and the othar one rifrily

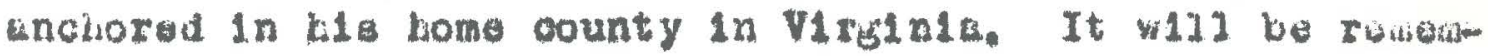
borud thet the fathers of most of the manorg in Weat Vir-

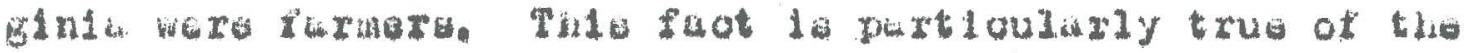

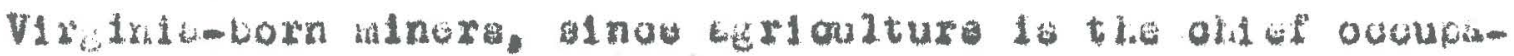
thon of wost of the wotern courtiag Prom whild most of the No row vone. Muny of tham cone from Montugowary, Rownoko,

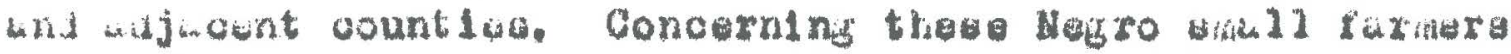

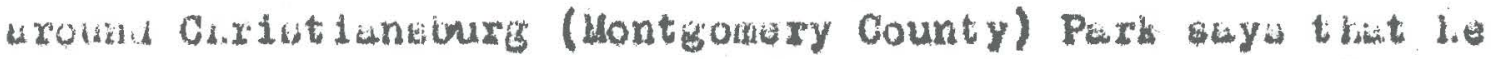
unow of no conarundty were faraers are more indepondent indid prosperous, or where the two rages get on bottior togetim 34

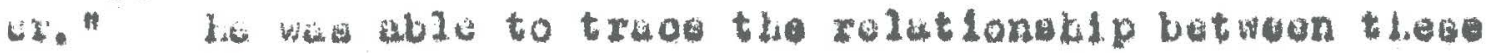

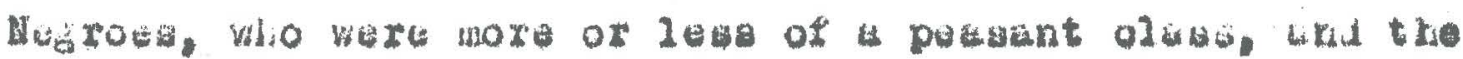
Necrose who remelnod on the pluntationo after the war.

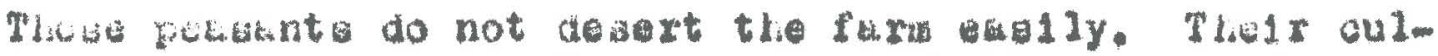
ture is is pereant culture und they tond to oling to the Iffe of the pousant oven though, for tamporury perlodis they may go to other places to make money. Many of the fue furwers would use ooul ralning as a cort of money orop." a Nugro prewoher in the Poouhontas Meld, In thit oonnootion, bind:

It used to be the common thing for men of uny people to own farius In V1rinia or North Carolini. They would go hone and get the orop atarted and parhaps, having a son who could carry it on, the fatler would go baok to the mining flel la and wor. on this socount viny of thelr ohlidren werte born in VIriginla or North Carolina wen thelr latiers

34 Park, Rotrort L. Nexro Home Lifo and Standiric of

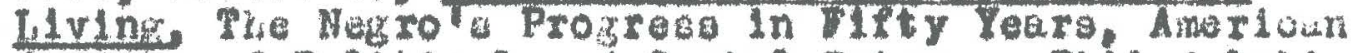
Academy of Politiokl and Soolal Solence. Phildedelplita. 1913, pp, 147-133. 


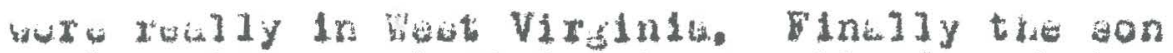
would not bu content to etay on the farm but would ingd on golng to the winlnis fleldo with the fether. So, the whole fumliy would oowe th 1aidit.

WhI I there vere doubtloas any who bove up the furms and ourde to live pornarently in the minlng flelde thero wora probsbly more wo looked upon VIrginia as "kome and ining 61acly at the mane to allow them to malntaln thef ferme. It $1 \mathrm{~s}$ olenteloant that root of the farms mentloned in the interviowo were lookted in Virginia. One superintendent baid, of a oertain winer" Ha'12 be learing lor hlo furm In the bpring. Plien in the fall when he gete out of money tu'l1 be wanting to teke him baok agaln,"

Fislo these home-golng miners cometimes offured a problem for the operator by quitting when he needed thelr Bervioes they wore often the meens of bringlag other winere to bin. Ono old Negro miner at Meystone. who bad worked for forty yeare in the minew, told the followlng btory with Lis unmistakable Virginis pronunclation:

I used to go badis to Virelnis und would to broke. I wowld wito to the superintendent wad

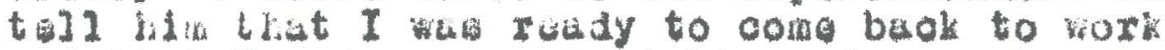
and that I bad geven or elabt good wen who waraticd

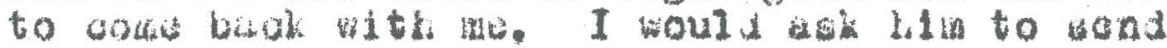
He Ifty or weventy-five doljaza for train fare.

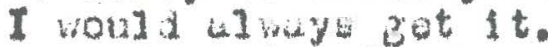

One trate I aqued the man at the post of 1100 to indto i luter for we waldng for seventy-flve dollars. Whe hitr kot down and wrlt it - but le

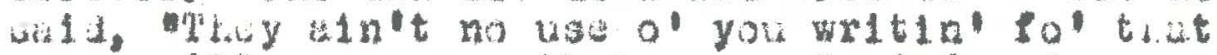
-.- you'll nevar we thut money." A few disyo ufter that le tol' he there diso a latter fol a. I opened it up und there was the monoy. hio deyt Whicet klada orist (braft) you got on thess inen out 
there in Mast VIngindai" I say, I alnt got no orift at ul1-i juk boen honest wla tew."

Woot of the Viruinians who oome to the ancin in

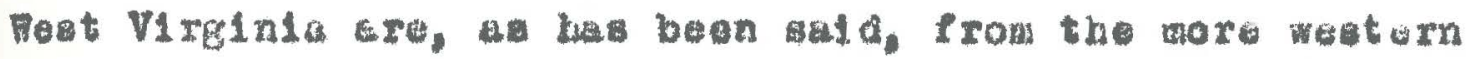

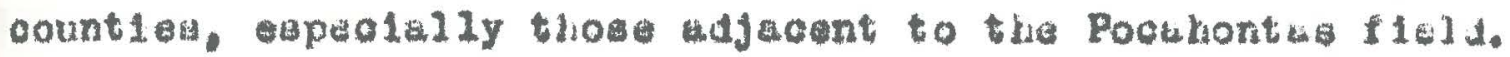

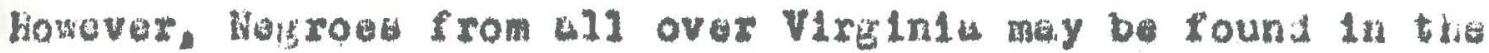
mining flelda, Leap, in a tudy of Hegro melghbortioous in

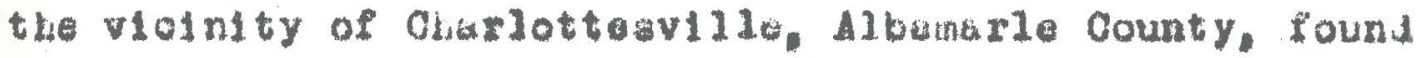
that, of 33 wisn wio want outulde tho oomandity to work. 11 went to wut V1xinlat. Al besarle county is in the cantsin

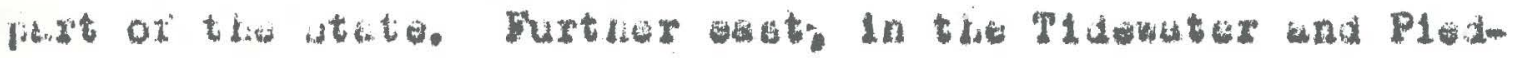

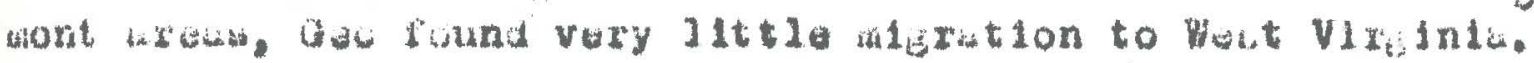

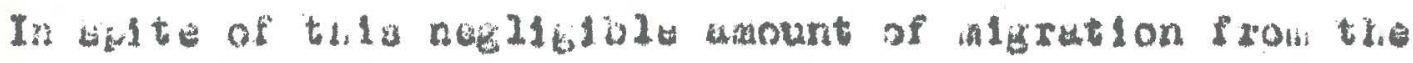

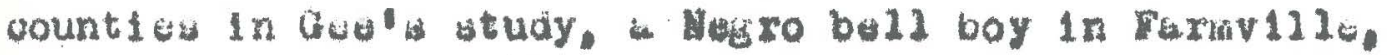
Prinoe Eutura County. in Boutbolde V1rjinla tola tio

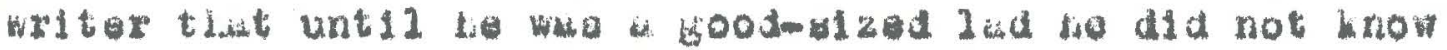

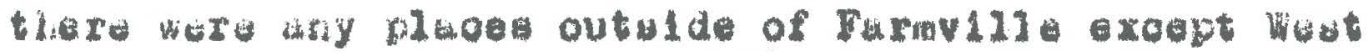

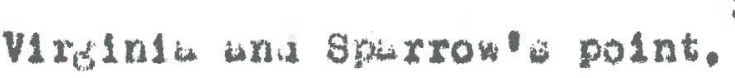
The bulk of tho Megrowis in

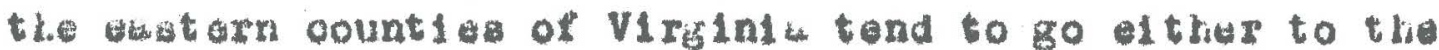
oft10u of the northern atutes of Penneylvanic. New Jerusy. and Warylund or to other Iargo V1rginla of tae.

The next atoto having the largeat nutber of

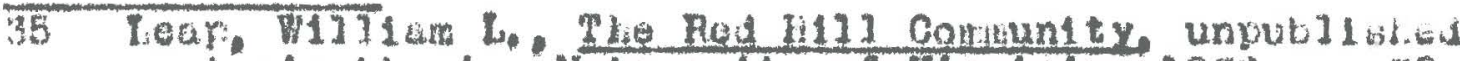

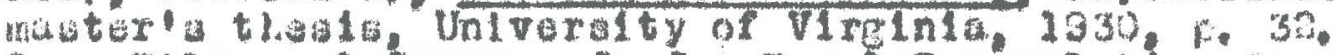

30 Deo, V11son, Corson, J.J. Eural Dacorulat Ln in Cortuin I lowatex and Plediont Areas of VIrginla Jniv. of Vt. Inatitute for Roeecroh in tho socik Sol to noe. $p .38$.

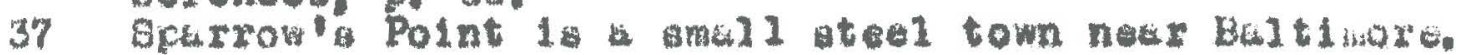
38 Co \& Ooraon. op. olt. pp. 34t. 


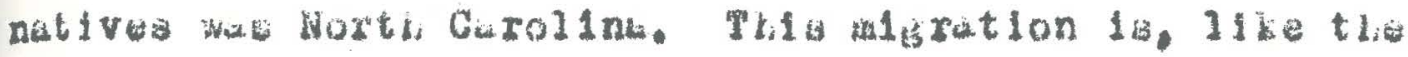

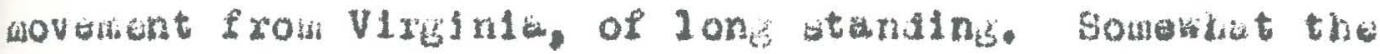

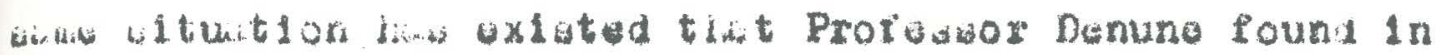

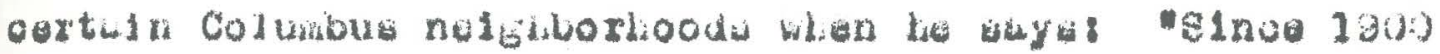

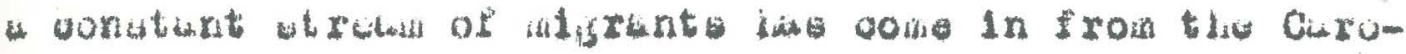

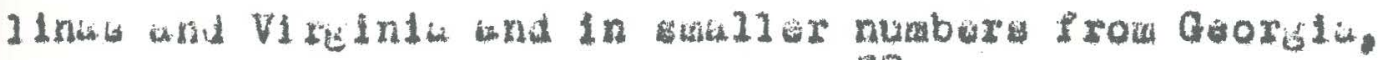
33

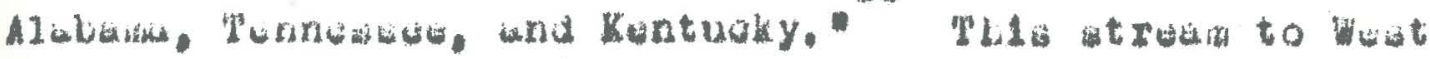

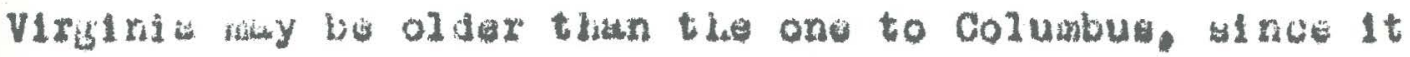

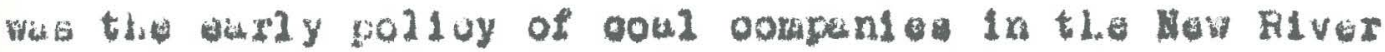
Fleld to send lubor agente Into North Oarolina and bring bugk number of Hegroos from that atate. Irom a whidy of cuse distorias of wome of the Hartio Oarolina Metroes it beous appurent to the writor that the igration from North Carolina took two direotiona, ono south and the other north, It Is quite oowaon to flad a Mortb Oarolina winer who hat

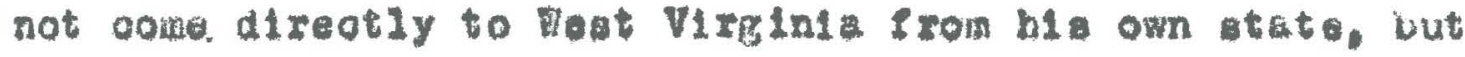
from Alubama. The two Industries that attraot hin there we the ooal Industry and the Iron feotorles and wints around Blrminglata and Bessouer, Onoe there th doeg as inany Alabumane do and comes to the mining flelde of Wut Viridnia. Othere come direotly to Hest Virginis while will othere

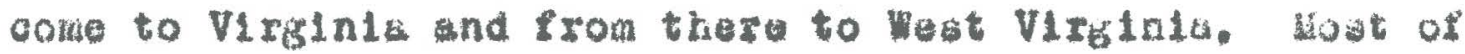
those who come direotiy from North Carolina are tobicoo

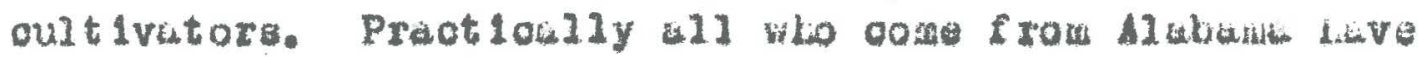

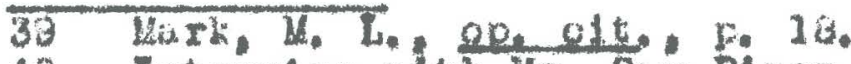

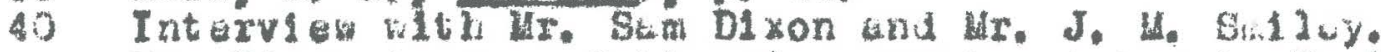

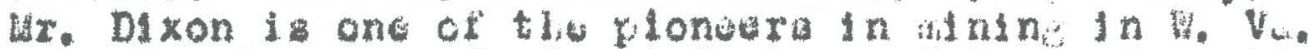

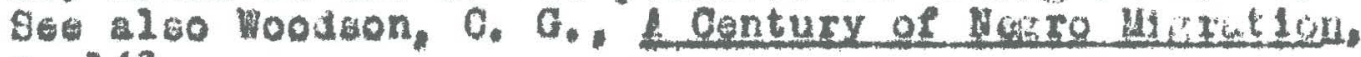
c. 14a. 
hod anlning oxpartenoe before they entor the ood wines in weet Virigina.

Epstain found in a Btudy that inoluded $507 \mathrm{ml}$ 41 grante that 177 of them had come from A3abama. Ttis number was over twloe as many the next atate, Georista, whok had 83 native among theo Negroes. Epateln scoountai for this alto thether diaproportionate influx from Alabaita" on the basia of the Baliarity of Induetrieg botween the Pittgburgh distriot and that around Blrmingham. Iabor ugentio mide a apectal affort to get thooe jaborars who ware

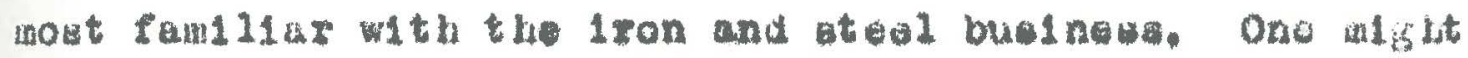
guy, with good roaton, the Bame thins in rogard to tre clallarity of indust rieg betwoon Wot V1relnia and Alduama.

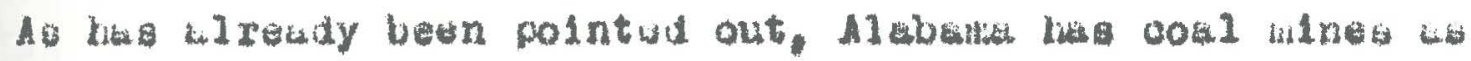

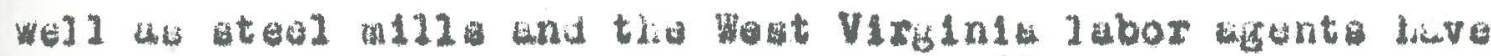
43

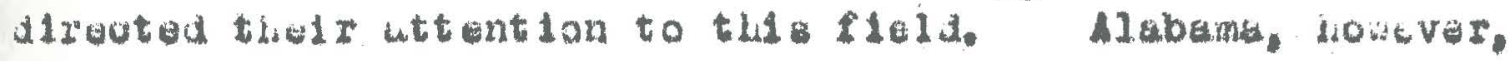
0) 1 me only $3 y$ or 11.16 per cent of the minerg interviewed

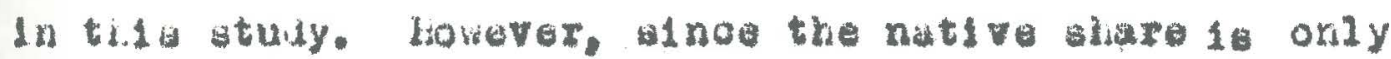

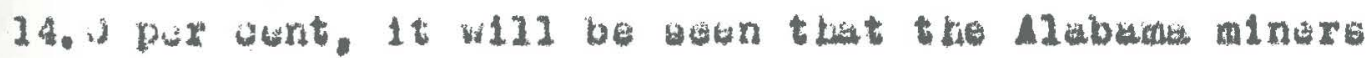
sowititute din laportant furt of the population.

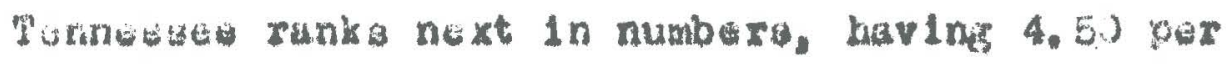

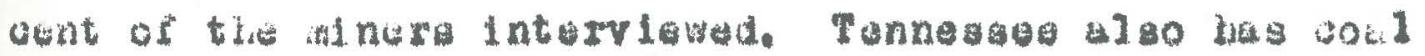

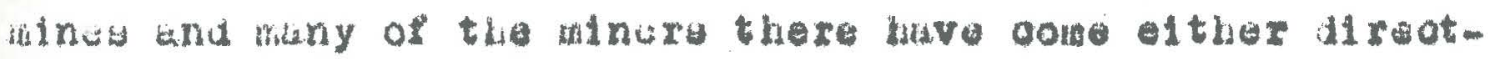

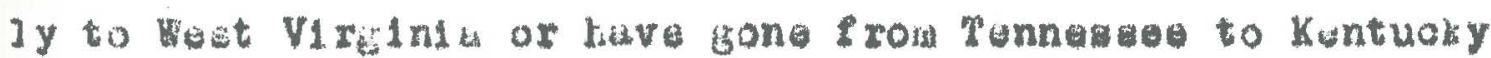
und thenoe to West Virginlu. Georgia nutivos oonetituted 41 Epotorn, 20, alt, p, 26.

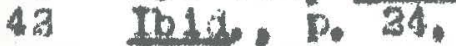

43 Herro Misration in 1913-12. Dept. of Labor Buj1et1n. p. 83. 
3.3 .3 per oent of the totul, Bouth Curolina 2, sis por oent, and Ponnsylvinl a and Kantuoky 1.16 por cant Gaok. A11 other atches lad lase than one par oent.

\section{THE STERAM OF MTORATIOH}

The strem of Uigro indgration 1 s not a now one. It uturted before the Civil War and ha been golno on wer sinoe. The tampo und the volume of thlo movement tuo reuponded to unuaual economlo foros whiloh heve betn fur from constint in thela uttruotion. Perbupa the erreateat ot latim

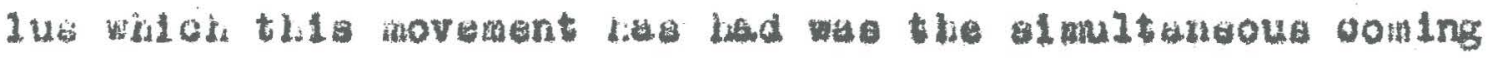

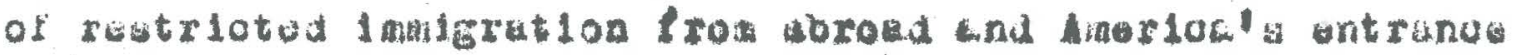
1rito tho horld mar. These ovants, particulariy the letter, 44 broust an unpreoedented exodue from the routh. Thist West VIrginla wa the plsoe of deotination for many of these wartime igranta we have good bit of evidonoe.

The unueual inaresee of the migrant Nezro wnera probably atarted about 1918. In 1913 there had bown wapression whioh was reflooted in the temporary slowing up of 45

the movement. From Apr11 1 to Dotober 12, 1320, however,

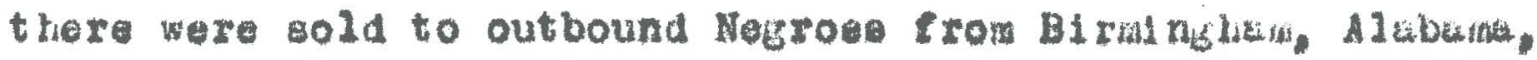
1,733 whole tlokets and 158 balf tokete, wooording to a 46

governinent atudy. Tre polnts of destinution ware Juning, Flealng, NoRoberto, MoClure, Hite Oak Junotion, und Buver

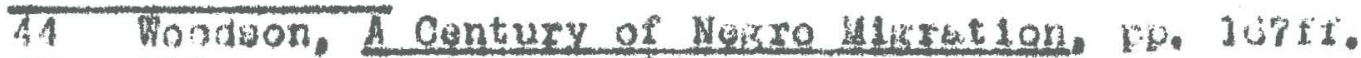

45 Alion, en olt $0.1 \%$

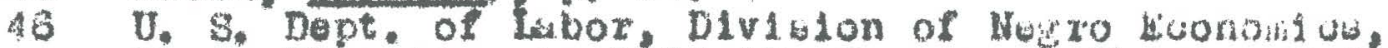
Nesro Migretion in 1310-17. Feport on Exodus of lic xocs from Alabara and Dorth Carolink, by Bnuvuly, $\tau, F_{*}$, po. 53-54. 
Creek, Ky,....... Glurkoburg, Falrwont, Sourbro, MoDonkld, Quinion, Thurnond, and Woodbay, Vaj Akron and Clnolnnat1. Ohlo and Kane, Ponnaylvanta. All the plooes above named in Vost Virinia are elther oltios in tho hast of atning 1101d or actusl ooal mining operationo. From Hovember 1.

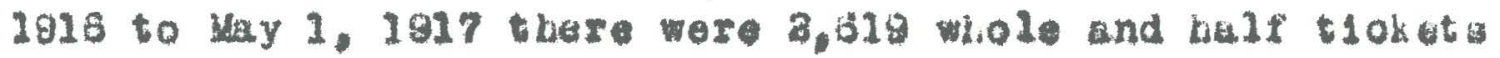
bouglt frow Blruingharn to Dooan ulne and Solilagel. Wast 47

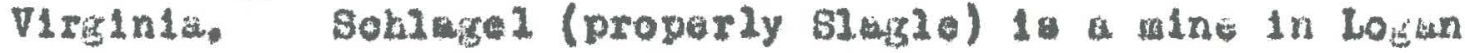
County. From North, Garollne after the spring of 1310 there wa a stody oxodus colng prinolpullyto polnt in Virginia,

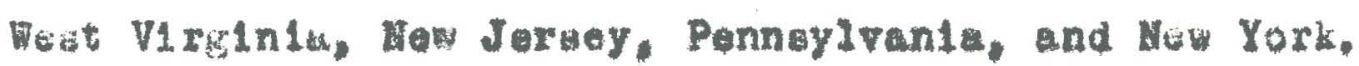
46

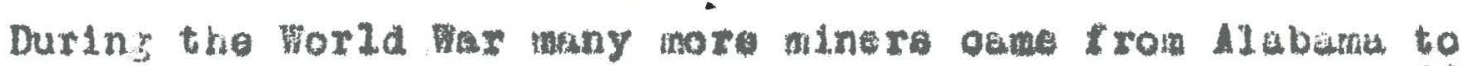
42 f111 in the gape left by any wo want into tho servico. After the World War coal development versin in 50

Greenbrier County in 1831-32. The opening of this fild made for somethat of an inorebse of Nogro populution, no Nogroes bolng rocorded as working in thut oounty in 1320. 61

Enil 203 by 1965. About the mame time of the opening of tha new Granbriar flelis another ovent intranolisi the

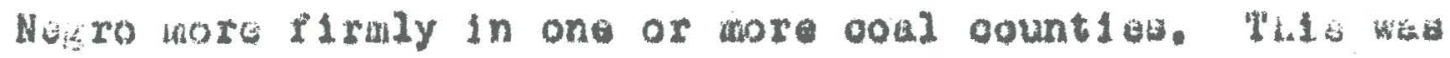

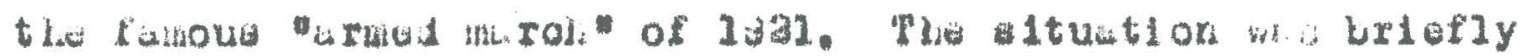

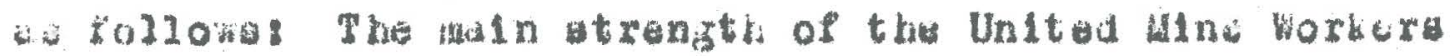

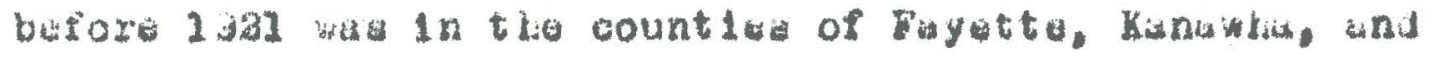
47 Th10. P. 55.

4 Ib11.

43 Farr1a, A, L, Opportunt ty, Fobruary, $1930,0.47$.

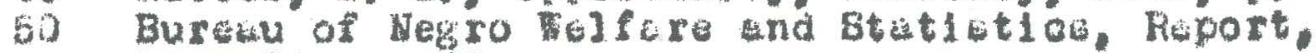
b1 Tbid. 
Purt of Palolgh.

Logan County and MoDowell Dounty, lov Ever, lad remalned non-union. wenover a atrike wa coljod

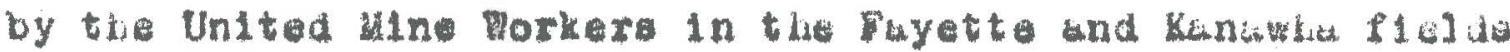

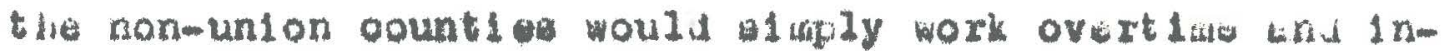
ortase their output, theraby breaking the gtrike. Ilo

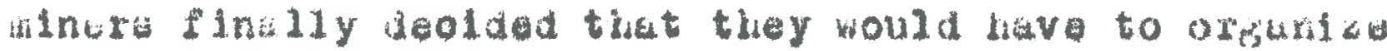
Lobin Courty or the day of organlade labor wero at wh und.

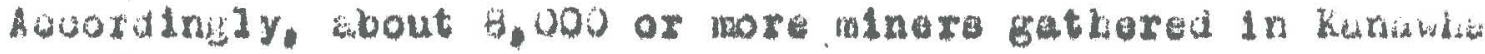
County for the maroh on Logun. One souroe of Intorantion

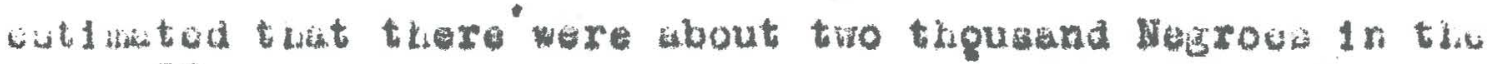

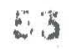

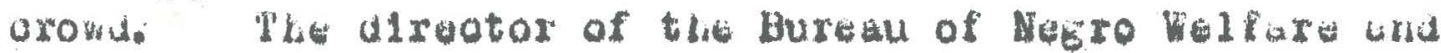
St..t Lition, Lowaver, In his annucl rejort to the covernor otatod that be had boen aotive in parsuadino Mcoroes not to particlfite in the arron and that 1060 than 200 Hogrous 54

wotialiy took part. At tho was time many Nagroed volun-

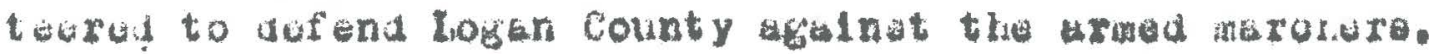
These were bugmented by othore who were thken over the Gountalne from HoDowe12 County wo 11 bht the rad necki." The vuoanoles Iot in Kanswha County by the wowa warali and

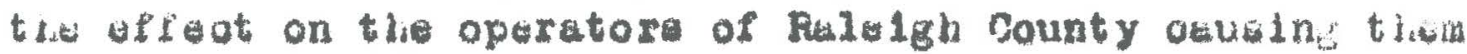

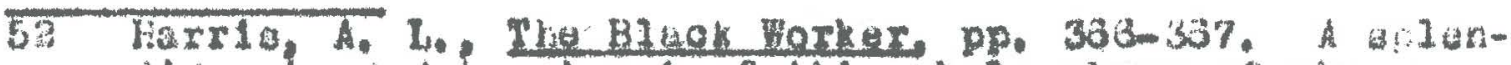
did extended treatiant of this whole phase of this Noso's role in unionien 1 s contalnod in tils volume. b3 Nition, Sept. 15, 1921, p. 288.

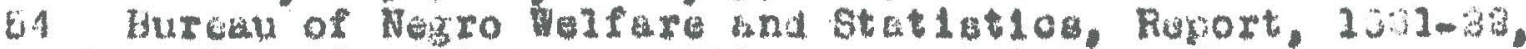

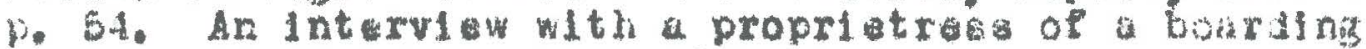

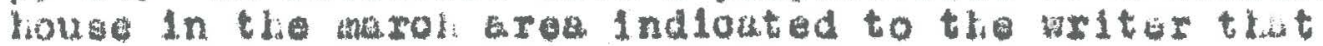

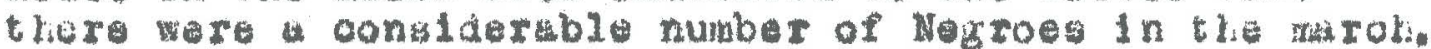

56 Bureau of Negro valfare and statitioa, Report, 1335-33, o. 20.

50 Interviaw with an old Negro miner at Keystono who liad opposed tho Negro' partiolpation in the detanas of Logan County on the grounde that it we wn operistor's pot. 
to employ inore Hegroca tanded to 1 noraside the resro inining 6?

pogujation in thesedistiotan

Labor troubla in the nortiern count is of OH.10. Brooke. Hanoook, Honongal1t, Harion, and Harricon in 1932 brousht unother wave of mistation, of this, Jolunson sayas

During the ooal stike in Wast Vireinia in 1.3: the numbar alx ady thare wara aupolemintaj by hundroda Irow VIreinla, Noth Carolinu. and Alubama many of these entaring the minos tor the trat time. Whey lave boen axrayed on both. aldos of the long und bitter apntroveray betwean operator and alners in the northorn and souttern portiona of the atate.

Thla wive of newoomere ousued the Bureau of lagro velsure and statiotlon to exprea come unxlaty conoerning their oliaraoter in tho refort of 1923-34, of the numbere the 50

report abyet

It 1 worthy of note that whlle lerctororc the gratest increate in Nerso population his

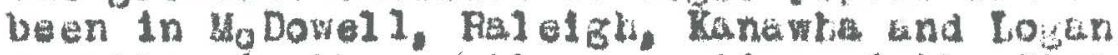

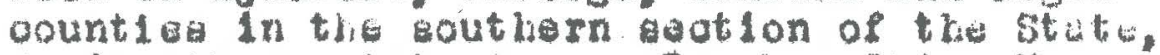
duxing the past two yeara Brooke, Ohio, Monon-

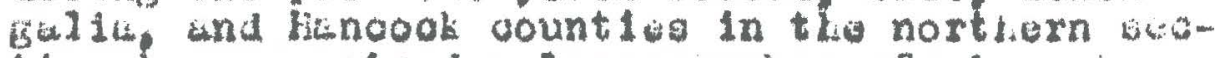

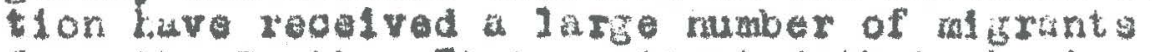
from the South. It lo catiated that cbout four thousind now comers have sett:ed in thes four count les and bive been absorbad into the $01 d e r$ copulation itil very 11 th e eldotion....

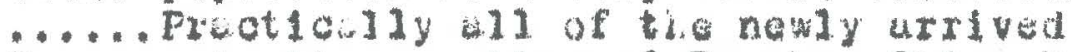
Negroce in the oountles of Brookv. Ol.10, limn

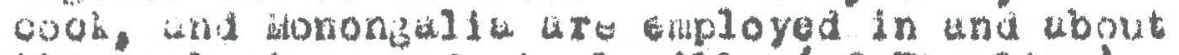

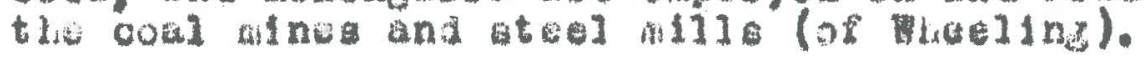

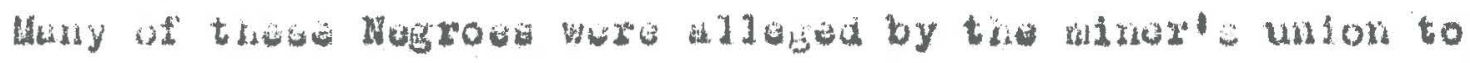
57 Toto

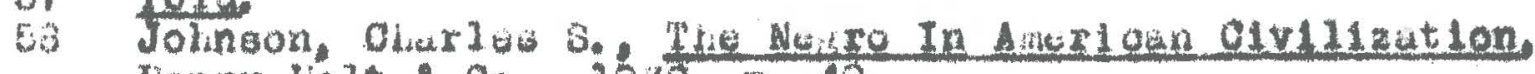
Henry Holt \& Co. $3635, p_{0} 49$.

5i Rewort of 1933-34, op. d-9. 
be strike brakkers. One unt on ofl10181 in northern wet 30

Virginia gald "If the present atrike fo loat it will bo ollefly due to the Importation of Negro ot $x$ lke breaker whon the omployers w112 kiok out as goon ws they lave forced ue to submit, "Whether this be true or not, the nusbers of Negroen in the $1 x$ northern oount 16 of Hurion, Hartion, Monongalli, Ot10, Brooke, und Marabill whowed a Nagro alnting population of 3,030 in $132 a$ and 3,603 in i1

jajs, whilow lo fact pertinent to the purpoises of the Hrowant alizgtur,

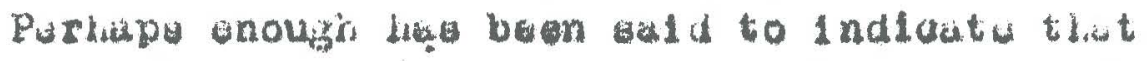

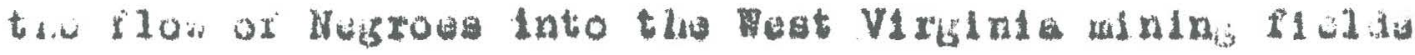

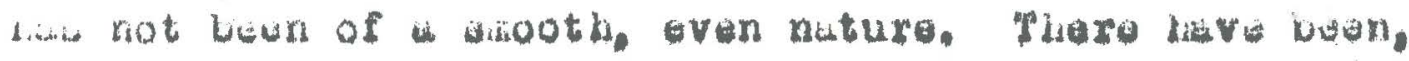

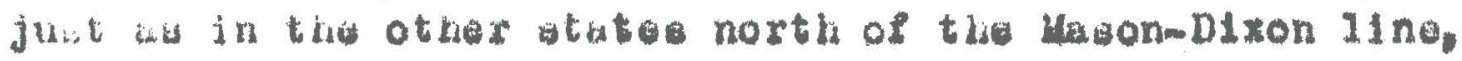
purlodid of deolded conoentration und rapla movewent. The curve of the coming of the vagrow whould akow hot a

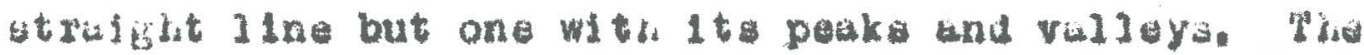

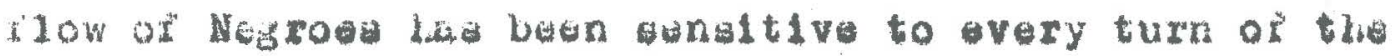
market. Skye the Director of the Burean of Werso Welture unit statiatios in hil 1935mas roport ${ }^{83}$ opile number of Negro minura omployed by years it alour index to the

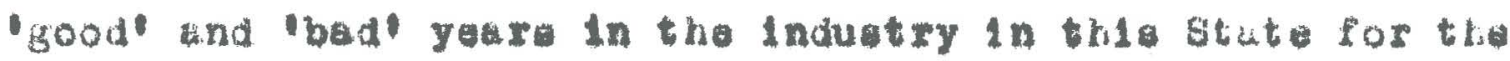
seriod oovored," We may now turn to a brial discuatolon of the effeots of suoh a palliating population movauent. 30 Bureau of Wegro Melfars and stat1st10s, Report, 102b-ä, p. 30.

81. Compliod from 1923 and 1923 Report of the Dupurtiwnt of Uines.

63 P. 20. 
It 1 o one thing to point out the owollibtory ohidacter of the igration atroam. It is quite insthar tidng to buy that an onusaration taken aeverul yours after

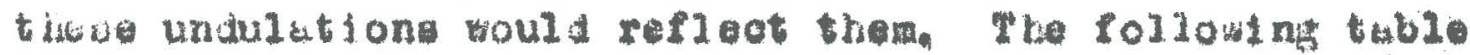

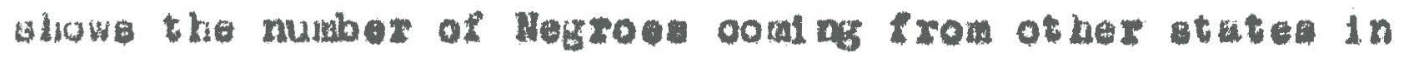

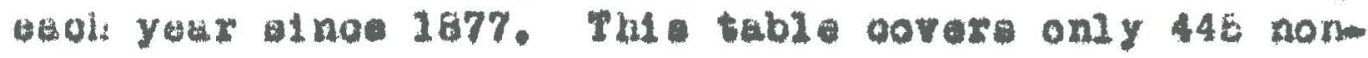
nutive ralners out of total of 516. In 72 adae tho ainer was not bure of the date, honoe the cohduled werd thrown out in the compliation of this table.

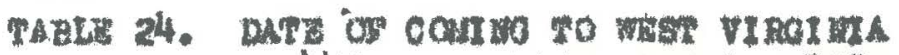

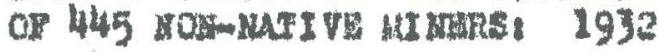

\begin{tabular}{|c|c|c|c|}
\hline Tenr & numbor & Yoar & thamber \\
\hline 1877 & 1 & 1909 & 25 \\
\hline Ig80 & i & 1910 & 26 \\
\hline 1882 & $i$ & 1911 & 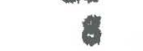 \\
\hline 1883 & $i$ & 1912 & 22 \\
\hline 1886 & 3 & 1913 & 11 \\
\hline 1887 & í & 1914 & 21 \\
\hline 1888 & 2 & 1915 & 20 \\
\hline 1889 & $i$ & 1916 & 19 \\
\hline 1892 & $i$ & 1927 & 17 \\
\hline 1893 & $i$ & 1916 & 13 \\
\hline 1894 & $i$ & 2919 & 10 \\
\hline 1895 & 3 & 1920 & 26 \\
\hline 1896 & 8 & 2921 & 8 \\
\hline 1897 & $i$ & 1922 & 22 \\
\hline 1898 & 5 & 1923 & 3 \\
\hline 1899 & 3 & 1924 & 15 \\
\hline 1900 & 10 & 1925 & 20 \\
\hline 1901 & 8 & 1926 & 11 \\
\hline 1902 & 14 & 1927 & 10 \\
\hline 1903 & 12 & 1928 & 10 \\
\hline 1904 & 9 & 1929 & 16 \\
\hline 1905 & 7 & 1930 & 9 \\
\hline 1907 & 23 & 1931 & 7 \\
\hline 2908 & 5 & 1932 & 2 \\
\hline Total & & & 445 \\
\hline
\end{tabular}


The writer is fully amake to the danger of generallatng on the baslo of any table whioh refleots dutis is Incomplete and oovering an shall number of mincrs we thia one does. however, certain conolualone tront the tuble dueta to lis both within the bounds of plausible and $10 \mathrm{~s} 1 \mathrm{lul}$ dto duction und, at the arne time, rakonable diution.

If any oonoluston may be drown from our tisble it would be that axparentiy the Negrope who cond in the whe ves

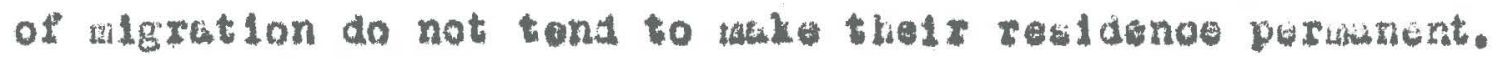
It 1 quite probuble the these andrante coulde in tiat of

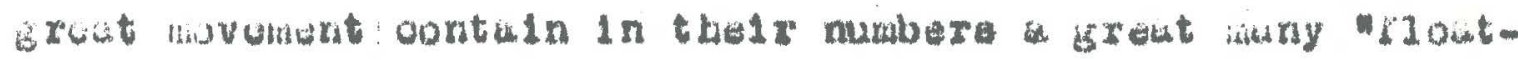
ar who resaln is alort the and then nove on. Pruaticalzy

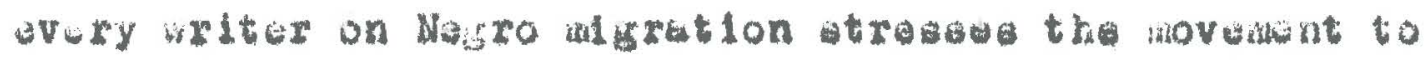

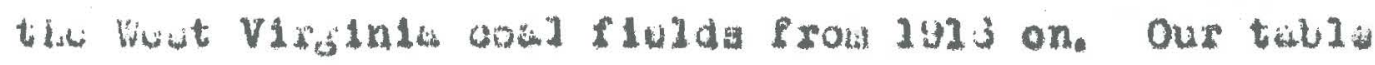

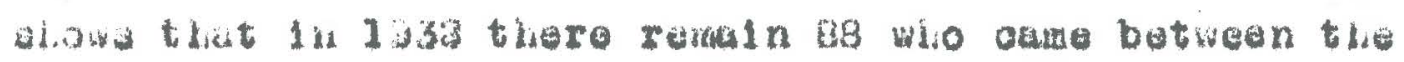
youre of 1910 and 1314 while only 73 owwe betwen 101 and

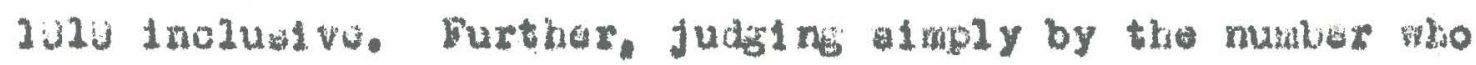
reximin in lusa, tho ramber of those coming betwoen the

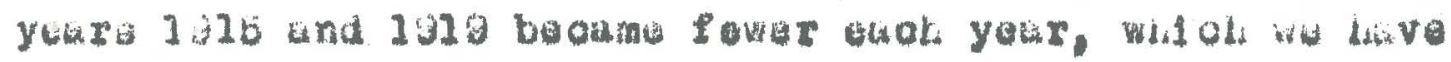

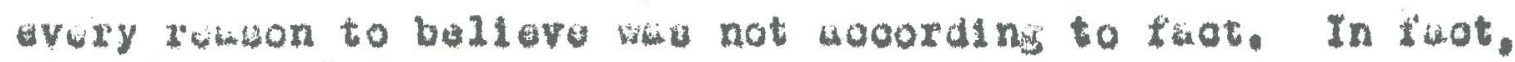

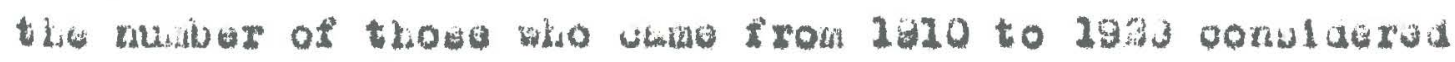
by five your perlods, showe atemdy doollne. The follow Int tuble w11 112uetrate the fuat: 


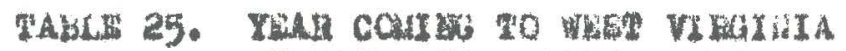

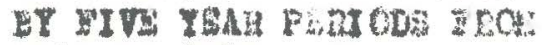

1910 To 1930

\begin{tabular}{lc}
\hline Poriod & Muber \\
\hline $1910-1914$ & 88 \\
$1925-1919$ & 79 \\
$1920-1924$ & 74 \\
$1925-1929$ & 67 \\
Total & 308 \\
\hline
\end{tabular}

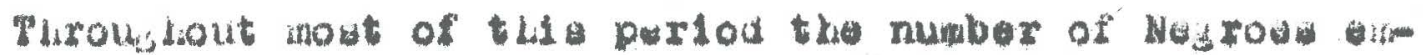

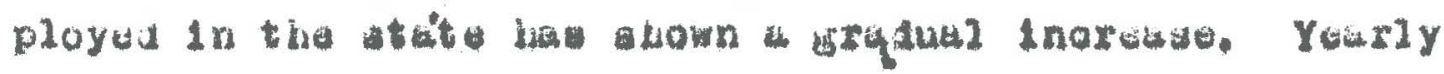

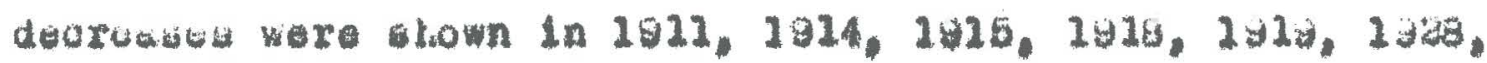
13\%o, and 1930 but the total Magro ulner population inoreased frow 23,067 in 1310 to 23,633 in 1930. Thio pewk yeur for Negro winera wa 1027, when 25,336 ware wayloyod Souse poeitive oorrelation is shown between the totul number of Merroes anployed in the tate enoh year and the nutuer remining who oane in that yoar. However, the corrujation 16 nazative in 1909, 1909, 1913, 1914, 1918, 1917, 1018, 1962, 1933, 1928, 1927, and 1929. That probably bappened was thut the group of Negroes who laft thetr southern howe during the exoltement of rapld and hurrled movewent contalned more of the adventurous type who were lookint for a sort of 1ark, at a time when golng north was the thing to do. and, henod, had a tendenoy to wander or return bone.

The part playad by 2 abor mento in stivaliat ind many Nogroee to loave the south is not to be ligrorvid.

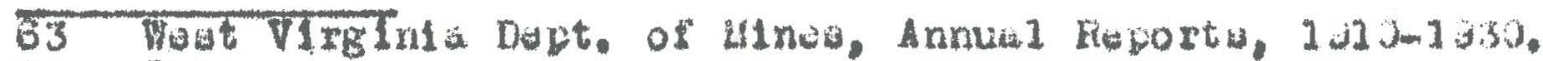
04 Ibid.

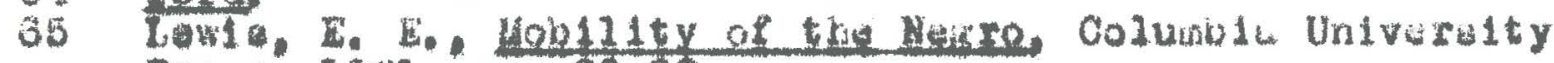
Preas, 1531; NP. 95-39. 
In Birminglum paid agente distributed the following b111:

\begin{abstract}
"Let'g go bok nortl. where there aro no libor troublas, no etrikga, no lookouts; large coil, good watiou, falr trectunent. Two weeks

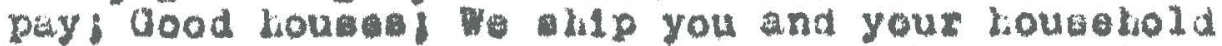
Goode; All oolored mintataro oan go free; 111 advanoe you thoney if nogessary; soores of tacn lave witten us thankl ne us for wending thom: Go now thlle you have the obanoe."
\end{abstract}

Wille it is doubties true that the algrant going into the winlng flelds onjoyed better oonditlons than miny wio want to sorse of the nortbern $01 t 100,37$ many of then found 1008 perfout conditiong than thay were led to apoct. This fuot, wht the oonsequent depreasad condtion of the coul Induatry may have regulted in inany of those more undidu.tidu iners leuving, for the south or other points north. fle older ponulation the more adjusted und remalned.

\title{
IV. THE OAUSES OF UTORATIOU
}

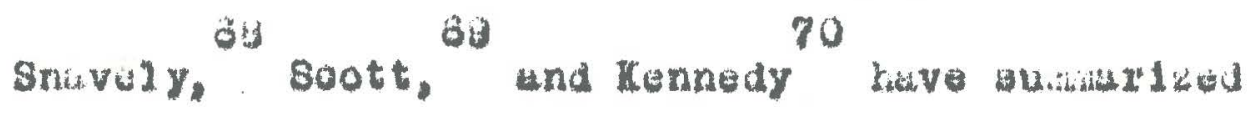

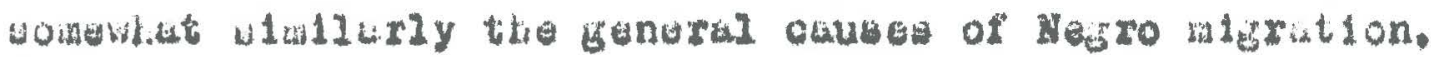

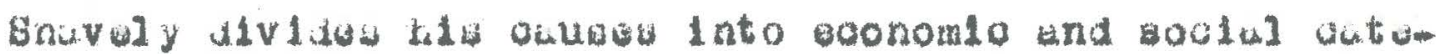

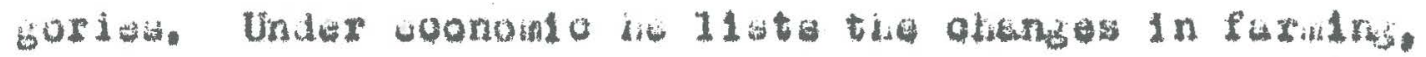

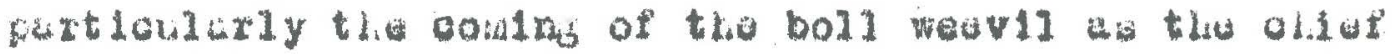

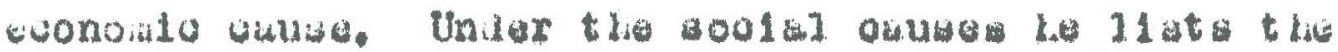

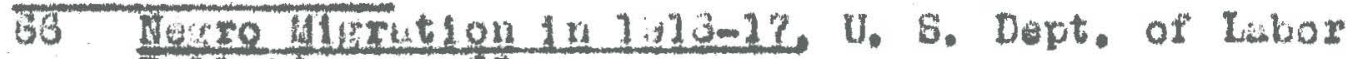
Buj]etin, ${ }^{\circ} .85$.

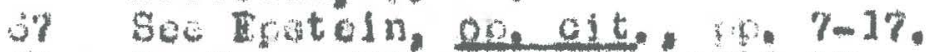

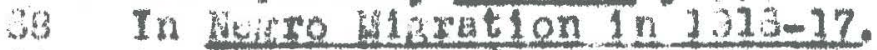

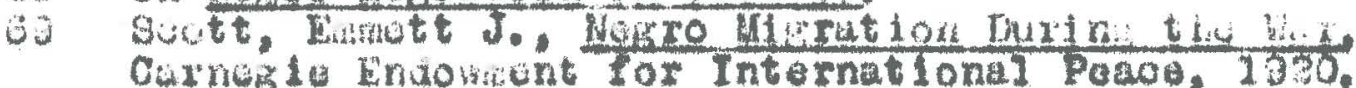

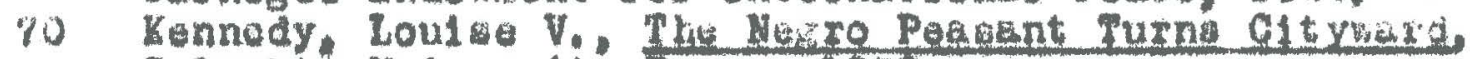
Oolunbie Univerolty Frose, 1930. 


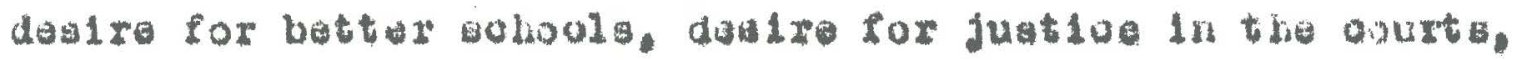
und a doalro tor un inorause of privilezes in viblio convaym Lnoes, Eaott, In a moli 2onger study, disousbes firot the

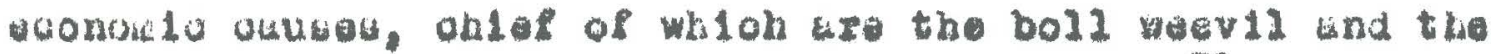

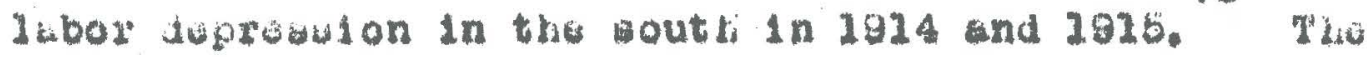
opportunity to arin a bottor 11 ving in the North where White wire double and trable thooe regelved in the south to Ilute wa porkip the most potant fautos. He then pro-

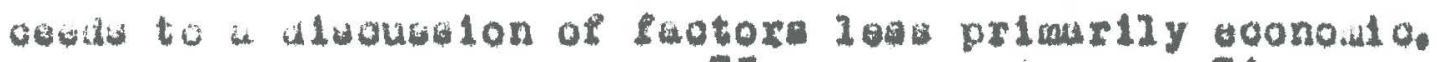
73 74

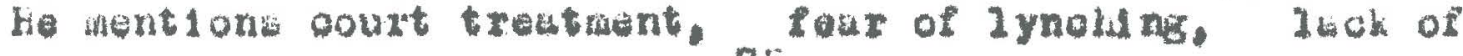
sood culustional fwo121t100, and the tendenoy for whito pooplo to beoome hoot1le toward ohlldren whlle at the diane the oxlufblting frienulinose toward thelr parents.

The fiotore numed above are wostly the "puat." whil oh ware inherent in the oonditione in the couth. Boott gowe on to discuse cartain other fuotore whol on ght be termed the "pulf" in a chapter on the ctimulation of tho 77

movement. Here he 118ta auol feotors aldequesion of the north as a plaoe for Magroes, lotters from frionde who had gone north, the augegestone of oubtl apakars, the Chlcago Defender, poems hout the migration, IEbor egents, and the social contaglon of the rapld movement toward the north.

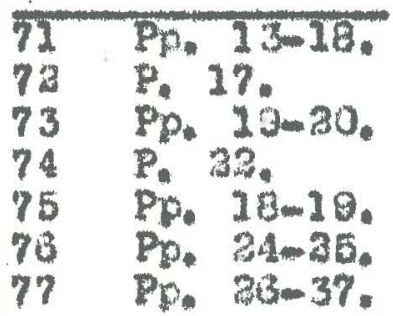


Kennady, in a book whloh appoared ton years aftar 78

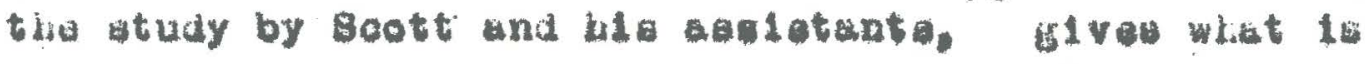
agantialiy a sumara of that otudy, apgarentiy witiout 73

glving conaplouous oredt to 1t. Bhe has, howover, glven outogortes to the causes stroased by boot to woll as wiking is ditinotion between the oause oonetituting "pusti snd those conatituting "pu22." She divides the ofuse into four astegorlat econoula, coolal, coolompeyokologloal,

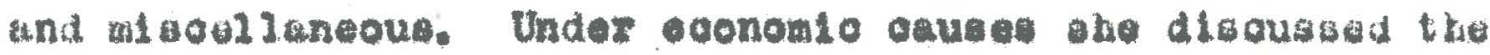
inoreace of opportunity in the north, whioh wes brought about by the outting down of Imalgation and the glaultam neoug increase of output; the bad oonditions on the furias

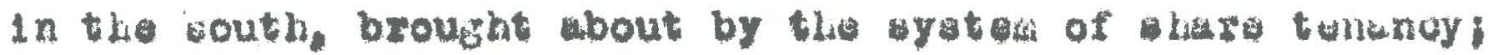
wh. the comins of the boll-weev11, Under soald chuses.

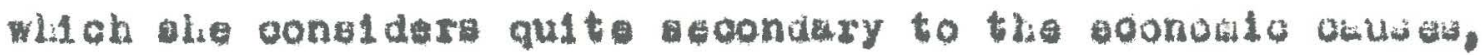

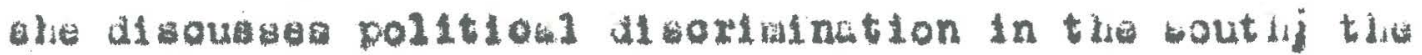
Inseourity of 1160 and $11 \mathrm{mb} / 2 \mathrm{gged}$ disorimination in the matter of undue arrebta and proseoutiones the lack of

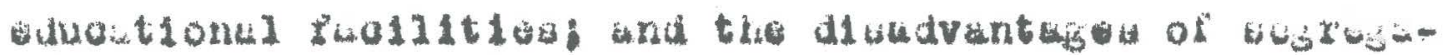

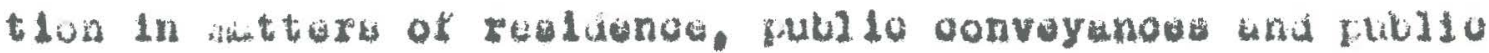

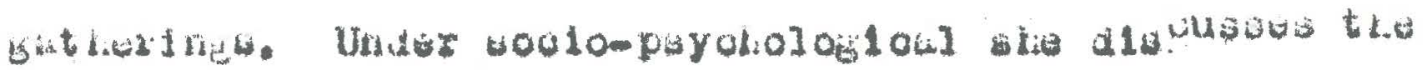

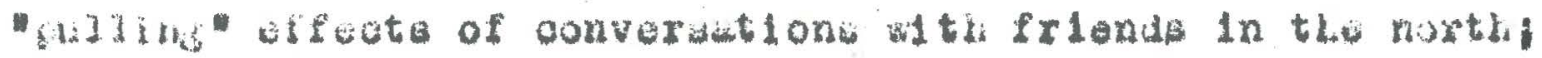

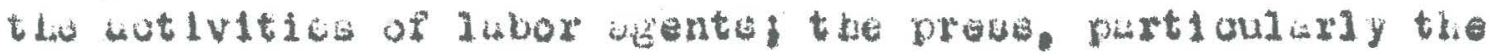

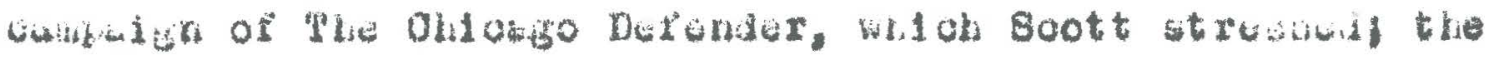

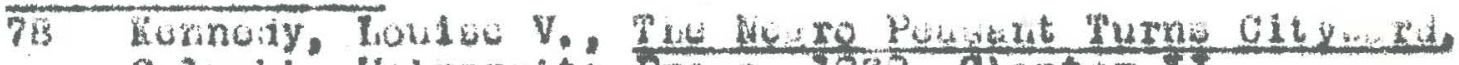
Collunbla University Proas, 133.2 Clapter II.

70 Boott' study 12 iluted in tho bibllography but in tila chsptar it ia referrad to infrequentiy if ut all. 
return of suoceasful migrants for vilits and the oontufion whoh resulted from great number going to the north. It 1. somewhat diffloult to woo why Dx. Kungedy used ber last

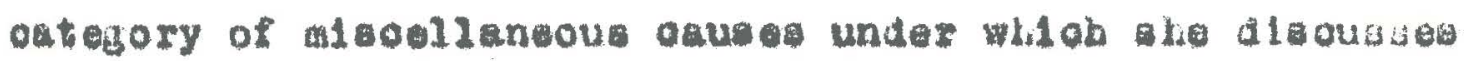

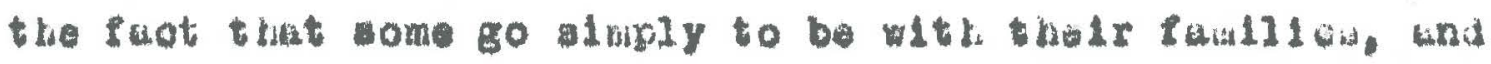
the tendenoy of profeablonal men, etore kooperg, to., to follow thelf ollentolen ghe add in conolueson that thero

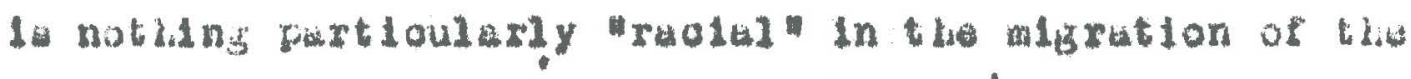
degrowa thist they ura aluply tollowine a law of neture

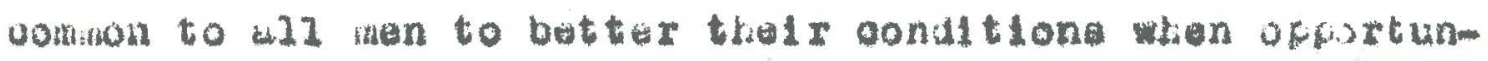

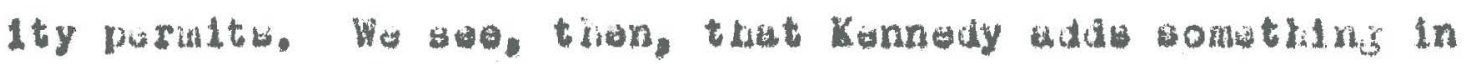
the wity of fork, but vary 1ittie in content, to the other studitia, Such thay have boen the purpose of Dr, Kannody, us hur win oontribution was in ber dealln with the effeote of ralgriation on the ofigrantw rather than the propess of theis boooming is asunte.

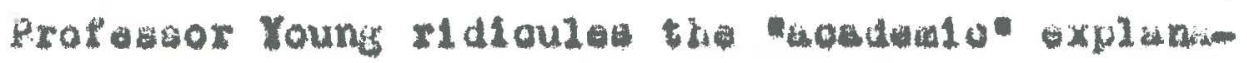
thon of the migration during the last fittean years bosed upon the caur of Iynohing and race projudioe in the south. Lie glvas we ev1denoe of the error of suoh thaortes the fict that if there had boen any ohunge In sooe relations in the South 1t wa in the disuotion of andioration suther than otkerw180. Further, he polnts out hat lynohing in the south was on the deorease. It would seen to the writer that Professor Young is perhapa partiy in error hituself

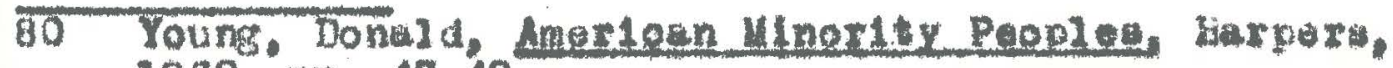
1933, pp. 47-48, 
hore. After boginnine his book with aplondid ohater on

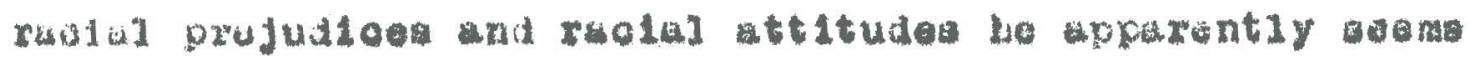
to foret momentarlly that people reast not o wuon to objective roelity un to atereotypod conoept lona of what ruality 1 d, and that these doreotypos aro oulturaliy pro duoed und y bo oulturally abanged, polnt whlah bo beis

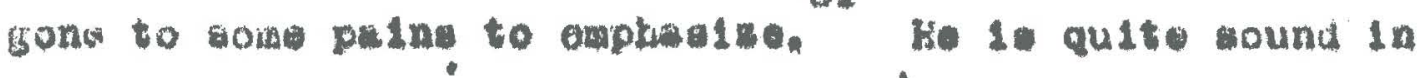
emphusizing the feot that theae oonsiderations are not the only one to be taken into soount. Howerax, conelders tion of the coolal peyohology of agitgtion and the intenglve

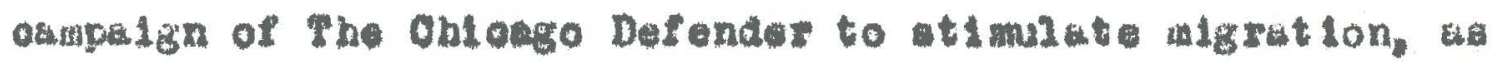

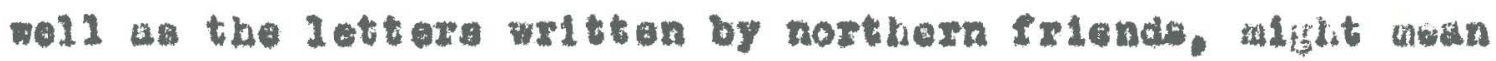

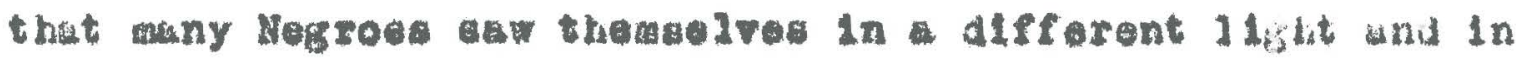
a different frame of reforono than ever before, thow new attituder mlght be over ao wistaken and not based upon unblesed observation, but that faot doed not man thet tiay are any the lase potent. Profenoor Young would bave been muoh nore oonvinolng oould he have demonstratod, not only

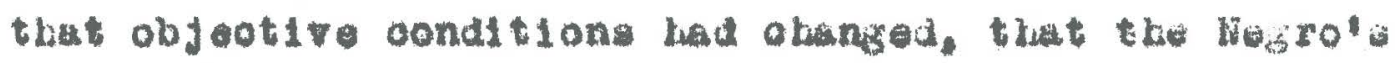
storeotype of the southern situation, or his attitude

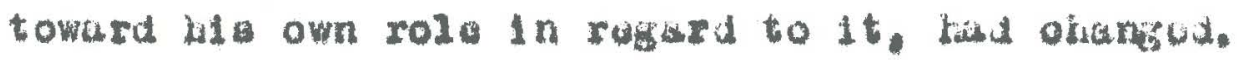

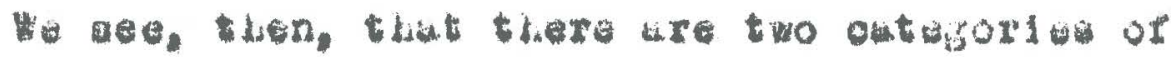
fuotore to be taken Into conaldoration in disousalng the

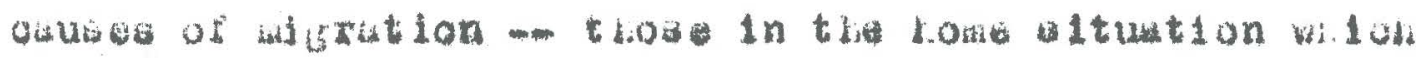

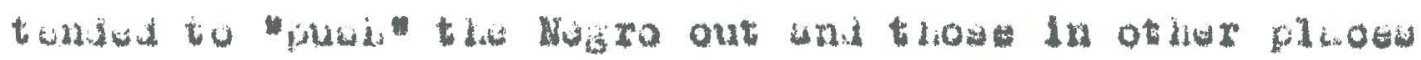

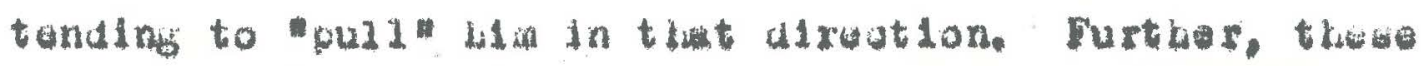
BI Pp. B-20. 
cause are to be sought not inerely in external econowlo and soolsl conditiona but in muman attitude and otereotypas tonard these conditiono. With tha general tractinent of

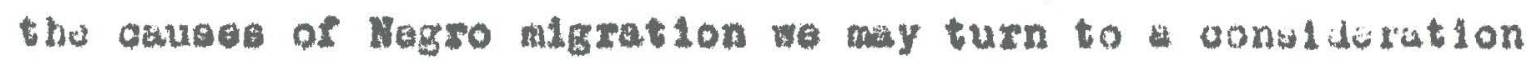
of the reasons whloh Negro ulners alve for thelr coulnis to West Virinia. Waile it 1 q quite true that many ramions ure meroly rationaliations, it 1 g belleved that thoy do reveal

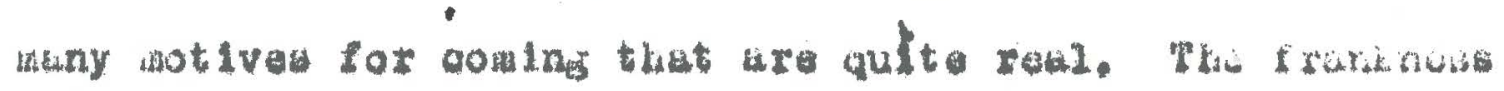

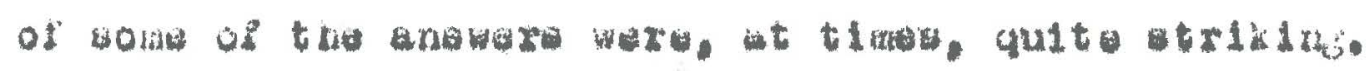

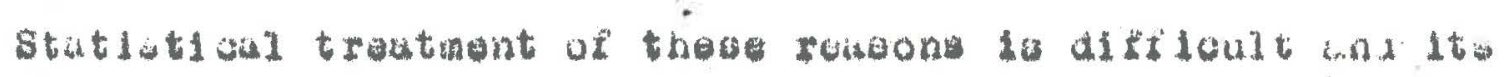

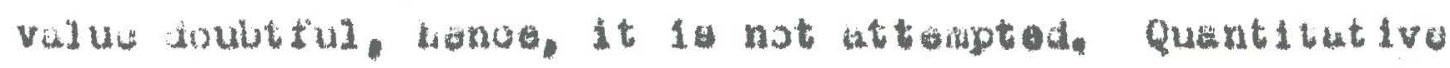

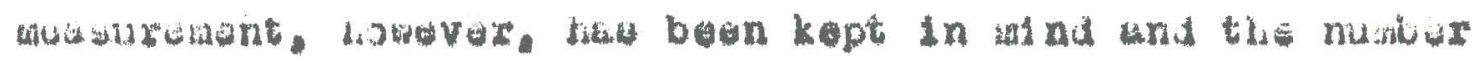

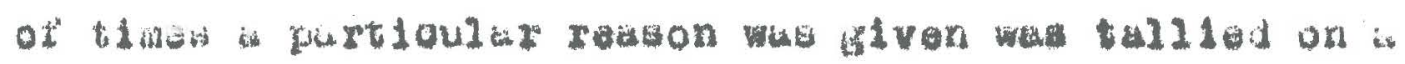
rokes dutis ahoat. The uttompt was then wade to olubalfy

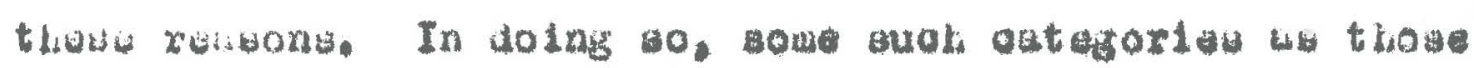
ukt by kannedy ware kapt in inind, although no latengt wa incide it striot adierenoe.

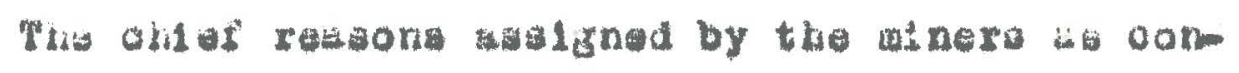

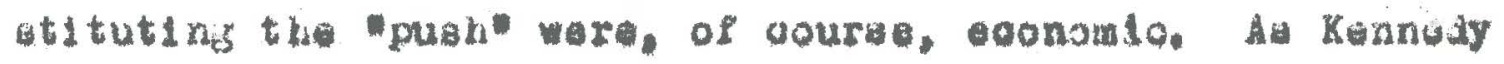
mokus ol our there are always two oonditiong nocadary tor wny algratory move - - disatiafaotion with the prasent look tion and the proml te of Improvement in the new. As Donald Young so we12 alayol The job 1 a alway a meano to an ond,

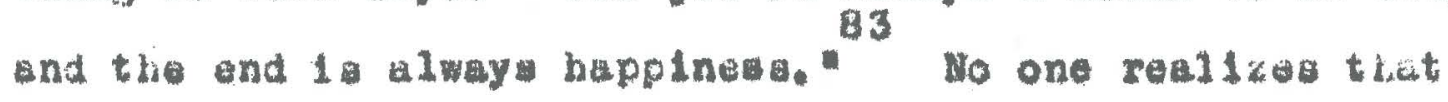
fict more than the preant writor who, after a atuy of the

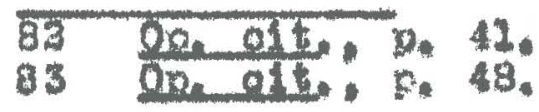


11turuture of Mugro evonoilo conditione frow 1830 to 233 , 84

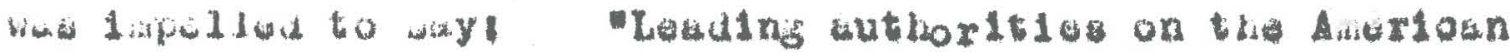

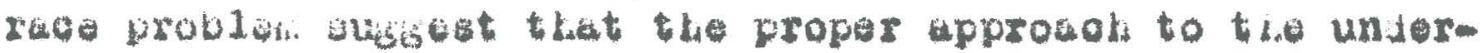

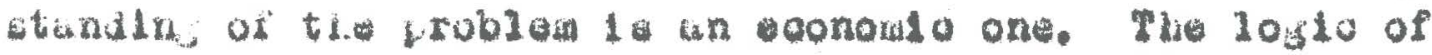

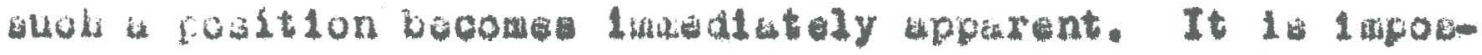
sitle to tilink of the Amorioun Nejro upart from the soonomio

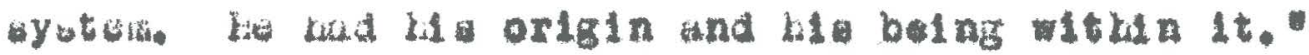

\section{sinoe itany of the algranto ware agrioul tura?}

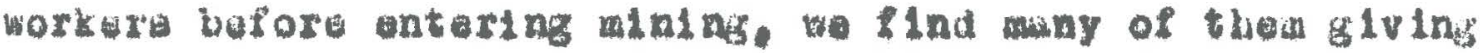
ar thes reswone for Ioaving the couth the oonditlon of the furm. The boll-meovil was the oause of the fallure of the ootton aropa of soins. The tobacoo bugs, coupled with the low prioe pald for tobrooo, wa given by geveral Iroin Nortis

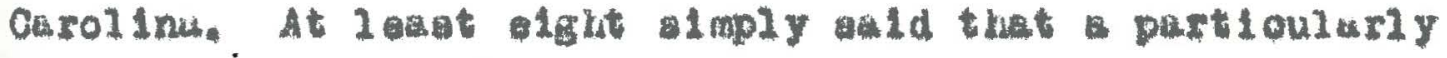
bud orop wat the Iranedlate cause of thelr conlng. On the contrury, otherg whoo orops had falled oma in order to auve thols farme and go baok to thom This laot 1 a pluta of the "monoy-orop" aspect of uning reforred to 65

bofore. Low wages on tho aouthern farme was given by ottura.

Gogie of the minera wero not expliolt about the1r oonilitione in the south, but no lese than 49 gald they

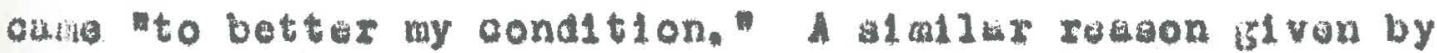

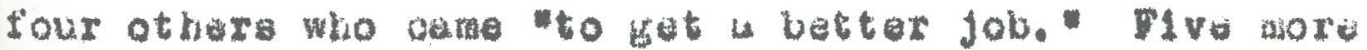

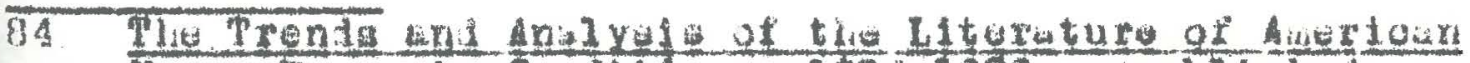

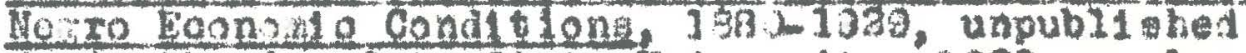

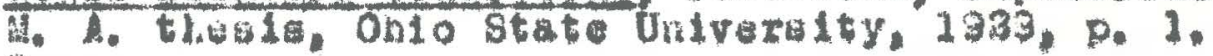
ub Sugrin, n. 


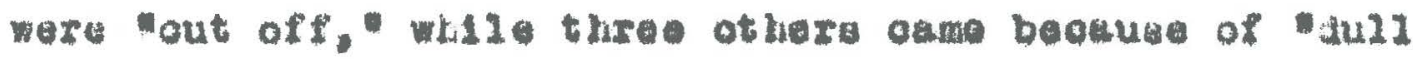
work." One oame to make my own start in 1160." Otherts who ware moro urtloulate, but tho labe frank, wakis for

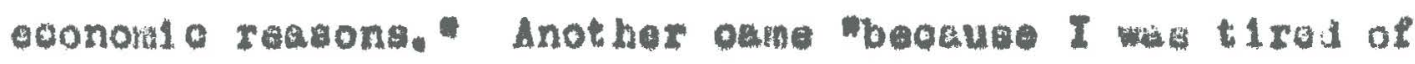
tho ten-lour day in Virinia factories. An Alabata oro mnor from Besgenez came becaus the woge puld in thic ooul mines in Weat Virglnia were better tum in the ore

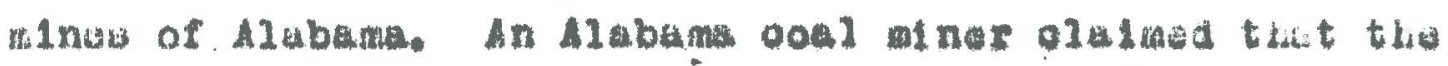

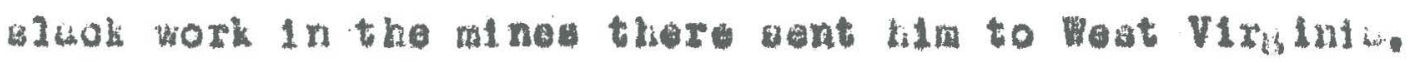
Two of tho sow Panneylvanla Megrodis in the dunplo Oub beoullas the intner olosed down in Pennaylvanl and one

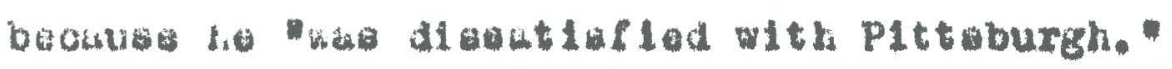

Some of the ininara gave rabone that, wh110 they wert fartly coonoulo, iave ovidenoe of other wotivating fuotoru. The following w12 exomplify ourtain of the wore

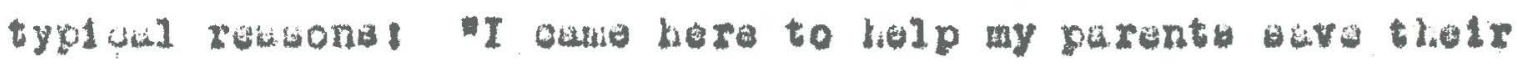

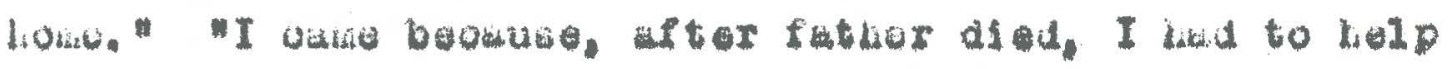

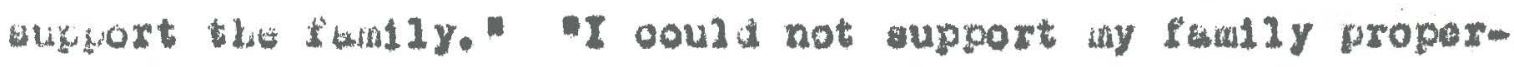

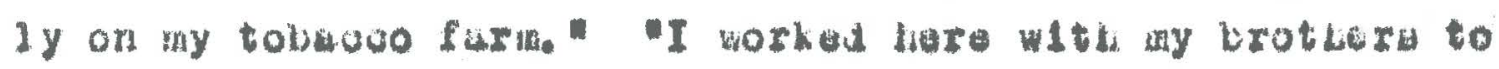

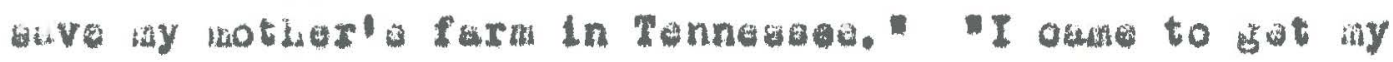

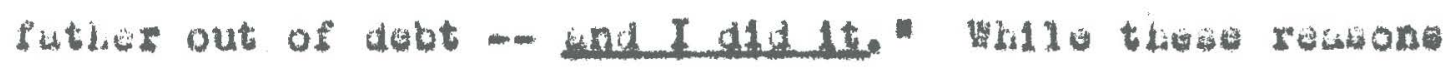
bro jrobubly acononto for tha wobt part, yet thero was u

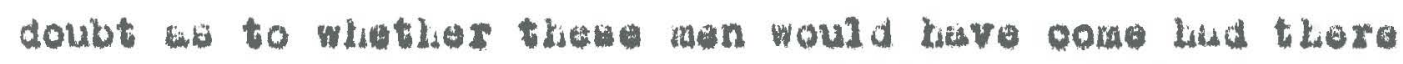
not bean otiver upoolal reasons, sentimental and otherwios. The more art loulate mabars of the Nesro igroup upoke more of what 8 cote und Xennedy sefer to as moolul reasona for conlng. The ordinary minar guve wore enplasta 


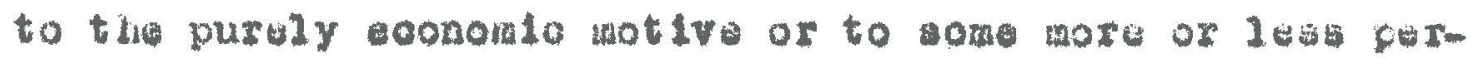

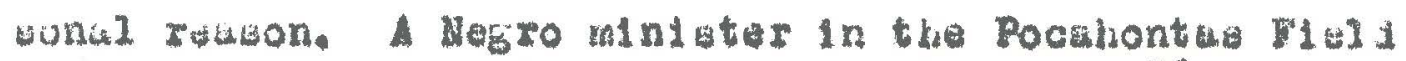
buvo the following rusune for the migration: Bo

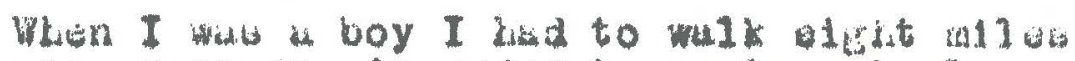
oul. way every day in order to go to oolool. I woula itart out before iny parenta were up in the rorning and in the minter often I would est home after they were in bed. Hy rather would lotivo suppor propurod and iny breukfat wiso, I would get ay lowsonw und 60 to bad and lave before they were up. Paople do not I earn to have affection for plisces whera euch condit tone axist. As rebult many have littio botooling whil lavo laft the home otate for peet viriglna. aly poople have oomo beomae they ware dickfod the franchido because they were doritud orrortunitio for education; beouve the labor acket was auok that they wanted to oone where the coupetition was leas kean. They manted an opportunlty for thelr ohlldron that hoy nevor had.

of glatlar optnion whis the Direotor of the Buruau of Vegro velfure und statistion in 18a6. He anyol 87

Not only do a large number of Negrous migrate to neet Virglnia buause of the con atunt denand for 1 iabor at better vagen than ure paid in any of the statios to the oouth of us and beoutse they enjoy wore 11 berty. more proteotion in the oourte and better eduoationit fuollities. but for coonomio reasone thany whil te people oonatantly migrate to thi groat State. thereby keopling the poraenterse of inorades of Marroes in the total population at very narrow miste $1 \mathrm{n}$."

To oay, hovever, that the more artloulate croup efvos the

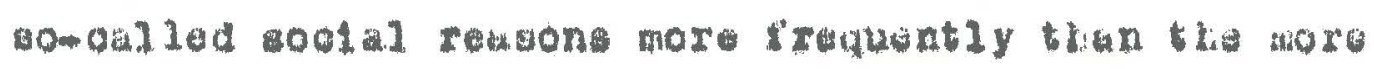

83 The priter apent almost an ont 1 re afterroon with this

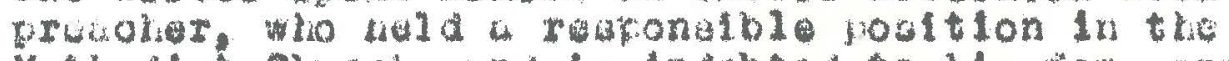

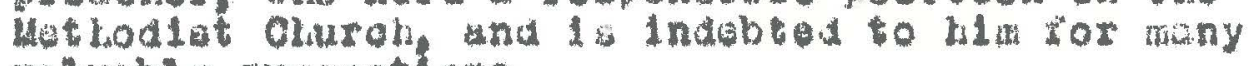
val ueble nupget tons.

Q7 Report of 1925-33, p. 7 . 
nunerous group is not to aey that tho lutter do not al wo

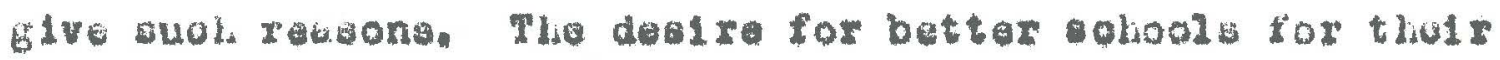

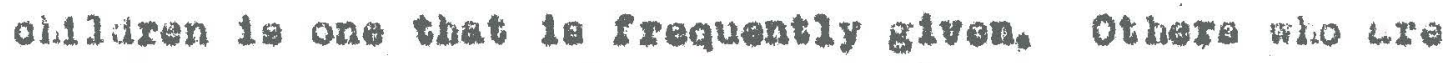
lewe apoolf10 lewe simply given blanket Indiotinent of the conditlons they left by raferring to bad moolal and labor conditions,"

Crises of verlous kinds whioh interfere with the acoustomed tenor of 11 fe have been potant okuses in bringlns

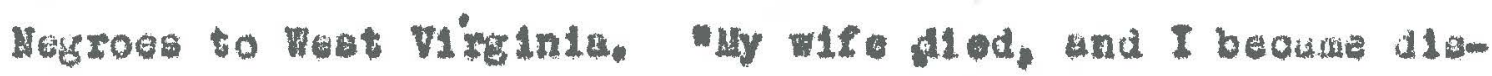
outiafled" was a very oomon reason. Ite very ropetition by Nogroee In many parta of the state would Indloute thit the Negroes at loast assoclate the breaking up of tais ly $12 \mathrm{~s}$ sonetimes with eertaln awount of personal dieorgunization, with tholx leaving their old homes, Another answor, My parents died - - and I juat drifted, la to bo pleced in the sune outezory. The Degro is not unlque in this, of course, Convarations with white alars live sollolted the sula

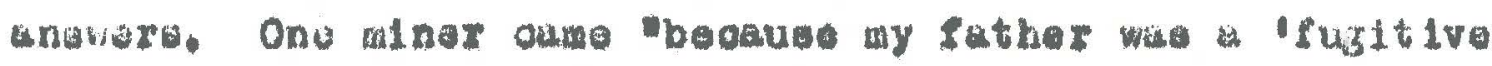

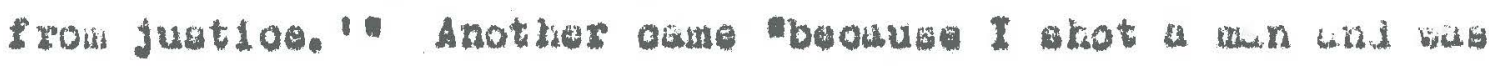
thet rist of bolng juldea,

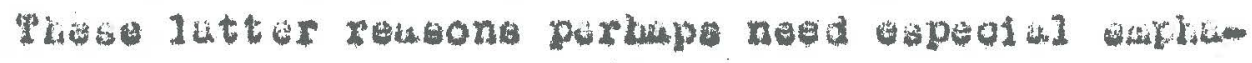

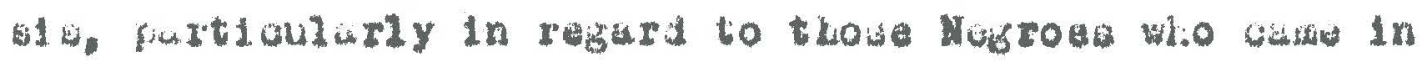

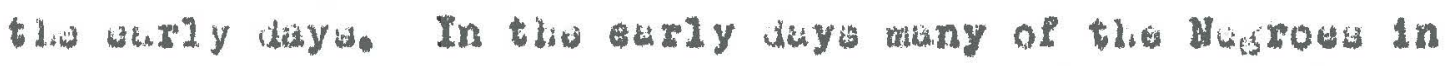

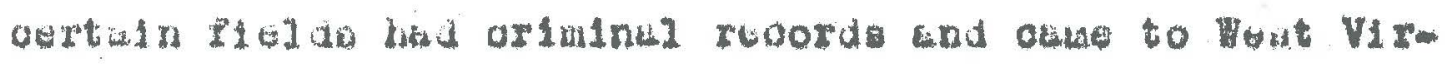

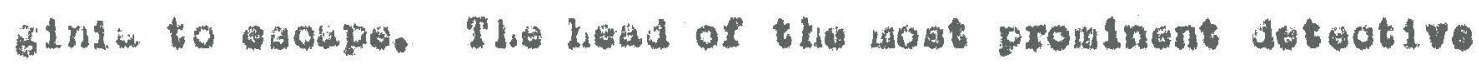
Henoy in the mining liolds, whose experienoe rund over 
many yours bald, in this rogard!

"I would fosy that at least flfty nor oent of the

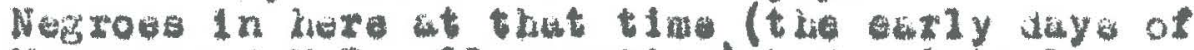
Heroer and Hobowoll oount1os) had orlminal recoxda, thist 14. Inoluding the depporadoes and thowe aooumed of sour minor offente."

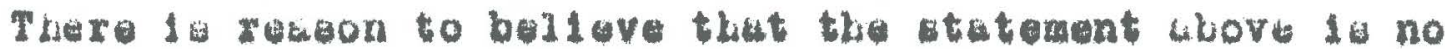
txugsuration, for the flret report of the Burutu of Hegro Wulfire unc statlotico ways

Alom; witi. thon (noxthy Hegroon and whttes) oume

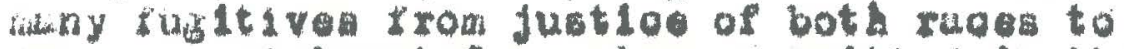

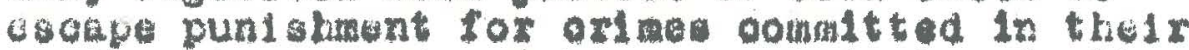
nutive totos and orooke the oxl degroes.

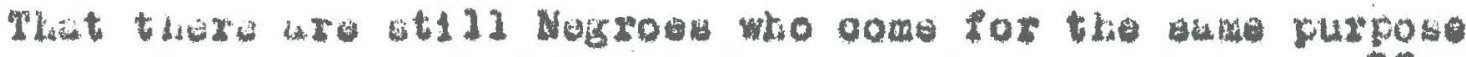
1 ovidenowd by mothor quotation from later report

A. Brute majority of these migrinte oume to west

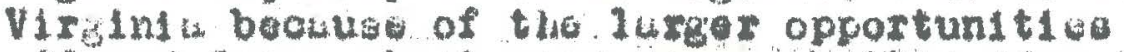
of ferca for work it good wegon, better eduout lonal cuvintages ror thel $x$ ohllaron, und noru 11 borty.

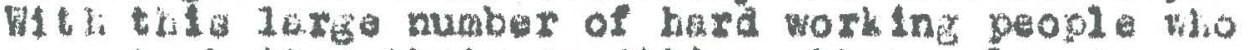
obise to bettor thelr oondtion, thore alao cuns

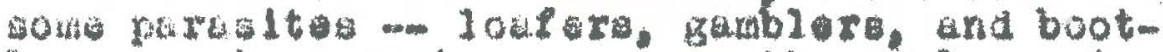
lagerers who oaw to proy upon the nowly wrivod woricere. Tha alas opereted through the ooal fislde of Brooke and hianoook countioa and in tho Whooling industiml ditri ot. They have beon reaponelble for most of the Iawlosenese reported disons Negroes of that weotion and when they are coustit by the offloers of the law in west Viriding they $g 0$ in hiding in the nearby oltles and town of Ohlo and Fennayivanta.

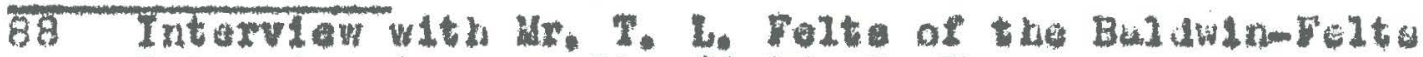
Deteotive Agenoy, Bivelold,

89 Report of 19a1-ded, p. 13.

90 Buremu of Hegro Telfare and stutiatios. Report of $1923-34, p_{0} .6$. 
rlere la no doubt that in the old days many ortalnals of both ruogs used the talno ats hideouts. The lootion of the mines in rearote bollowa und oreak vallays thi the laok of fecilities of comauni oution mede thein ideal for this purcose. However, with the bulzding of pared roads to wl parts of the mining 11 lds with lmproved asans of triats portation and oomani gation, tho loolation wo priaed by the oriainal has largely dLoppoared, That legroes atill 0ois beouuse they get in trouble at home, however, cannot be doubted. Miners of this type are apt to be vory asutious and supplolous, Friendy kegroes in wome of the ogaps told the writer thet his proseno caused areat dual of discuoslon, not to say aprehonation, anong nowe of the Magrous and that he was thought to be evorytulng fron prohibition Egent to s Toderal invegtigator. The ochedule used in the

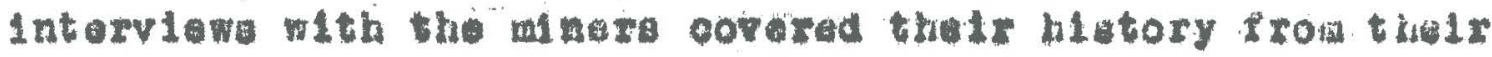
atete of origin to thatr present job. In the mida of one

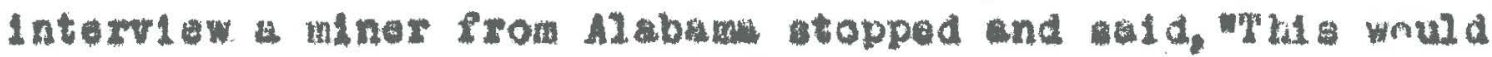
be g good way to track up somobody who had done something

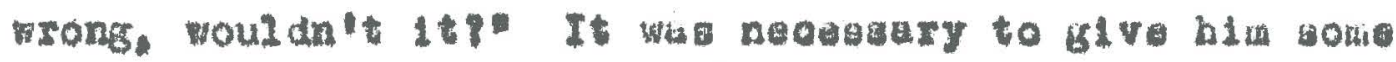

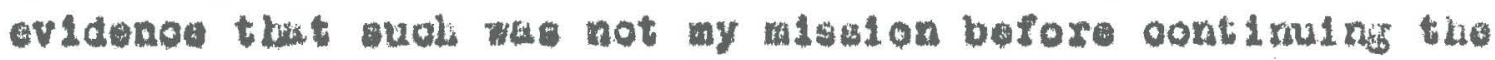
Interviow.

Another fiator wlon pluyed an laportant purt in

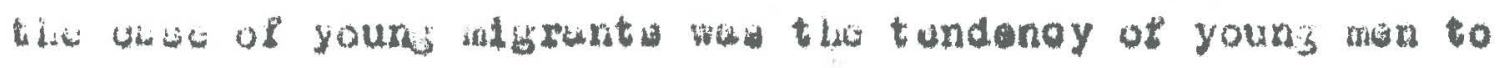

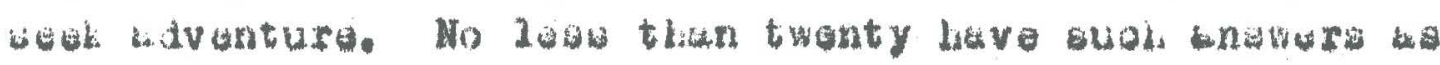

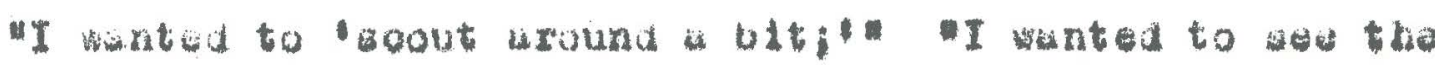

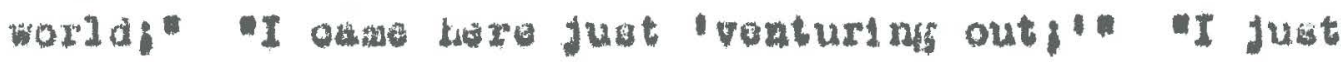


wandered here," This "vanturing out" is quite cowmon in cortuin wotlons. Several of the minara ren away irom how as children, To run away srom Virginla to Veat Viring

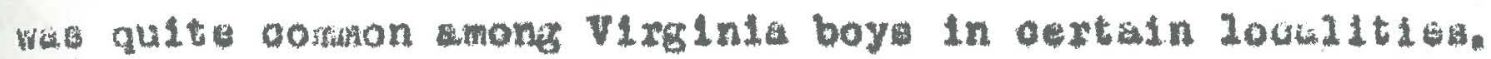
They would oone alther in groups or individualiy, Nogroos from the far wouth oftun got together with groups of thes boy friends and aame to the mintug flelds. Somo of thete boys "just got tired of the farm."

The deolaton of relutivos to go to the minlacs

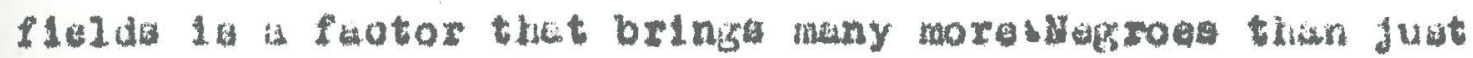

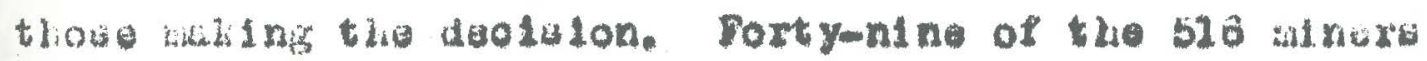

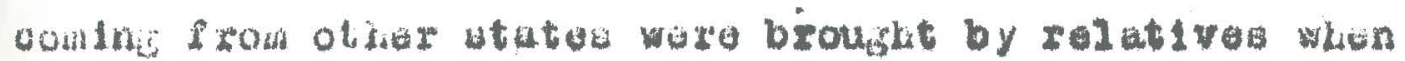

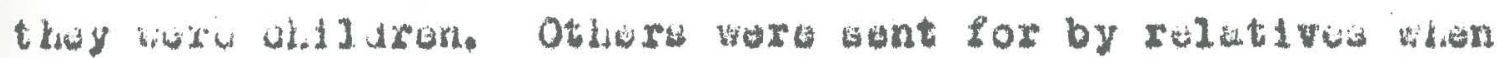

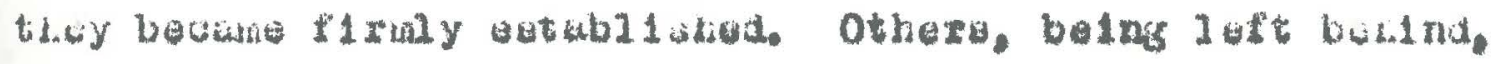

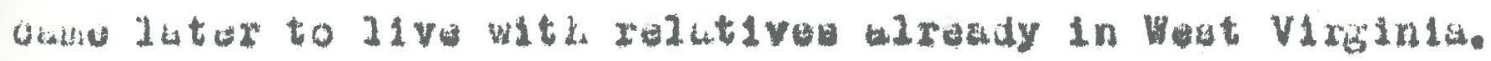

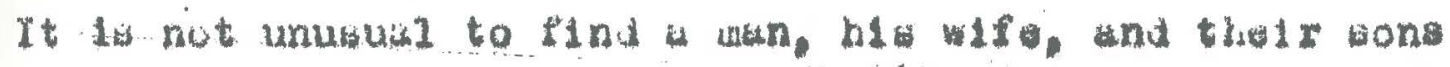

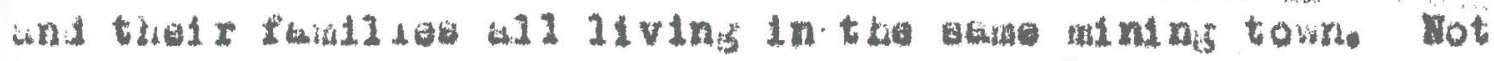
introguentiy sone of tholy old nefghbors in the uouth w112 wo folmi thate also. This tendenoy may be oomplas to the

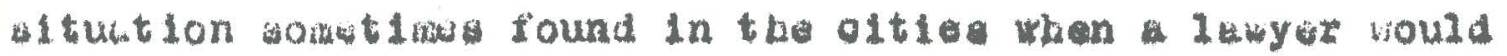

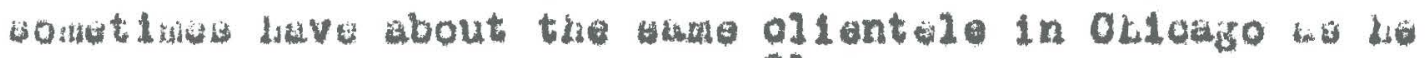

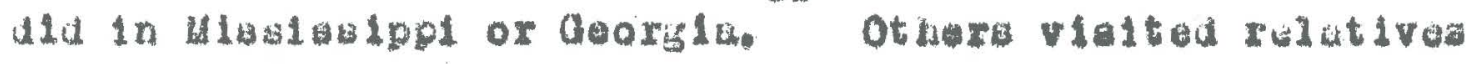
In wot Vixinla and deolded to gtay theraed vea.

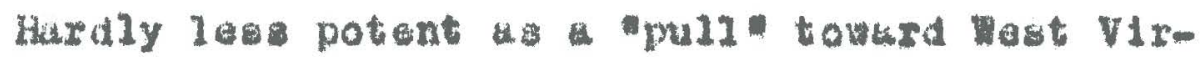

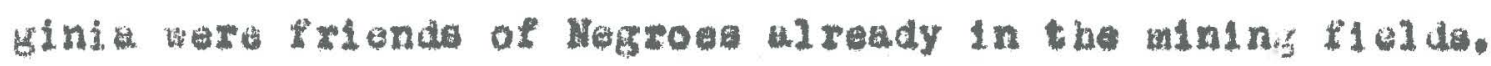
Filunde returning from the minea for $a$ it to thelr old 31 CF. Boott, are att, P. 45. 


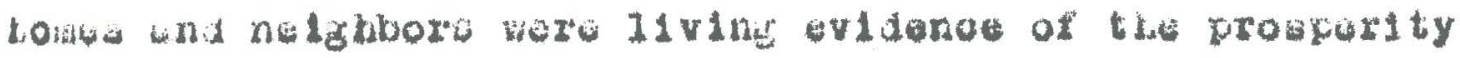

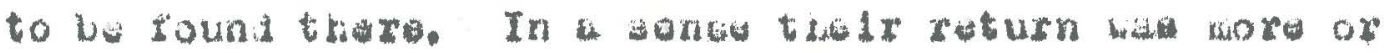

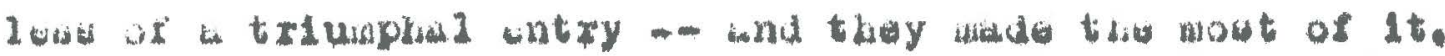
Oref-low ded with olothos sid money, they laft 1itilo doubt

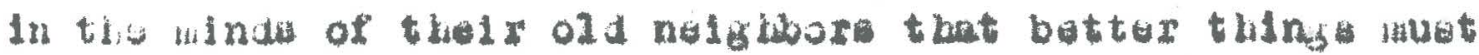

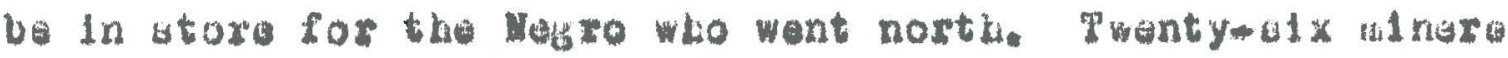
buvi xoturning filende of rejutives as tia direot audes of

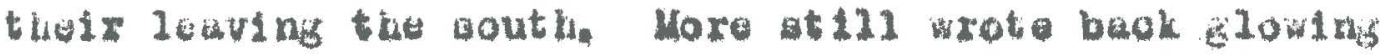

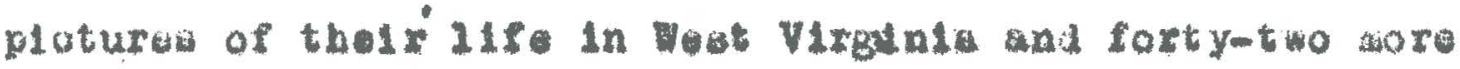
osme as a reavl

Forty-11ve miners gave as thelr roaon fot cotsing the migh whege whioh they heard about in one way or un-

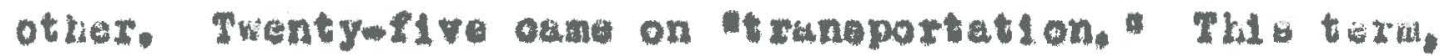
a has bofore beon explained, rafexis to the polloy of the oompentes, In times of 1abor hortage, of paying the txuin fare of ancre from the couth to the minos aftor which tha

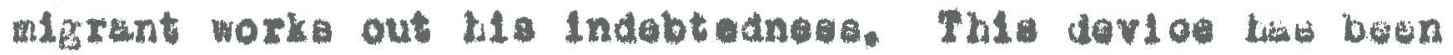
uged partioulariy often during tiug of atrike. Iwantym one ware attrated by the mooz in the ooal flulda." Two more were brought by bals employex when they outue to

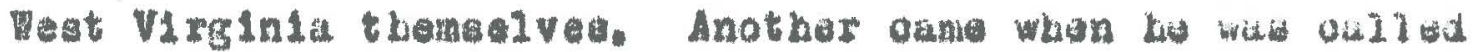

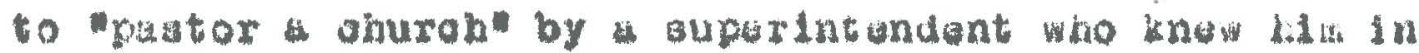
Kentuoky. Two othara ouda badilad thoy vero discurad of

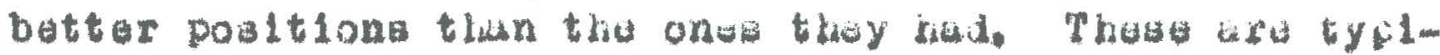

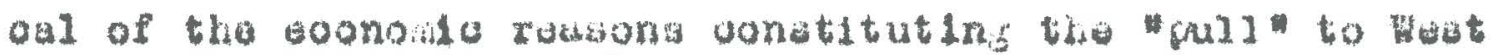

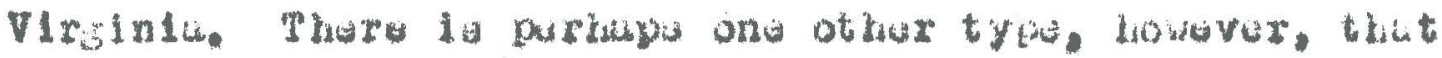

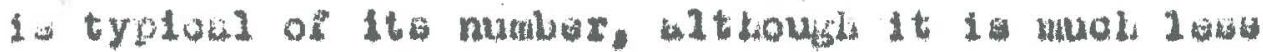


frequently Lound. This in the oage of the migrant wo goos north, tears thare of the minas in west Virginla and comes there from the north ratber than the south. More than one followed tinle route to the mines.

In genorel, therafore, It would caen that wo would bey of the Megro miner, a Lawl does aonotarning general industrial workere, that the offootive detaind for lubor hes been the nowt potent thotor in bringinis hia to the winlng 11 ide, Howover, ouoh a statent lo not to

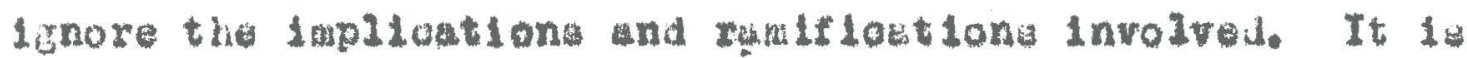
quito true that Negroea he followed induat ry to the north juet as they followed agriculture to the southwest.

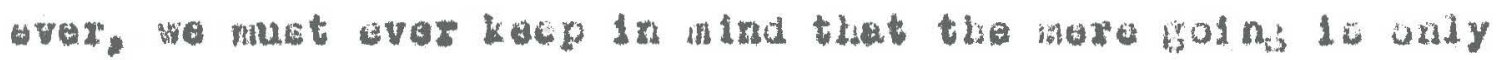

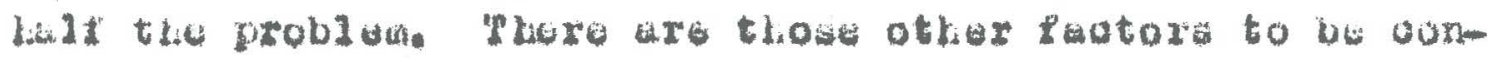

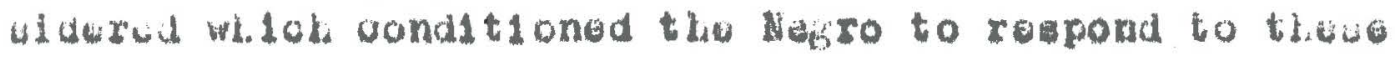

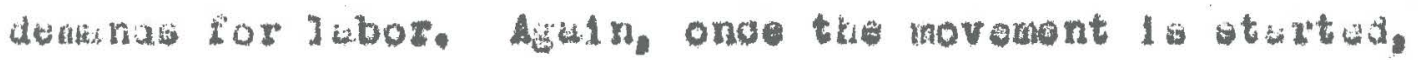

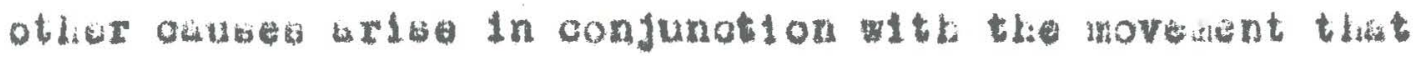
wro not buslcally eoonond o in tholr nature. To the the

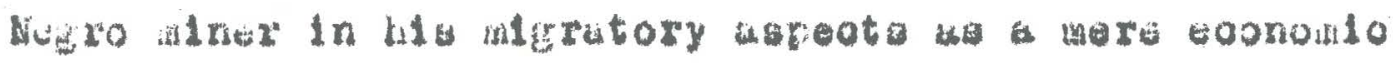
nupet is to ate only gartlinlly, but to lgnore the great

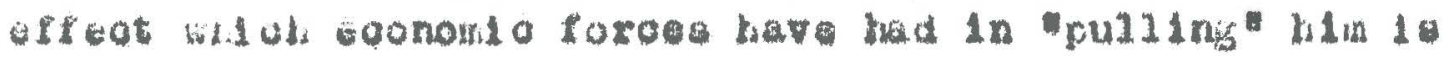
also to we ondy in purt.

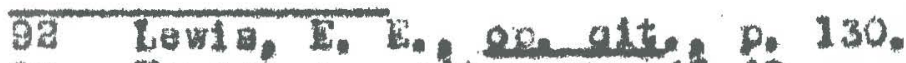
33 Touns, enc olte. Dp. 46-48. 
V. TYPEB of MTORATION

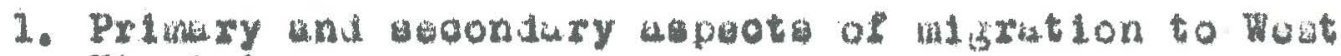
Virisiala

Row and Iruxml have polnted out the dietinam

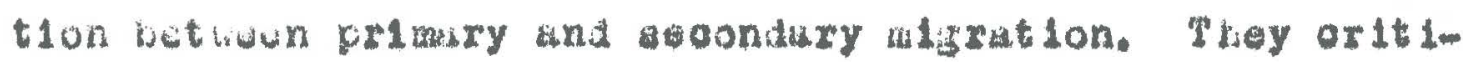
olat quite juatly the usual Inferenoe of witere on populathon woveants that an inorease, in ono atate, of nitives

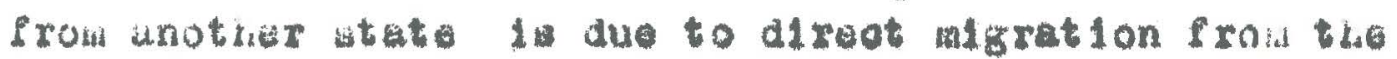
native wtate und that the inorease in tha nat ivo stat of

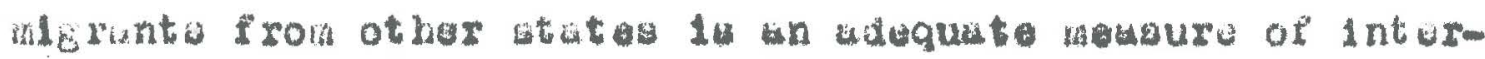
nul migrution. They ahow that these inoreases may be due to both primary and soondary migration. In othur words.

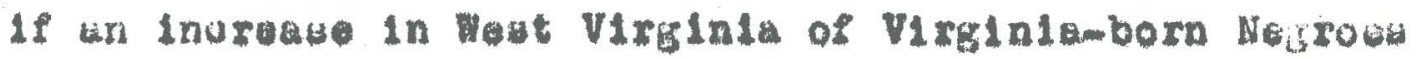
oocurs that leot dose not necossarily moan that thero hias been so moli knovement of people between Virginla and pest VIreinla, It may moan that tho movenent has boon botwoen Penneylvania and Wost VIrginia. It 1 eacily ceen thist the point is wall taken.

The efrort ha bean wade in the proaent atudy to aprosols the aubjeot of migration typologically as wil ac to 1wolkte certuin of the oauser of the movament und to

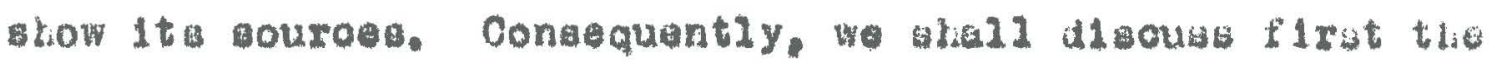
typea w1th ruferenoe to thalr direotnese and later with referance to their dirootion.

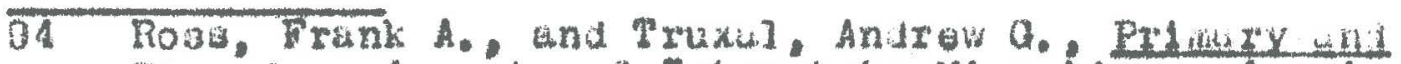

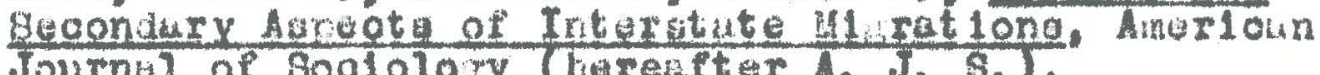
Journal of Boolology (horeafter $A_{0}$ J. \$.). Vo1. xxxv11. Novambar 1831, pp. 43b-444. 


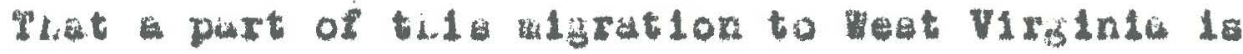

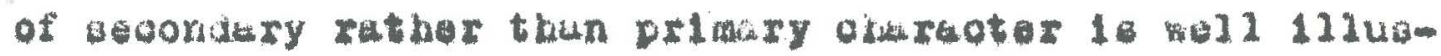
trated by

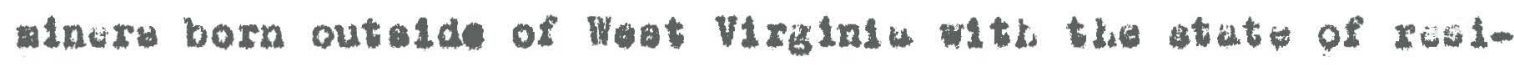
denoe of the aewe minera before coming to Wont VIrginit. 8uoh a oomparison 1 s bown in Tuble 28.

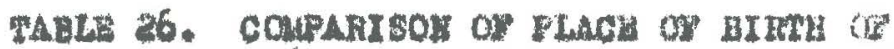

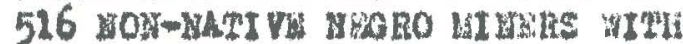

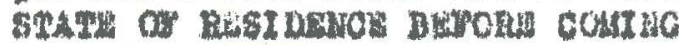

$$
\begin{aligned}
& \text { - To wost vinatita }
\end{aligned}
$$

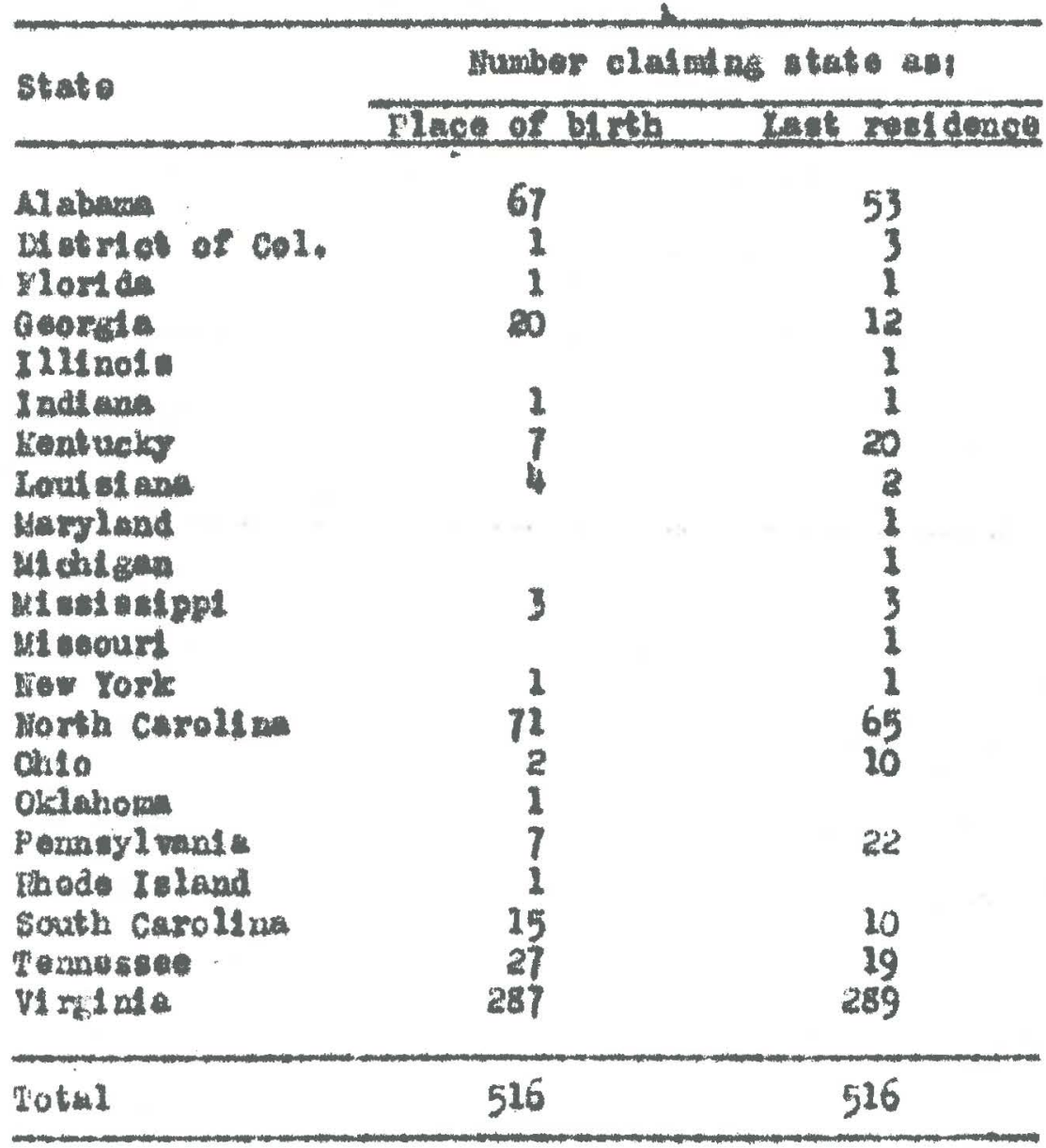


There ere two generel tendencles revoulod, The flrut 1 for the northern fooul polnt a the migrutory movaraent to appear the last resldence of the migrunte in isteuter number than thel a ative states, On the other hand. the couthern polnte of orlgln of the movanent atpuer is

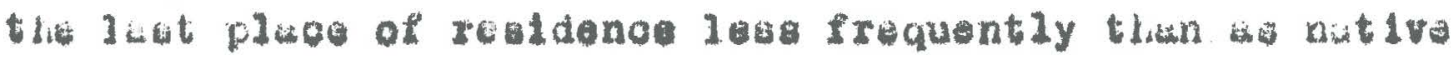
ututus. Plere are two notablo axouptions in the casa of

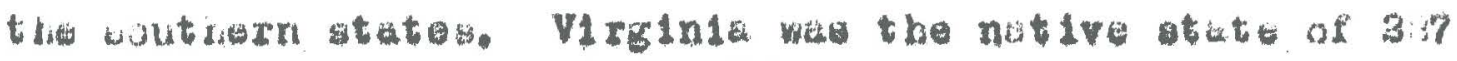

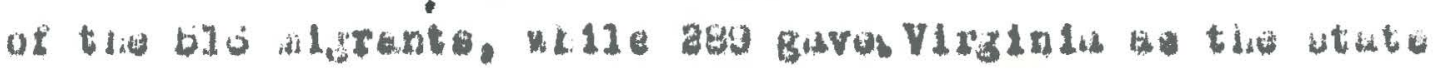

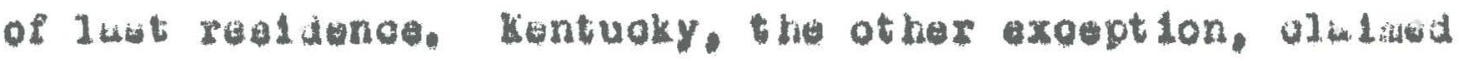

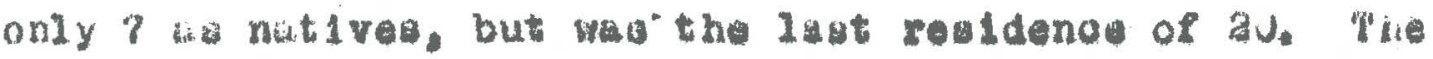

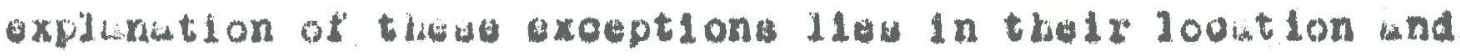
Indiatrial oldruoter. In the otge of Virginla there aro two ol.1 of flutore cocounting for the grater nunber of

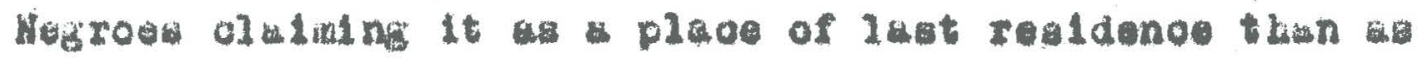
a native atute. Thero ia deolded internigration botween VIreinlu and Morth Oarolina with the balanoo groatly in

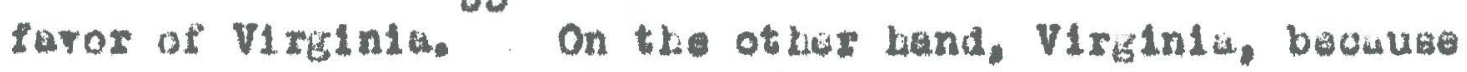
of her own ooud mine and faotorlea atract many outlerners on her own betilf. Sowe of these later come to West Virginie, It le true, of oourse, that there is also - tondenoy for VIrglniuns to go to other atates beforo oomInis to Wogt Virinia, but these ande are not wo numerove as those of migrants from other atates ooming to wat VIriglntio by the my of Virginta. Kentuoky 1 s also a cotid tute und many of the miners irom the pouth wom diret to 95 Roge and Truxal, ope alte. p, 437. 
Kantucky and later to mot 7inglati.

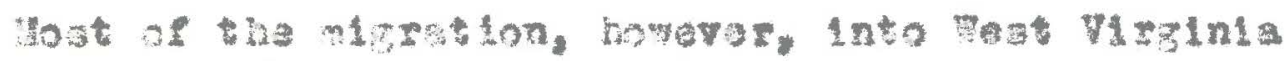

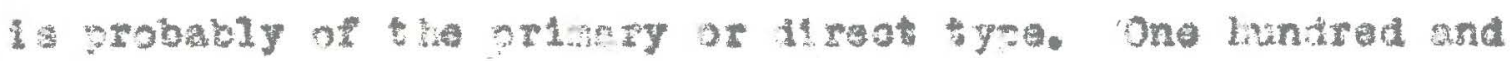

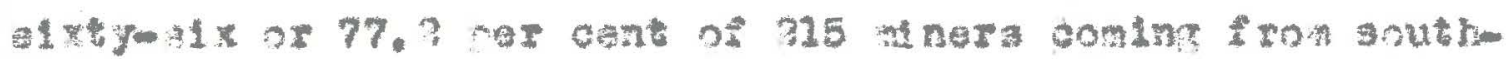

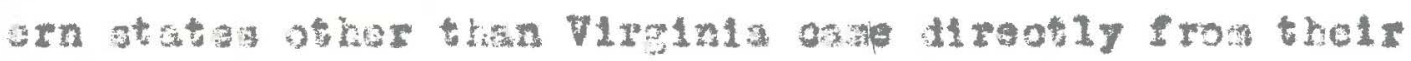

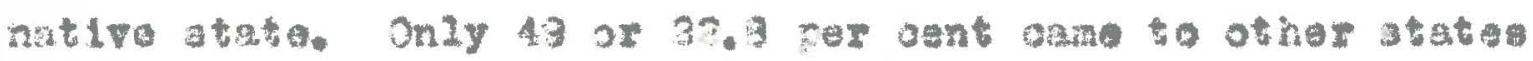
befora coning to Jost Virginis. A w zht bo expooted, the

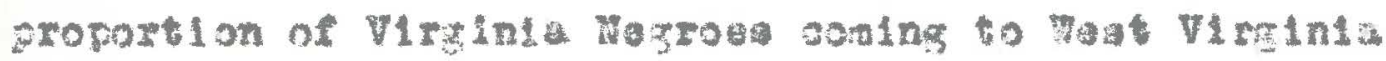

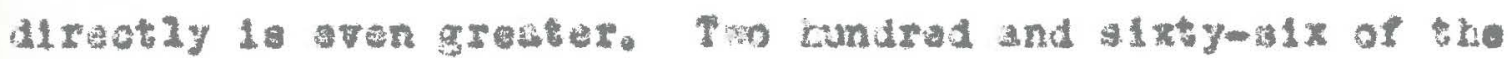
two hundred ard elgty-seven or 39.3 por cent of the Vit-

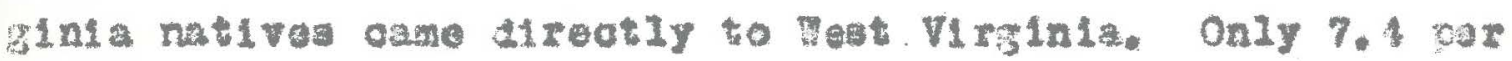
cent care to Wet Virinta from other atates. Congliersing all higrating minara from all atstes, To find that hs or 33.4 per cent dano to she stato alreotly from tralr atate of blrtb. and only 70 or 13.3 per cont oane from atatea other thon bhele nativo atate.

\section{Direot 1onk1 Types}

As has been polnted out above, host of the n1jration of legroes into tho nining Plelts of Deat Virginia 10

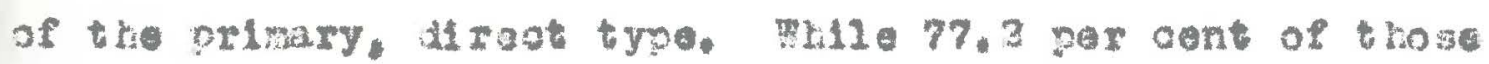
coming from the southern atates oame 11 reot $1 y_{3}$ all but one of the nitives of northern states came direotly to Feat VIritula. The number of northern natives ooming to the mining llelds, howerex, was only fourteen or 3.7 cer cant of the total. Wha north to south movement I not vary axtenslve, conlng largely from ststo like Pennoylvania, 
Oblo, and Indiana, whilob aso havo cosi operations, These

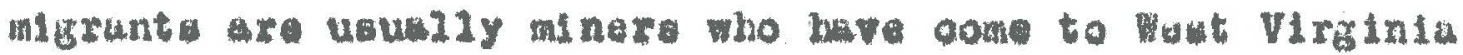
In order to ceoure the dvantages of higher wages or a moro prosporous marlet.

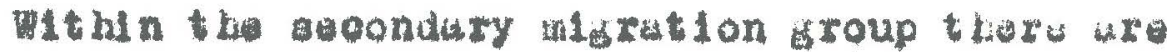
severul wel1-defined direational ty was. Ons very notiouable tendenoy to to be found partioularly among the nitifios

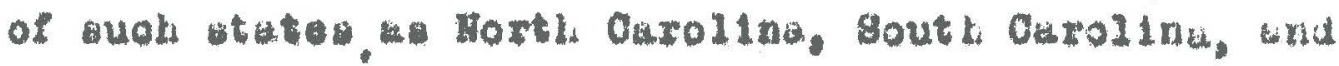

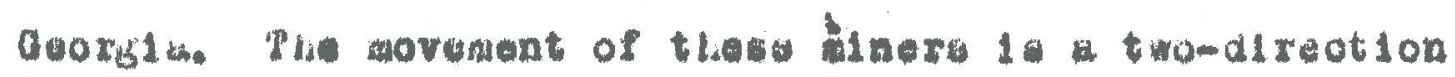

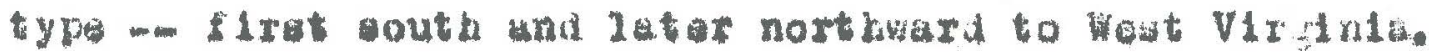

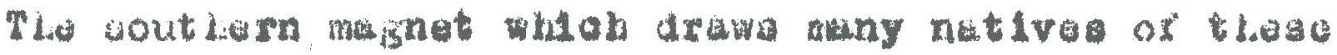
otutuo southward 1 it the coal und Iron wining dunter of

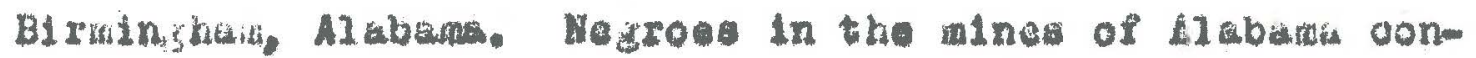
otituta more than 50 per oent of the ent1re population of 00

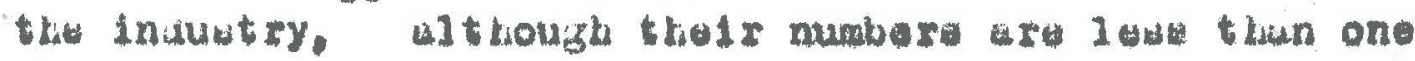

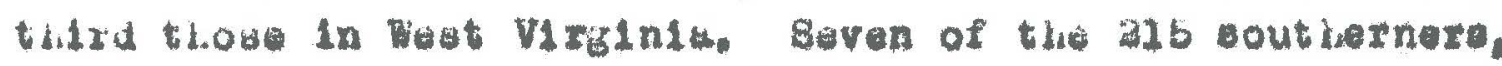

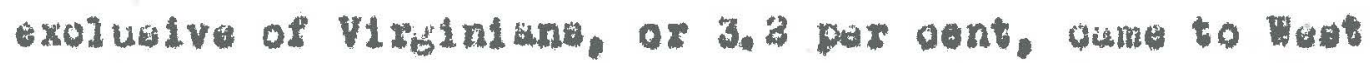
Vifiginis by way of Alabama.

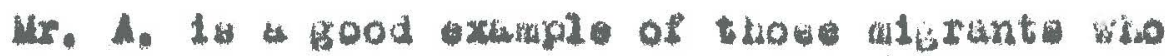
went wouth to work in the Blraingluw diotriot und luter came north to the Wast Virkinie Pieldu, It the dgo of twentyone Hr. A. left the farre near Telford, Georiti, becoming tired of poor exopo and poor pay, degirints to travel and see a bit of the world, He went to Mortgonery, Alibuint, where to seoured job in a briok yard. Hid worked horo for moven yeart, but doalded then to loure the briok

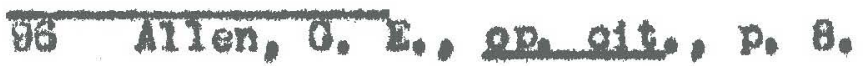




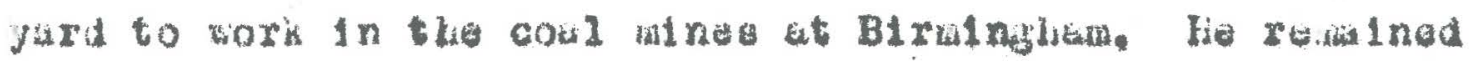

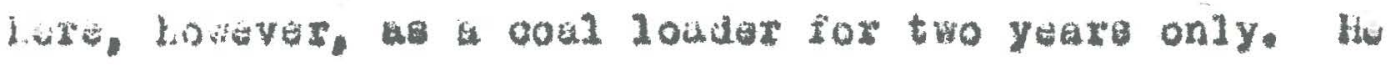

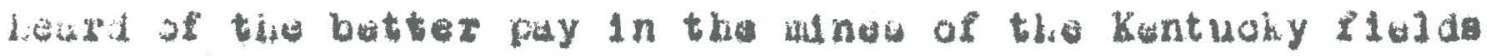
und Juft there to go to Jenking, where he worked for two

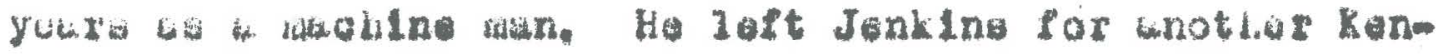

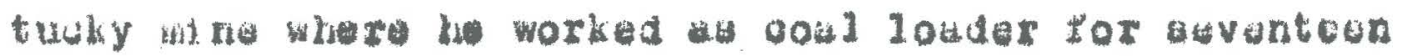

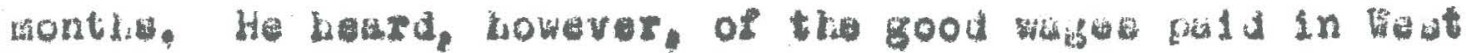
Virgiria and, wt11 demiring to travel, he inoved to whipple

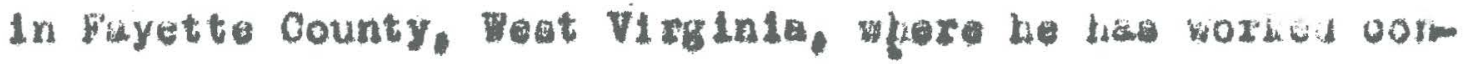
tinuouely tor the 18et elsht yocre.

Another direotion, followad more frequentiy by notives of w11 the wouthorn states eouth of VIrginfin. 10 ono-direotlon northward and extward movenent wit $b_{\text {. one }}$ ox more atops. the itst one in Virtinis frow wilab witio the nlgrent would come to veat Virginlas Geventeen or 7.9 per cent of the migrante from the etates couth of VIrolnds huve oome in this way. Virglnia, with ita ports bi Norfolk.

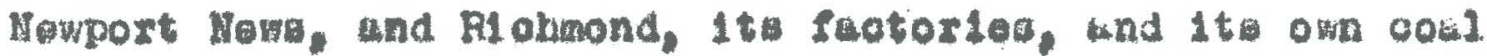
Ines hes attraoted many frow the agrioulturel atctos to the south. Bometime intermedsato stops in Gorgit. South

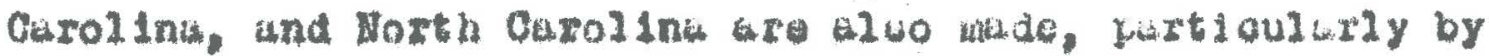
tha typo of migrant who is "just vonturins out. Ifo type

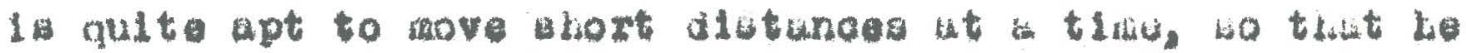
oftan guat wandero into lat virginita.

$$
\text { Ur. B. Wug i South Curol1niur wio followed ti. }
$$

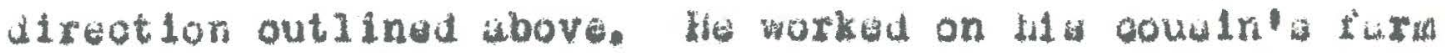

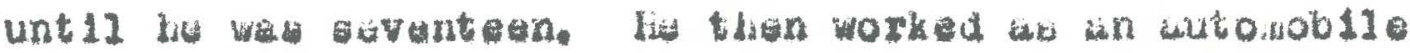


mechanio in gouth Oarollne for s1x yoara, 8laok work, howerer, Iod hive to go to Pinston-8alem, Horth Caroline, where ho obtalned work in the Reynoldo Tobapoo Footory. He worked here for thirteon wontha and then went to Naton, Morth Carolina, where he opent seren monthe in highwy grade work. From Newton be went to Balisbury were he found work with the South East Express Oompany, rall road work. He $11 \mathrm{ked}$ it better in 8aldubury than in vovton, staying bore for two yoare. He moved next to billaboro where to worked for the aty "grading ewere" tie pont onjy alx montius it tilda Job, however, golng baok to hidity work for wother alx montise perlod. Mr. B, thought he would try indosr work,

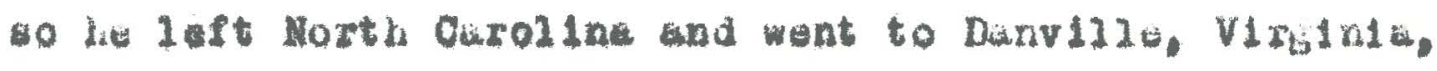
getting to job in a hotel ta geoond oook. Le 11 ved in Dar-

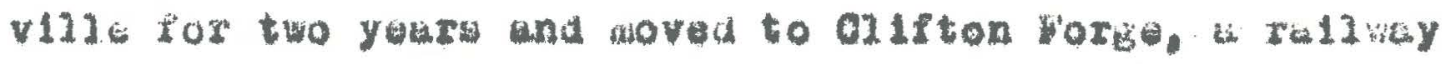
town. his did construction work in this violnity for pive

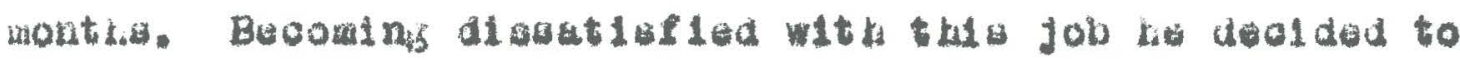

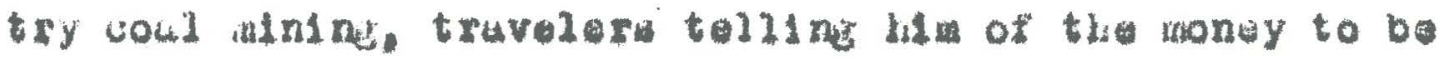

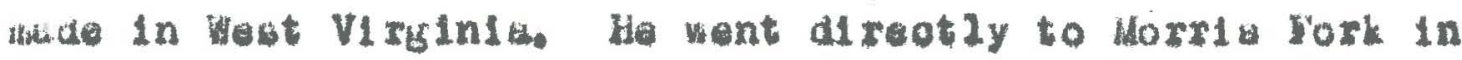

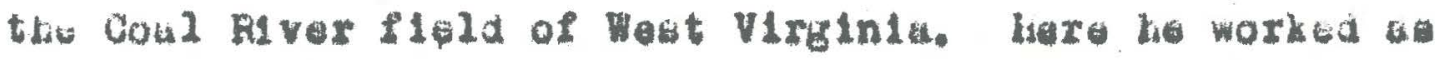
w cokl loader, brukeman, motorman, and maoks no helpor tor two youra. Ividentiy B. laute honoy, for bo noxt wont into the rasturant businew in Gharleston. He $f$ tled in $1 x$ montid and wont to kile prowent powition as voal lowder in Kanchila County where he has worked for sive yeare.

The type of movement representod by the cuse of Ur. B, might be oulled "the VIrglni way" of coming to 
West Viriglala Anothur way that 10 alao usal by nutbers

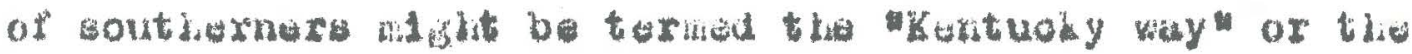

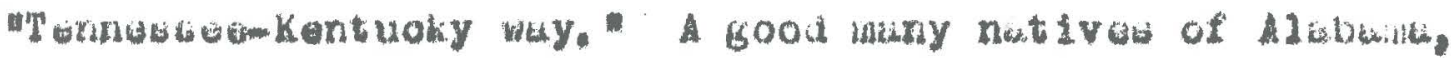

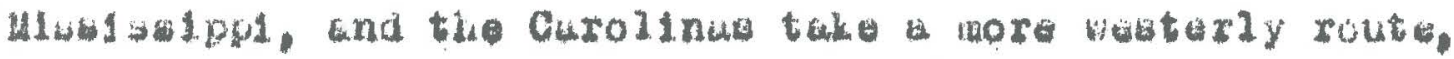

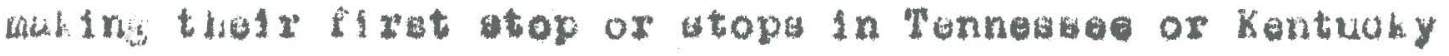
ox In woth, Elcht or 3,7 por oent of those ooming from the stater bouth of V1rginia, took this direotion. rennosise

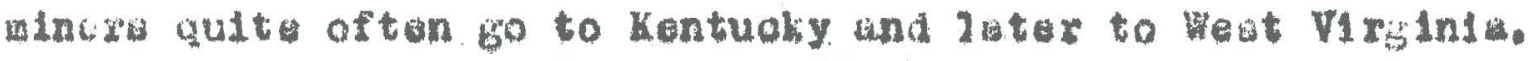

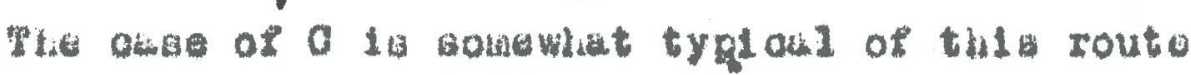

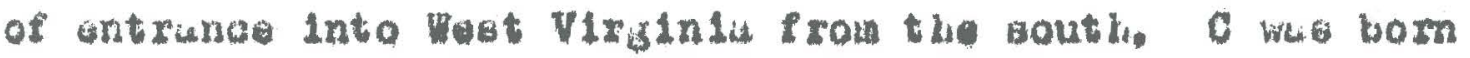
In Alubrk, where he worked in tivo ooul mines near birmine-

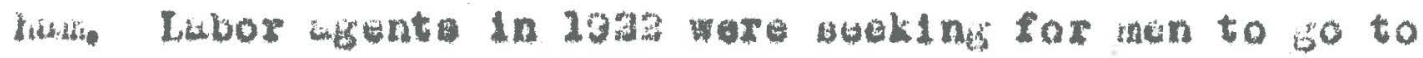

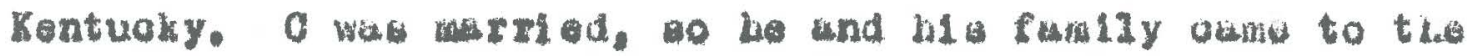
gtute of Kentuoky on toranaportation." He worked thara. howevir. only $20 n g$ mough to pay hls dabt to tha conpany.

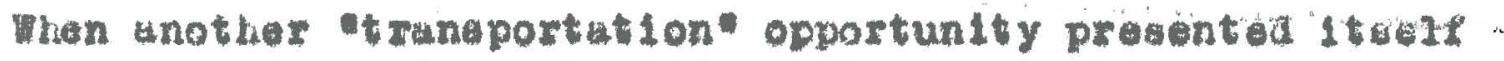

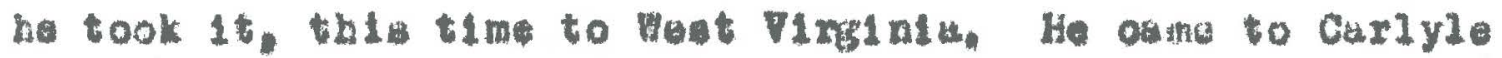
In Fyette County whare be worked as oon louder ror two yeare. From thore ho went to Rod Star in the shuo oounty for twonty montho and thon returned to cazlyle sor tal1ur period. He next went to logun Oounty but stayed there anly courteen inonthe. He returnod to rayotte County at a mine calied Whipple where he bas been for the pat four yearo.

Anotier type of twomay meration 1 a direot wovament from one of tho gouthem otited to w northem atato auob a Panneylvania. IIIInola, or Oulo and then w 
return from there to the Peet Virglnt sledda, Tuls bwokves of the movenent to the northarn urbun corter comes not infrequentiy to the mining ilelds. Mifteon or 3.9 por vent of those from atates couth of Virginia oame diseotiy to the north 12ret and then to heat VIrginla, Accorilng to 87

a rollablo oouroe. this group oontaina number of thowo who buve been in trouble in the northern oftios und roturn to blde for a tigo. It If qulte 11kely, however, that gany of them are lmply those Megroes who have beon unablo to mak at afaotory coonomio adjustment in northern urben 11fe.

D. reprusenting the type of raterant who coluwis to West Virginia on a wort of rebound froks the north, wais ouwali worker in Loulaluna, Mis native atate. Gien opportunity prosentod iteolf, however, he went to hattloaburts,

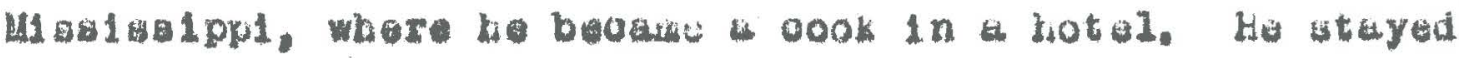

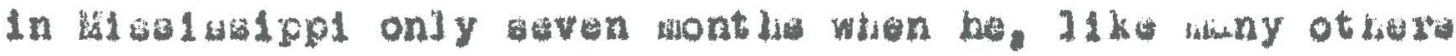

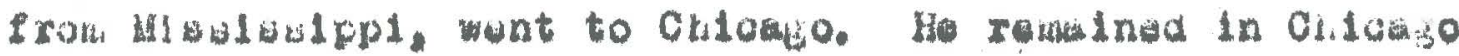

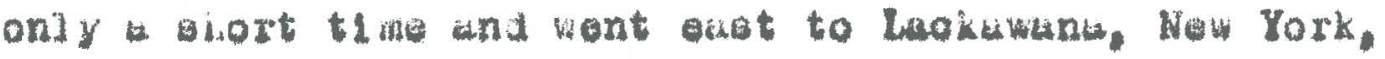

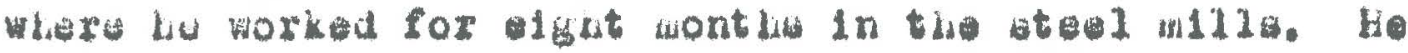

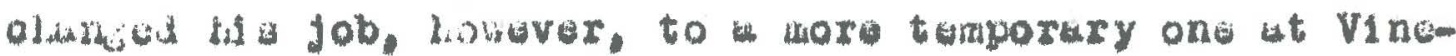
yurd, Hew York, where he ploked graper for two wont dus.

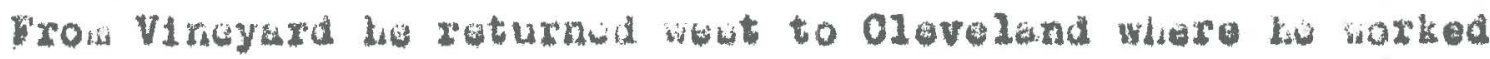

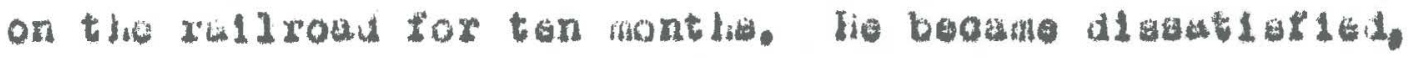
lowever, witi the nortis and the jova ha had hold and owa

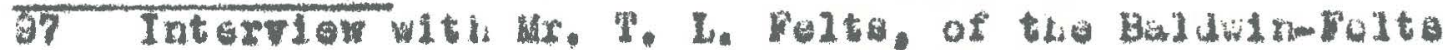
Deteotive Bureut, Brioflold, Va. 


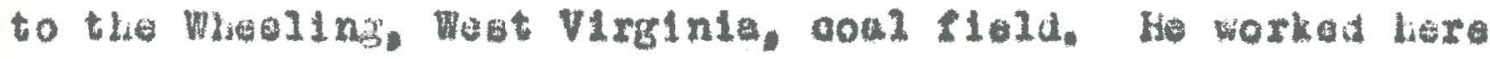
a a voul loddar for alght wonths, only laft, and oudd to Charlaston. ho atuyed here longor than sny of lif a othur plioes, enthding lis time in street work und in hotel work for two yours. Worh beque black on Ohardeston in 193.) and

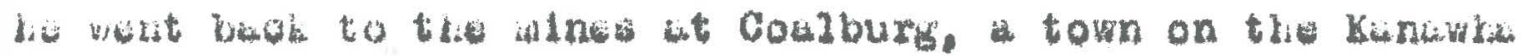

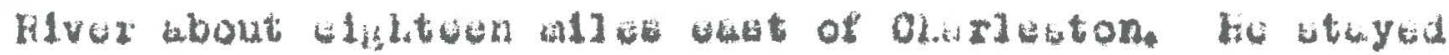

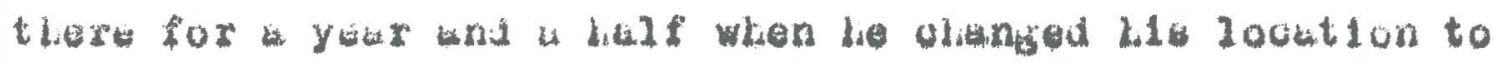

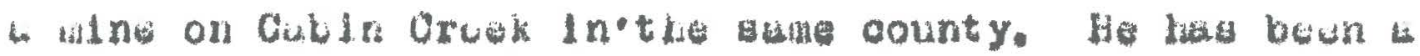
coul lowate lieru for light wontho.

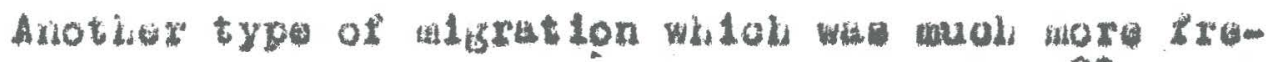
20

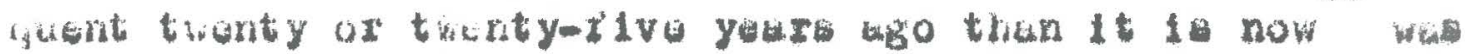

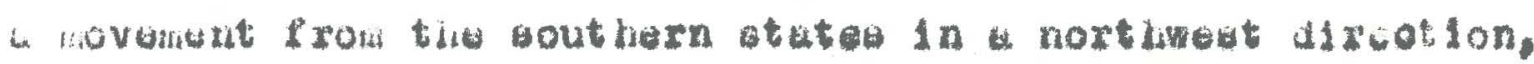

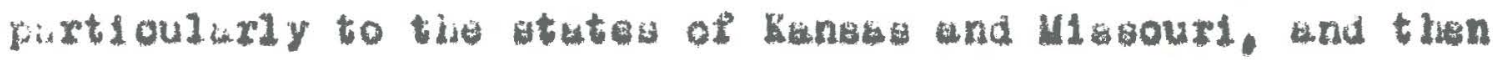
cust to Moat V1rinia, Only two or .93 por cant war of

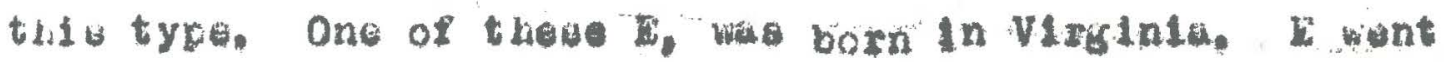

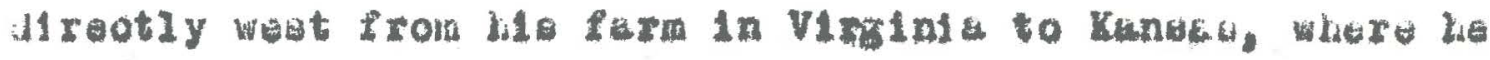
losded cos] for two monthe. He laft Kungas and went to Kinses Clty, M1swour1, where he oooked, morked as a packer. and loadea coml for year. Vialtore told him of the work and woney in tost VIrinia, wo weturned dicotiy frow Kunates City to Meroor County in Fast Virginis where he worked in the minew and a ooke yard worker for tive yearu. Leaving Heroer he went to Fayette County where lie lohided ooul for another PIve year parlod, He wont Iron luycte

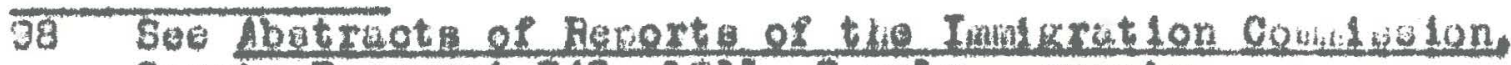
Benate Dooumant 747, 1512, 20018., pasalat 
County to Colmabus. Otio, where ho worked in the stoel 41114 tox thre years. Leaving columbus he wont to

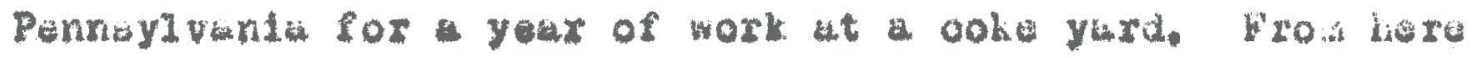

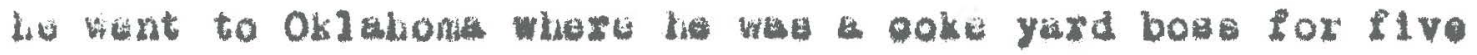
ycsxu. He went north agaln from Ok1ahoma to hincoln. I111-

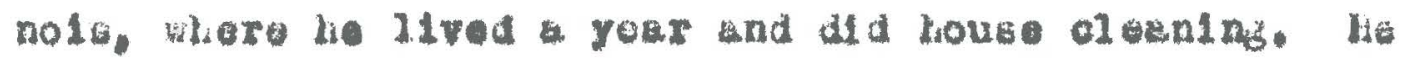
returned to West VIrginia and to HoDowel1 County, and uat been ooal loder at Gary in the oounty for twenty-tive ycara.

\section{VIrginla Negroes form euoh 1arge part of the} Vegro population in the mint teldi that it rag thought best to conalder the Ir migretion aeparately 1 zoin the reat. As hua boen polnted out. 82.6 per cent of the virinia natives oame direotiy into Wot Virginia. The othor 7.4 por ount of them form a acondary migration rroup wiluk

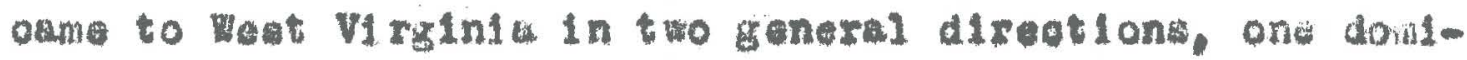
nant, tie other of minor laportanoe. The rain acondary wovement into vest V1rginla is to the statoe north of

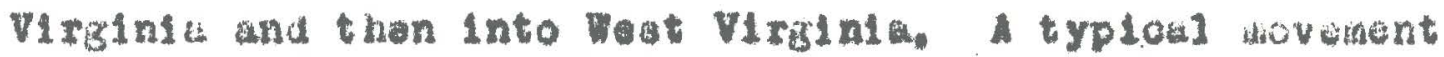
of thia typo 1 a to Balt lmorg. P1ttaburgh, and the wining flalds of West VIxinia Somotima the moverant 1 is entiraly oyoliow. onding in a return to V1rblniu. Sous-

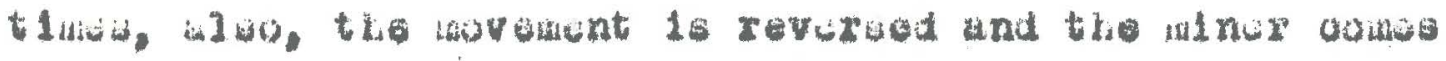

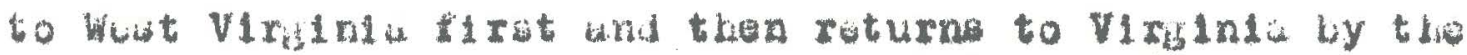

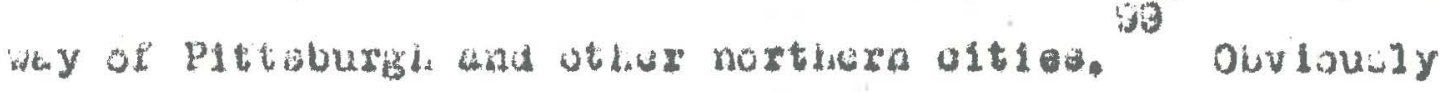

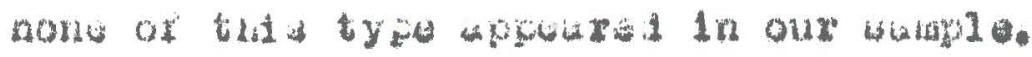

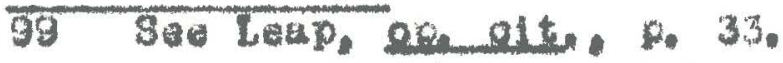


5 was a Vrginia tarmar wo was not maling anything on ha farm. Ho left Virginis and wont drootly to Minneapo11\%, Minnenota, where te worked in foundry tor

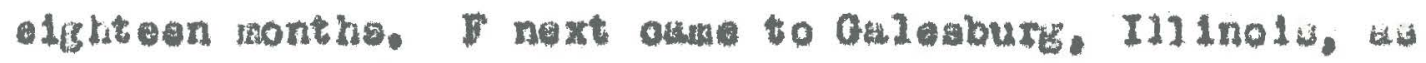
the severe wintere of Minnospolla wer too hard on hit w1fe. He worked here in a loundry also for olghtoun taontis. Relatives wrote to then hore and told then wbout tiv ralnos In Wat Virginia. Thay wera glad to return to tha Horiolk

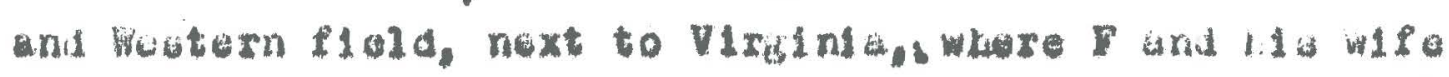

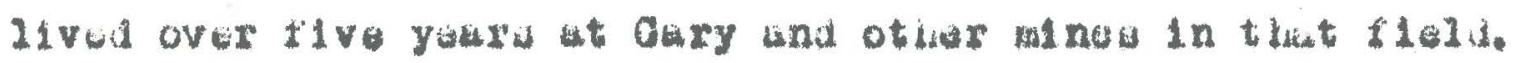

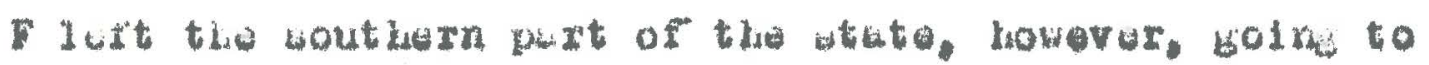

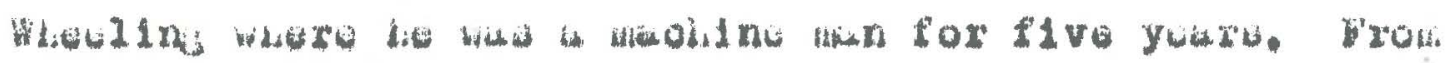

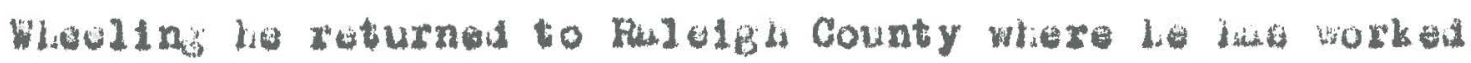
at stoteubury for more than three years.

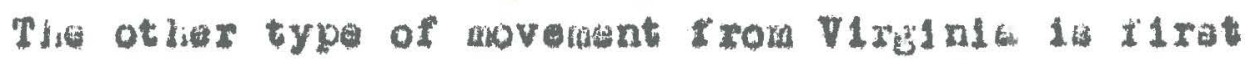

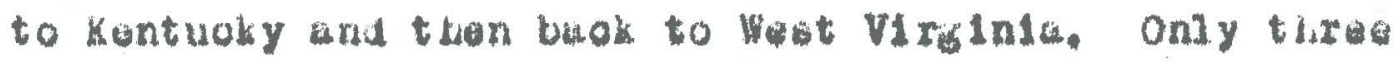
Viricinlans of those intorviomed took thls watturd oource before conld to Weat Vixglnik. The uxtrene wewturn oounthe of Virginle are quate noar to one of the rida voul Ilolda of Kentuoky, whioh faot booount for thil woverent. We they aumatime our finding oonoorning the mation movement into post viriginda into ten generial diroot lonkl types: 1. A dreot movement to west Virisinla from the ptatoe south of Virginia, 3. A moverant frou oertain southarn atates north of Alabama to that atute and

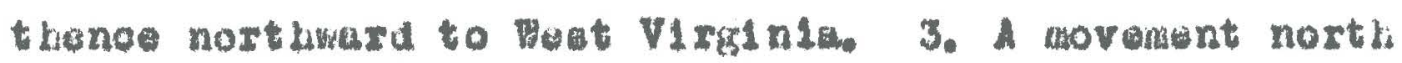
from the couthern tited with one or more gtope, the 1 ast 


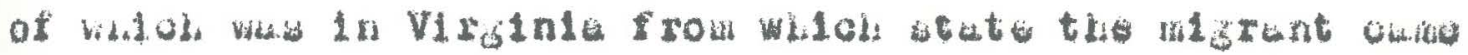

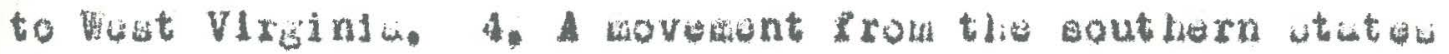

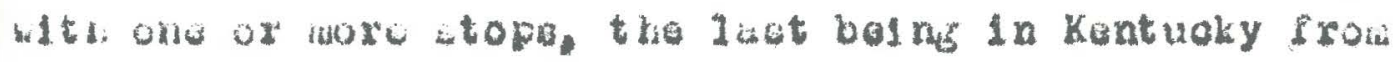

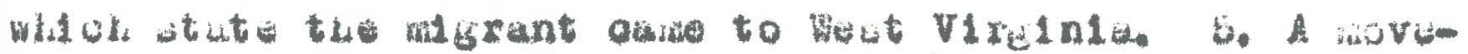

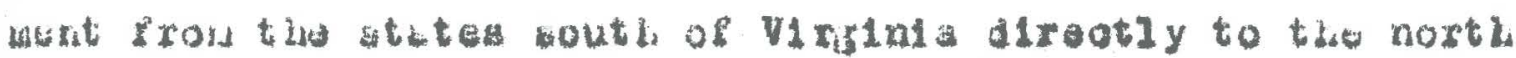

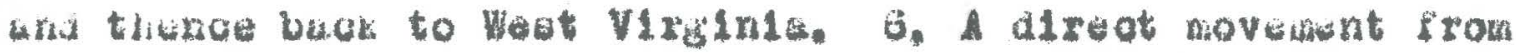
the northern atatos so Weat Virginia. 7 . A rovament frow

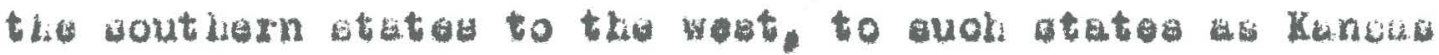
or Habour1, und thenge to vest VIrginla, $\theta, 4$ dreot movenent of Virginie migrunt s to beat Virginis. 9. 1 wovewent Isom VIrginla to the northern atates and bonoe to Voet VIrglaid. 20. A movement Irom Virginia to Rentuoky and thence to weat Virginita. 


\section{CHATTER IX}

THE NEGRO TALILY

I. THE WIVES OF NEGRO MINERS.-

Anerioan Negroes as a whole oonstitute a muobtarried group. A baobelor or a splnster is rerely seen and widows and widowere revarry more frequently than do membere of the majority group. In 1930 sevepty-81x and seven tenths per cent of legro females 15 years of age and over in the United states were elther married, widowed, or divoroed whlle only 71.6 per cent of native white femalea were so reported. The proportion of Megro males in these classification is also larger than for native whites, the percentage belng 67.8 and 63.3 respeotively. As has been pointed out before, 76.0 per oent of the legroes interviewed by the writer wore marriod, while 6.5 per cont more were either separated, widowed, or divoroed. The wife of the Negro miner has al ways been for ber "ole man" pretty largely the gine qua nen of mining town exletenoe, and no study of the Negro in the ooal Induatry would be complete without some mention of her.

The wives of Negro miners are, like their huabunds, largely a migrated group. Many of the miners were warried 1 Dowd, Jerome, The Negro in American Life, Century, 1326, p. 97.

3 Bureau of Census, Population Bulletin, U. S. Suricary, Population Characteriat108, 1931, p. 19. 
before coming to weat Virginla and brought their wives with them; the unmarried beoaume of propinguity ohoose their wives largely frow the daughtere, widows, or relativea of the other Negro miners. The states from whioh the wives of 489 Negro minere oame are shown in Table 53 A comparison

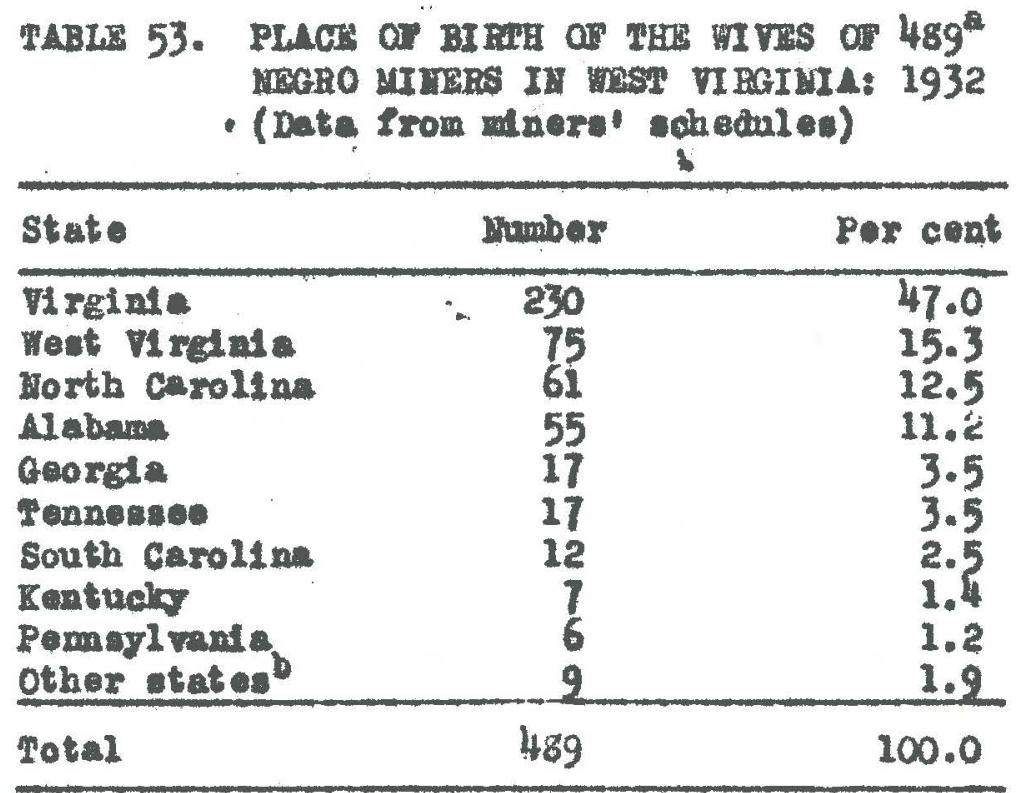

a Six of the 495 married wase uncertain concernit ng the blrthplace of their wives.

b Loul al ano, Miselsesppl, and Ch10 - 2 each; Plortda, D. C., and Iork - 1 aach.

3

of this table with Table 20 wll reveal that the proportion from eaoh atate 18 approximately the ame as for the Negro minera. There is a diatinct tendency for Negro miners from different stater to become clannish" and to ussoolate 4

largely with Negroes from thelr own home states and marry within these groups. Like their husbands Virginiamborn wives were more than three times as numerous as native West 3 P. 108.

4 See Chapter XIII for a disouseton of this faot. 
Virginlans, and Horth Carolinians and Alabamans were encountered almost as irequently as the native women.

Odum has pointed out the faot that many Negro 5

wives support thelr husbands in laleness. This condition 1s not found in the coal towns where a man must work for the company in order to ocoupy a house and the employment opportunitiee for women are definitely 11 mited. West Virginia, however, in 1930 had a larger proportion of its ulners' wives' gatnfully employad than any other of the coel 7 producing etates. A larger proportion of the wites of Negro miners in the United States were employed than were 8 elther the wives of native whites or foreigners. No separate figures for legroes were avallable for West Virginta. The proportion of the wives of both ractil groups employed in west Virginia, however, was 21.3 per oent. Later, In 1923, 863 family sohedules taken by the Women's Bureau in Penneylvania, Mest Virginia, Ohlo, and Illinola Indicated that 17.2 per cent of the wives of these familles 10

were gainfully employed. Almost four flfths, or 79.7 per cent, of these took in boarders or lodgers. Another 16.8 per cent were employed in laundering or oleantng by the day. of the remalning four wives, two were engaged in sewing or

5 Odum, ope o1t., p. 156.

6 In $w$. Va, a h1gher percentage of Negro men and a lower percentage of Negro women are employed than in any other state. (See Johnion, C. S,, op. olt., p. 391).

7 U. S. Dept. of Labor, Momen's Bureau Bullet in, No. 45 , p. 39.

8 Ib1d.

9 IbId. p. 38.

10 Ib1d. 
arocheting, one in telephone operating, and one in fariu work. The proportion of gainfully employed wives found In the present atudy was nearer to that of the census figures of 1930. N1nety-three, or 30,4 per ent, of the 456 wives I1ving with the1s husbands were engaged in some kind of Iuorat1ve activity. It 1 a I1kely that thie Igure would be somewhat larger if some of the women at whose homes relatives were etaylng were to be lnoluded as keeplng boarders. The miners or thelr w1vee $1 \mathrm{nal}$ sted howerer, that suoh persons were "not boarders." The following table w111 ahow the type of employwent of the ives as reported

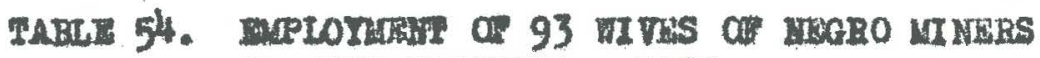
III Hesq IIATILA 1932 (Data Iron more echedules)

\begin{tabular}{|c|c|c|}
\hline Type of omployment & Number & Per cent \\
\hline $\begin{array}{l}\text { Boarding and lodgtng } \\
\text { Domentie and jund tor vervice } \\
\text { Peaching } \\
\text { Othure }\end{array}$ & $\begin{array}{l}10 \\
32 \\
13 \\
8\end{array}$ & $\begin{array}{r}43.0 \\
34.4 \\
14.0 \\
8.6\end{array}$ \\
\hline Total & 93 & 100.0 \\
\hline
\end{tabular}

a 5 ceam treses. 1 duly operator. 1 manger of own atore, 1 idd-ulfe.

As in the Woiten's Burasu atudy mantioned before more of those wives were employed in keeplag boarders and 1odigers than in any other ocoupation. Nobro wab-houses are leis frequently found than whit "olub-houger," henoe the oingle miners not living with relatives must otay it the homea of otber Megro minera. Since the housea are chall and eaol dwelling oan acoommodate only one or two of 
thew a number of the wires of lyegro miners have the opportunity of boording and rooming these men. Forty-three per cent of the earning wives ongage in this work. Domestio service conelate for the most part of cooking, laundering. oloaning, and nuraing for wine offlolals and their families. Negro "help" is much more Irequently omployed than white. Janitor service la restrioted to oleaning company officea, Btores and school bulldinge. More than a third of the workers, or 34.4 per oent, were engaged in work of this classifloation. The relatively large proportion of teachers is explained by the faot that Negro women teaohing in the mining flelde often marry Negro minern, The Negro toacher is much more likely to find some men sho considere eligible for courtakip and marribze axong the Negro miners than id the white tewoher amons the white rainera, for in mining a in other occupations Negroes fitted by education and trainIng for other work, are to be lound doing hard labor. Other occupations are aporadio and of negliglble inportanoe; a few of the Negro wowen earn woney by sewing.

The relatively small number of gainfulity employed wives of Negro minera does not indicate that only the enm ployed. women dealre to earn, but rather that work opportunity, ais wentioned before, 1a $11 \mathrm{mited}$. Throughout the oounties studied Negro women complained of the soarcity of work. A number of them atated that people for whom they used to work regularly were now dolng thelr own work during the dull times. In many familie the disoouragement of the 
Wfe was added to that of her husband becauge of the frug tration of habitual behavior pittarns.

The wives of the Negro alnerg, alt bough in wost oused not gainfully ewployed, are by no weans idle. Housekeopinif duties in the ordinary minlng town are made exoeedingly arduous by conditione which w11 be discussed a little later. Aooording to the writer's observationa, the Negro wives pluy the role of housekeper relatively well. This judgruent was confirmed by the dootoxts who vist the houses of all raolal groups. Miniotering to the animel oomfort of their husbande, however, 1 i not the only lmportant rolo played by the wives of many of the Negro xalnera, for wives provide a type of responal of the utroet importanoe to many of the miners who have oome to west virginia from othor states. It will be recalled that many of the Nogrose, partloularly those from VIrginia who make up suoh a large proportion of the Hegro mining population, did not oome to Weat Virginia with the intention of staying. They were to return in good tiwe riohly rewarded for thel s self-inflioted extle from the old home, and they have therafore never looked upon Feat Virginis as their home, but rather as a etopping place derold of sentiment. It 18 to be endured but not loved. Idealizations are focused upon the old howe "back East or elsewhere; hence there bas grown up what one preacher in the mining lields hao aptly oalled a "ourp. payohology. An adequate conception of this attitude is essential to an understanding of Negro fanily ilf in the 
mining fielde. Many of the wires, comlng from the saine early homes as their husbands, understand the wen's dis11lusionnent and many tensions are avolded by this mutual understanding. Fach provides for the other a response in their mutual longings. "Hard trials" in the mining flelda are made more endurable by the sharing of memorles and hopes,

The fam1ly, however, 18, as Burgess has polnted 11 out, a unity of intetacting porsonalitioa. A relationshlp sat1afylag between husband and wife who attempt to subatitute a oomminity of ear2y images for present dis11lusionment may have a very different effeot upon their ch1ldren. These ohlldren, who know only the mining fields, have heard only diseatisfaotion expressed for the one home of thelr experionoe and henoe lack 1dealizations and sent1mente assoolated with home whloh are part of the normal heritage of ohlidren. Since no emotionjl ties hold the young Negroea they are leaving the mining plelds, many of them at quite an early age, with consequent breaking up of family solidarity.

II. NUMBER OF CHILDREN. -

The Amerioan Negro group has I ong enjoyed the reputation of belng exoeedingly prolifio. Indeed, this belief has some faotual basis. The arerage number of

II Burgess, Ernest W., The Painlly and the Peraon, Publiostions of the American Soolologlogl Soctety. Vo1. 22, Deo. 1927, pp. 133-143. 
ohildren per Negro mother in the birth registration area in 1920 was 3.6 while that of native and foreign-born white mothers was 3.0 and 4.0 respeatively. 12 In more recent yeare the Negro women have malntalned their bixth rate at a level more nearly that of 1918-19al than either native white or forelgn born wite women, although thero have been large deolines in apeolfio birth rates for all three groups, fartioulariy in the case of the forelgn-born. 13 the birth rate of the Negro group in the weglatration area of the United Stater was 31.3 while that of the white group 14 was only 18.6. The Negro women in the oounties atudied, however, had a lower birth rate than the white mothers in 15

this year. The birth rate for Fayette, Logan, LoDowel1, and Raleigh counties, In whioh the graat bulk of the popula tion of both racial groups is ongaged in ralning, are giown In Table 55.

I2 Young, $D_{0,}$ op, oit., pp. 362, 365.

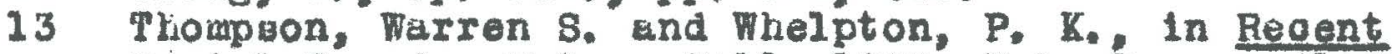
Soclal Trends, MoGraw-H111, 1933, Vol. I, pp. 41-42.

14 Birth, St11lb1rth, and Infant Mortality Statist108 for Birth Regiatration Area of U. S. (no date) p. 46.

15 See Birth, Stillbirth, and Infant Mortality Statistios for B1rth Reglstration Area of U, S., 1939, Waslington, Govt. Printing office, pp. 137-138.

16 Separate 11gures for hite and colored were not avallabie for Kanawhe County 


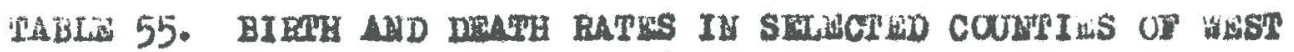
VIEAIUIA, VIRGIUIA, KORRH CABOLINA, AND AJABMA BY RACB: 1929

(Compiled from B1rth, St11161 rth, and Infant Lortal1ty Statistic for Binth Begl teration Area of U. S., 1929)

\begin{tabular}{|c|c|c|c|c|c|}
\hline \multirow{3}{*}{ State and county } & & \multicolumn{4}{|c|}{ Fate nes 2,000 population } \\
\hline & & \multicolumn{2}{|c|}{ Arthe } & \multicolumn{2}{|c|}{ Deathe } \\
\hline & & White & Veaso & Whe & Nevno \\
\hline \multicolumn{6}{|l|}{ Beat Vif red of a: } \\
\hline Fayet to & & 28.1 & 24.5 & 10.1 & 13.6 \\
\hline Logan & & 33.3 & 23.1 & 10.2 & 11.3 \\
\hline MeDowall & & 33.4 & 21. 5 & 10.5 & 14.6 \\
\hline Bal ed eh & & 32.3 & 26.7 & 9.3 & 14.7 \\
\hline \multicolumn{6}{|l|}{ Vingtalas } \\
\hline Albenarlo & & 30.9 & 32.7 & 20.5 & 25.4 \\
\hline Bedford & - & 19.8 & 21.4 & $10 . \overline{3}$ & 15.1 \\
\hline Praniclin & & 23.0 & 29.3 & 7.8 & 11.7 \\
\hline Benxy & & 29.0 & 30.7 & 11.0 & 17.2 \\
\hline Nontgomery & & 23.4 & 18.8 & 10.9 & 25.9 \\
\hline Pitteylvaina & & $23.9 \%$ & 28.1 & $7 . \overline{3}$ & 12.4 \\
\hline Boenotice & & 21.9 & 19.9 & 9.4 & 14.6 \\
\hline \multicolumn{6}{|l|}{ Horth carollinel } \\
\hline Caswoll & & 23.8 & 30.8 & 7.3 & 12.4 \\
\hline Rockd nohmin & & 26.2 & 22.3 & 8.0 & 12.8 \\
\hline \multicolumn{6}{|l|}{ Alabama: } \\
\hline Jefferten & & 24.9 & 23.5 & 9.1 & 16.2 \\
\hline
\end{tabular}

Some differenoe 18 apparent between the birth rates of Negraes in the four West Virginis counties and in those oounties in Virginla, Nortb Carolina, and Alabana from whlch many Negroes oome (Table 54). In sowe of these oounties, however, the Negro birth rate was higher than that of the whites, while in the Weet virginia counties it was lower without exoeption. The white birth rate in most of the West Virginla countiea was conelderably higher than that in the counties of the other states, howerer, which faot way be partially explained by the larger peroentege of forelgners in the inininis fielde. The bifthrate of Negroos was lower than that for whites throughout Weat Virginia and Alabama, whlle it was higher in North Carolina and 
Virginia. The average of the birth rates of Degroes in the Weat Virginia countiee mentioned, however, was 3.7 polnta higher than the birth rate of Negroes in the complete reglstration area of the United States.

The reason for the oomaratively lower birth rate of the Negro group 18 apparently not the absence of large familie but the large proportion of couples having no ohildren at al2. Of the 495 married Megro minero 22.3 per oent were ch1ldleas. The Iguree are shown it Table 50.

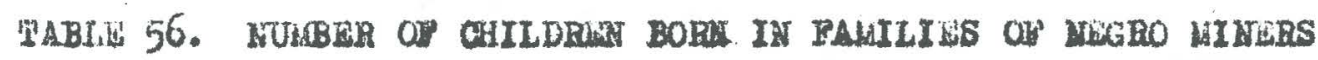
IN WHST VIRAIMIA BI XAIIVE STATH OF MIMER 1932

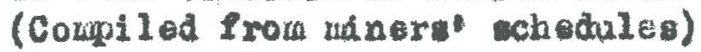

\begin{tabular}{|c|c|c|c|c|c|c|c|c|}
\hline $\begin{array}{l}\text { chabar of } \\
\text { chlldren }\end{array}$ & NIIII & ber 0 & f fet & thore & $\frac{\text { fram eagh }}{\text { Other }}$ & $\frac{\text { tate of }}{\text { tatos }}$ & birth & Porcontas: \\
\hline born & i. $\mathrm{Va}$. & Ya. & H. C & Ale. & Southern & Fortherm & & \\
\hline Wone & 12 & 52 & 10 & 14 & 17 & 4 & 110 & 22.2 \\
\hline One & 11 & 37 & 7 & 10 & 17 & 1 & 83 & 16.8 \\
\hline Two & 9 & 21 & 10 & 8 & 8 & 2 & 5 & 21.7 \\
\hline Three & 12 & 25 & 10 & 5 & 7 & 1 & 60 & 12.1 \\
\hline Jour & & 36 & 8 & $\overline{7}$ & 4 & & 55 & 11.1 \\
\hline Pive & 1 & 13 & 7 & 4 & 7 & & 32 & 6.5 \\
\hline $\mathbf{s i x}$ & 2 & 12 & 3 & 1 & 6 & & 24 & 4.6 \\
\hline Soven & 1 & 16 & 2 & 3 & 1 & & 23 & 4.6 \\
\hline Hect & 2 & 11 & 1 & & 5 & & 18 & 3.6 \\
\hline Mine & & 8 & 4 & & & & 12 & 2.4 \\
\hline Ton & & 3 & 2 & & & & 5 & 1.0 \\
\hline Bleven & & 4 & & & & & 4 & .8 \\
\hline Fwel we & & 4 & & 1 & & & 5 & 1.0 \\
\hline Thl at eon & & & & & & & & \\
\hline $\begin{array}{l}\text { Fourteen } \\
\text { Iifteen }\end{array}$ & & 1 & & & & & 1 & .2 \\
\hline S1 xt een & & 3 & & & & 1 & 4 & .8 \\
\hline Serenteen & & 7 & & & & & 1 & .2 \\
\hline Total & 49 & 247 & 64 & 54 & 72 & 9 & 495 & 100.0 \\
\hline
\end{tabular}

17 Tbld: $:$ pp. 46,50,52. 
This proportion of ollidieas families is spparently much greater than for elther native whites or forelgnborn.

Aocording to the study of the Pederal Wonen's Bureau before referred to, the proportiona of native white, foreign-born, and Hegro familles in the mining flelds of the United Statea having no ohlldren were reapeotively 12.0, 7.4, and 33.3 per opnt. 18 Three explanations have usually been given to the high proportion of bhlldlese marriage in migrated Negro familes. The 11ret 10 that iglation 1 t self 10 a raotor in reduoling the birth rate and that oterility results from pasalng from an agrloultural to an industrial coonomy with consequent rise in standard of living. An other reason frequently given is that steril1ty comes fros the prevalence of venereal disease among the Negro groups. Others see the answer to the queation in terms of the inoreasing praotice of contraceptive methods and abortion. There is probably some validity to all of these reasons in apeoif10 altuations, The writer, however, sinoe no great deorease 10 apparent in the birth rates of Negroes in the mining flelde below the rates in the states from which they I8 U. S. Dopt, of Labor Bulletin of the Women's Bureau, No. 45 , oge oit, p. 48.

19 Thompson and Whelpt on, ope git., p. 43; wooftur, t. J., Status of Raolal and ithnio Groups, in pocent soolal Trenda, Vol. 1, pp. 531-532.

30 Dublin, W. I., Health of the Nerro, Annalo, Vol. GXXXX, Nov, 1328 , pp. 79-80; Johnson, C. S., eq, oit., po. 164163; Odum, Op. olt., pp. 171-173; Reuter, E. B., op,cit., p. 181; Thompoon and whelpton, op elt., p. 43; wonter, 31 Thompson' and whelpton, ep. oft. p. 43. 
curie, is inclined aftor Interviews with dcotore in the mining field; to place the omphas upon renereal disease and

the practice of birth oontrol and abortion.

St 11 ibirthe and "misegen" were frequently men-

tloned by Negro miners or their wives in telling of their "chlidren not 11 ing. 23 st1libirth rateo ag reported in the Birth Reglatration Area are ahown in Table 57. No conparison of the West Virginia counties whth those in other states on the basia of these flguree, however, owing to the laok of unfformity in definition and wethods of roporting atillblrthe in the different states, may be mede. 24

22 Term used by the Negro minors and their wivos to wean miscarriage,

33 See miners' achedule, p. 2.

34 The Bureau of the Cenaus says in this connection, The interpretation of the etitiatios relating to atilibirths must be made with extreme oaution, because the compl etenese of regiatration is not known and the term istillbirth is not used in the arme sense in various Btates." (Birth, St111birti, and Infant Mortality Statist108, 1923, p. 22). See alou Gagnon, E., What Is a St111-birth? Canadian Public Health Journal, Vo1. XXII, Jan. 1931, pp. 16-27; Wàrk. W. L., Ten Yeare of Birth Statiatiog in Ohio, 1915-1924, Ohio Dept. of Hea1th, 1924, pp. 57ff. 


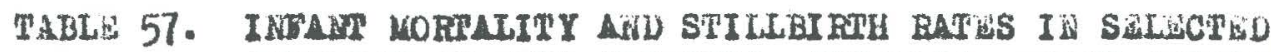

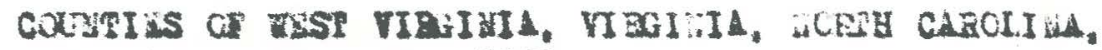

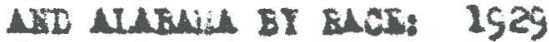

(Complled frow B1 rth, Stillbirth, and Irifant liortality Statiatice for B1 rth Regintration Aren of U. S., 1929)

\begin{tabular}{|c|c|c|c|c|}
\hline State and county & $\begin{array}{l}\text { Infant } \\
\text { Pate por } \\
\text { inte }\end{array}$ & $\begin{array}{c}\text { mortallty } \\
1,000 \text { blrths } \\
\text { Hegro }\end{array}$ & $\begin{array}{l}\text { st111b } \\
\text { Rate per } 100 \\
\text { pite }\end{array}$ & $\begin{array}{c}\text { rth } \\
11 \text { re birthe } \\
\text { Negne }\end{array}$ \\
\hline \multicolumn{5}{|l|}{ teat Vi rgt nf as: } \\
\hline rayette & 84.0 & 92.5 & 3.8 & 6.8 \\
\hline Logan & 79.1 & 69.6 & 3.2 & 7.6 \\
\hline HeDowe11 & 91.7 & 100.2 & 3.6 & 7.1 \\
\hline Fal atg & 78.8 & 83.3 & 3.8 & 6.9 \\
\hline \multicolumn{5}{|l|}{ Virednia: } \\
\hline Albomaxlo & 69.2 & 53.1 & 4.6 & 7.7 \\
\hline Bedford & 61.5 & 66.2 & 2.1 & 3.3 \\
\hline Franklin & 40.1 & 67.6 & 3.4 & 12.2 \\
\hline Henry & 84.5 & 108.9 & 3.2 & 3.6 \\
\hline Montgomery & 58.5 & -162.2 & 2.2 & 2.7 \\
\hline Pittayl vand a & 43.8 & 54.3 & 2.6 & 4.9 \\
\hline Roanoke & 67.9 & $140 . \overline{6}$ & 2.4 & 4.7 \\
\hline \multicolumn{5}{|l|}{ Worth Carolinas } \\
\hline 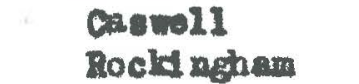 & $\begin{array}{l}59.3 \\
52.6\end{array}$ & $\begin{array}{l}43.7 \\
86.3\end{array}$ & $\begin{array}{l}3.7 \\
2.1\end{array}$ & $\begin{array}{l}3.1 \\
5.9\end{array}$ \\
\hline \multirow{2}{*}{$\begin{array}{l}\text { Alabemes } \\
\text { Jefferwon }\end{array}$} & & & & \\
\hline & 63.3 & 114.1 & 3.2 & 7.8 \\
\hline
\end{tabular}

Reuter estimated that from 10 to 15 per cent of all Negro babies ware ellminated before the olose of thelr first year of 11fe. More reoently Woofter put the 11gure at 15 per cent. The age of death of 275 oh1ldren of the minere interviewed is shown in Table 58 ,

35 Reuter, ep. cit., p. 175. 26 Woofter, op, oft, p. 584. 
TABLE 58. LOT AN DRAPH OP 275 CHILDREN OP MBGEO MIYIARS IN WTST VIFOIUIA

(Complled from mere' sehedules)

\begin{tabular}{|c|c|}
\hline Age at doath & Number of ch1ldren deceased \\
\hline 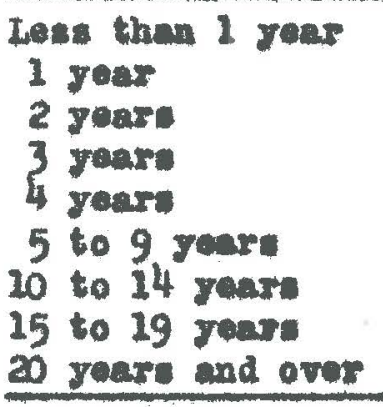 & $\begin{array}{r}142 \\
21 \\
18 \\
10 \\
11 \\
29 \\
13 \\
15 \\
16 \\
\end{array}$ \\
\hline Total & 275 \\
\hline
\end{tabular}

One hundred and forty-two, or 9.2 per cent, of the 1565 ohildren reported by the 495 marrled Negroes died in their flrat year of 11fe, whloh feot indicates an infant mortality rate below the minimum eatimate of Reuter and the bigher figure of Woofter, of these 143 oblldren, 7 a died before the age of one nonth. Two hundred and two, or 73.5 per oent of all ohlldren reported as not living, died before the age of 5 yeare, whlle 29 more, or 84.0 per cent, died before reaching the age of 10 years. The average number of birthe in each married Negro miner's family studied was 3.2 , but bocaus of the relatively high mortality rate, espeolblfy in the early yeara, the average number of living ah12dren in eaoh fam1ly was 2.6. 
III. HOUSING. -

The terma under which Negro minera live in compuny houses and the amount of rent pald have already been discussed. How satiafactory are these houseo for IIving purposea? In order to answer this question sore attention must be given to the types of houses in which Negro miners live, the conventences furnished, and the extent to whioh overcrowding exista. The best source of Information concerning these mattera 18 probably the atudies of the United States Coal Commision. Fleld agents found, by atudies made in 1932-23, that West Virginia miners' homes were better $11 \mathrm{ghted}$ than those of any other atate, 80.9 per oent of the 30,994 dwellin in 403 towns belng lighted with either 27 eleotricity or gas. In 2932 only one town visited by the writer was without eleotriolty. In this instance the mine was praotically inoperative bookuse of the dull summer and the eleotrlofty had been shut off as a money-aving measure. The wives of Negro miners usually have lectrlo faollities for 1 roning, waehing, and sweeping, as well as the operation of radios for those who deaire to work with malcal accompanlment.

Santary faollities are, however, far from actiofactory. In 28.3 per oent of the Vest V1rginia cormunities studied by the Coal Commission no oompany or public water systom was provided, the minera depending upon dug well or 27 Report of the v. S. Conl Commission, Pt. III, p. 1473. 
springe for their supply.

Only 11.2 per ent of the houes surveyed by the Coal Comisaion had running water in the 29

houser, and whle no eperate lgures were given in tho Commiasion's report of the proportion of Megro and white houses inoluded in this emal1 peroentage, the proportion of Negro dwel11nge with running water could not have been large and was probably slight. The writer found running water in Negro homes in a very fow of the best mining communit ies. but ordinar11y hydrants are looated in more or 1 ese oonventent alsances from the houses from whl oh all water used muet be carried home by the miner, hie wife, or thelr children, and muet be heated on the kttohen store for any purpose requiring hot water. This necesalty 6 reatly 1 noraases the emount of work whloh the wires of Jegro miners must do. The proportion of the dwellings of both white and Negro miners equipped with bathtube or ahower is neglig1ble. The Coal Commireion found only 2.5 per opnt of the dweilings In the Fest Virginis town it etudied with elther of these oonventences. In 1933 the writer found one town with Negro houses containing bathe. In this MoDowell County tow which had juat been bul1t, 850 of ite 300 housea laad bath rooms. Si noe ooal mintar is an extremely difty job the presenoe of bath roome alght reasonably be oonsidered one 28 In one oomunity vielted the wells beokne dry in thit summer and water (ol doubtful purity) had to be obtained from the river.

29 Reports of the U, S. Coal Comularion, Pt. III, p. 1473. 30 IbId 
of the neoesa1ties of an adequate standser of living.

It 18 true that in aome of the oommuntties a bath house is provided where the logro and white matne may ohange their dirty olothing and bathe before going to thelr homes. The faolities offered by bath houseg, however, are in woine plaoes more apparent than real. for sino most of the men come out of the mine at the asme time, they are $11 \mathrm{kely}$ to be sowewhat overorowded and orerheated. 32 The writer found bith hourea in a minority of the tome piofted and whore they were provided not all of the Negro minere used thea. The wh ner as a rule batbos in the kitohen where the bath victer 1 is heated, and after the bath he pours the water out on the yard, for the kitchene uaually laok drain plpes. Sinoe wost of the houses are emall, his privaoy durin.s the bath $1 \mathrm{~s}$ uaually insuffiolent. 33

Inolde fluah tolleta are almost a rare as bath tubs. Only 3.1 per oent of the west Virginla dwollinge survayed by the Coal Commiasion had tham. Only in the MeDowell County town already mentloned did the writer find Negro homes equipped with flush tolleta. In all but few of the best company town the outslde priry, except in the homes of offlolale, 18 universal. In some tome these

31 CF. V. S. Dept, of Labor. Chlidren'a Bureau, Publication No. 117 , p. 12 .

33 Rochester, ope oft. P. 91; U. S. Women's Bureau Bullet1n, No. 45, p. 17-28.

33 The effeots of this leok of privacy upon boys and Firle of adolescent age is etreseed in U. S. Women's Bureau Bullotin. No. 45, pp. 13-14.

34 Report of U. S. Coal Commi oalon, op. olt., p. 1473. 
privies are well conetruoted over adoquate pits whioh are periodicaliy cleaned. In othere they are of the dry, openbuok, surface type to whioh 11108, chickens, and hoge have caby docese. Odors from these privies are sometimes of funsive, eapeoially in Negro eotione where the oompanies olean them lea often than in other paxts of the towns. Negro miners frequently keep hoge and other domest10 animals as they did on the farme from which many of them oame, which udda to the variety of smelis sometimbs apparent. Owing to

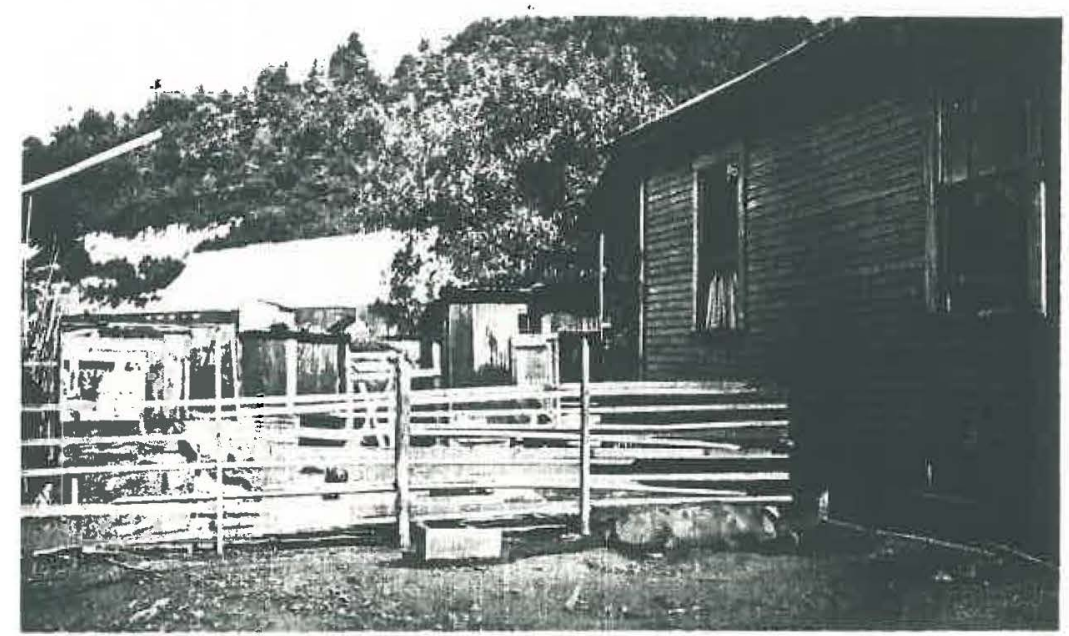

The Iegro miners and the 15 hoge nometines have edjolning bedrooms.

the 11 mited spece in the minlag towns the Vegroes frecuently risl. thelr health by oontinuing theoe rural ways of living. Pollution of apringe and wells has ofton oocurred from the filth of both privieb and animala.

host of the houses of Hegro minars are built of wood. In guality they range from the loosely-bullt, 35 See MoG111, N. P., epe Q1t. , pp. 14-15. 
A
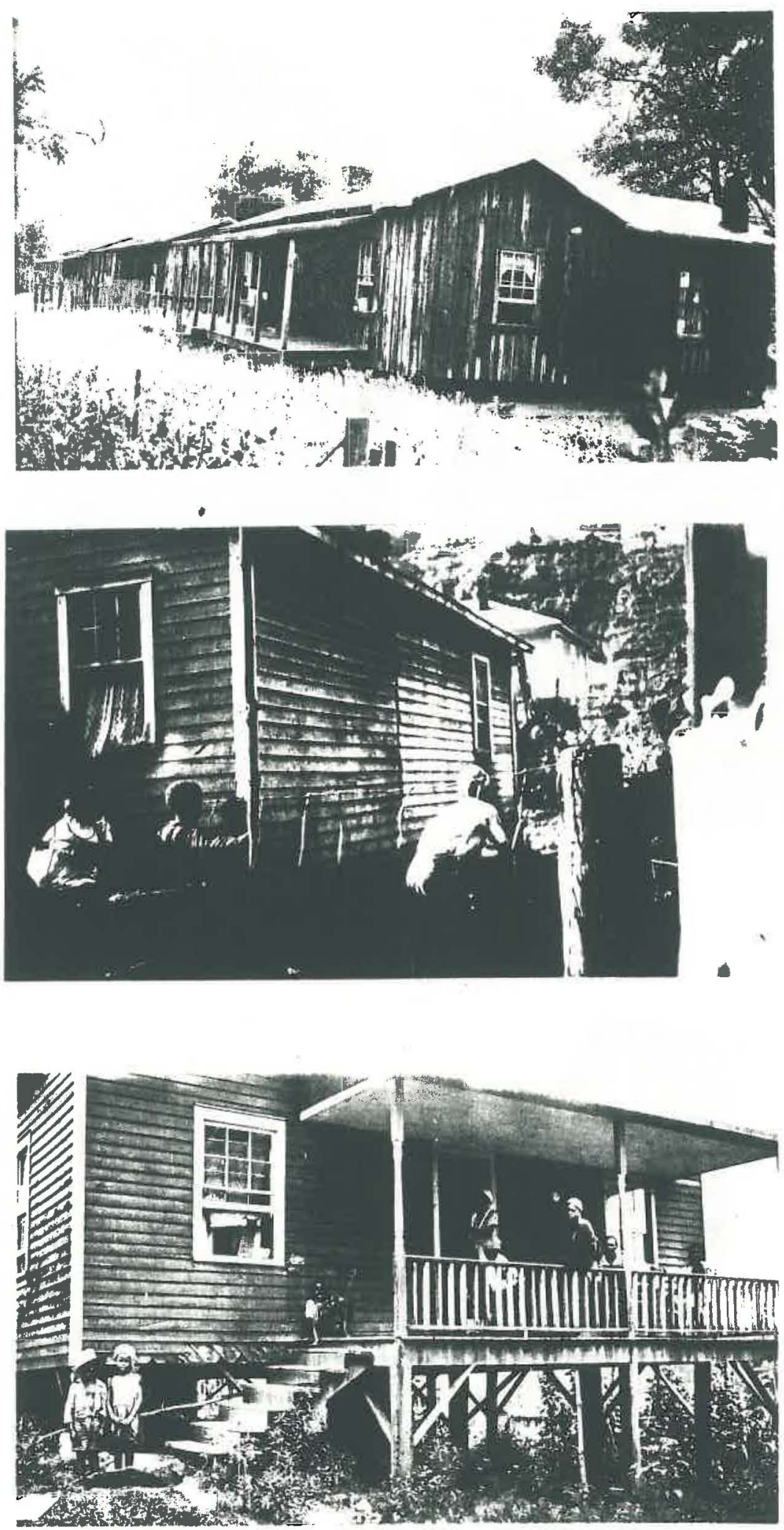

TYPES OF NEGHO HOUES

(A) Board and batten houre, Payette County, the poorest type.

(B) Negro house (al1ghtly better than 4), MoDowe11 county.

(C) Megro house on "at11tB, a frequent type, Fayette County. 


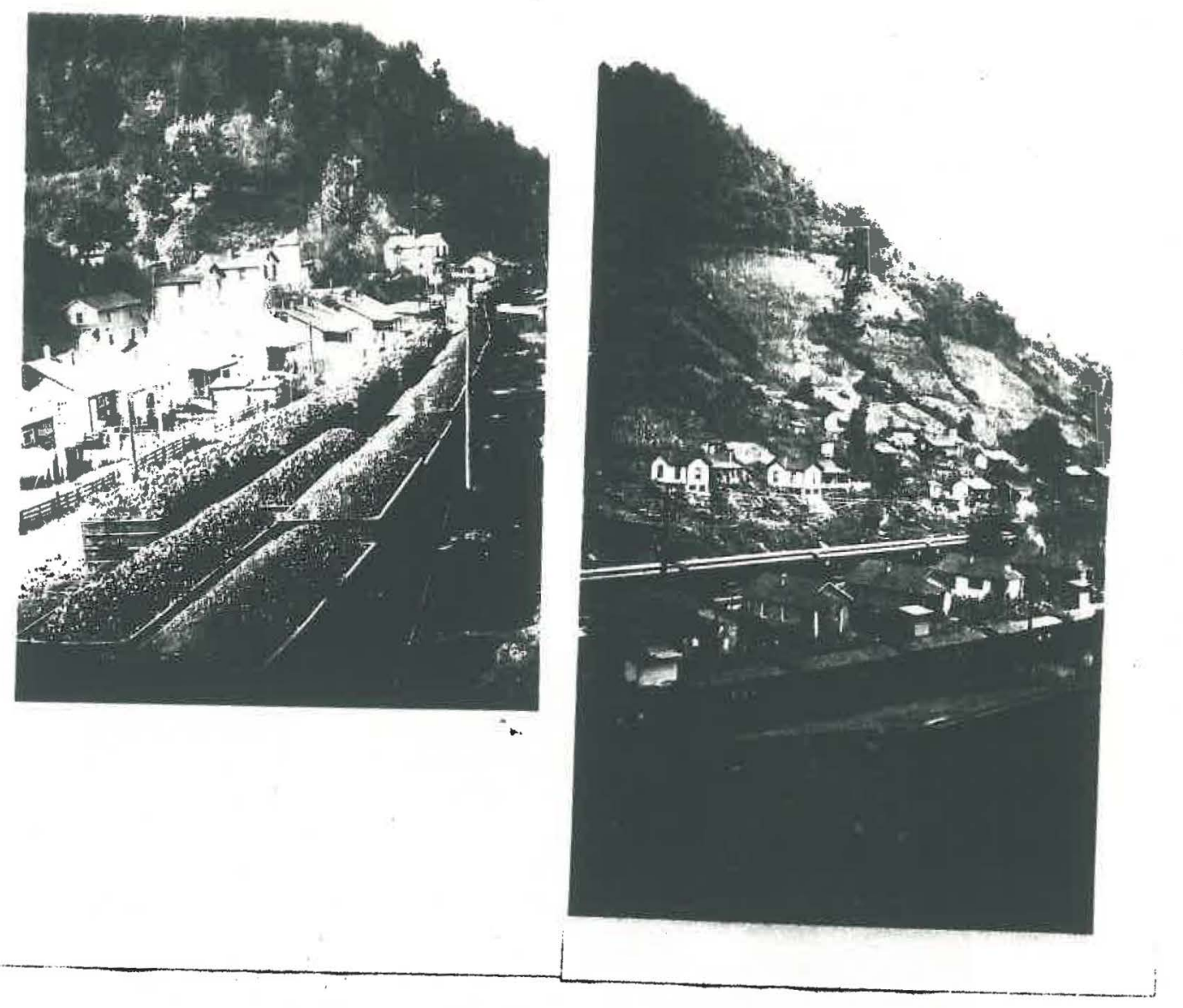

C

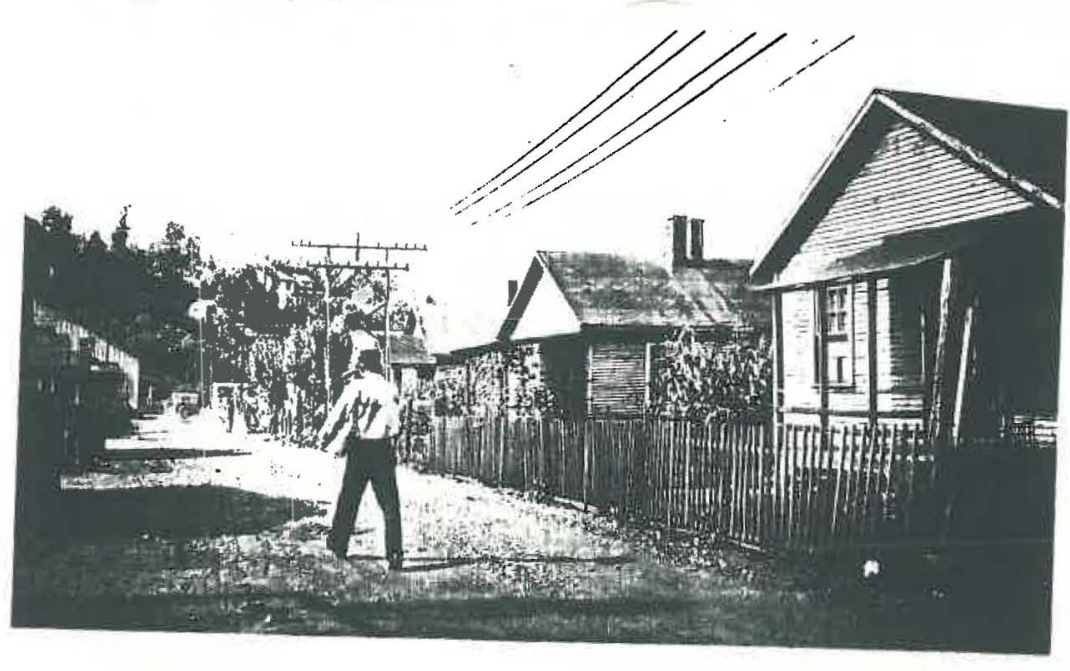

(A) Negro miners' homes near tipple, an undesiruble location due to coal dust. Kanawha county.

(B) Brick houses made from bricks obtained frok coke overis no longer used. MoDowell County.

(c) Negro homes, Raleigh County, In good looation. 

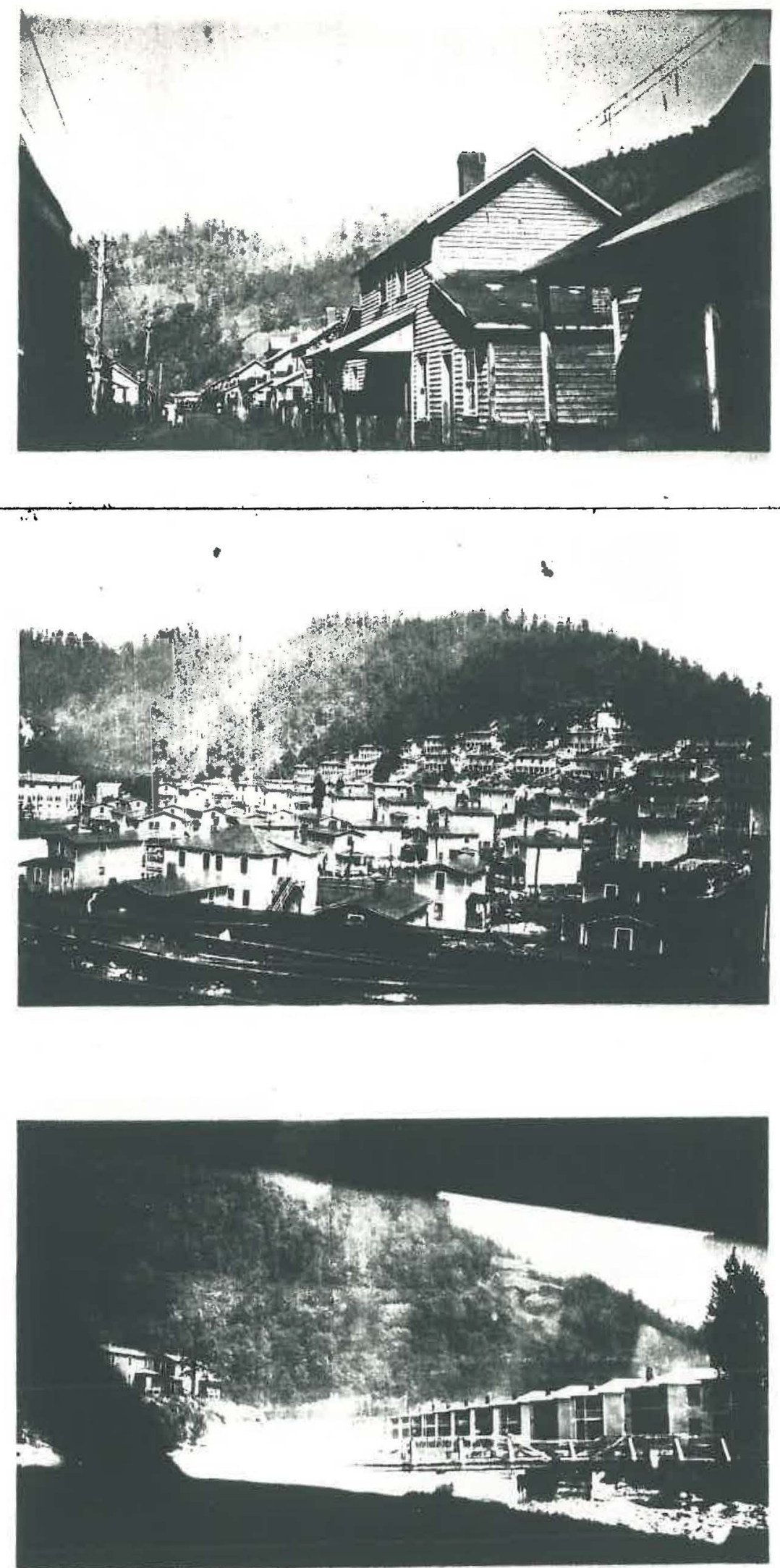

(A) Double houses in poor repa1r, MoDowell County. (B) Types of houses and locations, Fyoring County. (C) Better type of lange houbes, Logan County. 

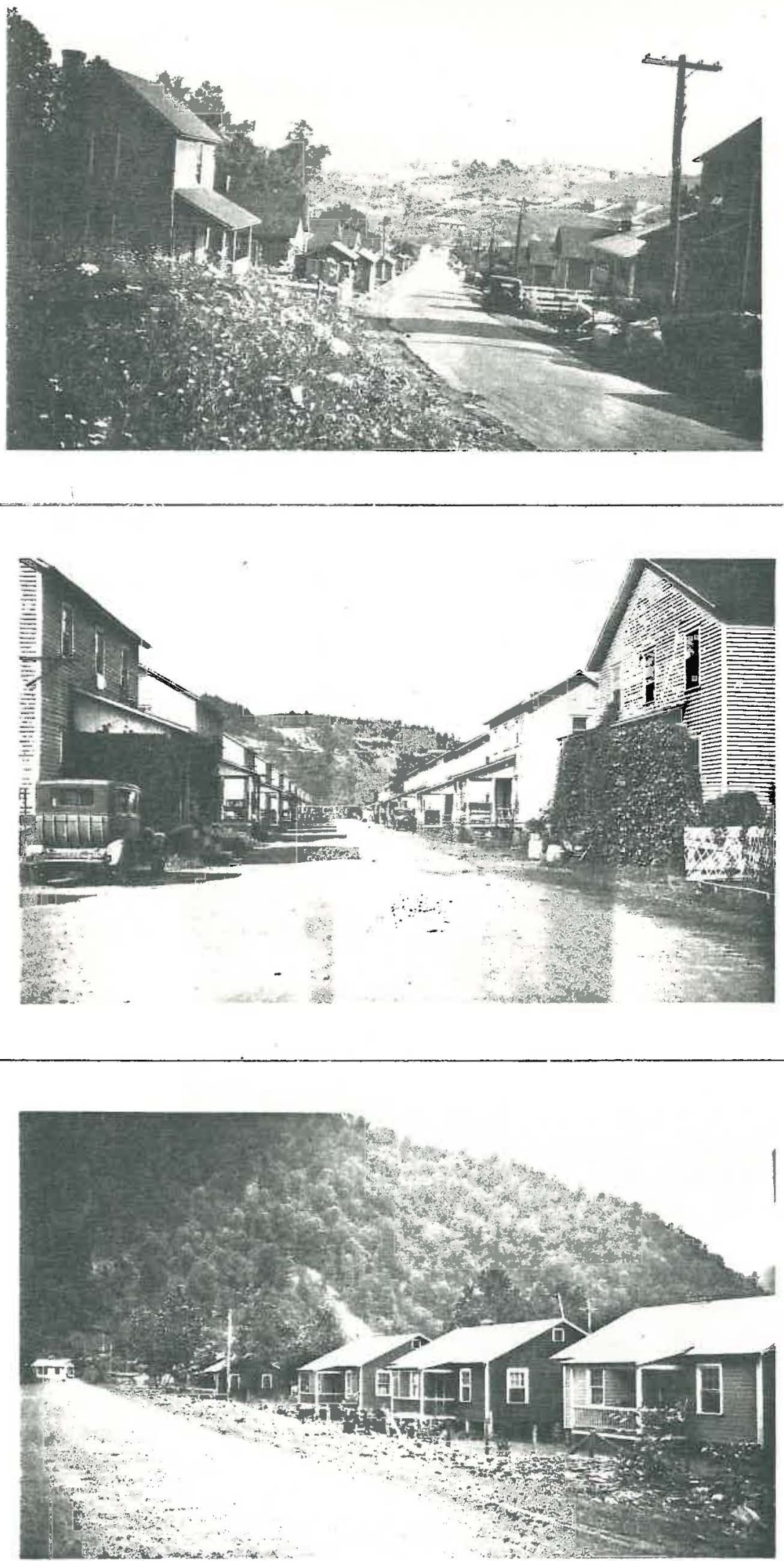

(A) Houses of better type, Fayette County.

(B) Large single fanlly houses in good repelr. Ralelgh County.

(c) Housea in newly-built tom with bath tubs and inside flush tollets, UoDovell County. 
unpalinted, board and batten type with leaking roof affording soant proteotion from winter drafts to woll-bullt coupes upon good foundations wht oh would wake a oredituble howing in an urban distriot. The Coal Cowilission found that 63.0 per cont of the 35,724 West Virginia dwellinge were furniated on the outalde with elther weatherboard or clapboard wh1 1e 39.4 per cent were of board and batten const ruotion. On the 1nside, according to the Coal Coranssion, 63.4 per cent of the housed were finlshed in wood sheathing, 30.5 per cent were plestered, and the remaining 6.1 per cent were finished with compoet ti on board or other materlals. The dealrability of a house was further found to be influenced greatly by 1 te $200 a t 10 n$, its atate of repair, and Ito

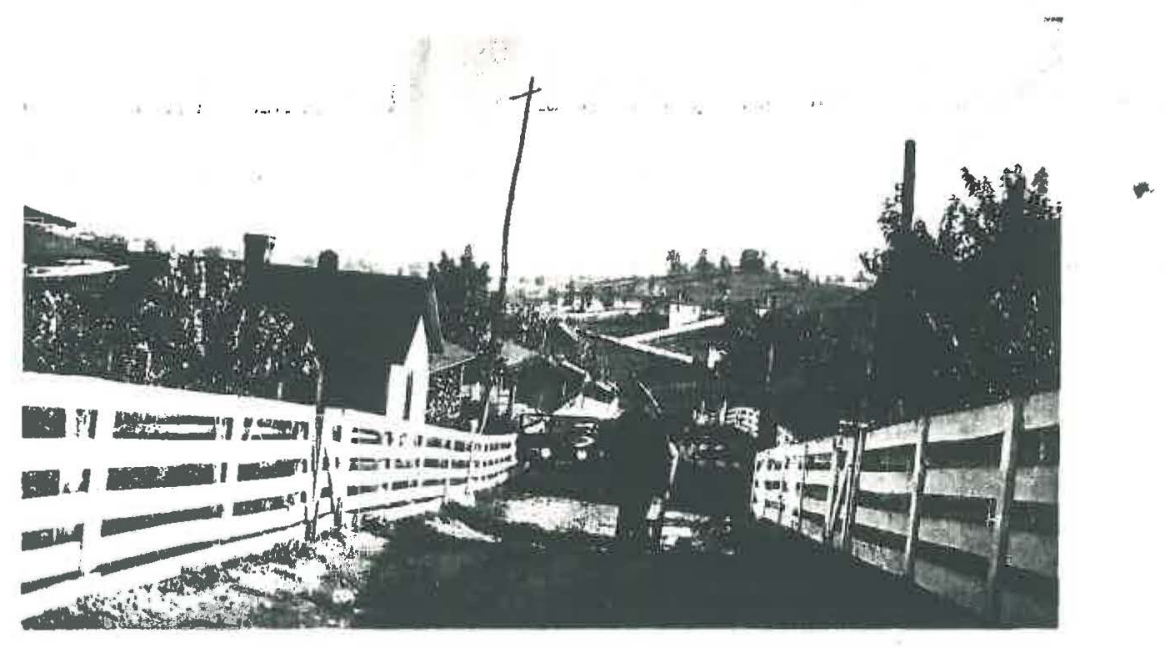

Qood houses in a hilly looation

age. A poor house in a good looution 18 sometimes preferred to a good house in a lese deairable looation. A poor house 36 Percentages oomplled from table in Report if J. S. Coal Commision, epe oft. p. 1471. 
with a ooat of new palnt may appear superior to a better bullt house Ion reontly painted but wore weuther reslstint. New houses are uaully not ony of better construotion but they laok the ouralation of dirt of many yoara and ininy fanilles; henoe in some plecee they rent for more than the 37

old houses.

It Is diff loult to generalize about the quality of the structures in whioh Negro minere live. One euch generalization, however, seems safe: where segregation Io the polloy of the company the Negrodes ax $11 \mathrm{kely}$ to be found in the Iers farorable loostions and in the 1008 desirable houses.

The houser in the minlng fleldr, usually monotonoubly alike in color and design, vary in aize irom two to eight rooms in most towns. In these houses the Negro households; congleting, among the Negroes of the present atudy, of from 2 to 16 persons, I1ve. Five hundred of the 600 Negro minero interviemed maintained separate licuseloldis; the other 100 either lived with other winers, their own Pamilies, or at the "olub house." A glanos at Table bo w11 reveal the fact that 252 or 50.4 per cent of the winers were living in fous-rook houses while 132 or 33.4 per cent wore ware living in houses of three rooms. One household of 13 pereons was found to be living in 3 roows while, on the other hand, I household of 2 persons lad a rooma. More than twenty years age in his olisalo atandard of living study Chapin considered any household overorowded 37 cf. Mogili, epe oft., p. 11. 


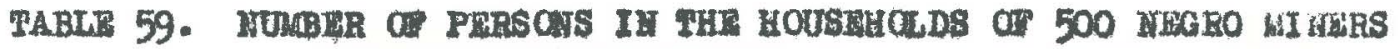

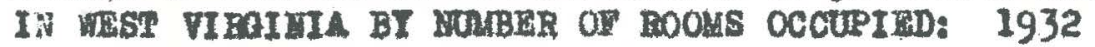
(Complled from mers' schedules)

\begin{tabular}{|c|c|c|c|c|c|c|c|c|c|c|}
\hline \multirow{2}{*}{$\begin{array}{l}\text { Person } \\
\text { per } \\
\text { household }\end{array}$} & \multicolumn{9}{|c|}{ Wumber of dwolli ags } & \multirow[t]{2}{*}{ Total } \\
\hline & 1 & 2 & 3 & 4 & 5 & $\frac{15}{6}$ & $\frac{1}{7}$ & 8 & 14 & \\
\hline 1 & 1 & 6 & 8 & 2 & & & & & & 17 \\
\hline 2 & & 13 & 19 & 46 & 6 & 5 & & 1 & & 90 \\
\hline 3 & & 6 & 39 & 47 & 5 & 2 & & 2 & & 101 \\
\hline 4 & & 2 & 16 & 39 & 2 & 5 & & 4 & & 68 \\
\hline 5 & & 1 & 16 & 33 & 6 & & 1 & 3 & & 60 \\
\hline 6 & & $i$ & 13 & 40 & 6 & 8 & & í & & 69 \\
\hline 7 & & & 8 & 27 & 2 & 1 & 2 & 1 & 1 & 31 \\
\hline 8 & & & 4 & 16 & 5 & 5 & & & & 30 \\
\hline 9 & & & 3 & 5 & 1 & & 1 & & & 10 \\
\hline 10 & & & 2 & 3 & & 2 & & 1 & & 8 \\
\hline 11 & & - & 2 & 3 & & & 1 & 2 & & 7 \\
\hline 12 & & & 1 & 1 & 1 & 1 & & 1 & & 5 \\
\hline 13 & & & 1 & & & 2 & & & & 3 \\
\hline 16 & & & & & & 1 & & & & 2 \\
\hline Total & 2 & 29 & 132 & 252 & 34 & 32 & 4 & 25 & 1 & 500 \\
\hline
\end{tabular}

where the mimber of rooms is lese than one to every one and a half persons. More recently Meeker upon the basis of careful studies ald, The atandard health and decenoy budiget must provide at the very lesat as many rooms per person as the average famlly were found to oooupy. A housing atandard of one room per person, exolusive of bath, has therefore been adopted as the minfmum requirement conol stent with health and decenoy." Edith Elmer Wood 38 Chapin, R. C., Tho Standard of Living Amon Workinmen's Fandles In Hew Tork CIty, Fused1 Sago Foundet10n, 1909, p. 80.

39 Heoker, Royal, HInl mum Quant1ty Budget Necesaary to Haintain a Worker's Gamily of Jire in Health and Deoenoy, in Ellot, T. D. (ed, ). Amerioan standardo of Hiting, Ginn, 1931, p. 515 .

40 Dr. Meeker refere here to the studieg of the Bureau of Labor Statistios in 1918-1919 in 20 oities in which the majority of workingmen of average inoome 11ved in houses whioh furnished approximately one room per person. 
reiterates this point of viow when she aays, Whe number of persona in the family divided by the number of roows which the family oocupy gives the ooefficient of room dena1ty. Any density over one is found to exert on unfavorable influenos on health, Inoreaslng with the density. Anything over two 1 grossly bad. M. L. Nark, in a otudy of Negro nelghborhoode in Columbus, Ohio, considers any household with atlo greater than one person to a room 42

overorowded. The small size of the roome usually found in the houses of minlag towne and the bonditions of 11 te in the mining lielde oertainly allow no more lenlent ratio in persone per room as a oxterion for overorowding. The number of Negro miners whose familles are 11ving under overorowded oonditions scoording to this otandard is ahown in Table 60.

41 Food, E. E. Recent Tranda in Ameriosn Housing, Haomillan, 1931, p. 27; 0ee also Caugal Faotors in Infant Mortality U. S. Chlldren's Bureau, Pub. 14\%, 1925, pp. 125-130 which ohowe the effeots of these rat 108 upon ohl1dren.

43 Mark, K, L, ope ait, p. 51. 


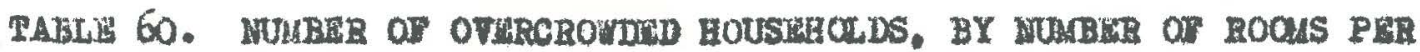
DUTHLIIISO

(Complied from uinere' echedules)

\begin{tabular}{|c|c|c|c|c|c|c|}
\hline Boovis & Munber & of houlcholde & averaxing as & 4 mumber of & pereon: & ir toog \\
\hline $\begin{array}{l}\text { per } \\
\text { dwel11ns }\end{array}$ & $\begin{array}{l}1 \text { or } \\
\text { lege }\end{array}$ & $\begin{array}{l}\text { More then } 1 \text {, } \\
\text { lese then ? }\end{array}$ & $\begin{array}{l}2 \text { and } 1000 \\
\text { then } 3\end{array}$ & $\begin{array}{l}3 \text { and } 1080 \\
\text { han } 4\end{array}$ & $\begin{array}{l}4 \text { or } \\
\text { more }\end{array}$ & Total \\
\hline 1 & 1 & & & & & 1 \\
\hline 2 & 19 & 6 & 3 & 1 & & 2 \\
\hline 3 & 66 & 32 & 25 & 7 & 2 & 132 \\
\hline 4 & 134 & 90 & 27 & 1 & & 25 \\
\hline 5 & is & 14 & $i$ & & & औ \\
\hline 6 & 20 & 6 & 4 & & & 32 \\
\hline 7 & 2 & 2 & & & & 4 \\
\hline 8 & 12 & 3 & & & & 15 \\
\hline 14 & 1 & & & & & i \\
\hline Total & & & & 1 & & \\
\hline Jumber & 274 & 155 & 60 & 9 & 2 & 500 \\
\hline per cent & 54.8 & 31.0 & 12.0 & 1.8 & .4 & 100.0 \\
\hline
\end{tabular}

Two hundred and twenty-81x, or 45.3 per oent of the Negro households are living in distinotly overorowded conditions, that is to say in households where the number of persons exceeds the number of rooms. A total of 71 or 15.2 per cent are 11 ving in households in whioh the congestion is extreme, or where there are 2 persone or more per room.

Althougli a b116ht minority of Megro households are acoording to our standard overorowded, a very considerable majority of the persons in these homes 11 ve under overorowded conditions. The number of such persons 18 obtained by inultiplying the number of hougoholds in Table 60 by the number of persons in each and olasslfying the produots into overcrowded and unorowded oategorles on the oriterion of persons in excess of rooms. The reoults of this oomputam tion are shown in Table 61. 


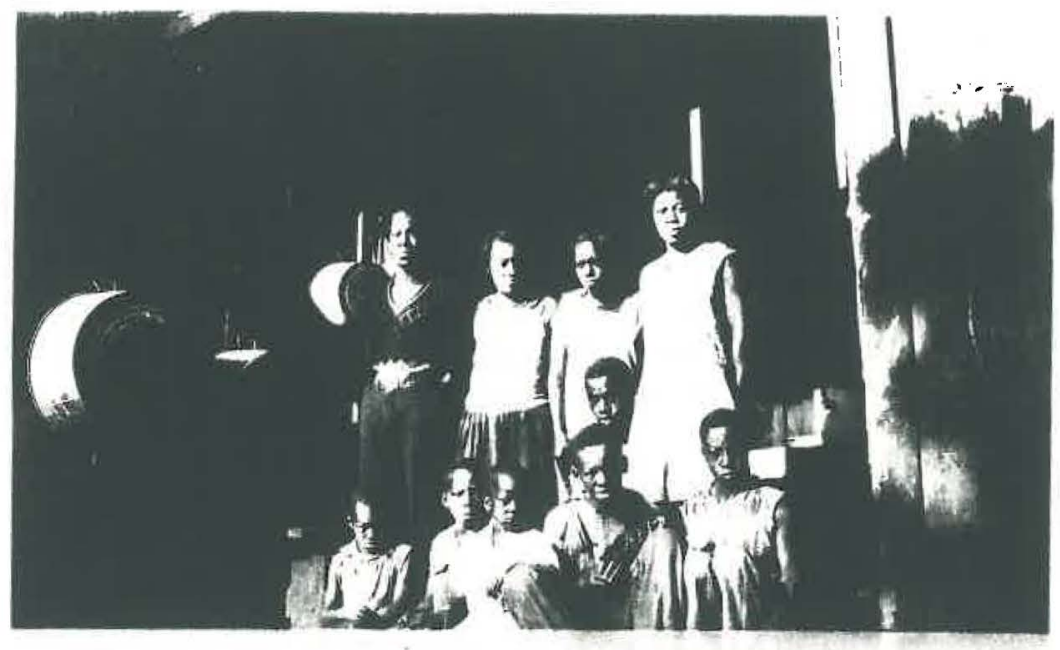

Wife of a Yegro wnez and her 9 ohlldren living in three roowa

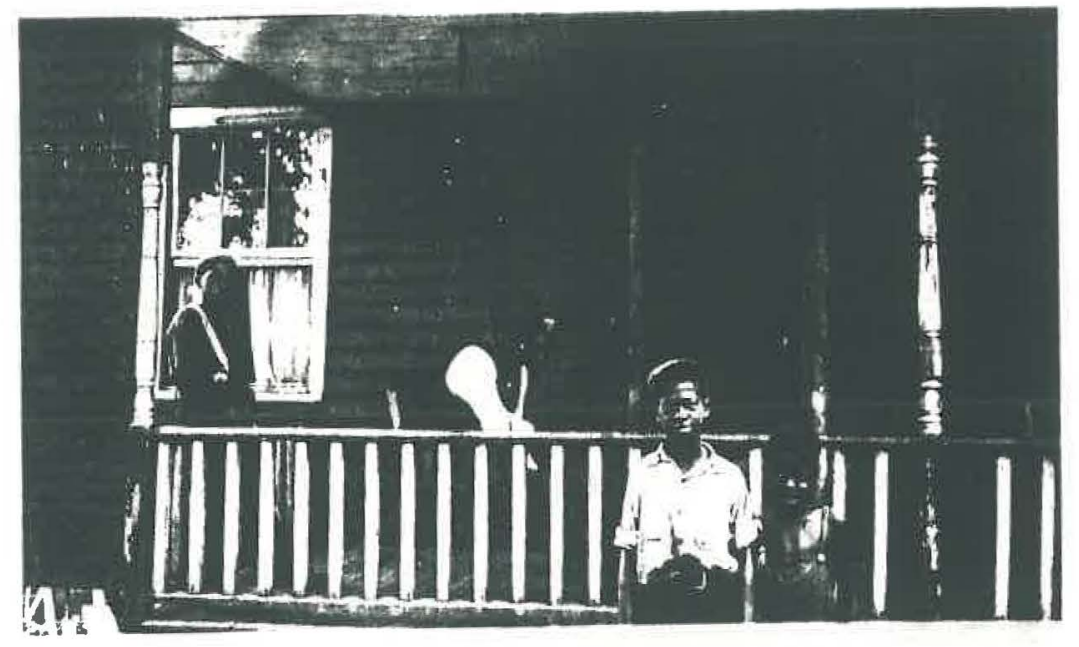

A Hegro winer and hlo boys 


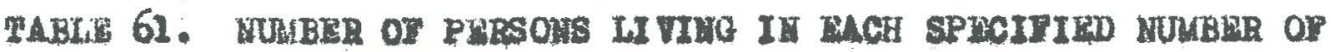

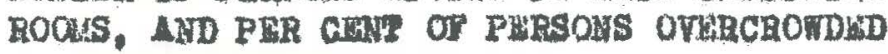

\begin{tabular}{|c|c|c|c|c|}
\hline \multirow{2}{*}{$\begin{array}{l}\text { SLze of } \\
\text { dwelling }\end{array}$} & \multirow{2}{*}{$\begin{array}{c}\text { Total number } \\
\text { of perwone }\end{array}$} & \multicolumn{2}{|c|}{ Perwon in overenowded dwelling } & \multirow{2}{*}{$\begin{array}{l}\text { Arerage number } \\
\text { of person } \\
\text { per noow }\end{array}$} \\
\hline & & Dumber & Per eent & \\
\hline $\begin{array}{l}1 \text { room } \\
2 \text { room } \\
3 \text { room } \\
4 \text { room } \\
5 \text { room } \\
6 \text { rooms } \\
7 \text { room } \\
8 \text { room } \\
14 \text { roorns }\end{array}$ & $\begin{array}{r}1 \\
69 \\
567 \\
1.163 \\
176 \\
205 \\
32 \\
85 \\
7\end{array}$ & $\begin{array}{r}37 \\
404 \\
772 \\
101 \\
121 \\
20 \\
33\end{array}$ & $\begin{array}{l}50.4 \\
72.3 \\
66.4 \\
63.1 \\
59.0 \\
52.5 \\
38.8\end{array}$ & $\begin{array}{r}1.0 \\
1.3 \\
1.5 \\
1.2 \\
1.0 \\
1.1 \\
1.1 \\
.7\end{array}$ \\
\hline Total & 2.305 & 1.488 & 64.6 & 1.2 \\
\hline
\end{tabular}

While only 45, a per oent of the Negro housebolds were orerorowded, 1,488 or 64,6 per oent of the 3,305 people I1ved in overorowded homes. The reason for mali of the congention in the dwelling of 3 and 4 rooms is that Negroes with large households are common whereas houses of more than four rooms are in many mining town very 11 mited and the vegro miner as well as the white must take often not what he wants but what is aval lable.

A number of the operators who were interviowed atated that the Negroes were very hard on company houses and did not keep them in good oondition. A very real reason for this situation is that the looktion and type of dwellingr which the Negro miners must often socept are more likely to disoourage them and thair wiver than stimulate them to "11x up." Aarge company in Foyette County, the towns of whioh are probably as oonulatently attraotive as any seen by the witter, attempts to enoourage miners of 
both races to boautify their homes by an annual yard and garden contest. Prizee of \$15,00,\$10.00, and \$5.00 are offered for the firat, ecoond, and third beet gardene in each of the $13 \mathrm{mind}$ g town of the oompany and prizas of $\$ 10.00$ and \$5.00 were offered for the two best kept yarda In euou town. The 1932 oontest was ot 111 in progress aben the writier vilited the towns of the oompany. In the 1931 oontest, in whioh 985 white and 431 Negro households conpeted, the Negroes made a relatively poor ahoulag. Tho scores nude by the two groupe were as followa:

\begin{tabular}{|c|c|c|c|c|}
\hline a & \multicolumn{2}{|c|}{ Hegr roes } & \multicolumn{2}{|c|}{ Whyt tee } \\
\hline $\begin{array}{l}\text { 8oore } \\
0 \\
10-24 \\
85-49 \\
50-74 \\
75-89\end{array}$ & $\begin{array}{r}\text { Mumber } \\
77 \\
97 \\
218 \\
85 \\
6 \\
1\end{array}$ & $\begin{array}{c}\text { Per gent } \\
8.3 \\
23.5 \\
50.1 \\
18.7 \\
1.3 \\
.2\end{array}$ & $\begin{array}{r}\text { Yumber } \\
33 \\
134 \\
344 \\
337 \\
106 \\
48\end{array}$ & $\begin{array}{c}\text { Per cent } \\
3.3 \\
12.6 \\
34.9 \\
34.3 \\
10.8 \\
4.3\end{array}$ \\
\hline ta? & 432 & 100,0 & 985 & 100.0 \\
\hline
\end{tabular}

요 On the basts of a posetble 100. The writer interviewed one of the Judges of this contest. a Preabyterian minister in one of the indepondent towno in rayette County, to ascertala the reason for the lower gradel of the legroes. His reply was that the Megroes did not have an eren ohance with the whites because of the faot that the grading was upon the appearanoe of the yard and gardens and not upon effort expended. The manager of mines who was also interviewed by the writer aaid that he was aware of the Contest 1931 through courtesy of this company whi oh al lowed free use of oompany files. 
diadvantages of the Negroes in the contest but was arerse to offering primes to whites and Negroes separately because of the peyohologioal effeot upon the Hegroes. He feelo that to allow the Negroes to compete only with Hegroes would make 44

for lower atandards. The followt gomanicat lons from the Judge to two llegro minero wil Indioate the disadvan tage of looation: 46

It is very hard to make a yard'bere whore you 11ve. We are glad to see you have whito-waghod the outoroppling rooks, put out roses and other flowers and have your premises pretty clean. We want to commend you very highly for your interest, and hope next year you can do oven better. Yard-45\% Garden-15\%

It 18 a great pity when the heavy rains apolled what work people have done in their yaxds, We see you have made Bome effort. You have some vines on your porch and a fen 1 lowere in your yard, and wo want to commend you for trying this year and hope that success w11 be yours noxt 1 me. Tard-30\% Garden-20\%

The interest of this oompany, however, 19 more than overbalanoed by the many that apparently have little intereat In enoouraging theif employees to better the phystoal surroundinge of their homes. As a rule it is due both to company indifferanoe and to apat by of the tenant that the physloal condition of the homes of many Hegro miners leavea muoh to be desired.

44 The polloy of the manager is hardiy consistently lollowed by the company, however, as each town has separate lirst-ald tesens, whioh do not compete.

45 From Report of Judgee, 1931 Iard and Garden Contest. p. 9. 
IV. THS MDORO TAYILX AED MAJORTTY STAKDARDS,-

Studente of the American Hegroes are pretty well agroed that, consldered as a group, thay have assinllated whit family and sex mores moh more blowly than most other tralts of the majority culture pattern. Not only have white writers suoh as Odum, Reuter, and Young 46 called attention to this feot but Megro studente suoh as Ou Bols and Frazler 47

have added their assent, The resoong given for this oondition by many different authors, however, have been at varlance. Sone of them, with. Odum, have stressed the faot that whe tendenolen of the present-day Negro, his restlesanese, his vagranoy and loafing, his love of excltement and censuality, his bumptlousnes, the ohlld and savage element in his nature, otill refleot forably the prevalent traite of the Negro in Africa." connection between African ways and the sex atandarde of the Amerloan Negroes and have stresbed the influence of 1950 slavery, the disorganizing effeots of emanolpation, the absenoe of family traditions and other faotors of 51 gocial hiatory in accounting for the lag in legro sex mores. The present writer is inolined to faror the oultural explana46 Odum, op. oft., Ch. IV; Reuter, epe oft., pp. 230-2a1; Young, D. Ope aft. p. 344.

47 Du Bois, E. E. B. The Hegro American Family Atlanta University studies, 1908, p. 37; Traz10r, E. r.,

48 odum, one olt. p. 186.

49 See Reuter, 2p, alt., pp. 300-204; Prazier, op, alt., pp. 28-29; Young, D. Ope olt. p. 347.

50 Reuter, ope olt. pp. 204-200; rrazler, op, o1t.. Ch, III.

51 Trazler, op. o1t, pp. 2a3-244. 
tiona of the latter in deaorlbing the extent of the legro group asaimilation of witte family and eex standards in the ining rields.

The heritage of the Negro family in the wining fielde has been for the most part promisoulty and sex 1icense. The Hegro failly gyotem under elavery, in aplte 53 of a faix thount of atability on wost plantations, was dealgned to keep the laves reasonably contented and to provide the ormer with more saves, The Negroes, in this prooeas, became individuallotio and have tended so to remaln. When these legroes anawered the oall for laborera in the West V1rginia 11elda, they were subjeat no more even to the fouble oontrolo of the Individuallet 10 primary groups in their home communities, and in the abserce of new controls they tended to throw off all restratints. 54 \& Megro ohurohman, commenting on the background of the present-day Negroes In the mining flelde, sald "In the early days men drifted In just for the sake of making fow dollars. They did not often come with the ides of permanent residenoe. Wany took up with women and malntained them as thols cominon-1uw wives. This mort of thing did not make for permanent howes but the oppos1te. A problem was oreated that the church has had to deal with ever ainoe. A legro teaoher in an liatorioal artiole conaerning the Megroes of MoDowell Dounty says of 52 Frazier, 20, elt, pp. $27-29$.

53 Young, D., Op. o1t. P. 373. 54 Ce. Park und M111ax, op, o1t., p. 61. 
the early daye:

It 18 not ne0essary to designate any p160e a being overwheluingly bad or laoking in morals. There seem to have beon oeveral places with their red 1 ights." And oommon lail wiven ware in evidenoe almost everywhere.

The denoraliation present in thowe early day was aggravated by the fat that the rall road and coal oompantes aotually enoouraged lmmorally etther by a polioy of indifference to lax oondit lons or, It is alleged, by bringIns in women as a meane of keptng a supply of labor. In this conneotion the Direotor of the Buroau of Negro Walfare 56

and Stat 1st1 os aye:

Weges were h1gh for those daye, money bus plentiful, the country almost insocesibible, railroad oontraotors wanted men to work and did not oare a fig about the kind or character of non. To hold the mon as long as posalble. in many oases they brought in gange of lowd women and settlod them in the oarng. The same conditions existed in the compe of many new coal dovelopments and the enforcoment of law was extremely lax beoause the contraotor and opertiors did not want the mon to run away.

Pam1ly and sex moree, Ilke all others, come dom 57

to us from the past. As Sumer ays, Each individual is born into them as he is born into the atmosphere, and he does not refleot on thom, or oritiolse them eny more than a baby anslyzes the atmosphere before he begine to breath 1t."

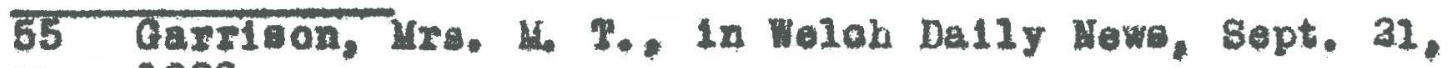
56) W. Va. Bureau of Negro Welfare and stat 18t109, Report. $1931-32$, D. 13.

57 Sunner, rolkweys, p. 76. 
We are formed by the mores before we are oapable of reaioninf wout them or evaluating thom in the light of other etandarda. It is not surpristng that, with suoh a background of laxity in sex mores, many Magroes in the mining flelda throughout the years bave taken aome of the mores of the whitea ad Herckovita saya, "with a grain of salt, " The fact that they have rlolated these standards with $116 t$ le compunction has led a reoent writer to refer to the mblithe anorallty of the negro miners."

For a number of the Hegro minera marriage has not been a preraquisite to more or less pormenent cohsbitation. Uamarrled perzons $11 \mathrm{v}$ together wh 11 ttle protest from e1thox the Negro mining group or frow thelr employers. Among the Negroes the feeling of outrage by the presenoe of such oonditione is keenly lelt onl by the upper olesses and thoy reat as a rul by drawing olase 1 ines more tightly. for many of then 100k upon any andlorative devioe as hope186. Some of the permanent unlone result from the minerst taking up with oomen law wives." lany of these winers, oaught with ohlldren on thel hands, rematned in the minims fielde and wade the beat of the situation, ith the oonsequent results of the grouth of family tenslons and diggruntled att1tudea whioh probably bare momothing to do with ohildron learing howe at an early age. 58 Herakovits, ope o1t. p. 54.

59 Ross, Maloolia, Fohine Age in the Hille, Maomilian, 1933, D. 78.

60 Gf. Young, D., op, att, p. 382.

61 Of. Odus, op. ott, p. 168. 
uninarried oouple have lived togother for yoare and are apparentiy contented and happy. Tho writer remembers diatinotiy certain of these bouseholde. The women, as a rule, are good housekeepere and are apparent $1 y$ oonduat 1 gg themBelves much the aame as they would have done had thelr union been accompanied by a legal marrige. Somotimes these "oomon lal w1vee" are older than tholr "huabands, "The writer remembere staking one of them for the winer's mother only to be later told by oompany offlolal that she was hi "women," These minere and thotr "wies" apparently guffer 11ttle soolal stigna beckue of thel unmarried atatus. Thoy visit and are vieited by most of the Negro group moh the ase as if they were warrled. The日e women are not ghamefsoed, as if Irom a conviction of wrong dolng. Sald one to the writer in answer to a quegtion cbout the Negro miner in the bousehold: I'm not reslly his wife. thoy just oall me his wife beoause I live with hip." The laok of any uppearance of oompunotion or apology in this answer Indicates olearly the presenoe of more than one set of nores within the mining group. The Megro miners who 11ve with woun to whom tbey are not married are more frequently than not from the southern states, a faot which must be taken into consideration in understanding an 1aportant balls of soclal differentiation to be discussed later.

Within the last 20 years a marked decrease in tho number of unmarrfed couples living togethor as man and wife B2 See Chapter XIII. 
has occurred. Young has pointed out that an important reason for the Insistsnce on formal marriage is the necessity for the legal determination of property righto. The property of most Negroes has been as a rule inconsequentlal. The passage of the Jorkmen's Compensation Law in 1913, homever, provided the property incentive mion led to this decrease In the muber of "common-1aw" husbands and 1 ives, for if a 1do is to receive any oompensation for the death of her husband she must, acoording to the law, produce a rarriage certifieate. Recognizing this now property intereat nuny of these "Comnon-law" couples have married. Sald a MoDovell County superintendent: "Even sowe of my old-timers here tho had big familles went down to peloh after the lav was gased, got their licenses, and were uarried."

2. Frankiln Frazler, who has conduotad ext ansive researches on the Negro family in the United Stater, fives home onnerahip as one of the possible indexes to the gtablilty of the Negro fanlly. Vary fen Negroes in the mining flelda, as to have already seen, may own the homes in which they 1ive even though they may destre to do so. The conclusion that this condition la partiy responsible for family instablilty seem inescapable. The Director of 33 Young, D.: op. o1t., p. 368.

64 State of W. Va. Anmual Report of the State Compenasm tion Commi asioner, 1926, p. 5 .

65 Tor explanation of many detalis of the admint stration of the Torkmen's Compensation La the writer is indebted to Mr. Hoyt H. Thornton of the $\mathrm{T}$. Va. State Compensat ion Department.

66 Frazlex, I. F., The Megro Family, Annals, Vol, Cxxxx, Hov. 1928, p. 43 . 
the Bureau of Vegro welfare and Statlatios probably had 87

some such idea in mind when he ald: whe greatest liand1oap to Negroes In the ood flelde 1s thalr inability to purahase homes near their work (exoept in a few places).

Frazier found that one of the great differences botween Hegroes in the areas of ohi osgo in which fam1ly disorganization was most apparent and those in which a more atable fam1ly 11 fe was oharaoteriatio was the matter of family tradition. 68 "The importanoe of member roles in families in the prooss of ahaping personsilty of children and in dotermining the type of adult roles they are 11rely to play wen they as sume the reaponsiblifties of family 11fe has been demonetrated. The al of temporarines, oasualness, and uncertainty, apparent in the attitude of many Hegro miners toward thelr mining town homes is not 11kely to provide a basio of atability for family $11 f e$. Desertion and non-gupport. wo other common indexes to family otability, aro extremely diffloult to mesaure because women who have been deserted or unsupported must leave the mining flelde to find work, and hence are not encountered by the investigator. The "widows" 70 usually present in numbers in the Negro community are consplouously absent in the mining towns.

67 V. V8. Bureau of Negro Welfare and Statiatios, Report, $1924-23$, p. 8.

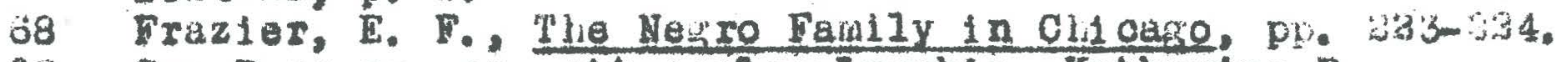

o) See Burgesi, op, o1t. jialso Lumpkin, Katherine $D_{1}$, The Family: I Study of Hember Roleg. Unt v, of North Carolina Prase, 1933, pasolim

70 See Reuter, op, o1t. pp. 208-207. 
Juvenile delinquenoy in the mining oount les as measured by commitment so the otate Industrial solool for colored boys and girle, is not large. The trend follow that of dult delinquenoy: the ofties contribute a larger proportion than the minling counties. For inatance, of the 98 boys in the Fest Virginla Industrlal sohool For Colored Boys, only 30 hare parente who are minere, 71 and of these, according to the euperintendent of this sohool, nine-tenths are from broken hone. Fewer girls ate oomitted for delinquenoy than boya; the Nest Virglaia State Industrial Hom For Colored Girla had onily 43 in $1938-30$. No fligures on trie number of girlo whose fathers were minero were aval sable for this institution. The 43 girlo were from 12 different oountiea. Kanawha County, wth large urban population, and Raleigh County, with a large mining population, had the largest number, with 9 each. MaDowell County, although it has the laxgest Negro population of any county in the etate and thia Megro population is elmost exolusively made up of minera, had only three girlo in the institution.

In writing somewhat oategonically of the Megro family in the mining t1elde the writer has not meant to infex, of course, that all legroes have standarda of their own or are baokward in assimilating white mores, Negro families in the upper etratum in the mining filelds conform 71 Correapondenoe with Mr. 8. S. Gordon, Supt. of W. Va. Industrial School For Colored Boys, Lakin, W. Va.

72 Va, State Industrial Home For Colored Giris, Annual Report, $1829-30$, p. 1.

3 In 10. 
to majority standarde as well as the members of the white familles of corresponding clase, 74 These Nezroes admit frankly the dffering standards of many of the other Negroes and are dolng what they oen to bring them into 75

1ine, Certain of the minl sters are deeply consolous of the dispartity between that $x$ own atandards and those of many of their rece-brothere. I dietriot auperintendent of the Methodiet Ohuroh oeld, in bis annual report to hie gonfor76 enos:

The need of the manifold ministry of our churoh 1s obvious in that seotion of our Distriot Whit oh erabraces Meroer, MoDowe11, Mingo, Logan, palelgh and Wyoming counties of the state of West Virginia. In these oountios the Negro population numbers about flfty-four thousand, whose moral, soofal and spiritual future depende very largely upon flective ministry of the ohureh. The most outstanding need in these oommunt 108 , soond only to thelr soul's salvation, is a better and more ohriatian bome 11 fie.

Race-consolous leaders, presohers, teachere, and other interested persons are working to hasten the process of asaimilation through whioh the masses adopt "aigher" standarda. They have not been without some measure of suopesa, aspeolelly with the younger generation. We may agree with a Hegro teacher when bhe agys: "Thut the

74 Cf. Reuter, op. oft. p. 221.

75 Cf: Young, D., ope oft. p. 383.

76 Rev. Mr. T. J. Howard, Distri ot Supt. of Bluefield Distriot, iast Tennessee Conferenoe of the $M_{\text {. }} E_{\text {. }}$ Church, offlotal Journal of the 5and Anmal Bussion, Sept. B, 1933, p. 39.

77 Garrioon, Urs, i, T. Teloh Daily News, Sept. 31, 1920, p. 2, H1 storloal gootion. 
Hegroes of MoDowell County, in the past thirty years have made moral progress is not to be denled. Still there is muob land to be poseesed. "That he says 18 applicable to conditions in other counties. The Nogro family has moved and w111 continue to more alowly in the direotion of major1ty atandards, for, as the teacher adde. "It w111 take more than 60 yeara to overoome 250 yeara of wrong inetruotion and praot10e." 


\section{CHAPTER V}

THE FUNOTION PERTORMED BY THE NEGRO UINER

I. DESCRIPTION OF OCGUPATIONS.-

Generally speaking, the oocupations of the mining 1 operation may be divided into four different categories, the exeoutive, Bupervigory, inside and outside labor. At the top are the administrative or exeoutive positions, These are likely to be superintendent, asalotant superintendent, and manager. of these the munkger's positionis the highest and frequent Iy his juriadiction extendo over wore than one mine. He 18 usually a heavy stookholder in the minea writoh he manager, alao. The manager may or may not IIve at any one of the mines, There are some tanagera who do not visit the operations more than once a nonth. The officlal nore atreat ly in oharge of the mining operation is the auperintendent. He stays at the rining town and is on hand from 6:30, when the glant siren sounds the call to work, unt11 operations are suspended late in the afternoon. He is the one directly in charge of both the inalde and outside working conditions in the mining towno. He thus mukes at least one trip tirrough the mines a day. In large operations, there 1s sometires the offloe of assistant superintendent. The assigtant ouperintendent us a rule

I See MoG1II, Nettie P., The Nelfere of Children in B1turi noue Coal Mining Comirunit les in West Vireinia. Chlldren's Bureau, Publication, No. 117, U. S. Dept. of Labor, 1923, $p, 4$, for a somewhet different class1floation. 
conoentrates his aotivities either on the inside or outalde of the mines, decending upon the polloy of the particular colipuny. Ilisis men oonstitute the top atratum of prestige and privilege in the mintng flelds.

The next group below the executive positions are the foreinen and bosger of varlous kinds who have sone supervision over other men, but who have a definite "employee" attitude toward those above them. To this group the higherups constitute "the company." and thelr attitude 18 imindiately of the type whloh makea tham a sort of lntermediate group, with many of the oomplexes that go to make up the labor mind, and yot not quite one of them. They are quite likely to refer to "the oompany" as something quito apart from them and yet not say "wo" in regard to the mon over whom they have superviston.

These foremen and bosese are of a good many varieties, depending upon the partioular mine. The mine foreman is perhap the one with most authority bolow the assistant superintendent or the ouperintendent. He has direot oharge of a group of miners as they work "on the 1nside" in the minling of ooal. He reporte direotly to the superintendent or higher offlalals. Aooording to the United State Department of Mines hla qualifloations ahould Inolude physloal strength, good health, more than average ab1lity, and ability in handling men. Ho should know mine gaser, 
mining methods, mine ventilation, and the use of explosives, He sometiwes has direotly under him an aselstant mine boss, lifft boss, or plt boss depending upon the nomenolature of the locallty. Thi assiatant mine boss or foreman has charge of a apeolf10 part of the mine. For inotanoe, he may have oharge of men working in a cortaln number of "rooms" in the mine. A "room" is a seotion of the mine out of from the main "entry" or tunnel into the mountain in whioh the actual mining of coal ia oarried on. These rooms vary in elze depending upon the oondition of the "roof" of the mines. It may be anywhere Irom ten to fifty reet wide and two hundred and flfy to four hundred feet long. If the "roof" 18 "bad" the room must elther be made narrowar than otherwise would be the case or a great deal of "timbering." propping of the roof with heavy pleces of wood, must be done. The miners work in these rooms and this room supervision often falls to a seotion bose, or some other subordinate of the mine boss.

Other bosaes have supervision and authority over perhape fewer men than does the mine foreman. The driver boss is found in the mines whloh still use mules or horses principally for haulage of the ooul from the "rooms" to the main line or aide track built up to the entrance of the room, the driver bose has oharge of the men who are driving G U. S. Bureau of Mines and U. S. Bureau of Labor Stat1st1co, Desoription of Oooupations, Mines and Mining; 1918 , p. 30 .

3 Shuriok, A. T, The Coal Industry, Litt10, Brown, 1934, pp. 70-73. 
mules or horsea (or ponles). In small nes he may also have oharge of the stables, but in the larger minos this position 1a held by a atable bosa. The tipple boss 18 in charge of all men worklng at the tipple. The tipple is a type of coal elevator in whioh the ooal 19 sorted into vurlous aizes by meane of screens and loaded into rall road curs. The tipple bов, supervisea the welghing (where they do not liave a weigh-boss), dumping, soreening and loading of the coll. The tipple ig often one of the most expeneive parts of mining equipment, some of them oosting hundreds of thousands of dollara. Another bose, in some operations, is the foreman of the late dump: Some mines have moh elate to be claaned eway and it is usually dumped over a hillside, often with a moat unsightly reault. The foreman has oharge of the men engrged in dumping the slate. A dispatoher of tripsholds also postion of some authority over the motormen.

Perhape apecial attention should be given to the so-oulled fire bose. This position, whlle it 18 less of a "boss" position so far as handing mon la oonoerned, is one of the most important in the mine. It is the duty of the fire boes to examine with a safety lamp the underground workings to see if gas is present. Some of the mines in West Virginla give out milion of feet of gas a year. Th1 s fat makes mining more hazardous in theae mines. The fire bosa also must see that the ventilation system is 4 Description of Oooupations, p. 18. 
properly funotioning. In addition, he must examine the thabering, look for dangerous roofa, and do anything elae which would make for greater safety in the ulnes. His work, as a rule, is done before the miners enter the wine. He rast have passed an exanination before a rining board before the oan hold this position.

Under these bosags are the mining operatives of varlous kinds. We may divide these roughly into two categories, the insd worker and the out ide workers. Those who work "on the inside" are thost who work underground. The outside workers are those who do work in handing the coal after it comes to the outelde, or any other position necessary to the malntenano of the operation. We may proceed to the inside positions firat.

One of the positions requiring a degree of skill 19 that of mabine man, or coal outter. The function of these workers 1s to "undercut" the coal so that it may be blasted down easily and loaded Into the cara. This underoutting is done by eleotrio machines whioh require two men to the machine. Several inches of the coal at the bottom of the sean is hollowed out for a depth of several feet. The purpose of the outting 18 to cause the coal to fall down when it is drilled near the top of the seam and blasted with an explosive. The machine men luve a very dirty job, as the cutting maohine throws out a fine dust which is called "buak dust," Although a stronuous job the Ib10. P. 20. 
Il luotration 3. Maokine Men at Work, Ralelgh County

position of maobine man is one of the most Iuorutive. The meohine wen work at night whlde the other operatives are out of the mine. Their job ig to underout enaugh coal to keep the loadera busy the following day,

The blasting and loading of the coal is the funotion of the mat numerous operative in the mining fielda, the coal loaders. When the loader oomes in his room in the inorning he finds his "plaoe" has been undercut by the mähine men. His firat operation is to take a very long shovel (see illuetration) and take out the "buck dust" from under the seam. He then drilis a hole near the top of the seam with a long drill, He then puts in a very olow powder, called "permisalblo explosive," to avold breaking the coal 6 See Rochester, op, Clt., pp. 108-109, for a more extended deseription of this prooess.

7 Shurlok, op, olt. pp, 73-74. 


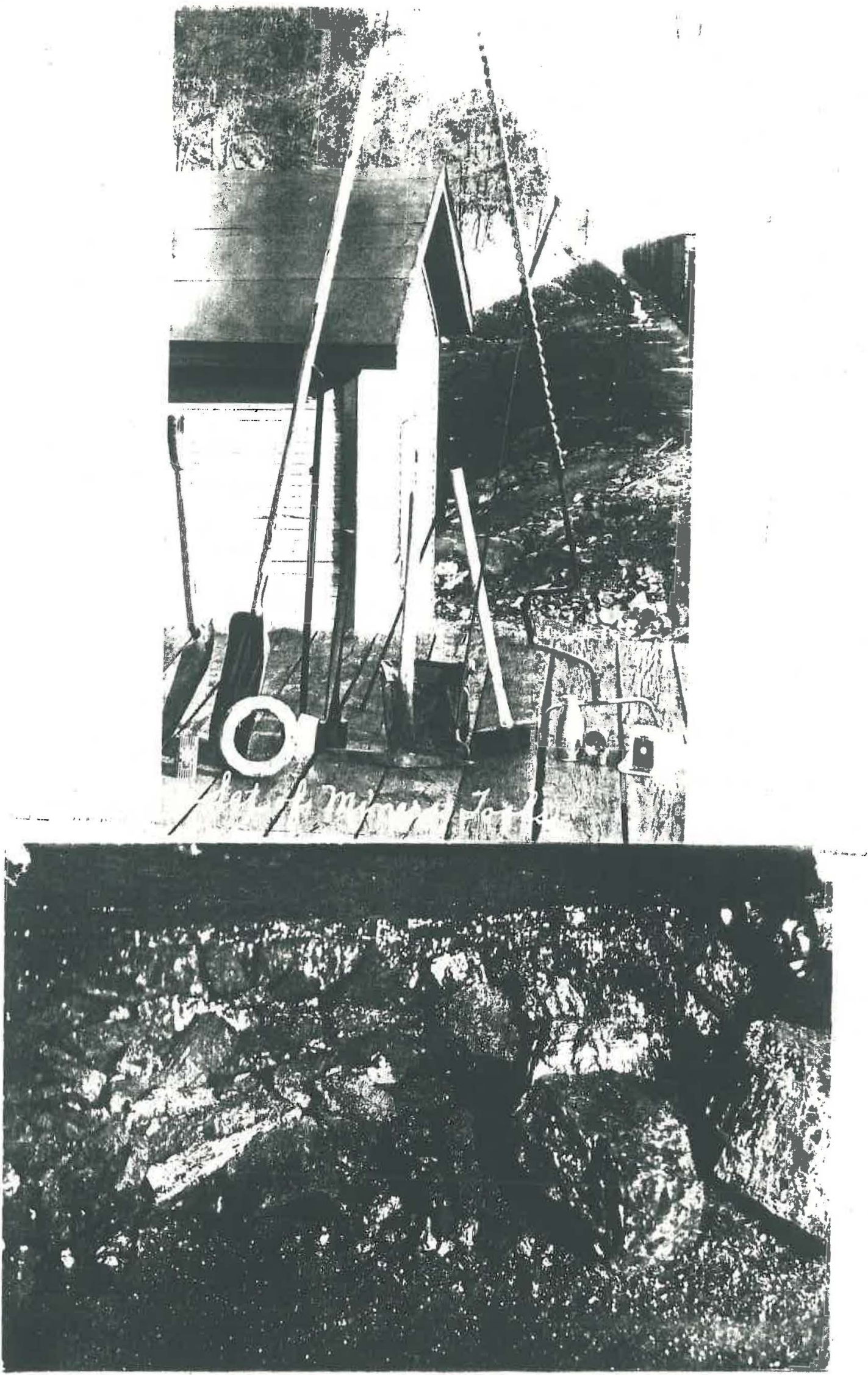

Illustration 3. A Negro Coal Loader and Ha ToOla, Raleigh County. 
any more than neoeseary, The ool belng underout, drops down in lumps at the flring of the powder. The loader then shovels his coal into the rine carm. In the non-union flelds of West Virginla the loader is also expeoted to do any propplng of the roof neosesary to h1s own sufety. In some placer he also pures his oar to the entrance of his room, where the gathering motor w11l plok up his "loads" and take thom to the main 11 no.

The small oars in whiob the ooal is loaded are hauled in most mines in Weat Virginla by means of electric motors. These have practioally eliminated the use of enimals for this purpose, although in the early dey is aules were used. There are two jobs in connection with the wotor, wotoruan and brakeman. The motorman, as the teru bugsesti, lands es the controla of the notor. The brakeman, like the brakenan on the rallroad, has to do a great deal of coupling the curs and seotng that the "trip" is in running order. This occupution is one of the most hazardous in the miner. The lurgest number of deathe in the mines $1 \mathrm{~s}$ not due to exploalons, in apite of the newapaper oopy they provile, but to fall of roos or coal. The fatality rate frou this cause 1 iroil 3.30 to 2.83 per thousand enuloyed uncios8

izround. Hulage wooldents are the next faportint octuse of inine fatalfies, anounting to about 17.0 per cent of the 8

total. These trips on whiob the motorman and brakeman must ride must travel at high rutes of speed, and, as 9 Ib1d. P. 90. 
Shurlok gaya, "... It oan be accepted as axiomatio thict a certain number of violent wreoks are un inevitable cocoin10

paniment of the your's run at any inine." Consequently we find wany fatmlitles among the motormen and eapecially awong the brakemen.

One of the causes of thear wreck is the condition of the trisok in the mines. It lo very diffloult, espooially In vine w were drainage la inadequate, to malntain these trabs in good order. It lo not easy to detect danger apota In the darkened conditions within the mine. As the coal 1e

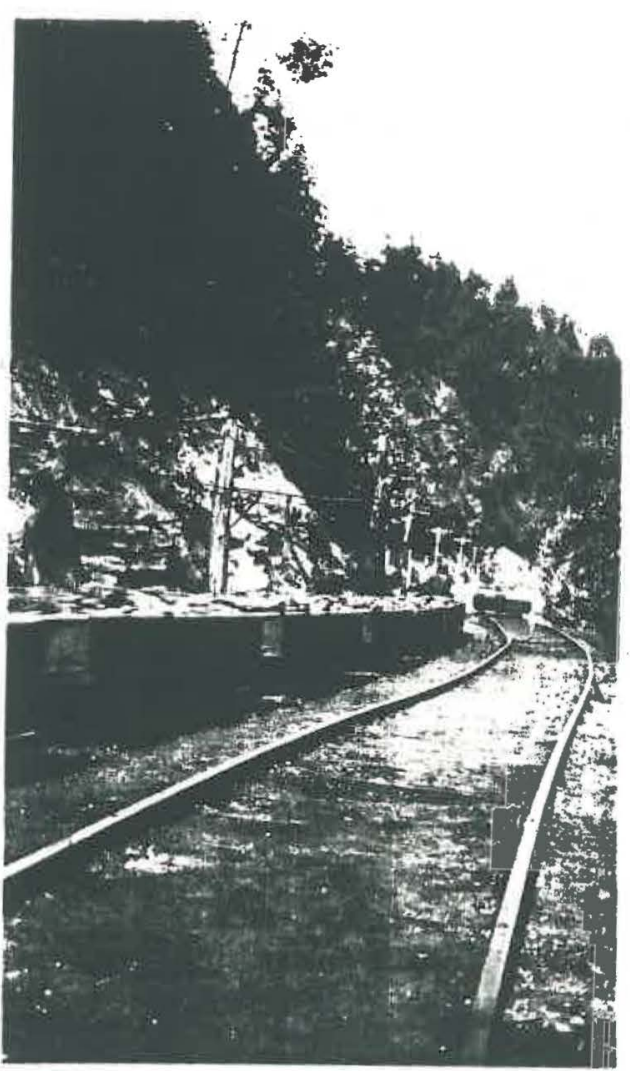

Illustration 4. A "trip" on its way to the tipole golng at high speed, Wyoming County. 
"robbed It is necessery to go farther into the mine. This fect means the continual bullaing of traok. The operative who does this is known as a traok man. This position also oal1s for a degree of ak121 and knowledge not required of the ordinary coal 1oader.

Phose already mentioned are the ocoupatione in

whioh the largest number of Negroes are engaged. However, there are certain othera of whioh bries mention aliould be made. It 18 still the praptioe to use horses and mules (ponies to a limited extent) for haulage purposes. For 1nstance, some minea prefer to use animale to haul tie oars from the rooms to the maln line traok instead of gathering motors. Consequently there are a number of drivere required. The trapper opens and alut gates in oertain plaoes in the mines for the motor to oome through. This position is usually ocoupled by boys just starting in the mines and by old miners who leve grown too feeble for the mort strenuous jobs. The timber man oute and sets tiuberis In wrid about the mine shaft, tunnel, slope, drift or otler claces where there is danger of a falling roof. ${ }^{11}$ itie brattioe man is a combination oarpenter and ventilution worker. He usually works under the direotion of the fire boss, oonstructing bratt10es of wood, aanvas, stone, briok, or cement for conducting the ais ourrent through the proper channels to the work1ng "face." A brattioe is usually of 11 See U. B. Dept, of labor, ope oft. pp. 34-35 for a fuller desoription. 
wood and is a sort of partition in the mine tunnel with a sliding window through which the alr passes or, when not needed, may be olosed. The flro boos himself irequently gots as brattioe man. The brattloe man is also known look12y as a "braddisher" In sorne plwoes.

There is one other ocoupation of the underground worker which 18 a sort of quala1-1abor job. This is the job of "boss miner" or oontractor. He takes a contraot from the mining oompany to produoe coal at a certain price per ton. He may employ other. miners and aselstanta to do the aotual wining work. Sometimes a man and his cons will take a contriot. In this oase the wen are considered partners and alare al1ke in the proosede of the transaotion.

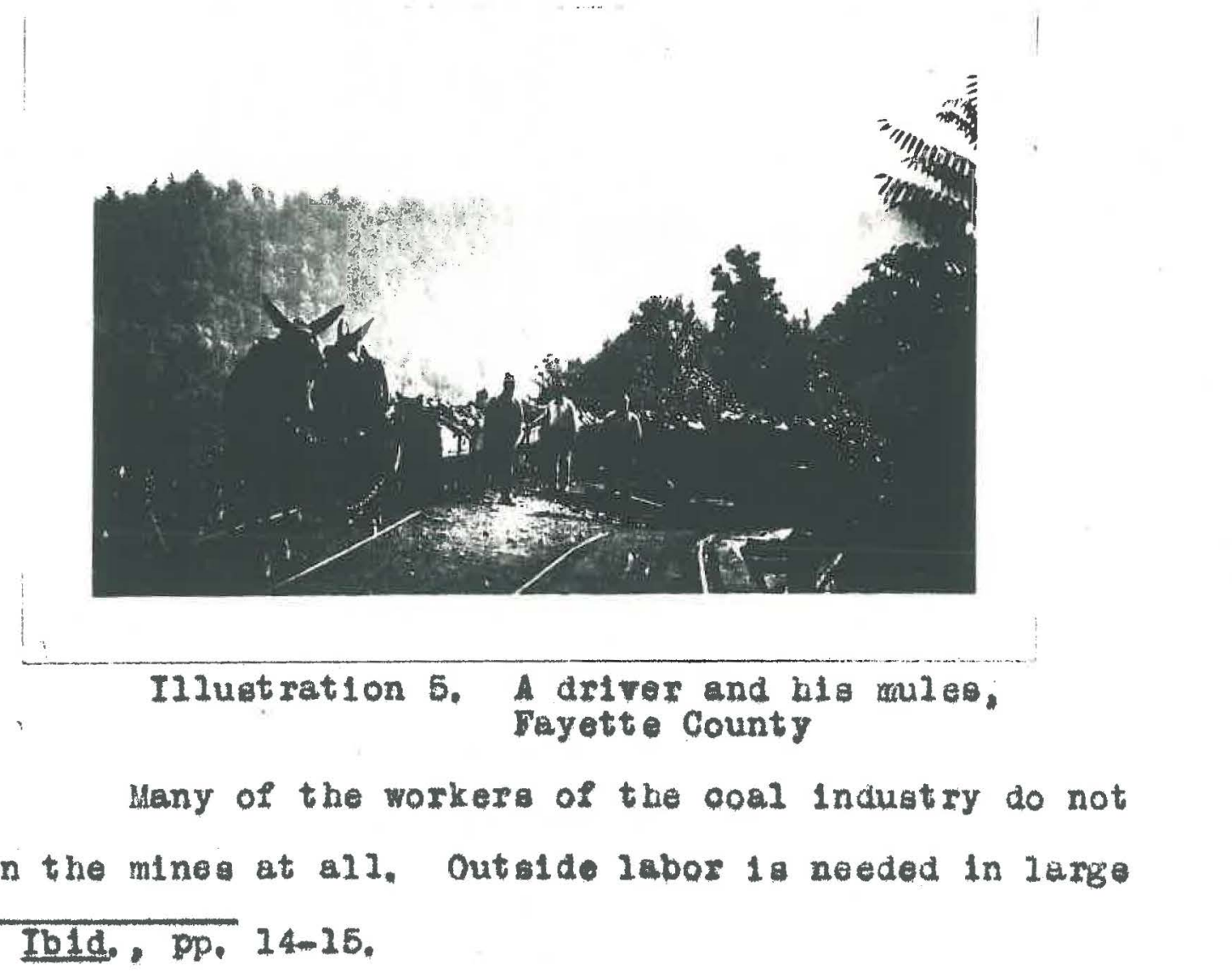


number for the loading of the ood into the rallroad cars and in maintaining the equipment. The nont numerous of these workers on the outside are known as tipple men. The operatione whloh a tipple man may do are many. He may push oara, dump ours, plok glate and objeationable coal from the rallroad cars as thoy are loaded, or do other task inoldent to the loading of the ooal. Other work $1 \mathrm{~s}$ almost selfexplanatory from the famfllar titles of blackemith, oar

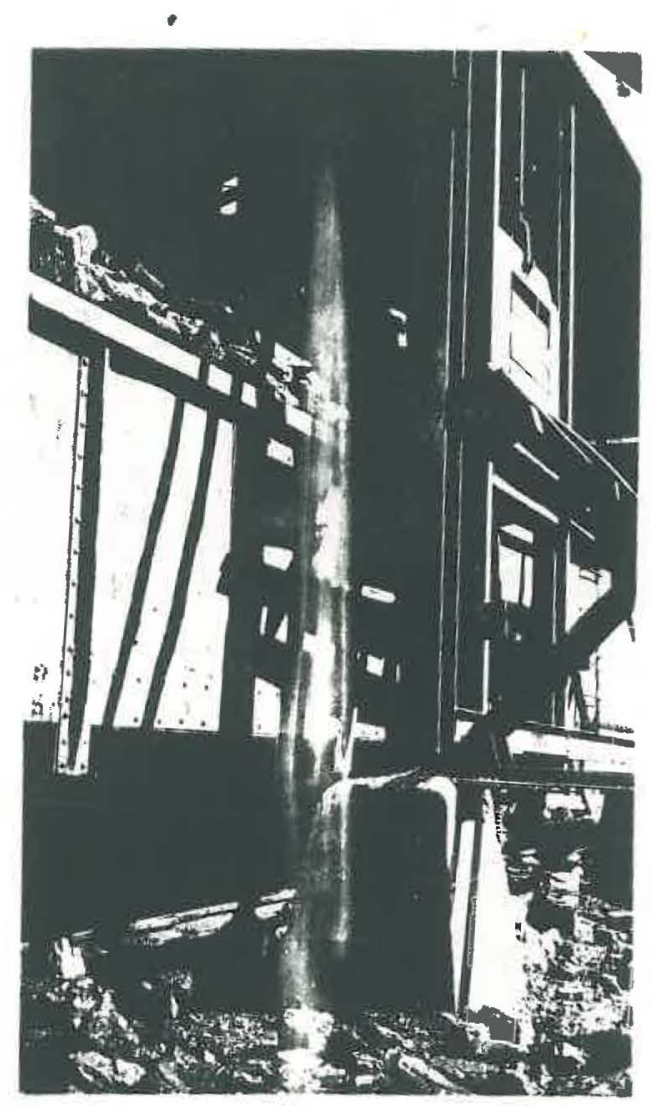

Illuatration 6. Negro mone ploker," a tipple man's position, Kanawha County.

repalrinen, stone mason, power-house worker, maohinist, engineer, truok driver, or "out lde labor." There latter positione are oomoniy known as "company jobs" and are pald 
monthly, weekly, or dally wagee rather than on a tonnage basis.

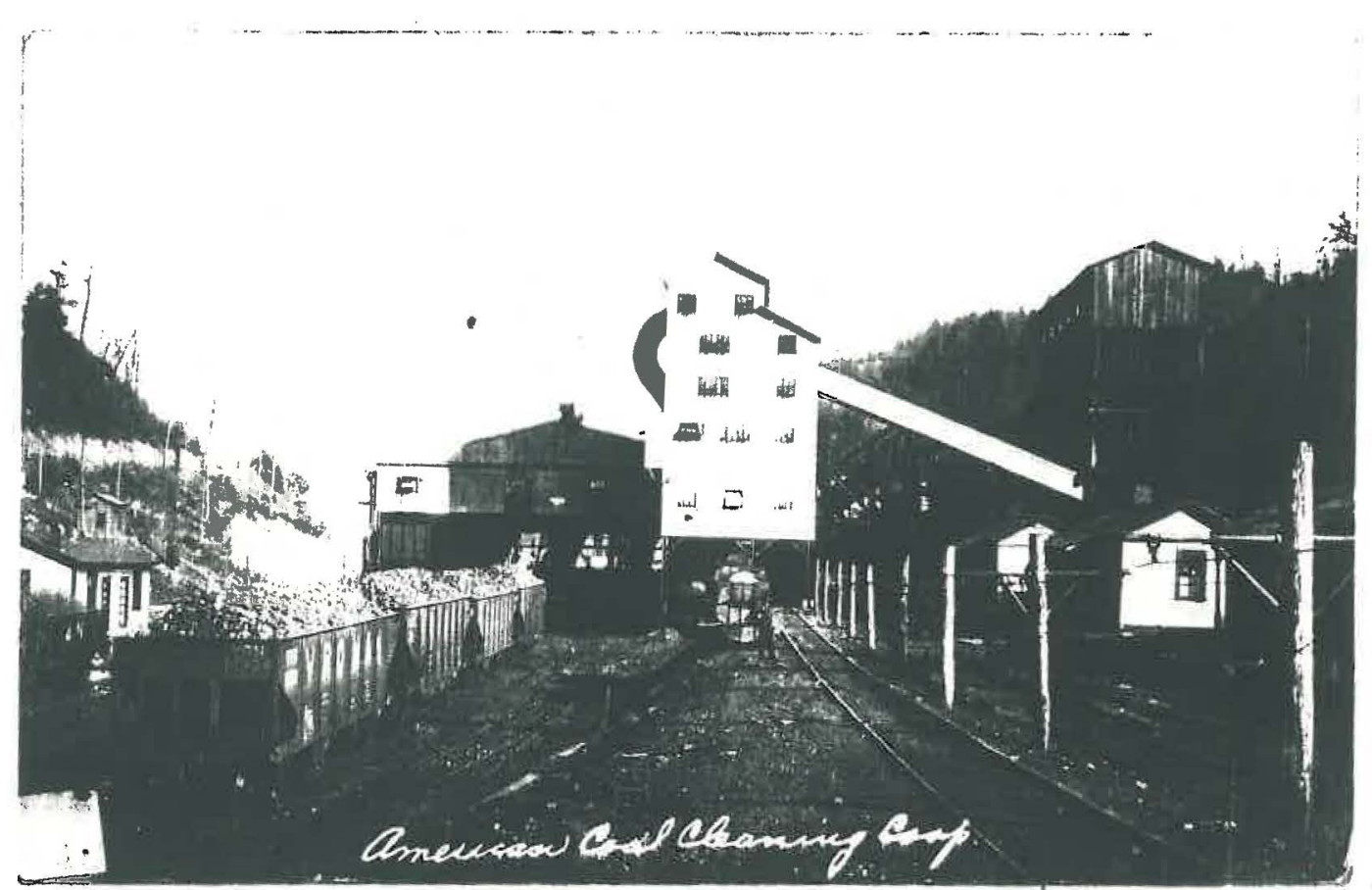

Ilustration 7. A tipple, Raleigh County.

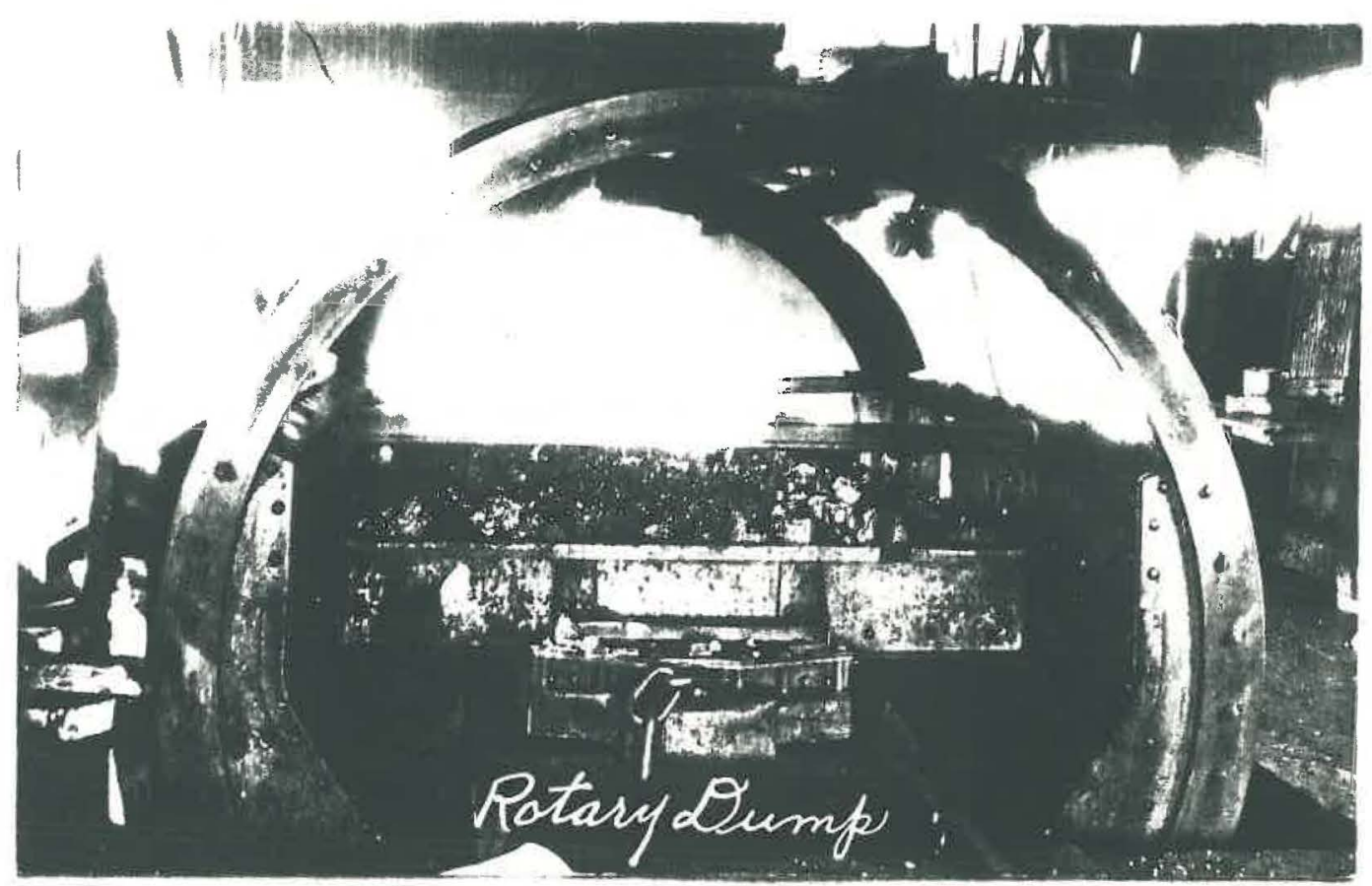

Illuetration 8. moohanical car-dumper, Raloigh County. 
II. THE NEGRO IN THE UINING OCOUPATIONS,-

At the present time apparently no Negroes are to be found employed in administrative or executive positions in the mining industry of West Virginia. Careful cheok was made at every operation not only to determine from both whites and Negroes the presenoe of a Negro in such a position at that wine but if anyone of either group knew of a Negro in suoh a position at any place in weat Virginia. Not only 1a this true today, but it was largely true in the putat. Evidenoe of one exception was found, however, in the pirst report of the Inspeotor of Mines. In 1883, "About three miles above Oharleston and on the north alde of the Kanawhe River, is now belng operated by w1lliam Morria (colored) the Black Hawk Mine. There are only four or five miners employed. 13 Evidently the 11 fe of this mine was an ophemeral one, for no record of tte exlstenos was to be found in the report for 1884 .

The highest of 1 ce attained by a Negro in conneotion with the mining industry at the present time is that of a former mine foreman in Raleigh County. He holds the offlce of sefety direotor with the Weat Virginia stute Department of Mines. The present bolder of the offloe is the second Negro ever to hold it. The first to hold the office Was a graduate of West Virginla State College and a former fire-boss in HoDowell County, The present sufety 13 State of W. Va., Annual Regort of the Inspeotor of Miner, $1883, \mathrm{p} .13$. 
direotor 18 not a collego man, but a praotioal miner who was able to work himself up to the poltion of mine foreman by hard study and passing the state examinations for offolenoy in oertain branohos. H1s partioular role in the department of mines is the instruotion of Negro miners in safety rules and first-aid measures. It is the boliof of the Chl of Mine Inapeotor that white men cannot teaoh Negroes

TABL 27. OCCUPATICAS OR 2,411 HQYROLS IN THI UIHIHO

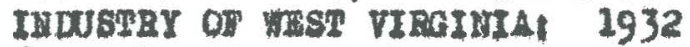

(Complled from anployers" schodules)

\begin{tabular}{|c|c|c|}
\hline Position & Wuraber & Por cont \\
\hline E0sse日: & 11 & .5 \\
\hline Assintent U1no Yoroman & 2 & .1 \\
\hline Stable bose & 5 & .2 \\
\hline Foreman, sate dump & $i$ & (a) \\
\hline Bose dritrex & 1 & (a) \\
\hline Job bown, Nogro rock gang & $i$ & (a) \\
\hline Di apaticher & 1 & (a) \\
\hline Inolde Labort & 2.322 & 96.3 \\
\hline Conl Losders: & 1,625 & 75.7 \\
\hline Uwoh1 nt man & 56 & 2.3 \\
\hline Irackenn & 132 & 5.5 \\
\hline Wotorman & 117 & 4.9 \\
\hline Brakenan & 164 & 6.8 \\
\hline Driver & 25 & .6 \\
\hline Contractor & 8 & $\cdot 3$ \\
\hline Trapper & 3 & .3 \\
\hline Brettice and & 1 & (a) \\
\hline Timber max & 1 & (4) \\
\hline Gutiul de Labori & 78 & 3.2 \\
\hline Ipple man & 38 & 1.6 \\
\hline out if de lebor & 8 & .3 \\
\hline Lachlnt at & 8 & .3 \\
\hline Blacknous th & 2 & .1 \\
\hline Banginesy & 2 & .1 \\
\hline Car ropal zman & 1 & (a) \\
\hline Power house work & 17 & .7 \\
\hline Stone mason & $i$ & (a) \\
\hline Truek dri ver & 1 & (a) \\
\hline Total: & 2,411 & 100.0 \\
\hline
\end{tabular}

(a) Loen than .1 per cent. 
a.s well as one of thelr own group.

When tho writer interviewed this safety direotor he was teaching at one of the otate 0o1leges durlng the summer session. The theory of his doing so was that he should teaon eafety eduoation to the teachers in the summer seselon, they would impart the Inforwation to the ohlidren, and the miners would get 1 t 25

from the ohildren. So far as la known, he 1 a the only Negro safety dirootor in the world.

There are few Negro bosseq of one kind or another among the more than 9,000 Negroes conoerning whom data were obtained, The number, howerex, le almoet negl1gible. The writer was able to find only eleven ceses of Negroed in positione whioh, oven by the most liberal stretchof the term, could be called positione of authority (seo Table 27). Interriews w1th thelr employere Indioated that they were in authority orer men of thelr own group almost exolusively. The one exception was the dispatoher in Logan County who had autbority over white motormen. The higheat position of those 11ated In Table 27 in perhape that of assigtant mine loreman, one of whom was over a Negro aeotion of a mine in Peyette County and the other in Logan County. It w11 be seen that stable bose 1 s the most frequently held position of authority oocupled by Hegroes. Whether or not some of the other positions listed a rould

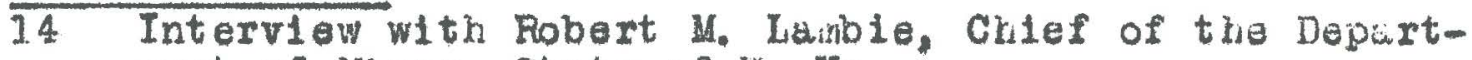
ment of Minos. State of $W$. Va.

15 Interviow with $\mathrm{Nr}$. John Patterson, Safoty Direotor, Dept. of Mines, at Bluefield State Teachers College, Bluefleld, Va. 


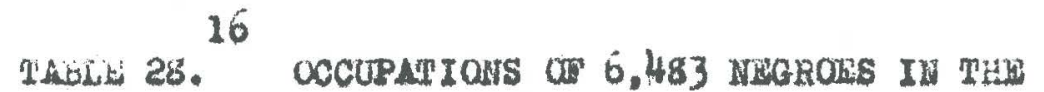

UINIWG INUSTHY COP WUST VIBGINA: 1922

\begin{tabular}{|c|c|c|}
\hline Pooltion & Humber & Per cent \\
\hline Miners (loaders) & 2,876 & 44.36 \\
\hline Out al de and indide company wan & 3.376 & 52.07 \\
\hline Motormen & 182 & 2.82 \\
\hline skd lled mochente. & 36 & .56 \\
\hline Foremen and other besesen & 7 & .20 \\
\hline officers and welfare worker: & 6 & .09 \\
\hline Totals: & 6,483 & 100.00 \\
\hline
\end{tabular}

$+$

be considered as postlions of authorty is open to question. Howevar, it is algnifloent that these were mentloned by employers when asked what positions of authority a Negro held in his mine. For that reason the writer prefers to 11st them as ach. The Negro seeme to have the best ohanoe

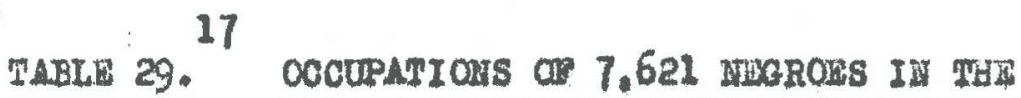
MINIMG INDUSTRY OF MHST VIFGIMIA 1927

\begin{tabular}{|c|c|c|}
\hline Position & Hurnber & Per cent \\
\hline Day 1aborer: & 2.233 & 29.30 \\
\hline Coal I oader & 4,674 & 61.33 \\
\hline Driver. & 125 & 1.64 \\
\hline Braksemen & 34 & .45 \\
\hline Treppere & 10 & .13 \\
\hline Notormen & 321 & 4.21 \\
\hline Mach1 ne operators & 215 & 2.82 \\
\hline Carpenter & 8 & .11 \\
\hline Fi re bose & 1 & .01 \\
\hline Total: & 7.621 & 100.00 \\
\hline
\end{tabular}

16 Conplled frow Bureciu of Negro Velfare and Statistioe, Report for 19a1-22, p. 58 .

17 Complled from Bureau of Negro Vielfare and statlation, Report for 1927-38, \%. 16. 
of promotion to boas poaftions where be is employad in the largent proportion. Stnoe the fleld work was done in thowe count les having the largeat Negro mining population our Ilguro ghould how a combat larger proportion of Negroes In positione of authority than for the atate as a whole. There is wome evideno that in some flelda there have alwayg been Negroes in positfons of authority. However, 1t would seem that these positions were more sporadio than usual. A Negro priter, commenting on the Negrols part in the development of MoDowe2l County ntmes few Negro 18

poremen. She saya:

Several of the leading operations, during these first years, employed Negro foremen. Amor then the Crozer Company who employed John Henry Taylor in 1888 and he remalned there for more than 13 years. The Houst on Company at Elkhorn whose first yard bos was 2 . Howard harper who served from 1888 to 1897. Hon. O. C. Froe, now Justice of the Peace of Adkin distriot, and James Mooranan, yet Itving at houston, have also served in the saine oapeoity. With the Lymohburg Company at $K_{y}$ le was James Dlokerson. As foremen, these men were honust, capable, effictent and served well. However, in lat years many or all of these places were rilled by native whit men or forelgners.

It slould be pointed out here that Mrs. Carrison, due to spae limitations, perhapo, nanes only foremen. Thut there were other Negroes ocqupying lesser postlone in the period wie disoussea, there is ample evidence.

of the fifty-seven euployers of more than 8,000 Negroes, only ten had Negroes in positions whilo they

18 Garrison, Mra. M. T., Waloh (W. Va.) Dally Hava, Sept. 21, 1936, Hiatorioal seotion, p. I. 
oongldered positions of authority. Eight more had no Negroes in positions of authority at the preaent time but had employed one each in suoh a position in the pest. Those onumerated by these enployera were two unine foremen, ono assibtant me foreman, two alate forearen, one flre bou, one shift boss over colored men, and one driving boss. The other thirty-nine exployers repliud that they lad no Nergroes in authority at the time of the interviow nor in the past. These flgures aeam to be eupported by aurveys conduoted by the Bureau of Negro Welfare and statistiog in 1932 and 1927. (see fables 28 and 29 ). Out of 6,483 Negroes employed in 1922 only ceven foremen and other boses were 11sted, The greater number shown by the present atudy is probably due to the fact that the sample here 18 more than 9,000 . In 1937, only one 11ro bos was 11 sted out of 7,631 einployed. In thls oonneotion, 21ttie basis was found, therefore, for the optintatio atatement of Qreene and Woodson that "In West V1Iginia, where the largeat number of Negro coal miners toll, a survoy of Negro workers in 1925 reported Negroes as holding positions whloh require skill and trainlng. Negro formen, bosses and Inspeotors, were beooming common, and few occupattons were olosed to the race. Negroes were also fllling all poelt lone from tripper to manager and as such were considered an important aseot to the coal industry, " 18 These authore give as their authority for the statement above a summary of the 1933-24 Report of the 19 The Nexre Wage Eernor, pp, 263-364. 
Bureau of Negro Welfare and Stat1at10s whloh was found in the United State Bureau of Labor Stat1etios' Monthly Labor 20

Revlew, and the roport above, The statement in the summary was a follows Hegro foremen, bosses, and inspeotors are beooming wore common, and few occupations are closed to aI

the race." By the omisalon of the one word, "more," Greene and Woodson glve a moaning not contalned in the summary whioh they afte. To eay that Megro bossea are becoming "more comon" is a mere relative gatevent, not necessar1ly connoting large numbers, To say, however, merely that Negro foremen "wore beooming ooimon" 1a cortalniy to indioat that such poeltion were held by Negroes more frequently than seems to be in consonano. with the facts. The pasage of the Bureau report whioh is olted as the further basis for their statement was as follows: The thousands of Negro miners and laborers, bundred of sk11led workmen and soores flling positions of reaponsibility in the oos industry are dally demonstrating their fitnos for any position in the coal Industry from trapper to manager, and the operators are realizing more and more that the negro is a valuable asset in the production of coal." "While it can readily be seen how the authore mentioned may have understood this statement to mean that Hegroes were actually fllline these positions, it lo probable that it was werely an expression of optnion ooncernins potential ab111ties by 30 Vol. 21, Mugust 1935. 21 Ib1a.. p. 21.

22 Bureau of Negro Welfare and Statiatica, Roport for $1923-34,0.37$. 
the Director of the Bureau rather than atatement of faot conoerning positions held by the Negro. 23

As a further oheok on the replies of employers to the question of Negroes in positions of suthority the miners intervlewed were also asked what the highest position they had heard of a Negro ocoupylng in the minlng fields was. Only one gave a position bigher than mine foreman and this exoeption was that of an assistant aperintendent in IIIIno1s. It is interesting to note that the langest number of Negroes gave the position of machine man in answer to this question, One even guve "loader" as hls enswer.

It is true that the Negro is opoupying position which require skill and training. Dr. Carpenter to somewhat in error. I think, when he olassifles coal mining as an ungk1lled industry, The Iino botween unskilled and akillod work is, of course, somewhat hard to draw, there are, however, oertaln jobs in poal mining performed by Negroes whioh require a great deal of akill, moh more, in faot, than wome whioh Dr. Carpenter olasalfles as "pushing up" or "vaouum" ocoupations. For instange, Negro f1re boss muat have muoh more teohnloal knowledge than a filling atation man, whioh oooupation Dr. Carpenter oonsiders in h1o ak1lied group. The positione of moohine operator, motorman, maohlnist, brattioe man, drum runner, f1re bosa, 33 It is Imposeible to verify just what the Direotor meant by this passage as he took his own Iffe a few month prior to this writing.

24 Carpenter, Niles, in Johnson, ope oft., p, 385. 25 Tb1d. P. 386. 
and other occupations in the mining induatry require suffioient akill to be olassifled in the skilled group.

The greatest number of Negro employees are to be found in underground ocoupations, of in "Inside labor." of the 2,410 Negroes conoerning whioh detalled employment informution was obtained 96,34 per oont were employed in these ocoupations, of these the most numerous oogupation was, of course, that of ooal loader. Coal loaders oonstituted 75.73 per cent of thl the Yegroes in tha group. It w121 be notioed that the eurveys by the Bureau of Negro Velfare and statistios show constantiy.inoreasing proportion of Negro coal loaders sino 19a3. In that year the survey shows that only 44,36 per oent were loadera, while in 1927 a simlar survey ahowed 81,33 per oent in that posit10n, Our own Bample, taken just ten yeara after the first shows that Megroes are becoming coal loader in a leadily inoreasing proportion. The gain in the peroentage in this oocupation was 16,87 per oent from 1823 to 1927 and 14.40 per cont from 1927 to 1932 .

The term "ookl looder" has aupplanted another term much older in the Induatry. The man who loaded the coli was, before the era of mohine raining, known as a "ooal digger." Ingtead of having the ooal underout by a maotilne the winer had to "dig coal" by Iying down and undaroutting the ooal a far wo he ould reach with his piok. The Negroes were very competent in this type of winlng and 28 See Table 38. 27 See Table 39. 
the coming of the moohlne caused some displacement of them. The firet mining malithe wa sald to have been used in Ohlo In 1877 and to have oome into general use about 1880. Weat VIrglaia has shown more than average progreas in 31 moline wining but the maohinas do not seern to have been in very genoral use unt 11 the years just prtor to 1900 . In 32 1897 only 16 out of 315 mines were using machlnes, These mines employed 652 of the $32,423 \mathrm{miners}$ in the state and mined 5.13 per oent of tho coal produoed in that year. By 1904, however, 248 minea using 988 maohines produoed 34 30.80 per oent of the ooul of the state. In 293 there were only 8,248 plok miners in the state whlle there were 45,551 wachine miners or doal loaders. Only $12,330,434$ tons of oodl were produoed by plok minlng, whlle 88,877,986 tons were produeed by maohine mining. only one employer wa Interviewed who mined coal oxolusively by piok mining. It is algniflcant that this mployer had more Negro plok miners than his native whites and forelgn miners combined. As a rule, however, piok mining is done only in those parte of a mino where it is not profitable to mine with maokines, due to looation.

The coming of the maohine, however, has allowed

38 Johnson, $0 p_{1}$ oit, p. 49.

29 Roohester, 20, oft, p. 108.

30 Shurlok, ope olt. p. 127.

31 Rochester, ope c1t. p. 108.

$32 \mathrm{~W} . \mathrm{Va}$, Dept, of Mlnes, Annual Report, 1897,

33 W. Va, Dept, of Mines, Annual Report, 1903, p. 3.

34 V. Va. Dept, of Mines, Annual Report, 1904, p. 2.

35 W. Va. Dept, of Mines, Annuel Report, 1931,

pp. 109-1io. 
the mine to assimilate men unstilled in mining anoli more gasily than in the days of piok mining but with increaging danger to thomselves. Saya the Chief of the Departinent of Hines in 1904 :

The changing conditiona at the mines within the pust deoade have materially revolutionized the oharaoter of labor encloyed. This condition has been brount abolit by reason of the introduction of maohinery to oupplant the work formerly done by manual labor and animala.

Tre t 1 me wa when minero had to serve an acprent 1oeship before bef ne vermitted to assume the reapons1bilities of a miner, but these condltions do not now exiat, and inexperienoed men are enployed who lodd ufter michines and who know pract 1cally nothing about the dangers within a wine and as a consequenoe they are unable to exercise the care essential to thelr own bafety, This $1 \mathrm{~s}$ an acknowledged atatus of labor and any safeguard that may deorease the list of fataltt1es will have to be made to operate through those heving Immediat supervision of the employee.

Thus, the Negro farmers from Virginia and the south were easily plaoed in the oos Industry, but ware also subjected to oonelderable danger due to thelr laok of experienos.

The next most numerous positions held by Negroes are those connepted with haulage. Our sample revealed 164 brakemen and 217 motormen, 6,80 and 4,85 per cent respeotively. There seems to be an apparent inorease in the numbers of Negroes in these positions in the last ten years. In the 192 arvey only 3,83 per pent of the Negroes were employed as motormen. 37

36 W. Va. Dept. of Mines, Annual Report, 1904, pp. 1-2. 37 Sec Table 28. 
Increased to 4,22 .

Elo Ilgures on the peroentage of brakemen are glven in the 1933 ourvey but the 1937 1 1gures slow a very omall pereentage, 45 per oent, of brakemen. ${ }^{39} \mathrm{Thua}$, the Nagro seoms to have hold his own in the position of motorman in the last ton years and made very rapid gains in the position of brakeman. In both theae positions the Negro seems to be f1rmly established, eapeolelly in the latter, No oomparativ Itgures are avaliable on the Negro as a traok man. That this position, horever, is held by a conalderable number of Hegroes lo evidanoed by the fact that 182 or 3.82 per aent of the gample were engaged in this ocoupation. The present study skowed aubstantially the same peroentage of Negroes employed as mackine nen as the Bureau survey of 1937. Ho 11gures were given in the 1933 survey. The 1937 survey ghowed 2,83 per cent holding this position whlle our study showed 3.33 or a dearease of one half per oent. The smaller percentage of drivers ahown by our oample to probably due to the increased mechenization of the rainea, The 1927 survey showed 1.64 per cent employed as drivere, while the present study found only .62 per cent. No comparative figuree are to be found on the number of Neero trappers, brattioe men, tirber men, and oontrcotors as these positions are grouped under more general hevdings. The positions "on the outulde" are of minor 1mportance so far a the Nergo is oonosrned. Althougth no oomparative figures can be obtained from the Bureau's surveys, 38 See Table 39. 39 See Table 29. 
wlich are muoh lese detalled than our own, it is afe to say that the Negro has never been employed in the outside positione to the extent to whith he he been inside. Only seventy-oight Negroes in the amplo, or 3.34 fer oent were engaged in these positions. Thirty-eight tipple men, mosti oar dumper and "bone plokers" (day men enguged in throwing out objectlonuble pleces of coal from the louded rallroad cars), were found. These wer the only Negroes in any outside position accounting for as many on per cent of the Nes ro minine group, t1pple men oonetituting 1.58 per cent. Tuble a7 show perkaps a dieproportionately large number engaged in powar house work. Most of these Negroes were located at one large operation in MoDowell County. A oom paratively amall number of oompanies maintain their own power houses at the preaent time. Moet of then have abandoned their power houser inoe the introduotion of falriy cheap eleotrio1ty by the power ompanies, Although the outside positions are nut numerioaliy 1 mportant a number of them are more luorative than some of the inside positions. Machinists, blackemiths, engineers, and stone meons are pald somparatively high salaries.

In summary, it may be sald that the Negro in the minlng industry in West Virginia, as 18 the case in many other 1ndustries, is engaged in largest numbers in those positions requiring the greatest amount of physical endurance and the least of ak111. However, he has broken the desdlines sot up by the introduotion of machinery and is 
found holding posttions whloh require both ok111 and training in every field in whiob he is omployed in lisfigo numbers. He is also to be found, to a very mall extent, in positions of sowe authority, although no instanoe was lound of a Negro's occupying a position higher than for forman at the present time, unlees one were to inalude the one mine foreman who has been given position with the State Dopartment of Mines.

III. JOB DISTRIBUTION AMONG MATIVE WHITES, FOREIGNERS, AND NEGROES, -

Are there any stereotyped ocoupations which have 40 been stamped a "Negro jobs" by the mining oulture? This question may be answered oategoriosily in the negative. Members of all raolal and national group will be found in every occupation in the mining flelds below the rank of superintendent. While there are no jobs whioh may be termed "forelgn jobs" or "Negro jobs," there is some difference in the distribution of oertain positions among the varlous raclal and national groups in the industry. This differenoe may bo due to the preference of the partloular group, or it may be due to laok of opportunity because of the operation of traditional factors. The effect of the corpetition of the foreign born has brought about a type of epooialization on the part of the native white workere. For inatinoe sometaing of the same altuation whiob the 40 Cf. Young, D., ge, c1t. , p. 131 , 41 Of. Luinley, F. E., OR. elt, p. 160. 
Unlted States Immigration Commisalon found over twenty yeara ago peralate today. In this regard the Commlssion reported: 43

This tendenoy is best 1llustrated by the distribution of einployees according to race in the bituminous 0001 industry. In this industry all the so-called "oompany" oooupations, whloh are paid on the basie of a dally, woekly, or monthly rate, are ocoupled by native Amerloans or older immigrants and thelr ollldren, whlle the southern Europeans are confined to plok mining and to the unskilled and cómmon labor.

While euch a deadine may have extated at the time of the Coimlsalon's raport it certainiy has been broken both by the Negro and the foreign-born. It is quite true thit the foralgn-born are found less frequently than el ther native whites or Negroes in the so-oalled "company work" jobs. However, thif fact is not due so much to the firm retrenohment of the native whites in suob jobs a to the preferenoe of the forelgn-born worker himself. Compeny joba, as hat been indicated, have a etriotly time wage. That fact means that long hours and exoptlonally hard work w11l not increase the remuneration of these jobe beyond the maximum as set by the working time of the mine. On the other hand, the coal loader is pald elther by the ton of poal loaded or by the oar. The forelgner may, by working long houra, earn very high wages as a ooal loader. Consequently, 87.68 per cent of the forelgn-born in the twenty operations from

42 U. S. Immigration Commisalon, Abstract of Report on Immigrants in Manufaoturing and Mining, 1911, p. 338.

43 See Ohapter VI. 
whioh data were gathered were coal loaders. This peroentage is higher than for elther Negroes or native whites. The foreigners, many of whom have relatives whom they want to bring over to America or who need the oupport of the miner

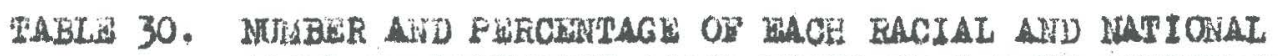
GROUF IN DIVTHEHT OCCUPATIOHS IAI THLHTY OFHRATIOHS IN IIV WIST VECINIA COUNTIMS: 1932

\begin{tabular}{|c|c|c|c|c|c|c|c|c|}
\hline \multirow{2}{*}{ Occupation } & \multicolumn{4}{|c|}{ Native dide Forelga-born } & \multicolumn{2}{|c|}{ Nagroes } & \multicolumn{2}{|c|}{ Totalo } \\
\hline & Number & $\begin{array}{l}\text { Per } \\
\text { cent }\end{array}$ & Guaruber & $\begin{array}{l}\text { Per } \\
\text { gent }\end{array}$ & Nuraber & $\begin{array}{l}\text { Pex } \\
\text { cent }\end{array}$ & Numuber & $\begin{array}{l}\text { Per } \\
\text { cent }\end{array}$ \\
\hline $\begin{array}{l}\text { Coel loader: } \\
\text { Mach1 no men } \\
\text { Hotorinen } \\
\text { Brakenan } \\
\text { Track nion } \\
\text { Thpple men } \\
\text { Other occupat1 on }\end{array}$ & $\begin{array}{r}1,329 \\
172 \\
199 \\
169 \\
177 \\
293 \\
224\end{array}$ & $\begin{array}{r}52.77 \\
6.58 \\
7.62 \\
6.47 \\
6.77 \\
11.21 \\
8.58\end{array}$ & $\begin{array}{r}626 \\
18 \\
16 \\
7 \\
36 \\
6 \\
5\end{array}$ & $\begin{array}{r}87.68 \\
2.52 \\
8.24 \\
.98 \\
5.04 \\
.84 \\
.70\end{array}$ & $\begin{array}{r}1,410 \\
36 \\
85 \\
128 \\
109 \\
24 \\
43\end{array}$ & $\begin{array}{l}76.84 \\
1.96 \\
4.63 \\
6.98 \\
5.9^{4} \\
1.31 \\
2.34\end{array}$ & $\begin{array}{r}3.415 \\
226 \\
300 \\
304 \\
3 ? 2 \\
323 \\
272\end{array}$ & $\begin{array}{l}66.16 \\
4.38 \\
5.81 \\
5.89 \\
6.24 \\
6.25 \\
5.27\end{array}$ \\
\hline Total. & 2,613 & 200.00 & 714 & 100.00 & 1,835 & 100.00 & 5,162 & 100.00 \\
\hline
\end{tabular}

\section{4}

are espoolally anxious to make bigh wages, When times are dull be 1o 11kely to be the flrat to leavo the mining fleldo. He 1s, therefore, 11ttio interested in the company jobe. There are a fow (see Table 30) in the most remunerative positions of maohine man, motorman, and traok ran, but the number in other position are negligible.

The tendency of the native whites to go into the oompany jobs is at once notlceable in their relutively amall number of coal louders -- only 52.77 per oent. With the exception of the position of brakeman, in whioh a larger number of Negroes are to be found in the southern oount 1es. 44 Interview with many employere. 
there 1s a higher percentage of native whites in all tho company Jobe, Sinoe the native whites are also in the majority in numbers most of these positions are likely to be held by them, However, the general distribution, a ahown in Table 30 may be quito different from the distribution in different mines. The postion of tipple raan is alnost exoluaively held by native whites. This position is less dangerous than oertain of the other jobs and is also considered as lighter work. The much larger peroentage of native whites in the unolassifled ocoupations indicates the1r further preemption of the company jobs.

The job distribution of the Negroes reserables that of the forelgn-born more than that of the native wiltes. With the exception of the position of manine man, whioh is paid on a tonnage basis in some mines, there is a larger proportion of this group in the company jobs than of the foreign-born. A larger percentage of the Hegro group 1 a esployed as coal loaders than of the native whites, but not such a large proportion as the forelgn-born, for the ressons givon. In the partioular mines studied they held a larger number of the positions as brakemen in proportion to their numbers than did the native whites, There are a few Negro tipple men, some of them bolng old minere who mat be given an easier job than ooal loading after having served the oonpanies for a number of yeara. The larger percentage of Negroes than forelgners in the unolasaifled group indicates their wider distribution in the jobs of the industry. Many 
Nezroes do not relish the competition of the forelgn-born and have been glad to enter some of the company jobs to esospe 1t. However, the freat majority, like the forelgner, reviain coal loaders, which position has other advantages, enjoyed by the Negro, to be disoused later. The trends of the racial diatribution of position is shown rather olearly by tie fact that the native whites how a smaller percentage In the job of coal loader and a larger percentage in the company job than the average of all workers in these jobs, The Negro, on the other. hand, shows a higher peroentage of h1s group ongaged in cosl loading than the average of all workers in this position and a percentage lower than the average of all workere in all company positions, except in the case of brakemen, Here the arerage of all groups 18 5.89 per cent, and 6.88 per oent of the Negroes were omployed as brakemen.

We have sald very iltile thus far about the relan \$17e mumbers of native whiten, Negroes, and foreignera in the different oocupationa. The reason for this fact is that the average of different mines would tell little of the actual aituation in the 1102 . If there were any unanimity of company polioy in tili regard auch figures would be meaningful, but such is not the case. Adjacent minee may tell a much different story as to the raolel distribution of jobs. A great deal depends upon the attitude of the particular operator towards any one of the three 
groups engeged in mining. Some mino are known as Negro 43

mine" and thelr operatore as Megro men, Other mines are known as white mines. ${ }^{47}$ The obaraoterization comes, as a rule, frow the faot of whether Nogroes are in a major1ty or conatitute a very small minority of the employees at: the partioular mine. No mine was found in whioh the forelgnborn were the most numerous group, although some were found in whioh thelr numbers exceeded those of the Negroes. mines studled employed some native whites and only one operator was encountered who employed no Negroes, wille one employed no forelgners. $49 \%$

Lttle oorrelation between the numbers of Negroes and their presence in certain positione is evident. For instance, Mine A and Mine 0 are looated not a dozen miler from each other. In both the Negroen are the largest aingle Eroup. In one the Negroes have 10 of the 13 positiona as machine wen, but in the other they hold only 4 of the 24 maoline men positione. In the seoond mine, however, was the Negro mine foreman who, as was atatod elsewbore, has now a better position witil the State Department of Mines. Any exposition of general trende eeeme impossible. One generallzation, however, way be madel that the Negroes seem to hold the better jobs in those operations where they form the large peroentage of the mining group. It 1 , in eat, 45 See Obapter VI for an extended treatment of these att itudes.

40 See Mine $A$, Table 31 , for an example.

47 See Mine B, Table 31.

48 See Mlne E, Tabl 31.

49 See Mine D, Table 31. 
TABLI 31. DISTRIBOHION ON JOBS BY EACS AND HATIOHALTY IU IIV WEST VIRGIUIA EINES: 1932

\begin{tabular}{|c|c|c|c|c|}
\hline Position and wo & $\begin{array}{l}\text { metre } \\
\text { Dites }\end{array}$ & $\begin{array}{c}\text { Forolen- } \\
\text { born }\end{array}$ & Wegroes & Motal \\
\hline $\begin{array}{l}\text { II A, Ralel gh County: } \\
\text { Coal loader } \\
\text { Hachl no mon } \\
\text { Track mon } \\
\text { Lotormen } \\
\text { Erakemon } \\
\text { Tipple man }\end{array}$ & $\begin{array}{r}30 \\
2 \\
18 \\
6 \\
3 \\
13 \\
\end{array}$ & $\begin{array}{l}21 \\
1 \\
1\end{array}$ & $\begin{array}{r}88 \\
10 \\
9 \\
8 \\
11 \\
2 \\
\end{array}$ & $\begin{array}{r}139 \\
12 \\
28 \\
14 \\
14 \\
16 \\
\end{array}$ \\
\hline Total & 72 & 23 & 128 & 223 \\
\hline 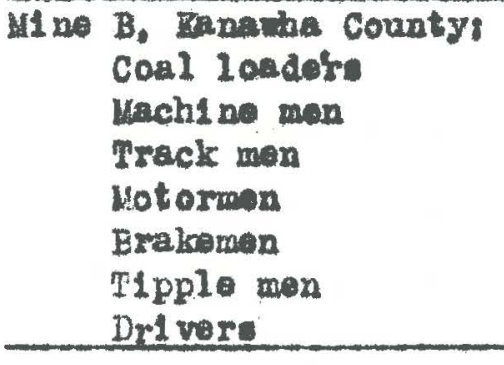 & $\begin{array}{r}145 \\
12 \\
8 \\
2 \\
2 \\
22 \\
17 \\
\end{array}$ & 15 & 20 & $\begin{array}{r}180 \\
12 \\
8 \\
2 \\
2 \\
22 \\
21 \\
\end{array}$ \\
\hline Total: & 208 & 15 & 21 & 247 \\
\hline 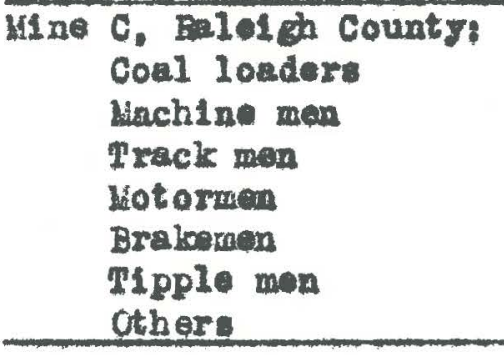 & $\begin{array}{r}160 \\
10 \\
48 \\
24 \\
24 \\
20 \\
7\end{array}$ & $\begin{array}{c}40 \\
4 \\
2\end{array}$ & $\begin{array}{r}200 \\
4 \\
48 \\
24 \\
24 \\
10 \\
8 \\
\end{array}$ & $\begin{array}{r}400 \\
14 \\
100 \\
50 \\
48 \\
30 \\
16 \\
\end{array}$ \\
\hline rotale & 293 & 47 & 318 & 658 \\
\hline 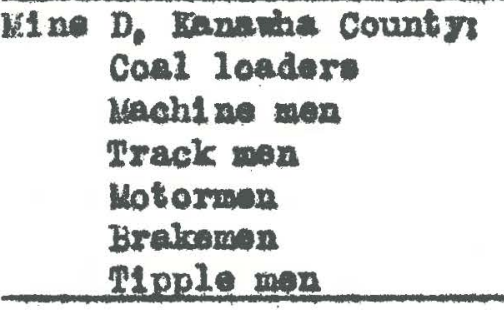 & $\begin{array}{r}135 \\
8 \\
10 \\
8 \\
8 \\
7 \\
\end{array}$ & & $\begin{array}{r}22 \\
2 \\
2\end{array}$ & $\begin{array}{r}157 \\
10 \\
12 \\
8 \\
8 \\
7 \\
\end{array}$ \\
\hline Totals & 176 & & 26 & 202 \\
\hline $\begin{array}{l}\text { Lilue Logan county: } \\
\text { coal loadere } \\
\text { wachlno men } \\
\text { Inside day men } \\
\text { Outalde day men }\end{array}$ & $\begin{array}{r}107 \\
17 \\
90 \\
59 \\
\end{array}$ & $\begin{array}{c}96 \\
5\end{array}$ & $\begin{array}{r}54 \\
1 \\
13\end{array}$ & $\begin{array}{r}257 \\
18 \\
108 \\
59 \\
\end{array}$ \\
\hline Totale & 273 & 201 & 68 & 442 \\
\hline
\end{tabular}


very diffioult for employere who employ only a few Negroes to keep them. Such exployers, if they have Negroen at all, are likely to have a $\mathrm{hgh}$ Negro labor turnover. 50

So far muoh has been sald of employer attitude in determining the jobs whtob Negrose hold in any partioular mine. There 10 another faotor, althougb employer attitude has had muoh to do with its oreation, whioh operates upon employer polloy. Most of the mining towns of wast Virginia 51

are company-ownqd. In other words, the only people who Itve in them are engaged in the mining of coll for a speolf10 company. Theae mining towns, more or leas 1 solated from one another, booame oulture areas in minlature. That 19 , habits grew up in one town whloh might be quite different from those of other similar towns. These waye have every charaoterlatio of a folkway. While the employer was inatrumental in inttlating many of them the laboring group also had their share in this process. As time pasoed the effeots of those ways and polioles constituted a oumulative foroe whioh reaots upon worker and employer al1ke. Th1s oultural aggregate becomes atereotyped and ohanges at a muoh slower tempo than oompany management. It is not unoommon for the ownership and control of a mining communtty to ohange hande frequently. However, the now management finde that the folkways of this partloular mine do not bend readily in the

50 Interview with Mr. U. G. Thomas, Supt. of llidvale Coll1ery Company, who operates suoh aine.

51 See Chapter VIII dealing with some of the effeote of this faot.

52 Cf, Ogburn, W. F., Sootel Qhange, 1923, pase1m. 
direotion of change. Employers have told the writer of the diffioulties they have had in Introduolng Negro labor into oertain poitions which have never been ocoupled by Negroes in that partioular wine, The abence of Negroes in certin positions in oertain plaoes, then, is not to be axplained wholly in terms of company polioy or employer attitudo toward thom but in terms of this oultural faotor. Large companies, with more than on mine, somotimes employ Negroes at oertain jobe in "one wine and none at another because of this factor. Thus, the mining fleld does not represent an area in which the employwent of Negroes al ways coinoldoe with employer attitude. Company polloy, in this regard, frequent2y acoommodates itself to the prevalling oommunity ways.

IV. NEGFO ATTITUDE AS A FACTOR IN JOB DISTRIBUTION.-

Up to this point we have beon disoussing those external faotore whioh operate to force the vegro into oextain positions and away from others. He $1 \mathrm{~s}$ found, as is the oase with all other groups, most Irequently a a coll loader. This fact, of course, Ia true primarlly because there are more of these positions to be ill1ed. A furtier faotor in regard to the Negroes is that coal loading perhaps requires the least skill of any position and a much hard work, to which most of them are hab1tuated. There are, however, certain other faotora whioh influenoe the Negro to ohoose the polition of ooal loader in preferenoe to some of 
the othera.

\section{3}

In the flrot place, many of the Negroes did not oome to the ratning flelds with the 1 des of remaining permanently. As has perhaps been indloated beforo, their notion was not to rise in the mining industry as best they oould. They wanted to make money a rapldy as posalble and then return aback Eact. They are, then, primarily intereated In making money qulokly and ooal loading in more luorative than oertain other positione. One mployex in MoDowell County writes followe conoerning this tendenoy of the Negro to ohoose ool 10 ading in preferenoe to oompany work "You w111 not10e that I haven't as many oolored day laborera as white, and this is due to the faot that the Hegroes do not seok day laboz 11 ke the natire whites. They can make more money loading oogl then they oan worklng by the day." As has been hown before, many of the Negroes in the mining induetry oame from agrioultural pureults. Farmero generally, for in this trait Hegroes are not exoeptional. are individualistio. It is also the opinion of the writer that the common dielike of the Negro for aloae whita supervision in matters of work is porbaps a oulture trait having 1ts orlgin in the elare systom. Be that ag it may, the objeotion to working under aloes watohlng $1 \mathrm{~s}$ a very real thing with many Hegroes. The position of conl loider offere less guperviaion than any other position in the miner.

53 The material here 19 based upon 1 nterviews with ituny Negro minere.

54 Cf. Roohester, ope o1t. P. 105. 
The territory over which mining uperatione extend in any mine is likely to be considerable. Iine foremen oannot and do not vialt the roome in whloh the men work frequently. Some mines require that the placing of the explosive to "Bhoot" the ooal be Inspeoted before discharglng it, but even this safoty measure is not prosent in all mines. The loader provides his own tools and 11ght, buys bls own exploalve, and controle the tompo of his work to gult hingelf. He is pald by the number of tons ho sends to the tipple and the operator a rule cares little about the amount. The only guestion the operator may ralae ooncerns whether he "cleans out" his "place" vo that the coel outtera may get to the "face" and underout his ooel after he 2eaves. If he leaves his coel unloaded it is Imposatble for the maohine men to get their maohinas to the fao to prepare the coal for ahooting. However, if the miner deoldes to work a while and then to alternat bla work periods with perlode of rast no comment is forthooming from the operator. Not only way the coal loader set his own speed for doing his work, but he may stop before quitting time 55 and "oome out" early. One employer told of meting one of h1s Negro minera ooming out of the mine at two o'olook in the afternoon. The exployer apoke to him, asking hia why he did not etay in the mino longer and make more monoy. The following oonversation passed between them: 55 CF. IIIOn, ope oft. p. 48. 56 Told as neariy a posalble in the exaot language of this Raleigh County operator who told it to the writer. 


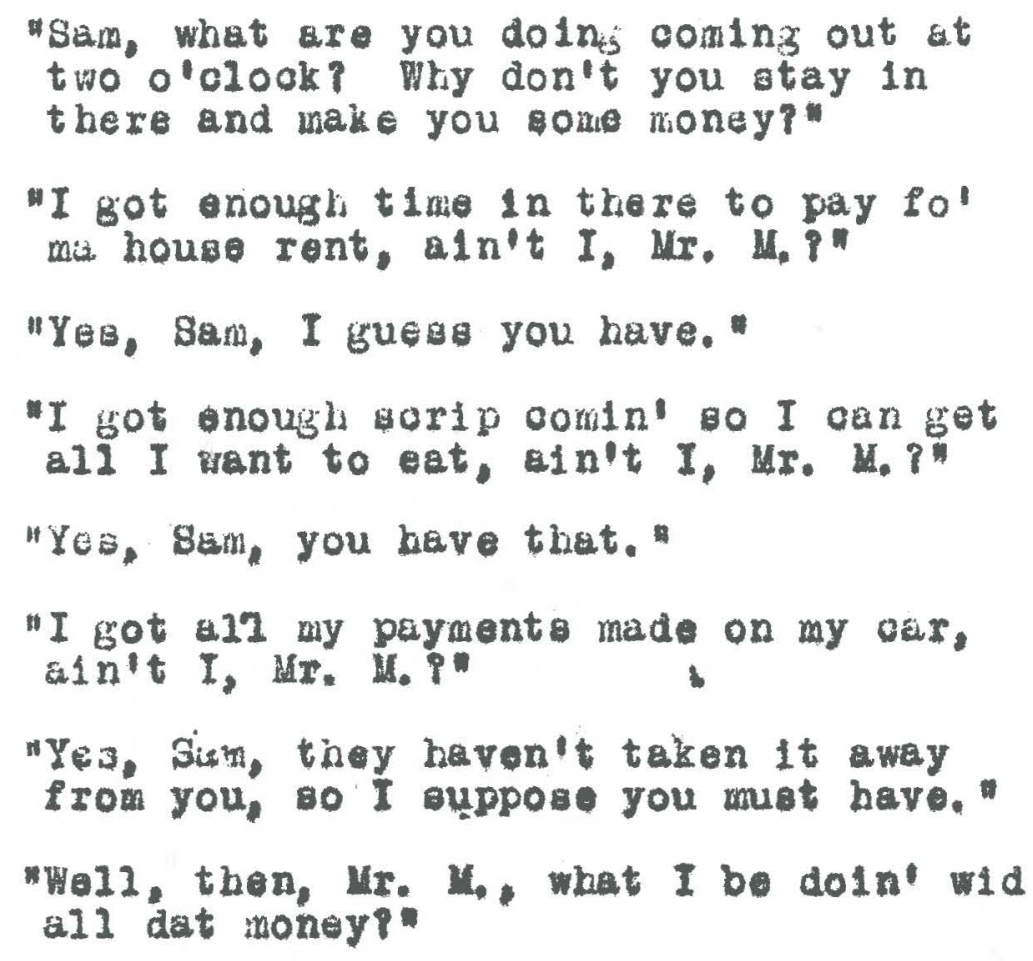

Whl 2e tbere 1s no intention here to give the inference that the. oonveraation 18 typloal of all Hegroes, nor that any "raolal" trait is revealed by 1t, thore are a good many who do not see the neosesity in ordinary times to work beyond that time necesary for the satiafeotion of thet immediate wants.

Another feature of oon loading is attrotive to the group just mentioned beoause of the faot that the loader may "lay off" or oease working for a day, a fow daya, or a week if he cares to do so. Employers do not olassify the Negro as the most rogular worker in tho mes. A Negro roisan whom the writer has known for many years told him of the struggle he had to get har husband to leave the oning 57 of, Banks, E. M., The Foonomios of Land Tenure in Georifia Columbia Univoralty Press, 1905, pp. 74-75. 
flelds becaus of thi feature of coal loading. He hesltated to move to the olty where regular work would be demanded of him in order to keep his posit Lon, Negro miners are quite frank in disouseing the attreotiveness of this peoullarity of coal loading.

These oharaoteriotion of the fob of coal loading allow the following of prevlougly established heblt perhaps more nearly than any of the other position in mining. The tempo of the Negro farmer is oat almost alwaye in part by hls own wishes, espeolaliy the Virginia farmer.

Katherine Coman has pointed out the situation in regard to tho strenuousness of white supervision in the south to whiloh the Negro has reacted. The same tendenoy to "lay off" and go to work is found on the farm as well as at the mine. The other positions in the mine would not allow thees privileges to the extent thet coal loading does. Motormen and brakemen must run regularly or they 2080 thelr orew righte. Hachine men trust do 11kewiso. The postions of brattioe man, timber man, tipole man, eto., are all subjeot to muoh more striot superviaton than that of ooal loading. This oultural factor has led Negroes to aay, There are higher jobs than loading In the inines, but loading is about the bost job of them al1."

58 See Russe1 1, J. S., Pural Economio Pros ress of the Negro in Virisinia, Journal of Negro History, Vol. XI, october 1926; al80 Park, R. E. Negro Home life and Standards of Livina, Annals, Vol. 49, 1913, pp. 147-163.

59 Coman, K., The Hegro ag a Pocuant Farmer, Publioatione of the Amer. Stat, A8800., Vol. 9, Juno 1904, p. 45.

60 Brooks, R, P., Asrarlan Revolution in Georgle, 1914 , p. 86. 
It ahould be pointed out, however, that some of the steadieat worker in the mine are Negroes. The faotor montioned alagly accounte for the preferenoe of a part of the Hegro group in ohoosing, voluntarily, loading ingtead of other positions.

Another factor whloh Negroos frequantly give as a reason for thelr preferenoe for mining in general and 1 aglde positiona in partioular is the relatively emall fluotuation in temperature within the mine in oummer and winter. The mine is alwayo 0001 in auminar and warm in winter. While the tipple man may be sweltering in the heat that somotimes prevails in the mining fieldo of Weat Virginia the ooal loader 1. worklng in a 0001 plaos. When he 18 ready to oome out at four o'olook the worat heat of the day in 11 kely to bo over and his work 18 over for the day. All that remains is for him to take hIs bath and derote himeelf to keeping cool. In winter he is subjeoted to the oold only in going to and returning from his work.

The att1tude of many Negroes toward the compet 1tion of the forelgner has been mentioned. The Negro is 11kely to look upon the forelgner a hls competitor with keoner interest than he does the native white. He 1s aocommodated to the superior position of native whites but resents the inroads of other minority groups into the 61 mines. One employer writes: "Negroes, as a rule, do 31 See ohapter on Race Relations for a further disoussion of this raot. 
not work ateadly but if they foel the forelgner w1ll profit by theif 1 dlenees they w1Il make it a polnt to be at the1r work every day. .." Some of the Negroes have avolded this comptition by going into some of the jobs in whl oh forelgners are seldom found. 
CHAPTER VI

THE EFTIOIENOX OF THE NEGRO MTNER

We have aeen in the preceding ohapters that the Negroes have for a long time oonstituted an Important part of the workers in tho mining industry of West Virginia. In 1931 the Negroes oonatituted 31.9 per oent of the workers of the Induotry. "whl oh was the largeat peroentage binoe 1907 when the Department of Mines began to take any acoount of raolal and nationality statiot108. This growing proportion, coupled with the long period in whi oh Negroes have boen assoolated with the mining industry in Weat Virginia, seems to Indloate that the plaoe of the Negro 19 well atablishod. How may we acoount for the seeming succese of the Negro? Is it due to bie unusual offiolenoy in the various positions of the Industryt Or, are there otber less ostensible reasone for the Negro's prosence in suoh large numbers in the most important mining fields of the atater It is the purpose of the present obapter to give some kind of an answer to these questions.

In order to arrive at these answers threa approaoho were used. The l1ret was a study of the attitudes of the employers of more than 9,000 Negro minere toward the Negro in the varioue mining operations. These opinions, of pourse, may not represent objective judgment alone. They do, however. reveal something of the stereotypes of the employers of $I$ See employer's gohedule in Appendix. 
Negroes wilio are more lmportant in determining the place of the Negro in the coal induatry than objootive truth. It makes little difference what the truth oonoerning minority traits is so long as the only entrance to the bettor positions is carefuldy guerded by mombers of the majority group. Where oertaln allogations of a partloular tendenoy were ao frequent a to indioate a present oharaoteriatio, investigation was made to determine whother or not these imputatione were based upon faot,

A more objeotive approsch, by way of a ohook on the attitudes of the mployers, was the atudy of pay rolls. Suoh an approaoh 18 by no mean an infall1ble method in indlcating filotenoy. It can, however, how pomothing of regularity of work and earning power, With very few oxoeptions the prinolpal jobs of ooal mining pay the same wage to all employees regardloa of oolor or nat lonslity, a condition whioh does not exist in all industry, where exoeptions were made to this rul they were as often in favor of the Negro as of the other groups. Although there are unknown varlablea whloh oannot be taken into aocount in such a etudy, suoh a partioular diffioulties in place of work, breakdown of mahtnery, staknoas of the enployee, and the $11 \mathrm{ke}$, it 18 as auned that the arerage semi-monthly wages will roughly show something to the amount of work done by Negroes an comparad with that of other groups. 
The three groups compared in these pay-roll studias were the native whites, Negroes and forelgn-born. It may geem that, to clavelfy the foreign-born under one head and to treat them a lump, is to be undiaoriminating. By ao dolng, howerer. I do not mean to indioate that the forelgn-born are not the representatives of many and diverse oultures. In faot, as I shall later how in greater detall, the Negroes in the mines of Weat Virginia are not a romogeneous group, However, when considered oolleotively, the forelgners do represent a group whioh is not of the majority group. They mast make oultural adjustment to the dowinant eroup, as for exasple, in termid of language, or alteration of folkways. Together thoy represent an "out-group," The Nerro represents another of these out-groups and has adjustmenta to make whilo the ordinary native white does not have to mike. Thus these three groups when oonsidered in this wy represent three different types of acculturation, each unlque in its own way. In the stereotypes of the mining fileld they conetitute three very definite groups, so that the thention of any one of them to a member of one of the others bring forth attltudes bullt upon these stereotypes. As a further cheok upon both attitudes and the etory told by the pay-rolls, as many as possible of the Neis ro preachers, teaohers, leaders and others were interviewed. They howed varylng degreos of disorimination and objeotivity, but, on the whole, they oonatituted one of the most valuable souroes of information of the whole study. 
They not only provided valuable orlt101 san of leads al reudy followed by the writer, but euggested new ones.

In prosenting the material of this chapter something of the order already auggested in the disoussion of the epproaghes w11l be followed. Employer attitude w11l be discusied first, followed by the presentation of the feote of the pay-roll study, and lastly by consideration of the other factors in what Professor Harris has aptly callad "the productive efficienoy" of the Hegro miner, a tera connoting the general atiafaction of the employer with the Negro rather than mere sicill and fineness of work.

I. EMPLOYER OPINION AND COMPARATIVE EARNINGS OF THE NEGRO UINER -

1. Previous Studies of the Efflofenoy of the Negro Miner. -

Although the Bureau of Hegro Welfare and Statiat108 has given some study to the question of the industrial effiolency of the Negro, It has been ahiofly oonoerned with the Negro in industrial plants. In the 1931-1932, $1935-$ 1926 , and $1927-1938^{6}$ reports are to be found the anewers to questionnalres sent to induatrial plant throughout the state. Only one report, however, dealo with angwers to question conoerning the efficlenoy of the Negro miner. In the 1921-22 report the atatenent to made that 111 coal com

\begin{tabular}{|c|c|}
\hline & $\begin{array}{l}\text { Spero and Harrio, ope elt, p. } 221 . \\
\text { P. } 58 . \\
\text { Quoted in Johnson, op q1t, p. } 70 . \\
\text { Pp. } 17-19 \text {. }\end{array}$ \\
\hline
\end{tabular}


pany offiolals reporting 256 operation whioh employ 6,483 Negroes, or more than one third of the entire number in the state, ay that Negroea oompare "favorably" in efflolenoy, regularity, and loyalty with workers of other reoes amployed. Just what the baslo was for the statement is not olear. No tabulation of answera was made nor wa any diatinction made between the comparative efflolenoy in the different jobs of the industry. The purpose of the present otudy was to provide comparative data on the different positions oooupled by the Negroes in the coal wines.

\section{The Negro in Positione of Authority.-}

A has been pointed out before, Negroes are seldom found in places of authorlty in the mining fields. The ficot that they have been used as foremen and in other positions so infrequentiy, however, may not mean that they are unfitted for the positions, but that thelr productive efflolenoy" is lower than that of the forelgn-born and native whites. It must bo borne in mind that the average coal operator is interested lesa in soolal reform than in production of poal. He is intereated in amoothly-working or tanization witb a minturm of corplaints of all kinda. He 1. I1keiy to dopt that employment system whioh seems to him to be conduolve to the greateat efflolency in coal production considered from all angles. It must be sald, however, that not all operators oondomn the Nogro as unfitiod 
for positions of autbority without trial. Three of the forty-four enployers whose sohedules were taken are sutfsfiod with the Negro in positiong of authority. Two of these three, however, epeoify that they like Negroes only in authority over colored man. Questioned concerning the affclenoy of the Negro in authority the angwers of these two wero:

A Negro la a very good boes among his own color. Sometimen it works among the whites but very soldom.

I would use a Negro in position of authority in any Job of all Negroes.

Both of these enployers, who were located in widely separated coal flolds, the former in Fayette County and the latter in the Pocahontas Field, had Negroes omployed as bosses at the time they were 1nterviowed. The third omployer did not generalize conoerning the Hegro in authority, but aimply sald he had had good ones and poor onea. He had one Negro fire boes, a graduate of the Mest Virginis State Col26ge, who he sald was "yery effioient."

The attitude of white workers is witbout doubt one lmportant element in $11 \mathrm{miting}$ the Hegro's attalnment of the hlgher postions in the Industry. Saya one operator in the New Rer rield

I have ceen but very few Nagroes whom I felt inclined to give positions of reaponalbility to and if I felt oo inclined to place them in a

9 It mat be borno $1 \mathrm{n} \mathrm{m}$ Ind that attitudes differ sowewlat from mine to mine as before indloated. 
position of authority this aot would be resented by other employees. This samo reason preventa the Negro from getting a job on motor runs, plans runs, fire bossea and other postions of this nature. The management oannot afford to incur the displeasure of 11 other employees by appointing a Negro to reaponalble politione.

The hesitancy of the operator to ridk inourring the displeasure of hls other workmen 1o apparent as one intervlews the operators in all 11elde. Perhaps the h1atorio struggle to keep the southern 11elds on a non-union basie is partly responalble for this attitude, although it is doubtful, as hes been pointed out before, whether the average operator 18 ever troubled very muoh orer the question of whother or not to elevate the Negro to hlgher positions. Such acts are infrequent nough to bo clased among those things which are "just not done." Cases are very rare in whiob a Negro must be given suoh a position in order to keep him, because of the fact that no other jobs better than the one he has are open to him in other mines. The Negro finds in mining as in other ocoupations that he reaches a deadine which be may not croes, except in rare instances. The following quotatione of employers w111 indloate this faot:

Whitea w111 not obey Negroes. In fact, they resont his "bosing."

The Negro in these positions 18 out of h1a element. Fe would be domineering and native whites would resent his authority.

Whites resent a Negro over them. I have had superior Negroes who could f11l some of the better positions, but I did not use them in such. 
Whitee do not I1ke 1t. A whit w111 brake for a Hegro on a motor, but he wants no Vegro foreman.

Too far South,

Wh1tes w11 not atand for 1 t.

Due to sootal prejudice we cannot use colored wen here in the sapacity of bose over any native whites.

These employer give the impreason that thoy would use Negroes in positions of authority if it were not for the opposition of their men:

Other employere, however, elther because they deern it to be poor polloy on the part of the company, or by reason of thelr own attitudes toward Negroes, w112 not use them in places of authority. Examples of the former type are indloated by the followling answors to the queation of why they did not use Negroes in plaoes of uthority

Wo think in our company that no Negro politiclans are desirable. We find there easier to bandle under white men,

Te don't use Negroes because with our mixed organization white leadership tond toward greater harmony.

The other type of employer may 11ke the Negro "In ble place" but does not oonsider him in his pleoe in the higher posit10ns. The following quotations will indicate this employer att1tude:

I would not work under a Negro -- and I will not ask other white mon to do 10 . 
What ruined the Negro in the Naw River Field was the northern operator who oame down and oulled him Miater.

Mever: Th1s has been tried many times but has alwaye been a fallure, Negroes are followers, not leadore.

This attitude is somewhat typloal of most of the operators in Weat Virginia. Suoh an attitude is not antagonistic to a preferenoe for Negro lebor or to an actual affection for Individual Negrroes. The author of the firat quotation to the effoot that he would not expoot hla whlte wen to work under a Negro also sald, "If I had my way we wouldn't have anyone but Negroes on the place." Both he and the duthor of the following quotation were known over a large geotion of the state as "Nogro men, 10

Perhap the most frequent reason asalgned by employers for the fallure of Negro foremen was the antagonist1o attitude of the Negroes themselves. One employer writes as follows in this regard:

I do not mean to say that a negro did not have enough eense to be a mine foreman. In my past fifteen yeara. I huve had oome exoellent negro minera; well tralned, underatood mining, and had a thorough knowledge of mine rules and safety and first ald measures, but when plaoed in a poaltion of authority, they fell down, due to the fact. I believe, as I statod in questionna1re, he uill not be diplomatic with his own raoe. He trles to drive the men instead of leading them, and it $1 \mathrm{~s}$ an experienced faot with me that I have yet to see a negro eaployee that likes to work under a negro employor. At this particular point,

10 Interview with Prof. Thos. C, Posey, of W. Vi. State College, who did some of the fleld work for Dr. A. L. Harris in preparation of "The Blaok Worker." 
we are right 010se to the V1rginia and Kentuoky gtate IIne, and of courge, you know just about how white employee here would foel towards a negro mine toreman.

Other quotation of employers relative to thle matter follow:

I use Negroes in plaoes of authority only in an emergency. The blggest troublo is with the Negroes themselves.

I have an egsigtant mine foreman, but he is not very ewocesaful. The Negroes do not $11 \mathrm{ke}$ him.

In an Englioh theme a student at West Virginia State College wrote:

If a Negro is given a good position nuch more is required of tim than would be required of a white man in the same position. A altuation of this sort was present in one of the mines operated In the district in which I 1ived, Negro was given a position as traok foreman over a group of workers. He worked h1 a subordi nates bo hard that moat men dreaded working under him. Wevertheloes, he was oompellad to work them unuoually lard in order to retain his position.

Another enployer at a mine whloh einployed a Negro foreman over a period of years ald the envy of the other Hegroes was one of the faotora limiting his auccess.

Sugh reagong were co common that an effort was made to verify there alzegod reasone for the limited supcess of Negro foremen. Interviows with member of the Nepro group tended to confirm the employers' interpretations of the situation. Hegroe were frank to adint that they would muoh rather work under a white rather than a Hogro foreman. One Negro, occupylag bos position himelf, told of the 
case of a Negro mine foreman who lost hls job beoause of the Negroeg. The Negroes, acoording to this report, expeoted him to favor Negroes more then any other group while In his position of mine foreman, Whon he would not do so the Negroes would Iun to the auperintendent with oomplaint These coraplainte wore ao frequent that the superintendent finally said he was tired of bolng bothered all the tiue and gave the poestion to a wilte foreman.

The Negro foreman in the mining flelde, then, 10 in a very diffioult altuation. His position 18 most oonoplououa and his every fault to $11 \mathrm{kely}$ to be magnified in the minds of both the minera, white and bleok, and the entployer who have boun familiar with all the old stereotypes of Negro Inefflolenoy and laok of leaderahip so comron in Amerloan oulture. In other worde, he mut wear the new mantlo of authority ath oven more grace than a white man more acoustomed to wearing 1t. He is also froed with an almost oomplate reversal of traditional mores in that he has whites under him as well as Negroes. In other words, the Negro foremen must how muoh more ability than a white man in the same poltion in order to be considered as auocosstul. He has the opposition of white workers, the suapioion of his employers, and the antagonl sm of his own group to faoe. In such a tuation it is not surprising 11 some Negroes havo been fallures.

II Of. Teldman, qRe oft, p. 38. 
The gradual disapposanoe of the larger number of Negroes in high positione roported in the early days of 12

MoDowell County would Indloate that the oompanies have preferred nat1ve white or forelgn-born bosass. The trans1tion from Nagroes to whlto in plaoes of authorlty in the mines of thlo county has been made by waiting until the Negroes retired and appointing whitea as aucessors. There is seme evidence that, In addition to the feotors already mentloned, some of these men were not as dependable a they might have boen in their pooltione, A prominent Negro educator in the mining fielde of this county says that the disappearance of Negro foremen was partly their own fault: "If there was work at the mines and $61 \mathrm{BO}$ a show that they wanted to see, some of thein would go to the show rather than to work. That is part of the story," It is quite $11 \mathrm{kely}$ that in preferring pleasure to duty these Negroes ware following early culture trait to which they were habltuated. In the farming reglons of Virginla and further aouth, from whioh most of the miners of Weat Virfinla come, It is expeoted that everybody will go to a stiow when it comas to town. Thua while this tralt, to the extent to which it was present among Negro foromen, lo by no meano an indioation of raolal laok of dependablitty but merely of the operation of cultural faotors, it io not induatrial efficlenoy, whlob is also gulturally defined.

12 Harrio, Opportunity, Fobruary 19a6, p. 47; Welch Da11y News, sept. 31, 1936.

13 Interviow with Mrs, $H_{0}$ T, Garrison, prominent state and county pol1t1oal leader, Gary, W. Va. 
3. The Nagro Coal Loader,-

In order to ascertain quantitatively the reaction of employare ooncerning the efflolenoy of the Negro minera In the varfous ocoupatione, cnawers were seoured from enployers of more than 9,000 Nezroes, 12,000 native whites, and 5,000 forelgn-born to the following question 1

As compared with the quality of work done by forelgnerd, 18 work done by Negroes in-the followInt ocoupatlons (ooal loade 1 , machine man, traok man, wotorman, brakeman, tipplo man, eto.) 1. muoh superior 3. considerably ouperior 3. slightiy guperior 4, about the same 5. elightly inferior 6 . oonsiderably infertor 7, muoh inferfort

1 sirilar question was used to oompare the quality of work of the Negroes and the native whitas. The omployers answerIng the questions were lookted in every oounty in which any inveatigation was made. 15 Although the employor hold all positions from mine foreman to general manager, most of the questionnaires were $11120 d$ out by ouperintendents. The superintendent wa oonsidered the pereon best fitted to answar the questions because he is in direct contact with the workers and yet is ouffiolently removed from the workers to have somewhat of an objeotive viewpoint. Since the general manegers have ugually ocoupled the poaition of superIntendent some time in theis lives they are fitted to answer the questions even though thelr present oontact with labor 18 not so olose as that of thaperintendents. The I4 See amployer's aotedul in Appondix. 15 8o map, p. 
answers to these questione oonoerning the efflotenoy of the Negro coal loadere are aummarized in the following table

TABCI 32. IMPLOYMR CPIMI ON OY MTORO COAL LOADERS AS COMPARBD VITH MAPIV WHITAS AND FORUIOH-BORN

(Data necured from employera' schedulen)

\begin{tabular}{|c|c|c|c|}
\hline \multirow[t]{2}{*}{ oplaton } & \multirow{2}{*}{$\begin{array}{l}\text { Asol gned } \\
\text { Wetght }\end{array}$} & \multicolumn{2}{|c|}{ 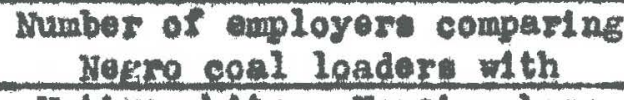 } \\
\hline & & Metre entes & Forel an-born \\
\hline Such Euperior & 1 & 1 & 1 \\
\hline Conelderably mupertor & 2 & 4 & 6 \\
\hline$\$ 11$ ght ly supertoz & 3 & 6 & 9 \\
\hline About the same & 4 & 25 & 7 \\
\hline Sl1ghtly 1nferlor & 5 & 4 & 13 \\
\hline Conal derably Infertor & 6 & 4 & 3 \\
\hline Wueh infortor & 7 & & 2 \\
\hline Totals & & 44 & 41 \\
\hline Hel ghted average & & 3.89 & 4.02 \\
\hline
\end{tabular}

The questionnalres from whloh this table is derived carry seven gradations of oplnion, namely equality and trree simllar gradations eaoh of superiortty and infer10rity. If the number of opinions in each gradation is multiplied by the assigned weight for that oplnion and the sua of the whole is divided by the total number of enployero expressing these opinions we find the quotients 3.89 and 4.02, the arithmetio mean in each oase. That 10, if all employere had given their answers in terms of approximate equility the quotient would bave been 4.00 ; or, 12 they had all oonsidered the Negro as alightly inferior the quotient would bave been 5,00. Since, however, differing oplnione are expressed, intermediate gradations are expressed in terme of fractions. Any auperiority of the Negro would be 
Indloated by quotient less than 4,00. Any inferiority, l1kewloc, would bo shown by any quotlent less than 4.00 . Hto of 10 lenoy, a gauged by the average opinton of the operators interviewed, may be indlcated by the nunstical Iutio above or below 4,00. In other words, these employers on the average conalder the Negro just a bit superior to the native white, although the superiority is 80 slight as to wean approximate equality. As oompared to the foreign louder, on the other hand, the average opinion of these enployers was that the lyagro coal loader was just a sade iniarior. The differenoe in the number of opinlons expressed is due to the faot that some employera did not use foreitn coal loaders, and, henoe, would not express an opinton regarding them.

We may now turn to the reault of the atudy of company pay-rolls to if there lo any oorrelation between the oplnions expressed above and the average arnings of each group in the position of oond loader. The pay rolla of three different oompanies were studied, each in a diferent county, Mine Kumber One in Kanawha County, Mine Number Two was in Raleigh Oounty, and Mine Number Three wae in Wyoming County. After conferenoes with superintendents, general managers, auditora, bookkeopera, and pay roll ol erke the deoleion was made to study the montho of January, July and Ootober. Thf seleotion was made beoause, although there 18 surprialngly 11 tt 20 variation from month to month in "normal" times, these monthe represent the work1ng 
tendencies of these groupe in three distinct types of weather conditione. The year 1938 was ohosen after simllar conferonoes because it ropresented the latest year in whloh market conditiona permitted "regular" work, A simllar atudy of pay rollo for 1938 would have indloated Iittle conoerning the work hablte of the three groups, since most of the mines were working not more than once or tw100 week, some even less frequently. The variation in the number of men in each group at eaoh coml-minthly period will indicate something of the turnover in the Induat ry. 
TABLE 33. AVERAOE 8MI-NONTHLY BARHIGGS OF WLGEO, WATIVE WITH, AND FOHEIGN COAL LOADRRS IN THRED WST VI RAIUIA UIMES FOR JAWUARY, JULY, AKD OCROBRA 1929

(Date cecured from pay rolls)

\begin{tabular}{|c|c|c|c|c|c|c|}
\hline \multirow[b]{2}{*}{ MIne and date } & \multicolumn{2}{|c|}{ Necroes } & \multicolumn{2}{|c|}{ native miter } & \multicolumn{2}{|c|}{ Fore $1 \mathrm{En}$-born } \\
\hline & Number & $\begin{array}{l}\text { Avarage } \\
\text { earninge }\end{array}$ & Krumber & $\begin{array}{l}\text { Average } \\
\text { earninge }\end{array}$ & Number & $\begin{array}{l}\text { Average } \\
\text { earnings }\end{array}$ \\
\hline $\begin{array}{l}\text { Number Case: } \\
\text { January } 15 \\
\text { January } 31 \\
\text { July } 15 \\
\text { July } 31 \\
\text { October } 15 \\
\text { October } 31 \\
\end{array}$ & $\begin{array}{l}48 \\
45 \\
57 \\
53 \\
58 \\
59\end{array}$ & $\begin{array}{r}\$ 57.27 \\
67.36 \\
47.09 \\
73.82 \\
56.92 \\
64.03 \\
\end{array}$ & $\begin{array}{l}54 \\
50 \\
48 \\
46 \\
46 \\
49 \\
\end{array}$ & $\begin{array}{r}\$ 63.47 \\
82.93 \\
57.25 \\
78.63 \\
68.37 \\
66.91 \\
\end{array}$ & . & + \\
\hline $\begin{array}{l}\text { Average }- \text { lif no } \\
\text { Jumber one }\end{array}$ & 52.33 & 62.58 & 48.83 & 69.15 & & \\
\hline $\begin{array}{l}\text { Jumbar swo: } \\
\text { Jamuary } 15 \\
\text { January } 31 \\
\text { July } 15 \\
\text { July } 31 \\
\text { October } 15 \\
\text { October } 31 \\
\end{array}$ & $\begin{array}{l}80 \\
84 \\
84 \\
86 \\
89 \\
84 \\
\end{array}$ & $\begin{array}{l}55.42 \\
57.46 \\
55.25 \\
59.45 \\
60.14 \\
57.46\end{array}$ & $\begin{array}{l}26 \\
27 \\
29 \\
28 \\
27 \\
23\end{array}$ & $\begin{array}{l}57.79 \\
65.21 \\
51.49 \\
64.15 \\
58.82 \\
68.69\end{array}$ & $\begin{array}{l}26 \\
22 \\
25 \\
25 \\
23 \\
22\end{array}$ & $\begin{array}{l}93.96 \\
86.55 \\
78.39 \\
67.83 \\
76.99 \\
86.58 \\
\end{array}$ \\
\hline $\begin{array}{c}\text { Average - ML no } \\
\text { Wunber two }\end{array}$ & 85.00 & 58.03 & 26.67 & 60.75 & 24.00 & 76.01 \\
\hline $\begin{array}{l}\text { Humber Threa: } \\
\text { Jamuary } 15 \\
\text { Jamuary } 31 \\
\text { July } 15 \\
\text { July } 31 \\
\text { October } 15 \\
\text { October } 31 \\
\end{array}$ & $\begin{array}{l}42 \\
41 \\
32 \\
30 \\
34 \\
29\end{array}$ & $\begin{array}{l}53.81 \\
70.84 \\
61.57 \\
74.53 \\
63.35 \\
63.71\end{array}$ & $\begin{array}{l}33 \\
43 \\
47 \\
59 \\
67 \\
60 \\
\end{array}$ & $\begin{array}{l}63.09 \\
74.55 \\
65.50 \\
68.79 \\
62.20 \\
68.18 \\
\end{array}$ & $\begin{array}{r}5 \\
10 \\
9 \\
9 \\
11 \\
11 \\
\end{array}$ & $\begin{array}{l}43.72 \\
47.95 \\
79.67 \\
90.13 \\
79.65 \\
89.20\end{array}$ \\
\hline $\begin{array}{c}\text { Average - Mine } \\
\text { vumber ru re }\end{array}$ & 34.50 & 64.34 & 51.50 & 66.97 & 9.17 & 73.10 \\
\hline $\begin{array}{l}\text { Average - the } \\
\text { three minos }\end{array}$ & & 60.68 & & 66.63 & & 76.66 \\
\hline
\end{tabular}


There 18 some correspondence between the employer rating of the Negro loader and hla average earning when he Is compared with the forelgn loader whloh does not exist when he is compared whth the native white. That is, the averoge earning of the forelgn loader, who was rated bigher than both Negro and native whtte, are greater than those of either group. The average earning of the Negro loader are, however, maller than those of the native white although his rating is highor.

The average earninge of the foreigner in all mines Is $\$ 10.03$ more than those of the netive white erery pay day and $\$ 15.98$ more than those of the Negro coel loader. As a 16

"ohamplon coal loader" the forelgn loader seeme to be in a olase by himelf. The native white, on the other hand, In these mines did not exoel the Negro as wuob as the forelgn loader excellod the native white. The differeno between the average earning of the native white and Negro ooal loader wa on2y $\$ 5.95$.

It is evident that the employer rate their coal loaders by oriteria other than mere amount of coal loaded. One reason for rating the Megro above the native white if that he is $11 \mathrm{kely}$ to complain about his oonditions of work lese than the native white. Conditiona under whioh the mon have to work in the mines are sometimes fur from pleasant. In the New River Fleld, part of which is a "Jow ooal" area, 16 Term used to designate phenomenal coal loaders, see The New River Company Employee' Magazine, Vol. 2 , Lay $1325, \mathrm{p} .21$. 
a man may have to work stooping over all day, One employer said: "In this Iow coal I would rather have a Negro than any other 10ader." Another consldered the Negro as being "better able to stand" suoh oonditlons. Says anotber, "The Negro is the beot human meohine in the world. If you take a full blood Negro who is the con of a olean blaok woman who has been covered with another good olean man -- there is no white man who can equal him a worker of brawn." This general laok of complaint on the part of Negro loaders, a voll as other Negro operatives, leads some exployers to prefer them to the forelgner in apite of the enormous amount of ooal loaded by them. One employer sald of the Negroes in this connection: whe best loaders at M........ are foreignera, However, if they do not get the beot places in the mine they w1ll not work. They must have two rooms. If you had the mine l111ed with suoh men there would be diseonsion all the time. That 18 one thins about the colored man - he will work anywhere you put h1m." Another trat of the Negro loaders plealng to the employer ia his tendenoy to obey orders. The forelign worker sometimes w11, according to employers, give their language handicap as an exouse for mlinuderatanding ordere if they do not ohoose to obey them. The Hegroes, accustomed to obeylng orders, are likely to follow direotione better than any other group. Write one employer: 
The foreigner is greedy - w1ll not proteot hinself by proper timbering in the bitne and $1 f$ the Gear contalns 1 mpur1t1es - so they usually do w11 load dirty coal regardless of how much you talk to him about 1t. He w1ll, however, turn out more work and work longer hours than the nogro in order to inorease his earnings. On the other hand the nergro, whilst he w112 usually obey your instruotions, w11 not work as regularly and you must have an excess of 20\% or $35 \%$ of negro labor in order to tret the aume amount of produotion. Native labor is about midway between the other two classes of labor and somewhat harder to handle. To boll it down I try to have about 55\% negro and 45 white nat ire labor and do not employ forelgnere unless in oases of a shortage of labor supply.

It w12 bo noted that this enployer nentions the faot that the Negroes load oleaner ooal. Thls 1 tem is exceedingly important in the present oompetitive coal market. The presenoe of non-oombustible material in a shipment of coal may oost the partioular mine Irom whioh it was raceived further ordere from that oustomer. Coal may be had so choapIy and in suoh good quallties at the present time that, Instead of akking the prioe of coal, oubtomers have actually told the operators what they would pay thom for it. In auch a stuation the miner who loads olean ooli is a valuable asset to the oompany, oven though he does not load as much as otber workere. This traotibility of the Negro miner in followl ng orders, a tralt oulturally developed in $\mathrm{hlm}$, is one of ohlef reasons he is preferred by many operators. One operator in the Kanawha rield sayat "The best points of the oolored coal loader are that ho will keep in a good humor and work in wet plaoes and in entrles where the als is bad with lese oomplaint than the white man." 
The faot that a oompany may have to employ a larg- labor foroe if Negroes oonetitute moat of it is not looked upon as objeotloneble by most oompaniea. Mining developments began in many remote logations in whloh tho oompantes IIterk12y had to bulld the towne to acoommodate their men. The "oompany atore was neoessity, and at the same time a profitable institution. With a larger working foros the sales of the oompany store as well as rente from company houses are larger. Within the last ilve years more than one company has been able to oontinue in operation because the company storere recelved baok a large part of the wages pald to their men. The Negro miner, although his earning are not so high as the native white's, has been one of the beat outomere of the company store.

In some fielde of West Virginia the Negro coal locider is pald by the ton of coal loaded. Eaoh oar bearing his "oheck" is welghed at the tipple before it is dumped into the loading booms. At other plaoes, partioularly in those flelds where the miners' unton has never had a foothold, the miner is pald by the oar. An averuge car is supposed to hold two tons, but in some places the miner is forced to load then "grave yard high" no that nometlmes, in the language of one bookkeoper. "damn near three tons" are 18

loaded. Beoause of this praotloe, one of the operators

17 Interviews with atore managers of several companies, Cf. Frazler, E. F., La Bourgeo181e No1re, Modern Quarterly, Vol. 5, No, 1, Nov, 1928- Feb, 1929, p. 82. Seo also U. S. Immigration Reporta, 1911, Vo1, 7, p. 303, 18 Cf. Harr1s, on oit. p. 376. 
Interviewed said, with a omile, that he was getting bla ooul loaded at a ridloulously low price. The Negro miner appears to be wllling to load ble car as full as any other loader when asked to do so, An operator, in giving his oplnion of the Negro loader, writes:

It has been my experlence for the past ifiteen years, that the negro is by far the beat coal loader. I mean to bay by that, that a nezro w11l keep his place in the mines in good oond1tion, wil load you oleaner coal, a fuller oar, and will also shoot your coal as you want it ahot. In other worde, he will live up to your rulee bottar than the native. white or foralgner.

The disousaton of the Negro coal loader has been conewhat extended boomse some of the reasons for the prom duotive fiflolency of the Negro coal loader we have oonsldered hare apply oqually to the Negro in other ocoupations. The charsoteristion of dooll1ty, oheerfulnees, obedienoe, and uncomplaining apoommodation to the will of the employer are confined to no one oooupation, but are valued by the employer in any job in whioh whites or forelgners are $11 \mathrm{kely}$ to exhibit traite quite the opposite of those mentioned. We shall asaume these factors in our disousalons of the Negro in these other positions. Where Negroes are found to a considerable extent in oertain positione in whioh their earning indioate leas regular work, it is probable that these other oonsiderations determine the oholoe of workers. In aumary, then, wo may that in tho opinion of the employere the Negro ood loadera are rated somewhat 
above the native whtea and somewhat below the forelgners. In average earninge, however, the Negroes rank below both of the other groups, Lower earninge, however, do not necessarily signify that Nagro effieleney is lower. The fact that the Negro will work where he 10 told without complaint is probably anough to insure hls getting those places which othere w111 not accopt. In the assignment of "places" In the mine the forman 10 11kely to give the pet pension 19

drawer" to other than Negro 2oaders. I A commont of a former Buperintendent from Alabama, now sel11ng insuranoo to the minere, is of Interest here. Aftor saylng that the only way to handle "niggers" was to k111 a fow, whiloh be claimed the had done, he remerked oonoerning my atudy of the pay rolla, Mut that won't show the efflolenoy of the Negro beouse he doesn't get a fafr how, The lagro is not apt to get a falr ohow in the mattor of plaoes to work. He cannot load as large an amount of coel under suob oonditions." He says that always some allqu sontrols the mine due to a favored position with the mine bous. He aya furtier. "The Negro 18 not apt to be in suoh a position, but does not oomplain. He olmply takes what he is given." It seems falr to conclude that the Nogro ooal loader 18 at least approximately equal to the nutive whito loader in effiolonoy, and, from the employer's point of view somewhat auperiox. Judged

I9 Term used in a report of a Negro hlgh school sentor on "General Mining Conditions as They Affect the Negro in the Kanawha Rogion" to mean those plaos in whioh I1ttie labor lo neaded to get the ooel. 
merely on the beale of loading average both Negroer and native whites are conslderably below the forelgn loadere. The explanation of this aftuation probably lies in tie fact that each group has ourried into the mining Industry work habits learned in three different oultural set-ups.

\section{The Negro Nachine Man.-}

Employer opinion of the Negro machine man is quite the reverse of that of the Negro coal loader. The general opinion of the mployers sems to be that the Negro Is superion to the forelgn worker in thic position but inferlor to the native white. It is interesting to note, however, that the modal answer glven in comparison to both native whttes and forelgn-born was equality. The welghted averageo were 4.77 and 3.66 respeot 1 vely. In other words; the average opinton of the Negro meontine man-in comparition with the native white was that be ranked between equality and elightiy inferlor, The average optnion of the Negro maohine man as compared with the forelgner, on the other hand, plaoed him between equality and alight inferiority. The relatively mall number of ofinions expressed concerning the Negro in comparioon with the forelgner was due to the faot that so few foreigners hold the poition as meohine men, and employers without experieno with them as makine men hesitated to express an oplnion. Consequently, aix employers expressed no oplnion here. 


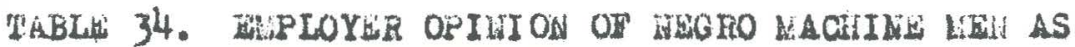
COMPARED WITE HATI YS WITES AND FOREIGN-EORN

(Data securad frow ouployer i chedules)

\begin{tabular}{|c|c|c|c|}
\hline \multirow[t]{2}{*}{ 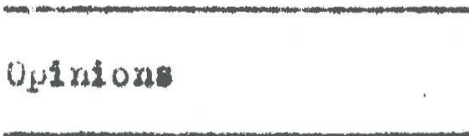 } & \multirow{2}{*}{$\begin{array}{l}\text { Asalgned } \\
\text { Welght }\end{array}$} & \multicolumn{2}{|c|}{$\begin{array}{l}\text { Number of moloyer couparine } \\
\text { Necro mahlne men with }\end{array}$} \\
\hline & & rat1 w intes & Pore1 gn-born \\
\hline Wuch exper10r & 1 & 0 & 1 \\
\hline Couat derably euport or & 2 & 1 & 7 \\
\hline Sllghtly mupertor & 3 & 4 & 10 \\
\hline Aluout the sam & 4 & 16 & 12 \\
\hline S11ghtly inforior & 5 & 9 & 5 \\
\hline Considerably inferter & 6 & 9 & 3 \\
\hline Anoh inforios & 7 & 4 & 1 \\
\hline $\begin{array}{l}\text { I'otal } \\
\text { Wolghted average }\end{array}$ & & $\begin{array}{r}43 \\
4.77\end{array}$ & 3.66 \\
\hline
\end{tabular}

Because the number of forelgn-born maohine men was small no comparison with the average earnings of foreign maohine men were obtained. Hone of the three mines whose pay rolls were atudied employed any forelgner in this capaotty. A rather olose oorrespondenoe between the opinlons of the employers and the average earning of the two groups is apparent from a comparison of Tablea 34 and 35 . 
TABLE 35. AVRRACR SPAI-MOWTHLX RARMIMOS OF MHORO

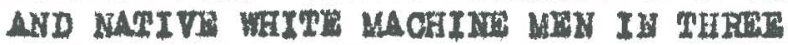
WLST VIFOIXIA KIHES FOR JAWTARY, JULY. AND OCROBDin 1929

(Data secured from pay rolla)

\begin{tabular}{|c|c|c|c|c|}
\hline \multirow[b]{2}{*}{ Mine and date } & \multicolumn{2}{|c|}{ Megroes } & \multicolumn{2}{|c|}{ Fat ive wites } \\
\hline & Wramber & $\begin{array}{l}\text { Average } \\
\text { etralne } \\
\end{array}$ & Mamber & $\begin{array}{l}\text { Average } \\
\text { ejrainge }\end{array}$ \\
\hline $\begin{array}{l}\text { Nurabor One } \\
\text { Jamuery } 15 \\
\text { January } 31 \\
\text { July } 15 \\
\text { July } 31 \\
\text { October } 15 \\
\text { October } 32\end{array}$ & $\begin{array}{l}2 \\
2 \\
2 \\
2 \\
2 \\
2 \\
\end{array}$ & $\begin{array}{r}\$ 91.00 \\
96.25 \\
73.50 \\
103.25 \\
-\quad 92.75 \\
72.56 \\
\end{array}$ & $\begin{array}{l}2 \\
2 \\
3 \\
2 \\
4 \\
4 \\
\end{array}$ & $\begin{array}{r}\$ 96.25 \\
115.93 \\
74.38 \\
126.38 \\
88.26 \\
76.44 \\
\end{array}$ \\
\hline $\begin{array}{l}\text { Averase - Mine } \\
\text { Number One }\end{array}$ & 2.00 & 88.22 & 2.83 & 92.07 \\
\hline $\begin{array}{l}\text { Number Two: } \\
\text { January } 15 \\
\text { Jamuary } 31 \\
\text { July } 15 \\
\text { July } 31 \\
\text { October } 15 \\
\text { Cotober } 31 \\
\end{array}$ & $\begin{array}{r}11 \\
11 \\
10 \\
10 \\
6 \\
11 \\
\end{array}$ & $\begin{array}{r}106.19 \\
119.52 \\
90.79 \\
106.41 \\
106.41 \\
119.52 \\
\end{array}$ & $\begin{array}{l}6 \\
7 \\
7 \\
7 \\
9 \\
7\end{array}$ & $\begin{array}{r}97.24 \\
91.99 \\
88.55 \\
102.82 \\
111.98 \\
91.99 \\
\end{array}$ \\
\hline $\begin{array}{l}\text { Average }- \text { ut ne } \\
\text { Number Two }\end{array}$ & 9.17 & 106,60 & 7.33 & 101.06 \\
\hline $\begin{array}{l}\text { Mumor Threes } \\
\text { Jamary } 15 \\
\text { Jamary } 31 \\
\text { July } 15 \\
\text { July } 31 \\
\text { October } 15 \\
\text { October } 31 \\
\end{array}$ & $\begin{array}{l}3 \\
3 \\
4 \\
4 \\
5 \\
5\end{array}$ & $\begin{array}{r}83.40 \\
153.13 \\
109.73 \\
152.10 \\
152.78 \\
127.52\end{array}$ & $\begin{array}{l}7 \\
7 \\
9 \\
9 \\
7 \\
6\end{array}$ & $\begin{array}{l}101.57 \\
146.34 \\
136.96 \\
148.46 \\
118.09 \\
134.09\end{array}$ \\
\hline $\begin{array}{c}\text { Average - Kine } \\
\text { Huraber Thre }\end{array}$ & 4.00 & 131.60 & 7.00 & 132.92 \\
\hline $\begin{array}{l}\text { Average - the } \\
\text { three minee }\end{array}$ & & 110.77 & & 112.57 \\
\hline
\end{tabular}


The differenoe in weekly wage is somewhat less than in the case of coal loaders. In fact, the difference of \$1.80 between the average earninge of the Negro and that of the native white overy pay day means that the wookly wage of the Negro 18 only 90 conts 108 s than that of the native whites. It io signifloant that in Mine Number Tro, the only mine in whi oh Negro maohine men were in the araforIty, they excerdẹd the whitee in average earning by $\$ 5.54$, whereas in the other two mines the native whites oxceeded the Negroes by $\$ 3,85$ and $\$ 1,32$ respectively. A possible explanation of this faot is that in the inines in which the Negroes are in the minority they may be asalgned the flore difficult places to out. Be that as it may, $1 f$ some places In the mines are better than othere lagroes would probably have a larger share of the better places where they hold the majority of the positions.

In postion requirling the use of maohinery the Negro workers have probably ouffered muoh from the atereotypes of white employere. Grave doubt has always accompanled the Negro workara in all non-agrloultural pursuita from Emanoipation to the present time. For many years the opinion was prevalent in the South that the Negroes could nevor be worked in a faotory beoause the maohinery would put them to seop.

A frequent reply to the writer's questlone conoerning the Negro maohine man waa, "You know, tho 20 See Dowd, Jerome, Colored Men As Cotton Manufacturers, Gunton's, Vol. 23, Sept. 1802, p. 364. 
Negro is not much good with mahinery," At times the tone of the employer seemed to $1 \mathrm{mply}$ ! Mverybody knows the Negro Is no good with maohlnery. A ooal outting msohine is a machine - hence, of course, he is no good." Donald Young is probably If ht in saying that employero a olass will hire anyone whoe labor they belleve will result in the B1 greatest profit for the $11 \mathrm{rm}$. The stereotypes of the employers are, however, lmportant faotore in determining what they will belleve the most profitable for the firr, and Dr. Young apparently does not oonslder this lmportant point.

The Nagro maohine men sean to have broken down to some extent these unfavorable preoonoeptions regarding their efficienoy. Some employer belleve that tha Negro is inferfor in the uEs of machinery, not bocause of any inherent Inability, but rather by reason of the laok of opkortunity. One such employer writes? "You will notioe that we do not have any Negro maohine men. This is due to the fect, I be11eve, as I stated before, that they are not good mohanics, and a I further sald before, I believe it is our fault. There is no doubt in my inind, that they would make good meohantos if they had the chance. Somo yeara abo when I operated a me on New Fiver, two of the best machine men I ever saw were negroes."

Some employers, who posses deoldedly unfavorable stereotypes of the Negro in moohanlos jobs, atate that 
they have been eurpriaed at the offlolenoy the Negroes oxhib1t. One of the operators, well known as the head of one of the largest operations in the state as well as for his crofioient ua of profanity, although bo $11 \mathrm{rm}$ y believer in the inferiority of the Negro raoe, remarked: When we put in wohlnery here these mountalneers knew nothing of it. I had, to tesob both whites and blacka what they knew about 1t. I'm damned if the Nigger didn't learn wore quiloky than the wiltes. Now, the Mlgger has a preathoul brain. He doesn't give dame as to why a thing happens - all he wanta to know is that it happons. I renember one day that a motor wouldn't go at all. The H1zger motorman drove a wodge into an opening in the motor and 1 t went. That 10 all he wanted to know - he didn't know why at a11."

Not only are employere Influenoed by the stereotypes of Negro inferiority in oertain ways, but the willingness of white fellow workers to work with them is also. While the writer was boarding at the "olub house" In Faloigh County where unatteohed white miners atayed he apent anore than one evening with a wite maobine man. The question was ralsed as to whether he would rather have a Nagro or a white holpor. Although hit helper was sotually Hogro be gald he would prefer the white man. The writer then asked whether the Negro was good worker. He answered? "Yos, he will do hIs work and half of mine 1 I want him to." He sald further that he never "gete famillar" and "keeps in hla plaoe." 
However, he thought whites were steadier and that the Negroes could not be depended upon in an energeney. He olal ned the Negro would run away if anything happoned. He told his Negro helper. "If I got a plooe of alate on me don't you run out - but stay and get me out." The Negro proml sed he would.

In aplte of the handicape already mentloned, however, the Negro sems to have made some progrese in breaking the deadines Into one of the most hiorative ocoupations in the ooal Industry. It is not unoommon for a good maohine man to make more than the mine foreman or some of the white collar men in the company offloes, A glance at Table 35 W11 reveal the high earninge in this position. Although Negro maohine mon are not yat exoeedingly oommon, they have domonstrated their ability to fill this position and with Increased mechanlation may share with the nat lve whites the new meaban1oal jobe.

5. The Negro Traok Man,-

Negro track men seemingly have not impressed their omployers with thel efflolenoy. Although the percentage of the Negro group engaged in treok work 1s almost as large ar that of the native whites and lareer than that of the foreign-born, the employers interviowed on the average considered the Negroes inferior to both. The average oplnton of the efflolenoy of the Nezro track men in comparison with the native whites, was that they were alightly infertor, 
ab Indicated in Table 36.

TABLE 36. HAPLOTER OPIHION OF" BEGRO TRACK

CONPARHD WITH HATIVE HAITES AND FOREION BOWA

(Data ocured from omployere' schedules)

\begin{tabular}{|c|c|c|c|}
\hline \multirow[t]{2}{*}{ Oplatons } & \multirow{2}{*}{ 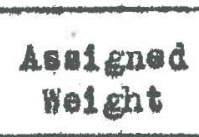 } & \multicolumn{2}{|c|}{$\begin{array}{l}\text { Krumber of omployers conparing } \\
\text { yegro treck men wf th } \\
\end{array}$} \\
\hline & & Mat 1 ve prittos & Forelgn-born \\
\hline afuch supertor & 1 & ? & 1 \\
\hline Considerably muperior & 2 & 1 & 2 \\
\hline silghtly supertor & 3 & 0 & 7 \\
\hline About the ome & 4 & 11 & 10 \\
\hline slight ly infertor & 5 & 19 & 19 \\
\hline Conet derably infortor & 6 & 9 & 1 \\
\hline Yuch inferter & 1 & +2 & 1 \\
\hline Total: & & 42 & 42 \\
\hline Welgted average & & 4.98 & 4.24 \\
\hline
\end{tabular}

Hore than a Pourth of the enployera interviewed considered the Negro equal to the native whites and only one employer considered the Negro euperior. The nodel oplnton wa that tho-Negro was ellghtly inferlor, while nilne more consldered him conaidarably inferior and two olassifled lin as woh infertor. While the comparison with the forelgn-born was more favorable to the Negro than the comparison with the native white, the average opinion of efflotenoy in this Oa日e wat 4.24 or gomewhat below equality. The modal opinion here was also that of alight inferlority and ten employere considered the Negro and forelgn track man about the same. only two employers oonsidered the Negro as more than Blightiy inferlor to the forelgn traok men.

Although flgures for the earninge of track men

F2 At Mine Rrumber Three, motormen, brakemen, and traok wen were paid at the eame rate. Separate flgurea were not obtained. 
were available for only two of the three mines, the earnings of the Negroes in both cases were higher than those of the native white traok men, as shown in Table 37.

TABLE 37. AVIRAGi SAMI-UOWTRLY ZARUIKGS OF NEOHO

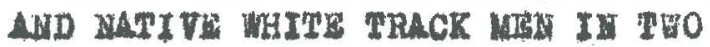
WESP VRTHIA UIHIS FOR JAMTARY, JULY, AND OCHOBDE: 2929

(Date ocured from pay solli)

\begin{tabular}{|c|c|c|c|c|}
\hline \multirow[b]{2}{*}{ W1ne and date } & \multicolumn{2}{|c|}{ Hezraes } & \multicolumn{2}{|c|}{ Int ive untee } \\
\hline & Thamber & $\begin{array}{l}\text { Avernge } \\
\text { exnlnge }\end{array}$ & Xumber & $\begin{array}{l}\text { Average } \\
\text { errolnge }\end{array}$ \\
\hline $\begin{array}{l}\text { Tumber One! } \\
\text { January } 15 \\
\text { Jamuary } 31 \\
\text { July } 15 \\
\text { July } 31 \\
\text { Oetober } 15 \\
\text { October } 31 \\
\end{array}$ & $\begin{array}{l}4 \\
5 \\
3 \\
1 \\
2 \\
2 \\
\end{array}$ & $\begin{array}{l}\$ 63.26 \\
69.41 \\
54.87 \\
73.16 \\
61.17 \\
72.54 \\
\end{array}$ & $\begin{array}{l}5 \\
5 \\
6 \\
5 \\
7 \\
7\end{array}$ & $\begin{array}{r}851.82 \\
73.34 \\
40.02 \\
67.26 \\
70.45 \\
71.24 \\
\end{array}$ \\
\hline $\begin{array}{c}\text { Average - Mlae } \\
\text { number One }\end{array}$ & 2.83 & 65.02 & 5.83 & 62.69 \\
\hline $\begin{array}{l}\text { Humbor Two } \\
\text { Janary } 15 \\
\text { Jamuary } 31 \\
\text { July } 15 \\
\text { July } 31 \\
\text { Octobar } 15 \\
\text { October. } 32\end{array}$ & $\begin{array}{l}7 \\
7 \\
4 \\
5 \\
6 \\
7\end{array}$ & $\begin{array}{l}55.10 \\
62.85 \\
56.54 \\
59.08 \\
61.82 \\
62.85 \\
\end{array}$ & $\begin{array}{l}13 \\
15 \\
17 \\
15 \\
11 \\
15\end{array}$ & $\begin{array}{l}49.88 \\
56.14 \\
50.20 \\
56.13 \\
58.74 \\
56.14 \\
\end{array}$ \\
\hline $\begin{array}{c}\text { Average - wine } \\
\text { Number Two }\end{array}$ & 5.33 & 58.85 & 13.17 & 54.63 \\
\hline $\begin{array}{l}\text { Average - the } \\
\text { two mines }\end{array}$ & & 60.97 & & 57.10 \\
\hline
\end{tabular}

- Tarninge for one foratgo track man for thl half wonth $\$ 59.72$.

With the gingle exception of one forelgn worker alifted into the position of traok men from other work for on half month, no forelgn workers wero used in these two mines as track men during the montha studied. The explanation of the prefer- 
ence of the employer probably 11 es in the faot that the Negro traok men are $11 k e 1 \mathrm{y}$ to do most of the rough work of traok laying. The omployers think of the vegro in this rolo rather than in the more skilled positions, Another faotor, however, in explaining the hlgher earning of the Negro track men is that they prefer loading coal to traok work unless they oan make h1gh wages at the los desirable jobs, Mine Number One, In Kanawhe County, had one Negro traok man who was so efflatont that they paid him more than any other track man. Negro or white; they had to do so to keop him in that position. Although the general attitude of exployers is unfavorable to Negroes a treak men, they apparently are getting their share of earnings in thet position.

\section{The Nagro Lotorman.-}

Wy own perbonal observation of the oolored man In the mines has been that he work beat and most efliolentIy at some job where he can rlde. He thus made an exoelient motorman or mule driver. There are also many effiaient Negro Coal minere," ayy Frank H, Kneeland, Assoolate Editor of Coal 4ta. That the opinion of the Weat Virginia eico ployer Interviowed was nomewhat 108 favorable to Nergro motormen than to Negro coal loadere may be oen by a study of Tables 38 and 39 .

33 AIIen, 20, o1t, p, 63. 
TABLT 38. TUPLOTR OFIMIOA OF MERO NORORUAN AS

CONPARD WITH HAIVI WHITCS AND POREIGN-BORA

(Data secured froin loyers schedules)

\begin{tabular}{|c|c|c|c|}
\hline \multirow[t]{2}{*}{ Oplulons } & \multirow{2}{*}{$\begin{array}{l}\text { Asal gned } \\
\text { Welent }\end{array}$} & \multicolumn{2}{|c|}{ 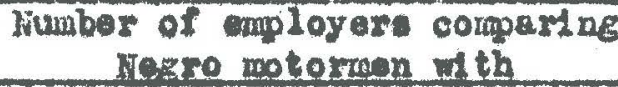 } \\
\hline & & Nathe risteo & Torel a-born \\
\hline Much ouperior & 1 & 0 & 4 \\
\hline Conaiderably supertor & 2 & 1 & 5 \\
\hline slight $1 \mathrm{y}$ upertor & 3 & 4 & 14 \\
\hline About the am & 4 & 16 & 8 \\
\hline S1lght $2 y$ inferdow & 5 & 13 & 6 \\
\hline Cons1 derably inforlor & 6 & 7 & 2 \\
\hline Euch Infortor & 2 & 1 & 0 \\
\hline $\begin{array}{l}\text { Total. } \\
\text { Wolghted average }\end{array}$ & & $\begin{array}{r}42 \\
4.57\end{array}$ & 3.33 \\
\hline
\end{tabular}

In the position of motorman as in certain other oompany positlons no forelgnere were employed in the two minee studied. Separate figure for motormen were not obtalnable at the third mine, The opinion of the efflotenoy of the Negro motormen, Indioated by the woighted arerage 4.67, was botween equalfty and alight inforlority as oompared with the nat Ive white. On the other hand, the Negro motormen were oonsidered somewhat ouperfor to the forelgn-born workers in th1 position. Although the modal oplnion of the Negro in comparison to the native whit te wa equality, only $1 x$ employer coneldered the Negro superlor to the native white and twenty-one of them conoldered blm infertor, the averase thus falling allghtly below equality. On the other hand, the modal oplnion of the Negro motorman as compared to the forelgn motorman wa alightly in favor of the Hegro. Twontythree employers belleved the Negro motorman auperior to the foreigner and only eight oonsidered hira inferlor. The 
weiblted average, or arithmetio mean, was 3.33 , indioating a judgment somewhat above equality.

The fact that the modal opinton of the Negro motorman, as compared to the native white motorman, was equality - hould Indioate that the Negro motorman oocuples a falrly firm position in this partioular position. Negro halage employees aro known among amployers belng quick workmen, but a number of employers expreseed an unfarorable opinton of Negro motormen beoause they oons1der the Negroes hard on maohlnery. Bome omployees have ald that Nogroes geem to take partioular pride in driving motore, but that they drive thom consploupus ly lat and reaklosely.

Althougb llegro motormen are frequentiy found operatIng main ine motore, they are more often found on what are known as "gathering" motors. A gathering motor is smaller than the main line motor and 1te partioular function is to "gather" the oare from the roome and take them to the main 1ine. Wages seem as rule to be paid at the same rate for both positions, The average earning, however, of the Negro motormen in the mines atudied were conslderably lower than those of the native white motormen, the difference belng \$5. 39 each half month, as sown in the following table. 


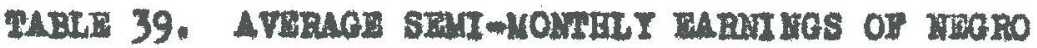
AID NATI VE WTITE HOTORMD IN THO WLET VROIWI MIMWS TOR JANUAR, JULX, AND OCTOBER 1929

(Date securod from pay rolle)

\begin{tabular}{|c|c|c|c|c|}
\hline \multirow[b]{2}{*}{ Mine and inte } & \multicolumn{2}{|c|}{ Terroes } & \multicolumn{2}{|c|}{ Wotive whtes } \\
\hline & Mramber & $\begin{array}{l}\text { Average } \\
\text { earninge }\end{array}$ & Number & $\begin{array}{l}\text { Average } \\
\text { earninge }\end{array}$ \\
\hline $\begin{array}{l}\text { Mrumber Ono } \\
\text { Jamuary } 15 \\
\text { January } 31 \\
\text { July } 15 \\
\text { July } 31 \\
\text { October } 15 \\
\text { Octobes } 31\end{array}$ & $\begin{array}{l}7 \\
7 \\
7 \\
9 \\
6 \\
6\end{array}$ & $\begin{array}{r}\$ 65.40 \\
69.43 \\
54.00 \\
62.73 \\
58.90 \\
57.94 \\
\end{array}$ & $\begin{array}{l}7 \\
5 \\
5 \\
5 \\
7 \\
7\end{array}$ & $\begin{array}{r}\$ 64.59 \\
83.64 \\
68.40 \\
76.88 \\
71.91 \\
68.95 \\
\end{array}$ \\
\hline $\begin{array}{l}\text { Average - MIne } \\
\text { Number Ono }\end{array}$ & 7.00 & 61.60 & 6.00 & 71.72 \\
\hline 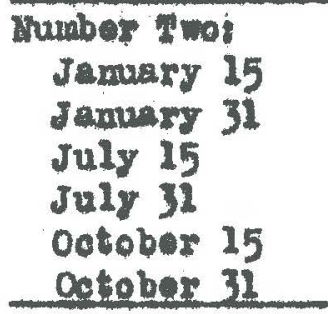 & $\begin{array}{l}12 \\
12 \\
12 \\
11 \\
10 \\
12\end{array}$ & $\begin{array}{l}55.36 \\
62.21 \\
50.76 \\
54.56 \\
58.70 \\
62.21 \\
\end{array}$ & $\begin{array}{l}13 \\
14 \\
18 \\
17 \\
16 \\
14 \\
\end{array}$ & $\begin{array}{l}65.96 \\
65.00 \\
57.28 \\
58.70 \\
63.63 \\
65.00\end{array}$ \\
\hline $\begin{array}{c}\text { Average - Ulno } \\
\text { number two }\end{array}$ & 11.33 & 57.55 & 15.67 & 61.72 \\
\hline $\begin{array}{l}\text { Average - the } \\
\text { two ut net }\end{array}$ & & 59.10 & & 64.49 \\
\hline
\end{tabular}

7. The Negro Brakoman.-

With one exoeption no position that the Negro ocouples in the mining indugtry brought forth more enthualasm oonoerning his fflolenoy than that of brakeman. The one exoeption wae that of driver, whioh position 1 a quite unimportant at the present time. Aocording to a MoDowell County employer. Negroes make good fact motormen, but are torribly haxd on maohinery. They make exoelient brakemen; 
fearlese and very elert." Another employer writes that Negro brakemen are "bast of all." The oharaoterization, "fearleas," 18 not without 1t weaning here, for the position of brukemen 18 one that oalla not only for quioknese, but for self-control in varlous dangeroua situations. The oplnion of the employer here is at areot varlanoe with the stereotype of the white maohine man formerly mentioned ocncerring the timldity and laok of courage of the Negro in a 34

cris1s. The frot that this most dangerous ocoupation of brakeman has a larger proportion of the Megroes in the minea studied than of elther of the other groups ahould indicate trat the oplnion of the enployers probably has a firmer footual basis than that expressad by the white maolif ne man. This is the only position in whioh the ample atudied rovealed a larger proportion of the llegro group engeged than native white, with the single exoeption of coal loader. This would seen to be anotber of those oases in whioh popular stereotypee of "Wegro traits" do not conform with the aotual facte. The superiority of the Negro brakeman as compared with both native white and forelgner $1 \mathrm{a}$, in the eatimation of the erployers, greater than in any other poe1tion, as indioated by the reapeotive weighted averages of 3.62 and 2.88 shown in Table 40 ,

\section{Supra, p.}




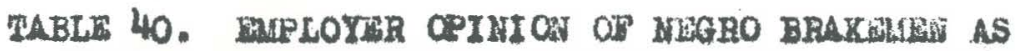

COUPARED WTH VIATIVH WAITUS AND TORZIGN-BORA

(Dat a secured from employern' echedul oe)

\begin{tabular}{|c|c|c|c|}
\hline \multirow[t]{2}{*}{ Opinton } & \multirow{2}{*}{$\begin{array}{c}\text { Aestgned } \\
\text { welght }\end{array}$} & \multicolumn{2}{|c|}{ 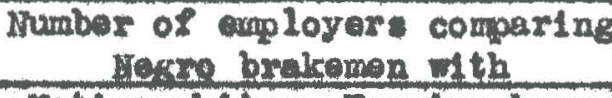 } \\
\hline & & ratire riftes & Borel ma-bors \\
\hline Luch axperlor & 1 & 2 & 8 \\
\hline Conel derably mpert or & 2 & 5 & 10 \\
\hline s11 ght ly muportor & 3 & 8 & 12 \\
\hline About the eame & 4 & 17 & 5 \\
\hline slighty infertor & 5 & 1 & 6 \\
\hline Conelderably Infertor & 6 & 2 & 1 \\
\hline Huch infertor & 1 & 1 & 0 \\
\hline $\begin{array}{l}\text { Total" } \\
\text { No1ented average }\end{array}$ & & $\begin{array}{r}42 \\
3.62\end{array}$ & $\begin{array}{r}42 \\
2.86\end{array}$ \\
\hline
\end{tabular}

The modal opinion of the Negro in oomparison with the native white was that of equality, although for every two employera who oonaldered Negro brakemen Inferior to white there were three who considered them auperior, wo employers ranked the Negroes muoh superior while only one gave them a similar rank of inferiority. The modal opinion of the Negro in oompariaon to the forelgn brakeman was that he was slightly superlor. Elght employers gave the Negroes the lifhest rank in comparison with the forelgn born, while none gave them the lowest rank.

Little differenoe existo in the arerage earnings of the three groups in the two mines at whioh reparate flgures for brakemen were secured, as Table 41 showe. 


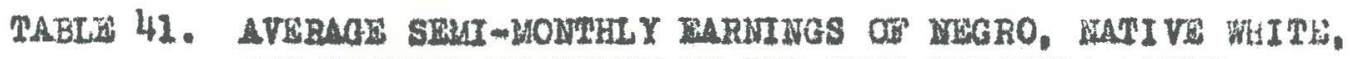

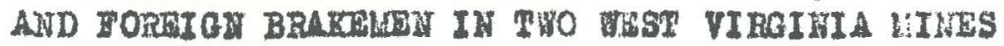
FOR JAMUART, JULY, AIID OCTOBIRI 1929

(Data ecured frow pay rolls)

\begin{tabular}{|c|c|c|c|c|c|c|}
\hline \multirow[b]{2}{*}{ l.Lue and date } & \multicolumn{2}{|c|}{ Nesroes } & \multicolumn{2}{|c|}{ Hative vinitea } & \multicolumn{2}{|c|}{ Foresen-born } \\
\hline & Muanber & $\begin{array}{l}\text { Arerage } \\
\text { Baralngs }\end{array}$ & Number & $\begin{array}{l}\text { Averuie } \\
\text { Sarntinge }\end{array}$ & Iruaber & $\begin{array}{l}\text { Averatse } \\
\text { Barnings }\end{array}$ \\
\hline $\begin{array}{l}\text { Suber one! } \\
\text { Jaruary } 15 \\
\text { Jamuary } 31 \\
\text { July } 15 \\
\text { July } 31 \\
\text { october } 15 \\
\text { Qctober } 31 \\
\end{array}$ & $\begin{array}{l}6 \\
6 \\
9 \\
9 \\
7 \\
5\end{array}$ & $\begin{array}{r}\$ 52.05 \\
57.23 \\
46.94 \\
61.09 \\
54.05 \\
46.62\end{array}$ & $\begin{array}{r}5 \\
5 \\
5 \\
5 \\
9 \\
9 \\
\end{array}$ & $\begin{array}{r}\$ 62.54 \\
60.74 \\
48.38 \\
71.88 \\
58.03 \\
60.94 \\
\end{array}$ & & $\$$ \\
\hline $\begin{array}{l}\text { Average - lolne } \\
\text { Number One }\end{array}$ & 7.00 & 53.32 & 6.33 & 60.22 & & \\
\hline $\begin{array}{l}\text { Tumber Two: } \\
\text { January } 15 \\
\text { Jamary } 31 \\
\text { July } 15 \\
\text { July } 31 \\
\text { uctober } 15 \\
\text { cotober } 31 \\
\end{array}$ & $\begin{array}{l}27 \\
27 \\
27 \\
26 \\
27 \\
22\end{array}$ & $\begin{array}{l}48.68 \\
49.64 \\
43.47 \\
47.06 \\
47.92 \\
53.95\end{array}$ & $\begin{array}{l}18 \\
23 \\
21 \\
17 \\
19 \\
16 \\
\end{array}$ & $\begin{array}{l}50.02 \\
51.69 \\
43.95 \\
58.70 \\
44.92 \\
51.49\end{array}$ & $\begin{array}{l}1 \\
2 \\
1 \\
1 \\
1 \\
2\end{array}$ & $\begin{array}{l}32.80 \\
57.40 \\
32.80 \\
32.80 \\
45.10 \\
57.40\end{array}$ \\
\hline $\begin{array}{c}\text { Avornge - Mne } \\
\text { wubube Two }\end{array}$ & 26.17 & 47.92 & 19.17 & 48.23 & 1.33 & 46.64 \\
\hline $\begin{array}{l}\text { Average - the } \\
\text { two wnes }\end{array}$ & & 49.06 & & 51.21 & & 46.64 \\
\hline
\end{tabular}

There was a differenos of $\$ 4.57$ botween the earnings of the one or two forelgners, the loweat in this occupation, and the native whites, the higheat. The differenoe between the Negroes and the native whites was only \$2.15. Although earninge of the forelgnera in Mine Number Two were lower tlian those of the other groups, the earnings in line Number Three of forelgn brakemen, motormen, and traok men were higher than in both other groups, as hown in Table 42 


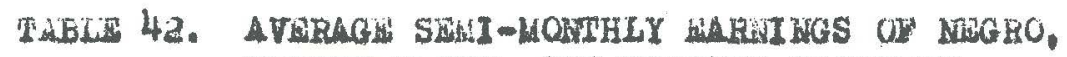

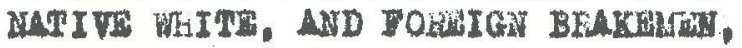

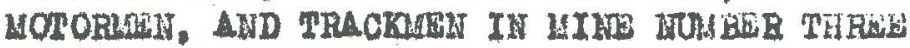
TOR JAWUARY, JULX, AND COFOBERI 1929

(Data secured from pay rolls)

\begin{tabular}{|c|c|c|c|c|c|c|}
\hline \multirow[b]{2}{*}{ Dato } & \multicolumn{2}{|c|}{ Iegroes } & \multicolumn{2}{|c|}{ Native vitso } & \multicolumn{2}{|c|}{ Toral $\mathrm{ma}$-born } \\
\hline & Kumber & $\begin{array}{l}\text { Average } \\
\text { earninge }\end{array}$ & Kumber & $\begin{array}{l}\text { Average } \\
\text { earntines }\end{array}$ & Number & $\begin{array}{l}\text { Averago } \\
\text { earnings }\end{array}$ \\
\hline $\begin{array}{l}\text { Januaxy } 15 \\
\text { January } 31 \\
\text { July } 15 \\
\text { July } 31 \\
\text { October } 15 \\
\text { gotober } 32\end{array}$ & $\begin{array}{l}18 \\
19 \\
16 \\
16 \\
14 \\
13\end{array}$ & $\begin{array}{l}79.42 \\
60.90 \\
48.47 \\
53.05 \\
57.54 \\
60.35\end{array}$ & $\begin{array}{l}39 \\
36 \\
49 \\
40 \\
43 \\
41\end{array}$ & $\begin{array}{r}\$ 40.17 \\
56.89 \\
52.38 \\
62.59 \\
59.38 \\
62.29 \\
\end{array}$ & $\begin{array}{l}1 \\
1 \\
2 \\
2 \\
2 \\
\end{array}$ & $\begin{array}{l}66.10 \\
57.91 \\
58.81 \\
58.21 \\
55.58 \\
\end{array}$ \\
\hline Aramage & $15 \cdot 50$ & 53.64 & 38.33 & & 1.60 & 58.65 \\
\hline
\end{tabular}

It 18 probable that these figuses indioate 11 thle as to the respeative efflolency of the three groups.

8. Other Positione,-

a. The Negro Tipple Man.-

Negroes are not found in tipple work to the extent that they are found in oertaln other positions, As a result, they are not known for any partioular sk111 in this position. As a mutter of faot, most of the tipple positions require 11ttle oki11. Few of the positions are very luorative, and the Nogro does not seom to seek them, Some of the tipple workers interviewed were old men, too feeble for efflolent 00al loading.

The modal opinton expressed, as shown in Table 43 , 


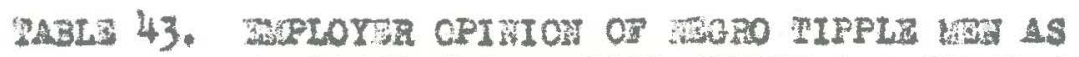

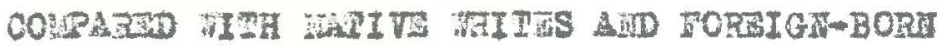

(Date secured from exployers' schedules)

\begin{tabular}{|c|c|c|c|}
\hline \multirow[t]{2}{*}{ Oplasono } & \multirow{2}{*}{$\begin{array}{c}\text { Assol gned } \\
\text { Pel ght }\end{array}$} & \multicolumn{2}{|c|}{$\begin{array}{l}\text { Tumber of erployere comparing } \\
\text { ie so injle nen with }\end{array}$} \\
\hline & & inclve onites & 3orelen-born \\
\hline Fuch supstor & 1 & 0 & 0 \\
\hline cons1dorably suger1or & 2 & 1 & 6 \\
\hline \$11ght1y supertor & 3 & 5 & 9 \\
\hline About the sam & 4 & 18 & 15 \\
\hline s11ghtly 1nfertor & 5 & 7 & 3 \\
\hline Donst derably infertor & 6 & 3 & 1 \\
\hline ach infertor & 1 & 3 & 0 \\
\hline $\begin{array}{l}\text { Total } \\
\text { Tolgtod areraze }\end{array}$ & & 4.37 & $\begin{array}{r}34 \\
3.53\end{array}$ \\
\hline
\end{tabular}

indloated Negro equality in conparigon with both native whtse and forelgn-born. Hoverer, the weighted averages Fere 4,41 and 3.53 respectivaly, 1ndeating that the aean opinion of the employers intarviered tha that the Nezro in this position was somewhat inferlor or, rather, 3omevhat lese than equal to the native white and someribat nore than equal to the forelgner. It is probable that the encloyers cad in inind steadiness of rork and the tendency to ramain in thie position once atarting in 1t. The lorelgner ia hardly content with the smaller vages in this posttion and Is 11kely to leave 1t, 1f, indeed, be over starta in it, and a almilar statement nay be made of the Negro, exoept in the case of the old rorkers.

No separate IIgures were obtalned for the t1pple *orkere. They are constered "outst de labor" and are usually olassifled with these workers. A refereno to Table 44 w1ll reveal the fact that the earnings in these positions 
wero considerably 106 than in oertain of the other positione.

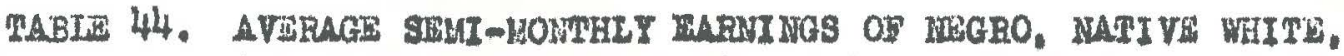

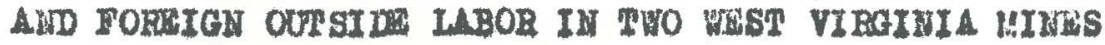
YOR JANUARY, JULY, AHD OCTOBER: 1929

(Data secured from pay rolle)

\begin{tabular}{|c|c|c|c|c|c|c|}
\hline \multirow[b]{2}{*}{ Line and date } & \multicolumn{2}{|c|}{ Hegroes } & \multicolumn{2}{|c|}{ gat 1 ve whit tes } & \multicolumn{2}{|c|}{ Forel sn-born } \\
\hline & Humber & $\begin{array}{l}\text { Average } \\
\text { carninge }\end{array}$ & Lumber & $\begin{array}{l}\text { Average } \\
\text { earninge }\end{array}$ & Shumber & $\begin{array}{l}\text { Average } \\
\text { earning }\end{array}$ \\
\hline $\begin{array}{l}\text { Number Onel } \\
\text { January } 15 \\
\text { January } 31 \\
\text { July i5 } \\
\text { July } 31 \\
\text { October } 15 \\
\text { October } 31 \\
\end{array}$ & $\begin{array}{l}8 \\
8 \\
5 \\
4 \\
5 \\
5\end{array}$ & $\begin{array}{r}\$ 52.67 \\
4.99 \\
44.25 \\
59.74 \\
49.99 \\
47.16 \\
\end{array}$ & $\begin{array}{l}6 \\
5 \\
7 \\
5 \\
9 \\
6 \\
\end{array}$ & $\begin{array}{r}\$ 5.50 \\
62.03 \\
43.99 \\
67.10 \\
52.32 \\
45.94 \\
\end{array}$ & & $\$$ \\
\hline $\begin{array}{l}\text { Averace - vino } \\
\text { Number one }\end{array}$ & 5.83 & 51.64 & 6.33 & 51.92 & & \\
\hline $\begin{array}{l}\text { Surabor Two } \\
\text { January } 25 \\
\text { January } 31 \\
\text { July } 15 \\
\text { July } 31 \\
\text { Ootobar } 15 \\
\text { Catober } 32 \\
\end{array}$ & $\begin{array}{l}2 \\
2 \\
2 \\
2 \\
3 \\
2 \\
\end{array}$ & $\begin{array}{l}47.43 \\
53.48 \\
42.96 \\
44.52 \\
44.77 \\
53.48\end{array}$ & $\begin{array}{r}3 \\
6 \\
9 \\
9 \\
10 \\
6 \\
\end{array}$ & $\begin{array}{l}40.63 \\
28.34 \\
42.51 \\
46.96 \\
43.10 \\
39.67\end{array}$ & $\begin{array}{l}1 \\
1 \\
1 \\
\end{array}$ & $\begin{array}{l}45.64 \\
43.40 \\
51.46\end{array}$ \\
\hline $\begin{array}{l}\text { Average - LIn } \\
\text { Irumber Two }\end{array}$ & 2.17 & 47.54 & 7.17 & 39.68 & 2 & 47.99 \\
\hline $\begin{array}{l}\text { Average - - the } \\
\text { two mines }\end{array}$ & & 50.52 & & 45.52 & & 47.99 \\
\hline
\end{tabular}

Otherwlso they have littlo olgnifloance.

b. The Hegro Dritior,-

Beoause of thelr deoreasing number and importanoe In the ooal Industxy, no sohedule study was made of the Negro driver. It was the unanimous opinion of all employers expreselng an opinion of the Negro driver that he was superlor to both native whites and forelgners in thla poeltion. 
It ray be that the explanation of this enthualaga for the Negro is in part found in oultural reasono aslde from mose superiority. Ihat 18, the oonneotion between the Negro and a alle, usually without the forty acres, 16 a olose one in the stereotyper of many whites. At the some time, it 18 probably true that many of these Negroes from rural Virginia and point further south made the intimate aqualntano of this animal before ooming to the mining fielda of West Virginia, Employere attest the kind troatment of the wules by Negro drivers, Salt one Fayett County operators M Negro makes the beat driver in the mines, Wo have had to disoherge men for mistreating mules - but never a Nagro. Te had one Negro driver who used to put a bundle of hay down for the mule to lay his head on botwaen trips. The mule would 11 down and rest hls had on the hay, when he heard the motor coming be would get up promptiy without any word from the driver. As a reeult of tha reputation for effiolenoy as a driver many Negroes have been promoted to the poeltion of atable bosa, partioulariy before the meohanization of the mines took place so oompletely.

o. L180ellaneous jobs,-

the

We have not discusad the efflolenoy of the Negro in ali/positions which to holds in the mining flelda. Some of the Jobs, Iike that of trepper, require so 11ttle sk111 as to make any auob disousaion not rery meaningful. other positions are not numerou enough to merit separate discus- 
olon, as for example, the posttion of drum runner mentioned in the employer'a sohodule. Comparatively fow of the ainea studied use druma a devioe for controlling the progress of the coal oara down steep inolines, for they are not necesary at many places. Sporadic postione wo as drainage man, pumper, oar graaser, car ropalrman, do not seem worthy of treatment alnoe the operatives employed are fow.

II. THE MOBILITY OF THE NDOFO MINER.-

A critiolom of the Hegro mithr in the Pittoburg Distriot in Pennsylvania io hla laok of dependability. One of the employero in tuls distirlot oomplained that whe Negroes are too much of a 'floating' element. " ${ }^{25}$ No suoh complaint was forthooming from the employer interviewed conoerninu the Negro miner in Neot Vireinia. Probably tho most irequent trait mentioned by employers in doeoribins the Negro miner was his loyalty, This tralt, whlow weans much to eaployere in an indugtry of gomewhat seasonal charaoter. Was given by wany omployere as thelr reason for preferring Negro labor. An aployer in HoDowell Oounty writea a follows: "If I had a mine loceted where nogro labor was plentiful, I would like to have praotloally all nagro employees. I any thi because I do not have, nor have I ever had any trouble handling negro labor, They are loyal, and w11 stiok to you as long as you treat them right."

This traft of "loyalty" perhap neod come interद5 AIIen, OD. Q1t., p. 47. 
pretation. What doe the exployer of the Negro coal uiner mean by loyalty? one thing that loyalty means to these employer 18 enduranoe of the leen montho inevitable in the yoar's production. The Nogro, porhaps partly through "loyalty" and partly beoause he does not know where to turn to better himeelf, tands to remain through these timon of slim wases or no wabes, and increasing debt to the company. Loyalty means also the acoptanoe of the situation with that ostensiblo 11ghtness of heart and oheerfulneas whiob have been taken as evidenoe of happinese and content by 26 many of the majority group. Loyalty moans furthor the posaeasion of an att1tude of indifference toward labor organization. All there things mean conventional loyalty, " Regardlese of the reasone for 1t, we have ample ovidenoe that the Negro miners interviewed in this atudy were far from a mere "floating" group, although the mining a? Industry, owing to 1 t eersonal oharacter and the conotant rumors of higher wage in other f1elds, has always had a problem of "turnover," 28 There is some eridenoe, also, that the same eoonomic faotor of $11 \mathrm{mit}$ ed opportunity which has held Negroes in many positions with whioh they were dissatisfied, operates to make the Negroes at least no more moblle then other population groupe. The Chlldren's Bureau 26 Cf. Moton, R, R, What the Negro Thinks, Doubledis, Doran, 1929, pp. 216-217.

27 Seo Devine, Eaward T, Cogl, American Review Servioo Presa, Bloomington, I11., 1935, p. 229 , for comparative data on turnover in the varlous flelds.

28 Cf. Allen, ope olt. p. 47. 
published in 1823 a etudy in Ralelgh County of some of the 29

same operatlons covered by the present atudy. Table 45 shows the length of resldence of each of the 339 native white, Nagro, and forelgn familles studied by the Bureau,

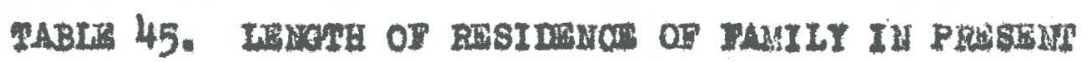

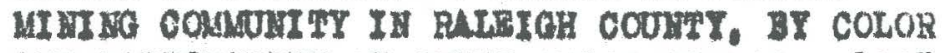

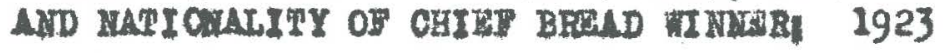

(Complied from HockL1, op. att., p. 5)

\begin{tabular}{|c|c|c|c|c|c|c|c|c|}
\hline \multirow{2}{*}{$\begin{array}{l}\text { Leneth of } \\
\text { Rest dence }\end{array}$} & \multicolumn{2}{|c|}{ Hegroes } & \multicolumn{2}{|c|}{$\begin{array}{l}\text { Hative } \\
\text { Hiter }\end{array}$} & \multicolumn{2}{|c|}{$\begin{array}{c}\text { Torelga- } \\
\text { born } \\
\end{array}$} & \multicolumn{2}{|c|}{ Total } \\
\hline & Nunber & $\begin{array}{l}\text { Por } \\
\text { cent }\end{array}$ & Jumber & $\begin{array}{l}\text { Per } \\
\text { cent }\end{array}$ & Truber & $\begin{array}{l}\text { Por } \\
\text { cent }\end{array}$ & Nunber & $\begin{array}{l}\text { Por } \\
\text { cent }\end{array}$ \\
\hline $\begin{array}{l}\text { Undor } 1 \text { year } \\
1 \text { year and under } 3 \\
3 \text { years and under } 5 \\
5 \text { yeare and under } 10 \\
10 \text { years and under } 15 \\
15 \text { years and over } \\
\text { Not yeported }\end{array}$ & $\begin{array}{r}62 \\
35 \\
25 \\
21 \\
14 \\
5\end{array}$ & $\begin{array}{r}38.3 \\
21.6 \\
15.4 \\
13.0 \\
8.6 \\
3.1\end{array}$ & $\begin{array}{r}132 \\
92 \\
58 \\
70 \\
20 \\
10 \\
1 \\
\end{array}$ & $\begin{array}{r}34.5 \\
24.0 \\
15.1 \\
18.3 \\
5.2 \\
2.6 \\
1.3 \\
\end{array}$ & $\begin{array}{r}26 \\
29 \\
13 \\
22 \\
2\end{array}$ & $\begin{array}{r}28.0 \\
31.2 \\
14.0 \\
23.5 \\
2.2\end{array}$ & $\begin{array}{r}220 \\
156 \\
96 \\
113 \\
36 \\
15\end{array}$ & $\begin{array}{r}34.4 \\
24.4 \\
15.0 \\
17.7 \\
5.6 \\
2.3\end{array}$ \\
\hline Total & 162 & 100.0 & 383 & 100.0 & 93 & 100.0 & 639 & 100.0 \\
\hline
\end{tabular}

The Nagroes have the largest percentage of fainllies residIng in the present oomunity los than a year. Hovever, the percentage of Negroes whose residence was longer than ten yeara wa largor than both native whites and forelgnborn.

Ihis tendenoy of the Nagro to "gtiok" is well 11lustruted in the present atudy. In order to make it a

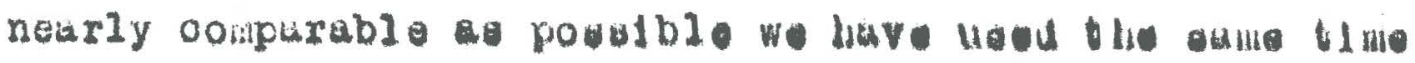
groups us did MIs Mol111, although we have found it necasm sary to inolude other grouplngs as well as those used in her atudy, a Indloatod in Table 46. 39 HoG111, 2D, elt, p. 5. 


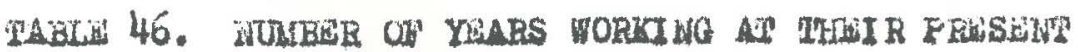
LOCAPI OA OF 589 WEGRO MIJWES IN H'I VS COUNMIIS ON WEST VIRAIHIA: 1932

(Date socurod from mere' sqhedules)

\begin{tabular}{|c|c|c|}
\hline Tine present location & $\begin{array}{c}\text { Tumbet } \\
\text { renorting }\end{array}$ & Por cent \\
\hline $\begin{array}{l}\text { Undor } 1 \text { yoax } \\
1 \text { yoer and under } 3 \\
3 \text { yoar and under } 5 \\
5 \text { yoar and under } 10 \\
10 \text { yoar and under } 15 \\
15 \text { yeare and under } 20 \\
20 \text { yoars and under } 85 \\
25 \text { yeare and under } 30 \\
30 \text { years and over. }\end{array}$ & $\begin{array}{r}33 \\
85 \\
102 \\
152 \\
78 \\
68 \\
43 \\
20 \\
8 \\
\end{array}$ & $\begin{array}{l}5.6 \\
14.4 \\
17.3 \\
25.8 \\
13.2 \\
11.5 \\
7.3 \\
3.4 \\
1.4\end{array}$ \\
\hline Total: & 589 & 100.0 \\
\hline
\end{tabular}

The faot that she was working in a county in whloh inost of the operations were lese than flfteen years old was probably respongible for her use of fifteen yoars and over as her lagt time group. The faot that our atudy inoluded older flelds made nooessary the additional time grouplnge for aocurate presentation. Our table reveals the fact that 23.8 per cent of the 589 Negro miners from whom it was posatble to get thi information had been working at their present looation 15 years or Ionger; 36.8 per oent for at loust 10 years; 62.6 per oent for at leat flve years; and 79.9 per oont for at 1 east three years. It should be underatood that this table inoludes both those workers who had been working only a bhort time and also those who had recently cowe to their present position, perhaps having apent many year at thair previous job.

In Table 47 we have plotured somewhat wore oowpletely the mobility of the Negro from mine to mine. 


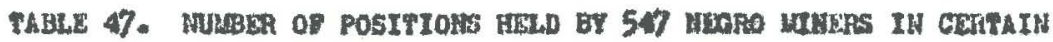

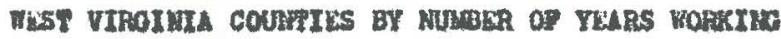

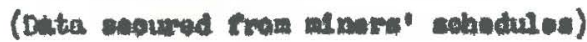

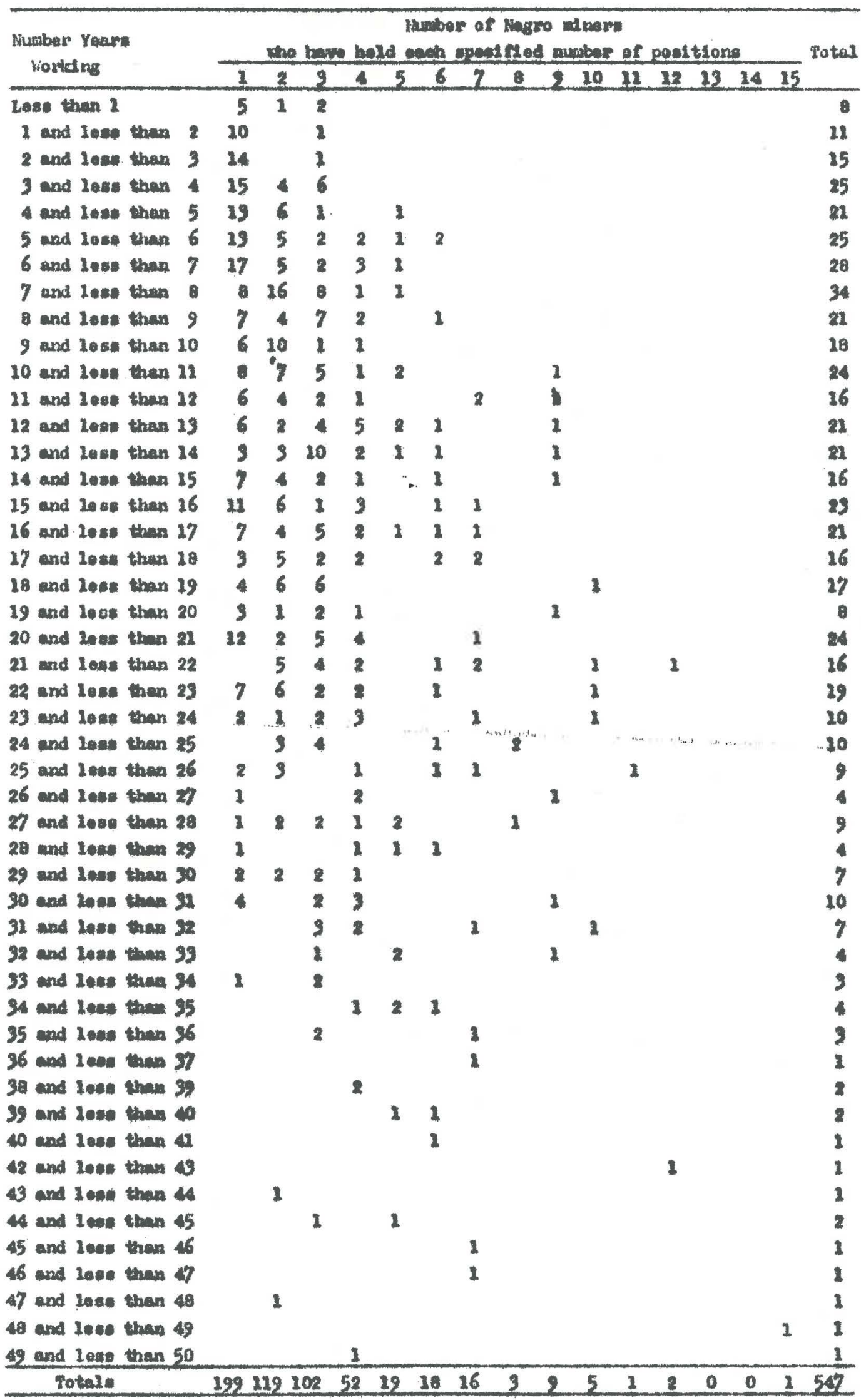


It is intaresting to note that, in eplte of the fact that the Negroes interviowed inoluded men who bad worked only a fow monthe to one who bad worked forty-nine years, more of thom had had only one poattion than any other number of positions. Of the 547 miners from whom it was posalble to get complete information, 198 or 33.38 per oent had held only one position. One hundred and nineteen more, or 21.75 per oent hed held only two. In othor words. almost three Ilfth of thos mindre had bold fewer than three positions, although 19.01 per oont of them had been working in the olnting industry for more than 20 years. 40.23 per cent for 15 years or more, 67,95 per cent for 10 years or more, and 80,80 per cont for 5 year or more. Such Ifures should give olear indieation that the Negro mining population is not elmply a group of tloatera, of course, that 18 not to say that the mining industry does not have ita Hogro 120aters, as doe any other Industry. one Negro miner interviowed bad worked during his thirtyone years in winlng in many plaoes in tennesser, West V1rginta, Ohio, Colorado, Ohlo, Iowa, Indiana, IIIInols, Kentuoky, VIrginia, Wahington, Oklahoma, and Michigan. Such a miner, howover, ia by no means the rule, but declded$1 y$ an axoption,

III. REGULARITY OF THE NEGRO MTNER. -

As has been already mentioned, one oritiolain of the Negro miner is that he works somewhat less steadily 
than the nat1re white or forelgn-born. One of the time which the Negro is supposed never to work is the day following pay day. There was a pretty general agreement throughout the mining f1elde with the statement of one of the bookkeepera in Ralelgh County who sald: "You couldn't get a Niger to work the day after pay day for love nor money." The probable origin of this oustorn probably goos back to the daye when mining communities were praotically isoluted. It can be read1ly understood that these migrants, many of whom had money in abundano to apend for the first time in 30 thelr 11ves, were anxious to spond some of it. Furthermore, as has been pointed out also, some of them could not see the necessity for working further, with a pocket full of money. The drabness of the ming town existence in those days when the chlef exaltement and prinolpal event of the day wa the coming of "the train, "was another fuctor in this periodioal suapension of work aotivities. The gra of paved roade and automobl le transportation kas broken orer this 18olation in all but a fow plaoes. The attitudes, however, for whioh there was probably somo basle, have persisted. An old Negro woman who lived in the New River Fleld until about 1903 apoke to the writer conoerning this tralt, and the faot that she oould not get her own husband to work following pay day.

The general manager of one of the largeat comm panies in MoDowell County cald hls company had made a atudy उo Cf. AIIEn, ep. olt., p. 49. 
of the question of "laysng off" and found that the Negro did not do so any wore often than workers of any other group.

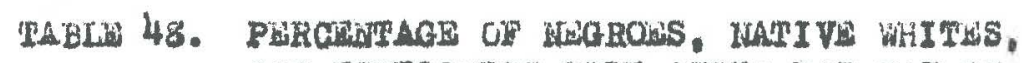
AND TOERIONEES IDLE ATRER PAT DAT IU THEHA WRS VIRGINIA MIMUS; 1929

\begin{tabular}{|c|c|c|c|}
\hline \multirow{2}{*}{ Llno } & \multicolumn{3}{|c|}{ Per cent of aach eroup $1 \mathrm{dle}$} \\
\hline & Hegroes: & Hot 1 indtas & Foralgnars \\
\hline $\begin{array}{l}\text { Jumber One } \\
\text { dumber Two } \\
\text { rumber Three }\end{array}$ & $\begin{array}{l}20.2 \\
21.3 \\
13.7\end{array}$ & $\begin{array}{l}17.4 \\
23.4 \\
18.8\end{array}$ & 7.0 \\
\hline $\begin{array}{l}\text { Averuge - } \\
\text { A11 minos }\end{array}$ & 18.2 & 19.8 & 2.5 \\
\hline
\end{tabular}

Beoause of the differenoe of opinion botween the employere conoernd ng the regularity of work of the legroes a careful oheck was made at the three mines whore acoese to the pay rolle of the company was possible. In only one of the three mines was there a larger peroentage of Negroes idle after pay day over a period Inoluding ix pay days. Tho general average of these three mines for bix pay days abowed that only 18.2 per cent of the Hegroes and 19.8 per cent of the nat 1ve whitee wore 1dle. The forelgers had only 2,5 per cent of theif group 1 de on the average. If these mines may be said to be somewhat typioal the practioe of ldieness after pay day seems to be oustom observed by a number of both groups, but not limited to the Nagroes. The juidment of the writer, after a study of both the pay rolls and the oplnions of the employers, is thet there is probubly iftie differenoe in this respeot. When forelgners are aboent 
from their work it is usually because of theis numerous holidays. One employer sald he preferred to keep about the same number of Negroes and forelgners employed so that the Negroes could work when the forelgners were takl ng their holldays and the forelgners oould work when the Negroes were attending funerals. The wldeapread disperelon of this judgment among employers in different 11 elds would indioate that there is reason to belleve that these observanoes were usual oauses of 1djeness by these two groups.

IV, AMBITION OF THE NDGRO MINER, -

Employers do not, on the average, conslder the. Negro mining group a being very ambitious. Says one employer in Kanawha County: "The worst tralt of the oolored men is their Irregularity in reporting for work. As you know, their raco is not partioularly ambitious, "This observation is no doubt an example of categorizing the Neyroen in terms of a stereotype, as has been pointed out before. Another employer in MoDowell County observed: - The Nogro is not makinis the progreas in mining that he should. Since I have been on thls job I don't remember of any of thear working for thelr mining oertiflostes." These oritiolane are largely typloul of nost of those made by the employera interviewed.

A oareful cheok-up was made on the opinione of the employero by interviews with Negro teachers, leaders, miniotorb, and othera familiar with the Negro miner. These 
were of a lmilar oplnion to that of the employers. Says one Negro miniater in MoDowell County: "No -- the Negro miner is not very ambitious. He is interested mostiy in getting something on his baok and in the atomach. When I first ame here there were Negro miners making \$buo a month cutting ooal. Today these miners are without roney. They spent it on automobiles, olothes, and wldout atook adventures, One Negro ininer owned a Linooln, Hudson, and another oar - - and now 10 without funde. Another man and his wife together were making almost \$1000 a month." It would seem that "consplouous congumption" is the order of the day in prosperous times. This Negro minister added: "Tre Negro miner is not content with driving a Oherrolet or a Ford - he muet have Auburns, Studobakers, Hudsons, ato." The observations of the writer, in the flelds before 1932, would substantiate this statement as oridonoed by the kinds of care driven by Negroes.

Although many of the employer take the majority group attitude that thl eeming leok of ambition and Improvidence are simply 2 ndioations of 1 nherent rao traita, suoh are not at all neoessary to an explanation of the iftuation. One of the most important factors in haping the Ilfe of the Negroes in the mining fielde, as has been mentioned before, 1a the faot that probably moat of them did not come to the mining 11elde with the 1 dea of making them their permanent home. Thl s faotor has oolored every phase of Negro 11fe, both corporate and Individual. He has 
not been intereated in trying to advenoe in the industry as he would is be intended to stay.

Another faotor doubtioa is the faot that the Hegro looks upon himele ag being in a bilnd-alley oooupation. No mattes how hard he may try to flt himself for a better position he know that the ohances of his rialng are very 11m, One Negro college student, wrtting on the dieadvantages of the Negro in mining ayys wone of the most outatanding disadvantages for the Negro in the rining indus try Is $\mathrm{hlo}$ enall ohenoe for advanoement. When ho begine work as a winer, there 1 a proviougly eatabliehod $11 \mathrm{~m} 1 \mathrm{ta}$ tion to the helght to whioh he w111 rise. He $1 \mathrm{~s}$ allowed to work at numerous jobs within a oartain range, but beyond that range he does not advanoe...... Whon boyo leavo mining ceotions to attend higher technical gchools, they cannot look forward to putting thelr tratning into practioe during vacation perioda. They muat return to ordinary takk and leave theis teohniogl activities off unt1 they return to 32 achool." The effect of this altuation, which the Negro feelo on woat any eoonomio front, not merely in mining, may be to etir come Negroes of great energy to struggle the 33

harder and wchleve, but it 1 entirely $11 \mathrm{kely}$ that many othere become digouraged and aooommodate themselver to

31 Student theme assigned ut West VIrginia Stat College. 33 See M1lier, H. A., op, o1t., pp. 35-33; also Varilngtor B. I. The Negro in Business, Gunton's, Vol. 20, March 1901, pp. 213-214. 
their present status.

Closely related to the faotor juet discussed is the further faot that the Negro feels that ha is being discriminated agalnat in job and place distribution. Another Negro college student write in a thene asignement of his oxpertences in the mines as follows: "The Negro minsr is confronted with many obstacles. Bafore I learned of these oonditions I frequently liatened with unusual interest to discussions between my father and other miners concerning thein, In these disoussions they contrasted the oonditions the Negro wa compelled to work under with thooe under whob the opposite raos workad. I war unable to obtaln a clear understunding of their conversation beoaus I was not failllar with the terme they used. On the other hend, I thought it was only a foeling of prejud10e, that is over prasent in the hearts of most men of opposite raoes. I learned later, however, that un thoughts were not woll founded...... I had not worked very long in the mlne before I learned of what handloapped conditions the Negro miner has to work under. The foremen, who are of courbe white men, are piartial to the laborers of their raoe; the best positions are given to white men and forelgnerp." It 1a quite 11kely that beoause of this attitude many Nogroes do not take advantage of evan those opportundties offered them, and tend to deserve somewhat their reputation for laok of ambition.

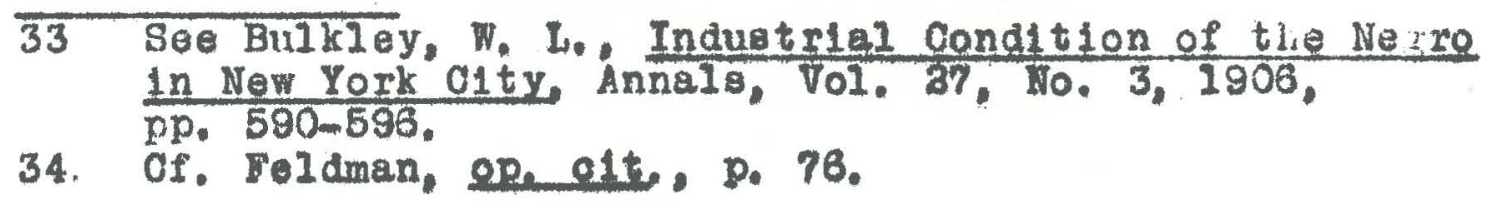


Although the general impreseion of the Negro grou: as a whole in the ininds both of white employers and oompetent Negroos in oloe touoh with the situstion, 18 that it 1s bornewhat laoking in ambition, there were some employero who pointed out individual and even group osaes of thrift and enterpriee. Says one employer in Kanawha County: "I would rather have a Negro any day than a whito. You have no trouble with bims ho is not always oomplaining, and is a good worker. You w11l find him with a garden when most of the whites let thelr yards grow up In weeds. He keeps his plaoe, on the average, better than the whites."

Negroes ware found working in the mines under unusual physioal handioape. One of the best ooal loadere

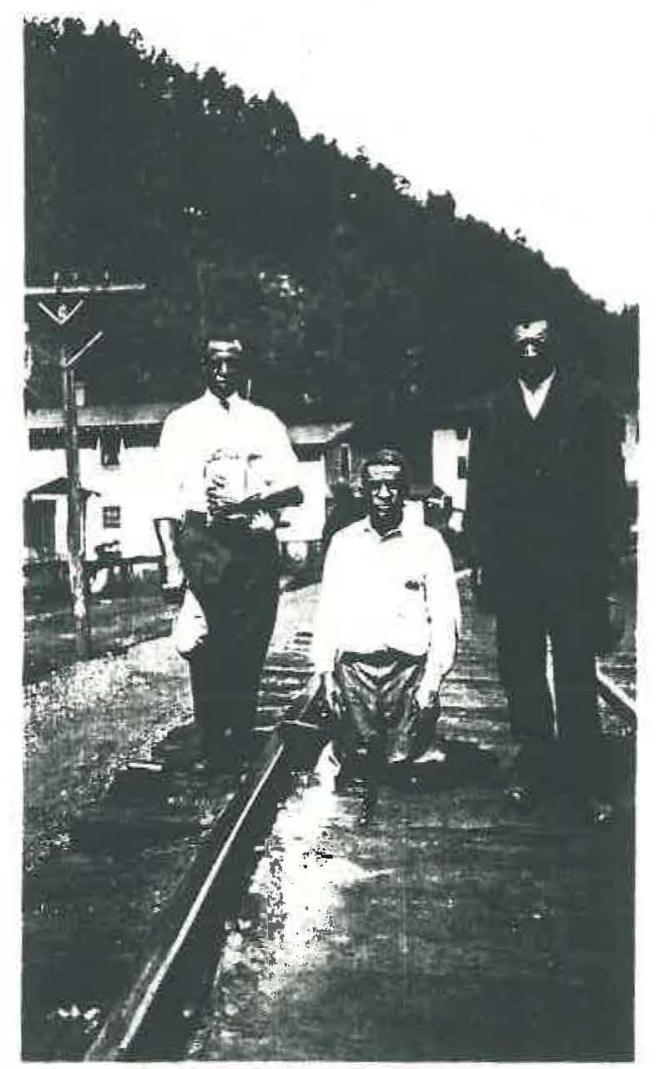

An Efflalent Coal Loader -- Wyoming county 
of a town in Fyoming County had both lege out of above the knees. He walked by means of pads on the stumps of his 1eg8, asalsting himself with short oane. Office men at th1s partioular operation tell a story of this Negro miner whioh 18 somewhat revelatory of a type of humor. There was a white beggar in the minlng town collolting belp bacause of the 1080 of a leg. Th1 segro with both $10 \mathrm{~g}$ gone stopped in front of the beggar, took out bla pooketbook, dropped in a dollar b111, and ald "I wuks fo' my money, brothah." Other Negroes were enoountered who were working although handloapped by the 108 of a leg or an arm.

\section{CASES OF OUTSTANDING ETTIOIENCY.-}

There were, of course, Negro miners who stood out from the mas by development of okill in certain occupations. At one mine in Kunawha County there was a Nogro druk- runner to whom the oompany gave a great deal of extra time because he was a valuable man and the company wanted to keop hlm. At another mine in Ralelgh County a Megro traok man was pald a higher wage than any other traok man of elther raclal group beoause of his efflolency in hls work. At unother inine in the Pocatontas Field the day the superintendent wa interviowed a Negro motorman and his brakeman had broken all reoords for gatbering coal in a single day. They were revierded by extra pay for this feat.

A general manager of a very large mining corporam tIon with sereral mines in MoDowell County spoke as follow 
concerning a Negro machine man: We try to standardize our work as much as posalble. One day one of the groups of $00 a l$ outters at a certain mine deolded that five pluoes were all that any one man could out in a day, I went to one of my Negro cutters and told him that I wented him to go down to that place and would give him all the places he wanted and 100 besides. That night this Negro out 25 placos. We standardized at seven." Another operator in Fayette Oounty told of a Negro outter who made elghteen dollara a day for s1x daye a wook all the time ho worted for the oompany. At one wine in Ralolgh County, a Negro blacksmith wa pald mooh more than any other blacksmith of elther raoo. Theoe are only a few of the oases whioh undoubtedly exist and which have alded the Negro in establiming himolf as firmly as ho has in the minlag induatry.

vI. COMPAITY POLICY.-

Company polioy in employing large mumbers of Negroes, however, is not determined solely by the factors we have disoussod, effloienoy, earning power, eto. There are other reasons why the oompenies desire not merely a white or a Negro group of workers, but a group composed of both elemente, All employere interviewed were asked whioh of the following employment poliolea they preferred and the1r reasons for so desiring 1t: 1. All Negroe日. 2. Many Negroes and fow whites, 3, About equal numbers of whites and Negroes, 4, Many wh1tee and fow Negroes, 5. All wh1ter. 


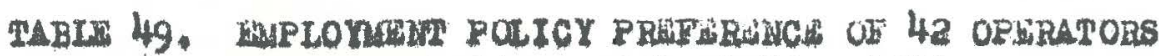
OF WST VRCIMLA COAT UIME, 1932

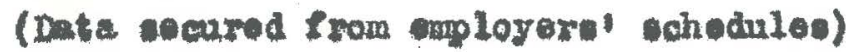

\begin{tabular}{|c|c|c|}
\hline Polley & Muniber & per cent \\
\hline 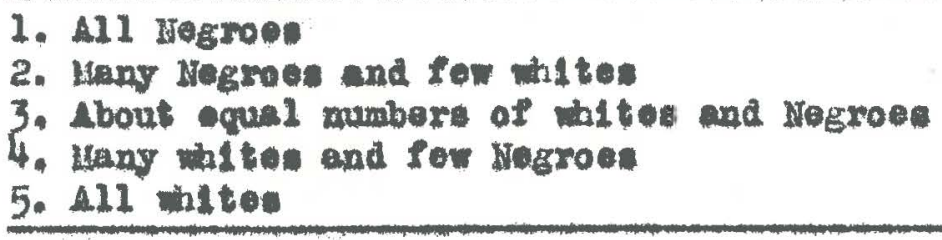 & $\begin{array}{r}4 \\
33 \\
4 \\
2\end{array}$ & $\begin{array}{r}9.5 \\
78.6 \\
9.5 \\
2.4 \\
\end{array}$ \\
\hline Total & 42 & 100.0 \\
\hline
\end{tabular}

More than three fourths preferred about equal numbers of whites and Negroes. Most of these ipulated that by equal numbers they meant an equal proportion of native whitos, forelgners, and Negroes, Some of the reasons given for this preference are hlghly revelatory of the employment situation.

I would prefer to have omployed at a mining operatIon a number of negroe日, a number of forelgners, and a number of native whites. We find that we get the best results whers one olass is looked upon by the others and try to get advantage of the other olasa in the way of good plaoes and responalble positions which pay more money.

The negro 10 more docile, easier to get along with and can be better handled than the forelgn born who cane to our shores a fully doveloped man. The Negro will listen to and follow the advice of the vilite omployer or fellow worker (more) than the foreign born. Usually you can geleot one of their number who are of hizher intelleot than the others, give him a little preference and thru him get all the inforaation needed for proper aotion in controlling the othor negroes -- whilet the forelgner vill listen to you - as a rule - and report to his fellow forelgners and decide among themselves what to do that w11l most promote their own interesta. 
Split 3 ways they will never agree on course of action in atrike.

Better labor control and better average of dally work.

Divialon in case of labor trouble.

Morale better. The witte lead and that makes rivalry.

The Negro knowe he is hardor to handle if they have a majority.

Easier to handle. If you have all Negroeg there is too muoh inoentive to be olunnish. Negroes st1 ok together.

I prefer a mixture of Negroes and native whiteo -more easily handled.

Easier controlled.

Balanced labor - better to control.

Negroes content with rode of 11 ving - no lebor trouble -. whites for leadershlp and to asplre Negroes tio higher plane of living.

Nogroes easler to get along with - a raturu keeps them from "colonla1ng."

Too Independent if ali vegroes - same if all whitem.

Digolplinary.

It w12l be seen that praotloally all of the statemente above emphasize the problem of control. Only a very few operatore gave any other reason and these two or three emphesized the problea of regular work. Say one of theses "Aotivities of mines are less apt to be interrupted to any great extent by soolal aotivities or otherwise," This conBolous polloy of mixing the races was utilized by the operem tore under union oontrol to make solidarity as diffloult on 
35

possible.

Sinoe the virtual destruction of the union in

West V1rginla, it peralete as a precautionary measure againet any inolplent union wovement. The whole problea of the Negro and the union has been dealt with so adequately by Dr. Harris as to require the merest mention in the present atudy. luoh aupporting evidenoe, however, was found for Dr. Harris' otatement: 36

ulany of the operators. prooeeding upon the theory of divide et 1mpera, 1naugurated the preotloe of $\mathrm{mix}-$ ing the different raoes."

In the minds of the employstre the Negro 19 a safets meadure againgt the threat of unlonism. Says one high offialal of Beveral oompantes We Ilke Negroes beoeuse they are not oonetant ly rala1ng trouble. There is not that Iradioal' element among them 11ke there is in the whiter." Another officer of the ame company added "The Nezro only walke out in oase of a etrike because he 1 afraid not to. He'11 be the flrst baok to work when be feels safo." Another superintendent in Kanawha County sald When I came here about twelve yeare ego there were only three Negroes on the pleoe. Now there are over a hundred. I oan Bet along with then moh better than I oan with white minera. And If you get in any trouble it doesn't take you long to find out who are your friends. I know boause I have been through it. The Negroes tre moh more 10yal. They don't care about organtzation at all. Often when I needed wen I would tell the wiltes wiso applied that I did not bave antyling open 35 Spero and Harrto, op. otte, p. 330. 36 Ibld. 
and would walt unt 11 agro applied.

In apite of this univeraal stereotype of tho Negro miner there 1 a some evidenoe that the Negro has been $10 y a l$ to the union in time of atrike where he has not been dis38 oriminatod againgt by 1t. A wh1te miner who had been dismiseed for partiolpation in the Keeney etrike in the aummer of 1932, was ploked up by the writer wh11e driving in Kanawha County. He disoussed the etrlke freely. He sald the miners lost bepause they would not atiok together. I akkd him whether the Negroes tuok to the otrike as we 11 as the whites. He replled They are juet like the whiteo - come Bood, come bad - but I belleve trey etuak eren battor than the whites." an interview whioh lasted an ontire evening. with a former high offlolal of the United lune Workere and one-time organizer for them aubotant lated that the Vagro, ono in the Union, may trunefor thie moyalty" to the union with quite the same fervor that otber group do. One Negro miner told me that the white men at a oertaln mino in Kanawha County struok, aring for the discharge of the Negro minera. The Negroes, not knowlng what the etrike was for, struok sympatbetioally. Finally, the superintondent asked them if they knew what the etrike was about. They sald they etruok becaue the white miners did. When told of the reason for the etrike they went back to work 37 It 111 be notloed here that the employer apeaks of loyalty and in the next ontenoe explains it in terme of Indifferenos to unionisin.

38 Soe Bureau of Negro Belfare and 8tatitiog, Report for 1835-1928, p. 40; also Harx1, op. o1t, ohs, $x$, XVII. 
and broke the otrike. In spite of admitted disorimination Gigainst thera in their 10cala, however, with only one exoeption those interviewed who had worked under union conditions sald they preferred the union. 39

At the ame time, there is undoubtedy reason for the operators' feeling that the Negro is his greatest secur1ty agrainst unioniam. Negroes opoke with the utmost franknesa, even with pride, of their atrikebreaking aotivities. I asked one Negro, miner in Wyoming County wether he had ever worked in the northern part of the atate. His reply was: "Sure, I helped break the soott's Run 8trike in 1936." The Negro, 2ike most Amerloan labor, 1s 11kely to be opportun1st10. There 1s mome reason to belleve that, perhap unoonsolously, he thinks of himself as ellgnod with his employers rather than with other workers. As Kelly Miller puti 1t: "Log10 allgns the Negro with labor, but good sense arraye him on the side of oapltal,"

As indicated in a quotation from one of the opera42 tors some companies bave found 1 expedient to ut111z. oertain of the Negroes in oontrolling the Negro group in oonformity with their wishes. A superintendent of one mine, having Imblbed somewhat more freely than was his wont, volunteered the information that during a union "scare" the company was paying several Negroes flfty dollars a wonth 39 Cf. Harris, ope oit., p. 376. 40 Cf. Waskington, B. T., Tho Negro and His Econoríc Value, International Montily, V01. II, De0. 1900, pp. 372-686.

41 The Negro as a Workingman, American Meroury, Vol. VI, p. 310. 
extra to lead the Negroes in the "right" direotion. They were known as "oompany niggers." Dr. Harris found that somet Imes preschere and welfare workere were aoting in this 43

oapaolty. When these methode fall there is reason to believe that in oertain plaoes etronger methods have been used. The following quotation from man in Fayette County 18 an example: When I was working on .......... we caught a nigger loading dirty ooal. I was with the mine foreman that norning when he went to the place of this man. He picked up a piece of ooal and examined 1t," It was dirty and he told the miner not to 2oad it. The miner sald that ho had no intention of loading 1t. Later that day down at the tipple I notioad two cars of coal come down. I ploked up a plece of it and found it just full of slate. I had the tipple bose dig down and find the chook and it belonged to thl a nlgter whom wo had told not to load 1t. We oallod the raine comittee and asked thein if they wore sat lafled that this was dirty ooal. They sald they were. We fired the nigger. However, the rule was that an must be caught three times in the ane month in order for us to fire him. What we did was to elip his ohock on another man's car and aocused him of stealing ooal and cent him to the penltentiary. We were justified in doing that beause that was the only way to get rid of him."

It is not meant to indioate that the polloy abore 1s uoual. It is simply given as an example of what one 43 Qpe alt, $p, 378$. 
oompany has seen fit to do in oontroling the omployment stuation. The riter was told further by a miner that threatr of arrest by offloers of the law, who aro very LOa to the oompanies in some placer, were aloo used. However, these measuree are most unusual. Were they needed often In controlling the Negro group they would not be proferred for the1r dooll1ty as they now appear to be. The conolusion that the Nagro group holds the plage it does partiy because it is controlled with the minimum of opposition seems inesoapeble. 


\section{GHAPTIR VII}

THE NDCRO MINER AND HIS IARWINGS

\section{EARNINGS OF NEGRO MTMERS.-}

The charaoter of the oocupat1ons by which Negro miners earn thelr 11 ving ha al ready been given consideruble attention, has also somewhat inoldentally the amount of wages paid. What in terme of a plane of 1iving do these wages moan? In order to answer this question we muat consider the degree of regulartty of inoome, 1ts purchasing power in the mining flelds, and the waye in whioh it 18 spent. Anyone presented with oompany statist1os, as was the writer, showing that for the year 1929 the average wage of maohine men was $\$ 10.93$ per day and of coal loaders was \$7.16 per day, may get the 1mpreselon that the earning of workers in the ood Industry are extremely high; but when the number of days the winer works is taken into conelderation this first lapression must be sornewhat altered. The work in the inininis indugtry has always boen 1rregular. In the early days the uaual reason for not "running" regularly was the laok of oars. The inability of the rallroads to oupply ull the mines with care to load was a condition not corrected unt1l comparatively reoent years. In late years. however, the roasons assigned on oompany day sheets for not running have been ohanged from "no oarg " to "no market." The early problem was the proouring of cara to fill orders already taken; the present problem ls how to dispose of 
cars already loaded.

1

TABLE 50. AVRRAGE BTHBER OF DAYS LIMES OPGRATED

IN CMETAIN WEST VI ROIIIA COUMIRS:

$1897-1931$

\begin{tabular}{|c|c|c|c|c|c|c|}
\hline Year & tayetto & Kanawha & Logan & MCDOEC11 & Ral ed eh & $\begin{array}{c}\text { wot } \\
\text { Vi ringla }\end{array}$ \\
\hline 1897 & 158 & 128 & & 197 & 150 & 197 \\
\hline 1898 & 199 & 188 & & 207 & 158 & 214 \\
\hline 1899 & 211 & 190 & & 243 & 214 & 240 \\
\hline 1900 & 247 & 222 & & 260 & 176 & 261 \\
\hline 1901 & 231 & 211 & & 259 & 127 & 225 \\
\hline 1902 & 208 & 249 & & 267 & 189 & 249 \\
\hline 1903 & 173 & 167 & & 215 & 208 & $\infty 1$ \\
\hline 1904 & 200 & 170 & & 227 & 189 & 209 \\
\hline 1905 & 205 & 163 & . 142 & 238 & 167 & 213 \\
\hline 1906 & 221 & 211 & 190 & 237 & 189 & 237 \\
\hline 1907 & 225 & 205 & 204 & 246 & 216 & 234 \\
\hline 1908 & 206 & 193 & 198 & 234 & 201 & 211 \\
\hline 1909 & 199 & 158 & 253 & 211 & 186 & 213 \\
\hline 1910 & 240 & 210 & 210 & .202 & 237 & 228 \\
\hline 1911 & 212 & 189 & 190 & 212 & 217 & 294 \\
\hline 1912 & 245 & 190 & 221 & 243 & 247 & 224 \\
\hline 1913 & $23 \overline{6}$ & 171 & & 232 & 236 & 220 \\
\hline 1914 & 227 & 193 & 214 & 218 & 229 & 226 \\
\hline 1915 & 179 & 170 & 174 & 193 & 200 & 190 \\
\hline 1916 & 237 & 199 & 195 & 245 & 226 & 232 \\
\hline 1917 & 205 & 184 & 189 & 225 & 205 & 215 \\
\hline 1918 & 222 & 184 & 203 & 250 & 232 & $22 \sqrt{4}$ \\
\hline 1920 & 173 & 165 & 181 & 209 & 190 & 182 \\
\hline 1921 & 165 & 135 & 172 & 167 & 184 & 155 \\
\hline 1922 & 105 & 77 & 173 & 169 & 145 & 131 \\
\hline 1923 & 137 & 128 & 141 & 150 & 158 & 158 \\
\hline 1924 & 142 & 128 & 169 & 164 & 166 & 155 \\
\hline 1925 & 201 & 176 & 241 & 223 & 229 & 194 \\
\hline 1926 & 211 & 196 & 238 & 246 & 258 & 195 \\
\hline 1927 & 213 & 200 & 229 & 219 & 241 & 206 \\
\hline 1928 & 210 & 196 & 218 & 216 & 249 & 196 \\
\hline 1929 & 228 & 204 & 247 & 243 & 252 & 207 \\
\hline 1930 & 193 & 184 & 207 & 182 & 210 & 170 \\
\hline 1931 & 168 & 155 & 176 & 152 & 181 & 161 \\
\hline Avorege & 201 & 179 & 199 & 218 & 202 & 205 \\
\hline
\end{tabular}

Sinoe 1897 the mines of Weat VIrginis have

operated an average of only 205 daye a year. The year

I Compiled from West Virginia Dopt, of Uines, Annual Reporte, 1897-1931. 
1900 seems to be the year of atoadieat produot $10 n_{\text {, the aver- }}$ age for that year being 261 days, The count1es with wish wo are mogt direotly concerned in this study, Fayette, Kanawha, Logan, MoDowe11, and Ralelgh, were, wtth one exoep t1on, below the average for the atate in average number of daye worked during thle perlod, MoDowell County, the exoeption, operated an average of 218 days a year. The Lighest average number of days operating in any one year was that of McDowell County in 1802. The mines of that county, profiting by the great otrike in thet New Alver and Kanawha flelds, were in operation on an average of 367 days. The year in whiob the ralnes of the atate vere in operation the smallest averade number of dayo was in 1821, the average being 131 days. Kanawha County had the smallest avorage of any oounty for this year, the average number of dayo operating being only 77 .

The figures used in Chapter VI and the present chapter are based upon the pay rolls of 2929. The reason for ohoosing thla year, as has been mentloned before, was beoause this year was the last rooent year in whioh the work was falrly steady, For the purpose of Chapter VI, oholoe of suob a year was eseent1al. It should be borne in mind, however, that the earning for this year are somewhat higher than average. Reforenoe to Flgure a w112 indioate that 1929 was a peak year, eapeolally for the couthern oount les in which most of the fleld work for this otudy was dono. The arerage for every one of our count1 es except 
Kanawha was higher than that of the entire atate, Kanawha being but one day below ita average. Coneequently, this falrly steady operation means high average oarnings in all poostions.

From the study of pay rolls of the three mines in Kunciwh, Raloigh, and Wyoming countiea already mentioned, wo find that the approximate average arning of Negro meokine men was $2,472.51$ for the year 1939. The averabe for all maohino men in lino Number Three was $\$ 2,770.23$ and for Mine Number Two wa \$2, 264,60, Mine Number One, now ever, wa in Kanawha Oounty and tonded to lower the average conslderably. Coal loaders reoelved the next highest average earning of $\$ 2,454,37$. Traok men recelved an average of $\$ 1,389,85$, and the Negro motormen almost as muoh with an average of \$1,347.48. The comparat1vely tew Negroes employed in outeide labor reoelved the noxt higheat everage annual wage of $\$ 1,241,86$. The offlolent Megro brakemen, however, recelved an average yearly wage of only $1,128.57$. The Negro trappers, mostly boye and old men, wero the lowest pald operatives inglde the mine, reoelving the average carnings of $\$ 848,39$.

As has been sald, the earnings of 1939 are not representative of the earnings of the Negro miner sinoe that time. Not only have there been frequent outs in

उ Figures taken from company cost ateets.

3 Cormany 1igures showed that one of the mbest coal loaders" at Mine Number Two earned $\$ 1,986,54$ in 1939 and one of the "best ood loaders" at Mine Nuniber Throe earned $\$ 2,188,59$. It $1811 \mathrm{kely}$ that these figures represent the earnings of forelgn miners. 
4

wages but the operation of the mines has been muoh more 1rregular sinoe that time. Figurea in Table 51, obtained from one of the coal operatorel aspoolations, conoerning

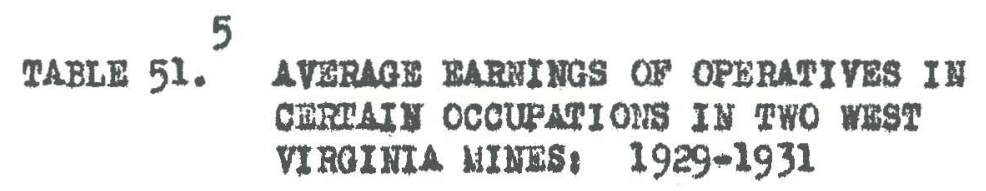

\begin{tabular}{|c|c|c|c|}
\hline \multirow{2}{*}{ Fostition } & \multicolumn{3}{|c|}{ Arerigo joarly warined } \\
\hline & 1929 & 1930 & 1931 \\
\hline $\begin{array}{l}\text { Loader } \\
\text { P1ck miners } \\
\text { Cutters ( } 6 \text { ) } \\
\text { Inside day men } \\
\text { Outal de day men }\end{array}$ & $\begin{array}{l}1.383 .90 \\
1.022 .26 \\
1.500 .40 \\
1.181 .26 \\
1.247 .36\end{array}$ & $\begin{array}{r}936.58 \\
838.05 \\
1,128.42 \\
612.45 \\
900.20\end{array}$ & $\begin{array}{r}637.17 \\
912.84 \\
+935.59 \\
485.71 \\
812.04\end{array}$ \\
\hline Total & $1,309.92$ & 854.88 & 642.76 \\
\hline
\end{tabular}

two mines are Indicative of a somewhat general condition. The carninge of coal loaders stowed a reduotion of 53.0 per cont from 1929 to 1331. The reduotions in other positions were as followe: plok minere, 10.7 par cent; outters, 37.6 per oent; ineldo day men, 58.9 per oent; and outalde day men, 34.9 per oent. The average of 412 workers in these positions dropped from $\$ 1,303.93$ in 1929 to $\$ 642,76$ in 1932, a reduction of 50.9 per cent.

Conditions in 1932 were much more dopressed than In 1931. In the sumer few of the mines visited were running more than once or twloe a week and some not oftener than twioe a month. Wages were so low that employers were 4 Ser Charleston (W. Va.) Gazotte, Feb. 15, 193a, p. 1. 5 Domplied from flgures provided by one of the ooel operators' assoolations.

6 Low amount for cutters is beoause of the faot that helpers wages are inoluded in everage. 
reluotant to state just what they were. A frequent anower to a question conoerning sutes of wages was: We are payIng what all the other operations in this fleld pay," Another vas: We don't give out information of that sort." Some idea of the oonditione in the flelde my be given by the fiat that at one operation the average earninge of netive white coal loadere for four eeml-montlily periods was only 13.41 a half, or $\$ 32.82$ a month, and that the mine operated only 37 days in the f1rst 6 montho of 1933. With wuoh wages it is necessary for the pompanies to "ourry" the wen; that is, to give them ordera for food at the company etore, oliarging it to their accountis. These food ordere ure culled "Hoover orders" by the Negro miners. Rent, fowder, 11glt, ooal, doctor foe, and other oharges acoumulute and will be, preaumably, written off when the condition 1mprove and work is more regular. In January 1933, one company official told the writer that the oharges on the $1 x$ books ran into many thousands of dollars. Beoause of this oondition many Negro miner, as well as white riners, do not recelve eny money on pay day. They are lesued "Borlp" with whloh thay may get oupplies at the company ytores and the balance goes to reduce thel I debte to the company. One Negro miner in Fayette County ald he had not had twenty dollare in two years,

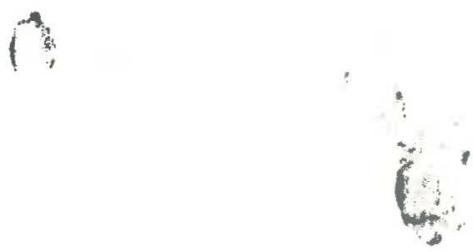


II. SOME NECESSARY COSTS OF LIVING IN THE UINING FIELDS.-

Even in 1329, when wages ware h1 ob, the Negro by no moans recolved all his uarning in cuab. Suoh is not the cuatom in the mining flelda. There are many fixed charges whilo are oharged to the miner and deduoted from his wage before he reoelves it. By this mesns the contpanles seoure prompt oollection of amounts owed thein by their men. The niner reoelves in osh only what remains after all account are settled. Twenty years ago the United States Immigration Coramsaton said in thetr report: "AIl Amerlcans, both white and oolored, uaual1y spend a greater peroentage of thoir earnings at the company store than do the reoent or bouthern and eastern European Imingranta. Thi 18 eapoolaliy true 1 th regard to the Negro, who usually oan draw but a small peroentage of his earningo in cash eaoh pay day, "There seome to tave been no $1 \mathrm{mpox-}$ tant ohange in this tendenoy by 1933. Study of the pay rolis revealed the fact that over a perlod of three montho the average gem1-monthly wage of 142 Negrose was $\$ 59.15$, of this emount, howerer, only $\$ 16.63$ was reoelved in oash. The balanoe of $\$ 42,53$ went to the company in oharges of some kind. Thus the Negroes recelved in oash, on the wverage, only 28.1 per oent of thel carnings and the ooingany recelved 71.9 per oent baok in charger of some kind. The average wage recolvod by twenty-elght foreigners, however, 6 U. S, Imalizration Raports, Vol. 7, p. 302. 
over th1s aame perlod was \$78,01. They reoelved an average of \$5a.84 in cash, or 67.5 per oent, The forelgnera, although recelving an avorage wage of 18.86 each pay day more than the Negroes, spent on the average 17,15 less with the company. The native whttes reocived 48.6 per oent of their wages in oagh.

A good part of the earning of the Hegro miners 18 spent in the oompany tore. The Immigration 0ommission found that ixteen Nog to minere spent 40,1 per oent of thelr earnings here, whlle 143 Negroes of the present study spent 44.6 per cont of tholr earning in this way. Thla money was largely spent for food, olothing, housekold suppl108, tobaoco, gasoline, and for playing in the company pool room. Clerka and offloe mon are unanimous in saylng that the Negro 19 one of the best company oustomere, One oompany tore manager in Kanawha County said "The N1gger will buy anything -- anything: - just so 1t's flashy." Another in Fiayette County aatd, in a confldential tone, "If I wanted to make a k11I1n' I'II tell you what I'd do I'd have nothing but Niggers on the plaos. You oan sell then anything; they 11ve woll, and you oan make if back oft thom that way." Another inoldent whi oh bappened in Raloigh County will show how general is the 1 dea that the Negro is a liberal spender. A bookkeeper was showling the writer which ones of the men listed on the pay roll were Negroes 7 C. U. S. Imunigration Commi arion, Report., Vol. 7. p. 203.

8 Ibid. P. 202.

9 Cf, Brooke, R. P, epe elt, p. 98. 
and which were whitee. He was in doubt about one man. He hesitated a moment and then 2ooked at the amount of sorip the miner had drawn. He sald, Yos, he was a Nezro -- he out oorip just as fast as he made 1t."

Some part of this portion of the legro miner's earnings may have been spent out side the company store, When a Negro miner needs oash for some other purpose than that proourable through oompany agenoles he often draws or "cuts" some sorip. There is usually some one in the mining town who w12l cash thls sorip at a dibount of 25 per ount. The company dootor not infrequently adde sorip disoounting to his professional servioes. This practioe at cortaln plaoes in aurprlolingly luorative.

The next largeat alngle item of the miner's wage spent with the company was for rent. The average rent for the visual typo of mining town house is about $\$ 2,00$ a room per month. Only 12 or 8.0 per oont of the elx hundred miner whose ohedule were taken af ther ownad or were buyIng thelr own homes; 98 or 16,3 per oent were alther boarding and rooming or 11 ving with relativee. The other 490 , a shown in rable 56 were paying rent to the various oompanies that employed them. The average monthly rental pald by these 490 Negro miners was $\$ 9,90$. The average rental pald by the 142 Negroes more carefully atudied was, however, \$6.92. In addition to house rent those Negrose who owned oars pald garage rent at the rate of $\$ 6,00$ a month. One Negro was in faot paying $\$ 4.00$ a month for his house and 
TABLE 52. AWOUNR OE RUMT PAID HOA COMPANY-OWHED HOUSES BI 490 WWGRO LIYSES IN WEST

VIRCIHIA: 1932

(Complled frow minere' echedulea)

\begin{tabular}{|c|c|c|}
\hline Lonthly rental & Aumber & $\begin{array}{c}\text { Por cont } \\
\text { detribution }\end{array}$ \\
\hline $\begin{array}{r}\text { Lene than } 18.00 \\
2.00-\$ 2.99 \\
3.00-3.99 \\
4.00-4.99 \\
5.00-5.99 \\
6.00-6.99 \\
7.00-7.99 \\
8.00-8.99 \\
9.00=9.99 \\
10.00-10.99 \\
11.00-11.99 \\
12.00-12.99 \\
13.00-13.99 \\
14.00-14.99 \\
15.00-15.99 \\
16.00-16.99 \\
25.00\end{array}$ & $\begin{array}{r}1 \\
1 \\
1 \\
23 \\
54 \\
55 \\
5 \\
215 \\
10 \\
37 \\
14 \\
50 \\
2 \\
3 \\
14 \\
3 \\
2\end{array}$ & $\begin{array}{r}.2 \\
.2 \\
.2 \\
4.7 \\
11.0 \\
11.2 \\
1.0 \\
43.9 \\
2.0 \\
7.6 \\
2.9 \\
10.2 \\
.4 \\
.6 \\
2.9 \\
.6 \\
.4\end{array}$ \\
\hline otale & 490 & 100,0 \\
\hline
\end{tabular}

\$0. 00 a month for his garage, a peouliar plane of living arrangement. We may ent1mate, then, that many of the Negro miners atudied epend between 5,8 and 8.4 per cent of their average earning for rent.

For one group of workere, the coal loader,, however, there is one 11 xed oharge whilon w11l perhape exceed or equal their oluarges for rent. This lo the expense of "ghooting" the coal. The ininer must buy his own powder, fuses, "duminles," and other appurtenenoes neoeseary to blasting the coal away from the solid face of the vein. This expense varies somewhat frow place to place but trexages about 1.00 for each working day. In other words. 
this oharge would run from $\$ 6,00$ to $\$ 13,00$ a half in times of regular work, although the approximation ia muoh more likely to be the lower rather than the bigher figure, for the higher is based upon the sesumption that the mines would run every day, a condition that rarely exlata, The United States Coal Commlasion, in the mad" year of 1922 found that miners apent an average of 4.4 and 4.5 per oent of thelr Inoomes respectively in the New RIver and Kanawha Dietricte for miners l oupplies and hardware. However, it must be borne in mind that this peroentage was for all workere, not weraly coal loadere. It is probable that $a$ glightly lower per cent was spent for this purpose in 1329, " "good" year, The 143 minere whose average earning were computed worked, in oage they took advantage of every day the mines operated, 388 days, an extremely high average of working daye. This would mean that they worked on an average of five days a wook, henoe, their shooting expenses, in the oase of ooal loadere, was probably around $\$ 10,00$ eaob half, or 16.9 per oent of the average earninge. This eat1mate 1s doubtlea blgh, as probably \$1.00, the flgure given by inowt of the employere, may hove been a convenient round number rather than an axaot figure. sino coal loader constitute as a rule 50 per oent or fower of the working: foroe at any mine the I1gures given by the Coal Commiseion would neoessar1ly be lower.

IO Report of tho U. S. Cosl Comminsion, 1925, Pt. III, p. 1456. 
Expenditure for bealth maintenanoe, contrary to the rule in most other industries, are oompulsory in coal inininis. Every operation has it "oompany dootor" who receiver his pay firom the company, which in turn charges it to the rinera. The charges for the doctor vary somewhat, ranging from a payment of 50 cent to 65 conta half for aingle men and from 87 cents to $\$ 1,00$ for marriod men, This oharge inoludes not only vistte from the dootor whenever requested but aleo the unual mediolne presoribed by him. One femlilar with'ilfe in the mining flelde never think of the oompany dootor w1thout the 1nevitable bag in which he oarries a large number ot p111s, powders, and potione which he leaves with the patiente, Dootors have told the writer that many Negro patienta do not feel aat 18m fled that their treatment ha been adequat unless some kind of mediolne acoompanies it. Henoe, they keop pills made of ordinary wheat flour to use in suoh oapes. Company dentists are praotioally non-exident. Only in the largest operations are there dentiots and these praotioe independently.

A further feature of the flxed pharges deduoted from the miner's alary is that for hoopltal oare. Faw of the towns have thelf own hospltale, most of them depending upon hospltals in near-by independent towns for this purpose. The coupanise make oontrate with these hospltals to treat any of their men or members of their families needing such attent10u. The oompany reimburses it aelf for tha service by taking from the miners' pay envelopes an average 
of 65 cents each pay day. Some of the oompanies malntain their own ambulances for use in taking the slok or injured to and from these hospltals. In addition, most coal oompanieg contribute to the State Compensation Fund. In case of an aooldent resulting in permanent or temporary disability of the mploye responsibility 18 thus enlfted to the state. Thus, approximately 1.00 to $\$ 2.651$ deduoted eaoh pay day from the minere' pay, depending on whether he is married or aingle, sinoe, wo have soen, 76 per oent of the $600 \mathrm{Neg} r 0$ miners whose sohedules weto taken were merried most of them paid the higher amount. The avarage peroentage of the earnings of these 142 Negro miners spent for malintenance of health was exactly the peroentage found by the Coal Cownifiolon, 2.5 per cent.

\section{1}

The usual fuel used for heating and cooking by the Negro aners 1s ooal. However, fow operation located in gar as woll as coel fieldo are provided with gas. In faot, one mining town in Wyoming County, although devoted to no other indurtry than the mining of ooal, does not havo a olngle coal fire. In the fow town where gas is used the miner paye for what he uses, the houses belng equipped with meter. Where coal is used, however, a uniform charge for coal 18 made regardless of the size of house or amount used. The oharges for soal ranged from 50 oent to $\$ 1.00$ a half. The problem of getting this coal to his house is often left to the miner himself, but in some places to may either have II IDId $p, 1456$. 
It delivered, for which servioe a oharge is made, or carry It himself. Many employees prefer to seloot the best lump anded and garry it home on thelr shouldars each day. Many miners expresed their complalnt that the oharges for coal were exorbitant. They felt that Bince they mined the coal there was no reuson why they ohould have to pay very muoh if anything at all for 1t. However, the 142 miners whose earnings were averaged had $11 t$ to to aay on thlo soore, ance they were paying 50 oente half or only $\$ 12.00$ for the year, and thus spent only 0.85 per oent of their earninge for fuel. This low price, however, was expeptional as most of the towns oharged double this amount. The average coet for fuel in the New River Flold in 2923 was 1.5 per cent of the averago arninge of the minere, or $\$ 35.50$. These 11 xed oharges, as bey been, fluotuete moh less than the prito of coal or wagen over a pertod of yeare. All ralning towns studied were equi pped with eleatriolty for use botb as power in the mines and for lighting and domeetio uses in the homes of the minera. 8ome nes bad motere Installed in the rarious house and othere ande flut rate oharges. Some oharged so muoh a room and otbero charged so much a house regardles of the plze of the house. Two towns oharged every house in the town the same arsount regardless of whether 1 was the one- or two-roon shanty ocoupled by Negroes who were matohing" or the superintendent's house of eight or more rooms. The flat olarge at I2 WId. Pp. 2456, 1453. 
these mines was $\$ 1,50$ a house, Hore unrest was manlfented by the Negroes at thie mine beoause of what the Negroes oonaidered unjust oharges than any other place visited in wx counties. Those oharges do not inolude all-day eleotrio servioe in all cormunities. Iight at come pluces are turned off during the day except on Tuesday morning when the hougewive aro permittod to ue leotrlolty for ironing. Operatore have sald this reatriotion is neosesary because of the fact that, whpre a flat rate is obarged, the 11ghts are left burning day and night. There was evidence in some plaoes that thi contention wat unfounded. Where weters are installed in the homes the usual rate ia about 10 cents a kllowatt hour. It lo very diffloult to estimate the cost of the eleotriolty to these 143 llegro miners beouse they all had metere and no separate oharges wero made on the pay roll for 11ghta, but if the nore frequent rates bo ued, based upon the number of rooms, the probable cost was about 70 oonte a half for lighto, or 1.2 per oent of the average eurnings. This entinate 18 somowhat larger than the forcentage found by the Coul Comingalon, thetr ligures being . 6 per cent and .9 per cont reapeatively for the New RAver 13

and Kanawha diatriote. It may be that the Commialon included mining towns whioh did not use eleotrioity to a great extent in the housos. At any rate, the oharger for eleotriolty in the towns in the Kandwia and New Miver distriote investigated by the preaent otudy are higher than 13 IbIS. P. 1456. 
those found by the Comm1sion.

Another oharge which is praotically univeral is for the burlal fund. These funds are for the purpose of bearing the expende of burlal in ease of the death of the alner or one of his fumlly. The amounts which these funds pay the ininer vary from wine to wine and with the age of the person dying. Tiso burlal of an adult oalla for a paywant of from 160 to 275 in most plaoes. Aleath of a villd usulily calls for a payment of about $\$ 50$. For this "insuranoe" beainst these omergenoles the miner pays an average of ubout 50 oente hall, or 0.85 per oent of his earninga. The figure given by thi Coal Commission wes 0.9 and 0.5 per cent for New River and Kanawhe districts.

Company oharges for the oupport of the ohurch are wlso customary in olaces, aystem in bigh favor with the preacher who hold oharges under 1t. More Irequently, however, the ohurehes are upported by voluntary oontributions. At oortain of the mines the amount to be oheoked off eaoh pay day 1a determined by the cholee of the miner. but at one mine, the one in whloh the Negroes complained most, the ohuroh oharge of 35 oente a half was made, and the writer we told by the bookkeoper tat the employee who "know what wa best for him" at that partioular mine pald 1t and asked no questions.

Another ohirge, optional in mot places, was for the use of the bath house. Very few of the operations have 14 Ib10. 
bath houses, Host of the miners take their baths in tin tubs in their kitobens. The usual bath house is an ordinary building with Beveral shower baths where the men ohange their clothes before going to work or going home. By means of a rope through a pulley the miner pulle hlo olothes to the celling above the reach of persone entering the bath house and looks them in position by a pad look through a ring on the end of the rope and a large etaple in the wall. Hany of the Negro minerg eleoted to bathe in tholr kitonena and save this ohargo.

Thus we find that the lixed ohargea disoursed above make up most of the 71.9 pet cent of the earninge whloh the Negro mers paid baok to the company. The remaining few per oent not aocounted for by these usual charges may be 100 i 1 nnumerable matters, The attitude of many of tive Negroes toward the companies 18 one of dependenoe in time of need, whether the need be the purohase of some new artiole of furniture or release from jall after some unfortunate affalr during a vist to a nearby olty. The oompany thue make advanoes of varlous kinde and writes thew of eaoh pay day. It 18 probable that the remaining charges were vostly of this kind,

III. PROPERTY OF THE MEGRO MINER,-

One of the wost signifloznt fsote which, because of its Importanoe as a faotor in underatanding the Negro miner in West V1rinia, w112 bear repetition 1 that woat 
of these Negroes did not come to Nest Virginla with the 1dea of making their home pormanently there. The very large majority of thom came from agrioultural parentis from V1rbinia and the atates south of 1 t. Thelr eoonomio values, in many cases, were agrioultural values with emphasi upon ownershlp of land. Their Idea, in most oases, was not to givo up tho fari home, but to leave it temporarily for the purpose of naking money enough so that with inoreased prestige and comfort their I1ves could be l1red out not in Weat Virginia, but in the places they peak of as "bak home." olroumstanoes have intervened to prevent this seturn in wany oases, and they have remained. It would seem, however, that their break from the land 1 a g gradual prooese, and even though they remaln in West Virginia inany of thom inveat their eurnIngs in farme or in some form of real estate. The Bureau of Negro Welfare and statistto raports that everal hundred Negro workere in the mines of MoDowe21, Meroer, and Mano oounties elther own farm in V1rginde and North Carolina themselves or have near relatives who own farme in these plaoes, Whon work is 1rregular and wageo reach a cortain minlmum they go to these farmo unt 11 work in Fest Virginia 1. more plentiful and wages higher, ${ }^{15}$

The effort was made in taking the sohedules of the minerg to asoertain the amount of real estate owned by oeob miner. Because of the economic oonditione of the flelds in 1933 the acoomplishment of this teok was most I5 Bureat of Hegro Telfare and statiotion, Report for 1932-1934, p. 9. 
diffioult. The epeolfic reason was that in oertain plasen it was necessary to give rellef to the miners, who were not raking enough during the summer of 1832 to feed themselves. If a miner had property, however, the agenoles of relief were hesitant about giving to him, The miner, on the other hand, was not able to see why he hould reosive less aid when he was w1lling to work than some other miner who had worked no barder and bad put his monoy in food, clothes, or automobiles instead of in land. He looked upon himell as entitled to ald, since bis ldienese was nat of his choosing. The miners core consequently on the alert for any kind of an Invertigator who might IInd out they had property and stop their rellef. Explo1ters, partioularly those with white skins, are no etrangers to the Negro in the mining 11elds. They have learnod muoh by b1ttor exporlenoe. Often the miner.would otop the writer and ask, What are you seli1n'p" As a result it is probable that the property liated is somewhat less than complete.

One hundred and nineteen or 19,83 per cent of the 800 Negro miners answered the queation oonoerntng the ownershlp of real estate in the affirmet1ve. These 129 minera owned 51 farms, $8010 t \mathrm{~s}, 36$ houses and lote, and one store Independently. Three others, Tennessee nitives, were part owner of farms in thelr native state. It must be remembered that the ownership of real estate by most workingmen weane tho ownership of home. This priv1lege 1s, for the most part, denied the Negro miner in weat Virginia. At 
atated before only 13 of the 600 miners were living in their own homes. If 1 were possibl to own the1s homes rather than rent company housea, it 18 probable that this 11 at of real satate owners rould be muoh larger.

Fifty miners owned 51 farms in $1 x$ atatee. Twentysix of these, al might have been expeoted, were located in Virginia. Nine were in North Carolina, four in West Virginia, tiree each in Alabama and Tennessee, two each in Now Jersay and Georgia, and one $1 n^{\circ}$ South Carolina. The looation of the remalning farm was not given. One miner owned two faras, both in VIrginia. The highest value plaoed on any of these furing was $\$ 20,000$. Another was valued at $\$ 20,000$ wille wost of thein were said to be worth $\$ 2500$ or 1ese. Some of the minera would not put any value on their farms. Nineteen of them, however, valued thelr farms at an aggregate of $\$ 58,850$, or un average of $\$ 3,097.37$ per farm.

Although only a few of the 600 minera were living In their own homes, that fact did not keop them from inverting in houses and lots. Thirty of them reported ownership of 33 houses and lote, 33 of which were looated in West Virginla, a rule in towns or oitieg near the mining operatlone to whloh the miner drive in their automoblies. Four of these homes were located in Bluefield, four in charleston, three in Huntington, three in Keystone, two eaoh in Weloh, Logan, and Hill TOP, and one each in W1 Ison, Institute, and Spring H111. Near or in Charleston, Beckley, Payettev11le, Logan, Bluefleld, and Feloh, the county seate of Kanawha, 
Hal olista, Dayetto, Loban, Heroor and MoDowell counties towpout lvely, were Nogro seotions in whioh many Negro minero and their families lived. Johnoon gives espoolal attention to Beokley, in which 95 per oent of the Negroes owned their

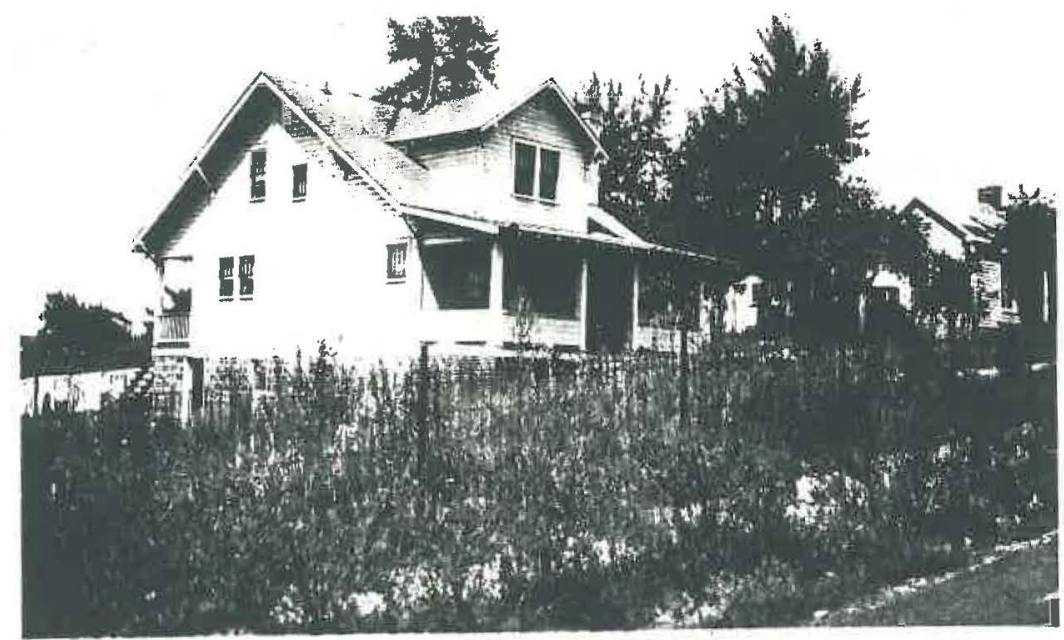

Home in Beokley Owned by a Magro Miner

own home in 1928, ${ }^{16}$ the Beokley realdent representing a larger peroentage of Negro home owners then at any other place ment 10ned. These homes ranged in value from $\$ 1,000$ to $\$ 15,000$, the average being $\$ 2633.50$. Of the f1ve per cent who live in rented property 63.5 per oent rent from Negro landiords. Twenty-two and elght tenthe per oent of the renters own property in other oftles. The average rental paid by the renters was 17.43 . The writer Viaited several homes of Negro miners in Beokley, or Lat Beckley as the seotion 18 called locally, and found them 16 The Negre in Amerioan Clvilization, p. 219. 17 IbId. P. 320. 
to be exceptlonally atsractire and well kopt. 411 isited were nicely furnished. Negro seotione were visited in all these towns mentloned, but none was as attractive or as well looated as wat of Beokloy, aenter of the rioh Winding Gulf and New Rdver coal flelds. Some of the 35 Negro businese establighments of Beokley were run by men who were formerly minera, some of whom were interviowad. of the thirteen homer owned outide of West Viriginia 5 were located in VingInia, 4 in North Carolina, 2 in Mlabama, und one each in New Jergey and ohio. Thewe homes sanged frow the "ahanty" of one Negro minex to home valued at $\$ 7,000$. One miner valued hlo property, four houses, at $\$ 25,000$. The elghty lot were owned by 40 minera. Like the houses and lot: most of them were loosted in West V1rginla. Eighteen were in Charlegton, 7 in Beokloy, 6 in Salnt Albane, 4 in Wyoming, 3 in Bluefield, 8 each in Ingtitute where the otate colloge for Negroea 1 g looated, and Levi, both near Charleston, and one each in South Charleston, Deepwater, Fayetteville, and Matoaka. The total of the lote loaated in West Virginda was 46 . Of the 34 lots located in other states 14 were in New Jerbey, 3 in Virginla, 5 in New York, In Ohlo, 3 eroh in Alabama and North Carolina, and tho location of one wa not given. The location of the Onlo lots was the olty of Warren and they were owned by Negroes in widely separated flelda. These lots as well as some of those looated in Weat Virinia 18 Bureau of Negro Welfare and statlatios, Report for 1827-1928, p. 36 . 
were probably sold as a regult of the activity of sales agents. These lats were valued by the miners from 150 to \$2,000 aplece, the avarage being about $\$ 779$.

Certaln of the Negroes, while they reported that they held no real estate at the time of the interview, sald that their property, previously owned, had been taken for tuxei. Otherg aeld thay were not sure whather their property had been sold or not as they had not pald their taxos for a good while. This lose of property is partly a result of the depressed oonditions that have existed since 1939. The writer was told, however, that those Negroes who come from farma to whiloh they huve no ldea of returning, if not able to diapose of them, often let them be taken for taxes.

One hundred and twenty-three of the Negro minere ownod automoblles at the time of the lnterviow. One hundred and forty more, although they did not own them at the time of the interview, had previously owned cars. Thus, 43.83 per cent of theae miners efther owned or had owned at some t1me an automobile, wh11e 30.5 per oent of thom aotualiy owned them at the time of the interview. The kinde of oars owned by the Negroes, covering a wide range of prioe and 81ze, ware a follows: 


\begin{tabular}{|c|c|c|c|}
\hline Make of onr & Numbar & Yake of Car & Number \\
\hline Chevrolet & 27 & 01 demob110 & 1 \\
\hline Ford & 26 & Stearns-Kntght & 1 \\
\hline But ok & 16 & overland & 1 \\
\hline Hudson & 9 & Cadiliao & $i$ \\
\hline Dodge & 9 & Mormon & $i$ \\
\hline $\mathrm{Nash}$ & 7 & W11yg-Knight & $\bar{I}$ \\
\hline Studobaker & E & Ohandier & $\overline{2}$ \\
\hline Esaex & 3 & Palge & $i$ \\
\hline Ohryoler & 3 & Desoto & $i$ \\
\hline Whilopet & 3 & Hupmobl1. & $i$ \\
\hline Jewet & 3 & Plymouth & $i$ \\
\hline Pont1ao & 3 & Roo & $\bar{i}$ \\
\hline & & Durant & 7 \\
\hline
\end{tabular}

Some of those who had formerly owned ours lost them auring the present depressed conditions, the f1rma from whom they were bought reposeasing them. One Negro miner aald that he had pald all but $\$ 30$ on a $\$ 1400$ our and, baing unable to meet the laet payment promptly, his oar had been taken from hIm. Some of the Negro minera were quite frank In gaylng that they logt their car booause Ilquor led been found in them. Liquor law vlolationg according to the err ployer are probably the most frequent oauses of arreats of Negro minere. Arreste beem in fact to be looked upon wore or lese is the normal thing to be oxpeated, by some of the Negroer. At one of the mining towns a man was interviewed who, while living at the town, was not working in the mines. Upon Inguiring what he did for a living, the writer was told: "Oh, nuthin' muoh, I just makes a little liokah onoo in a while,"

In the purchase of both homes and automoblles by Negro minere the companies take a prominent part. Trusted 
Negro employees are often glven large "advanoes" by compunies. For instanoe, one Negro miner at Mne Number Two was advanced 441.92 to pay on a house for whiloh he had paid oompletely exoept for \$600. This amount was cheoked off his socount each pay day until finally pald. While the writer was working in one of the company offloes on 1tis fay rollg a Negro miner who had bought a oar oame In to weo about borrowing money. The bookkeeper told tirn to get two good Nagroes to endorse for him so that "if you get buspad off" the company rould not 10se. Ho was not to get "anyone like Henry W." to endorse, but to get good workers. He oame bidok the next day saying that the man had oome for ble oar and that he could not get anyone to gign for hlm. The bookkeeper then told hill to get Henfy w. to eign for bla, which be did, and his oar was aved. He was bohind one payment beoause he had been slok.

These loane are sometimes not made through the ooal oompany direotiy but through loan oompanies which, because of Interlocklng di reotoretes and identioal offioers, amount to the same thing. Loane are made to the miners, as well as to other people, at high rates of interest. The present depression has ell but wrecked several of these compantes. In northorn Fest Virginia certain of the b1g coal companies and finanoe oompantes deallng in mall "personal" loang to miners were threatened with Indiotment, beoause of 11legal oharge日. The writer knowg of no slatlar 19 Lorgantown (W. Va,) Dominion-Hews, Jan, 8, 1832, p. 1. 
threats in the southern countios, however. Another souro of money, in umount allowinis the more expensive puraheses of automobiles and other comodities. 18 "Compenestion" for injuries reotred in the mines. The writer wa interviewing the mother of Hegro miner and the queation conoerning the ownerahip of an automobile wao asked. The reply was! Mo, we aln't neter had one - but the boy had his finger out off and we tillnk wo'12 get a car." Company offlolals olalm that minere deliberately chop thelf flngers off for this reason, atatement that the writer 1 a inclined on a priorl grounds to doubt. The orowds, whiob gather when the ambulanoe 1s oalled to the tipple to recelve someone who has been injured, express great catisfiction when the 1njury 1 a found to be merely a mabed foot, loss of finger, or some ouch injury. He luoky, observers say, "He!ll get 'oompensetion! "In compeneation olalms net the Injured miner muoh more then he can earn by working every time the mines operate.

As has been sald before, the Negro miners were reluotant to admit to the writer that they held real estate. To get them to say that thoy had any savings was almost in poeslble. Eleven miners, howover, adinited having saving acoount sotal Ins; $\$ 4,617,83$, and many more probably had subotantial saving accounts. Wany were also carrying insuranoe of various kinds, lokness, straight $11 f e$, and endowment policles. The ondownent pollcy was soemingly very popular with Norro minera and represent their preparation for old age. 
Suoh investment a those named abore are the ohlef maznets whioh draw the earnings of Negro winers not spent with the company. As we have seen, nost of the earnInga of the Negro miner find their way back to the compantes in some kind of oharge which fact adde to the frofits made in other ways than the direot produotion of coal. In oplte of tis faot, a conalderable number apparently biva been able to accumulate and to hold some property. 


\section{CHAPTER VIII}

THE COUPANY-OWMED TOWN

I. ORIGIN AND NATURE ON THE COUPANY-OWNED TOWN,-

\section{All but one of the towne viaited were company} owned. Company ownerehip is Indeed inevitable under the syotem in which the ooef flelda ware developed. For the moot part, the mines wero looated in undereloped and sparsely cettled country. Isolation due to zaok of roade and to the remote lootion of the operations from independent, self-eustalning towns or olt1as, was a vory real faotor in shaping company polioles. The operator, was forced in the absenoe of any other agenoy to build houses to shelter his mon and to provide all ot her resouraes necessary to even the almpleat and rudeat 11fe. The system persista almost undversaliy throughout wast V1rginia even though the former 1eolation has been partly overoome.

Company ownership of all agenoles in the town, whioh means that the agenoles are prationlly out of the control of the workers, brings about s oondition for oolored and white al1ke thet ounnot be overomphasized in any attempt to desoribe the life in a mining community. The Coal Cownisaion found that in Iners pay a smaller rental I See Report of the U. S. Coul Coimission, Pt. II I, P. 1438. $\Rightarrow$ Cf. Stark, Louls, In the Blikhted Realm of the Miners, New York Times Magaz1ne, Oot, 11, 1931, P. 9. 
for oorpany-owned houees than for others; that the oocupante of the oompany-owned house get their fuel and frequently their 1 ight at a muoh lower aost than other wage earnera; that they frequently are not oharged for water oven though 1t is piped to the premises; and that they may have medioal servioe for themselvea and thelr familles at small coot oomm pared with the expene of auch aervioe under ordinary c1r3

oumstanoes. The Inferenoe here is that these low costs allow a larger conmumption of goode and services on the part of the miner. Howerer, North point out, in desoribing any oulture we must bear in $\mathrm{m}$ nd that all of the altisfactione of a group are "not oovered by the plane of IIving." The same author in another volume refers to a writer who apeaks of the present order as a menevolent foudalismo" Whether or not the limiting adjootive above is applicuble to the system inhering in the mining industry, there are cortuin reomblanoes betwoen it and foudalism.

It is well. Lowever, to keep in alnd cortain aspoots of the situation soretimes overlooked. L part of this paternal18m, as has been ald before, is forced upon the operatora by oonditions they did not oreate. In the seoond place, because of the faot that oompantea have to provide all oommunity resouroes under the capitalletio development of the ooal flelde of West Virglnia, whatever 3 Report of the U. S. Coal Comal selon, Pt. III, p. 1437. 4 North, C. C., Soolal Problems and Boolal Planning. MoG raW-H111, 1932, p. 43.

5 North, c. c." Soclai Differentiation, University of North Carolina Pres8, 1926, p. 30. 
is furnished the employea by the oompantes 19 always aubjeot to their own linited resouroes.

Another selated consideration is the faot that the rating town is a single purpose community. When the mining of cual coases, it reason for exfetence cosses and it dies. Consequently the mining oompanies have in most oases been unwilling to bulld ootty houses and make expensive laprovenents, for they know. that these investments would be an almost complete lose were the operationts to stop. The Cosi Cominision infers that the restricted 21 fe of minlag operam tions is an overstressed reason assigned for fallure to provide aubstantial, permanent communty organization, equi pment and rosouroes. It polnt out the fact that over 60 per cont of the Fest VIrginia mines were estimated as having a probable 11fe of 30 years or more, running as blgh a 200 and areraging 43 years. It further indloated the faot that of the 82 oommunties whlob the Commisetion conBldered as ranklng loweot in this regard 31; or nearly 38 per cent, had a probable remalning $11 f$ of from 30 to 100 years. The inferenoe on the part of the Complagion that this reason is somewht overemphasized is no doubt correat. It should be borne in mind, howerer, that the probable ilf of the miner was based upon an assumption of the continuanoe of the oonditione provalifng when the estlmates were iade. Mines do not cease to operate beoause the ooal is exhsusted 6 Report of the U. S. Coal Comalarion, Pt. III, P. 1432. 7 Ib1d, p. 1433. 
but booque the inoraalng oost and decreasing returns as the mine is driven deeper into the earth reaoh a point where the company oannot oompete in the market wh the newer operations. Then, too, the ame oondition exista as a result of the oompetitive syatem in mining as in other industrles: the employer of soolal vieion 10 greatly handioapped by others interested only in profit who w111, in dase of his outlay for 1 mprovements, undereell $12 \mathrm{~m}$.

The mining induatry, 11ke otber Induatries, funotions through the agenoy of oorporate organization. Stook holders an a fule ask but one question. They are interested only in the regularity and amount of dividends. The averoge superintendent or manager of oompany-owned towns thereforo regards thee comuntios not a experiments in soolal welfare but as "busines propositiono" with all that the term infere. Mininis operations are, 11ke tnost other industries, what one writer has termed "profits factories." Mining operators are not, in the opinton of the writer, a group of consoious exploiters, as they huve often been described. They are playing the gune of Industry aocording to the aom oupted rules of the mintno fieldei if explodtation is pero uittad by the mores, only the very exoeptional entrepreneur over achleves a oritioal attitude toward provalilng norm of boukvior. Conformity with the mores of the time and place rarely realte in coupunotious behavior.

All gradationa of conditions were found in ooupany-owned town. Unfavorable physiosl looation, limited 
finanolal reacurces, and narrow woolal vision combine to maks some of the communt to bighly undesirable places in which to 11ve. As the Coal Cormis saion well sald, "In the worst of the corapany-controlled communities the state of diarepalr at times runa beyond the power of verbal deacriftion or even of plotographia 1lluatration, sinoe nelther words nor plotures oan portray the atmosphere of abandoned dejection or reproduce the smells, " Buqh sommuntities, Lowever, are by no means in the majority. It ahould be cbserved that the newer town are moh eupertor to the old towns. Thlity years ago oleotric 11 ght and muning water near at hand were very infrequently found. In 1932 none of the towns visited were without them.

The resources of the companies have a great deal to do with the oonventenoes provided by them. The leat dealrable of the oommunities visited were those of siall companies with little capitalization. It 1 a to the condit lons found In some of these smaller operatione that the term, "mining camp, owes 1te orig1n. Thi term, widely used to designate any mining oomminlty. 1s resented by certain of the operators as belng a misnomer, for many of the communities have none of the ear marks of a "camp," and, with pared atreets, running water in the houses, eleotric Ilghts, and sewage disposal, onjoy faoll1t1es ouperior to many non-mining rural communtt1es. Bathrooms in the houser, however, are unusual exoept in dwellings oogupied by a fow 8 Ib1d. P. I431 
men in the positions of authority. At oertain plaos, too, It is most diffloult to build attraotive and conventent

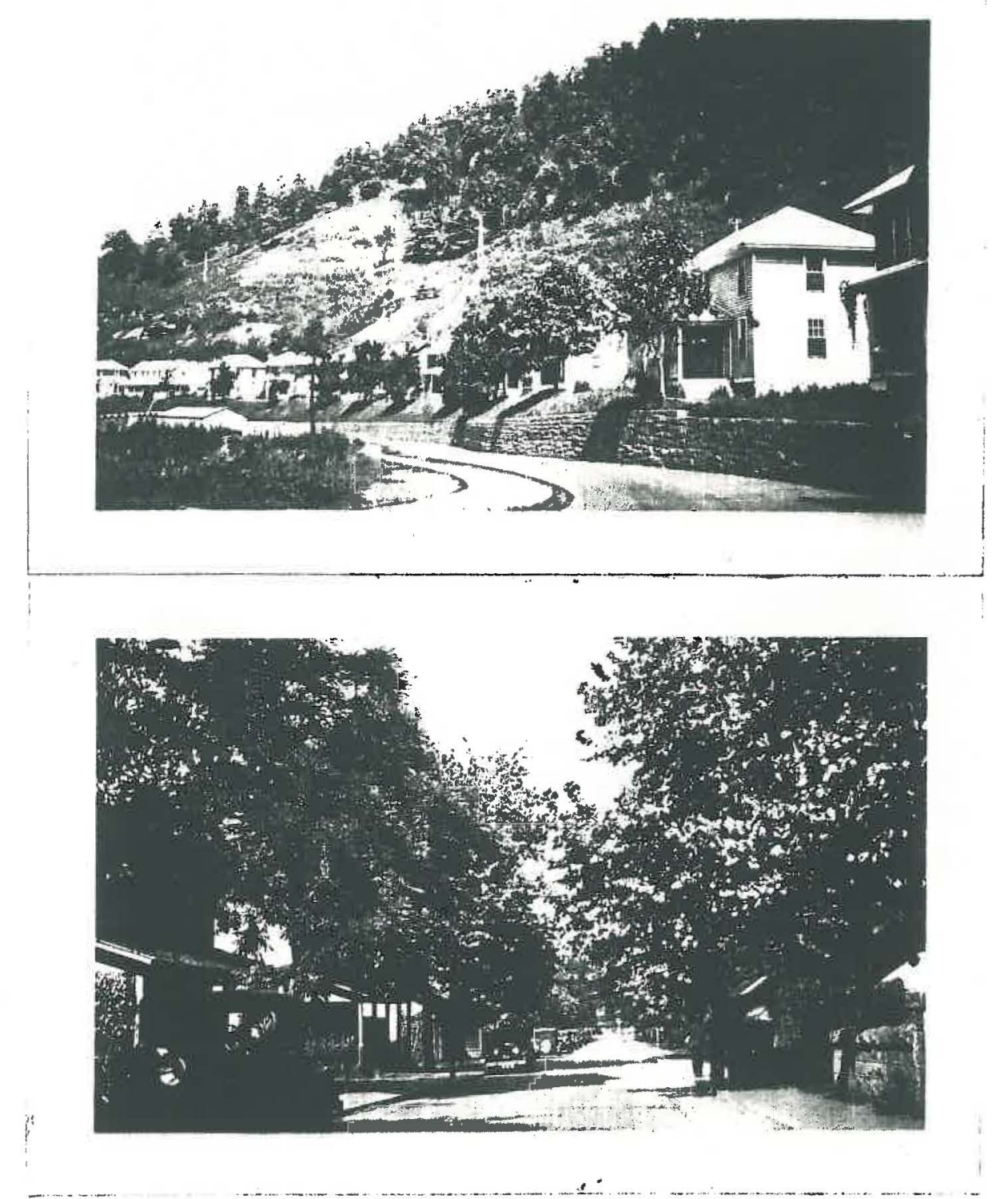

Two of the best company-owned towne

towns because the only avallable looations are anall spaces betwoen high hills. These physical handloaps influenco reoreation fucilities oonsiderably, A baseball ground or even a tennis court is impossible in some of the towns, 


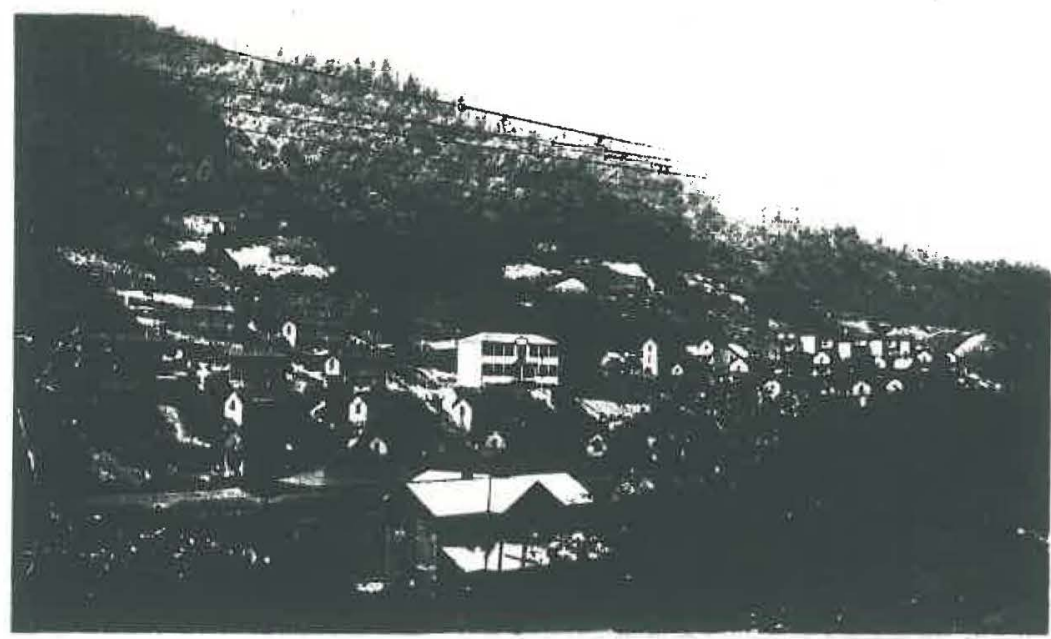

A Diffiquit Location Vegro geotion of a Ralolgh Oounty Mining Town

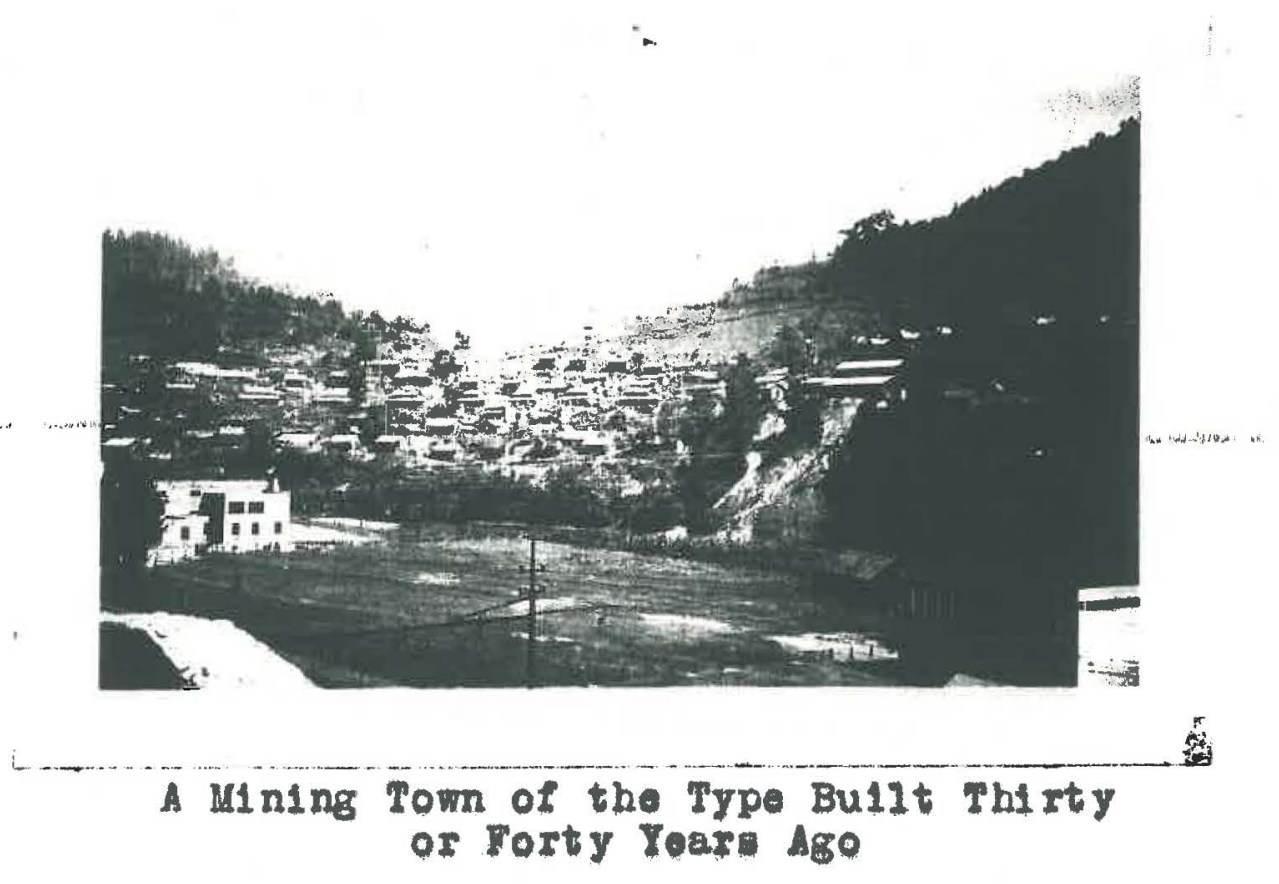

II. COMPANY STOREB,-

One of the inevitable conoomitants of the oompanyowned town 18 the company store. As has been pointed out before, the Negro miners appear to be, in proportion to their earnings, the best of the company outomers. Company 
atores are a souroe of a substantial part of the profits of many mines. These store are managed, for the most part, by store manegers who have lientilied thei intereete with 8

that of the company. Some of them take pride in making money for "our oompany" by ohafglng prioee blgher than are ordinarily oharged in independent oommunities, One of these atore managers boated of the faot that he had been able to "get baok" 46 per oent of the pay roll at that partioular mine. When the writer expresed surprise at his feat he showed him the store report for the years 1926 1989. The grosa profita wade by that company atore for these yeare were $43.7,49,9,50,2$, and 47,0 per cents respeotively. The manage's Iigures oonfirmed hla bosst. The re is no intent to infer be thet all oompany atoree operate at these exorbitant profiti. At some stores the prloes were found to be muoh lower than at others. A Iarge oompany with mines in sereral states was ald to be competing with the prioes ourrent in chain stores. These low prioes, however. existed only in the presenoe of compet1tion from independent atorea; in isolated oommunities where the miners leoked easy acoes to independent otores the prioen were not low.

The Coal Commasion made a study of the comparative prices of 54 food artioles that in the egrregate 9 Of. Payne, W. E. Belavilor of Conflioting Eoonomic Groups, Olito State Un1r. Pres8, 1930, pp, 100-101. Cf. also U. S. Coal Comml salon, ReportB, Pt. III, p. 1461.

10 of. Rochester, 2p, oft., p. 87. 
oonstituted 96 per aent of the total quantity of food purchas od in $18 a 2$ in the commun1ties where sohedule atudien 12

were made. The Commlesion found that a year's supply of food for a famtly in he Maw River and Kanawha ditriots oost 4. 3 per oent more in oompany atores than in the inde12 pendent atores. With the ooming of the many obain atores and of lower prises alno the Commi enton's atudy, the differenos between the priog oalos of the two syateme has apparentiy inoreased. The writer in comparting the prices in Individual conoern found oertaln artioles of Identioal brande selling from one-fourth to one-third higher in the company stores, Although the store managers are wont to ola1m superiority of quality for tholr produgts, 1dentity of brands of many artioles cold in both independent and company stores tends to controvert auob assertions. In faot one store making exorb1tant profits was ald by one of the bookkeepera to be salling second quality goods,

How oan the oompany atore oharge bigher prices and yet compete with tha independent stores? In the firat place, the oompany otore is looated convoniently in a oen tral part of the mining community, usualiy in the same building. with the past off10e, and honoe it is frequented by the miners when they go to get the wall. The oompany store, in other words, la not only a plape to buy goods, but in many towns it is a sort of oommunity center where II See Append1x II, Pt. III, pp. 1513-1541, Report. 12 Ib1d. p. 1461 . 
the men gather to loaf and talk wh one another. The stook of goode is thue "at the elbow" of the ohopper; it is also usually moh larger than in the nearby independent otores. Another potent reason for company patronage is that the independent atores conduct businese on a cash basio, wheread the company stores 1 seue sorlp with which supplies oan be bought just as fast as the oarnings of the miner aocuralate. Finally, no independent atorea may be ereoted on company property. In the more laolated seotione this restriotion 1 in in effeot a mandate to the 1 doal minere to trade at oompany atore.. 13 The partial break-up of the isolation of the mining fleldo has, however, tended to lessen the abuees of the oompeny etore monopoly. ${ }^{14}$ Grooery truoks and huoksters erequentiy drive through the mining village sollo1ting trade from the miners. When the mines are running steadily and the minere have oas the trade at these "Btores on wheels" become considerable, but in lea prosperous times it takes very 11tt 20 patronage amay from the company atore. At one operation a coneplouous algn read: MPrivate Property -- No Truoke Allowed,"

some employers olaim that they make no differenoe between the employees who trade at the company atore and those who do not, usually adding, howerex, that they feel that the oompany should have part of the minere' trade ainoe it provides them with work. There is evidenoe that I3 CI, Feesong giren by Coal Commiasion, Raports, Pt. III, D. 1462 .

14 Shuriok, ope oft, p. 306. 
some compante bring positive pressure to bear on thelr employeer to trade with them. In reoponse to the question as to the extent of the ninare' trade outside the company etore, a bookkeeper repl1ed "There is not muoh, You see we bring pressure to bear to make the men trade bere. of oourse, (he smlled here) we wouldn't flre man for not trading at the store - but he could be let out for conething else." At an operation in rayette County the wife of a Negro miner eald that men were out off if they did not deal at the oompany store. In one of the northern ooal countles not covered by. this study a Judge "soored the practices of oosl operator who dimis employees for failIng to buy at oompany stores and who permit the store operatora to oharge exorbitant prioes for oommoditios sold to 15

miners, A store manager at on of the operations Indloated a oertaln limited toleranoe 1n this matter. He sald We do not pay any attention to competition. We don't make the men trade in the etore. The only case in whioh we bring pressure to bear is when the miner gets to shooting off his mouth and IIghting the store,"

In bad timee, It 18 true, the oompany store al low the miner to oharge food and oupplies to tide him over unt1l work 1a more plentiful. In this inatanoe the oompany store may render a servioe Imposalble to the independent etorea, for the independent stores eldom have the ability to extend the thousand of dollara oredit noeded IE Morgantown (w, Va.) Dominton-Hews, Jan, 8, 1932, p. 1. 
In suoh timea, whereas the company store has the entire resouraes of the company back of it. In some instances the company seeme to inglat upon perforind no this service. One of the Iarger sompandes boasted that it took oure of its aen and pointed a disdainful finger at the compantea whose winero were being given rolief by the county. This company I soued a cortain anount of food to the minoro and oharged it to thair aooounte, to be repald when work should get botter. The auperintendent told the writer that he lud "fired" several men for sollofting county rellof, and that he would "fire" any others. who did.

The writer is inolined to agree with the Coil Comintesion thet the oompany atore is at 111 a necesary Institution in oertain places, That it hes not, bowaver, been free from abuen and that it oerlp oystem has operated to encourage extravagant and parelea buying on the part of both whiter and Hegroes pan soaroely be doubted.

III. COMPAKY DOCTORB. -

Company dootorn: I1ke otore managera and other members of the "white pollar" otore and offlo foroe, have a considerable 1dentity of interest with the company. The dootor indeed manffest a tranafereno of interest identity rore complete than do the store managera. The average dootor'a attitude prevalle in oplto of the faot that, whereas the atore manager reoelves his salary from the oompany I6 U. S, Coal Commission, op. o1t., p. 1463. 
and 1a pald out of oompany profits, the dootor reoolves his balary from the methe by a direot ohook-off from their wages and 18 properly not a "company dootor" but a miners" dootor. Payohologloal $1 y$, however, the arerage doctor is coneclously a "oompany" man. In any oase domanding loyalty to one side or the other he 1 wash more likely to be found on the side of the company than of the omployee. Although the minero pay him in the non-union flelds in whioh this study was oarried on, he is omployed and tdimissed not by the men but by the oompany, an arrangement at least partlally responelble for the rapport usually exlating botween him and the oompany.

\section{Clashes of interest usually ooour in questions} of oompensation for injury. Under the law of West V1rginia the olatmo of the injured minera axe handied through the company dootor. His reoommendations have muob to do with the disposal of the olalins of the miners in the operations where he practicea. The rate of a company, however, is based upon the amount of money paid out in olalms to miners of that company. It is thus to the interest of the oorapany to get the wen back to work as soon as possible and the dootor must profesalonally make the deolalon as to just when a miner 18 able to go baok to work. The oompany offlclal claim that muoh malingering oodurs among the miner who sometimes refuse to go back to work when the doctor orders them. The writer has been present in company offloes when conferenoes botween managers and dootors regulted in 
the disoharge of minere following thel refubal to go baok to work after the dootor had dimissed thelr cares. The writer cannot of oourse dealde upon the merits of these clalns. It 1s true, howerer, that the Hogroes in rome places voloe distruat of the dootore, The writer was told at one operation that the prealdent of the oompany had a son-1n-law on the ataff of the hoapltal to whioh the minere were sent for treatment, who had them dismissed from the horpital even before cure was complete. The valldity of suoh claims oannot bo established, but the fact that the olalms are made indloate that the Negro minera are diasatiafled with oertain features of oompany oontrol of medioal faoflitier,

The company dootor, 21ke the company-owned town and the company store, 1 s an inevitable oonsequenoe of oonditions in the mining fields. 17 Although good and bad phyaloian way be found emong the oompeny dootore, the 1impression of the writer is that the dootore are on the whole an unusually oompetent and oonsolentious group. Some of them have been outepoken in oppoelng company praotioes whioh endangered the healtb of the miners and their fam1lies, olinios are held oooesionally and, in certaln places, unueual programe have been fostered by the company doctora. Company dootore in the operations visited were without excoption white men. A Negro physiolan practioed in a emiIndependent town in Logan County; he was not, however, a 17 See U, 8. Dept, of Labor, Ohlldren's Buresu, Bulletin 117. 1923. 
oompany dootor. Although the doctors have pronounoed oompany leaning and vary few showed violent prejudioe, the attitudes were with few exoeptions friendiy to the Nerso winers, some of the physlotans expreselng themselves as prefering to make a professional oall in the average Negro's house rather than in that of a white miner. Probam bly the Negro miners get a a male better than average modical aare at a relatively small oost. Most of the dootors oldim that malingering by Megroes 18 1ees Irequent than by whited, Bald onel I have neref had a oase of trouble in getting a Negro baok to work. When I tell a Negro to go baok to work he does so -- and eske no quegt 1ons,"

IV. LIVING IN COMPAHY HOUSES, -

In dlosuseing some of the costs of $11 \mathrm{v}$ ing in the mining flelds we have already ind oated that the rentalo pald by Negro minere in company-owned towne are lower than those whioh ordinarily exist in independent towns. Not only is the rent oheaper but otber household expensed for light and water are frequently oo, little has been sald, however, conoerning the terme under whioh the rniner, elther white or colored, way I1ve in company houses. These terms are quite different from those he would enjoy under the ordinary lawe of tenanoy. In faot, a lease used in Raleigh County expresily atates that the ordinery relation of landlord and tenant is not oreated by signing of the agreement 
between operator and minex. Its wording 1 es followe:

And it 1a expressiy agread and understood that this agreement bhall not operate or be oonstrued to create the relation of landlord and tenant between the partioe bereto under any c1 roumstanoes whataoever, and that no holding over or continued oooupanoy of any house and prealies, wentioned rereln or contemplated hereby, after asd omployment or aervioe hae terminated, ohall Bivo r1se to the relation of landiord and tenant or be construed to e tabliab suob relation and this agreement is personal to sald party of the second part.

Leases whioh both white and Negro miners wot aign In West virginia do not differ matarially frow those required by the minlng compantee of other etates. The coal companies bu1ld houser because they want to keep a supply of workera, or, In other words, man geta his right to ocoupy a company house beoause of his atatu as oompany employe. When this relationshlp of employer and employee is terminated o also is the right of the miner to oooupy a oompany houre. whether or not that relationehip is terminated by the com pany with oause. The 19ase ordinarily may be terminated by elther winer or company upon five days notioe. In some of the mining oommunities the miner must agres not to allow anyone objeotionable to the oompany upon the premisea. In the wording of the lease quoted beforel

The rald party of the seoond part doth agree to take good and proper oare of the eald prexisen. and that he w111 not board or harbor, or permit to $21 v e$ or remaln on oald premises, anyone ob-

18 See Appendix, Exhlbit No. 3. 19 See Append1x III, pp. 1678-1586, U. S. Coal Cominsaton, Reportp. Part III. 
jectionable to. of agalnat the wiakea of the gald party of the firet part, and that the party of the firat part may enter upon asid promiag and eviot any such objectionable person or persons; .......

The coingany pays itsolf in advance by subtraoting the rentel Irou the earning of the miner. The company maly logally put the winer and ble family out without notioe in aaso of diaoharge, and the sompany may withbold all wages due until the house is vaouted, retalning $\$ 2.00$ to $\$ 5,00$ a day for auch time us the miner lball ocoupy the hquse after digoharee. Ihere is some reason to belleve also that the oompantes prefer thel mon to Lire in oompeny houges. An in the case of the oompany store it is doubtiess true that men in compeny house are sometimes given prefexenoe over men who do not IIve in them, One Hegro woman Insisted that at the operation at whioh her busband worked the wen who did not ilve in compeny house were being let out, even if they omed their own homes, On the other hand, it is quite true that miners are permitted to oocupy housen in bad timea whether or not they are ablo to pay their rent. This conoession 18, of oourse, necessary on the part of the company becaue It muat have a labor supply on hand for resumption of operations when orders are to be fllled. During the summer of 1932 the witter found that come compantas had ocased oharging rent unt1I work beoam ateadior, but these ocmpantes ware exoeptional, More often the oharges were made each wonth agalnst the miner to be paid at sowe future time. Even where suob oharges are omitted pr the minera. 
permitted to IIve on in oompany housea, the polloy 1 a indloat1ve of a liberal attitude on the part of the oompany rather than any expreseion of legal righte of the mployea. This inseourity of tenure of both job and shelter on the part of the minex and be family mat be taken into aocount when considering the lower prices pald by the miner as completely positive values. The traditionel Amerloan right that "a man's house is his oastle" has undergone some major modifioations in the mining 101ds. In the non-union mines covered by the preaent study a man may be di soharged for any reason. The unintentionat incurring of the displeasure of one of the officlal of the company may result in not only cesaltion of Inoome but immediate loss of shelter by the offender's fambly. It is not meant to infer were that all companies are ruthlese in enforetng these prov1sions, but theil right to do so and the conoomitant laok of legal proteation of the miner agalnat such proceedings is not to be doubted.

V. THE COMPANY-OWHED TOWN AND LABOR ORAANIZATION,-

The role of the company-owned town in labor et ruggles is perhaps well enough known to omit any disouselon here except the briefeat oomment. The ordinary olvil libert1es of free aspemblage or free speeoh instde company communt les have been frequently dented on the ground of property Iights, 20 The oompany has the right, of oourse, उo U. S. CoaI Commt ari on, Pt. I, Pp. 170-280. 
to expel any person from its land whloh it does not want there for any reason. No meet ing can take plaoe on ooripany property whioh the companies do not countenanoe. Minera in the Pooahontas Field are aked to bign an agreement before employment is given them. The firat part of this contraot reads as lollowe:

I ain not now a member of the United Mine Workers of Amerloa, the I. W. W., or any ot her orjanization of mine workers, and w11 not during this employment, Joln or affiliate with any suob wine labor organizat ion, because I belleve the preservation of the right of Individual contraot, free from interferenos or regulation by others, and payment in proportion to bervice rendered to be to my interest, to the best interest of the publio and of all industry, and I enter this ouployment with the underatanding that the polioy of the company is to operate a non-union mine, and that it will not knowingly mploy anyone belonging to auch Union, or organization, and would not give omployment under any other oonditions.

Not all the mines require the elgning of suoh a contraot. but all operations in the countles oovered by this study are non-union and contemplate remalning so. In realizing this intention the oompany-owned town lo deoldedly an asset to the companioa.

VI. POLICE CONRROL,-

In maintaining non-union statur and in times of labor disturbance the coal compant have depended upon the Law enforoment agenoies to proteot their righta a property 2I See Appendi $x$, Exhib1t, IV. 
ownera. At the preent time the otate polloe and perhaps a looal offloer axe about the only law enforoement offlolals to be seen in most of the fields. The looel offloers or 1n "equires" are $11 \mathrm{kely}$ to be/olose touoh with the oompantes they are in faot frequentiy to be found in the offices of the oompanies, having entered with no more oeremony than the offloe employees. These offloere are white men in all ceses expept in HoDowell County. There, one or two Negro Just1oes of the Peace.or oonetables are to be found. The state pollce also cooperate olokely wh oompany offlolals, Aocording to a report oubmitted to the Cosl Commisalon by the Bitumi nous Operators' Speolal Committee, August, 1923, the United Mine Workers have oonelstently opposed the oreation and oontimanoe of the atate polloe in West V1r23 ginia. This faot would seom to indoate that the miners' unfon felt that these polfoe were at leat nore of a handoap than an aid to unionization.

In one oount $y$, however, the eystem is somewhat different. In Logan County the regularly conatituted law enforoement officers ase ausraented by deputy sheriff are pald by the coel oompaniea. The syatem oweo ita origin to the faot that the looal government has been unable to maintain law and order. Nearly 50,000 people live In the mining towns of this oounty, in which there are but two inoorporated towna, Tax ratea are very low, for a high 32 "The United Mine Workers in West Virg1nia," Fo. 133-135. 33 See the Civil Liberties Union's study, "civil War in Weot VIrglnia, for a balanoed and seeningly 1 impartial treatment of the eystem. 
rate would be zulnous for the farmers of the pounty. Since sums ralsed by taxes are insuffiolent to maintain a largo number of offloers for the maintenance of order, the deputy sheriffs have been appointed by the courts and pald by the 34

operators, some of the deputies holding corpany positions as atable bosger, paymaters, sanitary offloero, and the 11ke. As the system has worked out these deputy sheriffs as one of their oluef dutieg have had to be on the alert for union organizers. Ae a result Logan County beome notorious for 1 te breanes of ofvil liberty. A fitend of the writer was atopped by one af theae deputies for no other reason than that he was a stranger in town, He was bluply walking around the streets of the ofty of Logen, but he was taken to the court house by the deputy and made to show as beat ho could that he had no ulterior motive in viewing the town. Other men known to the writer were beation by these deputies, The writer himelf we in faot warned to be oareful in dolng h1s f161d work in order to avold a oimliar fate.

That the Negro has not fared too well when auspooted under this syetem, Harris Indicates by using the followling quotation:

$$
25
$$

A Negro miner of Logan County tell of a converaation between himseif and the sheriff. "Don Chafin (aheriff) baya: II want you to go up and get around amons them men and I Ind out who is trying to organize and report baok to me.' Then be told the others, "Luther is going to come olean.'

at U. S. COQI Commleston, Roport, Pt. I, pp. $172-173$. 25 spero and Harris, ope o1t., p. 378. 
And Squire White saye, If you don't oome olean, by God, we w111 k112 you,' I Bays, II come olean, you let me go!"

This situation was probably not made better for the Negro winera In Logan County by the faot that, during the period in whioh the Ku Kaux Klan thrired in weat Virginla, Logkn County was atrongly Ku Klux, the organizat Ion adding ant1unioniom to it more familiar oriteria of Amorioaniam,

VII. THE MRORO IN THE COMPATY TOWn,-

How has the Vegro adjuated himself to oonditions in the oompany-owned townt. From the polnt of view of the employera of Negro miners ho hes in the main made a most admirable adjuetment. An ocoablonal Negro of course ralses his voloe in protent o1milar to one by aegro miner in 27

another atate "Company knowa too moh about you! Besldes, 11" they get stuok, the foremen sends up for you any time, even if you've just come off a 10-hour shift any maybe worked overtime and are tired. You oan't refuso, or you'd be flred." Some have even gone over to radicallam of different kinde. The great majority, however, have ahown the tendency to take whatover is offered to them with little opposition or oomplaint, of whioh faot we have had previous evidenoe.

26 Cf. Bureau of Negro Welfare and Statistios, Raport of $1925-1936$, p. 40 .

27 Rochester, op olt, p. 94.

28 Interview with Mr. T. L. Felta, Bluefiold, W. Va., Head of the Baldwin-relts Deteotive Agenoy, 
The tendenoy of Nogro minere in Penneylvania; mentloned by Harrle, to aooept conditions that no otber Broup would be $11 k e l y$ to tolerate, is apparent in large measure in the Weat Virginla group, Thit thla tendency should exite is not surprising. These West Viringia Nejroes, in lerge measure, ooming from atates in whloh ourvival value has been plaoed upon the oulture tralt of aubmisgiveness in dealing with whites, tend to repeat traditional patterns. The accoptance of Ioas than equality is not new to thelr bohavior patterng. The culture trat enderio to thair former homes are in faot dally exhibited in forms whoh have shown littlo modifioation as a reoult of their diffusion into Weat Virginia, for, after all, the differenoes between ootton flelda and mining plolds Ile moro lurgely in material tralte and okil1s rather than in wores controlling Negro and white relationoblps, The dependence of the southern Negro on bi mbuokre" flnde 1 to oounterpart in the attitude of truat on the part of the Negro miner that his securtty w11I be asaured $1 f$ be playe the proper oulturm ally defined role. Refereno has been made before to the innumerable matters whioh Negro minera bring to thels auporIntendente and managers. Those requesta are frequently taken oare of, for a real and lasting affection $1 \mathrm{~s}$ not infrequently found botween omployers and their trugted black workmen. The reward of unoomplaining and faithful servioe

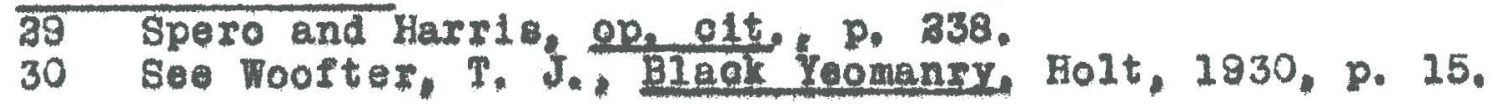


through the yoars is in many oases an easy job and freo house rent in old age. Hidows of Negro miners, grown old in service, are sometimes taken care of by the oompenies. Only one company had a pension aystem. The workings of a aystem reating on personal relations rather than legal guaranteas are ocoalonally tragio. The ohange of ownership whioh sometimes ooours when old Negroes have worked many years for the same oompany, or the death of a superintendent who has alwaye "taken care" of the falthful has meant real tragedy for oertim in of the aged llegroes interv10we"d.

Harris olalme that thic cyatem of welfare work mentioned above 18 moro produotive of yoophanoy than it 31

is of industrial demooray," With the statement the writer 1.e inolined to agreo. It 18 parhaps, however, too muoh to expoot thls group of migrante in the mines of Weat Virginta, oulturally conditloned a most of thom are, to be great ly interested in orusades for human righte which do not at the same time guaranteo security. Thelr real att1tude, were it to be expresed, would probably be more nearly represented by the words of their more artloulate raoo brother, Claude MoKay: 3a

"But it ain't decent to soab," sald Jake. -

31 Sporo and Harr1s, oce oft., p. 378.

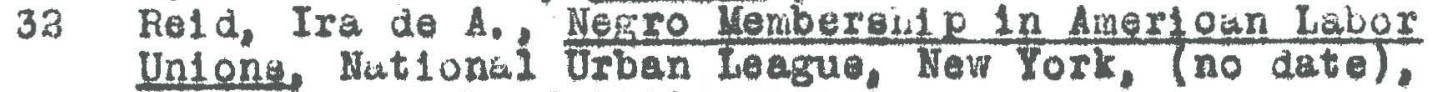
Quoted on baok of title page. 
"Deoent mah blaok moon!" shouted zeddy, I'II acab through hell to make mah $11 \mathrm{ving}$. Soab job or open shop or union am all the same job to mo. White mens don't want niggers in them unions nohow. Ain't you a good carpenter? And aln't I a good blackanith? But kain we get a lookin on our trade heah in this whit man's olty? Aln't white mens done scabbed niggers outa all the jobs they uater hold down heah in this olty? Waiter, bootblaok, and barber shopl -I I got to 11 ve and I'II soab through hell to $11 \mathrm{re}$ " 
CHAPTER X

EDUCATIOH

Sinoe emancipation from alavery eduoation for the Bouthern Nagro has become not only a badge of distinotion but the objeot of a cort of blind falth whiols will in some way lead him out of the wilderneas. I Illiteracy, whloh olaimod about 95 per cent of all Negroes in 1865; has been owift ly reduced eaoh decenntal consue until in 1930 but 22.9 por oent were unable to read and write, In Weot Virginis only 15.3 per oent of the Negro population, augmented as it was by migration from the south, was i111terate in $1920,{ }^{3}$ while in 1930 the proportion had fallen to 11.3 per cent. Illiteracy was stil lower in the mining counties, only 10.3 per cent of the Legroes in Fayette. Kanawha, Logan, MoDowell, and Raleigh oountles belng reported as 1111terate In 1930. The date of the present etudy tend to oonfirm the relatively low 111 iteracy of the mining group. of the 53 . miners from whon it was possible to get socurate information only 51 or 9.5 per oent reported that they had had no sohool1ng. Ill1teraoy data, however, tell us very little conoern-

I Woofter, T. J., Blaok Xeomanry, Holt, 1930, p. 180̃; Tashington, B. T., Up From Blarery, pp. 80-81.

a Johnson, C. S., ope oft., p. 228.

3 Cenaue Bulletin, 1820, Population, W. Va., p. 7.

4 Ceneus Bulletin, 1930, Population, W. Va., second ser1es, p. 10.

5 Computed from Ibid. pp. 30-32.

6 It is likely that a number of those minere who were Indefinite about their sohooling were 111 it erate but unwlling to admit the fact. 
Ing the educational lerel of the Hegro population. The Census ask almply whethor person oan read or write and rafses no question relative to the aotual uee made of this ablity. How much ohooling have the llterate" Negroes had Is the Negro minting group composed largely of men with one or two years of sohooling or has fallure to oross economio deadilnes 1 ato other fielde driven college men Into the 1ndustryt Are there differenoes in the average education of miners ooming from different itatent The answers to those questione, ooncerning the winers interviewed, may be geen in Table 6a:

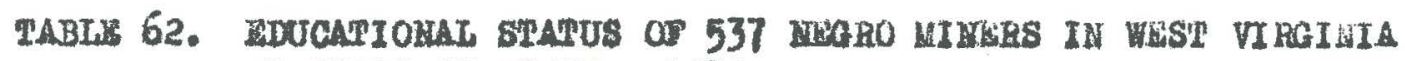
BI STATE OF BI ERH: 1932

(Complled Irom ner" "chedinlas)

\begin{tabular}{|c|c|c|c|c|c|c|c|c|c|c|c|c|}
\hline \multirow{2}{*}{\multicolumn{2}{|c|}{$\begin{array}{l}\text { Last year } \\
\text { of school } \\
\text { counolotod }\end{array}$}} & \multicolumn{10}{|c|}{ 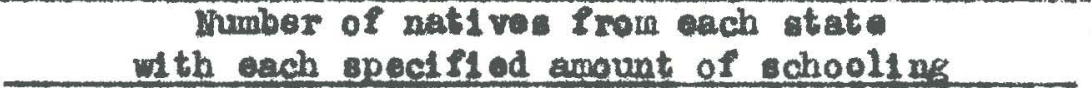 } & \multirow{2}{*}{$\begin{array}{l}\text { Porcentage } \\
\text { di st ri bu- } \\
\text { t10n }\end{array}$} \\
\hline & & W.Va. & Va. & H.C. & Ala. & 8.6 & Qne & Tonn. & $\mathrm{Br}$ & Other: & Tatal & \\
\hline yone & & & 33 & 3 & 10 & & 2 & & 1 & 2 & 51 & 9.5 \\
\hline 1 year & & & 13 & 2 & 2 & & & 2 & & 1 & 20 & 3. \\
\hline 2 year & & 2 & 21 & 6 & 4 & 2 & 1 & 1 & & 3 & 40 & 7.4 \\
\hline 3 year & & 2 & 35 & 7 & 4 & 1 & 3 & 1 & 2 & & 55 & 10.2 \\
\hline 4 years & & 10 & 41 & 11 & 8 & 1 & 3 & 4 & & 5 & 83 & 15.5 \\
\hline 5 year: & & 7 & 27 & 8 & 7 & 3 & 4 & 7 & & & 63 & 11.7 \\
\hline 6 year: & & 10 & 29 & 9 & 6 & 2 & 2 & & 1 & & 59 & 11.0 \\
\hline 7 yeare & & 4 & 12 & 4 & 2 & 1 & & 3 & & 2 & 28 & 5.2 \\
\hline 8 year & & 19 & 28 & 6 & 4 & 2 & 4 & 5 & 1 & & 69 & 12.8 \\
\hline 9 year: & & 4 & 5 & 2 & 2 & & & & & 2 & 15 & 2.8 \\
\hline 10 year. & & 7 & 3 & 1 & 1 & & & 2 & & 1 & 14 & 2.6 \\
\hline 11 yora & & i & 4 & & 1 & 1 & & & 1 & & 8 & 1.5 \\
\hline 12 year: & & 12 & 5 & 3 & & & 1 & & 1 & 4 & 26 & 4.8 \\
\hline 1 year & college & & & & & & & & & & & .0 \\
\hline 2 yeare & college & 2 & & & 1 & & & & & & 3 & .6 \\
\hline 3 yeare & $\operatorname{coll} \log ^{\circ}$ & & & & & & & 1 & & & I & .2 \\
\hline years & college & 1 & & & & & & 1 & & & 2 & .4 \\
\hline Tota & & 81 & 257 & 62 & 52 & 13 & 20 & 25 & 7 & 20 & 537 & 100.0 \\
\hline verage & ane & 7.8 & 4.4 & 5.0 & 4.3 & $5 \cdot 5$ & 5.0 & 5.8 & 6.1 & 5.9 & 5.2 & \\
\hline
\end{tabular}


The better eduoation of the native Mest Virginians is Indicated by the following figures:

\begin{tabular}{|c|c|c|c|}
\hline $\begin{array}{l}\text { Sohooling } \\
\text { Hone } \\
\text { One to four years } \\
\text { rive to eight yeare } \\
\text { High sohool } \\
\text { College }\end{array}$ & $\begin{array}{l}\text { He. Yat 1ree } \\
.0 \% \\
17.3 \\
49.4 \\
39.8 \\
3.7\end{array}$ & $\begin{array}{r}\text { others } \\
11.28 \\
40.3 \\
39.8 \\
8.6 \\
.7\end{array}$ & $\begin{array}{l}\text { Totel } \\
9.5 \% \\
36.9 \\
40.8 \\
11.7 \\
1.1\end{array}$ \\
\hline tal & 100.0 & 100.0 & 10 \\
\hline
\end{tabular}

The greater average number of years of sohooling of the Weat Virginia nativee ia to be explained in partby the faot that they have a larger proportion of younger men then do the non-nat1ves. Many more Negroes are going to sohool today even in the noet baokwerd southern states than a few yeare ago. The younger West Virginiana, therefore, have had as a rule educatlonal advantagea denled many of the older men. Anotber important reason for the greater wohooling of the West Virginians 1108 in the ohsraoter of the sohool system. Alnost Irom 1ts beginning on June 20, 2863, West Virginia took an interest in the education of regroes, The flrst oonatitution contalned no provialon for the oduotion of the ereedmen, but in 1864 the report of the atate Superintendent of Publio Sohools recommended the establishing of schoola for Negroes as follows I regret to report that there are not sohools for the ahildren of this portion of our citizens; as the law stand I fear they w111 be coin 7 Woodson, C, Gn, Early Negro Eduogtion in Weat Viricinia. w. Va. Colleglate Institute Studieg in Soclal solence. 1ə21, p. 9.

8 Report of the State Superintendent of Publio InstructIon, 1864, (quoted in Woodeon, epe olt. P. Q). 
polled to remain in ignoranoe. I commend then to the favorable notice of the leglelature." Apoording to Noodson the laglelature passed the law providing publia cohoola for Jegroes in 1866. In volume published in 1865, however. a member of the United stateo Department of Igrioulture 10

says: "A board of education is provided for each townahp. fully empowerad to act for the highest intereats of the sohools, and required to furniah faoll1tien for a full course of common Inglish education; and they may oall a townshlp weeting for an authorlsation of a High Sohool. when the interests of education in thelr diatriot eec to demand the establishment of euch an 1notitution. Sohools are also provided for oolored ohlidren, whether or not the first law was pasaed in 1885 or 1866 it was amended in 1867 to authorize local boarde of edueation to establish a Bchool for yegroes at any place where there were wore than 15 Negro children between the ages of 6 and 21.11 . In these early daye the whites and Hegroes pometimes used the sare Bohool houses. Sinoe the sohool term was only four monthe of 23 days each, the whites went from september to Christmas and the Negroes moved in after that dater.

Ater the completion of the Chesapeake and Ohto hall road in $1873 \mathrm{Veg} \mathrm{J}^{\circ} \mathrm{es}$ oame to Fayette County in Iarge nuribers. The first Negro sohool, however, was not established unt1l 1879 at Kontgomery. The second sohoo?

9 Koodson, epe eft. p. 9.

10 Dodge, J. R., Rest Jífginia, Lippinoott, 1865, p. 18. 11 Woodson, sp. att. p. 9.

i2 Inid. p. 10 . 
followed in 1880 at Quinnimont, a mining town on Iew River. Very soon after the eatabliahment of the Quinninont rohool, Negro sohools were to be found at Flxe Croek, Hawk'B Noat, Stone Cliff, Nuttalburg, Sewell, and Eagle, all of them 13

mining towns. In the southern count 1es of MoDowell and Mercer the instruotion of Negroen prior to 2888 wa 2 angely private. The first publio sohool was opened at the operam tion of the Turkey Gap Coal and Coke Company at Innis in 34.15 this year. Sohools ooon followed at Maybeury, Horth rork (1892), Eoknan (2894), weloh (2895), and Koyotone (1900). 18 From 1896 to 1906 one-room school were established in almost every communt ty in MoDowell County. After that time consolidation of sohools took place. ${ }^{17}$ The orlginal sohool terin of 3 montho in 1888 was lengthonod to 5 by 1890, and to 6 in 1896; at the present time it is 9 18 mont bs.

Today elementary sohoole for Hegroas are to be found in almost every mining town. Where there is no sohool the chlidren are provided transportation, usually by bus, to the nearest coneolidated school. Junior and senior high schoole Ith transportation provided for the etudents are looated in placos conventent to the largeet number of mining communities, Of the 6 juntor and 31 sentor high school in West Virginia in 2938, 3 and 15 reepeotively I3 IbId, op: 23-28.

16 Weloh Daily Nown, Sopt. 21, 1928.

15 Ibld.

i6 Foodson, op, att., p. 37.

17 Weloh Da1IY Vowr, sopt. 21, 2926.

18 Ibld 
wete looated in the wining fields. Some attontion is aloo given to adult education in njght Bohoola. In 1832

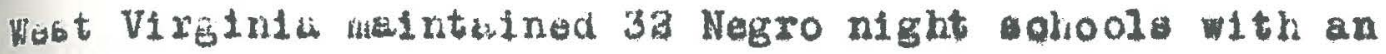
tnrollment of 377. twelve of theae chools wh an aggregate enrolluent of 151 being looated in the mining fielde. The state malntains two institutions of higher duoation for Nogroes. The larger, the Went Vifglala state colleg looatod at Inst Itute in Kanawha county, wa eatab11shed by an wot of the leglelature in 1891 and opened 1 ta 20 doors in 1893. The value of the bulldiags and grounds of the 1natitution was eatimated in 1987. by the rederal bureau of eduoation at $\$ 1,025,848$. Thla ool 1 ege was admitted to momberenip by the North Contral Assoolation of Beoondary Bohoola and Colleges In 1987 and 1ts graduater are admitted as full candidates for adranoed degreen at such unirersities as Ohio state, chioago, and Columbla. Th following onirses are offered: Four yeare in 11 beral arto leading to the degrees of B. A. and B. S. four yeare in eduoation leading to the degree of B. 8. In Jducation and at ate teachers oertiflcate; four years in home ooonomion leading to the degree of B. S. In Home Eoonomiar and a state teachers certiflcate; four yeare in musio leading to the degree of $B$. hus. I four years in commerce leading to the 19 T. Va. Educut10nal D1reotory, 1331-32, p. 17. 20 Lew18, Virgil. A. West Virginia. W. Va. Comminsion 21 of the Li. Piroliase zxposition, 190z, po. 122-123. 21 U. S, Dept. of the Interior. Bureau of Eduoation, Survey of Verro Colleger and Unlvereities. Bullet in 1.0. 7. 1938, p. 954.

32 Ibid. 
degree of B. 8. In Businoss Mdrintetration; lour yeare in Agrioulture leading to the degree of B. B. In Agrioulture; and four years in meohanio arts leading to the degree of B. S. In Mechanio Arts. Besides the courses leading to degrees are two-year course in premediaine and twoyear course in normal training leading to a state el amentary tesohers certificate. donoerning the work of this 1natitution the federal eurvey sald: The Weet Virginia Collegiate Institute for many years has beent rendering an excellent Bervice to sookety in the eduostion and adranoement of the negro race." $\Delta$ this inetitution the aggregate fees for the ohild of a Hest Virginia oftizen are about $\$ 20.00$ a year, while the non-resident must pay about \$75.00. Board may be obtained at the college for $\$ 4,00$ a week and a Ioorn in the dormitorles ooste from $\$ 9.00$ to $\$ 23.50$ a semester. The non-reaident student muat pay double the anount paid by the weot Virginia student. S1milar low fees axe charged at a second institution, the Bluefield state Tachere College, opened in Meroer County in 1895. Th10 Institution, devoted primarily to teacher training has geveral bulldinge and more than elght acres of oampus.

The Weet VIrginia atate-oupported colleges offer no courses in 1aw, mediolne, and dentiatry. They empheise, 33 Tb1d, P. 629. 24 Ib1d. p. 638. 25 Since the survey the name of the institution has been changed to West Virginia itate College. 36 Inid. p. 626. 27 Lewis, V. A., op.eit., p. 133. 
as do most of the Negro oolleges throughout the oountry, 38

propropessionul training. If, kowerer, a West Virginia Nesro student who has completed a yeare of college work desiras to pursue spealal couraes not offared in Hest Virsinia State College but offared in white colleges in the atate, he may have his tuition expenses paid in a college of his ohoioe outalde the state to an anount equal to the differenoe between the tultion expense oharged realdents and non-residente at Weat V1rginia Univeraity. In order to benefit by this proviston the student wat have been a oltizen of Wast virginle for at leat 5 years. 29 Tho intent of the leglelature in pasing this "lat wat to equalize the difference between the greater veriety of profesaional work offered in the white and Hegro tate oollegee.

The great $1 y$ disproport lonate share of the Negro and wht group in the eduostlonal funds of so many atatea following a polloy of segregated schools is not found in Heat Virginia. Aocording to the flgures based on the National Eduoational Assoalation's sudy of whe Ability of States to Support Eduoation the amount per year apent per eduoable ob1ld in Vest Vixg1nia for Negroes was $\$ 51,59$ and 30

for white $\$ 58.79$. Only two other southern or border states; M1ssouri and Delaware, spend more per educablo on1ld for Negro education than doeg Piest Virginia. A comparison of proportion of educational funds received by 28 Survey of Negro Colleges and Universitieg, p. 33. 29 Correspondenoe with Va. State Dept. of Education. 30 Johnson, ope oft. p. 261. 
Hegroes in West Virginia with hat in the other 16 atates with separate sohool for the two races may be made by referenoe to the following llat of expendituree por edu31 oable ohild:

Eegre Difte

South Carolina ............ Alabama ....................

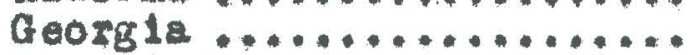

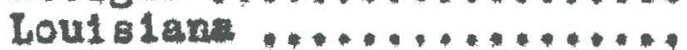

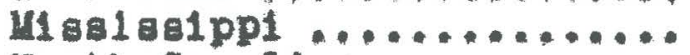

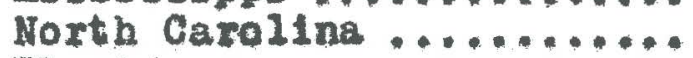

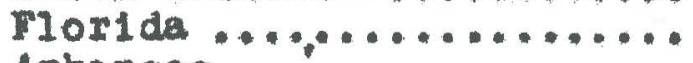

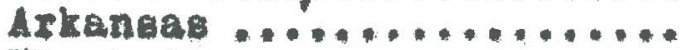
Virginia ..................

Tennessee ..................

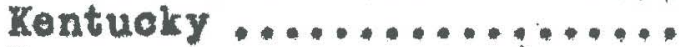

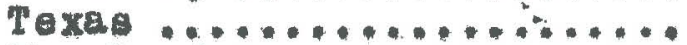

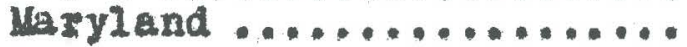

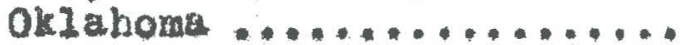
West Virsinia ............ Milosourt Delaware $\$ 4.48 \quad \$ 45,45$ 5. $45 \quad 37.63$ 7.4435 .34 $8.03 \quad 46.67$ $9.34 \quad 43.17$ $11.06 \quad 36.70$ 11.4175 .07 $11.60^{\circ} \quad 21.15$ 14. 8654.21 $30.15 \quad 33.47$ $36.57 \quad 26.57$ 38. $34 \quad 40.04$ $39.58 \quad 59.70$ $31.65 \quad 50.04$ $51.59 \quad 52.78$ $51.80 \quad 67.30$ $53.40 \quad 47.16$

In 1939 the lollowlng b111, written by 111 lam w, Sanders; State Supervisor of Negro Sohools, and introduced by $T$. Edward Hill, Hegro legislator from MoDowell County, พas passed by the state Legislature: 33

Salarieb of Negro teachera shall be the sara as sularies of other teachers in the same district, independent district, ofty or town with the sane training and expertenoe, and holding similar credentials, Any board of eduoation falling to comply with the provisions of this aot may be coinpelled to do so by mandamua.

Inquiry was made in all countioe in regard to the actual effects of this law on the payment of ealaries to Negro and white teachera. Elementary, seoondary, and ool lege teachers 3I TbId.

32 Tote of the N. Va, Legielature, 1829, Seotion 67-A. 
were pretty well agreed that elementary teaohers were paid approximately the same salarles as whites. All alleged souse disorimination in the alarieg pald to high wotiool and oollege teachers, and espeoially to sohool principals. AooordIng to the State Supervisor of Negro Soroole the Negro terohera and prinolpala are, on the average, better trained than the white teaohers because of the economic restrictions placed upon the Hegro in other flelda and the resultant corapetition between them for teaohing positlons. 33 asuming equality of training of white and Negro prinolpals of elementary sohoola the following comparison between the average annual salaries in the mining plelds indloate some differenoe in favor of the whites in all oountios etudied as shown in Table 6s: 34

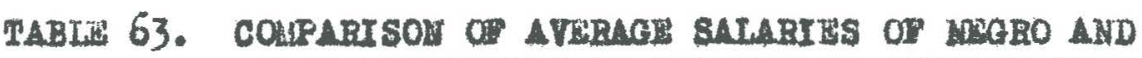

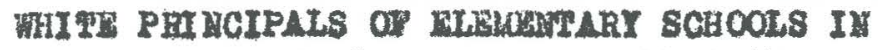

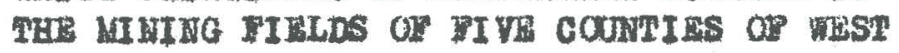
VI BOIHIA! 1931-32 (Complled from Pigure in the Hest Virginia Edueatlonal D1rectory, 2931-32, Pp. 84-137)

\begin{tabular}{|c|c|c|c|c|}
\hline \multirow{2}{*}{ County } & \multicolumn{2}{|c|}{ Number of school. } & \multicolumn{2}{|c|}{ Averag talary } \\
\hline & Hagne & 疽1te & Neare & nite \\
\hline Fayetto & 10 & 25 & $\$ 1,052.00$ & $\$ 1.245 .16$ \\
\hline $\operatorname{con}$ & 4 & 14 & $1,102.50$ & 1.259 .57 \\
\hline Lage & 5 & 31 & 920.00 & 1.107 .74 \\
\hline$U C D$ & 23 & 30 & 2.311 .96 & $1,607.73$ \\
\hline Bal ol ga & 14 & 32 & 1.123 .93 & 1.124 .22 \\
\hline 11 count & 56 & 132 & 1.168 .57 & $1,267.50$ \\
\hline
\end{tabular}

33 Interviow with W. W. Sanders, State Supervisor of Hegro sohools.

34 Figures were avallable only for elementary prinolpals. 
Aocounting for the diaparity between the calaries pald Negroes and whites in the secondary sohools and collegen a man in a high administrative postion in one of the atate Megro 001legee sald: Those people who want to be sinoere about the matter tell us that it is a matter of demand and aupply. While they may have to pay a good oum to get a white peraon to do a certain job they can get a llogro for less beoause the wh1te way do other thinge and the legro may not. He has to tedoh, so thay are payting on a basis of demand and upply." In apte of the diserimination which may still exist, notwithotanding the legal requi rement of strict equality, the salaries of Negro teachere are relatively high. The average monthly asary for elementary teachers in 1926-1927 was \$01.50, the salarie of only two other states, Oklabome with an everage salary of $\$ 85,83$ and Texa with an arerage salary of $\$ 87,70$, bolng higher. Comparable flgures were not available for high school aalaries, but the foderal survey of Megro colleges and univeraitiea reported the soale of salaries paid at weat Virginia state College as above the average in Negro ingtitutions.

In a letter to the writer an offiolal of the Weat 37 Virginia Dopurtment of Education saye: "....t the eduow tional advantagea offered Negroes in mining apotions are 35 Newbold, N. C. Comion Schoole for Negroeg in the South. Annals, vol. CXXXX, Nov, 1828, p. 317.

36 U. S. Dept, of the Interior, Bureau of Eduoation, Bulletin No. 7, $1938, p_{0} 636$.

37 Letter from I. J, K, Vello, V. Va. Dept. of Eduoation. 
the same as those offered to whtes in the ame communties. In many instanoes the sohool provided are auperior to those of other communties exoept ofties, The observations of the writer throughout the mining oountiea would lead to a substantial agreement with this statement so far as buildInga are concerned. The types of sohool bulldinge vary from oounty to county and from town to town but the fluotua tion of standarda is found in both white and Negro sobools. The Negro sohool, in faot, is superior to the white school in some comrunities. In one of the laxge wining towns in MoDowell County the white high aqhool basket ball tean playe its games in the Hegro high chool beoause of superior faoilities, Geveral of the Negro high sohools to whith the ons and daughters of miners oome compare favorably with thoe in the largest olties of the atate. Property valuation in the mining seotions are ueually higher than in atriotly rural diatriots so that adequate tax money is arallable for the oupport of adequste sohoola for both white and legro pupile. 

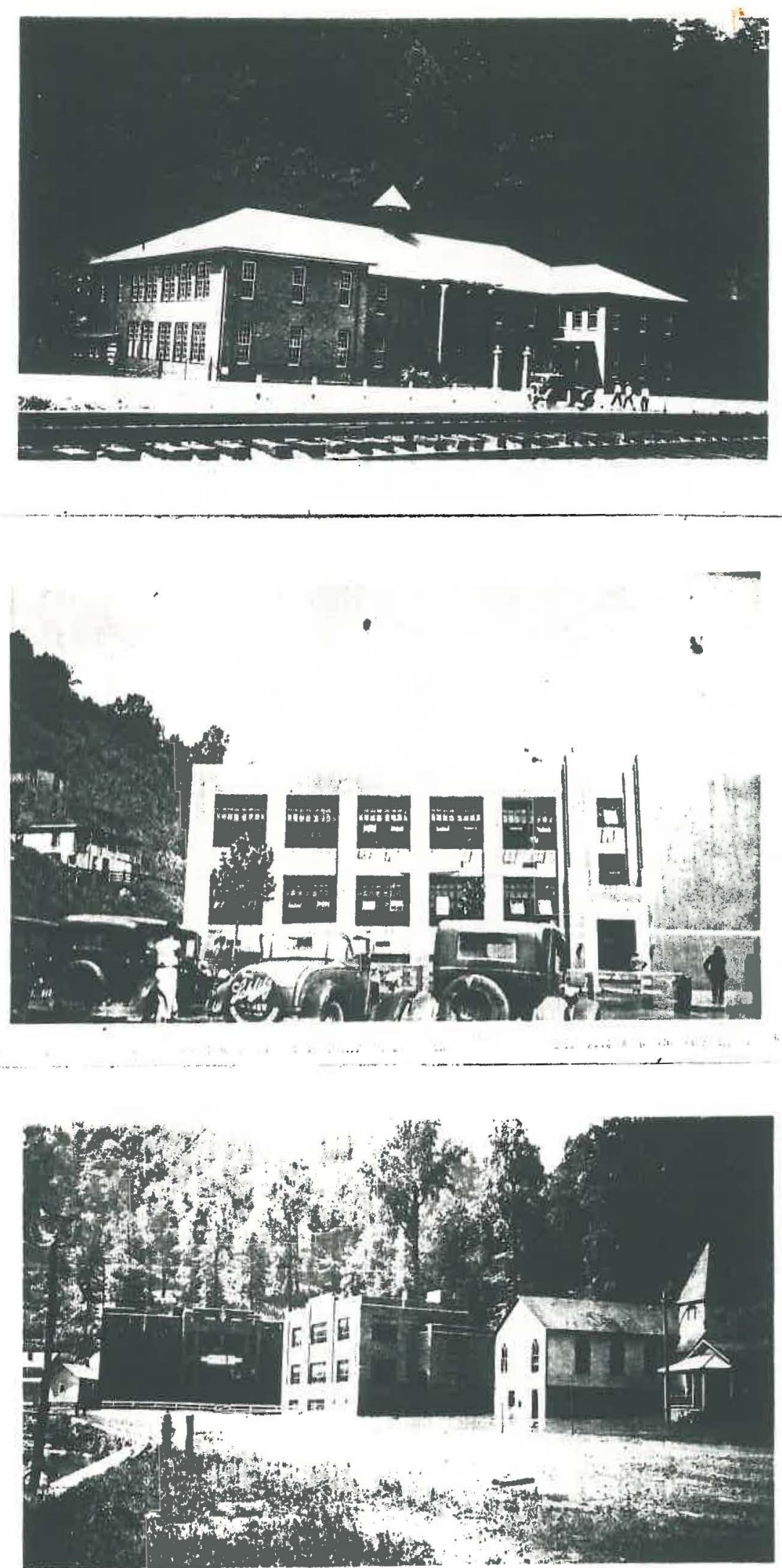

TYPES OF NEGRO HIGH SCHOOLS

(A) Elkhorn Distriot Colored High Sohool, KoDowell County.

(B) Araooma H1gh Sohool, Logan County.

(C) Gary IIgh Bohool, MoDowell County. 

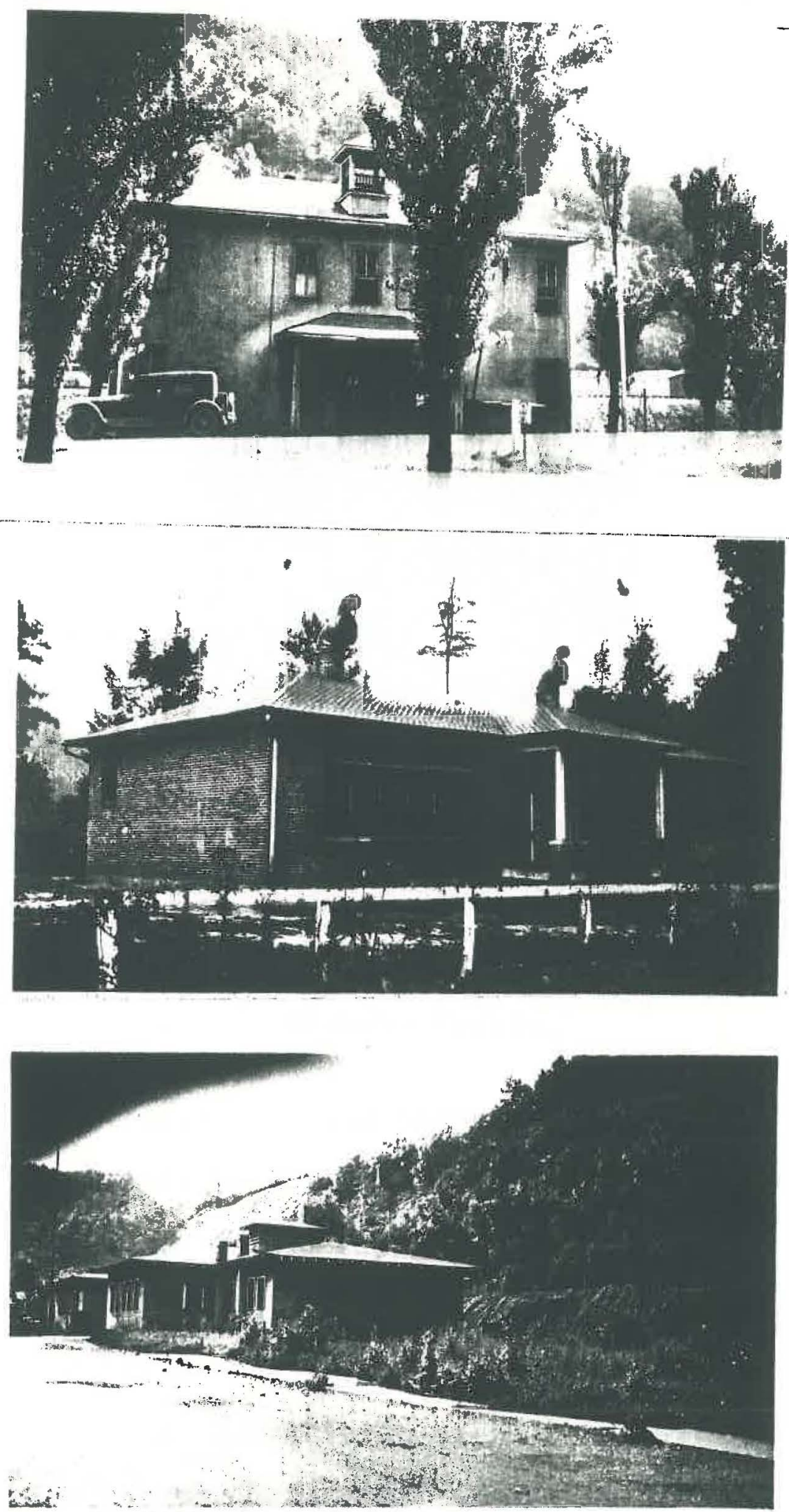

TYPEE OF NECRO ELEMENTARY SCHOOLS

(A) Omar School, Logan Ounnty,

(C) Rale1gh Bohool, Palolgh County. 


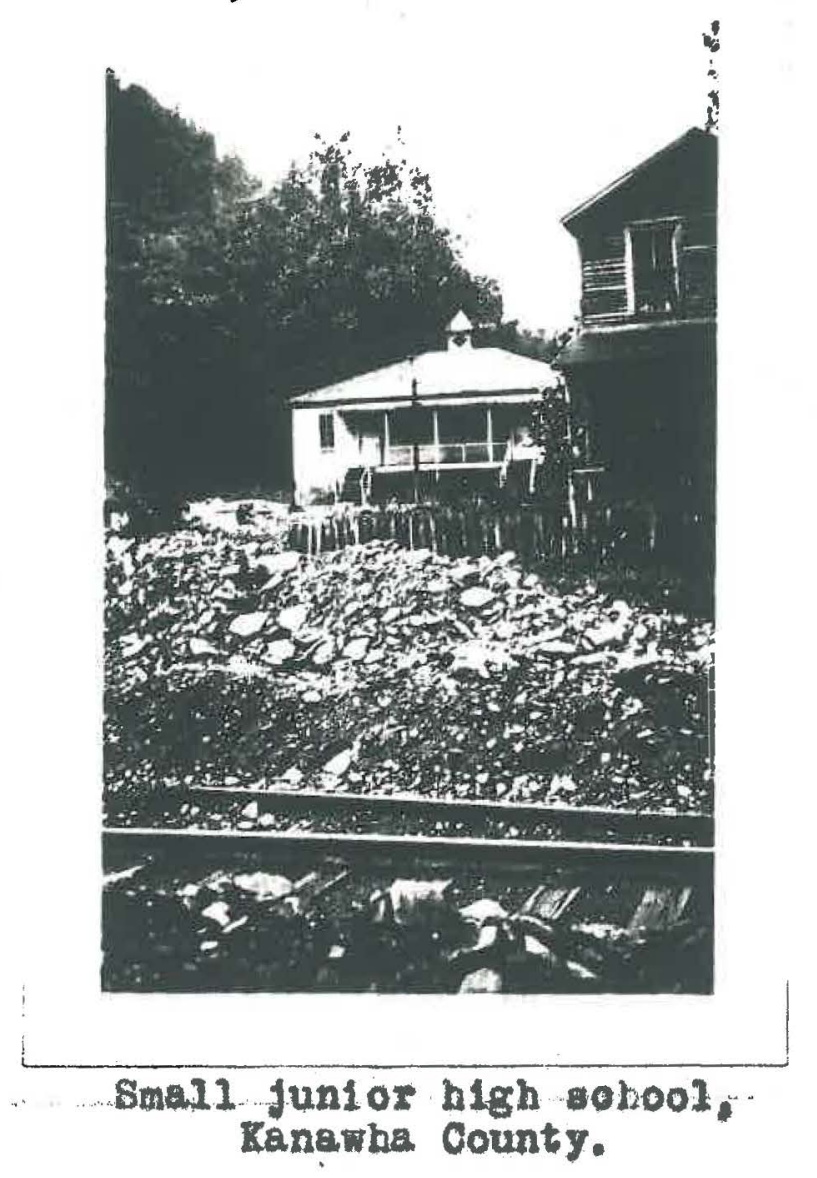

Apparently llegroes throughout the state of West VIrginia are taking advantage of the educational opportunities offered them. The proportion of Hegroes from 5 to 30 years old in all sohools in Mest Virglnta was, aocording to the 1930 census, almost a high as the proportion of the nat1ve whites, the percentages being respeotively 66.0 and 38

63.3. The peroentage of each racial and national group attending sohool 1 shown in Table 64 :

38 Filteenth Cenous, Population Bulletin, w. Va., Coinosition and Charecteristios of the Population, p. 9. 
TABLE 64. PERCEHAGE OR SCHOOL ATPRMDANCT OF PMRSONS FROM 5 TO 20 YHARS

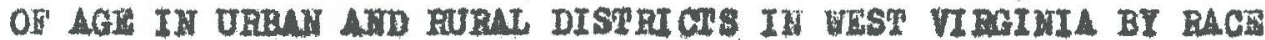
AND NATIOMALITY: 1930

(Coxplled from Conme Population Eulletin, Wost V1 rginda,

Coliposition and Characteriatic of the Population, 1930, p. 9)

\begin{tabular}{|c|c|c|c|c|c|}
\hline Dist at ct & $\begin{array}{c}\text { AII } \\
\text { Clanses }\end{array}$ & $\begin{array}{l}\text { Hati ve wite- } \\
\text { nati w } \\
\text { pareatage }\end{array}$ & $\begin{array}{l}\text { Wativo whito- } \\
\text { roplga ox mi xod } \\
\text { parentase }\end{array}$ & $\begin{array}{l}\text { Toreien- } \\
\text { born white }\end{array}$ & Negro \\
\hline $\begin{array}{l}\text { The Stat } \\
\text { Urban } \\
\text { Rural } \\
\text { fural-farm } \\
\text { Rural-nonfarm }\end{array}$ & $\begin{array}{l}66.6 \\
69.8 \\
65.5 \\
65.9 \\
65.3\end{array}$ & $\begin{array}{l}66.3 \\
70.0 \\
65.2 \\
66.0 \\
64.6\end{array}$ & $\begin{array}{l}71.2 \\
70.4 \\
71.7 \\
69.4 \\
71.9\end{array}$ & $\begin{array}{l}50.6 \\
52.5 \\
49.4 \\
(a) \\
49.4\end{array}$ & $\begin{array}{l}66.0 \\
69.2 \\
65.0 \\
56.5 \\
65.5\end{array}$ \\
\hline
\end{tabular}

(a) only 34 children.

Practioally all of the mining towns fall under the claseifiation of rural-nonfarm. Apparantly a larger proportion of the oh1ldren of Negro miners attend school than do the chlldren of any other group exoept the ohlldren of foreign or mixed parentage.

Atriking difference between the Negro achool population in Weat VIrginia and most of the other southern and border states 18 in the higher proportion of pupila in 38

the seoondary sohools. The number and proportion of

Negro puplle in the sohoola of elght wouthern and border states 18 shown in Table 65:

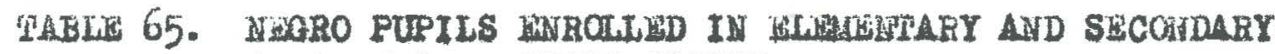
SCBOOLS III CEIPANA STATrS

(Covmiled from Burear of Bducation Eull etin, WO. $20,2931, p \cdot 73$ )

\begin{tabular}{|c|c|c|c|c|c|c|}
\hline \multirow[b]{2}{*}{ state } & \multicolumn{3}{|c|}{ Number of Nearo pupl le enrolled } & \multicolumn{3}{|c|}{ Per cont enrolled } \\
\hline & $\begin{array}{l}\text { Hl ementary } \\
\text { echools }\end{array}$ & $\begin{array}{l}\text { Secondary } \\
\text { echools }\end{array}$ & Total & $\begin{array}{l}\text { Hil ementary } \\
\text { schoole }\end{array}$ & $\begin{array}{c}\text { Secondary } \\
\text { echools }\end{array}$ & Total \\
\hline West Vretni & 23.414 & 2.724 & 26,138 & 89.6 & 10.4 & 100.0 \\
\hline Delavare & 6,144 & 587 & 6.731 & 91.3 & 8.7 & 100.0 \\
\hline Kontucky & 43.436 & 4,100 & 47.536 & 91,4 & 8.6 & 100.0 \\
\hline North Carol1na & 244.413 & 15,182 & 259.595 & 94.2 & 5.8 & 100.0 \\
\hline Vredala & 146.165 & 7.481 & 153.646 & 95.1 & 4.9 & 100.0 \\
\hline South Carollna & 212.936 & 8.234 & 221,170 & 96.3 & 3.7 & 100.0 \\
\hline Alabama & 188.356 & 6.375 & 194.731 & 96.7 & 3.3 & 100.0 \\
\hline ceorsta & 238,498 & 6.543 & 245,041 & 97.3 & 2.7 & 100.0 \\
\hline
\end{tabular}

39 See U. S. Dept. of the Interfor, Bureau of Education Bull et 1n, 1931, No. 30, p. 73 . 
The Censua flgures of 1930 show that in the rural-nonfarm diatricts of West Virginia a larger proportion of the Nagro oblldren between the aree of 14 and 20 attend sohool than the ohlldren of any othor raoial or national group. Sinoe these ages presumbly are 11kely to be those of high sohool children it seems safe to oonolude that many of the childrea of Negro miners attend high sohool. Sohedules taken in the present atudy revealed the faot that of the 553 ohllaren of Negro minere in sohool 440, or 79.7 per cent were in elementary schools, 101 or 18.3 per oont were in high sohools, and 11 or 3.0 per cent were in college.. Some omiselons were neoessary in computing these figures owing to the faot that Negro miners whose homes had been broken were unable to glve complete dsta concerning their ob1ldren.

Study of the ages and sohool status of 541 oh11dren of Negro minera in elementaxy and secondary bohools revealed considerable retardation and some acoeleration as shown in Tables 66 and 67. In Table 66 the sigures between the zigzeg IInes shov the number of pupils in their normal grades; 1 . e., ages $1 x$ and seven years are consldered normal for the flrat grade; seven and elght for the eccond grade; and so on. The flgures lieted to the left and below the IIne indioate retardation; the flgures to the right and above the ilne indicate acceleration. The extent of the retardation or acceleration may be eatimated by the relam tive length of the column of flgures above or below the Ilne. 40 Fifteenth Census, Population Bulletin, West Virginia, Composition and Charaoteristios of the Population, p. 9. 
Table 67 shows the number and percentage of pup1la retarded, sooelerated and in thelr normal grades.

TABLIE 66. GRADE IN SCHCOL OF 541 CEILDREN OF MDOHO MIUTHS IV BLISMEMMARY AND SECONTDART SCHOOLS: 1932

(Complled fros matne' schedules)

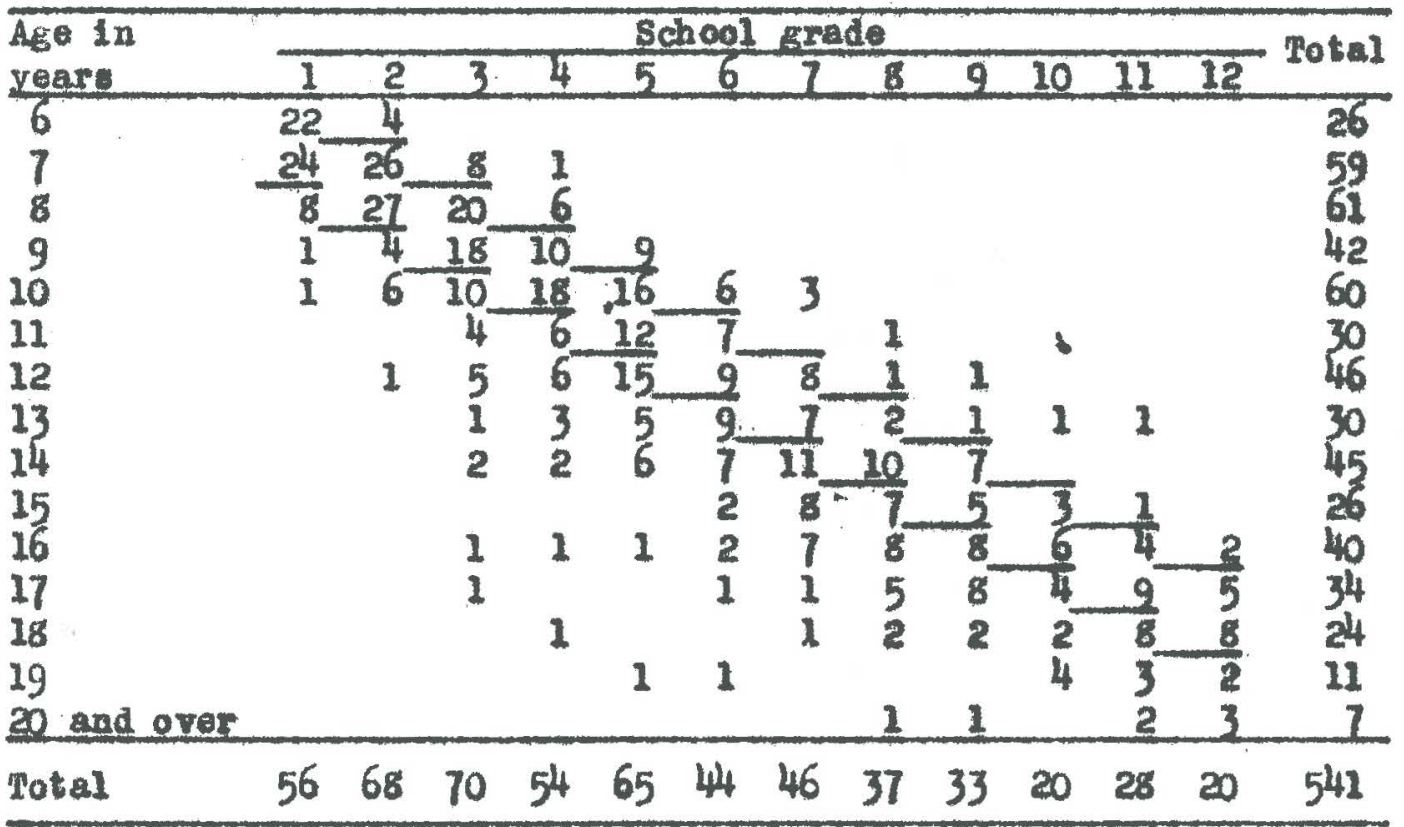

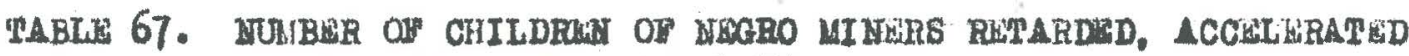
AND IV MORUAL GRADHS: 1932

(Conp1led from mners' schedulos)

\begin{tabular}{|c|c|c|c|c|}
\hline \multirow{2}{*}{$\begin{array}{l}\text { School } \\
\text { grade }\end{array}$} & \multicolumn{4}{|c|}{ Mamber of children } \\
\hline & Retarded & Accelerated & In normal grades & Total \\
\hline 1 & 10 & & 46 & 56 \\
\hline 2 & 11 & 4 & 53 & 68 \\
\hline 3 & 24 & 8 & 38 & 70 \\
\hline 4 & 19 & 7 & 28 & 54 \\
\hline 5 & 28 & 9 & 28 & 65 \\
\hline 6 & 22 & 6 & 16 & 44 \\
\hline 7 & 28 & 3 & 15 & 46 \\
\hline 8 & 23 & 2 & 12 & 37 \\
\hline 9 & 19 & 2 & 12 & 33 \\
\hline 10 & 10 & 1 & 9 & 20 \\
\hline 11 & 13 & 2 & 13 & 28 \\
\hline 12 & 5 & 2 & 13 & 20 \\
\hline \multicolumn{5}{|l|}{ Totalu } \\
\hline Bumber & 212 & 46 & 283 & 541 \\
\hline Per cont & 39.2 & 8.5 & 52.3 & 100.0 \\
\hline
\end{tabular}


The sons and daughters of minera compose a largo part of the student bodies of the two state Negro colleger. According to the Dean of the Bluefield State Teuchers College 33 is or 93.9 per cent of the 347 weat Virglaia atudente enrolled in that institution in 1932-33 are ohil 41

dren of ininers. The Weat Virginia State College, with an enroliment of 444 weat Virginia students in 1932-33, keepe no reoord of the occupation of the parente of their students. The large number of students in this institution from the mining oounties, however, indicates that bere too the oblldren of minere form a substantial part of the onrollwent although not so large in the ouse of the former 43

oollege. At Bluefield State Teachere College only 11, or 4.3 per cent of the etudent body, come from other statea. The number of etudents in esoh college from the nining counties is shown in Table 68 .

41 Correapondence and Interview with Dean H. L. Diokason of Bluefleld State Teaohers College.

42 About one fourth of the students come from other states, prinolpally North Carolina. Penneylvania, Kentuoky, Maryland, and the Distri of of Columbla, (Correspondenoe with Dean David $A$, Lane, Jr., of west V1rglnia State Collego,) 


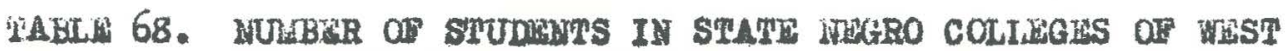
VI ROIMIA BY HOAS COUNTY OR STAPB 1932

(Countled from figures furulahed by deans of the two colleges)

\begin{tabular}{|c|c|c|c|c|c|}
\hline \multirow{2}{*}{$\begin{array}{l}\text { How county } \\
\text { or state }\end{array}$} & \multirow{2}{*}{$\begin{array}{c}\text { Number of } \\
\text { Negro wif ners } \\
1931 \\
\end{array}$} & \multicolumn{4}{|c|}{ Number of Nogro student enrolled } \\
\hline & & Fent & Mreinte state & Bruerleld State & Total \\
\hline Barbour & 117 & & $\mathbf{I}$ & & 1 \\
\hline Boone & 289 & & 1 & & 1 \\
\hline Brooket & 240 & & 7 & 1 & 8 \\
\hline I AYRPRT. & 3.060 & & 43 & -15 & 58 \\
\hline areonbrter & 221 & & 12 & i & 13 \\
\hline Barrt mon & 167 & & 8 & & 8 \\
\hline ranABHA & 1,054 & & 173 (a) & 12 & 185 \\
\hline Locess & 2,212 & & 12 & 4 & 16 \\
\hline LCDOHRLI & 6,092 & & 40 & 32 & 72 \\
\hline Herion & 893 & & 13 & & 13 \\
\hline Varmall & 106 & - & 1 & & 1 \\
\hline MFRCLAB & 965 & & 23 & $+150(a)$ & 173 \\
\hline LE ngo & 610 & & 10 & & 10 \\
\hline Lonongalla & 591 & & 8 & & 8 \\
\hline On10 & 439 & & 8. & 2 & 10 \\
\hline RALBIGE & 3.632 & & 21 & 15 & 36 \\
\hline Taylor & 20 & & & $i$ & 1 \\
\hline Totals & & & & & \\
\hline Lind ne counts on & & & 381 & 233 & 614 \\
\hline other countie & & & 63 & 14 & 77 \\
\hline Total W, Wa.: & & & & & \\
\hline yunber & & & 444 & 247 & 691 \\
\hline Por dent & & & 85.8 & 93.9 & 11.1 \\
\hline other states & & & 146 & 11 & 157 \\
\hline Total arollmeat & & & 590 & 258 & 848 \\
\hline
\end{tabular}

- Counties covered in the present atudy in capital.

(a) County 1 u wisch colloge is locatod.

The enrollwent of Negroes in the two oolleges in $1932-33$ is sonewhat sinaller than in 1931-33, having dropped in west Virginia state from 653 to 590 . At Bluefield state the drop in the number of ohildren of miners in 1932-33 has boen sharper than for the ohlldren of any other oocupational group, an effeot of the hard times, espeolally in 44

the ooal industry.

44 Correspondence with Dean Diokason. 
In epite of the large proportion of collage etur dents from the mining oounties it ie likely that only a small proportion of the sons and daughtere of minere ever go to college. Aocording to a MoDowell County teaoher about 5 por cent of all high sohool graduates go to oollege. Apparently a large number of the ohfldren stop their formal oducation after the completion of the eighth grade. The educational atatus of 198 working ohlldren of miners conoerning whom it wag poselble to get this information is ghown In Table 69.

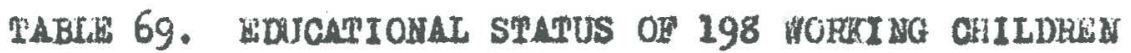
ON WBCRO WIWLES IN WRST VIBGINIA: 1932 (Coroplled fron ud nors' achedulea)

\begin{tabular}{|c|c|c|}
\hline Grade finisied & $\begin{array}{l}\text { Jumber of chlldren having } \\
\text { finl shed each goecifled trade }\end{array}$ & Fer cent \\
\hline Hone & 1 & .5 \\
\hline 1 & $i$ & .5 \\
\hline 2 & 2 & 1.0 \\
\hline 3 & 6 & 3.0 \\
\hline 4. & 21 & 10.6 \\
\hline 5 & 12 & 6.1 \\
\hline 6 & 21 & 10.6 \\
\hline 7 & 17 & 8.6 \\
\hline 8 & 56 & 28.3 \\
\hline 9 & 18 & 9.1 \\
\hline 10 & 7 & 3.5 \\
\hline 11 & 8 & 4.0 \\
\hline 12 & 21 & 10.6 \\
\hline 1 year college & 1 & .5 \\
\hline 2 yeare collog & 6 & 3.0 \\
\hline 3 yeare college & 2 & 1.0 \\
\hline 4 year college & 4 & 2.0 \\
\hline Total & 298 & 100.0 \\
\hline
\end{tabular}

45 Owing to the inability of many of the miners to state aoourately the eduaation of thel children who are now working, this table represent probably not more than Bo par cont of all working ohlidren. Conwequently any conolustons drawn from it muat be of a highly tentotive nature. 
The average education of thls group of working ohildren ia 8. 2 yeare, exactly 3 yeare more than the average of the niners.

The state of West Virginia, while it provides separate sohooly for the two races, has made no distinotion between the type of studies offered in the elementary and secondary sohools. Bays Mr. U. H. Prunty, President of the West VIrginia Btate Teabbera' Asaociation, "So far ws the ourrioulum is conoerned there is abolutely no differenoe in the type of eduostion offered to the Hegto ohlidren in West Virginia in comparison with that offered the wlite ohlidren. When our course of atudy was last revised it inoluded in speciflo detall the offerings to be given for all schoole. The only basia for different lation was that of Bize." Like most states West Virginia offere very 11ttle opportunity for vooational training in Negro sohools.

West VIrglata state College, beginning in the period when Booker T. Washington's 1deas on vooational eduoation were so popular, has almaye provided work in "meohanto arts " and agriculture. The students for some yeare have manifested very 11ttle interest in the rooational work. In 1936-37 only 9 students were enrolled in the four-year vocational coures and since 1921 the enrollwent wavered between 6 and 9 students a year, only 2 out of 30 froshmen so onrolled completing the oourse. Since 1980̈-37, however, apparently 46 The Hegro teachers' organization of W. Va. 47 Cf. Young, D., ope o1t., p. 453.

48 U. S. Dept. of the Interior, Bureau of Eduoution, 1928, Bull etin Ho. 7, p. 633. 
some renewel of interest in these courses seoms to have ocourred as 38 mon are onrolled in moohanio arto and 11 in agrioulture in 1932-33. The enrollment in the different oourses in 1932-33 10 as follows:

\begin{tabular}{|c|c|c|c|}
\hline Coureer & $y_{0}$ & Tema 1 & \\
\hline Arts $\ldots \ldots \ldots \ldots$ & $\frac{63}{63}$ & 49 & $\frac{113}{113}$ \\
\hline 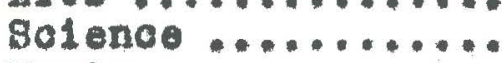 & 76 & 20 & 86 \\
\hline Musio $\ldots \ldots \ldots \ldots$ & 6 & 13 & 19 \\
\hline 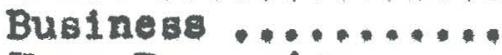 & 36 & 29 & $5 \overline{5}$ \\
\hline Home Economics ...... & - & 39 & 38 \\
\hline A B in Eduoation.... & - & 23 & 23 \\
\hline Meohanio Arta....... & 39 & -- & 38 \\
\hline Agrioulture ........ & 11 & $7^{-}$ & 11 \\
\hline Pre-Kodical ......... & 8 & 1 & 9 \\
\hline$B \mathrm{~S}$ in Eduostion.... & 54 & 115 & 169 \\
\hline Speo1als .......... & & 9 & 80 \\
\hline Totals & 398 & 298 & 580 \\
\hline
\end{tabular}

Nelther state college offers speolfio courses in mining although the West Virginia state College offered, in the summer of 1929 in cooperation with Weat Virginda Univeraity, a course in The Princlpies of Coel Mining the oontent of the courses in "Lesent1als of Economlos, "Labor Problema," "Rural Problems in Eduoation," and "The Famlly" is based largely upon materlal from minting communities. Bluefield State College has, as has been polnted out before, offered "First Aid" courses by the Negro sufety direotor of the Weat Virginia Department of Uines. In spite of ourrioulun 1dentioal with that of the whit to achools, the Negro sohools have doubtless alded the development of race consolousnese in the children of 49 Correspondenoe wh Dean Lane, 
the winere. Interviews with the teachera and their atudents substantiate this point of view. Said a Negro taucher: "Although there is nothing in the offering of the volsool to suggest raolal propaganda, still there is un attempt made to supolenent, oorrelate, and interpret history and all material in the traditional soursea in the light of Negro contributions and hi (the Negro's) relationship to all knowledge. This, I think, is the diatinot oontzibution of the Negro sohool." Another teacher writee: whe Negro ohlda in school learns that he has a groat handloup in the eolor of his fice. He learns that he does not have a oliance to be the president of the United States; a Governor of the State of west Virginla; sheriff of the oounty; or a judgo: wh1le on the other band, every white boy loarns that he kas a ohance to aohiere any of these positions. The Negro obild has to fight hard in order to keep from getting the inforlority complex. I belleve that the history of the Hegro should be made oompulsory for both groups to study." One effeot of the teachlng of raolal history and assoolation with the type of teacher which the writer found with few exoeptions in the wining lields is a holghtened racial self-respeot. At the ane time the procese of aseimilation of wbite standsrds has been wore rapid for many of these ohlldren than for thelr parente, theroby oreating a wide gap between thea. It in inevitable that If such a situation some are bewildered by the confliot of standards, family tonsiono inorease, and fandly atability 
1. shattered. The hypersensitivity conoomitant with the developnent of the reolal peyohosic leade many to dee in the minlng situation only raolal explottation. Soeing no hope at home they leave to faos the desalines of other industrles and other places. Some are sucoesefulf others return in defeat to add their more art1oulate roloes to those of thelt eldera in the choru of diecontent. 


\section{OHAPTIR XI \\ LEISURE TIUR AOTIVITIES}

Many white pereons in the Un1ted States oonsider the Nogroea a happy, oarafree, well batlafled group. In vlew of the restleseness indloated by the continued mieration of southern Negroes from the atates of thelr birti to the lese famillar sind more ldealized atates of the north these tralts would secm to be superflolal ang oompensatory rather than real. There oan be 11 th 10 doubt that Negro farmere of the south have come nortb in quest of happinesa, "to have a better time" or "to get more enjoyment out of life." High wares and a better job have boen, it is true, the imnediate incentive of thalr coming, but these were only means to the end mentioned above. The job which most Negroes mast aooept preclude, by thelr very nature, the satisfootion whioh oomes with many oocupatione.

What the Negro mean protty largely by "pleasure" is the posatblo use of lelaure timo. The Hegro whose quest has onded in the mintag flelds has found the variot 108 of waye in whioh he may "pleasure himgelf" definitely 11 mited. Wost of the Negro miners oome, ae we have eeon, from agrloultural seotions in which littie diversity in reareational 2 aotivities exists, and oan therefore adjust falrly easily to the monotony of mining town exlstinoe. In the mining Pashington, Forrester B. Reoreational Faoll1tieg for

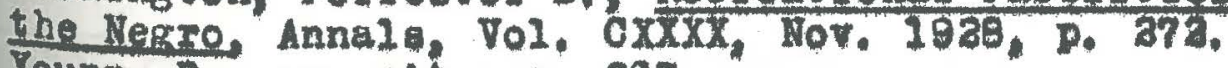
Toung, D., op oft. p. 267. 
Industry, however, they enoounter a new type of inaotivity. on the farm there 18 "always something to be done; In the winl fields there are perlods of enforoed ldleness without any task to enliven the day. The Negroes must therefore make a new and diffloult adjuatment for whloh their previous 11 fe has not prepared them and at the same time guffer the disiliustonment of flnding the 11f and oonditlong in the mining towne not all whiob they had Imagined, The pein of adjustment togetber with the pain of unrealized anticipation undoubtealy conatitut a real lement in the diseatiafaotion evidenoed by Hegroes in all the count 1 en studied.

Irregular work and 140k of fooreatlonal faoll1t1es to flt the1r neede have reaulted in the Iegro minerel opendIng most of the1I lelour in were time-k1111ng rathor than in activitier likely to promote individual or gootel improvement. Oring to the faot that the miners, both white and liegro, were 11ving at the time of the atudy upon a minimumpi-subelatenoe level" whloh left no money for purohase of reading materiala, no aystematio atudy of normal reading habite was made. Inquiry, howerer, Indicated that miners In West V1rginia regardlese of their raoe read very little. Occartonally an old Negro miner or hio wife may be seen reading the Bible but reading is deoldedly to be plaoed Imong the minor aotivities of the Negro miners. Libraries are praotioally inaosesaible to the miners and, by the Douglan, Paul H. Wageg and the Fam1ly, Univ, of Chloago Press, 18a7, p. है. 
surmer of 1932, most of the number ordinarily subsoriber to newspapers or perfodioal had had to disoontinue thelf oubsorlptions. Bookkeepers and postmestere reported that Negro nowapapere auoh a The Ohloago Defonder, The P1ttaburg Courler, Baltimore Afro-Amerloan, and the Norfolk Journal and Culde, ar well a the Crial and Opportunlty magazines, were reopived by a number of Hegro minere before the ooming of the eoonomlo ortale, These papers, howerer, require a relatively omall amount of time for thelr peruas. Loafing in varlous form take up muob of the time. Some of the men may be found at thels homes aeleep, or in some reatful aotivity like Natting down. More of them, however, seek amusement away from home, and on 1 dle days, weather permitting, w111 be found in groupg of varying sizea around the mining town. Some 11ttle groups are oompored of a few who have oome together at one epot mile vilating around, that is to say, going from one house to another and trading supplies of goasp and newe, 1 glanoe at the rallroad traok in the violnity of the company atore is almost oertain to reveal two long rows of men, seated on the ra11, faoing eah other. Talking, laughing, teasing, bantoring, gosstping, argulng, and story telling are the perpotual order of the day in these groups. In prosperous times thee gathering are made festive with puroheses of 0andy, peanuts, "oto' cakes," oheese, sardines, soft drinks, and other delloaples, Additional popular plaoes for pon4 of. Vashington, I. B., op. o1t. P. a72. 
gregating are ingide the oompany atore, on the store platform, and at the "olub house" of boarding bouse. These scenes are not unlike those commonly seen in the rural South at orossroada, ғы1 2 way gtationa, or atorea, Magroes learned the fine art of loafing before ooming to the mining flelds, and this trait represente a socondary diffusion of aotivity patterne rather than a now oltution.

These group not only provide amusement but also conotitute informal agenos of oommuntostion and cont rol.

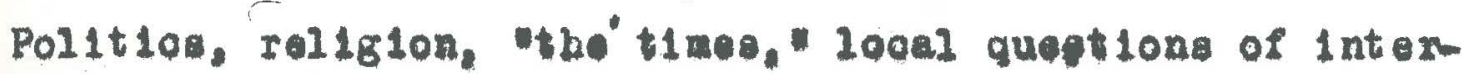
est, "the bose, and "the white folks axe frequent subjeot of disoussion. In the uouel oompany-owned town of arerage 120 Int Imate oonteot of the ont Ire Iogro group make theso gatheringe inesoapable forum of group judgment and opin10ne. In the amall mining town of village the laok of exoltement 1neures the afring of the most oomonplaoe happenIngs in the 11ves of the Inhabltants. Gossip diseeminated through male as well a female channel soon beoomes oommon property and gete baok to the peraons moat direotly oonoorned, reaulting at times in olashor between mombers of the Negro communty. Beoause of these oopaslonal alteroam tione, many of whloh are due to sex Irregulaxit1es, employers are almost unanimoue in eaying that Negroes get along with the whites more moothly than with momers of thelr own group.

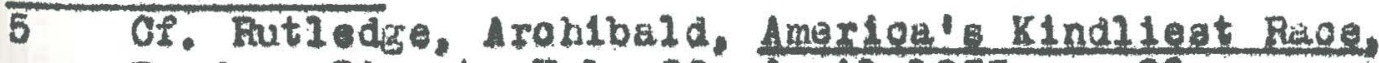
Readers Digest, Vol. 22, Ipri1 1933, D. 86. 
The women of the mining towne have, a a rule, jeBs time for lelsure than thelr spouses. Even though the ane is not running meal must be oooked, houses must be olsaned, and olothes mat be washed. The women, nevertho1eas, are much addioted to "vlsiting," The informal groupe are rarely composed of members of both saxes unless a man 1a visited by other men at his own home and his wife rem malns, The usual gathering is elther a woman's or a man's group. This informal visiting by the women goes on not only within the Negro group, but extionds outward to the white group as wel1. Megro and whiteminerel wites visit together informaliy at thel $x$ homes and exohange inews, Intorraolal loafing groups anong the men are more commonly found on the platforms of stores and along the rallroed traok.

$$
\text { In towns where they extat the "Y. M. O. A. "g" }
$$
(company-owned amsement bulldings) and the pool rooms are oongregating conters for men of both raoes, Negro pool rooms are numerous and somewhat notorlous in the United States. In the mining floldo whites and Hegroes frequentIy use the Bara bullding whioh, if under company suparviaion and managonent, are usually orderly plaoee, Pool rooms owned and run by Negroes are to be found in almost erery independent town in the mining 1101d8. " Some of these were found to be owned and operated by ex-minere who S See Young, D. 20. oft. p. 309, also Wash ngton, 7. B., op. oft., p, a79. See W. Va. Bureau of Negro Wolfare and Statiot10s, Report, 1925-19a6, pp. 74-79, Report, 1927-1938, pp. $20-23$. 
had been "expelled" from the mines on aooount of their age. They are frequentiy vilied by the minere on their ocoam sional tripa "to town." As a rule a crowd w1ll be found on the outside as well as the inglde of these pool rooms. Negro barber hopa, oommon reoreational centera in Negro-American $11 \mathrm{fe}$, are found infrequently, except in tho larger mining tows. What morbering is necessery is usually done by the Negro miners themelves, Not infrequently a Negro miner with, some okill in auob work supploment his arning by "barbering. 0ooalonally the "barber" works on the "olub-house" poroh, in whioh oase ho and h1s oustomerg beoome the nuoleus for a gathering and

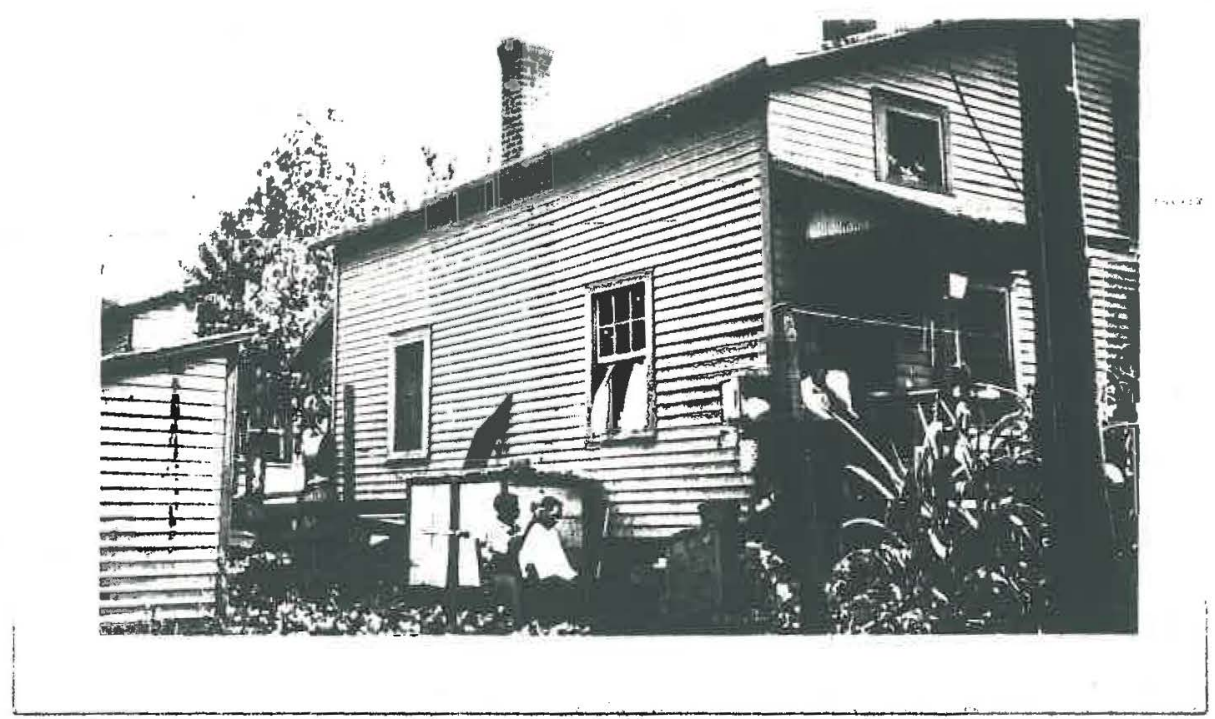

A Negro miner-barber

consequent "gession," In the Negro barber shops found in a fow mining town and in the independent town faolitite for playing cheokere and other games are oommon, wherefore thooe ohops also beoome loefing as well as busines oenters. 


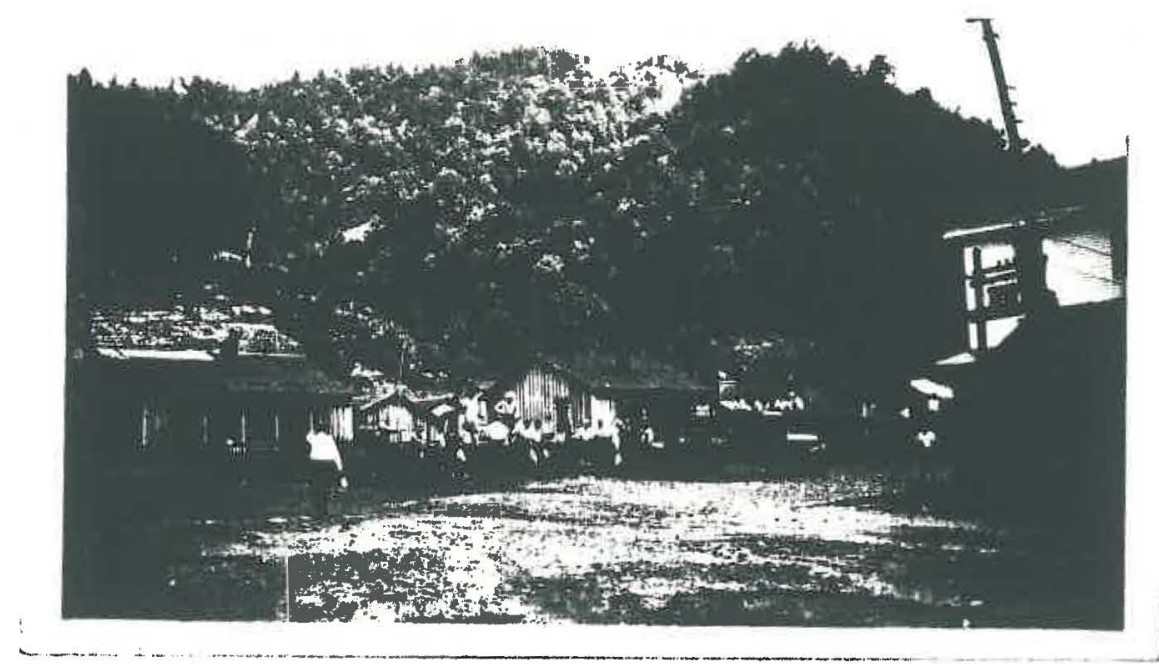

Loaflng near the oompany atore

Fith the soming of good roed to the mining f1elde the eutomob1 le afforded the Negro winers the enjoyment of pleasures theretofore unknown. Thelf vialts were extended boyond the $11 \mathrm{mits}$ of thelr. own mining fown to Inolude rolative in other towne of othor opunties... One of the keen pleasures of the MoDowell County Hegro minera was to P111 their oare full of $f$ flende and drive to Northork or Keyatone to attend the morlea, In some plaoss the miners may st11l enjoy the movies if they have enough sorip and the theatere are otill running. Many of the theatere, kowever, have been olosed alno early in the depression, One disoouraged. Negro woman who had lost her car as reault of the depresalon seide Our oer we about all the pleasure we had. We could at least get away from thia dirty plao 8 One of the factors that helped weaken the tias that bound the Negro to the soli in the south was the opread of automob11 ownerthip. (Washington, F, B, ep. e1t. P. 373.) 
gometimes then. Now that's gone," Hav1ng doveloped a 11king for the aotivitien wade poesible by thelr automob11es, the Negro miners who have loat thelr cars during the depression go baok to the lower plan of $11 \mathrm{ving}$ and the old 1801ation of the mining town only with the greateat diffioulty. The lose of thelr arro is an Important oause of the bitterness and consequent pereonal dieoriganization evideneed by some of the Nagro miners. Many of them foel deeply the faot that they loat theis ours through no fault of their own, for they were anxiou to work.

Attendano at publio dances is a form of pommexolallzed feoreation petronized almoet exolueively by the younger Negroen. A good many of the older Negroes do not look with favor on theer dencea. Pexhaps the disfavor they find in the minds of some of the good people" of the town Is not becaus of their miakdnes" per en, but beause dano1ng. Is one of those aotivities at which the Iegro Baptiote, in imitation of their white co-denominationelists, have looked akknoe, The occaslonal ocourrence of these danoes on sunday does not holp to bring about a meting of tho minds of old and young in this regard. It is not ourprlalng, however, that the young Nagrose patronlze this form of amusement inoe in the mejority of the comminitios Provision for reoreation and amusement 1 so meager as to be almost neglig1ble," Even during the aummer of 1832, however, not10es of danoes wore to be seen in some of the

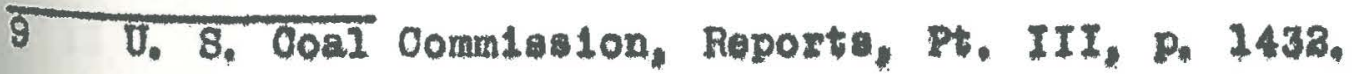


more fortunate coal towns.

It is not surpriolng, booause of 1 imlted reoreational autivit1es, that commerolalized oax v100 is well known in the rining fielde. Keystone in HoDowell County. for example, 1e notorious for ite Negro "red 11ght distraot, and similar conditione may be found in other town bordering on the mining flelds. As ha already been pointed out, the Neyro minere have a heritage of ex 110ense from early mining hlatory that make suogege diffloult for the Negroen who try to ralse the ctandards in their oommunties. White oftizene who look upon euph oondition with indifferent amuement ${ }^{10}$ a belng the thing to be expooted of Negroes Inorease thel I diffoultien, Although ome ompanies have made a conoerted ffort to abolloh oommerolalized vioe due to houses of prostitution within this towns, legroes and white employers alike admlt the faot that 112101 tex relom tions are relatively prevalent in the mining fields, FailIng to oontrol oommulty moral the atrlotex legroog have tightened soolal olase I1nes, wo that ohurah and non-oharoh people tond to be olearly differentiated, The VIIglnia and West Virginia native Negroen as a rul oonsider the Negroes from the atate farther couth a reaponatble for most of the lax otandards and tend to draw away from them.

Baseball playing has boen tradit lonal with tho winera of Wast Virginia, both white and Negro. As long aro 10 of. Toung, D, ope e1t., P. 304; H1so Allen, ope e1t,. 12 Se Chapter XIII for a more extandad alsoussion of this differentiation. 
as the writer can remomber wherever there was room enough to build a baseball fleld Nogxo and white ball alubs have been In evidenoe. In some loosiltien with no lerel opot rider than fifty or sixty seot team exiot just the oame and go to the neareat ara1lablo place to play, Nany oompantes oponsor both Megro and whlte basoball teame whioh play the team of rival compantes. Basoball games in normal timea are lmost alway played on Bunday. These ganes, eepecially in the days of comparative lBolation, were attended by praotically the whole town the they offered the only publio amuement avallable. Keen rivalries developed betwoen the different mining towne and the teame were the objeote of muoh $100 a 1$ pride.

In the present atatus of the minlng induatry, however, basoball teame axpensive luxurles for the enployers, many of whom in autting all unneoesary costs heve disoont inued eponsoring the teame. Thu at the time when publio diversion io most noeded it is least avallable, a very oommon condition, At Kanawha County operation the writer notioed that a splendid basobell fleld though avallable wa not used by an almost deaperate Negro group. The resson was rery simple. The miner oould not buy even one baseball, for the company store allowed them nothing but food.

While the playing of baseball ha thus been Iimited by the depresed condit lone it is still comon form of reoreation, for the Negro oblidren in the winlng 
town have refued to give up this activity merely for laok of oquipment. In a Monowell County town the writer was wetohing Negro chlldren playing ball. One of the boys asked a lad of nine or ten yeare to let him use hle glove. Hia reply was: "You ought to'al made you one," This reply aroused the ourlosity of the writer, who acked to see the 8love. The boys had all made thelr gloves out of oofiee gaok and rage. They were neatly done. I Hegro miner sitting near by gave a loud laugh a he walds "Dom's Hoover glovea !"

In MoDowell county over on the ${ }^{13}$ baseball was more in oridenoe than in any other county. Botwoen Welob and Bluefleld boye and girlo of blgh sohool age were observed playlng lther besebell of playground ball every day. Occasionally two glrlat playground ball teame played and sometimes the boys l team played agelnst the girle!. In addition to these boys! and 81riel teans overy one of the town in this ares ha 1 te men's team whioh plays on idle days. At one plaoe where owing to lack of apece thero was no ball ground, a large number of Negroes and whites were working together toaring down a row of old ooke ovens. Upon Investigation it was lound that they were making a bareball diamond. The oompany furntshed theis mules and the Negro and white miners were doing the work free, To make a usable ball ground out of that partioular looation ia This term was used by Negroes in every oounty violted to maan the territory oerved by the rorfolk and Western Ra12road, It 1 s an abbreviation of ${ }^{2} \mathrm{w}$. 
required the complete wrepking of the briak ooke arene, hauling away the debrte and $11111 \mathrm{ng}$ in and lereling the entire fleld. In the end the oompany would have the old oveno out of the way and the men would bave plage to play basebal1. This instance 111ustrates two outstanding faots about life in the mining flelde: (1) the epinit of cooperation and good w11l betwoon white and Negro minere and (2) the extent to whioh miners w11 80 to provide them selves with faolities for reoreation.

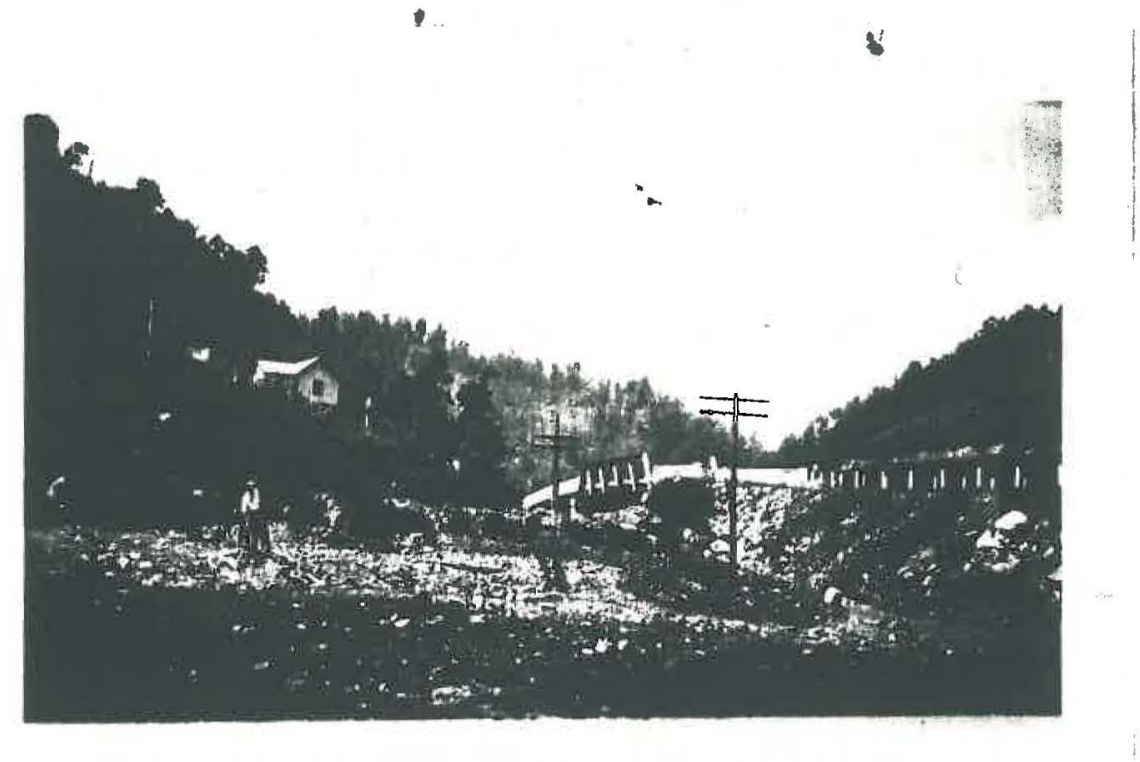

Megro and whito miners working together making a basebali field

Basabal1, of sourse, appeala moat strongly to the younger men, and, ua we have pointed out before, it was not played in all placas even by the young men. The Negroea in every oounty studied bave adjusted thomelves to the deprossion altuation by adopting a game whioh appeals to the old Es we11 as the young and, at the same time, enta11a praot1oally no expense. Thla game, in whtoh o phenomenal intereat 
was exhibited by Negro miners in every county atudied, was cheokers. Interest in oheokers has been ahown by Negro miners for many year but the game has come into its own during the depression. Formerly obeoker guraes were held in the homes of the different miners but more reoently the winers in several pleos have bullt rude sheltere from the sun at oentral looktions where oheoker games continue literally from inorning till night. At some places these shelters are referred to a "the olub." In some of these town where the rines operate very infrequently oheokel tournaments continue for days at a time. By proosen of elinination the olangion of one mine 18 ohosen and he is pitted agalnst the ohamplon of a neighboring town, These intermining town games are followed with keen interest by the Negro rainers. At other place no euoh tournamente are beld, but the sare minere were observed to play day after day, apparently without tiring. Negro miners, as a mule, are very eas to Interviow, but the writer found the interest of the Negro minere, both playere and spotators, so Intense that they were reluotent to be disturbed during thelr obeoker games. Ho suoh extrome intereat was apperent on the part of the white minere. 


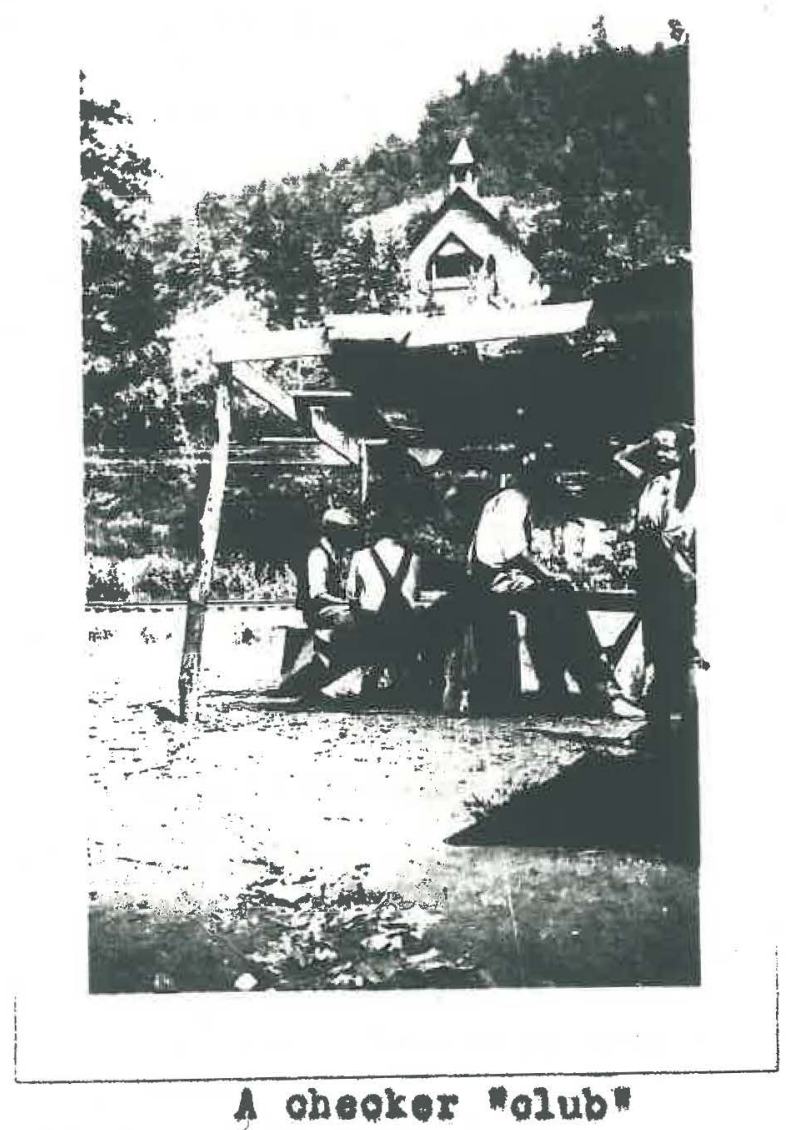

The only posetble rival of oheoker is horeasho pltohing. This game oloo has the virtue of belag inexpenolve and at the same time admitting wide partiolpation by both young and old. The horseshoe pitohing oonteat are attended by large numbers, when losing palrs drop out additional oontestante come forth from the orowd, the losere in turn becoming interested in soeing how the newcomers fare at the hands of the team whloh has just defeated them. The horseshoe pltohing games, naturally enough, are somewhat more widely attended than the obooker games, as vioarlous partiolpation on the part of spoctatore la a muob 
Blmpler matter.

Card playing 18 alwo very common among Megro minere. In more prosperous times there wa moh gambing, eopeolally after pay dayel the oard games of the present time are more I1kely to be afmply time-k111ing and not Iuorative aotivitioa. In the early days of MoDowell and other oounties the games of chanoe were aocompanied with 11quor drinking and many murdere resulted. Degro miners st111 drink 11quor and make 1t, ${ }^{14}$ but in the present depressed conditions consumption of 11 quor as woll as all other commodities bas diminished. The writor enoountered only one or two Negrose under the influenoe of 11quor during the ontire time in the sleld. Interviews with both Negroes and whitea, howover, revealed the faot that enough liquor is aoneumed by Negro miners to warrant mention of the time and monoy apent in 1 to coneumption.

Hunting and figing ocoupy some of the leleure time of the Negro minere. Unfortunately, though Negro minerg along the New and Kanawha rivere do somo flohing with "trot line" and pole, comparatively few mines are located on streams large enough to provide good lahing. Since the mines are located in the mountain seotione the Negroos can engage in hunting to a muoh larger extent than In fishing. The geasonal oharaoter of hunting, of course, Ilmits the time which the Nagro minere may opend in this 13 Feloh Da1Iy Now, Sapt, 21, 1930, p. a. 14 V. Va. Bureau of Negro Welfare and 8tatiat10s, Report, 1269-32, pp. 65-56, 
activity. Almost every Negro family has one or two doga, and families partloulariy intereated in hunting koep several. At one mine, in faot, where the minere had kardly enough food to keop them from belng hungry a Negro woman showed the writer with a great deal of pride her husband's 13 hunting doge. This miner and his doge were taken with the superintendent on b1s hunting trips.

S1noe tennis requiree so Ilttle apsoe one ralght expeot it to be popular game in the mining 1 ields, but neither whites nor Negroes have taken it up to any great extent. Anong Nagroes tenn1s is geldom found, exoupt among the upper olages whore it is looked upon oomowhat as a badge of caste. In only two of the mining town visited wore facilitios for tennio playing open to llegroes. Both town were large and both had large liegro populetions. At ono there wa a Negro tennt olub oxgeniced by the prinotpal of the Negro sohool. At the other the sompany furntebed tennis oourte for both wh1te and Jegro niner and a number of the older ohildren of Negro minere played, Tar mont of the Negro mintng groups, howerex, tennis is preotioally non-exietent.

It is not surprising that an awarenen of the importance of a reoreational program on an extansive soale 18 found among only alnority of the ooal operators in the mining 1101ds. Exoepting the baseball grounde and the ooos Blonal company-gupported basoball teame, relatively few lea111t1es have been provided by the coal oompantos. 
activity. Almost every Negro family has one or two doga, and families partioulariy intereated in hunting koep several. At one mine, in faot, where the minere had bardly enough food to keep them from bef no hungry a Negro woman showed the writer with a graat deal of pride her husband's 13 hunting doge. Thls miner and b10 doge ware taken with the superintendent on his hunting trips.

S1noe tennia requires so 11 ttie spaos one inight expect it to be a popular game in the mining flelda, but neither whites nor Negroes have taken it up to any great oxtent. Anong Nagroes tennis is peldom found, expept anong the upper classes where it 18 looked upon somewhat as a badge of calte. In only two of the mining town visted were factlities for tennis playing open to Hegroes. Both towns were large and both had large Megro populations. At one there wa a Negro tonnt olub organked by the prinolpal of the Negro ahool. At the other the oompany furnished tennis courts for both white and Negro minere and number of the older ohildren of Negro minere played, Tor mot of the Negro mining groups, howerex, tonnil 10 preotioally non-existent.

It 1 not eurprising that an awarenes of the importance of a reoreational program on an extensive soale 18 found among only alnority of the poal operators in the mining fields. Exoepting the baseball grounde and the oook Blonal company-supported basoball teame, relatively few fao111t1es have been provided by the conl oomantes. 
A part of the reason for this faot ia that many oos companies are so limited in their resouroes that, even though aware of the noed for foo111t10a, ouporintendent a who answer to boarda of direotore for doolining profite are not likely to recommend an outlay for suob "unproduat1re" oosts. A second reason for this laot is thet many, if not most, of the operatore of Weet Virginia have come up in the mining traditions of the atate. Some of these men reoall lng that they themselver had not eren the advantages of the miner. of today, consider pregent conditions relatively very favorablo. The initiative of the Hegro minere in providing tbeir own reoreational faolitio is further linited beoaut the miner in the paternallstio sompany-owned tome habltually look to the oompany for provielons of all oxts, and because they feel as a rule that whatever goe into improvements 1 mediately beoome "oompany" property.

It is not meant to infer hore, howerer, that oompanies have ent1rely negleoted this Important aspot of the welfare of thelr employees. Is a matter of faot, the coal operatore in their company-omed town lave probably gone furthor in this respeot than the arerage exployer of labor. For in tanoe, in the past fow yeara the state departinent of miner has carrled forward a safety eduoation oampalgn whioh has attracted wide attention. Lany of the waing towns bave thelr first-ald teams whioh compete in sectional and state meata one or more times during the yeax. Negroes and whites do not sompete, but a town 1a represented by both a 
white and a colored team, which mot periodloally and practio for the atate and seotlonal meeting with other teame. The writer has visted more than one Negro home in which the 21 ing room mantel was lined with silver oups won by the miner as member of these safety tesms, Some of the compantes look at the firotald teams as just some "foolishnese" of the offlolale of the me department and w11 have nothing to do wh th them othors conslder them just as fool1sh, but tolerato and aponsor thom beaus they Loel it to tho1r advantage to "burnor" the ntine departatent In this way, Others, partioularly some of the largest oom panies, bellove in thou strongly. Regardlese of the att1tude of the company, these safety teams constitute a worthwhlo leloure-time activity for minere of both raoes. At one place the "safety Olub." an orgentzation of all the miners, meets twioe a month for planned programm. A vegro miner gives hls talk and io followed by a white miner. The clubs of this company aro thus b1-raoial and are participated in by Negroes as muoh as by the witten.

One of the laggeat compenien in weat Virginia, with mines not only in different countion of this atate but in other states as woll. gives plonio for its omployees during tho summer months, The Negro pionio and white plonio are hold the same day, but in different plaoes. The writer attended one of the Negro plont os at whioh the wife of a Negro editor was the mletren of ceremonles. Since these plonion are "on the company" they are widely attended, 
apparently not only by the employees of the company giving them, but by others as well. On the day of the plonio mentioned the writer ploked up Negro boye of high oohool age on the highway and drove them far as twonty miles to attend this plonio, The fact that they were uninvited guestr made 11ttle differenoe to them, Tho boye desoribed the plontos as oocastons oo hllarlous and fantire that thoy oould not afford to mise them.

Oocasionaliy in the mining fielde an operator ia found with broad soolal vialon oombined wi th unlque knaok of ut1lizing all avallable resouroes so as to provlde the maximum amount of recreation and other servioes for his men. One superintendent, for example, had converted a pond once used as a watering place for oompany-owned wules into swimulng pool for the white oblldren of the mint ng town. He brought the water for the pool from an abandoned mine,

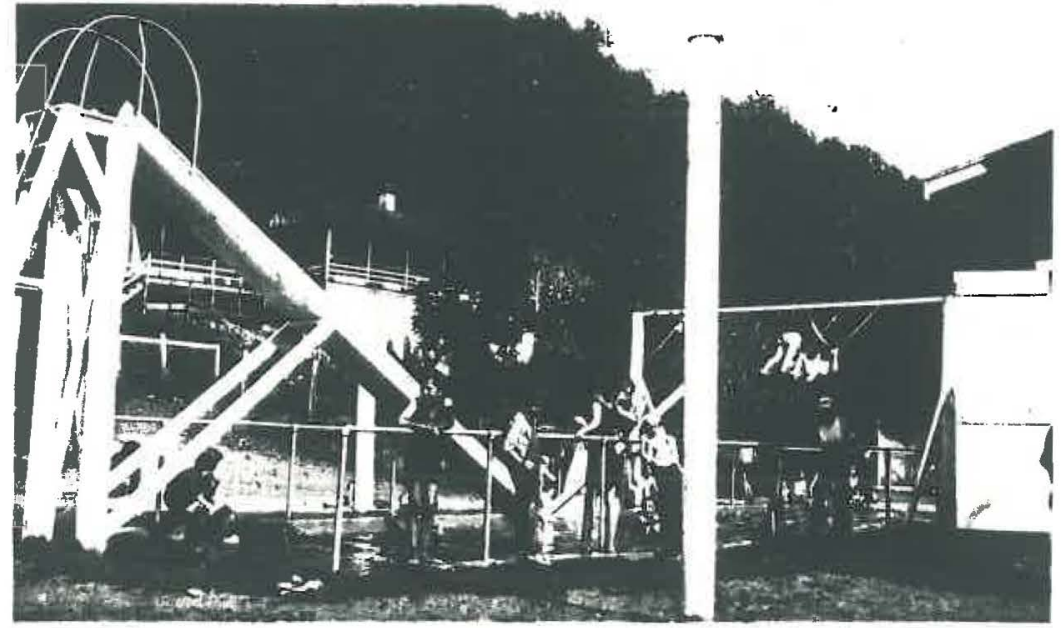

A oonverted mule pond 
At the time of the intervie: ho was oonatruoting a similar but larger pool for the use of the Negro oblldran. Although this town was not in Weat Virginla, but mile or so over the border in Virginia, ite inolusion here oemo warranted because the aeme company own more operations in meat Virginia than in Virginia. The bullding of the poola at this Virginla town was oonsidered an oxperiment and may result in the bullding of simliar feold1t1es at some of the West VIrginla towns. This instanoe suggests what a resouroeful ouperintendent may do at oomparatively ball cost.

A company, whlob is baoked by an interstate organ12ation and onormous resources, omploys poolal workers at severel oparatione. These 9001 el workere drent adult education and leleure time aotivitiee. At the time the writer wa in the town of this oompany canning axhlbits and demonetrations were being beld for the bonef1t of the housewives. The Negro women ware attending and found them quite helpful. Suoh work, howerer, ls quite unueusl in the mining flelds, for fow oompantes foel able to support it.

The Negro ohuroh in the mining I1elds, as 18 genersily the oase in mural seotlons. "15 ha in part mat the need for reoreation. In faot, the ohuroh has played a part in the reoreation of the nouthern Negro so important that Odum has seen 11t to olaselfy soolel gatheringe into two general divisiones whose whioh are held under the ausploes 15 OL. Toung, D., Qp. Q1t, pp, 264-265. 
of the ohuroh, and those which are not. ${ }^{18}$ The mere attondano at churoh servioes has immense reoreational ralue for many Negroes, whioh 18 refleoted in the faot that in some plaoes the Negro ohuroh ig open almost nightly oven though It may have a regular preacher only twioe anth. Mention has already been made of the Megroes' fondnese for funarals. Negro miners are here only following traditional 10lourem tIme activity of the Southern Negro, although there is some point to the etetement of Dr. Nesley when he saysi

Where the Negroes are shut off from the amusements and the reoreations whloh every normal person desires and which modern goolal workere are finding neoeseary for industrial workere, it is not ourprising to find that the oirous, the revivel, the funeral, and large reIIglous gatherings will take numbers $\mathrm{from}$ work.

Th1s trait of funeral attending is powerful enough to influenoe Negro: minere to remain 1 d 0 , even in the dull timea existing during the summer of 1938, Sald one employer in MoDowell County: "The Negro I1ken nothing more than a good funeral. One of my Negroes told me about attending the 'beat funeral! last weak he had over been to. There wa a funeral over at one of my mines last week and praotioally overy one of the Negroes 'Iald off,' I usually try to got thew to have their funerals on Sunday - but this woman diod on Monday and they couldn't very well keep her that long."

16 Odum, Howard W. Soclal and Mantal Traite of the Nagro, Columbla Univ, Press, 1910, p, 228.

17 Ins. $p_{0}, 230$,

18 Mesiey, O. H., op. olt., p. 240. 
Dunerale provide the Megro with reoreational aotivity, but allow him aloo kindrod but not identioal satiafaotion. The Megro has traditionally ahown "respeot" for the dead. Oocaslons for eympathy are, of couree. oulturally defined and become timull for folk beharlor. These ways beoome group ritual, the obaervanos of whob brings forth the attitudes upon whioh the group has plsoed value. The Negro 3 roup has plaod suoh a value upon exhibitions of sympat by in timea of aloknese and death, 19 and gete an immense emotionel atiafaotion from the observano of the ritual and bohavior in way deflned an proper. Recognition and etatus are attalned by adhering to the mores as developed by the ritual observanoe. 20 Thus a logno miner. in debt to the company and reduoed to a mintmu of subsistano 1eral, way profor a funorad to the opportundty of a day's work.

Funeral are not the only ohureb funotion which have reoreational value for the Hegro miners. "Baptialng and marriages are widely attended and are enjoyed to the fullest of their posmiblifties, Moet of the Negroes are Beptiataf hence the baptialng" are held in the ereak or Iver neareat to the town in wh10h the ohuroh 1 a looated. These gatberings, together with the "soolale, " festivale, meatings of missionary soolatien and young people's societles, and the giving of religlous plays, all serve the Ig C. Odum, ope olt, p. 250.

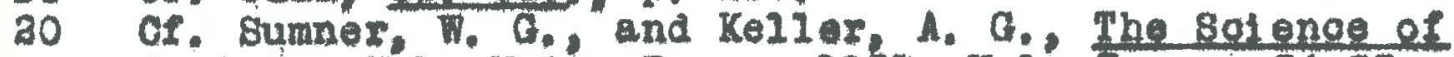
soclety, Yale Univ. Prase, 19k7, Vol, I, Pp, 34-35. 
funotion of allowing a development of self-foeling no noceary for the satiafaotion of the desire for recognition, Thege functions afford the ooossion for exhiblting "best olothes" or serve as meoting oentere for the young people ready for the marrlage maxt or the widowed looking for new companions, Not the leat pleasurable part of these various funotions is the informal meeting after thelf oonolusion and the return home in groups, News, gose1p, and otories are exobanged between peopl who meet mostiy on these ocosalons. The reoreational value of oextain rel1glous funotions of the churoh 18 not therefore the result of oonsolous effort in these directions, but in the Informal opportunities for expression whtoh ohuroh gatherings afford the people. The deoorum exhiblted by the Megroes on these pookelons, dresed In their best and beharing on the basle of norme of etiquette not oalled for in thelr usual routino, 1 a acompani od by the satisfaotion whloh comes from playlng 1 deelized roles 1 dent1fied with a heightenod status. The resulting oatharsi 10 Important in breaking the usual monotony of the mining town reg1men,

Negro lodges, whioh will be mentloned in more detall elsewhere in thle study, have, a a rule, been assoolated with the churohes in observation of funeral and other eervices, in fact many of the preachers have been also Iodse leadere. Lodge aotivity has been traditional with the 3I V. Va. Bureau of Negro Welfare and Statistion, Roport, 1927-28, pp. 64-65. 
southern Negro and ito presenoe in the mining flelds 1 a a 32

normal oultural sequence. In more proserous days the lodges were quite ative in the soolal 116 of the mining communition, It the time the present study was made, how -ver, these fraternal organization were practically inaotive due to depressed sinanolal conditione, An analysie

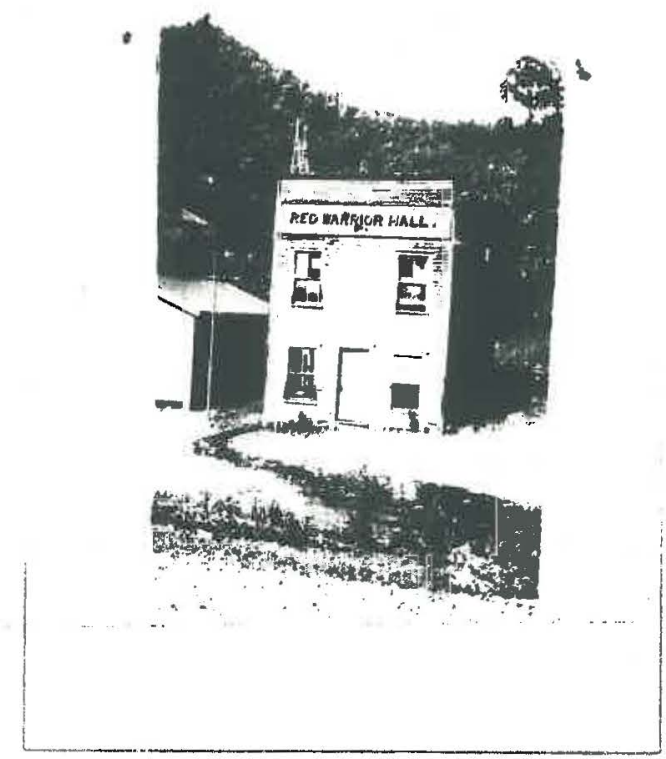

A rel10 of bettor day

of the repreationel funotion of the Hegro lodges would differ in no Important respeot from what hes al ready been sald concerning Negro oburohes. Partioularly does the use of brilliant regalls and $\mathrm{hlgh}$ aounding t1tles enhance the normel tendenol os toward a type of magalomanla lound anong minomities whose atatus 1 a IImited by what MIIler has named 35 800 odum, ope oft. Oh. III: 
"oultooratio domation," Most of the organtzation peraft meraborahip by women as well as men.

Negro teachera in the mining flelda, taken as a sroup, have exhibited a greater awareness of the soofal role of dueation than my other persons in position of potential leaderahip. Interviews with these teachera Ioval the faot that they bave eaorifloed conalderable timo and energy to provide programe of reoreational notivitien whioh would keep the young people, particulariy during the adolesoont yeare, at the sohool as long as posalble after the regular ol bea houre. Reogniming frankly the oharaoter of family Influenoes under whloh many of thelf gtudent 8 11ve, these tesohere have progoeded upon the aseunption that the sohool has mor to offer the pupll than the home, and heve provided olub of rariene kinde, ethlotios, olvio campaigne, dramatios, and othor form of profltable 2alaure time aotivities. But the Negro teaghere, though aware of the dearth of reoreational faclities in the mining flelda, have not been able to meet the 1tuation adequately. Many of them are untralned in reoreational leadership and are hampered by laok of funde. The sohool, moreover, is alwaya at digadvantage in oarrying lorward any program of voluntary aotivities on the part of the studente, because many of them aseoolate it inseparably with work and henoe are unxlous to get wway from tho solool plant as soon as pooslble. In splte of ite hundicaps, however, the Negro wohool 23 Mller, H. A., Rgoes, Mations, and clagses, pp. 37-31. 
hes apparentiy mede an honest effort to meot the noed fox recreation in the mining $1101 \mathrm{de}$.

In some places Negro teachere have hown oonstderable leadershlp in orgenizing lel mure time aotivit1a not only among the young people but mong thelf parents as well. Under the leaderahip of the teaoher in a MoDowell County communtty. for xample. Hegro high ohool boysl olubs, girlo' olubs, a women's Induetrial alub, and an's olub have been organized. The writer flrat heard of these aotivities from the wito of a Negro miner in a diutant sounty who had formexly lived in.thio community. Having become acoustomed to the active and profitable recreational Iffe here whe wery unhappy and disoouraged in ker present home. These olubs for adult take place of the usual gosalp gathoring and utilize thols time in Inatruo tion of varlou kinde, some work in wearing and in handiorafts has been done. The work of the different olubs is goordinated by a communt ty oounoll whlob aote as a sort of oloaring bouse for the different olubs.

The Agrioultural Extensi on Department of Weat Virginia Untversity has done nome work not only anong the rurel farm Negroo but among Megro minore well. Four H olubs have been farmed in a fow places and axe uppoxted onthusiastloally by. Negro minoze and thelr wives. Garden campaigns and inst ruotion In canning and weal planning are also furtbered by the state Und varalty in pooperation with the Federal Department of Agrioulture. In addition to thl 
Governmental aotivity the Ameriaan Priende Servioe Oommittee has, In addition to giving relief, organized aewing cluba and halth olubs, and has offexed some opportunity to the wien to work at oarpentry and pobbling. 34 Nogro minero in some places expresed a high ragard for the activities of thl organdation.

Negro mual oal organl atlone have been treditional in the mining fields, Wany yeare ago Hegro bands were somewhat comon. These bands played at different oooasion and were always present at the numerous hollday oelobratlons. Labor Day, Fourth of July, and 1mllax bolldaya were formerIy accompanted by $10 d g e$ parades and band oonoerts, These early demonstratione are now almost forgottan, exoept by the 01d Negro minere. 25 The writer, thinking the offices of the oompang would be olosed on Labor Day, seld to the bookkeoper, I auppose you w112 be alosed on labor Day, won't youp" Hi reply was "Ho, wollI be wore apt to run on that day than any other day - juet because it's Lobor Day. The oompany does not belleve in giving the men the day. Fourth of July and Ohristma afo the only days we reoognize. I belleve in giving the men a day, but the company doesn't - so I keop my thoughts to myence."

The praotioal disappearanoe of banda and enthugm 1aum for holidays 18 by no means a ohange pecullar to Negro 34 Report of tho Ohlld Relief Work in the Bitunitnous Coal Fields by the American Friends Service Committee, Sept. 1, 1931 - Aug. 31, 1932, pp. 7-8. 25 Cf. Lynd, Middletomn, Haroourt, Brace, 2838, p. 77. 
oulture; whit bands are woh less numerous than twonty yoars ago, for the breakdown of 1 solation and oonsequent opening up of othor ohannole of reoreation have reaulted in a Iessened interest in these direotions on the part of the majority group as well as the regroes. Only one mining town v1olted had a Negro band. Both uniform and inetrumente for this band wore furnt shed by the ompany. Funds for this purpose were given at the Instigation of an operator, now deceased, who was considered thetr patron selat by the Hegroes in the coal Llelde, Mogro meloal orgenizations in the mining lelde continue, however, the most oommon type being the rooul quartette, Uany of the mining towns have these quartetiten, ome of then oponsored by the ohurohes. The quartettes of the different towns compete agalnst ecob other for prifea, and the woete, which are frequently held on Sunday afternoone, ara moh more In favor with Negro churohmen than baseball gemes. 27 These quartettos eaphave a name, some of them taking the name of thels mining town and othere taking some dosoriptire titio suoh as "The Humming Birde" "Jolly Boyo," "Great 4 Wondera," eto. In many places these quartettes arese in formal attire for the1r appearanoes. Wh1le thor are many more male quartettes than any other type, ocosalonally a dxad quartatte is found, is well as alngtng olubs for glrlo alone. A contest in whioh 36 See Appendix for handb1li taken from company bulletin board announcting one of these contente.

37 C., Hooduon, O, G, The Rurat Hegro, Assoot ation fox the study of Jegro" LIf and Biftory, 2930, p. 145. 
both men and women oompeted was held in conjunotion with the State Baptist Convention whi ob the writer attended in the oumer of 1932. These organizations provide the opportunity for dreas, whloh is held in high regard as basis for atatur, espocially among the Negro women in the minlng fields. In addition, the numerous praotioe sesions and "soolale" provide opportuntty for contaots outside of the regular routine of the organizations. Vicarious partiolpation in the oonteate 1e.provided for many otber who become ent malaotio partiane in bohalf of the quartette or quar tettee representing thels town.

At one of the minlng town most nearly devold of reoreational organization the young llegro minere formed what they oalled The Kangaroo Club. The purpose of this organization according to 1 to offloer was the preservation of order and morality at this town, It was based upon the usual "Kangaroo Court" proosdure ourrent in many ja118, but Whether the Idea oame from some oonvert to the virtues of this organization was not asoertained. Whenerer a member rlolated the oode of the organisation he was alther beaten or fined by the other members. The violatione punished most often were breaches of the poeos and sex Irregularities.

It bas been Impossible within the IImit of the present ohapter to mention all of the lelsure time aotivitles of Negro miners and thoir families; the more lmportant through whioh the Negro group has adjusted Itrelf to oonditione in the mining fields have been discursed. Although 
delinite ilmitations are apparent, the ohsraoter and otandards of the use of lelsure are elm1lar to or. probably, superior to those found in the average rural Negro oommity. The popular assumption that wholeale reoreation alway tends to reduce delinquenoy ahould be questloned. The whole question of delinquenoy mot inolude many variables other then 39 the mere 1aok of reoreational faoll1t1es, The Importanoe of this laok in explaining oertain types of personel disorganization, however, way not be doubted, it is the opinion of the writer that an Intelligent drogram of eduoam tion and leadership in Ioloure time aotivities offers means of soolal control through whioh the Hegro oulture in the mining fields may be ohanged in the difotion of goals deened sooleliy deelrable. That ouoh a program is possible in the near future 1 very unlikely. \& gharmoteristio of the presont economio order seems to be that in times of depression and onforaed idlenes whis oh make the problem of Ielaure timo more aout the resouros for moting the bituation shrink; that is to say, they exiot in inveras proportion to the need. It may bo sald, howerer, that in this respeot the Negro miner ocouples substantially the same position as his white brother. This lack of differentiol leleuretine faollities is apparently one faotor in the
28 See Toodson, op, cit.
29 See Jones, Willam H, Recreation and Amusement Among,

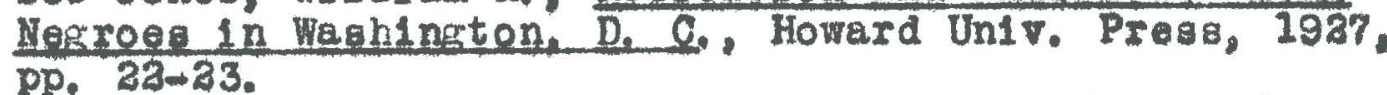
30 Park, R, E, and Burgesa, E. W. The City Unit, of OhI cago Prese, 1935, pp. 198-300. 
smooth relationship exlat ing between whites and black in the minlng 1102ds. 31

31 Cf. Young, D., ep. att. p. 319. 


\section{OHA PTER XII}

\section{RELIGIOR}

Ameriosn Hegroes have always taken a keen interest in religion. Sinoe thit day sometime between 1773 and 1775 wen the first Negro ohuroh in Amorlos was founded by Magro 1 Baptiots at Silver Bluff, South Carolina, the oburch has ocoupled antque place in the 11fe of the group. Their a oburohes were purely Megro Institutione and offered the Negroes a fleld, perhape the only one, in thioh they were 3

independent of white control. Chureh growth he continued unbroken from the beginning unt 11, eooording to Reuter, five out of every eleven Negroes belong to some churoh. In 1926 there were $5,203,487$ Negro ohuroh members, oonstituting 9.5 per oent of all ohurch member in the United 8tates, and this flgure, according to the Census Bureau, underestimates their relative numerical strength because many of the younger 5 ohildren are not taken into Negro ohurohes.

In the mining fielde of Woet Virginit, as in sural communities of other states, Megroes have been aotive in religious matters. In gowa of the towns visited the Negroes did not have a churoh bullding but they always had

I Puokett, N. W., Folk Bollefo of the Southern Nerro, Univ, of N. C. Pres8, 1926, p. 529.

2 Seo Haynes, G. E., The Churoh and Negro Progress, Annald, Vol. CXXXX, Tov. 1928, p. 366.

3 Puckett, op, oft, p. 529.

4 Reuter, op oit. p. 318.

5 Bureau of the Census, Religlous Bodles: 1926, Vol. I, p. 69.

- See Woodsan, C. G., The Rurel Degre, Ch. VIII. 
a ohuroh organization which conducted services in the Negro sohool or some other arallable plece. Three hundred and elghty-eight, or 71.6 per cent of the 543 miners from whom it was posatble to get the information, were ohuroh members.

Booker T. Wash1ngt on used to say, When I meet a Negro who is not a Baptist or a Mathodist, I know some will te man has been tampering with ble religion." Apparentiy very 11ttle "tampering" has been golng on in West Virglnia, eapeolally in the pining flelde, for in 1923 Negro Baptiats constituted 73.8 per oent of all Nogro otwroh moibors in the state, and information from reliable souroe indiates that the peroentage of Buptiate 18 even lifgher in the mining 10

communities. Two hundred and ninety-eight minore, or 76.8 per oent of the 389 ohuroh nombere 1ntervlowed, ware Baptista, while 61 or 15.7 per cent were lethodiste, ehown in Tabl 70.

7 Hegro teachers hint ed that, because of olas distinctions on the basia of ohurch membership in some places, it might be better polloy not to press the matter of ohuroh membership if the miner appeared reluotant; henoe, the somewhat large number for whon this inforration is not given.

8 Quoted in Eabree, E. R., Brown Aineriog, Viking Pres,, 1931. p. 342.

9 Rellglous Bodies: 1926, Vol. I, p. 69.

10 Corraepondenoe with The Rev. J. J. Turner, State Direotor of Religious Education and Missions of the Bept1 st Churoh. Mr. Turner put $s$ the proportion of Baptiats in the oosi lielde at 80 per cent or above. 


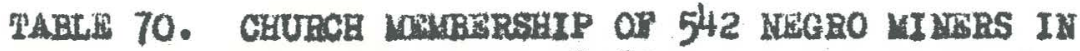
WEST VIMIYIA: 1932

(Complied from ud nerst gohedulos)

\begin{tabular}{|c|c|c|c|}
\hline $\begin{array}{l}\text { Denom natlonal } \\
\text { membershlp }\end{array}$ & Nuruber & $\begin{array}{l}\text { Per cent of } \\
\text { all mifner: }\end{array}$ & $\begin{array}{l}\text { Per cent of } \\
\text { church member }\end{array}$ \\
\hline All donom nations & $\begin{array}{l}154 \\
388\end{array}$ & $\begin{array}{l}28.4: \\
71.6\end{array}$ & 100.0 \\
\hline $\begin{array}{l}\text { Bapti int } \\
\text { Mothodi at } \\
\text { Hollineme } \\
\text { Othere (a) }\end{array}$ & $\begin{array}{r}298 \\
61 \\
20 \\
9\end{array}$ & $\begin{array}{r}55.0 \\
11.2 \\
3.7 \\
1.7\end{array}$ & $\begin{array}{r}76.8 \\
15.7 \\
5.2 \\
2.3\end{array}$ \\
\hline Total & 542 & 100.0 & 100.0 \\
\hline
\end{tabular}

(a) Presbyterian, 3; pheclple, 2; postolle Fat th, Pentacostal Church of Chel et. Chureh of God, Cathoile, 1 aach.

The reason for the exceedingly high proportion of Baptiats and Baptiot omrioho in tho mining fields 1 les in the different poliol os of the Mothodist and Baptiat denoninations in the matter of establishing thelr whargee." The Bapt1st Churoh, tradit1ona1ly Individual1st10, has tended to put few restriot lone upon the ereation of new ohurches, Many of the Bapti et ministers vere orlginaly miners with the knook of preaohing, who augmented their wages by conduoting services on sunday. The following of these preaching minere formed the nuolel of churches and were reoognized as such by the Baptiat denomination, many of the Baptist churohes originating in this way. Finally. with the growth of the oburoh, the ministers gave up mining altogether and became "reverende." The Methodist Churoh, however, has held that their minlatere must have a certain anount of training and go through a period of probation before a church may be established, henoe the comparutively fow Methodist ohurohes. The Methodist ministers in the 
mining towns are on the average consequently moh better eduoated than the Bapt 1at mini tere. Many of the Baptist miniaters still work in the mines, preaching being only their Sunday job. At the mest Virginia state Baptist (Negro) Convention whioh the writer attended in Logan August 34-26, 1938, the faot of poor training wes admitted by one of the ministera In a opeeph on the Heed of a Irained Milatry" when be sald milingly: wou know, we Baptisto on the whole are not very well trained."

Som of the preaching minere voloe antlpatby toward and auspioi on of the trafned olergy. Sald one such miner: "I ain't got imoh use for these fellowe who have to depend on other people for their support. When somebody els has h1s hand on the money in their pookete they don't tell people the truth - they just tell them what they want to hear. Theylre just a bunoh of woremongers. Al though laworality among olergymen is of oourse not unheard of, this utteranoe is apparently an example of "profeselonal" jealousy rather than a dispassionato disousation of facts. Seotarianiom anong the Legro miners, as among American Negroes generally, is a matter of considerable 12

importanoe, Asked about his oturoh membership a Raleigh County miner replied: "I'm a non-sextarian (non-beotarian)." Another legro miner nearby observed: We11, then, just put hlm down a a hypoorito." This emphasis on a ohurob of a II Speech of Rev. J. H, Younger, of the Zlon Bapt let Churob, Parkoroburg, W. Va.

13 Cf. Puokett, op, olt. pp. 5z1-32. 


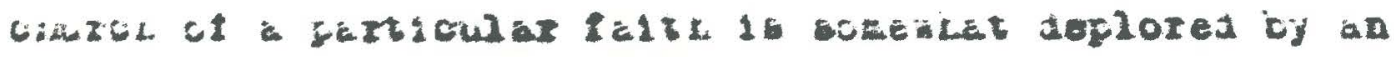
offiolul of the Baptlat denomination as followa: Aa a rule wherever there are any number of colored people on a mining job they effeot a omrob of their denomination. With the least enoouragement they start as many denominam tlonal olurohes as there are groups of denominat ions on the job. On some occasione juat one member agk for the opportunity to have a churoh establl bbed of his fath. Such 18 often mede posalble by the coal oompany an an induoement to hold people on the job: as they begin to build houses they also build a oluroh with the underetending that it is for the employeer with equal denoninational righte. This In some instances 18 good, but at times is detsimentel in thet it dividee the people up into co many groupe none $1 \mathrm{~s}$ atrong enough to eooomplish anything. * congregatione are. consequent 1 . small in most of the winting tomb. ... Among the ohlef denominations in West VIrfinda the arerage membersh p per omiroh, 1noluding the laxge urban ohurohes, is as fo110w: 14

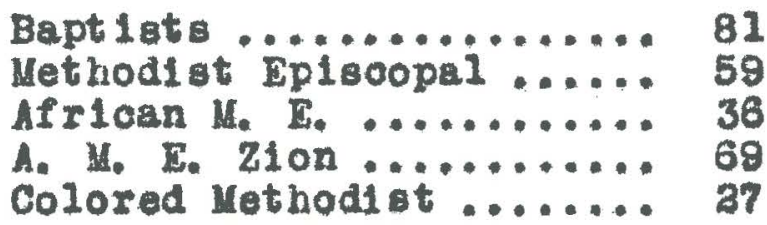

A11 denominat lons ...... 68

13 Letter from Rev. J. J. Turner, Nontgomery, W. Vu.

14 V. 8. Bureau of the Census, Rellglous Bodies: 1926. Vol. II, D. 754. 
Few mining towna have more than one Hegro ohurch and the sharing of this bullding by more than one denomination means that in many places Mothodlate and Baptists alternate from Sunday to Sunday in control of ohuroh services. Wh1le some miners and their familes attend the services of both denominetion, the olase lines based on denominational affiliation tend to kep many person away from any but their own services. In many placos regular ohuroh 18 held only once a month by an ifinerant preacher whose sohedule may inolude as man as four different infining towns, but in the meantime ohurch services are frequentiy held under the leadership of presohlng miners and officar: of the ohurches. Th1s condition 1s hardly conducive to regular ohuroh attendance. One hundred and fifty, or 30.3 per cent of the 495 miners from whom it was posible to get the information, reported that they had attended no church services for the month preceding the interview; considerably greater number attended at least once a sunday or oftener, as ahown in Table 71,

15 C. Router, epe att., p. 385. 


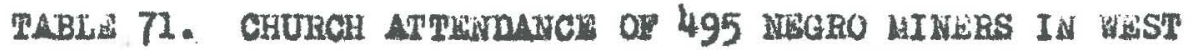

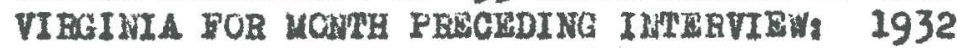
(Coupllod from udnere' echedules)

\begin{tabular}{|c|c|c|}
\hline $\begin{array}{l}\text { Nimuloer of } \\
\text { tines at tendt ng }\end{array}$ & \multicolumn{2}{|c|}{$\begin{array}{l}\text { Wumber and per cent of uf ners attending } \\
\text { ench seediled number of church services }\end{array}$} \\
\hline servelcen & Tumber & Per cent \\
\hline $\begin{array}{l}\text { Wone } \\
\text { One } \\
\text { Two } \\
\text { Throe } \\
\text { Tour } \\
\text { rive } \\
\text { SIx } \\
\text { il ght } \\
\text { Ten or more }\end{array}$ & $\begin{array}{r}150 \\
44 \\
94 \\
30 \\
126 \\
13 \\
7 \\
18 \\
13\end{array}$ & $\begin{array}{r}30.3 \\
5.9 \\
19.0 \\
6.1 \\
25.5 \\
2.6 \\
1.4 \\
3.6 \\
2.6\end{array}$ \\
\hline Total & 495 & 100,0 \\
\hline
\end{tabular}

In drawing any conclusions"-from this table it should be reoalled that these flgures were seoured during a period of eoonomio depreasion. The number of niners not attending ohuroh at all was consequently higher than in normal times; for 1 netead of atimulating to 1noreaged rollglous aot1vity as 18 ordinarily the ose the hard times have kopt many Negro chuzoh member away for reasona to be disoussed 1ater.

The Negro ohuroh, as has been polnted out before, I1ke the churobes of other minority groups in the United States, has never been a purely rellgloue organiaation. It must 1111 recreational and woolal neede whioh for the majority group aro fllled by more opeolallzed agenoles. The Negro ohuroh in the mining 1 elde continues depplte temporary Betbaoke ag. the center of reolal ilfe. The I6 Toung, op. o1t. p. 529. 17 cf. Reuter. 20, at., p. 332. 
reoreational and oolal funotions of the ohuroh are dealt with in other obaptere. The 1mportance of these funotions may not be overeatimated; the preaent ohapter, however, w112 be concerned more dirootly with religiou and moral agpecte not disoused elsewhere.

The ohlet role of wany legro ohurohed in the mining flelds ha been to provide a plaee where the Negro miner may givo full vont to hi emotlons and his unfulfilled 18

desires. Religion not only oonsole him in his pregent misery; it holds out the hope of a rloher reward in some 19

better world to be. Polnting toward the okles an old miner who bad been at the same operetion in Canswa County for 30 years ald: "I'w expeoting my good times to come from up there. I don't expect muoh here. I wouldn't want to live at all if I couldn't truat Jesus, " In the language of a Methodist preaober in the minlag fielda religion 18, for most Negro miners, a kind of anesthetio whloh will help them die an easy death 'when they come down to press a dying p1llow' ane hears them aay in their prayers and testimonies." The dullnese and monotony of mining town exiatenoe, the unoertainty of 11 fe underground, and the discouragement of years of unrealized hopes may all be forgotten for a little while in unintibited partiolpation in hlghly emotion a1. rhythmio, religious behavior.

Refleoting the charaoter of the churohes/In the 18 Cf. Young. op. elt. p. 539. 19 Cf. Ross, u. ope eit., p. 80. 
Bouthern states from whioh their membere came many ohurche日 have been somewhat remotely concerned with the inoulcation of white moral standards, Puckett, who see in tils charaoteristic a parallel to neat Afrioan religlong which are interested not in the relationships of man to man but only of man to God, ays in this connection, "An old Negro testifled in weoting that he cursed some, had atolen some, had drunk whlskey some, and had done other thinge some, but could thank God that he had never lost his religion." good bit of condexnation, however, has beenglven to dianoing. card playing, and ot her amusements of rolnor soolal consequence. Negro minister on being questioned concerning the attitude of the young people toward the ohuroh, sald simply, "They are golng away from the churob -- after games." Meny of the preschers, whose attitude is evangelloal, have, to the negieot of the ooclal minlatry, plaoed theis first emphasis upon inoreaning nemberahip.

What has been ald oonoerning many Vegro oburches and ministers in the mining fields applies by no means to all. Some of these men deplore the oondition of much of the religion in the mining flelds and sre doing what they can for the "progrese" of theis people which is always defined in terms of the aseimilation of majority standards. 20 CP. Odum, ope 01t. D. 54; Moodson, Rural Negre, p. 136; Router, ope oft. pp, 327, 330-31; Kreuger, E. T. Negro Re 11 gioug Expresgion, A. J. S., vol, xxxvili, July 1932, p. 25 .

21 Puokett, ope o1t., p. 526.

22 seo Morél and Ienners Among Negro Amorioans, Atlanta Unir, tub. No. 18, 1814, pp. 901, 
One of the very unusual men in the Negro nilniatry of the wining fields writes the author follows: what I' am personally trying hardeat to do 18 to oorreot what I oonolder to be a primitive ooncopt of my people ponoerning Christianity. ........ I an trying to oonvince them that Chriatianity is honesty, purity, truth in the inward parte, galvation from aln in all of ito uglinas, right here in th1s present 11fe." Another says wOne tmith we are endeavortag to emphasize in the lookl ohurobes cerving the mining population 10. we mot do more thas others. That 18, wo mut relate the churoh to the moral and o001al well-being of the oommunity in a definste way. It w121 do no communty any good aimply to add another oburoh to 1 to already orowded 118t. The only exouse for the olmeh in the community is 1ta ability to trangform the community into the kingdow of Ighteousnass. The churoh was orested for the community and not the community for the ohuroh. If the ohuroh wil thus dedloate itself to the service of the oomunity, it will prove a blessing and no other oredentials ill be necessary to oocupy the fleld." Buoh ministers as theae, men of eduoation and vision, are greatiy out numbered by wen of I1ttle eduoation and no conoption of the social mision of the churoh. 24

23 Offolal Journal of the Fifty-first Annual Sesaion and Laymen's Asociation, East Tennessee Conference of the Mothodlst Epl soopal Churoh, 1931, p. 37 (Report of D1strlot Supt. Thomae G. Howerd of the Bluefleld, T. Va. Di atriot).

34 of. Router, 2pe oft., pp. 326-a7; Young, ope elt. p. 535 . 
The educated clergy, raoe consolous to a certain extent, are striving to hasten the asaimilation of majority standards and the development of raolal elf-respeot. By reason of the very magnitude of the probleme with whioh they have to deal they ineritably aufer defeate and reverseg. Conoerning a recent disappointment a mister of this type writes: whe Negro, pertioularly the southern Negro, is dreadfully afraid of the white man and does not have the moral oourage to stike out on hls own initiative in selfdefense, and unt 11 he does his future is precarlous. The very people I tried to help fought agalnat we vigorously and those who helped me at first deserted and left we alone." Such a miniater is 11kely to get the cooperation of the wore intelligent Negroes in the mining flelds who are tenerally one with him in desiring soolal improvement rather than mere ritusl, emotionalism and preparation for death. ${ }^{25}$ Teachers, partioulariy, offer their cooperation to many of the minlaters although they admit and deplore the need for better tralned preahera. Sald a Negro teacher, Whe orying need of my raoe has been and is today a competent minlotry to lead and inotruot the mases in the application of the prinolples of right $116 \mathrm{f}$ and oonduct from the atandpoint of the B1ble. 111 honor to the pioneers who did their best under the ofroumbtanoes and who served well their day and generation. But this $1 \mathrm{~s}$ another age and a brighter day, one that demands improvement along all 11 nes 55 CY. Toung, ope elt. p. 515. 
and especialy in the pulpit of my raoe." In some parte of the inining flelde where this desired leadershlp lo laoking uinisters report that teachers take a "oritical attitude" toward the ohurob. This "attitude" is due in $2 a r g e$ measeure to the faot that mo many of the legro olergy are "oalled" rather than prepared for theis jobs and their linitations preclude their taking any but an emotlonal approsoh to 37 soolal reform.

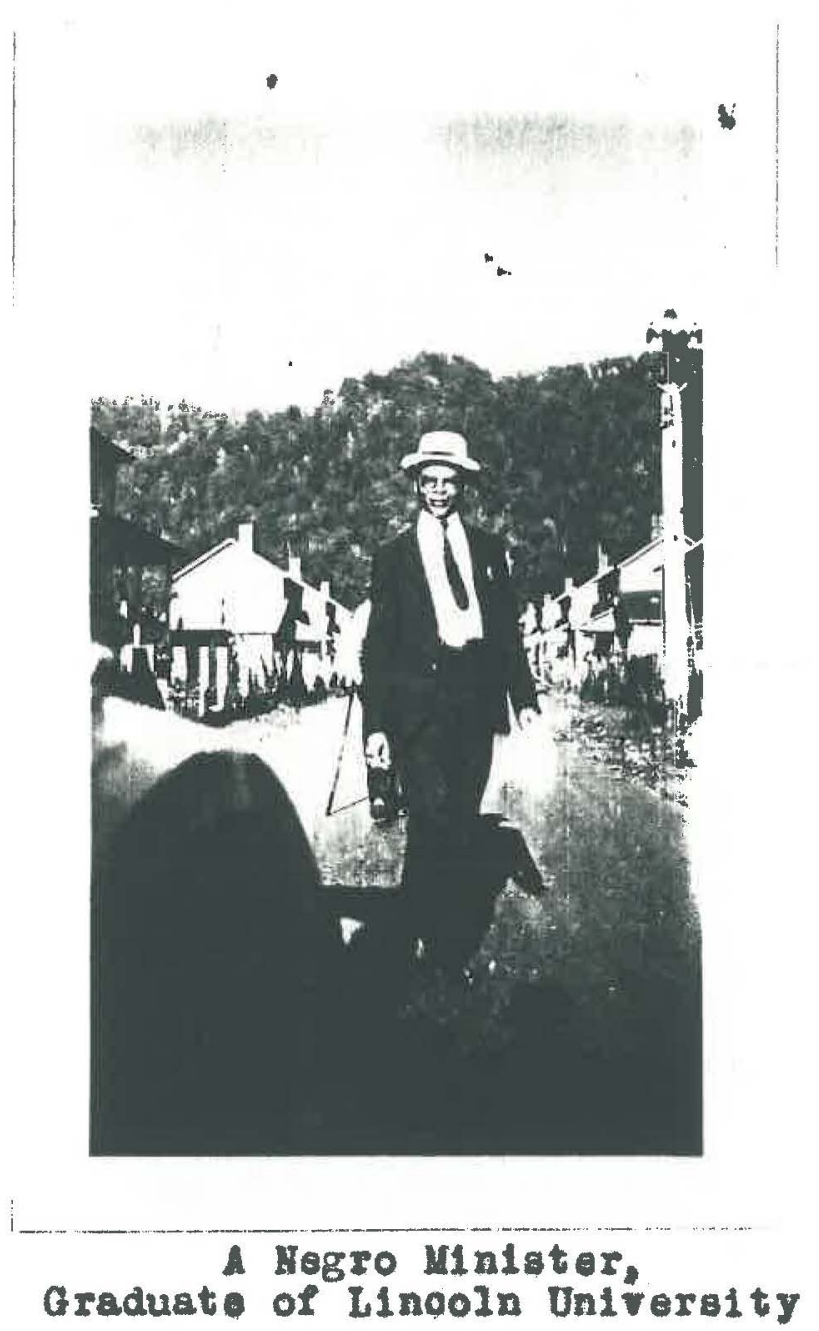

26 VeIoh DeIIy Haws, Sept. 21, 1926. 27 Cr. Young, epe eit. Pp, 534-535; Dowd, ope cit., p. 590. 


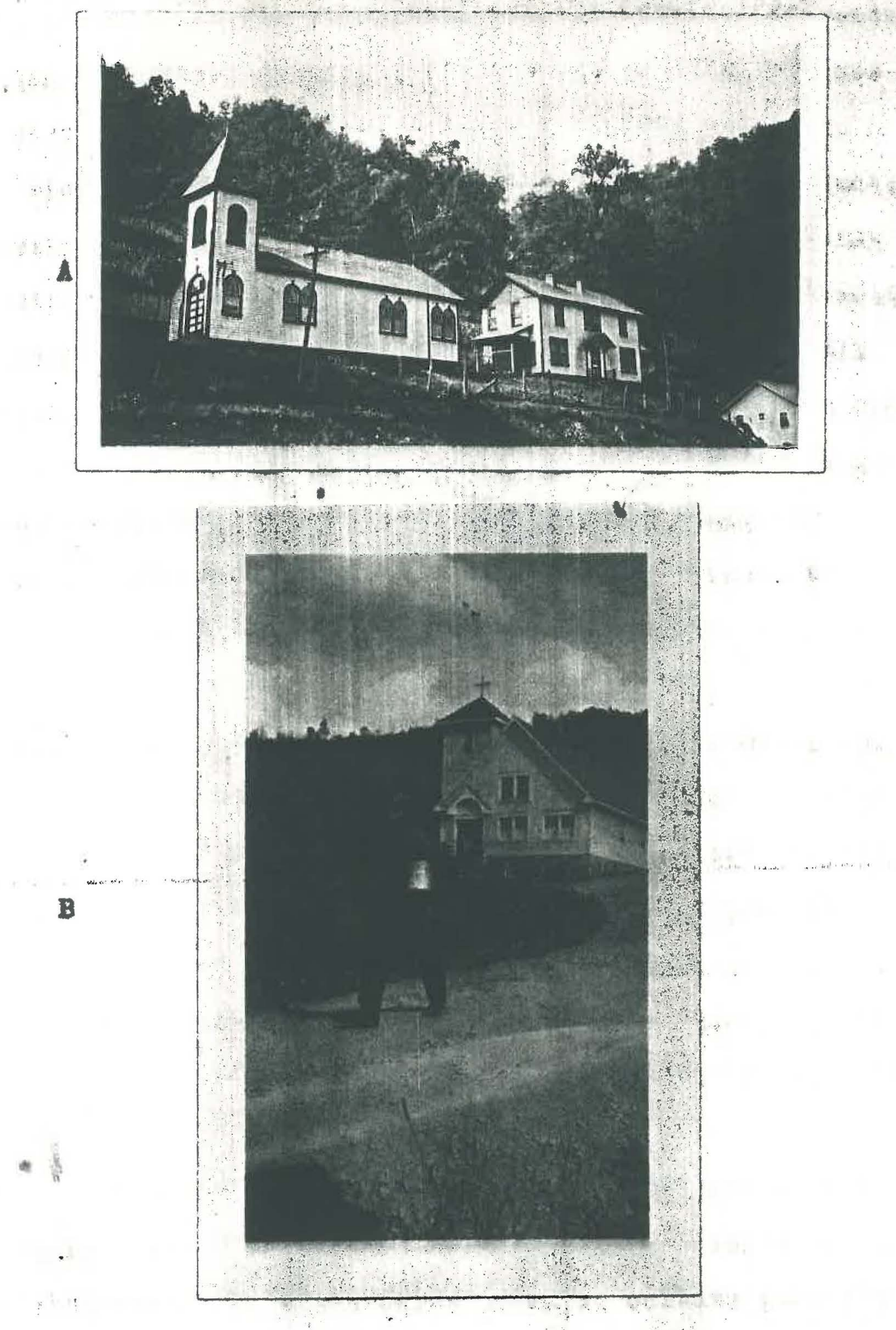

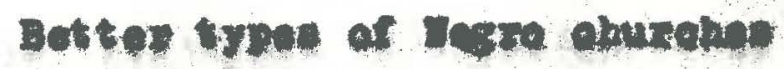

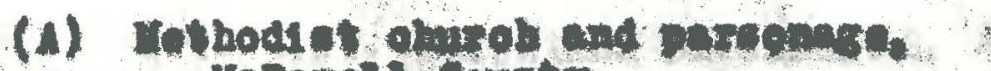
VoDow011. Gounty

(B) Ghiroh ohered by Baptiote and rothodiate. Ralelgh county 
Owing to the eduoational and oulturel differences between the several oongregations and between the virlous Miniaters in the mining fielde Negro religlous services vary widely. Sow Negro ohurohes have oome to approximate majorlty standards of religlous formality so olooely that the differenoes between them and whit oburohes are w most 1uperoeptible. At the other extrome are omurohes highy ewotional and "primitive" in their behevior. It 18 undoubtedly this type whloh lod Dr. DuBole to look upon the legro ohuroh as the only link between tbe Ameridan legro and 27

1fr108. 11 gradations and comblnetions of these two extremes exiet in the ohurohee of the mining towns. The type of service may not be prediotel on the basis of denomination, although in general formal behavior in whiob the congregation 11 at on quietiy to a bermon. listens to hymas gung for the most part by the ohols, and partiolpated vary quietly if at all in the gerrice may be found among the Methodiet ohurohe owing to the general higher educational level of the ministers. Methodist ohurohes, nerertheleas, as well as those of other denominatione, go to the opposite ext reme.

The Informal, emotional type of servioe in whioh the Negroes take part without apparent inblbition is auch more interesting to the student of Negro oulture than the type that merely duplicates white standarda. The writer

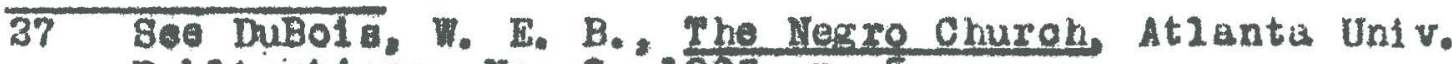
publications. Mo, s, 1903, p. 5 . 
romembers dietinotiy one euoh aervioe begun by the eemingly spontaneous outburet of ainger ralaing his voloe in the refrain of a familiar hymn. He sang only a 11 a or two before the oongregation begen to join in; by the time the song was conoluded the roow filled with a harmonious volume of sound whioh inoluded the deepent base and the highest soprano. The preacher next oalled on one of the ohuroh offlolulo to lead in prayer. The petitioner began sLowly but presently, ot fulated by many exolamat lons such as "Amon i" "praise God." "Yas, Jesus i" from membera of the oongregation, hl ward beoape rapld and eloquent. After the prayer the preacher, a blg, handsome muletto, began hil sermon speaklag with deliberate, faultlese diotion much after the fashion of any eduoated proacher of the majorlty group. The congregation appeared attentive, but onl mildiy intereated in the proosedinge. Presently the dellberate speech of the preacher quickened cadence and rhythin became apparent. As the tempo increased and rhythm beome unmlatakable he lapsed Into a aort of intonation oharaoterized by those indesoribable Negro endings so noticeable in the spirituals. ${ }^{30}$ The mombers of the congregation beoame eager, expectant now, many of them moving forward in their seate. As the contagion apread they began to reapond to the sermon by the ame oal2s heard during the 38 OT. Odum, ep. alt. p. 63. 39 Sec ible, pp. 73, 75 for a list of oomonly used expressions.

30 See 1bid. pp. 74-77 for musioal regresentation of a sermon whioh Odur says approeohes "mustoal reoltative." 
prayer. The preacher's valoe became htghor and faster as he gtrode about the platform. Seemingly 11ttle attention wae paid to what he anid, but the liatenera began to amay. Callo were so Iroquent that almost every bentence was punatuated by a chorus of reaponses. Smiles appeared on every face as the presober otrode about, talking fater and fastar. Ho broath came with gap and ot esch inhalation ho made a peoullar stacatto sound $11 \mathrm{k}$ " huh gu ferking hil 31 head forward as he did no. A woman jumped in the air twio and shouted after whioh, spiritusl datharais apparently complete, she bowed her head on the eat in front of her and remalnod quilet for the rest of the aervice. ${ }^{3}$ After the ollmax of the sermon the preacher dropped auddenly into h1s soit exbausted, pereplration treaming down h1 faoc. The geraon 18 the high-1ight of this type of service and by 1 to very nature effeotive moral teaohing is excluded. The interest of the oongregation is primarily in the dramatio element of the sermon, not in 1 to didact $101 \mathrm{am}$. It mattere 11ttle what these preachere, expert in etirring the enotions, say; thelr oongregations are ohlefly affected by the way thoy say it. Puokett. finding the aame charac teristio among the Mlesiesippl Hegroes, gives the following extraot. from a sermon that atired it hearere greatly: - Now I want you to get the bird alled the Curlosity that 31 Cf. Kreuger, op. oft. p. 28. 32 G. Meoklin, J. I., Demooraoy and Raoe Friotion, Maorn 11an, 1914, pp. 43-44; alao DuBo19, V. T. B., Soule of Black Bolk, Chloago, 1803, p. 190. 
can fly oixty-seven mundred thousand miles in a minute, and he oarried him in the valley and he sald tho oup foamed so wrathy and the wrath looked so bitter and won't drink it up, D-o-oh, nom (groans)." The wanner of presentation ia suoh that the liatener finde himself following the rhythm and aotions of the presoher rather than the elgnificanoe of the words. In spite of the laok of meaning of these sermons the writer $1 \mathrm{~s}$ inolined to agree with Puokett that their rhythm "has a wort of tom-ton effeot upon the nexwous system - even upon that of an eduoated white observer trained in enotional control."

Pollowing the eermon is the taking of the colleotion, an important part of the servioe in the mining fielda. Uaualiy it is prefaoed by a talk by one of the afflcers of the churoh who may atress the severity of the hard times upon everybody but emphasise the fact that the preacher and his family must live like other lolks. Ho exhorts the members of the oongregation to give even 1 they can give only a 11ttle. After the conolusion of this speeon the collea tion is taken acoording to one of two general patterno. The method usually found in ohurch servioes nearest to white atandard is the eimple paselng of the colleotion plate, whioh 10 preoeded or followed by the talk by one of the oturch officere conoerning the purposes of or the need for giving. The more characterietio method is what Odum 33 Puokett, ep, eit, p. 533. 34 In1d, pp. 533-534. 
has called the "table way." A table is pleced in the front of the olurob and frequentiy by 1t: side 18 a funotionary known in the south as a "oounter." The Negroes, partioularly the women, come up one by one and "lay on" their contributions. This mothod hes the praotioel advantage of making giving and not giving conepleuous a well to providing the opportunity to show off the Sunday olothes of the giver. In the outh, where this pratioe la largely used, some Hegroes inptead of giving all their contribution at once have been known to go up alx or geven times. At the time of the field work th. Elet virginia miners, however,

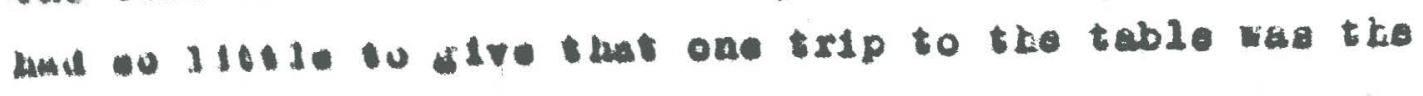
IImIt.

mul 0, whiob is an laportant part of llogro rel18lous practioe, varies from oburoh to churoh as much as other elements. in the servioe. Here again are gradations from the free, joyoug, uninbibited singing, rloh in rhyt hom and haimony, of tho ohuroh farthest from majority stendards to the "progresaive" ohurches that have disoarded the "old time" gong in favor of the newer book" songs. The elnging in some of the ohurohes of this latter type appars stilted. artiflcial and $108 \mathrm{~g}$ atiafying to the partlolpant than that in the more baokward" oburohes. Thl statewent, howover, muat be taken for what it 18, a mere improseloniut 10 observat10n, for the degree of lmard stistaction my sot

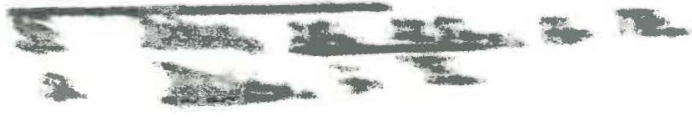


be determined eas1ly by superfiolal evidenoe. Furthermore. It must not bo underatood that all ohurohes that have adopted majority standards in other parte of their servioe hive discarded old musloal habite for now; the malo ooom alonally lags behind in the prooess of asimilation.

The same olash over rellgloue belief and att1tudes which exists arong parents and ohildren of the majorIty group is alco present among the Negro miners and their oblidren. The rural llegro olurob, the standards of whtoh are refleoted in many oburobes in the mining $1101 \mathrm{ds}, 18$ 37 extremely orthodox. Children, eapeolally those in high sohool, 00casionaldy gain fros ascoolation with thols tecohers and from thelr atudies something of a oritioal attitude toward the religlous as well as other standards of their parents. One afternoon when the wrtter was talking with a Negro family oonsieting of the miner, his wife, and hla con who had just llaliahed the alnth grade, another old Negro miner jolned the group. Learning that the writer was a teacher of soolology the old man delivered himgelf of a sermon on the departure of men of solenoe from the way of religlon. The boy apoke up and asid, But when you begin to think about 1t. Mr. S., do you belleve the firet ahapter of Genesiar" the old man thereupon oset asperoion upon the praotioe of thinking about auoh things. The boy replied, We11, I just have to think sometimes." "That's because you have never been converted, " bald his mother. The boy 37 Toodson, 2p, olt., p. 151. 
proteated that he had been baptized, at loast.

Opinions of Negro minlaters in the mining flolds

differ on the attitude of the young people toward the ohuroh, some holding that the young people are indifferent, othere that despite a oritioal and unoooperative minority they are generally loyal and interested. while etill othere olalm that high enthusiasm for the churoh marks the attitude of the younger generation. The following quotations are from two minlstera in the same ming town

The attitude of the young people in the cotil flelde toward the churoh is one of indifference, disregard, 1rreverence. Thte is due in the main to the breaking down of leadership in the homea, where family worahi $p$ and BIble otudy and the simple life are not observed. The young people are aimply following in the footeteps of their parenta.

In A-..- Dietriot there are ten Baptiat ohurches; nine of thege have $11 \mathrm{ve}$ young people's clubs that form a Young People's Diatriot club Convention. Theae young people are very enthuslastio in eupporting the ideals of the ehuroh.

The following are typlcal of replies recalved from preachere in answer to the question: What is the attitude of the young peoplo in the mining fielde toward the ohuroht

The young people in the mining 1 lelds attend churoh very readly, though they often express themselves as being muoh displeased at the old time methods of meeting the problems of ohuroh work.

The tendenoy eems to be away from the Churoh; the attitude aeme to be botter on the coal operetiong than in the towne. 
The Negro youth of the $0081 \mathrm{mining}$ flelds maintain a very fine attitude toward the ohuroh. In many respeots superior to that of their elders. They can be ared for the church with the proper sort of leadership from adult Chrlatians. This, to my ind ind is the saddest noed of the young people of the coal nining fields.

The attitude of the young people 18 favorable generally. There may be an isolated case here and there of irreverence and athelstic talk; but the great majority 1a with the ohurch. This is ev1denced by the large number conneoted with the ohuroh, and engaged in oburoh aotivitios, in youns peopleis societ 1es of various kinds.

Unt11 reoent Iy miners made good money. Many of them gave tholr ohlldren the bonefit of school and $001 \operatorname{leg} \theta$ eduoation. Returnt ng to their communities these young people, many of whon were brought up in the ohuro $h$, ingtead of rendering the churoh service oomensurate with their training and opportunities, in many oases hold off from the churoh and oritiol se 1t. Many teachers in these communities take the same attitude. There may be found, therefore, in many coal-11eld communitieg a group of young people whose attitude towards the ohurohe in the ooal flelda is one of orftiolsm. The vast majority of llegro ohurohes in the coal flelds are Baptist Churohes. In keeplng with the denominational viempoint, theae ohurohes look with disfavor upon card playing, danoing, and the 11ke. Thls attitude of these ohrohes has allenated numbers of young people, who, having learned these thing in sohool, and belleving them to be harmlese, consider the position of the churoh rig1d, baokward, and unintel11gent, and ohoose Ireedom and enjoyment rather than submat to the restraints of the ohuroh.

These, however, constitute a small group in these oosl-11eld commities. Young people in large number still support the ohuroh and acknowledge 1ts clalm upon them. The preponderance of young people in the ctrurches of Beokley has caused me to take note of the proportlon of old and young in churohes elsewhere as I go about over the state and inquire of pastora as to the proportion of young and old in their services, and of their attitude towarde the oburoh. Invariably, I learn that young people are attending and oupporting the ohuroh and of ten in larger mubers than their elders. 
The writer 10 inolined to belleve that the lagt quotation presents an optini at1o but fairly doourate desoription of the aotual eltuation. The oblidren of miners under the influenoe of the sobools, having in most oages assimllated white atandards to a groater oxtont than have their parente, refleot the oonrentional unoonventionality of white young peoplo in rel1glous watterw. Nany of them, as says the last psstor quoted, do hold to the ohuroh and are one of the foroes maklng for the regheping of the Negro ohroh more nearly after the patterne of white ohurehes. In those communities where oturgh mombership ia a distinot badge of soolal status the young people are $11 \mathrm{kely}$ to be supporters of the churob, Oconsionelly the ent1re obolr is made up of young high sohool students. Churoh-sponsored musloal organizations al ready disoured, to well as the conventional "B. Y. P. U. "a "and Epworth Leagues of the Baptlet and Nethodlet ohurohes, draw a oertain following frow the young people. Toward the more "emotlonal" type of churoh servioe, however, many young people are likely to assume an attitude of superiority and disdain.

It is a common generalization that in times of adversity the ohurohes are f11led and in progperity attendanoe wanes. The generalization, however, does not hold true in the mining flelde during the dull times oince 1929; sone preachers report that attendance has fallen off about 50 per oent, and othere admit that the ohuroh is aotually fighting to maintain it oxiatence. The Negro miniaters 
unaniwously ofte as a reagon for the deoline the traditionil

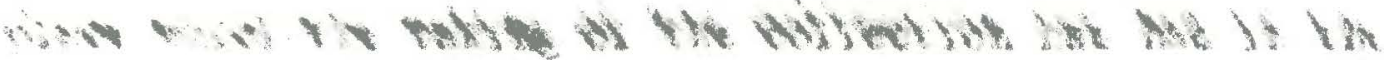
Negro ohuroh servioe. Mogroes have been sooustomed to supporting theis ohuroh libersily and sonspicuously. The trip to the "table", as has been noted, allowed the Negroes dressed in their sunday best, type of self-expression upon whloh high soolal value ha been plaoed by the group. HayIng neither new olotbes to exhlbit nor money to give, many Negroos have ohosen to remain at homo rather than admit what 18 to them certain 108 of atatus, Aegro miner explained that he had gone to olmirah only 3 time during the month because he laoked olotbes. He went only at night when be oould not be seen. St111 another variable in the Bltuation appears to be the general weakening of the habits and the personal morale of all glasese of workers in tiwes of prolonged ldleness and adveralty.

The depresaion has been a real disater to many of the preachere in the ming fielde, sald the Superintendent of the Bluefield Dietriet of the Methodiet Cliuroh in Beptember 183a: Our pestore and hole fantiles base borne a large sbare of the euffering, Hot beling on the companieg: pay roll they are not ont1tled to an allowanoe. They ast trust God and the loyalty of thel paribhioners, out of thoir poverty falthful christians have shared with our pators and their fand 1100 in a way that evidenoed the real 38 CF. Odum, ope oit., p. 79.

39 See Williams, J. $\mathrm{u}_{\text {. Human Aspeot }}$ of Unemplovment and Relief Univ, of North Carolina Proes, 1833, pp. 80-94. 
Chrlatian apirit. Then, too, companies have been generous and conalderate conoerning the welfare of our minietere," A Negro ainiatar in letter to the writer ays in this conneotion, "lithy have beoom so severe poonomlcally here that my good wife and I have reaorted to a life of faith and prayer alone for our eupport in what we are trylng to do for the Master, and I am happy to aey hat without tel2Ing anyone about our neede but Hits alone, day by day out of Hi unseen treasury belp come to us. Whenever our atore gets empty, we foel oonildent He is going to work a mracle for ue, and up to the preasnt time He has not dimappointed us. In spite of herdebipe the miniaters, like the Negro minera, are apparentiy standing thelr ground and hoping for better times. Concerning the behavior of the preachere in tho economio oriels the president of the vest V1rginta Baptlat State Sunday Sohool Convention ays: if do not know of a aingle inetanoe where a pestor has restgnad because of the Inablitty of the obureh to pey he salary. On the other hand. I know of numerous instanoed were paetoro have voluntarily reduead thelr alarles and oontinue to serve at a great sacrifloe. A number of ministera who live in Beokley and hold patorateo in near-by coal aamos recalve Irom thelr oburobe on their eervice days leas than expenae 41 In going to and from their oharges,"

40 Offiolal Journal of the Fifty-second Annual Seseion of the East Tennesses Conferenoe, Hethodl at Eplacopis Churoh, Sept, 38, 193\%, p. 28.

41 Correepondenoe with Rev. P. F. K1ng, Beokley, W. Va. 
While wont of the ohurohes have probably lost in attondanae ainoe 1929 some preachers olain that their ohurohes are maintaining thelr pro-depression numbers, and et112 others olalm actual 1noreases. The preacher. who report ouoh increase acoount for it on the basis of the bellef on the part of many llegroes that the depression ia a curse sent by the Almighty as punisment for ain and the only way to end the hard times lo to make friende with 42

God." The writer found among the Hegro minere much ev1dence of this bellef that perional or public misfortunes are the reault of a vindiotive aupernatural power. As the self-maintenanoe organization orumbles many feel the need of rellanoe upon aplritusl powers as an ald to their own 43 impotenoe. The following inoident related by a Fayet te County superintendent 1 llustrates a bellef typical of many of the older Negro mere: A superintendent was opening up a new mine and was very anxious to complete it as aoon a poseible. Consequentiy, he was working every day, including Sunday. One of his Negro minere came to bim and ald: "ur. Superintendent, I don't beliore it is quite right to work on Sunday - de good book don't say to do dat." The superintendent, a 11ttio out of patienoe at the time. replied gruffy: "I'm running thle me on moner. I fow daye later a terrifio oloudburat deatroyed practically all the work done up to that time. The Hegro ohanoed to see 43 OY. Woortor. Blagk Yeomanry, p. 14a, 43 Cf, Ruokett: ODe OIt. D. B45, 
the auperintendent and rewarked: Well, Mr. Superintendent, 1t kinda look to me like de Good Lawd had more water than you had money."

The one okuroh whioh has shown a remarkable growth during the dull times is the "Holinese" oburoh. Wew branohes of this denomlation for both whites and Negroos are apringing up here and there in the mining flelde and the membership is growing rapidly. This faot is easily explatned inasmoh as the appeal of the Holinees oburches 10 entirely motional and rhythalo, the servioea being oharacterlzed by all the emotlonal phengmena of the old-time revival. Negro and white miners ollke seok rellef from monotony and find it hero moro easily than in a servioe in which thoir role 18 malnly pastre. A Jegro moman at Koystone explained her preferenoe for the Hollnese Churoh: "At the otbers you juat have to alt ot 121, At the Holiness Chroh you can get up and preach or pray and sing. I 11 ke 1t !"

The Negro churoh 1a the tning flelde $18,11 \mathrm{ke}$ the Negro fam1ly and the school, slowly, but surely approach Ing majority gtandarda. The chlldren of the Negro miners and race-oonsolous preachera, teachers, and laymen are the mot effeot1ve agenoles in bringing about this oulture change. The steady atream of migration from the south, whlch stopped only with the depreseion, has been the conBervative force in the prooess. Aseimilation of white waye moves on irrespeotive of the immediate religlous neade 
of many minere. Study of the Negro ohuroh in the mining flelds has convinoed the writer that diverse oultural elements, even in a group with raolal homogeneity and bonds of common di eadrantages, may not have their religlous neds filled in the same way. 9lmple regro peasante lately from the south, oaught in the meslatrom of coonomio maladjustment, desiring the oostagy whioh onl coertaln type of religlon can give thom, complain that thoy osnnot "understand" the prekcher. Eduoated and pao oonsolous Negro miniatere, for whom the adoption of white atandards oonstitutes the moet important deslderatum complain beçause they must "talk down" to their oongregetions. Both are ungatiofled, 


\section{CHAPTER XIII}

SOOTAL STATUS

One of the oommonest popular fallades in oonventional white stereotypes of the Negroes la that of regarding them as belonging to unifled and bomogeneous group. Negroes were differentlated even before the abolition of Glavery into free Negro and olave lements. ${ }^{1}$ Differentia tion on various bases continued after mancl pation so that the Negro group of the present is divided by many class a sohlsms. Membership in partigular soolal olabs in Amerioan white coolety is based ohlefly on eopnomio cansiderations. Amerioan Hegroes, however, most of whom heve ocoupled a definitely 10w oonomio position, have developed other criteria for aoolal atatus in addition to that of 3 wealth or oocupation. .... In this ahapter the main bases of statue as defined by the oulture of the Negro miners in west Virginia are disoussed.

A common basis for the agalgnment of status to an 1ndividual in contemporary Amerioan oulture 1s his funotion

1 See Moodson, 0, G, The Negro In Our History, Assoclated Publiahers, 1927, pp. 236, 246, 253; Foodson, C. G., Iree Negro Heads of Tamilies in tho U. 8. in 1830 , Aseoclated Publichers, 1935; Nelson, A. D., People of color in Loulatana, Jour. of Hegro History, Vol. 1 , pp. 331-376. Dodge, D., ope oft.

2 See Frazier, E. F." Le Bourgeo1sie Noire, Lodern Quarterly, Vol. 5, No. 1; Fraz1er, E, V., The Negro Famlly in chicage, Ch. III; Dunford, F. M. Conflleting Toroes in Negro Progress, Soolal foroes, Vol, 3, p. 703; Park, R. D., Bases of Raoe Prejudioe, Annalo, Vol. Cxxxx, Nov, 1928, pp. 11-20; M111er, K. Rooe Adjugtment. Neale, Now York, 1809 , pp. 181-187.

3 Young, D., op. olt., $356 \mathrm{ff}$. 
in the economi o organization. The different funotions performed by the Negroes in the mining flelda have already been disoused. The relationship betreen the position held by the Hegroes and their apolal status $1 \mathrm{~s}$ not striking. Preachers and teachers of course constitute the aristocracy of the mining tom. Machine men, contractors, or night ratohmen, as vell as certain others who occupy positions denoting a partioular trugt in the men by the compantes, are 11kely to occupy a somewhat higher status becsuse of that fact: but the thrift, energy, and far-sightedness in saving and ualng money whioh these men usually exhtbit probably aff ect thelr prestige more than the mere holding of responsible 5 positions. Some of these men have become small capitallats, cashing sortp at 35 per cent discount and lending money for a consideration. The possession of money and the ovidences of auch position are highly respected by moat of the miners, and espeolally by their wires and daughters. The style and quality of clothes morn by the momen, 11 ke other kinds of "consplouous oonsumption," have a sreat deal to do with the status the famliles hold in the ming town. The oblef value of certaln soclal and publio function to many of the Women 18 that such occasions afford the opportunity for exhlbiting a new dress. In the "dull times", as they are

4 See North, O. Q., Speial Differentlation, pp. 21-33.

5 In verifying and cisrlfying many of my 1 deas in this ohapter interviow $71 \mathrm{th}$ Mr. $\mathrm{U}_{\text {. }} \mathrm{H}_{0}$ Prunty, Prinolpal of Elkhorn Distriat Colored High Sohool, MoDowell County. 7ere espectally helpful.

6 Correopondenoe with 118 saure Thornh111, Negro teacher in the mining flelds of Logan County. 
called in the wing lields. the women Bometimes greatly alter thelr routines because of the1r inability to continue on the bans plane of consumption they formerly followed. As rough indux of the relation between the positions of the Negro miners and their poolal atatue a atudy was made of the opoupations of the leaders in many mintng towns visited. The 1dentity of 2eaders was deterulned by interviewe with Nagro teachers and preachers a well as wh th employera., The oqqupations of 66 Magro leadera exolualve of preachere and tacolers aro shown in Pable 72. Phe faot that Ieadera are drawn from all oocupat lons 18

TABLE 72. OCCUPATIOHS OF 66 HERRO LARADRS

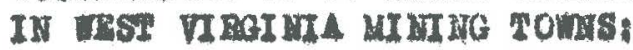
1932

\begin{tabular}{|c|c|}
\hline Occupat1on & Number \\
\hline 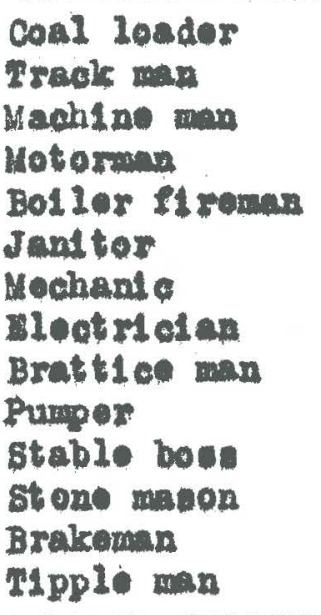 & $\begin{array}{l}39 \\
3 \\
3 \\
3 \\
2 \\
2 \\
1 \\
1 \\
1 \\
1 \\
1 \\
1 \\
1\end{array}$ \\
\hline Total & 66 \\
\hline
\end{tabular}

shown rather olearly. Uaually the teachera or proachers also aro considered as leaders. Sometimes, on the other hand, the Hagro leader 1 one of the most 1121terate 
members of the Nezro group. These leadere express their leaderahip in politios, olvio mattern, and in ohuroh and lodge affalre. The Megroes enjoy theis full pollt1eal righte in all parte of weat Virginia. They may, it 18 true, rote at times as the opertetors wish them to, but quch roting does not seen to dotraot from the satiafaction of part 101pating in politioal preot10ut. The rexy fapt that thoy have been able to eleot nembers of thelr own race to offloe, and to gain conoeselon from the pol1tiogl partiog in the form of appointment to various thate and federal offloes gives the Negroes, espeolally thoes who come from states in whioh euoh aoblevement is not poesible, a feeling of progress and protection. The Hegroes have engaged atrongly in these politioal aotivitien in the wining lielde and the politioal leader. even though he may oome to the oompany off 100 to find out who are our men, atill matalno hil preatige. Although the ahuroh leader ho traditionaliy been a man of high standing umong the Negroes, he does not seem In some place to exert the Influenoe he onoe did. The developent of oulture tralta through whioh status 1日 reoognized in any group ia determined in many cases by the viciasitudea of group history. A olroumstanoe in the history of the Negroes in the mining fleld had resulted in an attitude whioh has bean inoorporated into the mores of the upper atratum, The olroumatano is the lurige number of Negro oriminals who undoubtedly oonetituted a 7 See spero and Herriti, epent, pp. 371-374, 
1arge purt of the Nogro population in oextaln parta of the mining flelde in the early day the Negroes belonglng to the upper stratum, not only in the ming fielde but turoughout the state, fael that they have been done great harm by the presenoe of thi esrly oriminal element. They frankly admit the exideno of thic oriminal groug and make a doolded diatination botwen thom and other Nagro grouga. Sald a Negro teacher oonoerning this eltuationi In justioe to thowe who have tolled upward und are atriving for tho good of their fellowman, do not judge the entixe ruoe by the Olas of oriminals that bolong.to all raoes." Som of the Megroes wh th whom the writer talked were hyperseneltive on this aubjeot of Negro oriminality. The Direetor of the Bureau of Megro Welfare and Statiotiog requested the newe papers of the stete not to une the saolal adjeotive in roporting orime newe. 10

Ao a matter of faet the Mogro minero have a rezat1vely favorable reoord, so far as comitmonte to the atate penitentiary is an Index of oribinality. A2though winere, aoooxding to the Bureau of Iegro Nelfare and statlatios, constituted in $1925^{12}$ about 75 per oent of al1 Vegro males over 16 yeare of age, the Megro minere admitted to the penitentiary botwoen July 1, 1924 and May 1, 1926 eomprised

8 See Va. Bureau of Negro Welfare and statiatios, Repoxt, 1921-3a, pp. 13-14.

9 Weloh bally Noxk, Sept. al, 1926.

$10 \mathrm{~W}, \mathrm{Va}$, Bureau of Megro velfare and Btatiatiog, Report. 1925-a6, Pp, 114-116.

11 Tb1s. P. 18. 
only 34,4 per cent of all Negroes admitted during that 13

poriod. The dorresponding peroentage in the period Januixy 1, $19 a 7$ to July 1, $19 a 8$ was somewhat larger, bel ng: 28.9 per oent of all Hegro malo commitmenta, but it was at111 muoh amaller than the peroentage whloh nats form of 13

the total Nogro population. During the eaxlter period Oaboll County, with llegro population only ono eixth as 1arge as that of MoDowe11, but with its Megroes ooncentrated in the city of Huntingtion. went 4 moxe Hegroea to the penttontlary than MoDowe11. 14 Kanawha County, with about half 1to Negro population resident in the ofty of Oharleston, sent 43 Negroes to the penttentiany, whereas HoDowell County, with about tinl oe the number of Megrose, sent onl 51 . In all of the oounties in whloh Hogroes ope conountrated in olties the numbers of Negroes sent to the penitentiary por thougand population exe grater than in the oold count 100 having no large olty. These Ilgures may mean that, under the aggia of the paternalistio poliey of many ooupanies, the Negro miner has been more proteoted agalnst prosecution than Lwe h1s brother in the afty. It 10 muoh moro $11 \mathrm{kely}$, how ever, that the 11gures are mone neariy an index of the relative number of mor orimo comaltted by the two groups, poosibly bocause the Negroes from the rural south lind adjustwant $108 \mathrm{~s}$ difiloult in the comparatively rural mining domaunitios $t$ ban in un urban environment. In of ther gase, IE Computed Irour Iblo, p. 114.

13 Ibs. 1027-38, D. 53.

14 कात, $0,112$.

15 mox? 
horrever, the faot remalne that the motter element malntalns its distanoe from the "oriminal " in the towne. One very deflatte basio for differentiation is based upon the plaoe of origin of the Negro winers. The West Virginia and VIrginia Negroas tend to look down upon Negroes from more southern states, partioulariy the Alabamans. A Hegro in Fayette County almost hung his head. when he admitted he was Irom Alabama, A Hegro in Kanawha County being asked whother he was from the south replied, "No, subl" with ovident pride in the faot that he was from Virginia. Many Negroes deny their far southern origin. wh1le atill otbere are lnolined to be non-oomittal, saying: I've been here twenty yeara." wh1le the V1rginiane and Weat VIrginians in the minlng 11 lds show the greateot antagoniam for the Mlabama migrant, they are by no meano cordiel to the Negroes from M18elentppl, Georgta, South Carolina, and North Carolina. The North Oerolinian, bowover, is moh leas dieliked than the othore.

1 Megro woman to whon the writer meationed the Lesitangy of the Alabamans about teling thet birthplace had an explanation: Mhey won't tell it. Many of them got in trouble down there and that is the reason thoy oame up here, They think the Hest Virginia people are lover bearin!: So do the Joxth Carolina people. I went down to North Carolina on a visit and otayed six monthe, I wont to a house-party and there were three people k1120d. I man out a woman' head olean off and poople went by her laylng 
there and didn't even so muoh as look at her. I told them wo might be overbearin' up here in West Virginie -. but wo at least would glanoe at a dead pereon. I came out of there just about as quiok ae I oould get."

While the cohime besed on stat of orlgin are not al ways apparent on the surface, and the casual observer may not notioe any 2aok of fraternization, there 18 a deolded differentiation due to a olab of mores. The Llabama Negroes and others of the outh in many oase take pride in being bad." ${ }^{16}$ Thl exiterion of distinotion 18 not rospeoted by the V1rginla and Wont V1rginle Iegroes, who are habltuated to a degree of Independenoe whloh has given thom pride in order and eelf-reapeot rathor then in the oruder standard of the southerner. They oonelder the southernere a. "buzlies" and "too loud" and tend to hold themselve apart from thom, Bald rayatte County woman! some of these Alabama boy brag about how bad they 18. One of them was bragging to me one day about how mean he was. I told him that Alabama peopl wasn't the only onea that God gave a tomper to. Wo don't $11 \mathrm{ke}$ llabam people any bettor than they 11ke us," An older woman neer by, overhearing the converation, salds "I don't mese with these 1labama peoplo. They'11 k111 you in a minute" As a result of thit a 1801am tion of the southerners by the Virginians and the west V1Iglaians the Negrons of the minority group have been driven to seek the assoolation of persons of like origin 16 Of. Poterkin, Jul1a, Blagk April. 
and the southerners heve therefore been more ologely 17 .

oemented togethex. Teet Virglnlans and Virglnlans whose attitudes have had muoh to do with this faot, however, regard the southerner merely as "olannieh, "

A degree of personal dicorganiation in this altuation is inevitable. Meny of the minority otrive ald the harder for reoognition by the development of extreme aggressiveness and by becoming even meanar" than before. Says one West VIrginia" woman: "The minexo from Alabama and Qoorgla are not aocopted by the west VIrglnians. In the ohuroh the southernero w11 jolit and take oharge, putting the West Virginians in the rear. They belleve in aotion, that 18 to say thoy are omotional and, of course, the West Virginians are not. Virginians do not have moh to do with those from Alabama and Misalasippl bocause moat of them are mean and oarry guna." The Want Virginia and Virginia Hegroes, then, feelling the dif erenoe between themselves and the oruder and more "emotional" southerners are oonoerned because of the posible effoot the migrants may hare on the attitudea of whites towerd the ont1re legro group. In oelf-dafena they have loolated the far-\$outhern minority 30 thus scoentuating the tralte they dislike. of oourse,

I7 Of. Park, R, E., and Miller, H. A. Old World Tralta Transelanted, Soctety for Soolal Reseerch, Unit. of Chloago, 1921, Ch. III.

18 Cf. Milier, H. A. Rroeg, Nat Lons, and Classes, Ch. IV.

19 Cf. the attitudes of legroes in northern oftles toward newcomara frow the south see lark, $W_{0} L_{n}$, epe alt.

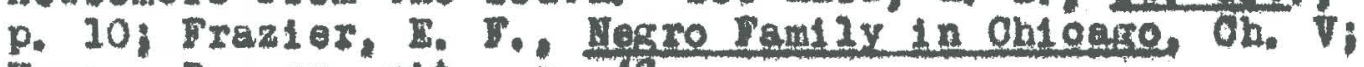
Young, D., ope elt. p. 46.

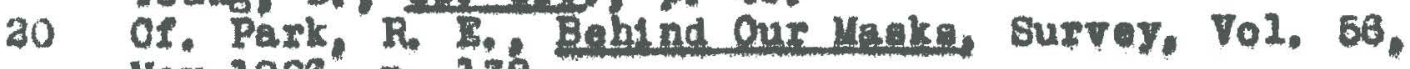
Lay 1926, P. 138. 
It Is not to be inferred here alther that all noutborn Negroes take pride in their "meanneas" or that all Virginlang or Weat Virginians do not. Tho unfavorable stereotypos of the scution Begro held by the latter groupa do, however, play an laportant part in oresting intramgroup attitudes anong the Negroes of the mining flelds and produce a very real difterentiation. Sowo of the goutherners, as has been pointed out bofore, attempt to esosp the effeote of this disorimination py "paseing" Into tho majority Nagro group through a denial of their ortginj others do so by living in towns in whloh legroes, from southera wates have conoentrated.

Another oleavage in the logro mining population Is between the "ohuroh peopl and the non-omiah poople, for the ohuroh group a rule nonelders ltede as of a somewhat higher order then the group whoh i lndifferent. to the institution. The Megro oluroh has never been puraly a religlous organtzation, Soolal, oonomi, 01710, and IIterary aotiritied have alwaye formed a part of 1 ta pro21 gram, and therefore mombrehlp in a ohurob means more than the mere demoeratio ettendance at religlowe servioen. The ohuroh members are $11 k 02 y$ to be the olt1mene eotive soolaliy and economically, or in other words, the aristoareoy of the town. In towne where existe more than one denomination, the aoolal otatus of the individual is partiy II So0 W. Ve Bureau of Megro Welfare and statiotion, Report, $1027-28$, pp, $65-67$. 
daterined by the shuroh to which he belongs. If, for exemple, both Metrodlat and Sept1 st churches are found in the same torn the kethodists are 11kely to sonsider ther selvas somemat superior to the Eaptists, while the membere of both of these larger denominations foel themselvas sep arated pretty definitely from the adherents of the "Holy Rollere" or "Hol1ness" churoh. By far the largest number of toms, howerar, have only the Baptiat denomination. Before the present "dull times" the Negro loszes were very active, "3octals" and parades, in brightiy solored regalla, beling very comon. Funeral were usualy conduoted by the lodges, for it wa the aroeptional Negro mine that did not belong to at least one of the varlous lodges in the ining fields. The Odd Fellowg and Housohold of Fith claimed the largest number of Hegroes. They mere followed, in order of thotr regcective numbers, by the knights of Pythias and Court of Galanthe, Order of Salnt Luke, Golden Rule Endowat Association. Masons and Merolnea of Jerico, Masone and Eastern Star, and the Elks of the Morld. At the present time, howerer, the lodges in the mining flelda are practically insotive, for tic ainere have had to drop all activities calling for unneceseary expenditure, Consequent ly, although nembership in these lodges signified a oertaln status, thls basis of 3tatue lo of historloal rather than present importance.

In aplte of thse olase differentiations operators 23 1016, 1325-35, p. 33. 
report that the Hegroes how a great deal of group loyalty. In mining town where the girling of rellet has bepn neceesary Negroes have shown deolded tendenoy to share with others of thel group what erer materiel ald $18 \mathrm{given}$ thom Negro aolidarity in often hown in any ituation Involving the Hegro group as a whole. Evon when dffloultion arise between Negroe they lrequently how thelr proforenoe for adjustment without recouree to members of the white group An employer giver an example in the following gonversation: "You would be aurpried at the loyalty the Negroes show toward each other. They gamble good bit, but if tboy have a shooting sorape, or a outting osape, they are loathe to tell on the one who injured them. One alght one of them cam to the dootor with atab wound in a very dangerous place. It was gash in tho nook about two Inohe deep and 1 to a wonder 1 t did not K11I bin, The dootor sald: 'What's the matter, Johni' He replied! 'I - I think I have been atabbed, sub,' The dootor anowered: 'John, you know you have been atabbed. Where were your' 'I was down to the lower end,' (the Magro seption of the town) he replled, (Who stabbed youl' 'I just don't know, sub.' 'Now, John, you know you know who atabbed you, Who was itp' 'No, suh, you know all of a sudden the lighte went out and I don't know who stabbed me. '"

An antagoniatio attitude, on the other hand, was exhlbited by some of the Nagro mathere toward Megroes wooenful in othor flelds than ming. The witer found this 
att 1tude to be quite prevalent, erop, in some oases, to the detriment of the minere thomeelvee. The following 111ustrates how this attitude of antagonim and ausplon may have stood in the way of thelx correoting an alleged wrong being done them, At a mine whore rellof was adminiatered onoe a week by a oounty truck whioh pame up and loft baga of food for the minere whose names had been turned in by the oowpany as needing help,/Megroes, a disgruntled and proteeting group, clalmed, that thoy had not boen getting their ahare of reliof as oompared with the watios. The writer, knowing the nawe of the prealdent of the neareat branoh of the National Association Por the Advancement of Colored Poople, suggeated that they commungate tholf grievanges to this man. The reply of the epokesman for the group was? "Mr. B. ? What he oare Ibout ual Why hols a riah man - I! he don't worry none about us poople up hoxe. Hellit take our esses (the man was a lawyor) but be does it for the monoy in 1t. He donit arre about un pol folke. That 'Boolation won't do nuthin' for un." The reat of the group agreed that such was the oses.

We have hore an exhibition of he attitude that makes the part played by the regro in poattions of authority in the industry a diffoult one. Perhaps one of the reasona for this attitude is to be found in the faot that the suooesaful Negro tends to be seperated to a oertain extent from the group a a wolo. For Inatanae, the Negro of means has striven to allow his fan1ly the adrantege of a good nelghbor- 
hood, and henoe in many oases has moved out alde the Negro 23

nelgbborhood into a white area, Thls more 1 made not beosuse of any desire to leate the legroos, but beoause the better nelghborhoode are to be found out 1d the Megro vectione, but to the leas fortunat legroes the ohange of realdenoe aimply meane that the members of this faily feel themselves "too good" to $21 \mathrm{re}$ wh thelr people any more. The Mational Assogiation Tor the Advanopment of Colored People is the object of some of thie antagontsm because it hes often fought for the right of these Hegroes to Iive in white nolghborhoods. In the "Dr. Bweet dase" in Detrolt, for Instance, the Ascoolation was 11ghting agalnat the prinoiple of gegregation. 1 good wany of the Heroer County Negroes sald, however, of this ensel mell, he got too good to I1ve among ble own people, Let him flght his own oage." Sinoe the Assoplation must light a number of these cases many of the less fortunat Negroen have thought it was interested in the upper group rather than in the common man, ${ }^{24}$ on the other hand, ome steunoh supporters of the Assoctation are to be found among the Hegro miners. Mention has boen omitted, up to this point, of one of the most common bases for olasa distinotions within the Negro group. Distination based upon color is disoussed last not because of its abpenoe but because, anong west Virginla winera, ita rolo 18 apparentiy leas luportant than

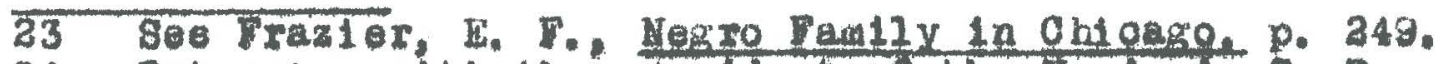
24 Interview with the presldent of the h. A. A. C. P. branoh, Bluefleld, va. 
mome of the others already otressed. The advantages which the "bright"-gkinned person has over his darker brother within the Negro group are probably ubiquitous in tho Amorioan oulture pattern. Inquiry revesled the paot that In the minting flelds there is littie differenoe in the nuidber of Negro leadere of 1 lght and dark skin oolor. Anongs the women, however, the altuation is difforent. In Wost Virginta as elsewhere woman with a dark skin is at a tremendous dicadvantage in the marriage, mant. For the Negro men the posaession of a light wife ta adge of distinotion. She is for him on artiole of oonsplouous consumption whioh refleote upon him art of artifiolal prestlge, The wife of Iight oolor and, through her, her husband may enter economio and soglal areas whioh would be 26 closed to persong of darker pigmentation. To the young woinen, tben, color le of moat vital importanos, Just what Hen inay esoure the more destrable women of 11 ght oolor. however, and from what women the moot destreble men w11l seleot thelt wives ia determined by other oultural factore already diseussed.

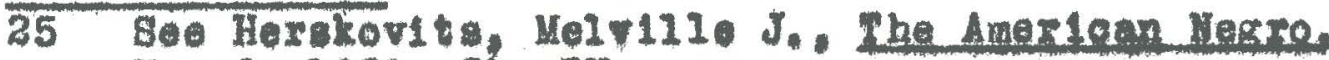
Knopf, 1988, oh, IV.

36 Ib1d, $\mathrm{pp}, 69-66$.
} 


\section{CHAPTER XIV}

RAOE RELATIOHS

I. THE PRESENT SPATU8 OF RAOT RELATIOUS,-

1. General atatewont.-

Perhaps in no great induatry bave divera raolal and national element beon able to work together more peocefully then in that of mining. Rao ooplist between white and blook in the mining flelds of Feat Virginia $1 \mathrm{~s}$ meldom known. This oondition 1 not peouliar to Weat Virginia but is found in other states a we12. Payne says of the situation at lange in the Unitod atates!

Raoe oonflict is noted as a very minor oause of unrest in winlng commult 1es, Miners are so acoustomed to forelgners thet for the most part their different culture is generally aocepted by Americans as a matt or of course. Sometimes, of oourse, too wuch raolal diversity oeams to interfero with unionization; at other times it aotually aids.

This attitude toward the forelgn born 1a paralleled by the attitudea toward Hegroes. They too are acompted as a mutter of course. Allen found raoe confliot in the mining fields of the PIttoburgh dietriot almost non-existent. Johnson mentions the oordial ralations existing when he gays:

1 Payne, W. k., eqe alt. pp. 139-130.

3 Allon, op. oft. pp. $57-58$.

3 Johnson, The Jegro in Amerioan C1 v111zation, pp. 360-361. 
In 1 ines of work in whioh Negroes are given preferenoe by employers, by virtue of auperior akiII, strength or longer tenure. e. B., hod oarrylng and b1tuninous oos mintag, it is plessing to note how cordial and how laoking in raoe consolousnose tho men are.

Negro teaohere, preaphers, and other leaders in the mining flelde are unanimouply in agreement that relations between the raoes in the mining fields are oordial. Noot of them were hard put to remember even aporadia putbreak of 111 feoling and oonfliot within reoent yeers. Many of them made it a polnt to say that they know of no other plaoes in which relationa were more amloable than in the aining comrrunities. Sald the Negro Director of the Bureau of Negro Welfare and Statiatios, himself formex delegate to the state Ieglolature from MoDowell County. in ble roport for 1921-1923:

In the light of the low soolal order existing in the oamps and oommunities to whioh regroes oame in such large numbers, it is remarkable that West Virginla now has auoh aplendid Negro population -in intelieot, thrift, and morals, and that there has been 11 tile 11 any bitterneas, strife and outbreakr of violenoe botween the races. The harmonlous relations whioh exlot between the raoes speak well for the oonservati sm, toleranoe and restraint of the great body of white lieat Vinginiane, the long line of State and County officlals, the pub110 press and the haads of Inatitutions also, the Negro preachers, teachers, leaders, editors and ane conservative home makers who oame wh the orowd to take advantage of the wonderful opportunities offered in this young state for the 1 mprovement of their conditions and to give to their olildren greater ohance for adranoement. 
In $t$ ines of rapld movement of Negroen in large numbere oonfliot of tuations often develop. Following the Mingo atrike In 1921 many degroes went into the northern count les of Brooke, Oh10, Mononeal1a, and Hanoook oounties, This rapld penetration of these mining flelde by the Negroes was $8000 \mathrm{~m}$ plished without racial friotion.

Leat the preceding paragraph may oontey too anguine an Impresolon some explanation lo adviable at this polnt. While all persons agree on the exleting state of atable equilibrium of race relations in the Weat Virgiala mining flelda, they are apoaking, of course, in relative torms. There is no intent hore to ploture conditions in West Virginta coal mintag communitio as ideal in any sense. Vest Virginia, being a border state, represents rarylng attitudes on raoe subjeots. Som segregation exl at throughout the state. State law provides for separate sohoole for the tro raoes; Hegroes ind it diffloult to own property in oertain parts of the towne; Hegroes and whitea attend different churobes and theater and stay in different botelsi Intermarriage is legaliy forbidden. On the other hand, the Hegroa hate full pol1tical privilegen in all parts of the atete and they are not agregated in oommon oarriera, The question of race relations out olde of the mining fielde 1 s, 5 See Ohloggo Commision on Face Relationa, the Nerre In chlogere. Univ, of chlcago Prear, passin.

6 V. Va. Bureau of Negro Welfaro and Statiatiog, Feport. 1923-24, p. 37.

$7 \quad$ U. S, Bureau of Labor gtatiat1os, Monthly Labor Revi aw, vol. 21, Auguet, 1925, p. 11. 
however, beyond the soope of the present atudy. We may now prooeed more apeolfically to oonditions as they oxlat in the mining fielde at the preant time.

2. Negro miners and thetr employert.,

Relations between employer and their Negro miners were observed to be almoat whthout exaeption oordial and friendly. The only host1lity noted was dieplayed by auperintendent who had como to Nent Virginia erom atnortiorn state, but who assured the oriter that his attitudes were "gouthern." The Weat VIrginia nat170"operator is as a rule muob more oordial in hio relationships with individual Negroes than this northern operator ovidentiy was. A certaln superintendent in rayette County, for instanoe, was walking with the writer up the rallroad towerd the tipple past a group of miners who ware a usual seated on the ralls talking. The superintendent pald no attention to the white miners, but as he paesed a Negro miner he gave bim a friendly, bantering blow with a strap he held in bis hand. Tho Vegro, obviously plessed with thle attention, grinned broad2y. The superintendent explained that the Vegroes like to bo kidded" and that be did so a great deal.

Th1 a attitude toward the Nogroes has been Imitated somowhat by the bookkeapere, olerkn, and other employeas of the "white oollar" olaes. While the author was working in ooal company offioe be watohed oarefully the tranactions whloh went on between the Megro minera and these mon. The 
same good natured bantering whioh oo often goes on between bigher offiolalo and the llegro employees take plsoe between the minor offloiale and the Negroes, An example or two will Indloate the relations that the writer found typlogi in overy county.

The flrat lilustrates the friendilness of a Vegro toward a bookkeeper. A Vegro wner in Kanawha County aupplewent his earnings in dull times by selling peanuts, whioh nu trangporte in baby oarriag all over the town where bo is enployed and in near-by toms. The bookkeeper and the writer were tulking on the poroh as ho.went by pushlas his buby ourrlage. He sent over a bag of peanut for each of us by a little Hagro boy. The bookkeeper aald he had a great deal of respeot for and confidenoe in this legro miner; that he was in no aene trying to make a bid for farors by hig gift. The fol lowing oonvereat ion betweon the bookkeoper of a Raleigh County ookl oompany and a Megro miner unmiotakably impliod the most Informal and cordial relationa, Forelgnera, native phitea, and Megroes had all been coming to the offloo on this partiouzar day adking for "advanoes" of money, which whout exoeption had been refused. One Negro oame in after the rest and sald, Mr. I. (the bookkeeper). I would I1ke to hold you up for about $\$ 4,00$. Ur. L. replied that he had no money and had turned down many requasts that day. The Negro replied: "Shuah, I know you oan't fix them all up - but you aan $11 x$ mo up all right." Nore converoation engued in whiob the Negro, 
always amling, Insiated that he noeded monoy badly, Ur. $L_{\text {., }}$ however, was not to be moved, and IInally the Negro went out chuokI1ng, The Hegro ooneumed several minute of the bookkeeper's time on buey day, but the wht wen was friendly and goodnatured throughout.

Exoeptions to auoh friendilneas were oocasionally observed. Some bookkeepere and store men showed dealded antagon1s to the Megroes, whom they had to eerve, and some Negroes, Including come wives of llegro miners, were disagreeable in thelr attltude toward these omployees of the company. Suoh persone were, however, oonsplcuousiy in the minority. The existenos of cordial relatione between the employing olas and the Negroes is not eurprining. Employers are far enough removed from the plane of oompetition with the Negroes and are sure enough of their etatus to be able to take a generous attitude toward them. The clerical foroe too oan indulge in a liberal and friendly attitude toward the Negroes without 108 of otatue, for the Negro role 18 too far renoved from thelr own to warrant uneasiness on theif part. No Negro was found in the offloes of tho company at any operation vialted. These aane mployers, however, quiokly reaot in a different way toward Negroes in other roles. Gald a ouperintendent in Meroer County at the oonoluaion of an interviow: "I suspeot it is pretty olear to you that I Iike Negro minere. I like thern in their 8 C. KIIIex, Kelly, The Negro As a Eork1ngman, American Meroury, Vol, 6, p. 310. 
plaoe -- I don't 11ke Negro lawyer and dootors," 9 The attitude of some of the operators is tinged by rel1glous 10 convent ional12at 1on. Writes the prestdent of a company employing large numbere of Magroes: My fore-fathers were slave ownere, but opposed to lavery and I was taught to reapeot negroes' feelings and have by dolng so, nearly always had pleasant relations with them I don't belleve as a whole that the Negro will ever be equal to the Caucasion. St111 he lis buman, bis soul is as dear as thd white man's, to is our brother in Christ and it 1 s our duty to load him in bigher ways." This attitude 18 quite wideapread, but thowe holding it wean, for the most part, by Migher way" lmproved sex relations, honeaty, and the adoption of "whIte" atandards of pereonal conduot in general, The diohotomy betweon soul and body is well established, and "hlgher wayo" are to be found within the oulturally ofroumsortbed area of "his place."

The generally friendly attitudes of employers towerd the15 Negro employees is undoubtediy a lator in the labor situation in Weat Virginia mines, Employers have nothing to 108 by the sort of paeudo-1ntimay praotioed by them in showing suoh 11ttle attentions a have been mentioned. The Negroes, on the other hand, are likely as a reault to feel a sort of artiflolel prestige and are thus drawn more closely to employers who manifest these tralta. 9 Cf. Bogardus, $E, S_{*}$. Immigrat $10 n$ and Rsoe Att 1 tudes. Heath, 1928, pp. 92-8\%.

10 See Sumner," G. Golkways, G1nn, 1806, pp. 68-70.

11 Cf. Bogardus, ope eft. pp, 81-82. 
3. Negro Miner and their follow employees,-

Evefy employer interviewed wa oarefully questloned oonoerning any oames of trouble that he had known between Negro and white miners. The answers were almost unanimous $2 y$ in the negative. Nont of the mployere exhibited a sort of taolt but obvious surprloe that such a question should be ralsed. Race confliot at the present time ia a very minor problem. The witer has observed white and Negro men working $\mathrm{B} 1 \mathrm{de}$ by olde at the eame job with no apperent effort on the part of the whites to keop a definite ine of demaroation between thomselves and the Negro workers - a work rolationship by no means common to all incustries." Thla lack of friotion may be due in part to the faot that muoh of the work inside the mine is individual in 1 ts nature, esoh miner having his own work out out for him with 11 tt help from others necessery.

Some eridenoe of race prejudice does, however, exist in oertain plaoes whero whites must work in oooperation with Negroes in an inferior position. As has been polated out before, the rore vary from town to town. In some places, for Instanos, a wite man does not brake on the same motor with a Negro motorman; at other places a white man does not brake for a Negro motorman but w1Il run the motor with a Negro brakeman at the ame rate of pay. Another widely dispereod distinotion is the relatively I2 OF, IIIIOF, K., ope elt., p. 311 , 
oommon regtriotion of Nogro motorman to the "gathering" motor and away. Prom the main I1no motore, whioh in some plsoes are reserved for white motornen, The distinotion here is one of latus, for motormen are usually paid at the seme rate regaraless of their runs, In cono cases, however, Negroes were found on main 11n motor with whit brakemen who reoclved smaller wayos. Thus hermontous relations are

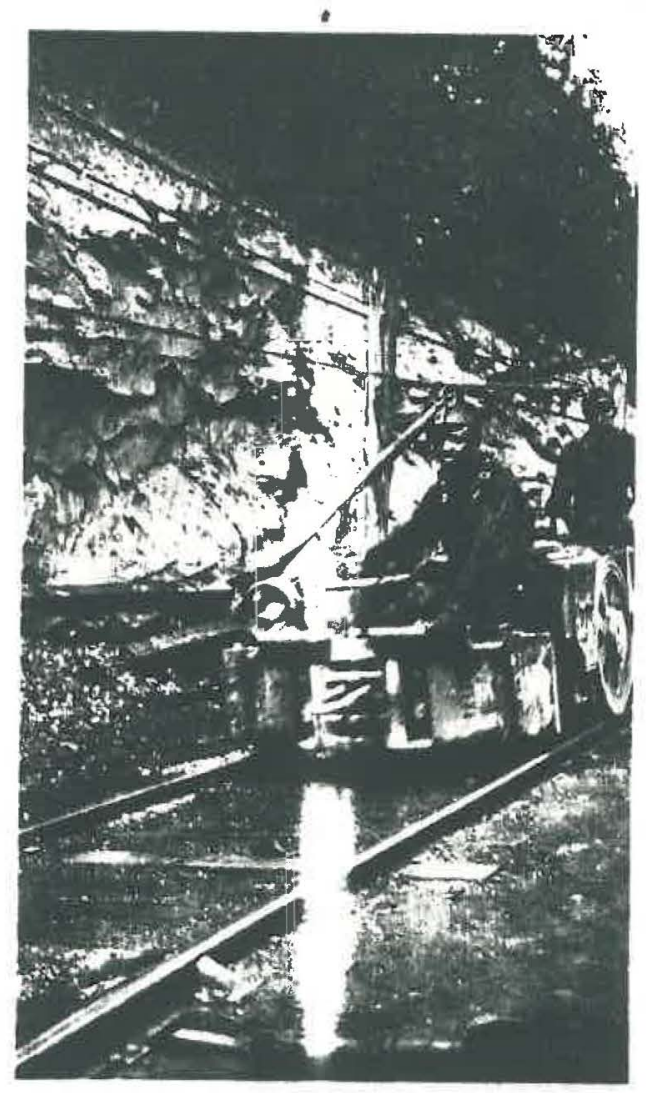

A Negro motorinan, with white brakeman, on a widn line sun in pyoming County

pronoted in aom plaoes by oulturally eatabliahed roles to which both whites and Negroes are cacomodated whereas in other plaoes no suoh reatrlotions are to be found. The 
faot that whites w111 sonetimes Impose on the Degroes Ied one employer to ay that he preferred not to have too many wh1tes. He gald Hou know the white man juet knows he is better than the Hegro and wants to ahow it sometiaes." This employer Indlated, however, that the bettar olass of whitee do not aot in this way.

Forelgners axe diallked by many Negroes, for in the effort to beoome Amerioan they have boen gulok to imitate conventional white attitudee toward"minority raoes. gome of them, as might bo expeoted, have according to Negroes outdone the native whites in tils respeot. A Neiso principal of a high sobool olalus that a foralgner in the position of foremen is 11 kely to exhlbit bls prejudioe, and olted a forelgn-born foreman who was made to go baok to 1oad1ng coal - to the joy of the Negro miners, for as one of them put it, I juat can't atand be1ng 'J1m-Orowed' by one of those fellows. A converation betreen two Negro miners wa ovorheard in mhioh the right of the native whites to suoh un attitude was almost adnitted, wh11e the right of the fore1gn-born was enthus1ast1oal1y denounged. There $1 \mathrm{~s}$ a good bit of evidenoe that the oontention of the Negroes oonoerning the antagoniam of the forelgners 1 a not groundless. The Bureau of Negro Welfare and Stat1atios quotas an employer as eaylng the Poles and Slave in bls mine have always opposed the hiring of Negro miners. The words of the report are: He further ald that the forelgn element would drive the Negro out of his own country if he 1 ets it and that a 
Wagro is a fool to turn 'red' w1th huskles and Rusalans whose first words in Engliah are usually 'I won't work with 4.--- black -- of a -.-.-." $" 13$ The most bitter expression of race prejudioe in the writer'a personal experience was voloed by a forelga-born minar.

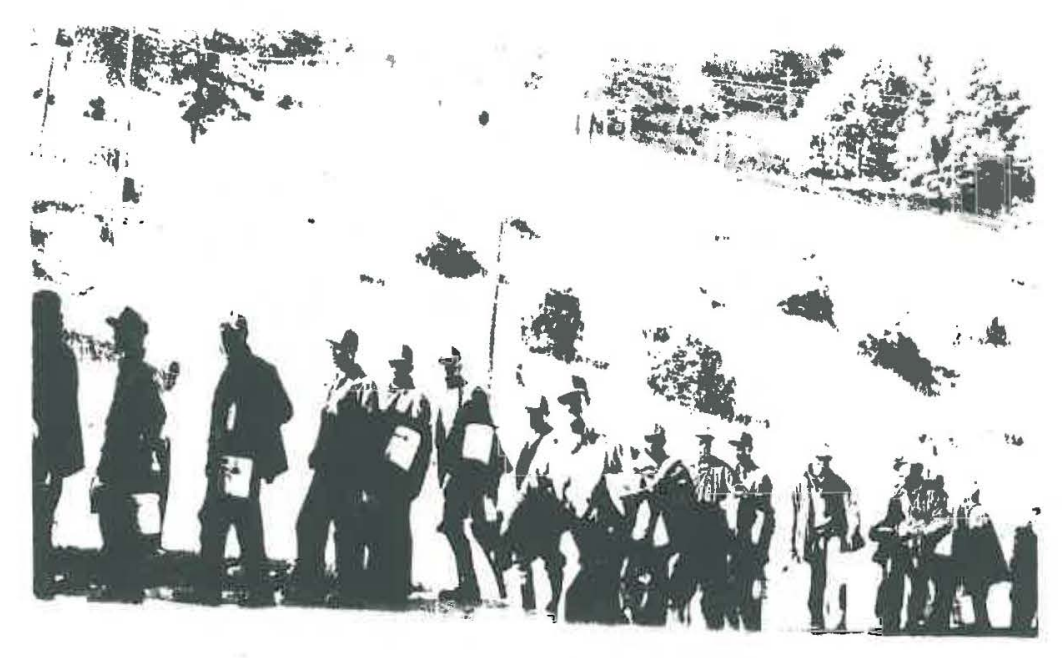

Negroes and whites in ine

at the company off 100

Wh12 in normal times the relationshlps between Negroes and whtes are frlendly enough, under certain cond1tions confliot, always potential in the Amerioan raolal situation, may beoome kinetic. One of these danger apots has been the enployment of Negroos in times of atrike. The use of "traneportation" to bring in blaok workers to the strike area has been resorted to by employers in the past. The strike breaker is persona non grate at any time and in 13 T. Va. Bureau of Negro Welfare and Statiotios, Report, 1935-26, p. 39 .

14 Ibid. $p, 36$. 
any situation. However, when "apabs" are Negroen the corm petitive element 18 brought to the forefront, race prejudice thrives, and a confliot stuation easily arises.

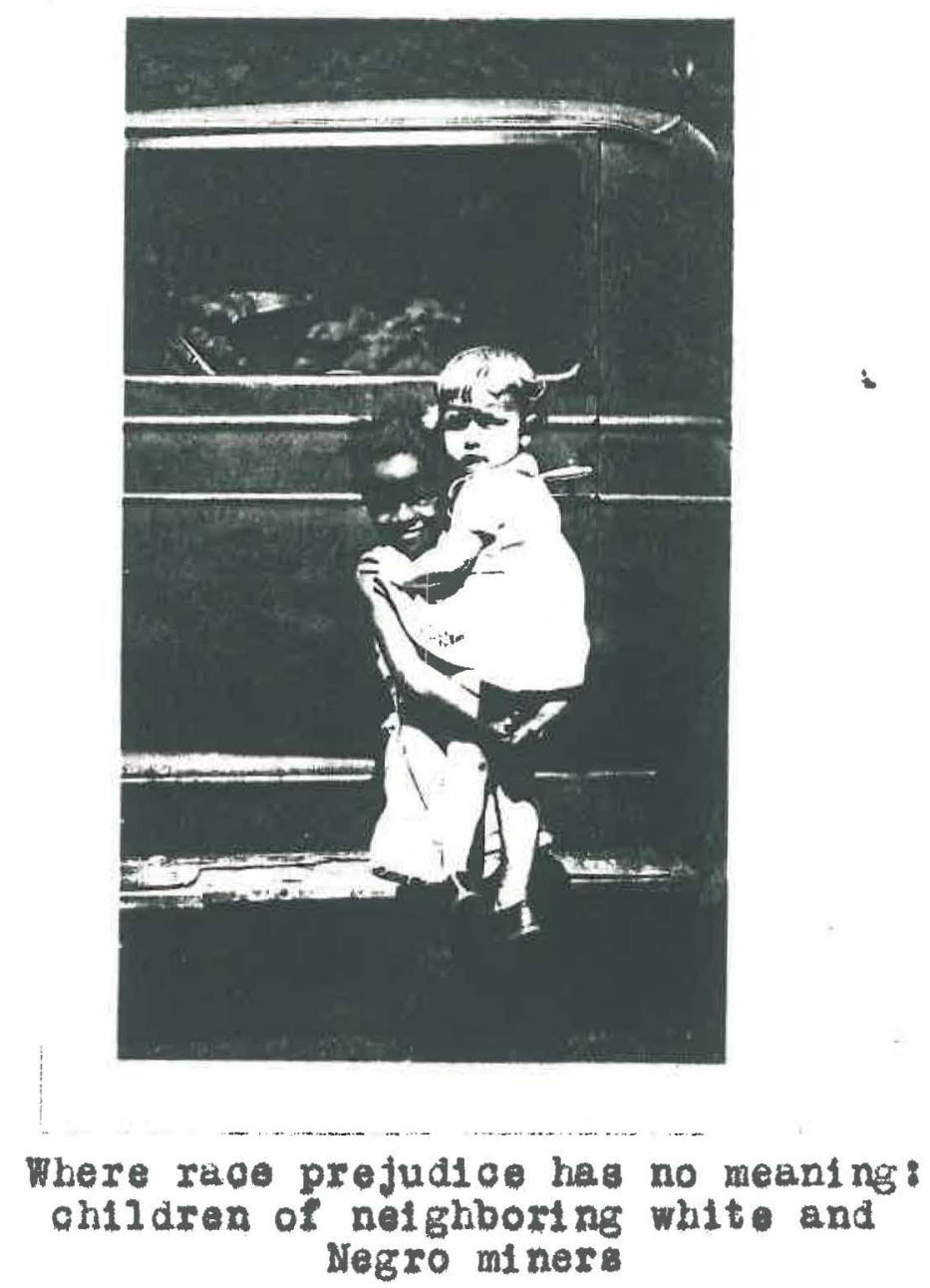

At Ward, in Kankwha County, in 1931 dur1ng the 16

sulatier atrlke the company brought in about fifty Negroes for the purpose of breaking the strike. They were kept in a lurge boarding house, whioh the state polloe guarded, and were taken to work in box cars. The striker dynamlted the I5 Cf. Spero and Harris, ope oft., p. 333. 16 Sec W11son, Eamund, Coal Diggers, Now Republic, July 8, 1831. 
boarding house and shot at the box cars and, although by chance there vere no fatalities, the ifegroes all loft. Sald a rife of one of the thite miners: atcat's what is the trouble with the country today - these colored fellers would rork for a loaf of bread a day. That hakes it all the karder for the white wen." Then asked if the whites ever tried to run them out. she replied: arhey did at during the strike. "Then asked further about any attengts In normal times ahe sald: Wo, you see you have to keep within the $1 a n .{ }^{18}$ During the 1925 strike la the northern counties union miners mrohed to the hone of a Negro miner at Glendale in Harshall County to make a demonstration. Gun play resulted in whloh two white men and one Hegro vere seriously wounded. In the union counties of the north frtotion also developed in some place when Negroes zero placed on mine comittees.

Another danger spot $11 \mathrm{es}$ in the relationship of the white ainera to Negro momen. The Negro, while be ray be, as Young has polnted out, "more readily assuaged" Then hila apouse proves unfaithful, is quiok to resent any threatened or actual irregularities of behavior between his wife or sweetheart and men of elther race. There is reason 17 Interviaw th wifo of a white miner engaged in this strike.

18 Ib1d

19 T. Va. Bureau of Negro Welfare and Statistics, Report, 1925-26, p. 34.

30 U. S, Department of Labor, Bullet1n 361, 1923, Labor Relations in Fairmont, Ta $_{*}$

31 Toung, D., op. o1t., p. 333. 
to belleve that sex commero between wht to bers and Negro women 1 not uncoramor. Sald a superintendent: "Ofton a whito man who will refuse to brake İor a Hegro may think nothing at all about 'pluylag around' with bis wife." sooording to the white minere questioned on the matter, many of the whites prefer 111101 t sex relations with Megro women. There is popular superatition among the white miners that gexulal intercourse with a Negro woman w111 ohange one "s luok from bad to good. Sald a white miner: many white mon say that all nigger wenohes are crooked. I just about bolleve that. You know, they just can't stand temptation at a11. They are wore like brutes than we are, "stereotypea of the laok of morality of Megro women in the minde of the white men probably gives rise to a boldnees in approaching then that resultis at times in a clash.

1 group of white painters who were staying at the same boarding house as the writer in one mining town were employed to peint all the oompany houses. One of the painters got in trouble with one of the Negro miners. The painter Imediately fled the town. One of the painters eald that the man had been painting one of the Negro houses at whleh bo had been getting home brew. He olaimed that a Hegro oame In and threatened to k111 a moman in the house. He remonotrated with him, but the Negro drew a knife and hit him With a rook. The defuty sherief in the oompeny offioe, however, having made the arrests of all conoerned told a उद Cf. Ibla, p. 381. 
different story. He asid the Negro had disoovered the palnter cokablting with the woman, The outcone of the matter was that the woman was taken to jall on charge of adultery and her busband on a oharge of drunkenness. The painter apparent $1 y$, harlng left the town, esoaped without punishent. Trouble of this type, howerer, is very infrem quent.

There are certain Negroes neverthelese who are known as "bad niggers" both among the whites and theif own raolal group. These have sometimes been involved in trouble not only with thel $x$ own group, but with wh1tas a well. A superintendent told of his mothod of handling such men: "After the wax we found the Negroes were espeolally hard to manage. Before the war Bome of the 'bad niggera' were tinid bad men. When they came baok from the war they were atill bad man - but they were no longer timid. They wore bold bad men. Flght lag for thelr country semed to make them muob more impudent and aggressive, I would find some of them ooulng from the mine at 2:00 0'0lock and would eay, 'How ooine you wen can't do a day'a work?' They would answer, ' We11, what you goin' to do about it -- pay us off if you want to." I got one of the Baldwin-Felte men, Buster -....... and, belleve we, he was a buster. In fact, I think he wes a litile too drastio in the means he used. He would hit theit. Once he oraoked down on one and cut a big gash in his head with a pletol shot. One day they began to bunoh up on him. He drew a mark in the dirt and caid: 'Now, 
I don't want to kill anybody - but the firat who steps aoross that Iine $1 \mathrm{~s}$ a dead man. They hated him - but he certainly oalmed them down." Due to the fact that the early diys brought many men of the "bad man" type, the companles have made a conoerted effort to weed these out and If theraselves of them, The MoDowell County suparintendent who told the story above indloated that suol haprenings wero very exceptional.

4. Segregation. -

Although no separation or segregation of Negroes and whiteg in their work was found at any me, some segregation was found in other ways. In houaing, polloles differ froin town to towa and from pompany to oompany. Some towns had complete segregation of Iegroes and whites while others had absolutely none. One town even had separate seations for Negroes, native whltee, and forelgnerm, Probably the places with some degree of aegregation were in the majority; the lines of demaroation were, however, very flextble in many places. In fact, although some oompantes were very omphatio in their statement of separation, the writer often found Negro miners 11ving in the white seotlons and vice versa. One of the oompanies wont so fer as to paint all their white houses wht te and the1 Megro houses brown, but oven here Negroes and whites were found 11 ing in the seme soction alde by side. 
Where separation was made the Negro sections were, If different, less desirable than the white locations. In a very comwon typo of appration the Negro seotion was divided from the white aection by some prominent oompany bullding, suoh as the tipple or atore. Sometimes the two sections were deslgnated as coolored town" and white town,"

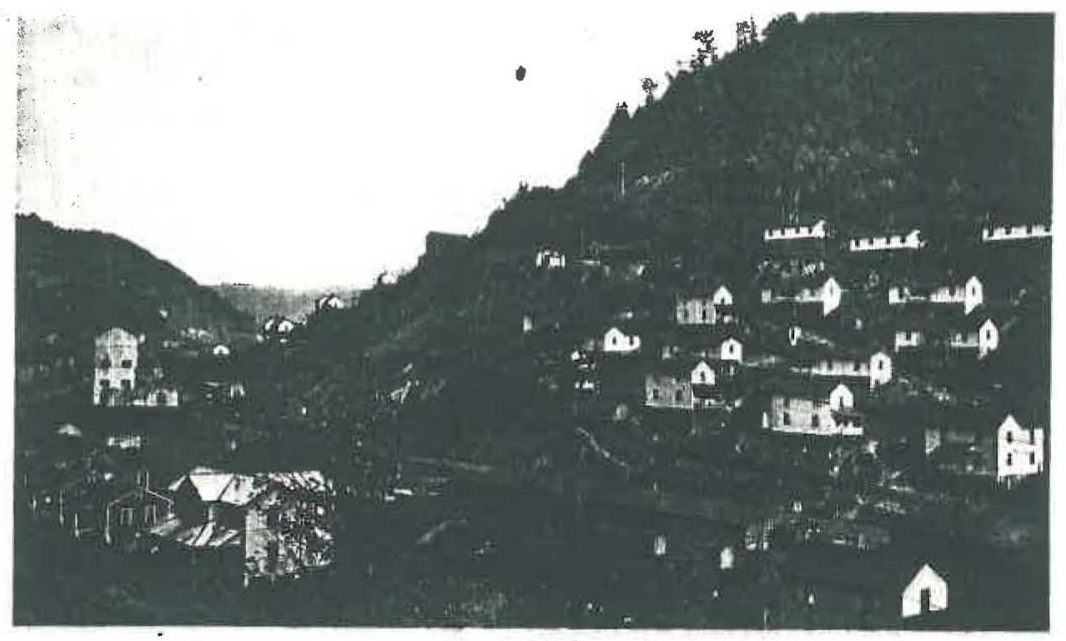

Typlcal separation of white and Negro geotiona. Negro aection in foreground. Houses of white rection are to be ceen beyond the tipple.

In one of the Fayette County mines a Negro gection was found in the center of the town and a white section on elther alde. The superintendent was questioned as to the reason for tils arrangement. He rep11ed: "I do that po the whites wi11 have to pass the Negro seotion and the Megroes the wlite. I think they learn to get along that way. what's just ay ldea but it has seemed to work."

The prealdent of one of the oompanies owning probably the boat town visited so far wo housing is concerned 
sald: We do not segregate our Negroes here. The only segregation is in the case of a double bouse. We do not put a Negro and a white famliy in the same house -- otherwise we do not separate them. Investigation proved this statement correot. Other companies allowed the Negro miner to have any house in the town so long as he oould pay tho rent for 1t, but the higher rents soinetiwes keop the Negroes, and some whites as well, frow getting the better houses. Eaoh of the oowpentes, however, Leela pretty sure its system 1. the better one, whether it gegregates the races or allows complete freedom of oholoe of looation.

Where whites and Negroes live as neighbore there seems to be no more raoial strife than where they do not. Both whites and Negroes have teatifled to this faot. Sald one Negro miner concerning his white next-door nelghbors, mifhey couldn't have been nicer people, even if they were Negroes." Some of the Negroes, however, prefer not to live next to whites beosuse "they borrow so moh and never pay buck." On the other hand, some whites do not like to live next to the Negroes because they are out late on Saturday or pay day and are nolay. The faot that the leak of separation has not reeulted in unf riendiy reletions is supported by the statementa of two superiatendents who faror the polloy of segregation. One in Kanawha County sald: "I have trled to separate my white and colored minere, but they won't let me. Of course, right down bere next to the store I can keep them separate - but not up the hollow. Another in 
Logan County says that he finds very little trouble betwean the natlve white West Virgintans and the Negroes. He says he has even had whites ask to be tranaforred to a legro camp. Ho has tried to bring about a ayatem of segresation in camps where formerly no suoh oystem existed but has had trouble in getting the whites to move. He ays they do not uind being with the oolored.

Bath houses, where they oxloted, were separato. In most oases, however, the acoomadationo wero identical. In some placss the baths wer looated in the boarding housea or in the alub houses whioh were alivay separate. As a rule, the white olub house wae the better struoture, but in one case the Negro alub house was equal or superior to the white. Segregation 18 also observed in reareat lon build1ngs and theaters. In theatere the Megroes an a rule sit on one alde of the conter alsle and the whites on the other.

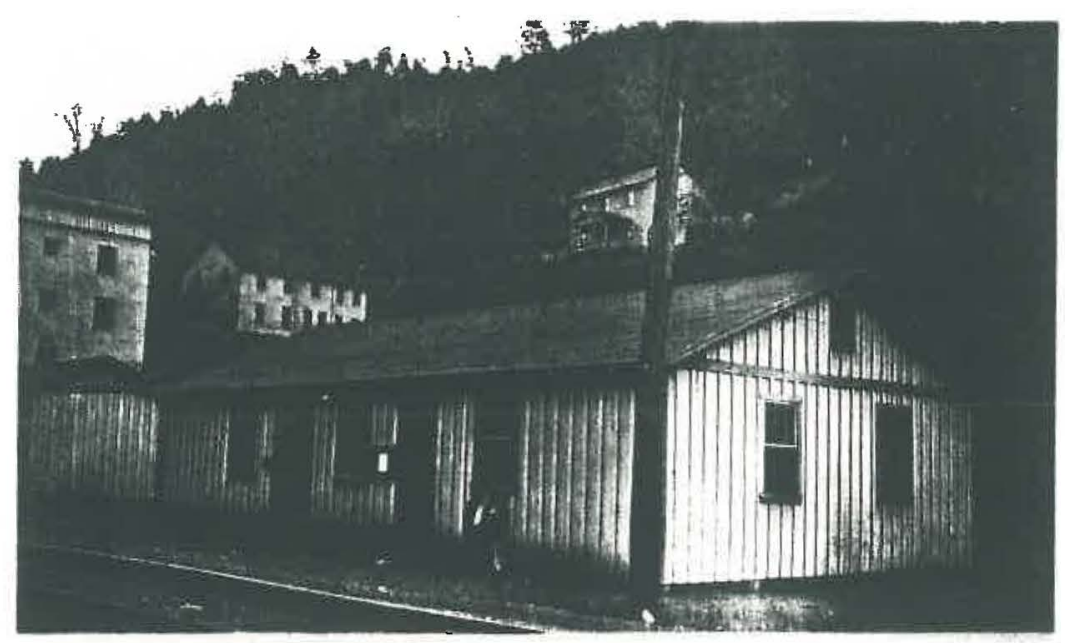

A pool room in Raleigh County. The door on the right 18 for Hegroes; the one on the left for the whites. 
In pool rooms a somewhat o1milar plan is util1zed. Father than bulld separate struotures ome of the oompanieg have put up a alngle bullding, ueualdy a one atory affais with a counter bullt entirely across the room aeparating it into two 1dentical compartmente, one for the uar of the Megroes and the other for the whites. Persone of the two races riay and frequently do talk acros the oounter to one another and both buy drinks and candy at the ame counter from their respective ides. They do not, howerer, play together and they enter the bullding by separate doors. In other places entirely separate cocommodation are provided. These anusement placas are often roferred to looally aq "X. M. C. A's" although they have no oonneotion with that organization, and serve no function other than comerolalized reoreation. At one plico where the "Y. M. C. A." was used by both whitea and Wegroes a polloy of segregation was used, but over a

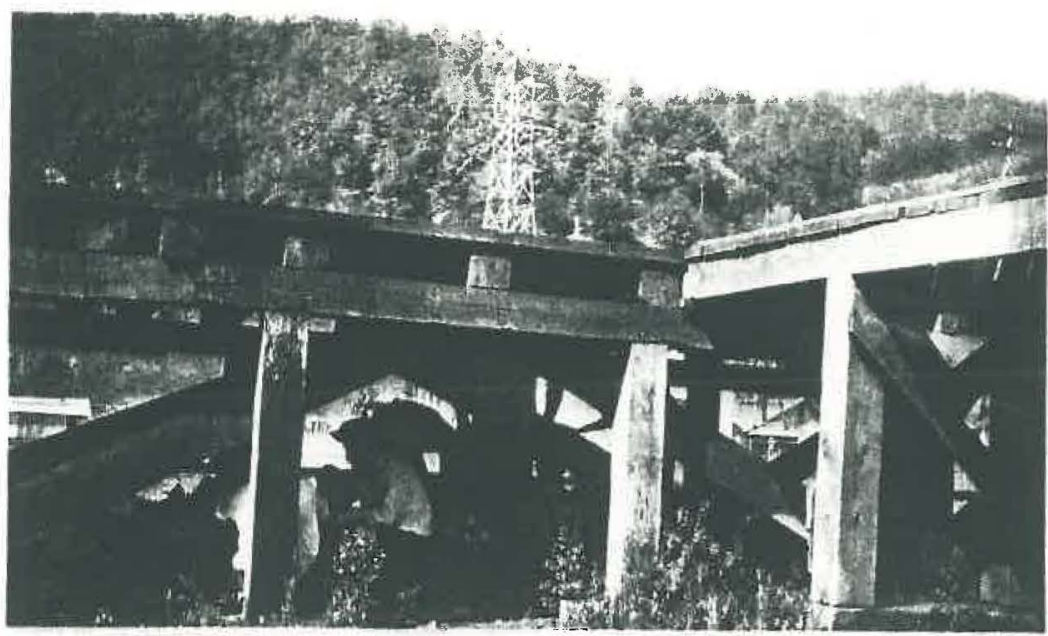


period of a few yeura the whiteo and Negroes gradually care to play together rather than separutely.

the Negroes and whites mingle frequently in inforital reoreutional activities. Sometimes oard gumes in which weribore of both racea pirtiolpat go on by the hour. The writer has also observed Negro and white boys play baseball together on the same tean, a surprising all lanoe in viow of the fact that in Fest Virginia the Negroes and
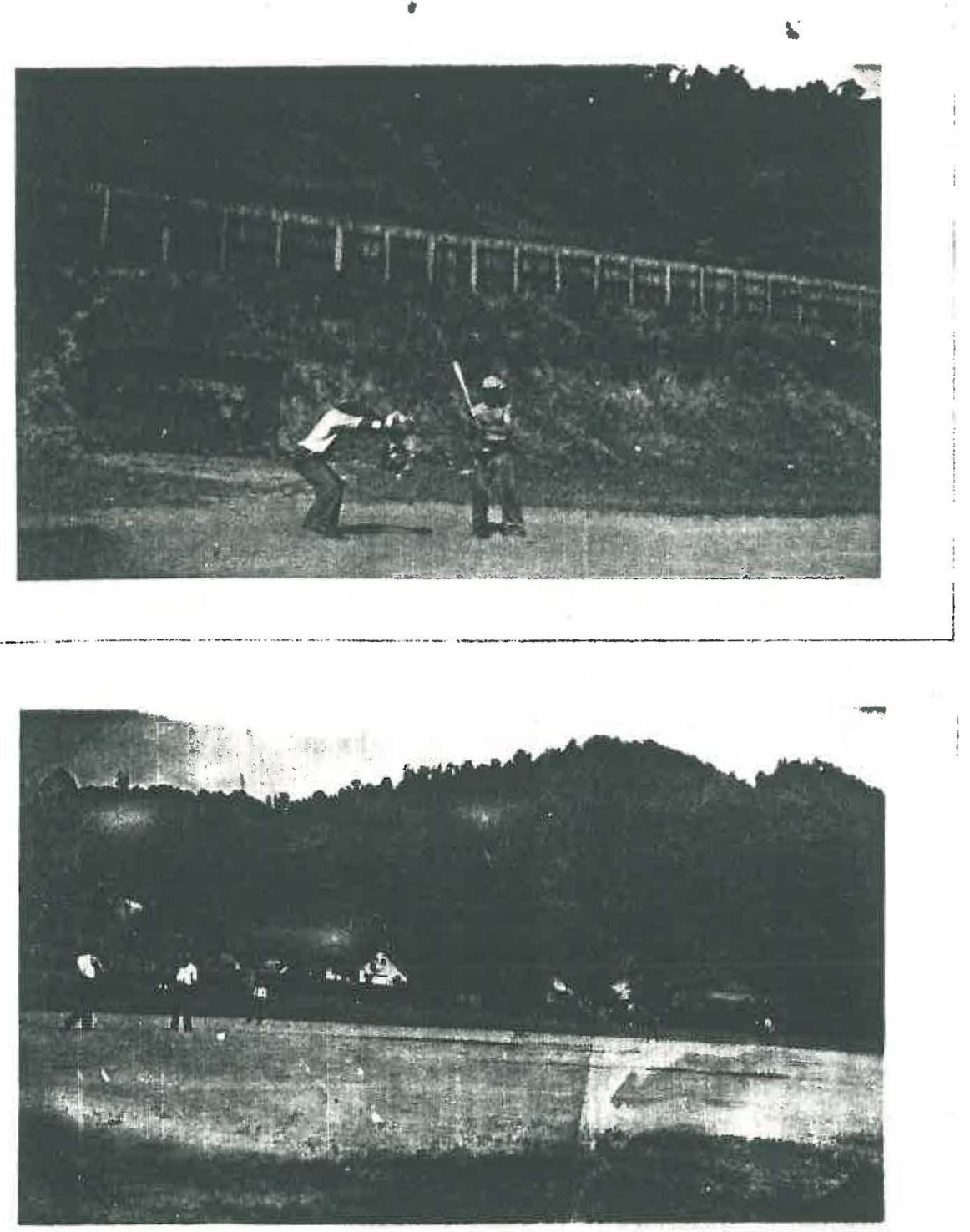

Negro and whit te boys playing baseball together 
whites are otriotiy eegregated in separate solools. The writer has not observed suoh intimaoy outalde of the coal Ilelds. Oocasionally, a might be expeoted, these contacts result In oonflict. One of the writer's early ineradioable memorles of the ooal fielde in that of a ball game between whites and Negroes at whioh one of the whites during an alteroution was all but k112ed by a bat wielded by a Vegro. In vlew of the risk of confliot aome euperintendents beve attempted to enforoe pegregation on oompany bal1 groundo. a separation accomplished with diffoulty in some places. Wh1le these olashes hare ocourred, "they are quite exoept1onal.

5. Menifeatation of race coneclouaneas.-

A raolal group 18 composed of a muber of people the recognition of woes ldentity la called fortb by a aymbol in terms of certain hereditary features; hair color and texture, skin color, eto. Raoe conoclouaneas develops. however. only in a confliot altuation in which these comon physical feutures are assoolated with and become symbols for a common condition shared by members of the group. Where these physical characteristios beoome the aymbol for separation, disoridination, represeion, and peracution the soolal cohesion of the group is strengthened and a distinot "we feeling is developed in opposition to the oppressor. There follows a hypersensitivy to insult or disorimination 33 Cf. Reuter, E. B., op. o1t., pp. $393 f f$. 
of any nature and compensatory behavior whioh tralts, taken together, are the result of the development of that neurotic condition whioh willer has called "the oppresalon psyohosis." While differences in energy botween indiriduals and oultural faotore accounting for different degrees of accommodation wake it inaccurate to say that raoo consolousness exists in direot proportion to the extent of the repression, st111 it is true that ito development does not take place except in those situations in whiop a recognition of oppression, either real or lmagined, exists in the minde of the group. Considering the fxlendly relat lonships whioh exist both between the Negro miner and thelr employere as weIl as their fellow workmen of the white race it is not surprising that they exhibit relatively 11ttle of what we have desoribed as rao consolousness. An lmportant reason for this fact is that in coming to the mining flelda of West Virginla raost of them come from an a rea of greater repreasion to one of 108 , so that a feeling of recognition and freedom tends to retard any inolpient race oonsolousnese whloh may have been developing. Equality of wage payment and opportunity for lucrative employment also tended to reduce any tendenoy in this direotion. A further factor has been a distrust of the leadership of their own race. 25 Extreme suppicion of the sinoerity of Negro leaders and successful men, with the possible exoeption of Negro politicians in whom they have great faith, 34 Milier, H. A. Haces, Nations, and Classes, Ch. IV. 25 Gf. Garvey, Marcus, The Hegro's Greatest Enemy, Current History, Maroh 1925 . 
whe exprosued by Vogro minere.

Eforadio Instanoes of raoe consclousness have, Lowever, ocourred among Hegro miners in West Virginia. One of these oases developed as a counter-ruaction to the frowth of the Ku KIux Klan after the World War. Opposition to the cmployment of Negro minero inoreased in the northern counthew of the state as the result of the growling Ku KIux KIan wpisit in vertain of the minaw. 33 The attitudes of union brothers who were also members of the Klan led some of the Nerroes to withdraw from theix 100k1s. In some places in the northern countles where ractal ani mosity of the Ku KIux Klan was highest there was a corresponding growth of Garvey18m. whloh is to the legro nationalistio movement what Zloniam is to that of the Jews. 37 In some places in the southern counties, however, the Negro viewed the aotivities of the Klan with a nonchalance that must have been bighly disappointing to the KnIghts of that order. At Grozer, in MoDotell County, the white members of the organization planted thelr flery crose on the hill perlodioally and each time the Hegroes got their rifles and ahot it full of holes. In the fleld of politios the Negro miners have ahown what is probably the greateat evidence of their group solidarity. The Negroes believe their politioal and oivil rights are best guarded by a member of their own race; 26 W. Va. Bureau of Negro Welfare and Statistios, Report, 1925-26, p. 35.

27 Spero and Harris, ope o1t., p. 371.

38 Interview with Mr, U. H. Prunty, Prinolpal of Elkhorn District Colored High Sohool, Eikhorn, W. Va.

29 Spero and Harris, ox, oit., p. 373. 
consequently in those oount les where they have held the balance of politlad power they have sucoeeded in eleoting solite of their numbers to off10es. In 1892 the Negro vote Eave the control of LoDowell County to the Republicans and har enabled thera to keop it over bince. By 1896 the Negro wi ners elected merabers of their own race to offioes of justice of the peace, constable, and member of the board of 31

eduaution. The same year Chriatopher Payne, a Negro, was aleoted to the House of Delegates from Fayet te County. since that time Hegroe have oooablonally been eleoted to the atate leg1alature from Kanawha, Fayette, and MoDowel1 oount1ea. The growth of tate inst1tutions for Negroea and the bolding of many etete offloes by Kegroes is indicative of the political power wielded by the Negro group.

Negro nenspapere are commonly read by the Negro miners. In a eingle mining community In 1836 two hundred and reventy-f1ve Negro papere vere diatributed weekly. These papere inoluded the Orisie, Chicago Defender, PItisburgh Courier, Opportunity, The Mearenges, Chioago Bee, and the MoDowe11 Times. Th1s 1at, the oldest Megro paper in Teat Virglala, has been publiahed a1noe 1904, It 1s intereating to note that one operator refused to allow the Chloago Defender to be oold in his oompany-owned town. 30 Weloh (T. Va.) Da11y News, Sept. 21, 1936. 31 Ibld.

32 Spero and Harsis, op, olt. p. 372.

33 Weloh (T. Va.) Da11y Nowa, Sept. 21, 1926.

34 Interviow w1th Mrs. M. T. Garrison, teaoher and Seoy. of the Gary Branch of the N. A. A. C. P. 
The National Assoolation For the Advanoement of Colored People has eight branohes in west Virginia located at Bluefield, Charlest on, Huntington, Keystone, Lozan, Montgomery, Glen Rogers, and Gary. Keyetone, Glen Rogers, and Gary are coal mining commities; it is probable also that miners belong to the branches at Montgomery and Logan, The branohes at Gary, Bluefield, and Keystone were somewhat inective during the sumber of 1933. The offloers interviewed Indleated that owling to the coonomic oonditiot of the coal f1elda the organization had loot many membere, but before the depression rome of the branohes hid as wany a a huadred members. Theac branches whon aotive devoted themselves, as doea the national organization, walniy to flghting legal disorimination and providing funds for ald to llegroes cooused of orimes of which they are probably innooant.

Some of the Negro preachers attempted to otimulate the ambition of their omaroh mombers by various appeals to race pride, in some instanoes a diffioult takk. While it may be true, as has been sald, that some of the Negro preachers lasd their flook in the direction dealrad by the coinpanies, the sincere effort of others to atimulate their member to group aotion and self-help ounnot be doubted. These attempts do not alwaya, howover, gain favor with everyone. A scotoh ralner of defint te raolal prejudica sald: "The boys that keep feeling high are the Negro preachers. They do it for their own benefit. You never find b good nibser who shoots off his mouth. I found one talkins about 
how some day Ithiope would spread its wings over the entire country. I told hin to shut up. They would take the country if they only felt they were atrong enough."

Some of the younger Degroes show a somewhat different attitude than do their parents. At one wine in Fayette County, as is the oustom, representatives frow each family oongregate in the atore after the train runs und the bookkeeper-postmaster oalls out the names on each plece of ual1. The older Negroes; on the ocousion when the writer was present, rewulned in the background, not answering tleir names when called, and after the rest had gone they cawe up quiletly for thelr mail. A young Negro, however, pughed to the front when his name was called, jootling the whites, who were orowded near the counter. At another place in UoDowell County a movement was sponsored by some of the younger Negroes to try to have "Amos and Andy" taken off the alr. They felt thia program was creating a bad ldea of the Negro in the uilnds of white people.

\section{THE RACE RELATIONS PROCESS,-}

Up to this point the attempt has been made to describe the atatus of race relations in the mining fields at the present time. The oonditions as they exist today, however, represent only one stage of a development which has been going on over a number of years. In other words, inter-raoial prooesses in the mining flelds of west Virginia have tended to follow a more or less prediotable oyolioal 
movement as disoussed by Park and Bogardus. While

these writers bullt thoir "race relation cyoles" in studies of Orfentals in the United Statea they conatituto a hypotheals and an approach for a tudy of any altuation in which members of two distinct races come in contact in lurgo 37

numbers. From this point of view, then, we ma briefly examine race relations in the mining fields.

The flret relationships which the Negro ainers bad in West Virginia was the hearty ecopomio welcowe given them by the exployers. Individualistio mountaineer whites did not take too readily to the mining flelde and Nagro labor which was easlly obtalnable from Virglnia and point south fllled the need for a labor supply. As has been pointed out before, the promise of high wages brought the Negroes in great numbers to the mining fieldo. Many of those ariy Nogroes in the1r native states had not had as favorable contuete with whitea as had the native Negroeg 39

of West Virginia. They settied in opunt 108 sometimes where the native whites had had no contaot with legroes and bad in some cases reached manhood without seding a colored

35 Park, $R_{0} \bar{E}$. in the Paoffla Coast Rsce Relations Survey (unpubli shed manusoript 8 ), guoted in House, F. H. . Range of Boclal Theory, Holt, 1939, pp. 49-50.

30 Bogardus, E. S. A Roce Relations Cyole. A, J. S., Vol. 35, p. $612^{2} \mathrm{f}$.

37 The atages in the oyole of Park are oontaots, compet1tion, accomodation, and eventual assim1lation. Those of Bogardus are: ourlosity and sympathy, oponomio weloome, Induetrial and eoclal antegons $\mathrm{Bm}$, leg1elative antagoni am, falr-play tendencles, and quiemoonos,

38 Cf. Bogardus, ope o1t, p. 613 ,

39 W. Va. Bureau of Begro Welfare and Stat1st1os, Report, 1931-2a, p. 13 . 
man. With the Hegroos came nhtted attracted like the Negroea by the high nages. These white norkers were nostly 1gnorant, often 111iterate "poor whito" from states whero they had coupeted $n$th and the contractora and operators, needing inen, were not too cholcy in thelr selection. Among the groucs of both colors vere any orizatnals, soine of thea fugitives for orizes committed in thelr native states.

As might have been expeoted, the ensulng perlod 41

of industrial and sooial antagonism resulted in a great deal of confliot. In 1287, at whlob tine the minerg in the Hew River District were moatiy Negroes, a Negro k11led a grade foreman near ouinnimont and was 1 gnched by a white nob. In reprias a mob of vogro miners formed at Stonecliff in Fayette County and began to march toward Fayetteville, the county seat. By the time they reached Oak Hill the mob 7as estinated at 3,300 . Although they pere dispersed rithout confllot the whites at the mines in the New River valley were terrified for the report was sent to them that the Nesroes expeoted to lolean out overy whlte person along the river. 42

A sinilax inoldent occurred in igercer County about 1888. Two old hucksters were returning to their homes after having sold out their mares to the miners at Goodwill. They were robbed by two Negroes who told them to run and shot at 40 IbId

41 Cf. Bogardus, op. olt., p. 614.

43 Interview with tr. John Laing. 
their feat as tiey did so. A white wob formed and ynclied one of the Nesroes. Soon word came that a Nero mob wa

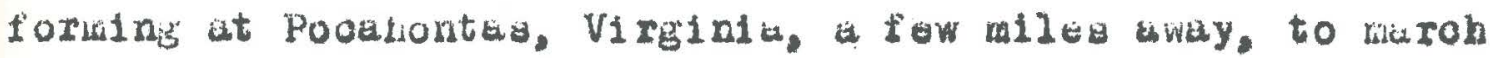
up Flpking Creok and k111 all the whtoo. The Nogroes in that territory were greatiy in the alajurity at that time, but the wilites ialde plans to hide the women and ohildran in the laulel thickots noar by and got ready to fibiti. The wob, hovevar, aisperaed before aotual flgbting had begun. Two otker outbraks ocourrad in that sawe roglon, in one of witich tho Hegroes attempted to drivo out the toralgners. When the whites of Mercer. County grem wore numerous they attempted on several occasions to drive out the 44 Negroes. In faot, Mduring the two deosdes from 1890 to 1910. whioh marked the greateat development of the ooal flelds in southern West Virginla and the great inorease of Negro population, orimes of murder and robbery were of very frequent oocurrence and, in these oounties, whites lynohed Negroes and each other and there ware a few oses where Negroes lynched other Negroes, but none of these lynchinge wer for orimer againgt whit women and it 1 worthy of note that in these oounties f11led with a very orude and 1111 terate population, with oriminals of all kinds in largo nuabers and weak law enforoement of $1100 r$, there wore in the early daye of developinent and there have been einoe only a few cases of Negroes obarged with orimes agalnst wowen of 43 Interviow vith the writer's mother, who was at coodwill during the entire inoldent.

44. Interviow with Mr. T. L. Felta, Bluefield, W. Va. 
either race. 45

S1milar conditions exiated in other count 1e日. The coming of Negro saloons to MoDowell County rebulted in many 46

clashes, New Aiver, cocording to white miner living

there at the time, was a "tough place up to 1908." At South Capertion for many years no Negroes ith the aingle exoeption of a Negro gervant of the superintendent were allowed in the 47

town. A similar situation existed in Mason County in the mines above Polnt Plesant on the Ohlo fiver, for the Weloh who came there in the early day to teach the natives how to mine did not allow the Negroes there for many yeara.

Since the operators found these oonditions unprofitable in many ways they inaugurated plans for definite labor polloles and a controlied oompetition. Although the motive back of these policles undoubtedly self-interest they resulted in fuproved race relations and a lessening of raoe confliot. Other variables in the Weat Virginia eitua tion, such as the relatively stable race relations to whioh wany of the Virginie Hagroes, who later forwed the bulk of the non-nutive population, were already aooustomed before 49

aisrating, and the 2aok of prejudioe on the part of the West VIrginita nativea in the early days, alght be considered; but the influence that seews to huve been most powerful in

\footnotetext{
45 V. Va. Bureau of Negro Welfare and Statiatios, Refort, $1921-32, \mathrm{P}, 14$.

46 Weloh (W. Va.) Dally Nowe, Sept. 21, 1926.

47 Interview with Mr. John aatherum, miner and former union of 101 al.

48 Interview with Mr. Clifford C. Myers, State Historian. 49 See Russel1, J. S. epe oft., D. 561.
} 
promoting the rapld aocomadation and partial assinilation of the Hegroe is in the judgment of the writer this oontrolled competition, one feature of whlok has been equality of wages for every raoial group in the mines.

The we virginia al tuation in tho mining fieldo has, In the writer's opinion, oertain implioationg for the theory of race relations. It is a comaon generalization that race prejudice in the case of white poople lo $11 \mathrm{kely}$ to axist in inverse proportion to the atatus of the white pur50

Bon. As Rark puta the matter, race projudice is a detense 51 reation against the 1088 of atatus, The praotiod offeot of race prejudice is to restriot iree interraolal competition which eeeine to be a potent etimulus to race prejucice. In other words, a long as the Negro is in his oulturally defined "place" pesce is secured through a sort of conven53 tionalized gegregation. The acculturation of the white has led him to expeot the Negro to be necessarily lower, and to receite less of rights and privileges than he himgelf doen. He therefore etruggles to keep the Hegro down. Whenover the Negro attains a position whioh approximates tho statur of the white man opposition is aroused.

The interraolal situation in the minlag lields of West V1rginia, howerer, seome to provide auficient evidenoe 50 Cf. Alexander, w. W. The Negro in the low South, Annalø, Vol, CXXXX, No, 339, Nov, 1938, pp, 145-152.

51 Youns, Kimball, Soc1al Paychology, Knopf, 1930, 0. 500.

52 Park, R. E., introduotion to Stelner. J, F.,

53 The Japenese Invagion, HoClurg, 
for questioning the univarsal applicability of this general1zation. Here there has been oreated a somewhat different cultural situation. Wlthin the company-owned town oompetition la not free but oontrolled in large measure by the coupany. The relativo number of nombers of different races who are to be employed and the posttions they occupy are also decided, for the moat part, by the company. Race prejudice is largely a response to the appearanoe of the unueual and the unexpeoted. In the mining fielde, with few expept lons the whites do not expeat llegroes to recelve andler wagea or ocoupy a definiteit lower plane. The status of the two groups has become, thus, mnre nearly identioal, wh the eventual deorease rather than increase of raoe prejudice quite contrary to the usual generalization. Conditione at the present time are in a state of flux and there are many avidenoes of oulture lag. It appeara, however, that under the stimuli of equality of wage payment and oontrolled oompetition the transition to the later stages of the race relations oyole has gone firtler tian in any comparable oltuation within the knowledge of the writer. 


\section{CHAPTER XV}

\section{PROSPECT}

Since 1939 conditiong in the cold industry of West VIrginta have made an extenalve program of rellef alinost continuously necessary. A Kunawha County miner, in unswer to the question conoerning what he did when be was not working at a mine, whlob was "running" only one day a week, replied: WOb, just get around -- Lookin' and wishin' -- wiblin' for the raven." ${ }^{2}$ Hia.."wighin'" was not entirely in vain for about once a week the raven, in the form of a county relief truok, came "up the creak" dispensin flour and bacon. In adation to rellef given by the county the Ainerloun Friends Service Committee, agked by the Federal Chlldren's Bureau and Presldent Hoover's Organization on Unemployment Relief to undertake relief work among children of unemployed miners in the bituminous ool flelds, has alnce september 1, 1931, given food and olothing to many school and pre-sohool ohlldren as well as to nursing and expeotant mothers. The $1000 \mathrm{l}$ Red Cross untts added their help by perfodio gifts of flour. Finally, as has before been Indicated, most of the coal companies have "carried" their men by allowing ohargee at the company stores, some advancing the necessitles of 11 fe more liberally than the

1 This remark refere to the ravens whom, socording to Sorlpture, Jehovah oommanded to leed Elijah. See I King $8, i 7: 4-6$.

2 Amerioan Friende Service Comittee, Report of the child Belief Work in the Bituminous Coal Fields, Sept. 1, 1931 - August 31, 1932, p. 3. 
county rellef agenclea, othera allowine kardly nore than enough to keep soul and body together.

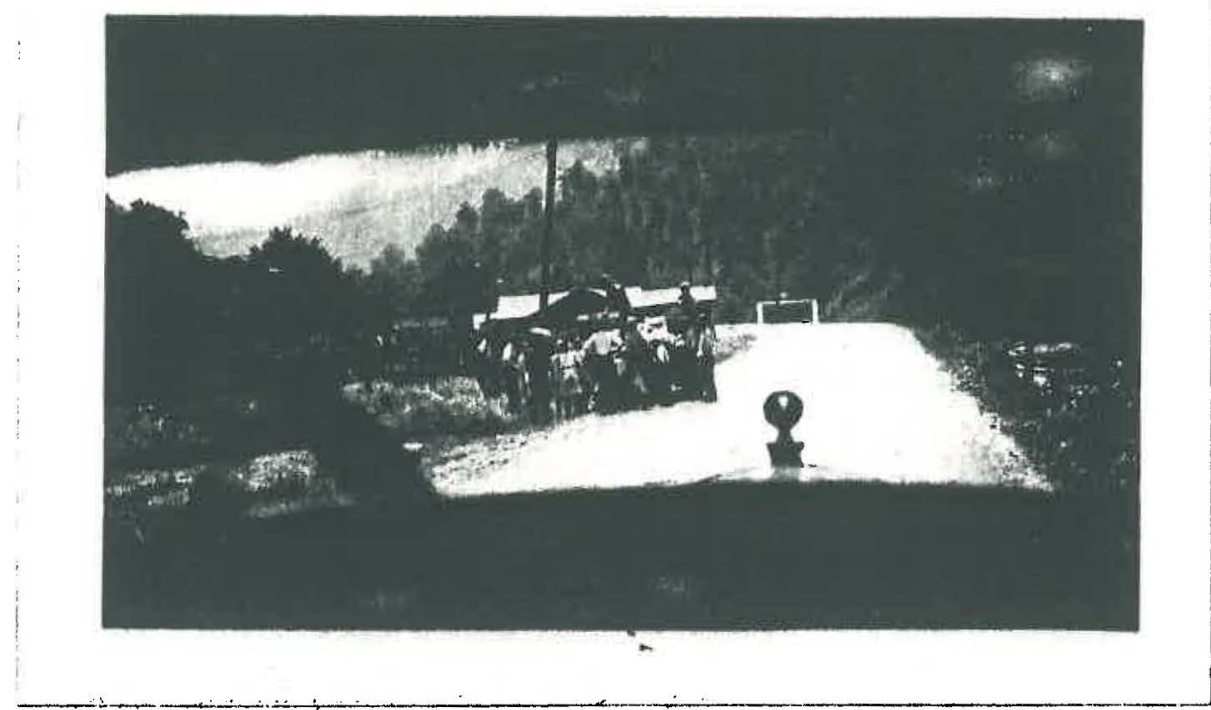

"The Raven"

In aptte of the aotivity of all these agenotes the problems of rellef whioh they have had to face have been so great that undoubtedly many oaees of hunger or perhapg even starvation have ocourred. Conoerning the state of affalro in Kanawhe County. where conditions lisve been anong the worat in the central and ooutbern count 1es, D. E. Shaffer, County WeIfare Seoretary, olalming that several tundred persons were on the polnt of etarvation," gitd durlag the winter of 1931: "Tis pltiful conditions in Cabin Creok cannot be exaggerated and relief must be gIven at onoe or inany peraons, partioularly chlldren w111 die." An Investigation into the oonditions in Monongalia, Marion. Harrison, Kanawha, Logan, and Boone count 1 ea was thade in 3 Char1eston Gazette, Murch 11, 1931. 
April 2832 by Frod C. Croxton and Porter Loo, mombere of the prosldent' easeryenoy employment oomittee. Croxton, returning to wash netton, reported oond1t lons co bad that "they were almost unbellevable." Other detalls of his 4

report are as follows:

Childran and grownups fare al1ke. The stindurd food is oornmeal, some llour and beans. There 18 no weat and little $1 f$ any green food.

Thes poople are not farmers and oannot obtuin Bovernment loane.

Jany of the men have not worked for mont he and otherg only a day or two eaoh week.

We wont into homes everywhere we could. Some of the conditions we found were so bad I hesitate to try to desoribe them.

There is one thing about the coal fleldd, thay have had slielter and fuel during the winter mont ho. But beyond that there is little.

These conditions, whlch during the past few years have been by no means peouliar to the mining fields of West Virginia, have persisted and have lod Kaloolm fose in a recent book to bay with a great deal of feeling and some exaggeration, moday the clty of Charleaton spreads over both banks of the Great Kanawha River. Coal profite bullt dignified manBlons for wiles along the shore where the old frontier fort otood. At the far end is the State's now Capitol, a magnifloent mase with gold onoruated dome dedicated to the children of West Virginia. Within sight of the dome are ohlldyen unable to go to sohool for laok of shoes, ohlldren who sloep four in a bed and woar f12thy underwear because they have no ohange, oh1ldren 1gnorant that the world is 4 IbId. April 4, 1931. 
larger than two hillo framing a oreek, a rallroad traok und 5 a row of hovels." During the depreseion the plight of West Vireinia winers, both white and black, has been hard, but beoause of the paternalistio polioles of the compandes it is doubtful whother they have been as cold or as hungry a thousends of their fellow Americans in urban diatriots where 108 of work has meant no simllar "oarrying" on the part of their employers. Some of the miners were nevertielese suffiolently bungry to atage a "hunger maroh" to the otate oapltal to appeal to Governor Conley for help, some 600 parsons 6 part loipating.

Because of these hardships the Negro miners are today a disatiafied and downoast group. As a rayette County miner put 1t: "You see, we haven't worked but one day a week for a long time. Rent and all the charger were just the ame during that time although we are w1111ng to work, All these things are marked up against us in the office and when we finally do get to work we will be so far in debt it wll take years to get out. It makes a man direncouraged." A sort of complaining hopelesaness charaoterzies the attitudes of many. In spite of their present ituation, however, migrated Hegro miners as a rule do not regret thelr coming to WeBt Virginia. Better schools for

5 ROEs, M. 우, oit, pp. 41-4a.

6 Charieaton Gazette, May 22, 1931; also Norton, H. G., Coudalism in West Virginia Mation, Vol. 133, Auguet 31, 1831, p. 155.

7 This 1a not merely the opinion of the writer; Negro teaohers and othere in a position to know are agreed on this point. 
their chlldren and a larger opportunity for olvic expression whloh they have exeroised to the full in roting and pollt1cal aotivity mean moh to them. Nany of them have made "a plenty of money" eren though "it all got away." Thoir experienoes in Hest VIrginla aro looked upon as advancement, and, having gone forward thla one stop they enviage newer opportunities, which at preaent they are largely denied because of economic paralya18. The total situation is produotive of an attitude of dis12zusionment und disatiafia tion, but not of regret. Even though the economio altuation crusher, they foel that they have aobleved a oertain stitus which would have been inposible had they remained in their 8 nat Ive states.

The reaction of many of these Negro binera to the entire configuration bears an interesting relationsbip to the growth of raoe consolousnose. Ruoe oonsolousness, like race prejudice, exists in quantities, and it should be possible to plot diagramatioaliy a curve of its development from a condition in whiob it is lackins to another whore it 1s manifeeted in ita most extreme forms. In other words, the acquisition of race consolousness in the oase of any individual is a proces of transition from a state of unawarenes to one of awareness. Their awareness of an enbanood personality as a reault of their weat Virginia 8 C. Scott, E. J., QDe Olt, pasalm. Lettera writton back to thelr friende in the south indloate a similar attitude on the part of man migrants, 00 Johnoon, op. oft. pp. $32-38$. 
experienoe is, however, movement, be it ever so slight, in the direction of race consolousness. Curnulation of such awarenesses with consequent frustration of the desires oreated thereby is the atuff of whloh race consolousness is made; hence the attitudes of the majority of the Negro miners, while they are not manifestations of raos consolousness per se, may be regarded as the inciplencios of an emergent evolution the logloal termation of which la race conbolouenees.

It is a cominonplace that upon the economic front $\theta$ Megroes are "last hírod and first fired." Sayo Feldinan:

The Negro's experience in earning a living involves a furt her complexity in the difficulty of holding on to his job. of course, it la trus

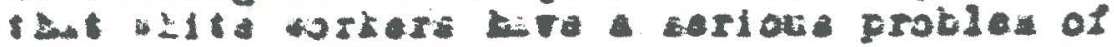

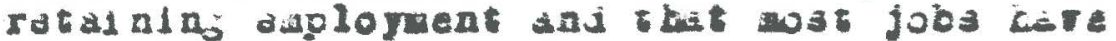
elements of insecurity. But it is also true that when emplojers hire, Hegroes are ainong the last to be seleoted, and in times of depression, Hegroes are often the first to be discharged.

Such is not the oase and has never been the case with the Negro miners of WeBt V1rginia. In nine years between 1913 and 1931 the total number of miners employed was maller than in the preoeding year, but in each of these nine years the percentage of Negro minere inoreased, with the exoeption of a singlo year in which the peroentage remalned the same. The total mintng population of West Virginia in 1931 was 9,879 or 9.3 per cont lower than in 1930 whlle the porcont9 Feldman, $F_{0}$ op. oft., pp. $42-43$. 10 See Table $13, \frac{\text { p. } 94 .}{}$ 
aige of Negroos amployed inoreased from 21.8 per oent to 21.9 per oent. The figures for 1933, which are not yet avallatle, wil probably show a further deoline in population and an increased proportion of Negroes. 11

The inorease in the peroentage of Negroes as the total number of miners deoreases may be attributed both to the reluotano of the Megroes to leave the industry and to the favorable attitudes of employera towards thom, Minino coal is a job wht oh has in normal times combined a oertain anount of "freedom" in working conditions with relatively high earning posalbilitiea. The eos mines have afforded opportunity for the uneduoated Hegroen to earn in prosperous years wages not posslble for thon in many other industries. Then, too, the controlled oompetition, the lriendly raoc reletions; and the onjoyment of of 11 right mentloned before have added to the desirablitty of remalning in min ing. These considerations, whioh might be termed "holdo" as contradlstingulshed from the "push" or undesirable features of the induatry and the "pulla" or attractions of other industries, together with the Negro heritage of southern mores regarding whito omployer - Negro employeo roles, have operated to make the Negroes as a whole a docile labor element. Consequentiy, in times of depression the ewployer prefer them for thelr "loyalty" and acoeptano of the oiturm tion with ostensible good gruoe. A great deal of the white undnere generally had left the mines by the summer of 1932 in greater proportion than the Hegroes. 
complaining by Negroes is done elserhere than in the presence of "the boss. Another condition which operates quite independentiy is the laok of opportunity in other industries. No matter how badly they may wis to leave many Negroes must stay because they hare no other place to go.

That are the prospeots for Negroes in the coal mines of west Virginiat Since the Negroes are already firmy intrenohed in the mining tradtions of the state. probably the best answer that can be given to this gueation Is that thelr future is inextricably bound up with the fate of the cosi induatry. Today the fallure of our present individual 1st10 econoulc organization 18 nowhero nore evident than in coal mining. Hany carloads of coal vero actually given away foring the vinter of 1931 to save demurrage oharges while miners were hungry and many Anericans were cold. Whils it is beyond the scope of this ohapter to anter into an involved discussion of the causes of the present conditions, some of the obvlous ones are overospltalization, surplus of miners, curtaliment in the use of coal owing to competition of other fuels and development of water power, the seasonal obsracter of the demand for coal, and the unwillingneas of the operatore enjoying unusual advantages in the conditions of production to conperate with the lese fortunate operators in any plan for 13 Roos, I., OD. O1t., p. 334. 
etabilization. During the war boom period when coal sold

as high as \$25.00 a ton any Vest Virginian who oould get

his hande on a few dollars opened a coal mine; even the 11ttle "wagon" minea proved profitable. since the reduc tion in the demand for coal these ralnes have been gradually going out of business, but the prooese is by no means oolm plete. Many companies, in olosing one operation, litempt to "take care of" thatr wen by aboorbing them into others; overarowding resulta which leads many Nogro miners to say: "Yes, we're workin' but they's 80 many miners we can't labe nothin'. Finally, some operatiors who could operate with 11ttle overhead because of good maturel mining conditions have preased their advantages by underselling thelr coispet1tors who have had to spend large amounts in order to provide reasonably ase working conditlon for thelr men, and oompany and eeotional competition of the "out-throat" variety has proved disastrous for both operatora and miners.

For the most part the coal operators, ateeped in an individualistio tradition, have reacted in the face of the crisis in a dazod and bewildered manner. They have gazed in valn for a Noses who would point the way out and bave done 11ttle abcut the matter. Phey are bardly to be blamed for their insation, however, inoe for years they were prohibited by oourt interpretation from forming 13 See U. S. Coal Commission Reports, Part I, pp. 303-333; Johnson, op, alt., p. 97; Roohester, ep, oit., pp. 1133.

14 Hose, $M_{0}$, LoO, dt. 
cooperative sales organizations. Under the Sherman Aot of 1890 onch oooperative ueasures wero declared 11 legal, interferins do they did with "Free Competition," the Saored Cow of an individualiatio eoonomic ordex, whiok now even one of the mining trade journale conalders "destruotive." Prevented from ualng this avenue of approuch to their problems many operators looked to Congrass for rellef. The result was the muoh-disouseed Dav1s-Kelly $B 112$ whloh after some revision proposed federal oosl commision which should be empowered to license all coal oompanies in the 17

United States.

At the international conference on biturn Inous coal held under the auspioes of the Carnegie Institute of Teohnology in 1931 the assembled cosl men were addressed by Governor Albert C. Rltohl of Maryland who advised them "to keep clearly in mind that government control and ownerahlp 18 in the last analyolo a spolos of communism and deoried "this new Amerloan bablt of looking to Washington 18

for help." at the same time suggesting that some revieion of the ant 1 -trust laws would be necessary.

Evidunty the coal men acoept od the Governor's advioe, for the neweat move to preacribe for the ills of the "glok glant of Industry" has dome from the coul wen themelves. The operators of the high-volatile coal fleldo of West VInginia and Kentuoky organized, for the purpose of I5 See Cogl Age, Vol, 36, pp. 65, 648; Vol, 37, pr. 34, $85,123$.

16 Coal Mining, Vol. 10, Maroh 1933, p. 24.

17 See Coal Mining, Vol. 9, June 1932, p. 97.

18 Charleaton Gazette, Nov. 17, 1931. 
a teat oase in the supreme Court, a cooperative sales agency known a "Appalaohian Coals. Incorporated" with the object of stabliling conditions by oooperation among the competing companies. On March 13, 1833, the deolston of the Court was handed down reoognizing 1ts legal1ty, an exact reversal of former deolsions. This eales organizat1on, which began formal operation on April 17, imnediately beoame the model for eimilar orgenizations in other terri30

tories. After a meeting on Haroh 31,1233 , the central Pennsylvanta operators applied for a oharter for Eastern Coals, Inc.; the operators of not hern west Virginia on Afril 18 voted to fom Northern West Virginla Colis, Ino.; representatives from eastern Ohio and the northern Panhandle of West Virglnta met in Cleveland and approved plans 31 for forming Worthern Coals, Ino.; and 1 t $1 \mathrm{~g}$ 11kely that the operators in the low-volatile flelds of West virglniu w11 soon form Smokelesa Coala, Inc.

The new plan has been accorded a good bit of ont basiasm. Editorially, Coal Mining olatms: "In the end it will mean the emanolpetion of the mas of men employed in our mines who as well as the operators are being made victiwa of conditions for whioh they are in no way reapon33

oiblo," while Coal Age looke forward to an era of

19 Coal Age, Vol. 38, April 1933, p. 109.

30 Coal Ae, Vol. 38, May 1833, p. 168.

21 Cool Age, Vol. 38, May 1933, p. 168.

22 Charleston Gazette, Hay 6, 1933.

33 Coal lining, Vol. 10, Laroh 1933, p. 24. 
"Freedom -- and Opportunity." ${ }^{24}$ It 1 s too soon, of course, to say just what the offeote of the sales agenolos will bo. From predictlons in the West Virginla preas concerning the Ikelthood of "enlarging the market" of West Virginic 0oula the writer suspects old wine in new bottles. The extending of the fiurket for Weat Virigini is coals, whlot must be done only at the expense of some other coal produoing section, meane coupetition, the only change being in the inoreased gize of the ooupeting unitio.

Two things seem almost oertain to happen. The firat is the eventual ellmination of the smaller companies from production in favor of the 1arger. This procesa, acoording to the study of the Jetional Industrial Conference Board, "will be worth the price that must be paid, if the final outcome is the elimination of inelfiolent producers and distributors, of destructive and unsound competitive units, and of uncontrolied and unbalanced production." The other is a reduotion in the number of men employed. Saye R. M. Lamble, Chlaf of the Feat Virginia Department of Mines, in his latest report: There is atill a deoline in the number of men employed. This, with the ourtalled working time, has brought about a serious oondition in the coul mining area of the state. It is to be hoped that this condition will correct 1 trelf in the near future. However, it 18 unlikely that the tonnage of 1927 will be surpessed 24 Coal Age, Vo1. 38, Apr1l 1933, p. 109. 35 National Industrial Conferenoe Board, The Compet it 1re Position of Coal in the United States, 1939, pp. 269270. 
for many yeare to come; therefore, many men who have been attraoted to mining durlng the high tonnage period will be corapelled to return to thelr former oooupations, " $30^{\circ}$ If the Negroes remain during this perlod of reduction, and order replaces ohaos as a result of a different oystem, they may be able to preenpt for themselves "a plaoe in the sun" superior to any they have yet oocupled in the mining indugtry. If, on the other hand, the new devloee mean only anarchlat 10 competition and production on the part of larger unts the conolusion seems inesoapable that the youth of the mining fieldo will oontinue thelr exodus to other parts, the vold w112 be filled by reorulte from the oouth, brief periode of prosperity will alternate with squalor, and Negro miners will continue, as in the pust, to be "more easily hundled."

26 T. Ve. Dept. of Mines, 1331 Report, p. 15; sec a180 Wolman, Leo, Unemployment Insurance - Ite Limitations end Its Promise Mation, Vol. 134, May 4, 1932, p. 509. 
APPINDIX A

THE MINER'S SCHEDULE 
1. Place of birth

5. Ir. starting mining

9. Places worked:

\begin{tabular}{l|l|}
\hline & LOCATIOI \\
\hline 1 & \\
\hline 2 & \\
\hline 3 & \\
\hline 4 & \\
\hline 5 & \\
\hline 0 & \\
\hline 7 & \\
\hline 8 & \\
\hline 9 & \\
\hline
\end{tabular}

10. Cccupation of father

13. Type of work done by wife outside home duties

15. Iivine children in home:

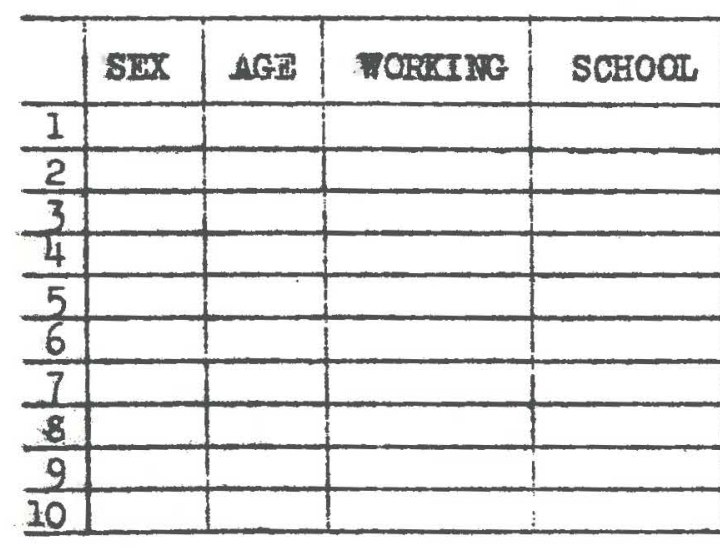

3. Narital siatus 6. Age starting 7. Wo. yrs. schooling

4. $\operatorname{col} 0 \mathrm{r}$

8. Grade fini shed

\begin{tabular}{|l|l|l|}
\hline MOMTHS WORKMD & POSITION & JOB SECURRD THROUGH \\
\hline & & \\
\hline & & \\
\hline & & \\
\hline & & \\
\hline & & \\
\hline
\end{tabular}

11. Birthplace of wife

12. Color

14. Approx. weekly earnings

RWASONS FOR IRAVIIG

16. Iiving children outside home:

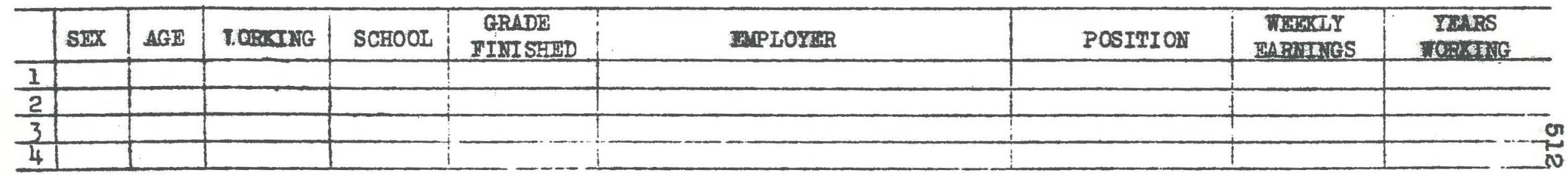


17. Children not living:

\begin{tabular}{l|l|l|l}
\hline & SEX & AGE AT DRATH & CAUSE OF DEATH \\
\hline 1 & & & \\
\hline 2 & & & \\
\hline 3 & & & \\
\hline 4 & & & \\
\hline 5 & & & \\
\hline 6 & & & \\
\hline
\end{tabular}

19. No. rooms

20 Rent per month

22. No. times attended church in last month

23. Nembership in clubs, societies, lodges, organizations, etc.

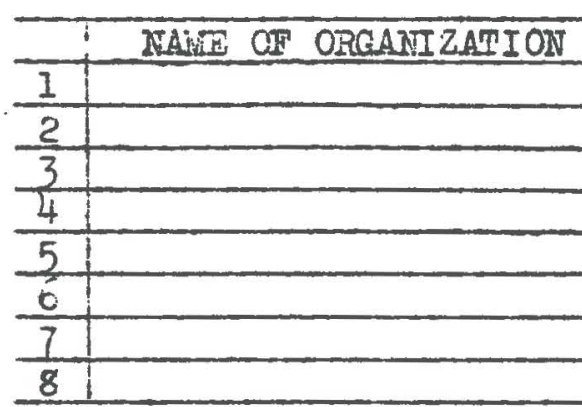

FUNCTION OF ORGAHIZATION

\begin{tabular}{|l|}
\hline \\
\hline \\
\hline \\
\hline
\end{tabular}

24. Iei sure time activities last week:

\begin{tabular}{l|}
\hline Mondar \\
\hline Tuesday \\
\hline Tedresday \\
\hline Thursday \\
\hline Friday \\
\hline Saturday \\
\hline Sunday \\
\hline
\end{tabular}

25. Real estate owned: a. Value

26. Amount savings rccount

27. No. yrs. owning present artamobile

31. Investments:

32. That ir highest position you know of coinred man having in mines?

\begin{tabular}{l|l|l|l}
\hline & SEX & AGE & BRTATIONSHIP TO MINER \\
\hline 1 & & & \\
\hline 2 & & & \\
\hline 3 & & & \\
\hline 4 & & & \\
\hline 6 & & & \\
\hline
\end{tabular}

21. niember what church? 


\section{APPENDIX B}

THE EMPLOYER'S SCHEDULE 
1. Name of mine

2. Company

3. Field

4. As compared with the quality of work done by foreigners, is work done by Negroes in the following occupations. (rate by number)
1. mach superior
2. considerably superior
3. slightly superior
4. about the same
5. slightiy inferior
6. considerably inferior
7. mach inferior

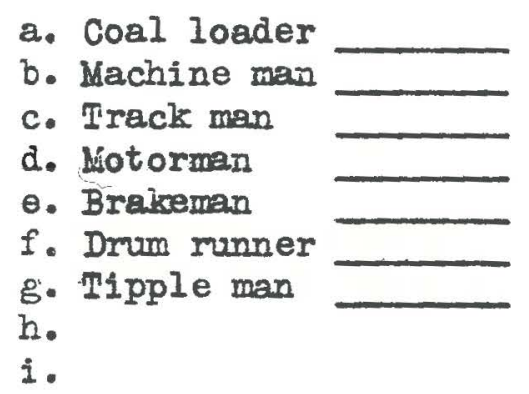

5. As compared with the quality of work done by native whites, is work done by Negroes in the following occupations (rate by number)
1. mach superior
2. considerably superior
3. slightig superior
4. about the same
5. slightly inferior
6. considerably inferior
7. much inferior
a. Coal loader
b. Machine man
c. Track man
d. kiotorman
e. Brakeman
f. Drum runner
g. Tipple man
h.
1 .

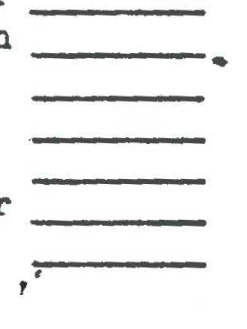

6. On the wiole, wich of these employment systems would you prefer?
1. 111 Jegroes
2. Many Hegroes and few wites
3. About equal numbers of vites and Negroes
4. Lany hites and fow Negroes
5. $\Delta I I$ wites

8. That positions of authority does a Negro hold in your mine? 10. Measons:

7. Reasons:

9. Used a Negro in place of authority? 
11. Reasons for discliarge of Negroes in past year:

1.

2.

13. That cases of trouble have there been in your mine between Negro and foreign or between liegro and native white Individuals or groups?

14. Bank ( ) the native white, ( ) the foreigner, and ( ) the Negro in order of their abuse of company property

15. Rank ( ) the native white, () the foreigner, and () the ilegro as a law-breaker

16. What crimes are the Negroes ordinarily convicted for:

17. That provision do you make for old Negro miners?

18. Whom do you consider the leaders among your Negro employees:

\begin{tabular}{l|l|l|l}
\hline & NALE & POSITION & REASON FOR I EADERSHP \\
\hline 1 & & & \\
\hline 2 & & & \\
\hline 3 & & & \\
\hline 5 & & & \\
\hline
\end{tabular}

19. What means do ycu use to keep order among your Negro employees?

20. Rate of pay and numbers in each occupational group:

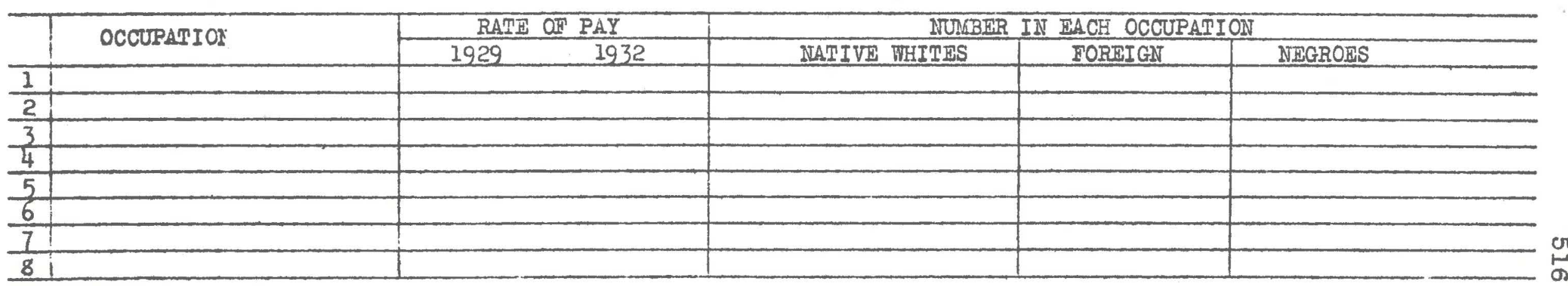




\section{APP EMDIX C}

MOTE ON METHOD

IN

THE SCHEDULE STUDIES

While the general method of the study has been disoussed in Chapter. I It seems 1 se to append a somewhat more detalled treatment in order to answer the questions concerning the entree obviously needed in order to get the information included in the study and the selection of the sample in the schedule studies.

I. ENTREE.-

The unfavorable preas reports of conditions in the nining areas of We st Virginla and fear of union organleers have led to a defenglve attitude on the part of coal operators which precludes the securing of informations by anyone not considered "Insiders" by them. The writer's fainily have been for three generations in the coal business of the state. Consequently he was able to malre contacts necessary to permit the study. Letters of Introduction were secured from the Governor of the State, the Chlef of the Department of Mines, and from the socrotarles of the different cosl operator's associations, as well as personal letters of introduction from one operator to anothar. 
II. SELECTION OF THE MINES.-

In the most inclusive sense the selection of the mines to be studied extends over a period of years. The writer was born in the mining flelds of West Virginia, lived in a mining community of Fayette County unt1l the age of seven, spent every sumner at the mines unt11 the age of thirteen, and has been in close touch with the minIng area all his $11 \mathrm{e}^{\circ}$. This background of famlliarity with the mining towns in the different fields alded greatiy in the selection of particular mines for study. After studying carefully the history of the minIng flelda by reading all sources of material in the hest Virginia State Library at Charleston and Interviewing men who were ploneers in the mining industry of the state,contact was made wth the Department of Min s. The chler of the Department of Mine gave important information in regurd to the miles in the state in which Negro labor was especially consplcuous and offered the cooperation of the one Negro member of the Deportment, whlch mas, of course, gladly accepted.

Before beginning the fleld work in any particular coal fleld the writer first interviewed the secretary of the coal operator's assoclation whose jurisalction covered the territory. These secretaries not only provided, In some cases, important factual material to be obtained from no other source but always eave advice concerning 
whlob wine should be visited in order to study all types of aning toms. Purther suggestyo rare obtalned from the deferent operators intorvened.

The suggertions of the employer alss rere crecked by 1ntervies gith Negro tenchers, srose nanes sere secured from the state Supervisor of liegro Sctools, preachers, lenders, and key-mirers. So gources of informatisn here may mot be divulged.

III. SELECTIN $6 \mathrm{THE}$ औIM-S.-

sost of the ining toms of sina11. Negroes a rule constitute not are than one tilird of the total number of miners emplozed. The cest "sampling" procedure, therefore, sppes red to be to select tomna carefully and to intervio 11 the miners in trem. By an "ontire" tom is rean "11 miners avallible for intervien the tive of tre call. Bxcept in rare instances It was not pract lcable to pay more tban one visit to a Arer's rome. In order to get lnformat 1 from the niners no nares yere asted and, tence, no check on trose not at home สas posstble, sinse the houses in most cases aro not mabored. Ow1ng to the fact that nany mineg were in operation so little the grast najorlty of winors aere at hose and avallable for intervie at the first vistt.

Th1s procedure, if followed excluglvely, would mean that miners in relatively fex toms could be studied. In order to allow alder selection of toms smaller pro- 
portion of the miners were studied vihere the writer was wble to make contgct with and secure ccoperstion of Negpo teachers, preachers, or ather pernons whom he falt conf1dent, were rellsble and inteljectualy copable of supertiding tre selestion of miners. Because of the stmilarlty of conditions in nost of the towns of Loggan county and nost fortumateonontacts witr capable persong this method wes followed excli.sively there.

a few miners were intervieved in varlous onsce situations. Sorre of trem sare "pioker un" slong the rosd-

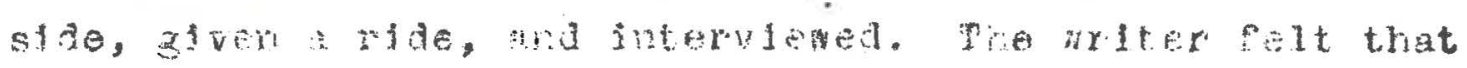

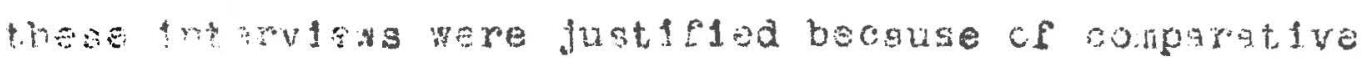

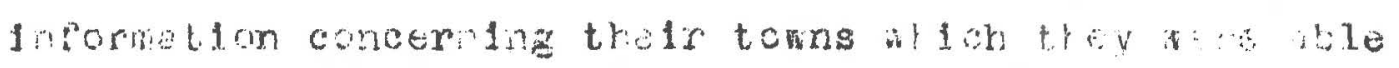

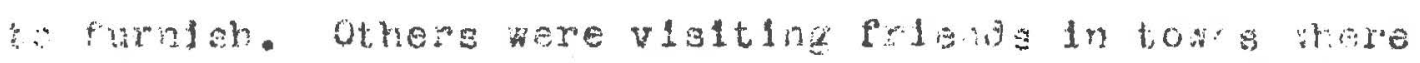

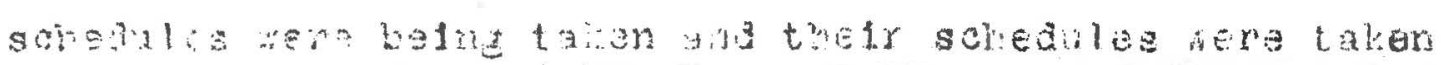

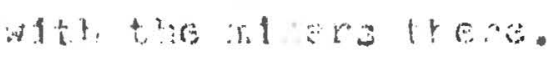

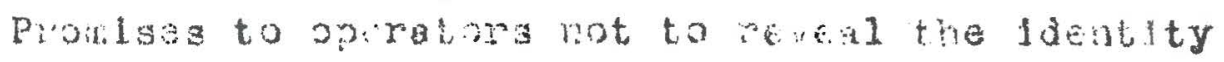

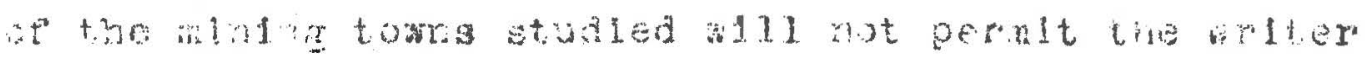
to yive the nares of then; lewo they are Indertad by

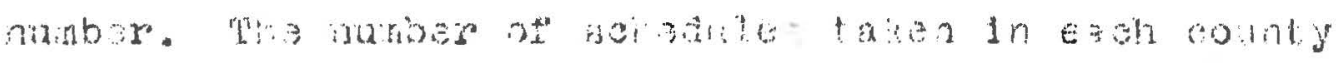

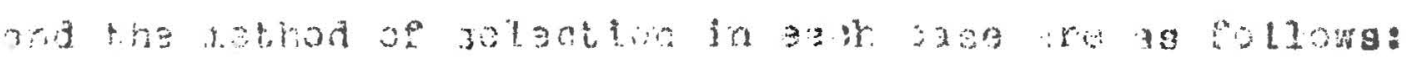

County and town Number Eags of selection

Lanawha County: Hine Number 1. uine Nunver 2 . Ane Number 3 . Hine Nu iber 4. Total

$$
\begin{aligned}
& \text { AIl miner. } \\
& \text { Chance interview } \\
& \text { " }
\end{aligned}
$$




\section{County and tam}

Ralelgh Gounts:

Mner number 5

uIne vubber 6

Une number 7

Ine Dumber 8

Fote 2
Domber

78

3

18

1

197

4

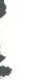

7

Payette county

110e number

4 ine lumber 10

ine nuaber 11

Ina Lumbar 18

uine number 18

4tno Humber 10

IIne tumber 16

rotal

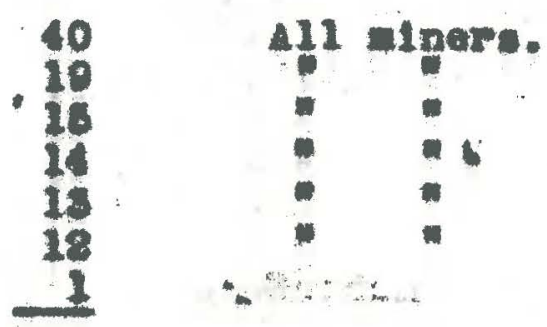

214

\section{Mopowell count \\ 1149 mumber 16 \\ vine Imber 17}

Ine Eumber 10

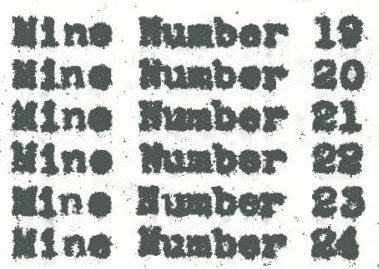

rotal
$10 \times$

48

4

6

8

2

1

1

\section{Gonreater of sample}

11 minere. sumortiaton of rorro Prinotonl of echool mot in ation of tom Chance interview 


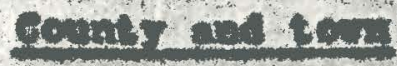

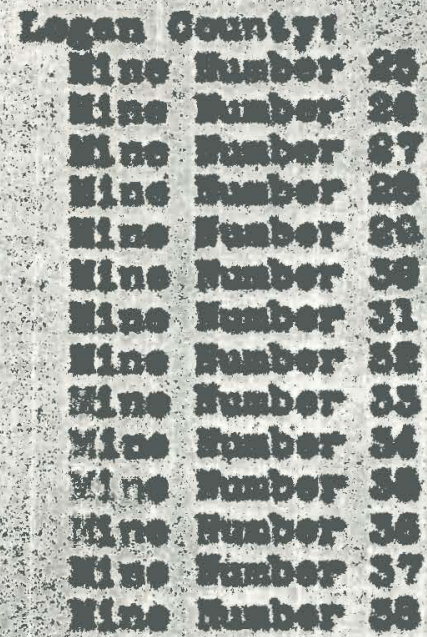

rotel

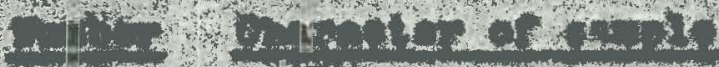

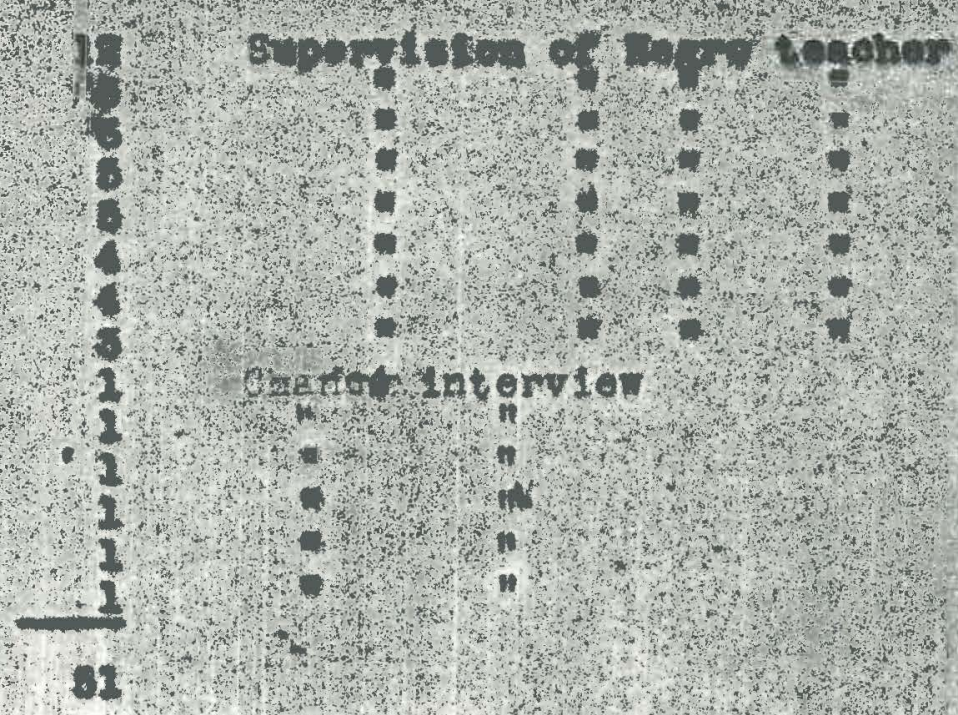

\section{solitix}

tharevter of acine 20
Honstas

40

1 .

n 4. 
fros pounty to county were not apparent. 


\section{APPENDIX}

HOUSE CONTRACTS

\section{HOUSR CONTRACT}

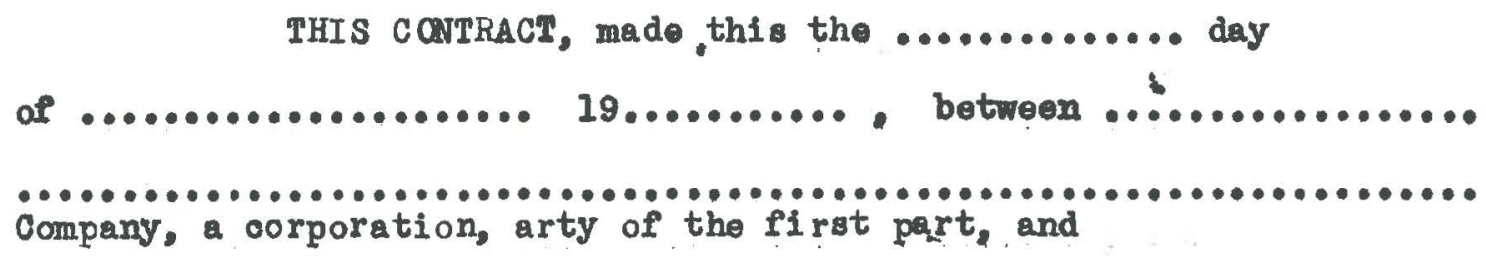

party of the second part,

WITNESSETH, That the said parties hereby agree as follows:

That they recognize that their relation is that of employer and employee respectively, and not that of landlord and tenant; that the said party of the first part, employer, hereby grantsto the said party of the second party, enployee, Dlely as incident to his employment and to enable him to better perform the duties of said employment, the privilege of occupying house No.......... at ......................... so long as said employment eontinues, and no longer, for the consideration of $\$ . . . . . . . .$. per month, payable in advance in equal semi-monthly installments on the regular pay-days of said party of the first part, to be retained by said party of the first part out of the earnings of said party of the second part; provided, that if and when said employment ceases, any sun which has been so totalned for any future period, the same shall bo repaid to said party of the second part by said party of the first part; that when the right of occupancy hereby granted to said party of the second part terminates hereunder, said patty of the second part shall revmove his effects from said housesand surrender the ocoupancy thereof within a reasonable time, which it is agreed shall not exoeed five days, and, upon his failure so to do, said party of the first part, by its officers, agents, or employees, shall have the right, without iny further notice, demand or proceeding, to re-enter upon said premises and expel the said party of the second part therefrom, and remove therufrom any and all of his goods and ohattols, there found, wi.thout liability for any damage resulting therefrom, to whioh actions the said party of the se:ond part shall offer no objection or resistance, and that any holding over or oontinued ocoupunoy of said premises by said party of the second part beyond the expiration of sald five days shall be deemed unlawful and shall in nowise ohange the relati nship of the parties hereto or be construed to create the relationship of landlord and tenant botween them. 
It is further agreed that if, during said employment, said party of the second part ceases to occupy the ob ove described premises and moves to and occupies another house belonging to said party of the firtt part, such oocupanoy of such other house shall be under and subjeot to the terms of this contract.

Witness the following signatures.

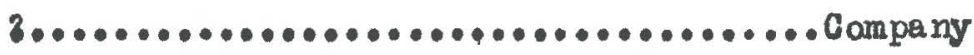

-

By

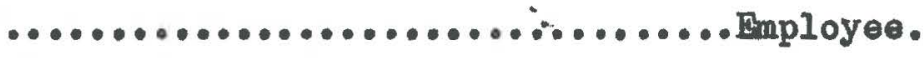




\section{APPENDIX E}

\section{"YELLOW DOG" CONTRAGT USED IN THE POCAHONTAS FIELD}

I am not now a member of the U nited Mine Workers of America, the I. W. W., or any other organization of mine workers, and will not, during this employment, join or affiliate with any such mine labor organization, because I believe the preservation afthe right of individual contract, free from interferenoe or regulation by others, and pyment in proportion to service rendered to be to my interest, to the best interest of the public and of all industry, and I enter this employment with the understandige that the polioy of the Company is to operate a non-union mine, and that it will not knowingly employ anyone belonging to such Union, or organization, and would not give me employment under any other conditions.

This is a contract for employment in the state of Virginia and the laws of that state are to govern in all matters pertaining to, indident to, or growing out of this employment.

I he reby aclonowledge receipt if a copy of the Mining Laws of Virginia, and the Rules efld Regulations of this Company:- I he ve also been instructed in the hazards of this occupation. 


\section{APPENDIX F}

\section{HANDBILL TAKEN FROM A}
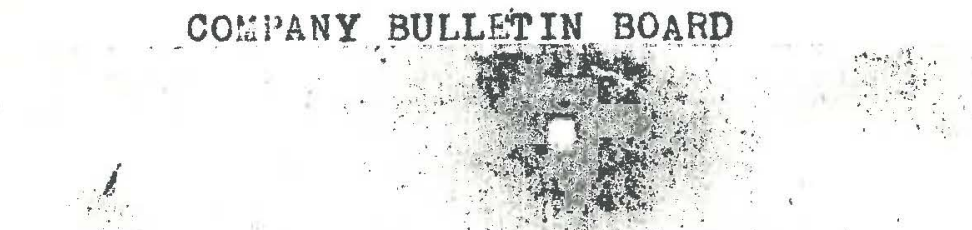

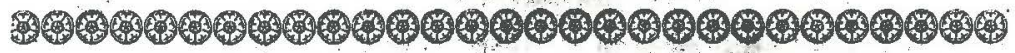

\section{Look! Look! Look!}

WHAT IS GOING ON AT McALPIN, W. VA.

\section{Sunday, July 24, 1932}

A BIG QUARTETTE RALLY AND CONTEST WILL BE GIVEN BY THE HUMMING BIRDS QUARTETTE NO. 2 AT 3:00 O'CLOCK THE 4th SUNDAY.

First song by the Humming Birds of McAlpin then the $f r^{\cdot}$ owing Clubs will beght in the contest: Jolly Boys, Tams; itotesbury Male Quartette; W. Va. Rain Bow No. 4 of Glen White; Great 4 Wonders, Carline; Hill Top Quartette; W. H. F. S. Quartette; Lowe, W. Va. Quartette; Giatto Quartette; Nuriva Quartette; Mullens Quartette.

The Contest will be udged on tone, time and harmony.

A prize of $\$ 5.00$ will be awarded to the Winner.

After the contest is over the congregation will be entertained by the Silver Leaf Quartette of McAlpin, W. Va.

An admission price of $15 c$ and $25 c$ scrip or cash McAlpin and Stotesbury only will be accepted,

Rev. H. Hunt, Master of Ceremonies

A. J, Evans, President

Rev. S. A. Abram, Pastor.

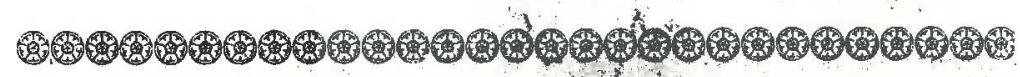


Ambler, Charles H., Sectionaliam In Virginia, Chicago, 1910.

Banks, E. M. Econumica of tand Tenure in Georgla, Colunily uñiversity Press, 1905.

Blghop, J. Leander, El story of Manufactures in the United

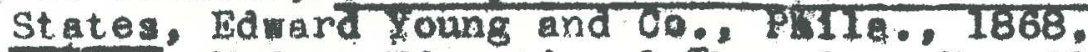

Bode, Boyd T. Mndern Educational Pheories, Macmilian, 1927.

Bogardus, H. S., Immigration and Raoe Att tudes, Heath, 1927.

Bruce, K. VIrginla Iron Manufacture in the Slave Era, Century, 1931.

Bullock, Sketch of a Jourrey. Phough the Western States of lorth america from rev Orleans by the

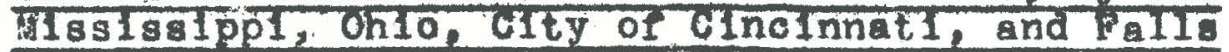
of Niagare, to Na York, In 188\%, London, 1827.

Burgess, E. T. (see Park and Burgess)

Callahan, J. M.o Sem1-Centennial Bistory of Wast Virginia, Charloston, 1913.

Chicago Commission on Race Relationa. Negro in Chicago, Un1v. of Chicago Press, 1922.

C1st, C., Cinoinnat 1 in 1859. CineInnat1, 1859.

Clark, $V$. HIstory of Lanura otupe, 1790-1860, Camegle, 1916.

Competit1ve Position of Coal in the United States, National Industrial conference board, I832.

Devine, B. T. Coal. american Revlew Service Presa, Bloomingt on, TI., 1925.

Dodge, J. R., West Virginia, Lippincott, 1865.

Douglas, P. H. Wages and the Family. Univ. of Chicggo Press, 192\%.

Chapin, R. C.. Standards of Living Arong horkingmen's Families In Now York CIty, Russel Sage poundation, 1909.

Dowd, J., Negro in American L1fe, Century, 1926.

Drake, B. and Mansfleld, B. D. Cincinnat in 1826, Morgan, Dodge and Fisher, Cinci.. 182\%.

Du Bo1s, W. E. B., Souls of Black Folk, Chicago, 1903.

El1ot, T. D., American Standards of LIving, Oinn, 1931.

Embree, E. R. Brown America, Viking Prese. 1931.

Feldman, H.: Racial Fectors in merican Industry, Harpers, 1931 . 
Frazler, E. F., Hegro Family in Chlcago, Univ. of Chicago Press, 193\%.

Greene, L. and Woodgon, C. G., Negro Wage Earner, Assoclated Publ1shers, 1930.

Hale, J. P.. History of the Great Kanawha Valley, Charleston, 1891 .

Hele, J. P., Trane-Allegheny Ploneerg, Cincinnat1, 1886. Hamliton, W. and Wright, H.. Case or B1tuminous Coal. Macmllian, 1925.

Harris, A. L. (see Spero and Harr1s).

Herskov1ts, M. J., Amertcan Negro, Knopf, 1930.

Johnson, C.,S:. Hegromin Amertean Civ111zation, Holt, 1930.

Johes, W. H., Recreation and amusement Among Negroes in Washington, D. C., Howard Untv. Press, 192\%.

Keller, A. G., (see sumner and Keller).

Kennedy, L. V., Mogro Pesant Turns Cityerard, Columbia Untv. Press, 1930 .

La1dley, W. S., H1 st ory of Charleston and Kanawhe County, Richmond-Arnold, Chlcago, 1911.

Lew 18, E. E.. Mob1lity of the Negro, Columb1a Univ. Press, 1931.

Low 1s, V. A., West Virginia landbook, Va. Commission of the Loulslana Purchase Exposition, 1904.

Lumley, F. E., Principles of Soclology, McGram-H111, 1928.

Lumpk In, K. D., The Family: A Study of Member Roles, Univ. of worth Carolina Press, 1933.

Mansfield, E. D., (see Drake and Mansield).

Meoklin, J. M., Demooracy and Race Friction, Macmillan, 1914.

Miller, H. A., Races, Nations, and Classes, Lippincott, 1924.

Mller, K., Race Adjustment, Neale, New York, 1909.

Miller, H. A., (860 rark and M11ler).

Moton, R. R., What the Negro Thinka, Doubleday, Doran, 1929

Lowrer, E. R., The Fam1ly, Univ, of Chlcago Press, 1932.

National Indust rial Conrerence Board, Compet 1t 1ve Position of Coal in the Urited States, 1932.

North, C. Q. Soc1aI DIFlerentiat1on. UnIV. of North Carolina Press, 1926.

North, C. C.. Soclal Problems and Social Planning, McGra-BIT, 1932.

Odum, H. W., Soc1al and Mental Tralts of the Negro, Columbia Univ. Press, 1910.

0lmstead, F. L., A Journey in the Seaboard Slave States, Mason and Bros., Ner York, 1856.

Park, R. R. and Hllier, H. A., Old World Tralt Trangplanted. Socfety for Soclal Redearoh, Unt. or chloggo, 1921.

Puckett, N. H. Polk Bellefs of the Southern Negro, Univ. of Morth derolina Prose, 1926. 
Park, R. E., and Burgeas, E. W., The Clty, Unlv, of Ch1cago Press, 1825.

Recent Social Trends, 2 vols., Ncoraw-Hil1, 1933.

Reuter, E. B., Amerlcan Race Problem, Crowel1, $192 \%$. Rockester, A.. Labor and Coal, Internat1onal, 1931.

Ross, Malcolm, Gchine Age In the H111g, Macmillan, 1933

Scott, E. J., Negro IIgration puring the War, Carnegte Endowment for International Peace, 1920,

Shur1ck, A. T., The Cosl Industry, L1ttle, Brown, 1924, Spero, S. and Harrio, A. L., The Black Worker, Columbla Univ. Press, 1931.

Steiner, J. F., The Japanese Invesion, Mcclure, 1817. Suffern, A. E., Conoliation and Arbitration in the Coal Industry of Amerlea, Houghton, MItPIIn, 1915.

Sumner, T. 0., Folkways, GInn, 1906. \&

Sumner, 4 vola., Yale Univ. Press, 192\%.

Taylor, A. A., The Negro in the Fiecongtruction of Virginie, sssoclated Publishers. 1926.

Taylor, A. A.. The Negro in South Carolina During the Reconstruction, As8001a ted Publishers, 1926.

Washington, B. T.: Story of ihy Life and work, W. H. Ferguson and Co. Cinolnnat, 1801.

Washington, B, T. Op Frum Slavery, A. L. Burt, 1800 , Wesley, C.H., Negro Labor In the United Stateg, Vanguard, 1927.

W11lams, J. M.. Human Aspects of Unemplopment and Reller. Un1v, of worth Carolina Prese, 1935.

Wood, E. E., Beoent Tronds in American Housing, Macmillan, 1931.

Woodson, C. G., A Contury of Hegro Migration, Assoclated Pubil shers, 1918.

woodson, C. G.. Free Negro Heads of Familles in the United States in 1830, As8001ated Publishers, 1925,

Woodson, C. C.. The Negro in Our H1 story. Assoclat ed Pubilshers, IS27.

Woodson, C. G. The Rural Negro, Association For the Stuty of Negro IIfe and History, 1930.

Woodson, C. G., (see Greene and Woodson).

Woofter, T. J., Black Yeomanry, Holt, 1930.

Wright, H. (gee Hamilton and Wright)

Young, D., American Minority Peoples, Harpers, 1932.

Young, K., Soc181 Pgychology, KnopI, 1930. 
SPECIAL STUDIFS, THESES, BEC.

Allen, G. B., The Negro Coal Min ar in the P1ttsburg D1atrict, Unpublished uasters Thesis, univ. or PIttsburg, 1927.

Brooks, R. P., Agrarlan Revolution in Oeorgia, Hilv, of W1 aconsiñ, History Series, VoI.III, I9I4.

Civil War in West Virginia, American Civil Liberties Union. Corson, J. J.s (see Gee and Corson).

Du Bo18, W. E. B.. The Negro timerican Pamily, Atlanta Untv. Publications, 1908.

Du Bols, W. E. B. The Negro Church, Atlanta Univ. Publ1cations, No.8, 1903.

Epste1n, A., The Negro Mlgrant in P1ttgburg, Univ, of P1ttgburg, 1918.

Gee, W. and Corson, J. J., Rural Depopulation in Certain Tidewater and Pledmont Areas or Virginia, Unive or VIrginta, Institute ror Research in tho social Soiences, 1929.

Laing, J. T., The Trends and Analysis of the Literature of Amer 1 can Negro Economic Condit 10ns, 1880-1928, unpubished Y. A. Thes1s, Oh10 State Untv., 1929.

Lama Il, C. E., GIven, I. A., and Kennedy, H. O., Mining Methods in West Virginia, West Virginia UnIV. Enginearing Experiment station, Research Bullet in, No.4, 1929 .

Leap, W. L., The Red Hill Community, unpublished M. S. thesis, Un1v. or V1rgin12, 1930.

Mark, U. L., Nogroes in Columbus, Ohfo Stat Univ. Pross, 1928.

Mark, M. L., Ten Years of Birth Stat 1st1cs in Oh10, 19151924. Ohio Dept. of Health, 1924.

Maury, F. ., and Fontaine, Wm. M., Fesources of West V1rginia, State Board of Centenñal Lanagers, Whooling, 1876 .

Mcaill, N. P., Vielfare of Children In Bltuminous Coal Mining counties In Test Virglnia, U. S. ChIIdren's Bureau pub. 10.117. 1923.

Morals and Mnnners Among Negro Anericang, Atlanta Un1v. Pub. 10.18, 1914.

Negro Migration in 1916-17, U. S. Dept. of Labor, Division of Negro Economics, 1919.

Park, K. E., Pac1fic Cosst Race Relations Survey, unpubIi shed manugcripts, quoted In House, F. N., Range of Soclal theory, Holt, 1929.

Payne, H. B., Behsvior of Conflict Ing Economic Groups, Onio state Un1. Press, 1930.

Snavely, T. R., (see Negro Mlgration in 1916-17).

Woodson, C. G., Early Hegro Education In West Virginla.

w. Va. Colleglate Institute studies in Soclal

Sclence, 1921. 
REPOETS, BULLETINS, ETC.

American Friends Service Commlttee, Report of the Child Kellef Work in the Bituminous Corl Flelds, Sept.I, I931-August 31, 1932.

B1rth, St11lb1rth, and Infant Hortality Stat1stios For B1 rth Reglst rat i o Area of the United States, 1929, Ho dete.

Causal Factors In Infant Nortallty, Onfldren's Bureau, Pub. 10.142, 1925.

Description of Occupations, Mines and Mining, prepared for the U. S. Brployment Service by the U. S. Bureau of Mines and the U. S. Bureau of Labor Statiat1cs, 1818 .

Home Enviponment and Employm nt Opportunit les of Women In Coal un rorkers Familes, U. 8. Dept. of Labor, Women's Bureau, BuIlatin, To.45, 1925.

Labor Relations in Falrmont, "W. Ve., U. S. Dopt, of Labor Bulletin, $10.361,1923$.

letrodist Fpicoopal Ghurch, East Tennessee Conference, 5lat Annual Session and Laymen's asoctation, Orficial Journal, 1931.

Methodist Fpiscopal Church, East Tennesgee Conference, 51at Annual Session and Laymen's Association, offlcial Journal, 1932.

Nonshly Labor Rev1el., Vol.21, U. S. Bureau or Labor Statigtios, hugust igas.

011-Dorado of West Virginia, American Nows Co., New York, 1865.

Re1d, Ira, Kegro Membership in Ame rican Labor Unians, MatIonal Urban league, no data.

Religlous Bodies: 1926, 2 vols., Bureau of the Census. Survey or Negro Colleges and Univergities, U. S. Dept. of the Interlor, Burequ of Ed., Bullet in No.7, 1928.

The United Mine Worker"s in West Virginia, Report submitted to the Coal comision by the BItuminous operator's Special Committee, August, 1823.

U. S. Census Reports, 1840-1230.

U. S. Coal Comm1sa10n, Reports, Pts. I-IV, 68th Congress, Document 185, 1926.

U. S. Dept. of the Interior, Bureau of Ed., Bulletin, Mo. $20,1931$.

U. S. Immigration Comm1ssion, Abatract of Report on Imm1grants in Manufacturing and Mining, 1911.

v. S. Immigration Commission, Reports, 7 vols., 1811.

West Virginia, Stat of, Act of the Leglalature, Section $67-A, 1829$.

West Virginia, Bureau of Negro Welfare and Statist1cs, Reports, 1921-22, 1923-26, 1925-26, 1927-28, 1929-32. Crole ol be miness m 1925 
West Virginia Department of Hines, Annual Feports, 1883-1031. West Virginia Educational Directory, . Va. Dept. of Ed. $1932-32$.

West Virginia State Induatrial Home for Colored alris. Annual Report, 1929-30.

West Virginia, State of, Annual Report of the State Compensation Commissioner, 1926.

\section{AKT TCLES}

Alexander, W. W. The Negro in the Wew Bouth, Annels, Vol. CXXXX, Nov. 1928, pp.145-152.

American Journal of science and Arts, Vo1.29, Jan. 1936, p. 117.

Bogardus, E. S., A Race Relations Cyole, A. J. S., Vol.25, pp.612ff.

Browne, H. M.. The Training of the Negro in the North. Anna 18, Vol.2\%, No.3, P.582.

Bulkley, W. L., Industrial Condition of the Negro in New York C1ty, V01.27, N0.3, 1906, pp.590-596.

Burgess, E. W., The Family and the Pfrson, Publications of the American Soclologlcal Society. Vol.22, Dec. 1927, pp. 133-143.

Capehart, Stepi on P.. Coolsmouth, W. Va. Historicn Magazine, Vol.5, No.1, Jan. 1905.

Carpenter. N.. The Negro in Industry, In Johnson, The Negro in Ame rican CIviTization, Ch.xxv1.

Clark, H. I., The Migrant in Pittsburgh, Opportunity, October, 1923.

Coal Age, Vol.36, pp.65, 648; Vol.37, pp.34,85,123; Vol.38, pp. 108,168 .

Cogl Minfrg, vol.g, June 1932, p.97; Vol.10 Uarch 1933, p.24.

Coman, K., The Negro as a Peagant Earmer, Publications of the American Statistioal Asociation, Vol.9. June 1904 .

Debow's Rev1fw, Vol.IX, Juhy-Dec. . 1850, p.435.

Dodge; D., Free Megrof of North Carolina. Atlantjc Monthiy. Vol.4\%, Jan.1886.

Dovid, J., Colored Men Aa Cotton Manul'scturers, Gunton's, Vo1.25, Sept.1902.

Dubl1n, W. I., The Health of tre Negro, annals, VolyoxxXX, Nov. 1928, pp. $71-85$.

Dunford, F. H. Conflicting Forcus in Negro Progregs. Social Exes, vol.3, p.ro3rt.

Foudal1sm In Vest Virginde. Nation, Vol.133, Aug. 31, 1931. p.155.

Frazier, E. F. La Bourgeo1sie No1re, Modern Quarterly, V01.5. No.1, November 1928-PCbruary 1929, p

Frazier, E. F., The Negro Family, Annals, Vol.CXXXX, Nov. 
1828, pp. 44-51.

Gagnon, E., what Is a St111-b1rth9 Ganadian Publ1c Health, Journal, Vol.XXII, Jan.1931, pp.16-27.

Garrison, M. T: Negroes Play Horthy Part in Development of county, Wolch (W. va.) DaIIy Hows, sept.21, 19.6.

Garvey, 1. The Hegro's Greatest Enemy, Current History. March T925.

Harris, A. L., Negroes in the Cosl Industry, Opportunity, Fab. 1926 .

Haynes, G. F., The Gurch and Negro Progress, Annals, Vol. cxxx, $\sqrt{0 v .1928,264-271 .}$

Kreuger, E. T. Negro Religloug Exprens1on, A. J. S., Vol. XXXVII, JuIY 1932.

Meeker, R., Minimum quant 1ty Budget Necessery to ida intain a Workex samily or Five in Hesth and Decency. In EIIOt, 1 . D., Ame Mcan Standard or Living. pp. $515 \mathrm{ft}^{\mathrm{f}}$.

Hiler, H. A., Ruce and Clase Parallel1sm, Annals, Vol. GXXXX, Nov. 1928, pp.I-5.

M111, $\mathrm{K}, \mathrm{K}$, The Negro as a Workingman. American Mereury, VolevI, pp.310ef.

Nelson, A. D. People of Colpr in Loulstana. Jour. of Negro History, VOI.I, P..36I-376.

Nembold, N. C." Common Schools for Negroes in the South.

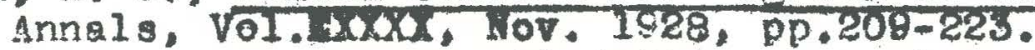

Park, R. E., Bsseg of Rnce Prejudlce, Annals, Vol.CXXXX, Nov. 1828, pP.IITZO.

Park, R. E., Behind Our Makg. Survey, Vo1.56, May 1926, pp. $138 \mathrm{TH}$.

Park, R. E. Negro H e Life and Standards of Living. Anris 1. $101.49,1913, p p .147-163$.

Foss, F. H., and Truxa1, A. G. Primary and Secondary A -

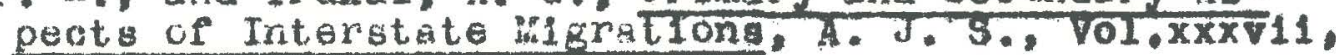
Hov. 1931, pp435-444.

kusge11, J. S., Rural Econamic Pragress of the Negro in Virglnia, Journal of Negrolisator, Vol.XI, oct. 1926.

Rut leage, A. Ane rica's Kindllest Race, Readers Digest, Vul. 22, ipril, 1933, p.86:

Stark, L.. In the Blighted Keslm of the Ming rs, New York Time gagazine, oct. II, 1931, p.9.

Surgace, G. T. The Negro Mine Laborer: Central Appalachian Coul Fleld, Innal, Vol.33, waroh 1900, pp, 338-352.

Thompson, H.S., and Frelpton, P. K., (see Recent Soc1al Trends, Vol. I, P.41).

Vuanlngtion, B. T., The Negro and 11 E Economic Value. International Monthig. Vol.II, Dee. 1900, pp.6\%-686.

Washington, B. T., The Nogro in Business, Cunton's, Vol. 20, Harch, 1901.

Fashington, F. B. Recreational Fac111ties, For the Hegro, Annals, Vol. CXXXX, Nov. 1928, pp.272-282. 
Whelption, $P . K_{0}$, (see Thompson and Whelpton).

wite, I. C., Mineral Rosources of West Virginia. in Callahan, J. 1., Sent-Centenntal HIstory of west VIrginia, pp.359-391.

W11son, K., Coal Digeera. New Republic, July 8, 1931.

Wolman, L., Unemployment, Ingurance - Its Limitations and It 8 romier, Nation, Vol.134, ray 4, 1932, p.609.

Woofter. T. J. Status of Racial and Ethnic Groupa. In Rocent Soctal Tronda, VoI.

IEWSPARERS

Charleston (W. Va.) Gazette, Maroh 11, 1931, April 4, 1931, May 22, 1931, Hov. 17, 1931, May 6, 1933, Peb.15, 1932 .

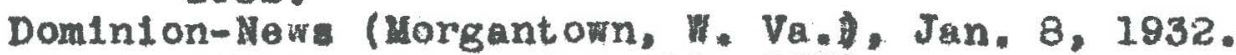

Kanawha Vallay Stat. Oct. 10, 1889.

Polnt Plesant (w. Va.) Independent Republ1osn, Oct. 4, 1855.

Welch (W. Vu.) Da1ly Neva, Sopt. 21. 1926. 


\section{AUTOBIOQRAPHY}

I. Jemes Tamplin Laing, was born in wontgomery, Payette Courty, west Virbinla, Auguet 26, 1898. I recelved uy elementsry and seoondary school education in the public and hlgh sohools or Cherleston, West Virgin1a. I obtained the A. B. degree from Hest Virginle

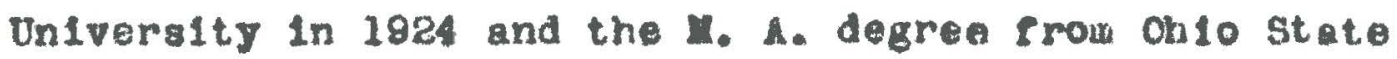
UnIvergity In 1929. Upon recelving my Mater'a degree I wa offered an assistantship in the Department of Soclology of Onio State Univeralty which position I have reld while conpleting the requirements for the degree of Ductor of Philosophy. 